
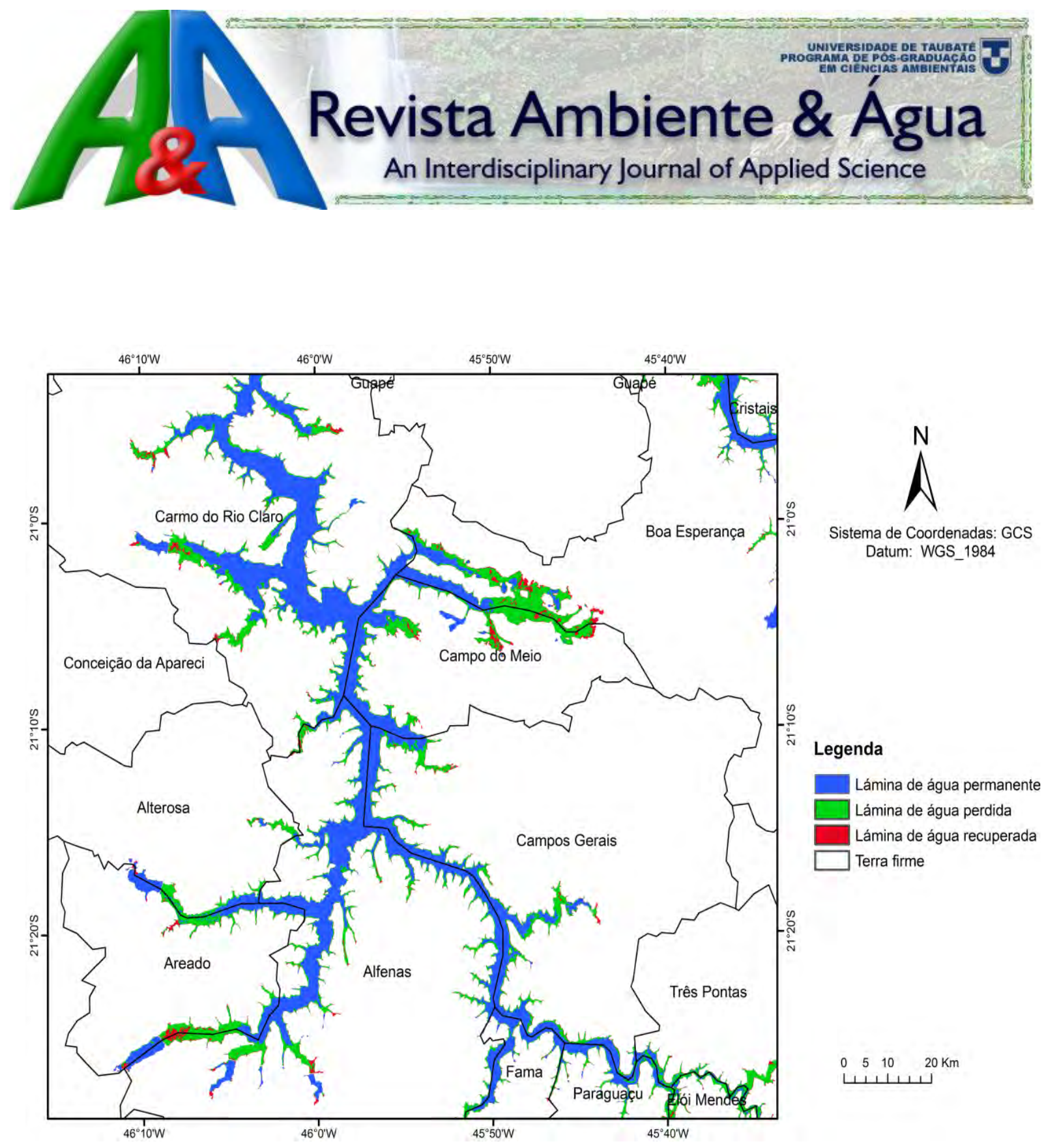

$\mathbf{N}=1980-993 X$ (Online)

http://www.ambi-agua.net

$27^{\text {th }}$ Edition of Revista Ambiente \& Água - An Interdisciplinary Journal of Applied Science, 


\section{EDITORIAL BOARD}

\section{Editor}

\section{Getulio Teixeira Batista}

Instituto de Pesquisas Ambientais em Bacias Hidrográficas (IPABHi), SP, BR

\section{Associate Editors}

Amaury Paulo de Souza

Ana Aparecida da Silva Almeida

Andrea Giuseppe Capodaglio

Antonio Evaldo Klar

Antonio Teixeira de Matos

Carlos Eduardo de M. Bicudo

Cláudia S. de C. M. dos S. Cordovil

Dar Roberts

Delly Oliveira Filho

Ehsan Noroozinejad Farsangi

Gabriel Constantino Blain

Giordano Urbini

Hélio Nobile Diniz

João Vianei Soares

José Carlos Mierzwa

Julio Cesar Pascale Palhares

Luis Antonio Merino

Marcelo dos Santos Targa

Nelson Wellausen Dias

Petr Hlavínek

Richarde Marques da Silva

Sergio Francisco de Aquino

Silvio Jorge Coelho Simões

Stefan Stanko

Teresa Maria Reyna

Yosio Edemir Shimabukuro

Zhongliang Liu Beijing
Universidade Federal de Viçosa (UFV), BR

Universidade de Taubaté (UNITAU), BR

University of Pavia, Italy

Universidade Est. Paulista Júlio de Mesquita Filho (UNESP), BR

Universidade Federal de Viçosa (UFV), BR

Instituto de Botânica, IBT, BR

Centro de estudos de Engenharia Rural (CEER), Lisboa, Portugal

University of California, Santa Barbara, United States

Universidade Federal de Viçosa (UFV), BR

International Institute of Earthquake Engineering and

Seismology(IIEES), Farmanieh, Tehran, Iran

Instituto Agronômico de Campinas, IAC, Brasil.

University of Insubria, Varese, Italy

Inst. Geológico, Sec. do Meio Amb. do Est. de SP (IG/SMA),BR

Instituto Nacional de Pesquisas Espaciais (INPE), BR

Universidade de São Paulo, USP, BR

Embrapa Pecuária Sudeste, CPPSE, São Carlos, SP, BR

Institute of Regional Medicine, National University of the Northeast,

Corrientes, Argentina

Universidade de Taubaté, (UNITAU), BR

Inst. Bras. de Geogr. e Estatística (IBGE). Aracaju, SE, BR

Brno University of Technology, Czech Republic

Universidade Federal da Paraíba, UFPB, BR

Universidade Federal de Ouro Preto, UFOP, BR

Univ. Est. Paulista Júlio de Mesquita Filho, UNESP, BR

Slovak Technical University in Bratislava Slovak, Slovakia

Universidad Nacional de Córdoba, Argentina

Instituto Nacional de Pesquisas Espaciais (INPE), BR

University of Technology, China

\section{Nelson Wellausen Dias, PPGCA, UNITAU, IBGE, BR}

Theodore D`Alessio, FL, USA \& Getulio T. Batista, UNITAU, BR

Liliane Castro, Bibliotecária - CRB/8-6748, Taubaté, BR

Vera L. F. Batista, IPABHi \& Getulio T. Batista, UNITAU, BR

Tiago dos Santos Agostinho, LAGEO, UNITAU, BR

Library catalog entry by SIBi - Sistema Integrado de Bibliotecas / UNITAU

Revista Ambiente \& Água - An Interdisciplinary Journal of Applied Science / Instituto de Pesquisas Ambientais em Bacias Hidrográficas. Taubaté. v.9, n. 4 (2006)Taubaté: IPABHi, 2014

Quadrimestral

ISSN 1980-993X

1. Ciências ambientais.

2. Recursos hídricos. I. Instituto de Pesquisas Ambientais em Bacias Hidrográficas

CDD - 333.705

CDU - (03)556.18 
Ad Hoc Peer Reviewers that effectively evaluated submissions in 2014

(Revista Ambiente \& Água, volume 9, n. 1, 2,3 e 4, 2014)

\begin{tabular}{|c|c|}
\hline Adalberto Luis Val & Instituto Nacional de Pesquisas da Amazônia (INPA) \\
\hline Adriana Koumrouyan & Instituto Nacional de Pesquisas Espaciais \\
\hline Adriane Martins de Freitas & Universidade Tecnológica Federal do Paraná (UTFPR) \\
\hline Adriano Luiz Tonetti & Universidade Estadual de Campinas (UNICAMP). \\
\hline Abel O. Talabi & Ekiti State University, Nigéria \\
\hline Agnes Barbério & Universidade de Taubaté (UNITAU) \\
\hline Alberto Adriano Cavalheiro & Universidade Estadual de Mato Grosso do Sul (UEMS) \\
\hline Alberto Wisniewski Junior & Universidade Federal de Sergipe (UFS) \\
\hline Alethea Ernandes Martins Sallun & Laboratório de Engenharia E Consultoria (LENC) \\
\hline Ana Lucia Suriani Affonso & Universidade Estadual do Centro-Oeste (UNICENTRO) \\
\hline Ana Emilia Siegloch & Universidade de São Paulo, Ribeirão Preto (USP) \\
\hline Ana Teresa Lombardi & Universidade Federal de São Carlos (UFSCAR) \\
\hline Andrea Nunes Vaz Pedroso & Instituto de Botânica (IBT) \\
\hline André Belmont Pereira & Universidade Estadual de Ponta Grossa (UEPG) \\
\hline Annibal Duarte Pereira Neto & Universidade Federal Fluminense (UFF) \\
\hline Aníbal da Fonseca Santiago & Universidade Federal de Ouro Preto (UFOP) \\
\hline Antonio Laverde Junior & Universidade Tecnológica Federal do Paraná (UTFPR) \\
\hline Antonio Carlos Campos Pignatari & Universidade Federal de São Paulo (USP) \\
\hline Antonio Jose Teixeira Guerra & Universidade Federal do Rio de Janeiro (UFRJ) \\
\hline Antonio Marozzi Righetto & Universidade Federal do Rio Grande do Norte (UFRN) \\
\hline Antonio Sergio F. Mendonça & Universidade Federal do Espírito Santo (UFES) \\
\hline Aparecido Osdimir Bertolin & Universidade Federal do Tocantins (UFTO) \\
\hline Armando Augusto H. Vieira & Universidade Federal de São Carlos (UFSCAR) \\
\hline Ayrton Figueiredo Martins & Universidade Federal de Santa Maria (UFSM) \\
\hline Beatriz Monte Serrat & Universidade Federal do Paraná (UFPR) \\
\hline Bianca Ferreira da Silva & Universidade Federal de São Carlos (UFSCAR) \\
\hline Camilo Allyson Simões de Farias & Universidade Federal de Campina Grande (UFCG) \\
\hline Camilo Daleles Rennó & Instituto Nacional de Pesquisas Espaciais (INPE) \\
\hline Carla Semiramis Silveira & Universidade Federal Fluminense (UFF) \\
\hline Carlo Collivignarelli & Università degli Studi di Brescia, Italia \\
\hline Carlos Augusto de M. Tamanini & Universidade Estadual de Maringá (UEM) \\
\hline Catarina da Silva Pedrozo & Universidade Federal do Rio Grande do Sul (UFRGS) \\
\hline Claudia Albuquerque Linhares & Instituto Nacional de Pesquisas Espaciais (INPE) \\
\hline
\end{tabular}


Cláudia Maria Luz Lapa Teixeira Instituto Nacional de Tecnologia (INT)

Claudinei Fonseca Souza

Claudio José Cavalcante Blanco

Claudio Luis Frankenberg

Claudio Marcio Souza

Conrado de Moraes Rudorff

Daímio Chaves Brito

Danielle Palma de Oliveira

Débora Astoni Moreira

Debora Cristina Rother

Denise de Castro Pereira

Didier Gastmans

Eduardo Bosco Mattos Cattony

Eduardo Pereira Cabral Gomes

Eduardo von Sperling

Eliane Pintor de Arruda

Eliane Sloboda Rigobello

Eliezer Menezes Pereira

Eline Simões Gonçalves

Elmo Rodrigues da Silva

Edenir Pereira Filho

Elmo Rodrigues da Silva

Elvis Vasquez Rimachi

Eny Maria Vieira

Eugenia Cristina G. Pereira

Evlyn Márcia Novo

Fábio Kummrow

Fabio Laurindo da Silva

Fabio de Oliveira Sanches

Fabrício Motteran

Gabriel Constantino Blain

Gannabathula Sree Vani

Gersina N. da R. Carmo Junior

Gesinaldo Ataíde Cândido

Getulio Teixeira Batista
Universidade Federal de São Carlos (UFSCAR)

Universidade Federal do Pará (UFPA)

Pontifícia Univ. do Rio Grande do Sul (PUC-RS)

Universidade Fed. dos Vales do Jequitinhonha e Mucuri

Instituto de Pesquisas Espaciais (INPE)

Universidade do Estado do Amapá (UEAP)

Fac. de C. Farmacêuticas de Rib. Preto (FCFRP/USP)

Universidade do Estado de Minas Gerais (UEMG)

Escola Sup. de Agric. Luiz de Queiroz (ESALQ-USP)

Pontifícia Universidade Católica (PUC Minas)

Univ. Estadual Paulista Júlio de Mesquita Filho (UNESP)

Inst. Fed. de Educ., Ciência e Tecnologia do Ceará (IFCE)

Instituto de Botânica (IBT)

Universidade Federal de Minas Gerais (UFMG)

Universidade Federal de São Carlos (UFSCAR)

Universidade Estadual de Maringá (UEM)

Inst. Fed. de Ed., Ciência e Tecn. do Rio de Janeiro (IFRJ)

Fundação Oswaldo Cruz (FIOCRUZ)

Universidade do Estado do Rio de Janeiro (UERJ)

Universidade Federal de São Carlos, UFSCAR, Brasil.

Universidade do Estado do Rio de Janeiro (UERJ)

Instituto Nacional da Amazônia (INPA)

Universidade de São Paulo (USP)

Universidade Federal de Pernambuco (UFPE)

Nacional de Pesquisas Espaciais (INPE)

Universidade Federal de São Paulo (UNIFESP)

Universidade Federal de São Carlos (UFSCAR)

Universidade Federal da Fronteira Sul (UFFS)

Universidade de São Paulo (USP/São Carlos)

Instituto Agronômico de Campinas (IAC)

Universidade de Taubaté, (UNITAU)

Universidade Federal de Mato Grosso (UFMT)

Universidade Federal de Campina Grande (UFCG)

Universidade de Taubaté (UNITAU) 


\begin{tabular}{|c|c|}
\hline Gilberto C. Sediyama & Universidade Federal de Viçosa (UFV) \\
\hline Gilvan Sampaio de Oliveira & Instituto Nacional de Pesquisas Espaciais (INPE) \\
\hline Giordano Urbini & Università degli Studi dell'Insubria, Varese, Italia \\
\hline Giovani de Oliveira Garcia & Centro de C. Agrárias da Univ. Fed. do ES (CCAUFES) \\
\hline Gordon Tami Amangabara & Federal University of Technology, Owerri, Nigeria \\
\hline Gannabathula Sree Vani & Universidade de Taubaté (UNITAU) \\
\hline Gustavo Soares Leão & UNICAMP, Faculdade de Ciências Médicas \\
\hline Helio Grassi Filho & Universidade Estadual de São Paulo (UNESP) \\
\hline Hélio Nóbile Diniz & Instituto Geo. do Est. de São Paulo (IG-SMA/SP) \\
\hline Herminia Yohko Kanamura & Universidade Federal de Alfenas (UNIFAL) \\
\hline Hugo Alexandre Soares Guedes & Universidade Federal de Pelotas (UFPEL) \\
\hline Hycienth Nwankwoala & University of Port-Harcourt, Nigeria \\
\hline Iria Fernandes Vendrame & Instituto Tecnológico de Aeronáutica (ITA) \\
\hline Irineu Bianchini Júnior & Universidade Federal de São Carlos - UFSCar \\
\hline Ivanildo Hespanhol & Universidade de São Paulo (USP) \\
\hline Jairo Osvaldo Cazetta & Univ. Estadual Paulista Júlio de Mesquita Filho, (UNESP) \\
\hline João Santos Nahum & Universidade Federal do Pará (UFPA) \\
\hline Joel Dias da Silva & Fundação Universidade Regional de Blumenau (FURB) \\
\hline Jorge Morgan Medina & Universidad Autónoma de Baja California (UABC). \\
\hline Jorge Sobral da Silva Maia & Universidade Estadual do Norte do Paraná (UENP) \\
\hline José Antonio Tosta dos Reis & Universidade Federal do Espírito Santo (UFES) \\
\hline José Carlos Mierzwa & Universidade de São Paulo (USP) \\
\hline José Dias Corrêa Junior & Universidade Federal de Minas Gerais (UFMG) \\
\hline Jose Domingo Medina & Instituto Venezolano de Invest. Científicas, Emeritus. \\
\hline José Marinaldo Gleriani & Universidade Federal de Viçosa (UFV) \\
\hline José Jailton Marques & Universidade Federal de Sergipe (UFS) \\
\hline José Max Barbosa Oliveira Jr. & Universidade do Estado de Mato Grosso (UEMG) \\
\hline Josely Dantas Fernandes & Universidade Estadual da Paraíba (UEPB) \\
\hline Josino Costa Moreira & Fundação Oswaldo Cruz (FIOCRUZ) \\
\hline Julia Ferreira da Silva & Universidade Federal da Bahia (UFBA) \\
\hline Julio Cesar Pascale Palhares & Pecuária Sudeste (EMBRAPA) \\
\hline Julio Vieira Neto & Universidade Federal Fluminense (UFF) \\
\hline $\begin{array}{l}\text { Junior Alexandre Moreira Pinto } \\
\text { Katia Canil }\end{array}$ & $\begin{array}{l}\text { Universidade de Taubaté (UNITAU) } \\
\text { Universidade Federal do ABC (UFABC) }\end{array}$ \\
\hline Kelly Cristina Tonello & Universidade Federal de São Carlos (UFSCAR) \\
\hline
\end{tabular}


Leandro Vinícius Alves Gurgel

Leila Queiroz Zepka

Leonardo Fernandes Fraceto

Leo Heller

Liber Martin

Liliana Rocio Botero Botero

Luciano dos Santos Rodrigues

Luís Henrique Mancini

Luis Antonio Merino

Luiz Carlos de Faria

Luiz Fernando Nascimento

Luiz Fernando Scheibe

Magali Rezende Gouvea Meireles

Marcelo De Julio

Marcelo Sandin Dourado

Marcia Terezinha Zilli

Marcos Antonio Gomes

Marcus Aurélio Soares Cruz

Mariachira Zanetti

Maria Cristina Borba Braga

Maria Cristina Crispim

Maria Cristina Rizk

Maria do Carmo Martins Sobral

Maria Gizelda de O. Tavares

Maria Helena Rodrigues Gomes

Maria Isabel Sobral da S. Escada

Maria Marlucia Freitas Santiago

Maria Jesus Robim

Mariko Ueno

Marta Margarete Cestari

Maurício Alves da M. Sobrinho

Mauricio José Borges

Mauricio Luiz Sens

Mauro Martinez

Messias Borges Silva
Universidade Federal de Ouro Preto (UFOP)

Universidade Federal de Santa Maria (UFSM)

Univ. Estadual Paulista Júlio de Mesquita Filho (UNESP)

Universidade Federal de Minas Gerais (UFMG)

Universidad Nacional de Cuyo en Mendoza, Argentina.

Universidad de Medellín, Colombia

Universidade Federal de Minas Gerais (UFMG)

Universidade de Brasília (UNB)

Inst. Reg. de Medicina - Univ. Nacional del Nordeste

Universidade Federal de São Carlos (UFSCAR)

Universidade de Taubaté (UNITAU)

Universidade Federal de Santa Catarina (UFSC)

Pontifícia Universidade Católica de Minas Gerais (PUC)

Instituto Tecnológico de Aeronáutica (ITA)

Universidade Federal do Paraná (UFPR)

University of California, Santa Barbara, USA

Universidade Federal de Viçosa (UFV)

Embrapa Tabuleiros Costeiros (CPATC)

Polytechnic University of Turin, Italy

Universidade Federal do Paraná (UFPR)

Universidade Federal da Paraíba (UFPB)

Univ. Estadual Paulista Julio de Mesquita Filho (UNESP)

Universidade Técnica de Berlin, TU BERLIN, Alemanha.

Universidade Federal de Goiás (UFG)

Universidade Federal de Juiz de Fora (UFJF)

Instituto Nacional de Pesquisas Espaciais (INPE)

Universidade Federal do Ceará (UFC)

Instituto Florestal do Estado de São Paulo (IF)

Universidade de Taubaté (UNITAU)

Universidade Federal do Paraná (UFPR)

Universidade Federal de Pernambuco (UFPE)

Instituto Taquaritinguense de Ensino Superior

Universidade Federal de Santa Catarina (UFSC)

Universidade Federal de Viçosa (UFV)

Universidade de São Paulo (USP) 
Mêuser Jorge Silva Valença

Michele Morais Oliveira Pereira

Miguel Mansur Aisse

Natacha Deboni Cereser

Nei Kavaguichi Leite

Nelson Wellausen Dias

Núbia Natália de Brito

Osmar Gustavo Wöhl Coelho

Patrícia Bilotta

Paula Dias Bevilacqua

Paulo José Adissi

Paulo Cesar de Jesus

Paulo Fortes Neto

Paulo Henrique Caramori

Paulo Romera e Silva

Pedro Daniel da Cunha Kemerich

Rafael Mingoti

Regina Teresa Rosim Monteiro

Regla Duthit Somoza

Reinaldo G Bastos

Renato Gavasci

Renato Fontes Guimarães

Renato Igor da silva Alves

Ricardo de Oliveira Figueiredo

Richarde Marques Silva

Roberto José Carvalho

Rodolfo Carapelli

Rodrigo Fernando dos S. Salazar

Rodrigo Medeiros

Ronaldo Borges Barthem

Ronaldo De Almeida

Ronaldo Fia

Ronaldo Teixeira Pelegrini

Rosana Icassatti Corazza

Rubya Vieira de Mello Campos
Universidade de Pernambuco (UPE)

Universidade Federal de Viçosa (UFV)

Universidade Federal do Paraná (UFPR)

Universidade Federal de Pelotas (UFPEL)

Universidade Federal de Santa Catarina (UFSC)

Instituto Brasileiro de Geografia e Estatística (IBGE)

Universidade Federal de Goiás (UFG)

Universidade do Vale do Rio dos Sinos (UNISINOS)

Universidade de São Paulo (USP)

Universidade Federal de Viçosa (UFV)

Universidade Federal da Paraíba (UFPB)

Universidade Federal do Rio de Janeiro (UFRJ)

Universidade de Taubaté (UNITAU)

Instituto Agronômico do Paraná (IAPAR)

Centro Tecn. de Hid. e Recursos Hídricos - CTH/DAEE

Universidade Federal de Santa Maria - UFSM/CESNORS

Embrapa Gestão Territorial (EMBRAPA SGTE)

Universidade de São Paulo (USP)

Instituto Nacional de Pesquisas Espaciais (INPE)

Universidade Federal de São Carlos (UFSCAR)

University of Rome "Tor Vergata"

Universidade de Brasília (UnB)

Universidade de São Paulo (USP)

Empresa Bras.de Pesq. Agropecuária (EMBRAPA)

Universidade Federal da Paraíba (UFPB)

Pontifícia Univ. Católica do Rio de Janeiro (PUC-Rio)

Universidade Federal do Rio Grande (FURG)

Centro Univ. Franciscano (UNIFRA)- Santa Maria, RS

Universidade Federal Rural do Rio de Janeiro (UFRRJ)

Museu Paraense Emílio Goeldi (MPEG)

Universidade Federal do Amazonas (UFAM)

Universidade Federal de Lavras

Universidade Federal de São Carlos (UFSCAR)

Faculdades de Campinas (FACAMP)

Fac. Est. de Ciên. e Let. de Campo Mourão (FECILCAM) 
Sandro G. de Castro Britto

Selma Gomes Ferreira Leite

Sergio Francisco Aquino

Sergio Nascimento Duarte

Sergio Renato Noguez Piedras

Sigrid Neumann Leitão

Sidney Sára Zanetti

Sílvia Maria Alves C. Oliveira

Solomon Dauda Musa

Sueli Yoshinaga Pereira

Suzana Gico Montenegro

Tadeu Fabricio Malheiros

Teresa Cristina Brazil de Paiva

Teresa Cristina Tarle Pissarra

Tereza Cristina Souza de Oliveira

Teresa Maria Reyna

Tulio Assunção Pires Ribeiro

Vládia Pinto Vidal de Oliveira

Valéria Peixoto Borges

Vandré Barbosa Brião

Vidal Dias da Mota Júnior

Vicente de P. Rodrigues Silva

Vincenzo Torretta

Vivian Castilho da Costa

Walter de Paula Lima

Waterloo Pereira Filho

Wesley A. Conde Godoy

Willames de Albuquerque Soares
Laboratório de Biologia e Ecologia de Peixes

Universidade Federal do Rio de Janeiro (UFRJ)

Universidade Federal de Ouro Preto (UFOP)

E. S. de Agric. "Luiz de Queiroz" (USP-ESALQ)

Universidade Federal de Pelotas (UFPEL)

Universidade Federal de Pernambuco (UFPE)

Universidade Federal do Espírito Santo (UFES)

Universidade Federal de Minas Gerais (UFMG).

Universiti Putra Malaysia

Universidade Estadual de Campinas (UNICAMP)

Universidade Federal de Pernambuco (UFPE)

Universidade de São Paulo (USP)

Universidade de São Paulo (USP)

Univ. Estadual Paulista Júlio de Mesquita Filho (UNESP)

Universidade Federal do Amazonas, UFAM, Brasil.

Universidad Nacional de Córdoba, Argentina

Universidade Estadual de Campinas (UNICAMP)

Universidade Federal do Ceará (UFC)

Universidade Federal da Paraíba (UFPB)

Universidade de Passo Fundo (UPF)

Universidade de Sorocaba (UNISO)

Universidade Federal de Campina Grande (UFCG)

University of Insubria, Italy

Universidade do Estado do Rio de Janeiro (UERJ)

Universidade de São Paulo (USP)

Universidade Federal de Santa Maria (UFSM)

Universidade de São Paulo (ESALQ/USP)

Universidade de Pernambuco (UPE)

Note: 1) Some of these reviewers evaluated more than one manuscript.

2) This list includes reviewers that evaluated submissions that were not accepted for publication. 


\section{TABLE OF CONTENTS}

\section{COVER:}

Water surface of the Furnas Reservoir in 2010, 2012 (dry year), 2013, showing the permanent surface covered by water (both in 2010 and 2012), the area without water due to drought (2012) and the surface recovered in 2013.

Source: BROCHADO, G. T. et al. Uso de imagens do LISS-3/Resourcesat-1 e do OLI/Landsat-8 no estudo espacial da queda do nível de água no lago de Furnas no ano de 2012. Rev. Ambient. Água, Taubaté, vol. 9 n 4, p. 664-678, 2014. http://dx.doi.org/10.4136/ambi-agua.1430

\section{REVIEWERS}

Ad Hoc Peer Reviewers that effectively evaluated submissions in 2014 (Revista Ambiente \& Água,

ii-vii volume 9, n. 1, 2, 3 e 4, 2014)

Getulio Teixeira Batista

\section{EDITORIAL}

An overview of the Ambiente \& Agua journal nine years after its inception

doi:10.4136/ambi-agua.1541

Getulio Teixeira Batista

\section{ARTICLES}

Kinetic parameters of biomass growth in a UASB reactor treating wastewater from coffee wet processing (WCWP)

01

doi:10.4136/ambi-agua.1280

Claudio Milton Montenegro Campos; Marco Antonio Calil Prado; Erlon Lopes Pereira

Agricultural recycling of biodigested vinasse for lettuce production

doi: 10.4136/ambi-agua.1313

Camila Roberta Javorski Ueno; Antonio Carlos Saraiva da Costa; Marcelino Luiz Gimenes; Gisella

Maria Zanin

Characteristics of irrigation tube wells on major river flood plains in Bauchi State, Nigeria

Abdullahi Abubakar Sadiq; Sunusi Abubakar Amin; Desa Ahmad; Baba Gana Umara

Identification of volatile organic compounds (VOCs) in plastic products using gas chromatography and mass spectrometry (GC/MS)

Nerlis Pajaro-Castro; Karina Caballero-Gallardo; Jesus Olivero-Verbel

Tissue levels of the antioxidant enzymes superoxide dismutase and catalase in fish Astyanax bimaculatus from the Una River Basin

doi: 10.4136/ambi-agua.1473

Maria Tereza Oliveira Batista; Edson Rodrigues; Mariana Feijó-Oliveira; Anne Caroline Ribeiro;

Edson Rodrigues; Cecilia Nahomi Kawagoe Suda; Gannabathula Sree Vani

Diagnóstico físico-ambiental como subsídio a identificação de áreas vulneráveis à erosão na bacia hidrográfica do Ribeirão do Espírito Santo, Juiz de Fora (MG), Brasil 
Condições físico-químicas e biológicas em águas superficiais do Rio Tapajós e a conservação de Floresta Nacional na Amazônia, Brasil

Sarah Suely Alves Batalha; Lucieta Guerreiro Martorano; Adriele Giaretta Biase; Gundisalvo Piratoba

Morales; Altem Nascimento Pontes; Leonardo Sousa dos Santos

Uso de imagens do LISS-3/Resourcesat-1 e do OLI/Landsat-8 no estudo espacial da queda do nível de água no lago de Furnas no ano de 2012

08 doi: 10.4136/ambi-agua.1430

Gabriel Thomé Brochado; Lucrêncio Silvestre Macarringue

Estudo da aplicação de tanino no tratamento de água para abastecimento captada no rio Tubarão, na cidade de Tubarão, $\mathrm{SC}$

Everton Skoronski; Bruno Niero; Mylena Fernandes; Mauricio Vicente Alves; Viviane Trevisan

Determinação simultânea de estriol, $\beta$-estradiol, $17 \alpha$-etinilestradiol e estrona empregando-se extração em fase sólida (SPE) e cromatografia líquida de alta eficiência (HPLC)

10 doi: $10.4136 /$ ambi-agua.1346

Marina da Silva Daniel; Elizabete Campos de Lima

Avaliação da qualidade da água para abastecimento no assentamento de reforma agrária Canudos, Estado de Goiás

11 doi: 10.4136/ambi-agua.1386

Paulo Sérgio Scalize; Elaine Franciely dos Santos Barros; Lorena Acelina Soares; Karla Emmanuela Ribeiro Hora; Nilson Clementino Ferreira; Luis Rodrigo Fernandes Baumann

Correlação entre condição da superfície do solo agrícola e o coeficiente de absorção acústica

doi: 10.4136/ambi-agua.1423

Rosane Freire; Célia Regina Granhen Tavares; Paulo Fernando Soares; Marco Henrique Meletti de Abreu

Variabilidade espaço-temporal da temperatura e difusividade térmica do solo de Lagoa Seca-PB

Júlio Mannuel Tavares Diniz; Renilson Targino Dantas; José Fideles Filho

Efeito da aplicação de esgoto doméstico primário na produção de milho no assentamento Milagres (Apodi-RN)

Zailton Vagner Barreto da Costa; Marcelo Tavares Gurgel; Lucas Ramos Costa; Sandra Maria Campos Alves; Miguel Ferreira Neto; Rafael Oliveira Batista

Degradação de trilhas na Reserva Ecológica da Juatinga em Paraty - Rio de Janeiro

Luana de Almeida Rangel; Antonio José Teixeira Guerra 


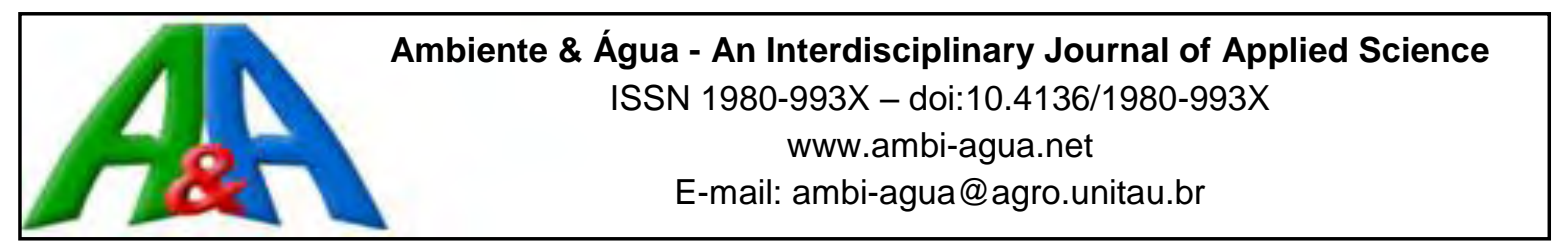

\title{
An overview of the Ambiente \& Agua journal nine years after its inception
}

\author{
doi:10.4136/ambi-agua.1541 \\ Getulio Teixeira Batista \\ Universidade de Taubaté (UNITAU), Taubaté, SP, Brazil \\ Programa de Pós-graduação em Ciências Ambientais \\ Editor-in-Chief of Ambi-Agua Journal \\ e-mail: ambi-agua@agro.unitau.br
}

\begin{abstract}
After nine years of continuous on-time publication, we thought it appropriate in this editorial to review some of the journal's accomplishments. To date, we have published 27 issues, on schedule, totaling 440 articles selected out of 1093 submissions. All of the articles have been peer-reviewed by at least two reviewers. Our average overall rejection rate is $60 \%$, and this trend is steadily increasing due to the more stringent standards applied as the journal interfaces with various databases and indices, and also due to the increasing number of submissions we receive as the journal achieves greater prominence and recognition. The journal's system currently includes 1,904 registered users, 682 of which are members of our ad hoc peer reviewers' panel. Our Editorial Committee was recently augmented with the addition of outstanding scientists from the European Community, Asia, the Middle East and Latin America, and it continues to grow. In recent years we have been publishing about 60 articles per year. All of the articles have doi ${ }^{\mathrm{TM}}$ registration with CrossRef, which enhances their accessibility and visibility through interaction with many indices and publication search engines. We promote the visibility of the articles in many venues throughout the world and more recently in academic and social networks. Another major accomplishment was the recent inclusion of the journal in distinguished collections such as SciELO and SCOPUS.
\end{abstract}

Keywords: Ambi-agua, Impact Factor, SciELO, SCOPUS.

\section{Uma visão geral da Revista Ambiente \& Água nove anos após a sua criação}

\section{RESUMO}

Após nove anos de publicação rigorosamente em dia, julgou-se apropriado neste editorial se rever algumas realizações da revista. Até agora, foram publicadas 27 edições, totalizando 440 artigos selecionados de 1.093 submissões revisadas por pares. Todos os artigos são avaliados por pelo menos dois avaliadores ad hoc. A taxa média de rejeição global é de $60 \%$ com tendência a aumentar devido às normas mais rigorosas aplicadas em decorrência dos padrões de exigência das várias bases e índices em que a revista está indexada e também devido ao aumento do número de submissões à medida que a revista alcança maior destaque e reconhecimento. A revista tem 1.904 usuários registrados, dos quais 682 são membros do painel de avaliadores ad hoc. Recentemente o Comitê Editorial foi reforçado com a inclusão 
de renomados cientistas da Comunidade Europeia, Ásia, Oriente Médio e América Latina e está em contínuo crescimento. A revista tem publicado cerca de 60 artigos por ano. Todos os artigos têm registro doi ${ }^{\mathrm{TM}}$ na CrossRef, o que aumenta a acessibilidade e a visibilidade deles, devido à interação com vários indexadores e mecanismos de busca de publicações. A visibilidade dos artigos é continuamente promovida em muitas bases mundiais e, recentemente, nas redes acadêmicas e sociais. Outra grande conquista foi a inclusão da revista em coleções de prestígio tais como SciELO e SCOPUS.

Palavras-chave: Ambi-agua, Fator de Impacto, SciELO, SCOPUS.

\section{DISCUSSION}

The publication is available at http://www.ambi-agua.net. Additionally, since the end of 2013 the most recent issues are hosted in the SciELO server at http://www.scielo.br/ambiagua. The complete collection of articles is also hosted by Redalyc, accessible at: http://www.redalyc.org/revista.oa?id=928. All articles are forwarded to Mendeley, and more recently to Academia.edu. EBSCO started publishing our full texts in their collection "Environment Complete" on December 18, 2008. We also promote the visibility of articles in many collections and search engines by making their metadata available, as can be seen in: http://www.ambi-agua.net/seer/files/indexadores_AA_ Outubro_2013.pdf.

There are many ways to assess the impact of a scientific journal (Moed, 2010). However, the most commonly used and accepted index, the Impact Factor (IF), is proprietary and operated on a commercial basis. We therefore monitor our journal by examining indicators that are free of charge, such as Google Analytics and also the SciELO metrics since August 2013, when Ambiente \& Agua was first included in that collection. For the period of August 01, 2013 to October 10, 2014, Google Analytics found that the journal's site (http://www.ambi-agua.net) had 26,669 visitor sessions, from 15,470 users that viewed 162,613 pages (6.10 pages / session). In the equivalent period, at SciELO's site (http://www.scielo.br/ambiagua) the journal had a total of 20,449 article requests (7,900 of vol. 8, n. 3, Sep. - Dec. 2013; 5,846 of vol. 8, n. 1, Jan. - Mar. 2013; and, 5,429 of vol. 8, n. 2, Apr. - Aug. 2013). This is quite remarkable, since SciELO has only the most recent issues, and demonstrates the great visibility of SciELO.

SciELO publishes several metrics of its journals, and some of those relating to Revista Ambiente \& Agua have already begun to appear (Table 1).

Table 1. Number of citations granted and received by Revista Ambient. Agua from 2012 to 2014 .

\begin{tabular}{ccccc}
\hline $\begin{array}{c}\text { Rev. Ambient. } \\
\text { Água }\end{array}$ & $\begin{array}{c}\text { n. of } \\
\text { issues }\end{array}$ & n. of articles & $\begin{array}{c}\text { n. of granted } \\
\text { citations }\end{array}$ & $\begin{array}{c}\text { n. of received } \\
\text { citations }\end{array}$ \\
\hline 2014 & 3 & 47 & 1248 & 35 \\
2013 & 3 & 61 & 1596 & 36 \\
2012 & 3 & 63 & 1717 & 37 \\
\hline
\end{tabular}

Source: adapted from SciELO metrics at:

http://statbiblio.scielo.org//stat_biblio/index.php?no=03.xml\&state=03\&lang=en\&issn=1980-993X

The analysis of the Impact Factor of Revista Ambient. Agua reported by SciELO at http://statbiblio.scielo.org//stat_biblio/index.php?state=05\&lang=en\&country=scl\&issn=1980 
-993X\&CITED\%5B\%5D=1980-993X\&YNG\%5B\%5D=2014 shows that in 2014 the journal received 35 citations (all years, Table 1). Ten of these citations related to articles published in 2013, and nine to articles from 2012, totaling 19 citations received in 2014 for articles published in the two previous years (2013 and 2012). Since 124 articles were published in 2013 and 2012, the journal Impact Factor is 0.1532 on a two-year basis. This is the first published IF of the journal.

The citations granted by Revista Ambient. Agua are mostly to journals indexed by ISI WoS and SciELO (Table 2).

Table 2. Report of SciELO on granted citations by Revista Ambient. Agua for articles published in 2013 to journals published in all previous years.

\begin{tabular}{lllc}
\hline \multicolumn{2}{l}{ Cited Journal Title } & Indexation & $\begin{array}{c}\text { Citations of the } \\
\text { Title }\end{array}$ \\
\hline 1. & Water Research & ISI & 29 \\
2. & Chemosphere & ISI, MEDLINE & 24 \\
3. & Revista Brasileira de Engenharia & SciELO & 23 \\
4. & Quicola e Ambiental & SciELO, ISI & 21 \\
5. & Desalination & ISI & 16 \\
6. & Journal of Hazardous Materials & ISI, MEDLINE & 15 \\
7. & Journal of Hydrology & ISI & 15 \\
8. & Water Science and Technology & ISI, MEDLINE & 15 \\
9. & Revista Ambiente \& Agua & SciELO & 14 \\
10. & Revista Brasileira de Ciencia do & SciELO & 14 \\
\hline & Oolo & & $\mathbf{7 6 2}$ \\
\hline
\end{tabular}

Source: adapted from SciELO metrics at:

http://statbiblio.scielo.org//stat_biblio/index.php?state=12\&lang=en\&country=scl\&ng=b\&issn= 1980-993X\&CITING\%5B\%5D=1980-

993X\&YNG\%5B\%5D=2013\&YED\%5B\%5D=all\&COUNT_SCI\%5B\%5D=10

Table 3 shows the journals that cited articles published by Revista Ambient. Agua. The "Revista Brasileira de Engenharia Agricola e Ambiental" and the "Engenharia Agricola" journals were the journals most frequently citing our journal, excluding self-citations, followed by the Brazilian Archives of Biology and Technology. This fact to some extent indicates the journal's focus towards Environment, Engineering and Biology.

Upon reviewing these figures, it may appear that the journal may still have a long way to go in terms of international recognition; but our goals are clearly defined and will ensure that the journal achieves a prominent place in the international scientific forum. Since January 2014, the SciELO Citation Index (SciELO CI) has been integrated with the Web of Science (WoS) platform. This will certainly increase the international visibility of the SciELO collection, as it will share all functions and resources available in the WoS. More information about the SciELO CI can be found in the SciELO Citation Index in the Web of Science (Parker, 2014). 
Table 3. Citations received by articles published in Revista Ambient. Agua from 2007 to 2013 from all journals.

\begin{tabular}{clc}
\hline & Journal that cited Revista Ambient. Agua & $\begin{array}{c}\text { n. of } \\
\text { Citations }\end{array}$ \\
\hline 1 & Acta Botanica Brasilica & 1 \\
2 & Acta Limnologica Brasiliensia & 2 \\
3 & Arquivo Brasileiro de Medicina Veterinaria e & 1 \\
4 & Zootecnia & 1 \\
5 & Biota Neotropica & 1 \\
6 & Bragantia & 6 \\
7 & Brazilian Journal of Chemical Engineering & 3 \\
8 & Cerne & 1 \\
9 & Ciencia e Agrotecnologia & 2 \\
10 & Ecletica Quimica & 2 \\
11 & Engenharia Agricola & 13 \\
12 & Engenharia Sanitaria e Ambiental & 3 \\
13 & Idesia (Arica) & 1 \\
14 & Journal of The Brazilian Society of Mechanical & 1 \\
15 & Sciences and Engineering & 1 \\
16 & Pesquisa Agropecuaria Brasileira & 1 \\
17 & Planta Daninha & 1 \\
18 & Quimica Nova & 2 \\
19 & Revista Ambiente \& Agua & 48 \\
20 & Revista Brasileira de Ciencia do Solo & 1 \\
21 & Revista Brasileira de Engenharia Agricola e Ambiental & 1 \\
22 & Revista Brasileira de Saude e Producao Animal & 1 \\
23 & Revista Ciencia Agronomica & 1 \\
24 & Revista da Sociedade Brasileira de Medicina Tropical & 1 \\
\hline
\end{tabular}

Source:

http://statbiblio.scielo.org//stat_biblio/index.php?no=09.xml\&state=09\&lang=en\&issn=1980-993X.

For 2015, SciELO Brasil has established new criteria for indexations, emphasizing actions of professionalization, internationalization and funding sustainability of journals. These actions will certainly improve the performance of the journals in the collection (Parker, 2014). A detailed description of the new SciELO criteria can be found in SciELO (2014).

Statistics of the journal from the OJS system used to manage the editorial process indicate that the number of submissions is increasing (Figure 1) and that the number of articles published each year has stabilized at 60 . The rejection rate is therefore increasing (Figure 2), allowing a better selection of manuscripts to be published.

In addition to the two major servers (http://www.ambi-agua.net and http://www.scielo.br/ambiagua), several other sites host our articles, with special emphasis on 
http://www.redalyc.org/revista.oa?id=928. However, we do not currently have access to the metrics of these sites.

One interesting feature of Ambiente \& Agua journal is the short time required to process a submission while still maintaining the quality of peer review. As shown in Figure 3, this time is short compared with most other Brazilian journals of similar thematic scope. These times are averages; and can be found on the first page of all published articles, the date of submission and the date of acceptance. This can sometimes be as short as one month. This figure shows that publication time follows closely the evaluation time. In fact, the correlation between the time of evaluation and the time to publication is very high, with $\mathrm{R}^{2}=0.91$ (Figure 4). Therefore, it is clear that the peer reviewers are doing a thorough and prompt analysis. As in every final yearly issue, we include a list of the peer reviewers that evaluated manuscripts for that particular year. In 2014, as of the time of this writing, a total of 200 reviewers had evaluated at least one manuscript. Some had evaluated several submissions. Of these 200 reviewers, 142 have joined the journal this year, demonstrating the journal's increasing momentum and acceptance. We are greatly indebted to them for their voluntary service and for their excellent, insightful and professional product.

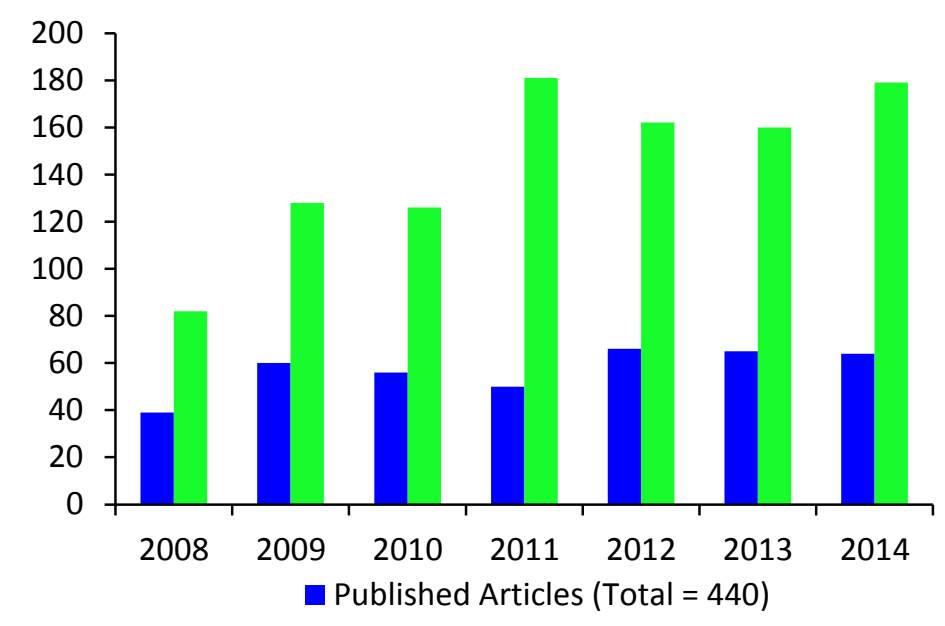

Figure 1. Number of submitted manuscripts and published articles from 2008 to September 2014.

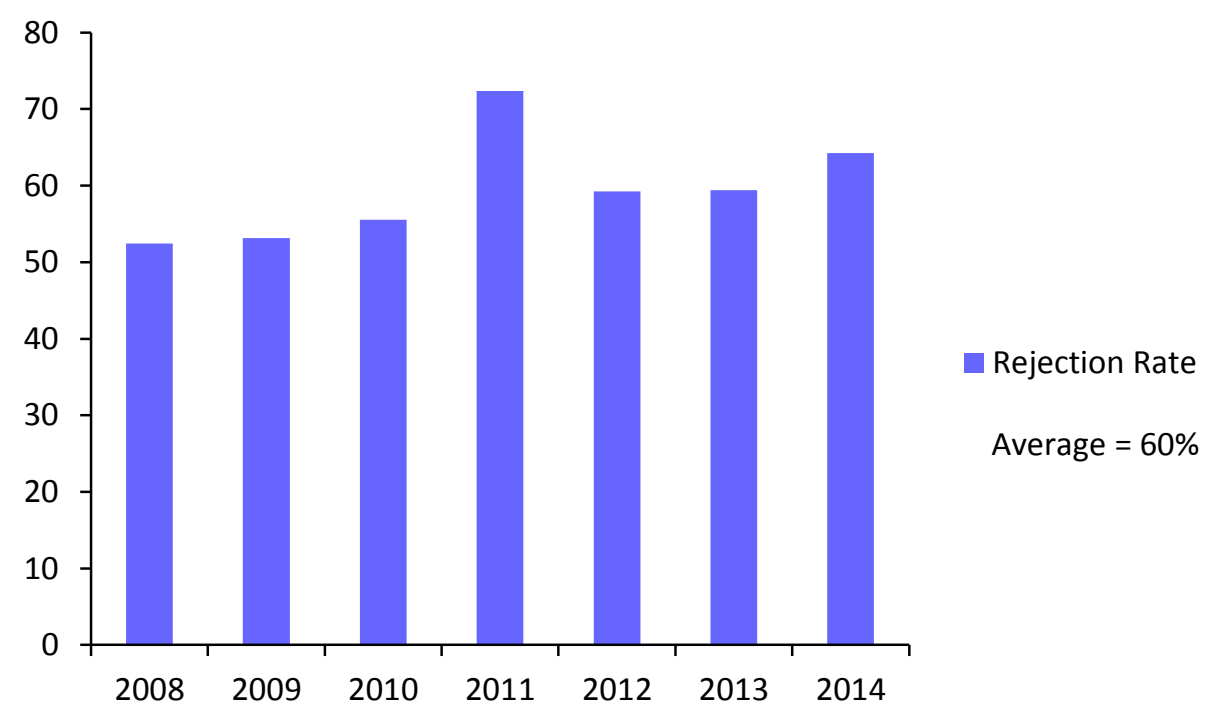

Figure 2. Rejection rate of submissions from 2008 to September 2014. 


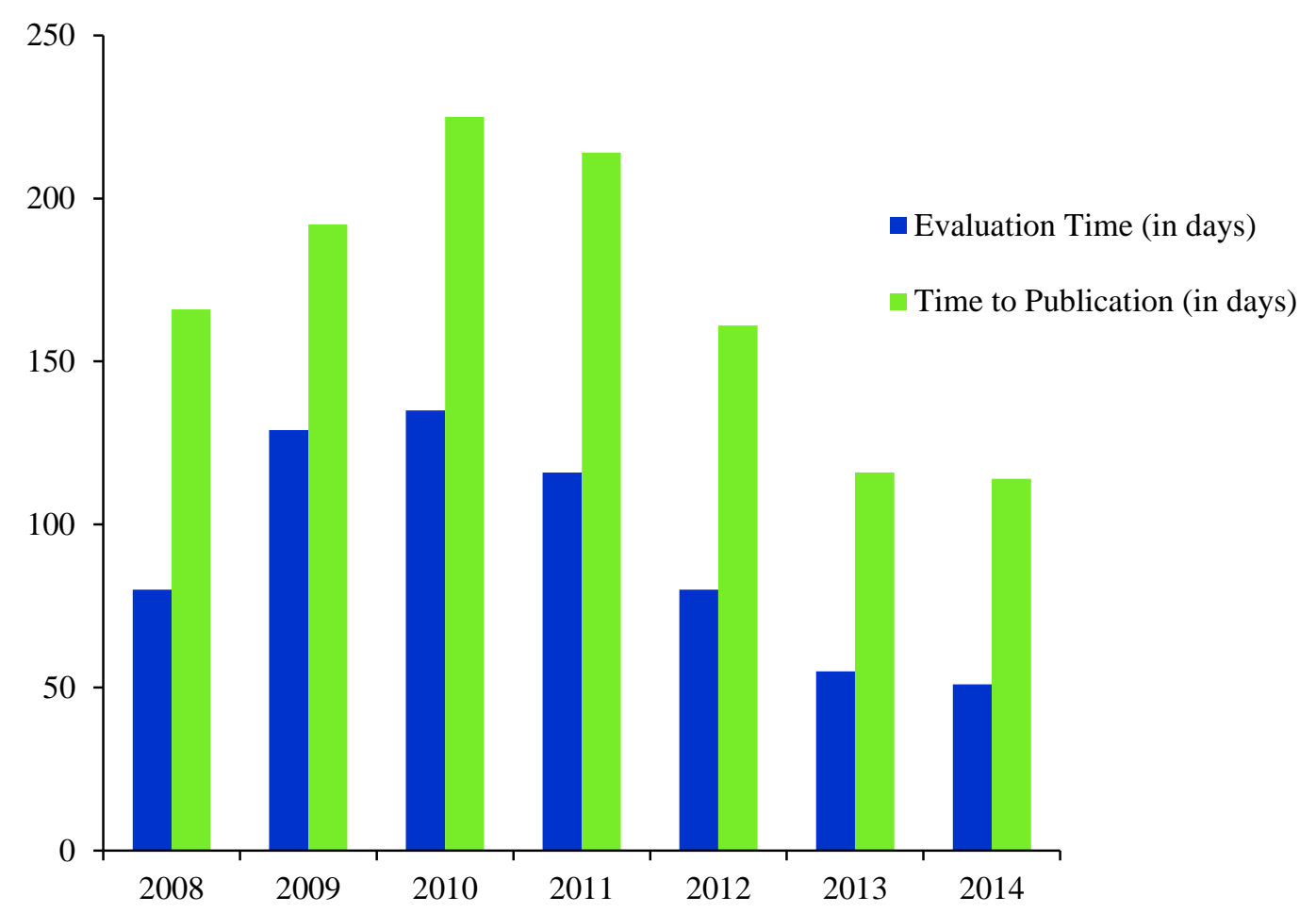

Figure 3. Average times for manuscript evaluation and for submission to publication of articles processed from 2008 to September 2014.

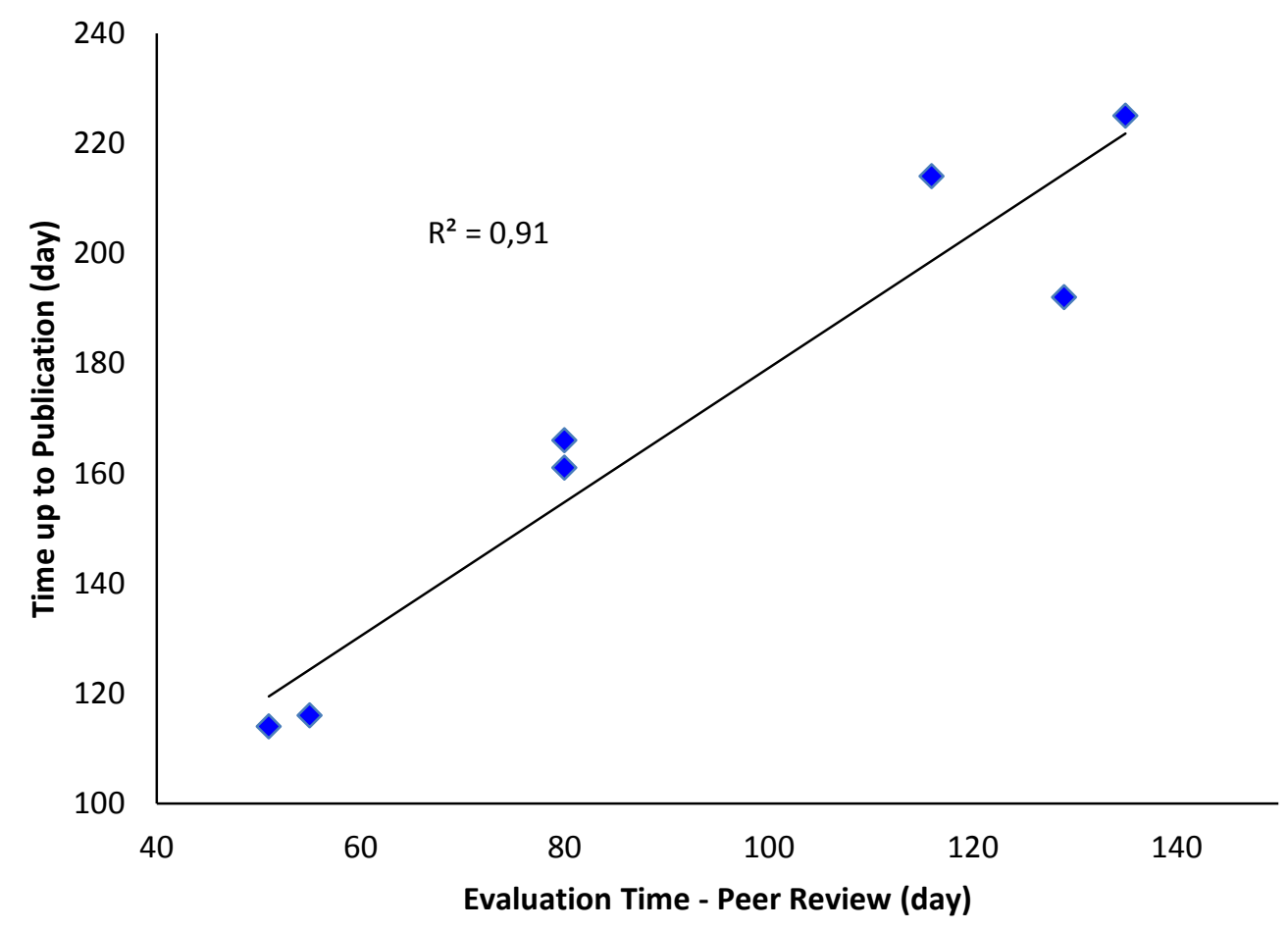

Figure 4. Relationship between evaluation time and time to publication for submissions from 2008 to September 2014.

Another interesting aspect of our journal is the low rate of endogeny, as shown in Figure 5. With an overall endogeny lower than $6 \%$, we opened the journal to the worldwide scientific community in the interdisciplinary area of environment and water resources. In fact, 
the journal draws authors from a large geographical area and a diverse institutional background both nationally and internationally.

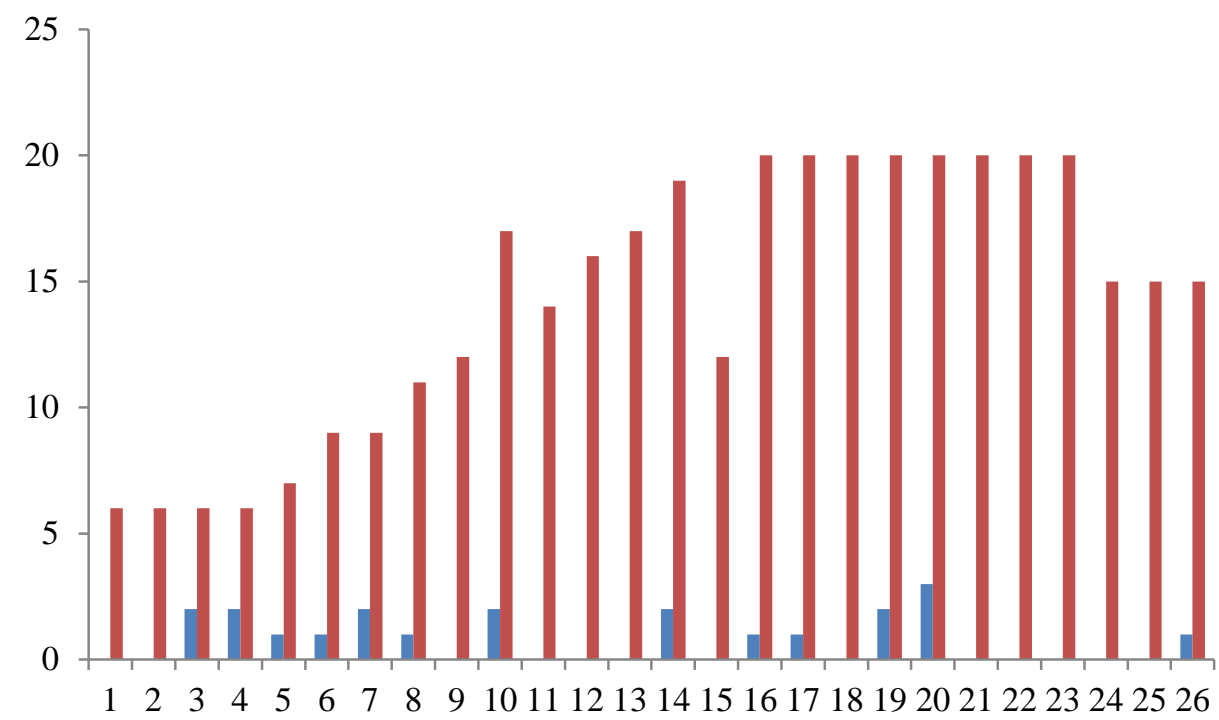

Figure 5. Endogeny analysis of Ambiente \& Agua journal considering the number of articles with first author from the University of Taubaté (in blue) and the total number of published articles (in red). Overall endogeny is 5.6\% (372 published articles analyzed).

\section{CONCLUSIONS}

Ambiente \& Agua journal has come a long way in just eight years of continued publication, as the number of collections in which the journal is indexed clearly establishes, especially the SCOPUS and SciELO. It is also significant that the MCTI / CNPq / MEC / CAPES call for bid proposals N. 44/2013 selected the journal in the top one third among the proposals it granted. This was quite rewarding, considering the call's objective of encouraging the publication of Brazilian scientific journals of high specialization in all areas of knowledge in order to contribute significantly to scientific and technological development and innovation in the country. Our Editorial Committee has recently welcomed new members from several different countries, further increasing the internationalization of the journal. However, several challenges lie ahead as we work to implement the new SciELO Brasil criteria, and to further professionalize and internationalize the journal and to ensure its financial sustainability. The first Impact Factor of the journal is 0.1532 on a two-year basis. While this is a point to be improved upon, we remain confident that we will not only meet, but exceed our goals, thanks largely to the quality and impact of individual articles.

\section{REFERENCES}

PARKER, A. L. SciELO Citation Index no Web of Science. SciELO em Perspectiva, 28 Feb. 2014a. Available from: http://blog.scielo.org/blog/2014/02/28/scielo-citationindex-no-web-of-science/. Access in: 13 Oct. 2014.

PARKER, A. L. Reunião anual do SciELO sinaliza nova etapa do programa. SciELO em Perspectiva, 03 Oct. 2014b. Available from: http://blog.scielo.org/blog/2014/10/03/ reuniao-anual-do-scielo-sinaliza-nova-etapa-do-programa/. Access in: 13 Oct. 2014. 
SCIENTIFIC ELETRONIC LIBRARY ONLINE - SciELO. Critérios, política e procedimentos para a admissão e a permanência de periódicos científicos na Coleção SciELO Brasil. São Paulo, 2014. Available from: http://www.scielo.br/ avaliacao/Criterios-SciELO-Brasil-20141003.pdf. Access in: 13 Oct. 2014. 


Ambiente \& Água - An Interdisciplinary Journal of Applied Science
ISSN 1980-993X - doi:10.4136/1980-993X
www.ambi-agua.net
E-mail: ambi-agua@agro.unitau.br

\title{
Kinetic parameters of biomass growth in a UASB reactor treating wastewater from coffee wet processing (WCWP)
}

\author{
doi: 10.4136/ambi-agua.1280
}

Received: 16 Jan. 2014; Accepted: 15 Sep. 2014

\author{
Claudio Milton Montenegro Campos ${ }^{1}$; Marco Antonio Calil Prado ${ }^{1}$; \\ Erlon Lopes Pereira ${ }^{2 *}$ \\ ${ }^{1}$ Universidade Federal de Lavras (UFLA), Lavras, MG, Brasil \\ ${ }^{2}$ Universidade de São Paulo (USP), Lorena, SP, Brasil \\ *Corresponding Author: e-mail: erlonlopes@gmail.com, \\ cmmcampos@gmail.com, calilprado@posgrad.ufla.br
}

\begin{abstract}
This study evaluated the treatment of wastewater from coffee wet processing (WCWP) in an anaerobic treatment system at a laboratory scale. The system included an acidification/equalization tank (AET), a heat exchanger, an Upflow Anaerobic Sludge Blanket Reactor (UASB), a gas equalization device and a gas meter. The minimum and maximum flow rates and volumetric organic loadings rate (VOLR) were 0.004 to $0.037 \mathrm{~m}^{3} \mathrm{~d}^{-1}$ and 0.14 to $20.29 \mathrm{kgCOD} \mathrm{m}^{-3} \mathrm{~d}^{-1}$, respectively. The kinetic parameters measured during the anaerobic biodegradation of the WCWP, with a minimal concentration of phenolic compounds of $50 \mathrm{mg} \mathrm{L}{ }^{-1}$, were: $\mathrm{Y}=0.37$ mgTVS (mgCOD removed $^{-1}, \mathrm{~K}_{\mathrm{d}}=0.0075 \mathrm{~d}^{-1}, \mathrm{Ks}=1.504 \mathrm{mg} \mathrm{L}^{-1}$, $\mu_{\max }=0.2 \mathrm{~d}^{-1}$. The profile of sludge in the reactor showed total solids (TS) values from 22,296 to $55,895 \mathrm{mg} \mathrm{L}^{-1}$ and TVS 11,853 to $41,509 \mathrm{mg} \mathrm{L}^{-1}$, demonstrating a gradual increase of biomass in the reactor during the treatment, even in the presence of phenolic compounds in the concentration already mentioned.
\end{abstract}

Keywords: agro-industrial waste, bacterial kinetics, pollution control, rural sanitation.

\section{Parâmetros cinéticos de crescimento da biomassa em reator UASB tratando água residuária do café (ARC) processado por via úmida}

\section{RESUMO}

O presente estudo avaliou o tratamento das águas residuárias do processamento por via úmida do café (ARC) em sistema de tratamento anaeróbio em escala de laboratório. O sistema utilizado foi composto de um tanque de acidificação e equalização (TAE), um trocador de calor, um reator anaeróbio de manta de lodo e fluxo ascendente (UASB), um equalizador de pressão e um gasômetro. Os valores de vazão mínimos e máximos foram: 0,004 a $0,037 \mathrm{~m}^{3} \mathrm{~d}^{-1}$ e os valores da carga orgânica volumétrica (COV) foram 0,14 a 20,29 kgCOD m${ }^{-3} \mathrm{~d}^{-1}$, respectivamente. Os parâmetros cinéticos encontrados durante a biodegradação anaeróbia da ARC com concentração mínima de compostos fenólicos de $50 \mathrm{mg} \mathrm{L}^{-1}$, foram: $\mathrm{Y}=0,37 \mathrm{mgSTV}$ (mgCODremoved) ${ }^{-1} ; \mathrm{K}_{\mathrm{d}}=0,0075 \mathrm{~d}^{-1} ; \mathrm{Ks}=1.504 \mathrm{mg} \mathrm{L}^{-1} \mathrm{e}$ $\mu_{\max }=0,2 \mathrm{~d}^{-1}$. O perfil de lodo no reator apresentou valores ST de 22.296 a $55.895 \mathrm{mg} \mathrm{L}^{-1} \mathrm{e}$ 
de STV de 11.853 a $41.509 \mathrm{mg} \mathrm{L}^{-1}$, demonstrando o crescimento gradativo da biomassa no reator durante o tratamento, mesmo na presença de compostos fenólicos na concentração anteriormente mencionada.

Palavras-chave: cinética bacteriana, controle de poluição, resíduo agroindustrial, saneamento rural.

\section{INTRODUCTION}

Coffee is one of the most important products of Brazil because of the enormous income it generates. The quality of the coffee bean determines its value and the resulting market price as well as its acceptance international trade. In turn, this quality is determined by inherent characteristics of the fruit, such as color, appearance, number of defects, aroma and taste (Borém, 2008).

The coffee bean can be processed by dry or humid methodology. The wet processing of the coffee Cherry uses water to wash, separate and remove the rind (exocarp) and mucilage (mesocarp). This increases the amount coffee rind waste as well as the amount of mucilage removed (Borém, 2008). Post-harvest processing of coffee by the wet method generates solid waste and liquid effluents in significant quantities, and with a high potential for pollution. The residual liquid is called "wastewater from wet coffee processing" or "WCWP".

Campos et al. (2010) analyzed several fresh samples of WCWP and characterized their physico-chemical and biochemical composition in terms of their potential as polluters and their environmental quality. The authors showed that the WCWP is rich in sugars, protein, starch, pectin, soluble oils and greases which result in high concentrations of COD, $\mathrm{BOD}_{5}{ }^{20^{\circ} \mathrm{C}}$, solids, nitrogen, total phosphorus and phenolic compounds. The high concentrations found characterized the WCWP as a high-potential polluter liquid that cannot be discharged untreated.

Based upon the result of such analyses and the high potential for pollution, several processes for WCWP treatment have been studied with the purpose of removing organic matter. Jung et al. (2012) and Campos et al. (2013) stated that the liquid has high concentration of carbohydrates and may therefore be used for bio-energy production in an anaerobic process.

Jung et al. (2012) used UASB reactors in two stages to treat WCWP for the production of methane and hydrogen. The first UASB reactor was used for hydrogen production, and was operated in thermophilic condition with hydraulic detention time varying from 6 to 10 hours. The WCWP had a carbohydrate concentration of $20 \mathrm{~g} \mathrm{~L}^{-1}$ and peak productions of hydrogen

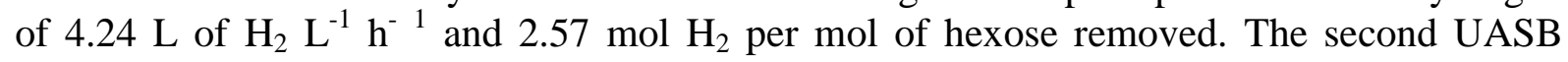
reactor was used to produce methane and operated in mesophilic condition with hydraulic detention times varying from 6 to 10 hours with OLR of 3.5 gCOD L ${ }^{-1} \mathrm{~d}^{-1}$. The first reactor effluent as WCWP obtained a maximum production of methane of $325 \mathrm{mLCH}_{4}$ gCOD removed and 93\% of COD removal. Campos et al. (2013) using a UASB reactor to treat WCWP concluded that the percentage of methane in the biogas ranged from 48.60 to $68.14 \%$, the superior and inferior calorific value was 25,654 $\mathrm{kJ} \mathrm{m}$ and 23,777 $\mathrm{kJ} \mathrm{m}$, respectively, and the Wobbe number was $7,851 \mathrm{kcal} \mathrm{m}^{-3}$, resulting in their interchangeability with natural gas.

Due to the large energy potential of WCWP, many studies have been performed aiming to achieve anaerobic processes that are highly efficient in removing pollutants and synergistically consistent with the production of bio-energy. According to Ramakrishnan and Surampalli (2012) and Fia et al. (2012) the phenolic compounds are inhibitors of concern in the biological process and can negatively intervene in the anaerobic process performance during the treatment of WCWP. In addition, it is necessary to know both the performance of the reactor under various load conditions and the biomass growth kinetic parameters that 
govern the anaerobic process in order to accurately predict the bioenergy production and optimize the process to obtain maximum efficiency conditions.

This work therefore evaluated the performance of a UASB reactor operating under conditions of progressive increase of organic loads during treatment of WCWP and determined the kinetic parameters of anaerobic biomass growth.

\section{MATERIAL AND METHODS}

\subsection{Experimental apparatus}

The experiment was performed at the Laboratory of Water Analysis of the Engineering Department (LWAED), at the Federal University of Lavras (FUL). The system consisted of a acidification and equalization tank (AET), an Upflow Anaerobic Sludge Blanket Reactor (UASB), a gas equalization device (GED), a gas meter (GM), two membrane pumps (PROMINET), and a thermostatic controlled heating system. The AET was a 45 liter polyethylene container which contained a positive displacement pump, Prominent brand, Model Gala 1602 Gamma-LM70, with a maximum pressure 10 bar and maximum flow of $2.1 \mathrm{~L} \mathrm{~h}^{-1}$, used to pump the WCWP to UASB reactor at constant flow. The UASB reactor, the GED and the GM have been constructed with glass $3 \mathrm{~mm}$ thick, with volumes of $12.5 \mathrm{~L}$, 2.6 L, and 16.8 L, respectively. The three-phase separator (TPS) of the UASB reactor was also built of glass and had a pyramidal shape. Pipes in the heating system and in the UASB had a coating of polystyrene thermal insulation. The GED was used for maintaining the level of biogas within the TPS. The heating system worked as a heat exchanger using a coiled copper pipe and had a thermostat for temperature regulation. The WCWP system was fed in batches in the AET and the effluent was subsequently pumped to the UASB reactor. The biogas produced in the UASB reactor passed through the TPS, through the gas equalization device (GED) and then through a gas meter using water-displacement in order to measure and accumulate.

\subsection{Starting up and monitoring the system}

The WCWP used in the experiment was provided by the experimental farm of the agricultural-livestock research company of Minas Gerais (EPAMIG). Due to seasonal production, the WCWP was generated only during 3 months. Since the experiment was conducted over seven months, the WCWP was collected and stored refrigerated in $50 \mathrm{~L}$ containers. Fresh samples were collected and analyzed concerning COD and pH. Due to high concentration of COD, it was necessary to dilute the WCWP to operate the system with the desired loads. Due to the low $\mathrm{pH}$ value, it was necessary to adjust the $\mathrm{pH}$ of WCWP after dilution to achieve the range of neutrality $(6.8 \leq \mathrm{pH} \leq 7.2)$ using sodium hydroxide solution with title $10(10 \% \mathrm{NaOH})$. The WCWP was prepared (diluted and $\mathrm{pH}$ adjusted) and placed in the AET and pumped to the UASB reactor. During the seven months of the experiment the UASB reactor was organicly loaded 6 times; each load represented a period (I to VI) as shown in Table 1.

Each period's changes were made with the progressive increase of the VOLR, and just when the UASB efficiency reached steady-state, in accordance with the concept established by Metcalf and Eddy (2003). The operational parameters such as hydraulic retention time (HRT), volumetric organic loading rate (VOLR), hydraulic loading rate (HLR), and biological organic loading rate (BOLR) were calculated using the equations described in Metcalf and Eddy (2003). The UASB reactor was inoculated with $5.19 \mathrm{~L}$ of biomass from the anaerobic treatment of wastewater from pig farming with an STV concentration of $12,774 \mathrm{mg} \mathrm{L}^{-1}$, totaling $0.6 \mathrm{~kg}$ of biomass inside the reactor which provided a BOLR for start-up of about $0.02 \mathrm{~kg}$ BOD $\mathrm{kgSTV}^{-1} \mathrm{~d}^{-1}$. Throughout each period, the WCWP in natura and WCWP 
prepared were analyzed according to the procedures outlined in Table 2. Physical-chemical analyses were performed at three points of the system: influent of the AET (I-AET), effluent of the AET (E-AET), which represents the influent do UASB (I-UASB) and the effluent of the UASB (E-UASB). The analysis, methodologies and their frequencies are shown in Table 2.

Table 1. Volumetric organic loading rates and operating conditions in the UASB for each studied period.

\begin{tabular}{|c|c|c|c|c|c|c|}
\hline Period & $\begin{array}{l}\text { pH in natura } \\
\text { WCWP }\end{array}$ & $\begin{array}{l}\text { COD of WCWP in } \\
\text { natura }\left(\mathrm{mgO}_{2} \mathrm{~L}^{-1}\right)\end{array}$ & $\begin{array}{c}\text { pH of } \\
\text { WCWP } \\
\text { prepared }\end{array}$ & $\begin{array}{c}\text { COD of WCWP } \\
\text { prepared } \\
\left(\mathrm{mgO}_{2} \mathbf{L}^{-1}\right)\end{array}$ & $\mathbf{Q}\left(\mathbf{L} \mathbf{d}^{-1}\right)$ & $\begin{array}{c}\text { VOLR } \\
\left(\operatorname{kgCOD~m}^{-3} \mathrm{~d}^{-1}\right)\end{array}$ \\
\hline I & 4.70 & 64467 & 7.09 & 658.3 & 4.872 & 0.26 \\
\hline II & 4.08 & 15867 & 6.99 & 1077.0 & 9.912 & 0.81 \\
\hline III & 4.36 & 14667 & 7.11 & 1901.4 & 9.816 & 1.50 \\
\hline IV & 4.43 & 11767 & 6.87 & 2353.3 & 14.520 & 2.80 \\
\hline V & 5.17 & 19594 & 7.02 & 2689.7 & 19.872 & 4.20 \\
\hline VI & 4.67 & 20367 & 6.80 & 5624.8 & 31.008 & 15.26 \\
\hline
\end{tabular}

Obs.: COD of WCWP: fresh COD in natura WCWP total collected after processing the coffee EPAMIG. COD of WCWP prepared: COD total obtained after dilution of WCWP in natura and neutralization. Q: flow applied to the ballast UASB in each period. VOLR: volumetric organic load applied to the UASB reactor in each period using the WCWP prepared.

Table 2. Parameters analyzed in the WCWP, frequency and methodologies used.

\begin{tabular}{lll}
\hline \multicolumn{1}{c}{ Physical-chemical parameters } & Frequency & \multicolumn{1}{c}{ References } \\
\hline $\mathrm{pH}$ & daily & APHA et al. (2005) \\
Total Alkalinity (TA), Partial (PA) and Intermediate (IA) & 3 x week & Ripley et al. (1986) \\
Total chemical oxygen demand (COD) & 3 x week & APHA et al. (2005) \\
Total biochemical oxygen demand (BOD ${ }^{2{ }^{\circ} \mathrm{C}}$ ) & weekly & APHA et al. (2005). Wincley \\
& & Methodology \\
Total solids (TS) and volatile solids (TVS) & 3 x week & APHA et al. (2005) \\
$\begin{array}{l}\text { Total Kjeldahl nitrogen (TKN) } \\
\text { Total phosphorus (P) }\end{array}$ & 2 x month & APHA et al. (2005) \\
Total acidity (T Ac) & 2 x month & APHA et al. (2005) \\
$\begin{array}{l}\text { Electrical conductivity (EC), total dissolved solids (TDS) e } \\
\text { salinity (SA) }\end{array}$ & 3 x week & APHA et al. (2005) \\
Phenolic compounds (PC) & & Electrical conductivity meter \\
Temperature ( $\mathrm{T}^{\circ} \mathrm{C}$ ) & 2 x month & $\begin{array}{l}\text { Spectrophotometer; Institute } \\
\text { Adolfo Lutz (1985) }\end{array}$ \\
\hline
\end{tabular}

The kinetic parameters of biomass growth as: $\mathrm{Y}$ (coefficient of biomass production in terms of mg TVS mgCOD removed $^{-1}$ ), Ks (saturation constant in terms of COD in mg $\mathrm{L}^{-1}$ ), $\mathrm{K}_{\mathrm{d}}$ (endogenous respiration coefficient in terms of $\mathrm{d}^{-1}$ ), $\mu_{\max }$ (maximum specific growth rate in terms of $\mathrm{d}^{-1}$ ); $\theta \mathrm{c}$ (cell retention time or age of biomass in terms of days) and $\mathrm{k}$ (specific rate of substrate utilization by biomass in terms of mg COD removed $\operatorname{mgTVS}^{-1} \mathrm{~d}^{-1}$ ), were determined according to the calculation described in Bhunia and Ghangrekar (2008), and Pereira (2014). 


\section{RESULTS AND DISCUSSION}

\subsection{Initial characterization of the WCWP in natura}

Table 3 presents the physico-chemical properties of coarse WCWP. Very high concentrations of phenolic compounds reaching up to $1,284 \mathrm{mg} \mathrm{L}^{-1}$ may be observed. In order to evaluate the susceptibility of the WCWP to biological treatment, biodegradability tests were performed using the values of $\mathrm{COD}$ and $\mathrm{BOD}_{5}{ }^{2{ }^{\circ} \mathrm{C}}$ presented. The relationship $\mathrm{COD} / \mathrm{BOD}_{5}{ }^{2{ }^{\circ} \mathrm{C}}$ provides information on the biodegradability of the dump and the treatment process to be employed. Low relations indicate that the biodegradable fraction is high and that biological treatment is most appropriate. High ratios show that the inert fraction (non-biodegradable) is high and that chemical treatment is indicated. Campos et al. (2002), treating wastewater of cherry coffee in a identical system, found an average ratio of 2.1 COD/BOD ${ }_{5}{ }^{20} \mathrm{C}$ observing good biodegradability. The average ratio found for the WCWP in this work was nearly the same, about 1.82, which is considered low, indicating that the biodegradable fraction of WCWP is high and that biological treatment was more appropriate.

Table 3. Characterization of 6 batches of coarse WCWP collected at WCWP EPAMIG.

\begin{tabular}{|c|c|c|c|c|c|c|c|}
\hline WCWP & $\mathbf{p H}$ & $\operatorname{EC}\left(\mathrm{dS} \mathrm{m}^{-1}\right)$ & $\begin{array}{l}\text { SA } \\
(\%)\end{array}$ & $\underset{\left(\mathbf{m g O}_{2} \mathbf{L}^{-1}\right)}{\operatorname{COD}}$ & $\begin{array}{c}\mathrm{BOD}_{5}{ }^{20^{\circ} \mathrm{C}} \\
\left(\mathrm{mgO}_{2} \mathbf{L}^{-1}\right)\end{array}$ & $\mathrm{T}\left({ }^{\circ} \mathrm{C}\right)$ & $\begin{array}{l}\text { Phenolic compounds } \\
\qquad\left(\mathrm{mg} \mathrm{L}^{-1}\right)\end{array}$ \\
\hline WCWP 1 & 4.70 & 5.7 & 3.1 & 64,467 & 37,600 & 25.2 & ----- \\
\hline WCWP 2 & 4.08 & 6.2 & 3.3 & 15,867 & 9,800 & 27.5 & 1284 \\
\hline WCWP 3 & 4.36 & 3.9 & 2.0 & 14,667 & 9,200 & 30.7 & 693 \\
\hline WCWP 4 & 4.43 & 3.6 & 1.8 & 11,767 & 8,489 & 28.4 & 519 \\
\hline WCWP 5 & 5.17 & 5.5 & 2.9 & 19,594 & 7,616 & 20.1 & 1063 \\
\hline WCWP 6 & 4.67 & 5.3 & 2.8 & 20,367 & 9,950 & 24.8 & 1212 \\
\hline
\end{tabular}

\subsection{Performance of UASB reactor in treatment of WCWP}

The Table 4 shows the concentrations of phenolic compounds after each treatment.

Table 4. Concentration of phenolic compounds throughout the system, operational parameters submitted to UASB reactor and removal efficiency of phenolic compounds in the liquid medium in each period.

Concentration of phenolic compounds in the liquid throughout the system $\left(\mathrm{mg} \mathrm{L}^{-1}\right)$

\begin{tabular}{|c|c|c|c|c|c|c|}
\hline \multicolumn{4}{|c|}{ 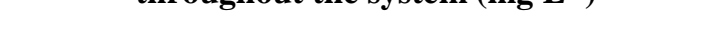 } & \multicolumn{3}{|c|}{ reactor } \\
\hline Period & I-AET & I-UASB & E-UASB & HRT (h) & 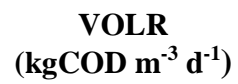 & Removal (\%) \\
\hline I & 44.42 & 50.54 & 24.60 & 62.2 & 0.26 & 51.32 \\
\hline II & 69.40 & 81.41 & 33.94 & 30.5 & 0.81 & 58.31 \\
\hline III & 106.89 & 73.74 & 50.42 & 30.7 & 1.50 & 31.62 \\
\hline IV & 150.05 & 84.55 & 77.37 & 20.9 & 2.80 & 8.50 \\
\hline $\mathrm{V}$ & 114.18 & 158.86 & 104.56 & 15.2 & 4.20 & 34.18 \\
\hline VI & 348.74 & 381.80 & 128.84 & 9.9 & 15.26 & 66.25 \\
\hline
\end{tabular}
compounds from liquid medium in the UASB reactor

Operational parameters and removal of phenolic 
Analyzing the influent concentrations of the AET, it is observed that the increase of COD concentration also increased the VOLR synergistically and caused a progressive concentration of phenolic compounds applied to the UASB reactor. This demonstrates that the UASB reactor operated with organic load shocks in terms of COD and phenolic compounds (Table 4). The same table shows the concentrations of phenolic compounds of WCWP prepared throughout the treatment system decreasing in all periods studied, indicating the removal of phenolic compounds from liquid medium.

Ramakrishnan and Surampalli (2012) studied the removal of phenolic compounds in UASB reactors and Anaerobic Hybrid Reactors (AHR) operating under conditions of organic shocks. The authors observed that the progressive increase of VOLR of 1.02 to $1.58 \mathrm{gCOD} \mathrm{m}^{-3} \mathrm{~d}^{-1}$ synergistically with reducing the HRT from $1.5 \mathrm{~d}$ to $0,33 \mathrm{~d}$, provoked a drop in efficiency of removal of phenolic compounds from $99 \%$ to $77 \%$ in the AHR and from $95 \%$ to $68 \%$ in the UASB reactor, respectively. The authors concluded that the AHR performed better than the UASB reactor due to the presence of plastic brackets in its interior, which prevented the sweep of the biomass. However, the decrease in HRT negatively affected the efficiency of the process in terms of the removal of phenolic compounds due to the toxic effect.

Table 4 shows that the same phenomenon was observed in the UASB reactor, because the decrease in HRT from 62,2 h to $15.2 \mathrm{~h}$ caused a drop in efficiency of removal of phenolic compounds of $51.32 \%$ to $34.18 \%$, a phenomenon similar to that observed by Ramakrishnan and Surampalli (2012). However, while decreasing the HRT from $15.2 \mathrm{~h}$ to $9.9 \mathrm{~h}$, an increase in the efficiency of phenolic compounds removal from $34.18 \%$ to $66.25 \%$ occurred, indicating a probable adaptation of biomass to the inhibitor compound, decreasing the toxic effect on it, as described by Zeeuw (1984), Speece (1996) and Chen et al. (2008).

According to Chen et al. (2008) other factors besides the phenolic compounds may interfere in the inhibition of the anaerobic process, such as COD: $\mathrm{N}: \mathrm{P}, \mathrm{pH}$, temperature and buffering conditions. Based on the factors mentioned, it was possible to control the $\mathrm{pH}$ value (Table 1) and influent temperature of UASB. These were, respectively, kept within the range of neutrality (6.8-7.2) and within the range mesophilic temperature (approx. $30^{\circ} \mathrm{C}$ ) using thermostatic control heating. However, due to dilution of WCWP in natura for preparation of the influent of the UASB reactor, it has not been possible to maintain a constant relationship of COD: N: P; this varied throughout the experiment. The ratio of COD: N: P related to each period can be seen in Table 5 .

Table 5. The values for COD: N: $\mathrm{P}$ in UASB reactor in each studied period.

\begin{tabular}{cc}
\hline Period & COD:N:P \\
\hline I & $17: 0.68: 1$ \\
II & $8: 0.25: 1$ \\
III & $15: 0.12: 1$ \\
IV & $12: 0.10: 1$ \\
V & $11: 0.08: 1$ \\
VI & $35: 0.09: 1$ \\
\hline
\end{tabular}

According to Chernicharo (2007), the ideal ratio for COD: N: P in the degradation of carbohydrates is 350:5:1. Low values for COD and nitrogen in the relationship will cause 
variations in methane production in the process. According to Pereira et al. (2010), when the concentration of carbon is higher than nitrogen, the nitrogen compounds are used first and anaerobic digestion slows. If the carbon concentration is lower than nitrogen, carbon is totally consumed and digestion ceases.

In Table 6 presents the values of concentrations of organic matter in terms of solids (TS and TVS), $\mathrm{COD}_{\mathrm{T}}$ and $\mathrm{BOD}_{5}{ }^{20^{\circ} \mathrm{C}}$ throughout the treatment system for each studied period and the values of UASB reactor efficiency for both parameters, in each period.

Table 6. Concentration of organic matter in terms of solids, $\mathrm{COD}_{\mathrm{T}}$ e $\mathrm{BOD}_{5}{ }^{20^{\circ} \mathrm{C}} \mathrm{T}$ in the WCWP throughout the system and removal efficiency in the UASB reactor for each period.

\begin{tabular}{|c|c|c|c|c|c|c|c|c|}
\hline \multirow{2}{*}{ Period } & \multicolumn{2}{|c|}{ I-EAT $\left(\mathrm{mg} \mathrm{L}^{-1}\right)$} & \multicolumn{2}{|c|}{ I-UASB $\left(\mathrm{mg} \mathrm{L}^{-1}\right)$} & \multicolumn{2}{|c|}{ E-UASB $\left(m g ~^{-1}\right)$} & \multicolumn{2}{|c|}{ Removal efficiency } \\
\hline & TS & TVS & TS & TVS & TS & TVS & TS $(\%)$ & TVS (\%) \\
\hline I & 1217.31 & 767.66 & 1041.87 & 610.81 & 753.82 & 319.72 & 27.65 & 47.66 \\
\hline II & 2285.33 & 1506.67 & 1805.00 & 1113.18 & 967.01 & 385.53 & 46.43 & 65.37 \\
\hline III & 3634.62 & 2512.08 & 3240.57 & 1537.83 & 2147.64 & 917.26 & 33.73 & 40.35 \\
\hline IV & 3837.93 & 2896.69 & 2519.68 & 1669.17 & 1408.57 & 730.45 & 44.10 & 56.24 \\
\hline V & 5295.83 & 4155.83 & 7582.50 & 6158.33 & 1998.33 & 966.67 & 73.65 & 84.30 \\
\hline VI & 5822.2 & 4087.41 & 9357.41 & 6918.52 & 3517.22 & 1622.04 & 62.41 & 76.56 \\
\hline \multirow{2}{*}{ Period } & \multicolumn{3}{|c|}{$\begin{array}{c}\text { Concentration of } \mathrm{BOD}_{5}{ }^{20^{\circ} \mathrm{C}} \mathrm{T} \\
\left(\mathrm{mgO}_{2} \mathbf{L}^{-1}\right)\end{array}$} & \multicolumn{3}{|c|}{$\begin{array}{c}\text { Concentration of } \mathrm{COD}_{\mathrm{T}} \\
\left(\mathrm{mgO}_{2} \mathbf{L}^{-1}\right)\end{array}$} & \multicolumn{2}{|c|}{ Removal efficiency } \\
\hline & I-EAT & I-UASB & E-UASB & I-AET & I-UASB & E-UASB & $\mathrm{BOD}_{5}{ }^{20^{\circ} \mathrm{C}}(\%)$ & $\operatorname{COD}(\%)$ \\
\hline I & 405.3 & 379.3 & 52.8 & 727.0 & 658.3 & 173.1 & 86.1 & 73.7 \\
\hline II & 1049.0 & 611.7 & 164. 3 & 1469.3 & 1077.0 & 194.4 & 73.1 & 81.9 \\
\hline III & 1341.0 & 1162.5 & 263.4 & 2696.7 & 1901.4 & 545.3 & 77.3 & 71.3 \\
\hline IV & 1884.0 & 1399. 9 & 239. 9 & 3493.9 & 2353.3 & 557.4 & 82.9 & 76.3 \\
\hline V & 1800.3 & 1524.8 & 378. 5 & 3630.1 & 2689.7 & 654.7 & 75.2 & 75.7 \\
\hline VI & 3414.7 & 3689. 7 & 1004.8 & 5918.8 & 5624.8 & 1420.5 & 72.8 & 74.7 \\
\hline
\end{tabular}

Selvamurugan et al. (2010) evaluated an anaerobic hybrid reactor (AHR) in the treatment of WCWP with the aim of removing organic matter in terms of solids, $\mathrm{COD}_{\mathrm{T}}$ and $\mathrm{BOD}_{5}{ }^{20^{\circ} \mathrm{C}}$. The reactor operated under a progressive increase of VOLR and decreasing HDT as performed in this study. The authors submitted the AHR to HRT values of 24, 18, 12 and $6 \mathrm{~h}$ with VOLR of 7.01; 9.55; 14.23 and $28.41 \mathrm{~kg} \mathrm{COD}_{\mathrm{T}} \mathrm{m}^{-3} \mathrm{~d}^{-1}$ obtaining for each condition the removal of $70 \%, 61 \%, 52 \%$ and $46 \%$ in terms of $\mathrm{COD}_{\mathrm{T}} ; 71 \%, 66 \%, 59 \%$ and $54 \%$ in terms of $\mathrm{BOD}_{5}{ }^{20^{\circ} \mathrm{C}}$ and $64 \%, 58 \%, 49 \%$ and $42 \%$ in terms of TS, respectively.

Fia et al. (2012) described the removal of organic matter of WCWP in three fixed bed reactors filled with different media and operated under progressive increase of organic load. Reactor 1 was filled with slag of blast furnace cinders and operated with values of HRT 1.19; 1.54; $1.54 \mathrm{~d}$, and VOLR values of $0.81 ; 1.57 ; 3.17 \mathrm{~kg} \mathrm{COD} \mathrm{m}^{-3} \mathrm{~d}^{-1}$, respectively. The response for each operating condition was $47 \%, 61 \%$ and $64 \%$ for COD removal efficiency and $20 \%$, $49 \%$ and $47 \%$ for removal efficiency of TVS, respectively. Reactor 2 was filled with polyurethane foam and operated with values of TDH: 1.07; 1.03; 1.06 days, and VOLR values of $0.98 ; 2.4 ; 4.41 \mathrm{kgCOD}_{\mathrm{T}} \mathrm{m}^{-3} \mathrm{~d}^{-1}$, respectively. The response for each operating condition 
was $58 \%, 73 \%$ and $80 \%$ for COD removal efficiency and 24,57 and $60 \%$ for removal efficiency of TVS, respectively. Reactor 3 was filled with gravel (crushed stone) and operated with values of HRT 1.26; 1.58; 1.51 days, and VOLR values of $0.81 ; 1.67$; $3.35 \mathrm{kgCOD}_{\mathrm{T}} \mathrm{m}^{-3} \mathrm{~d}^{-1}$, respectively. The response for each operating condition was 42, 54 and $72 \%$ for efficiency of COD removal and 26, 46 and 55\% for removal efficiency of TVS, respectively.

Tables 7, 8 and 9 present the values of $\mathrm{pH}$, relative to Ripley (IA/PA) and concentrations of total acidity (TVA), total alkalinity (TA), partial alkalinity (PA), intermediate-alkalinity (IA), total phosphorus (TP) and total nitrogen Kjeldahl (TKN).

Table 7. Characterization of the AET influent.

\begin{tabular}{|c|c|c|c|c|c|c|c|c|}
\hline \multicolumn{9}{|c|}{ Parameters } \\
\hline Period & pH & TVA & PA & IA & $\mathbf{T A}$ & IA/PA & $\mathbf{T P}$ & TKN \\
\hline I & 7.09 & 48.31 & 146.61 & 194.65 & 341.26 & 1.8 & 66.33 & 30.43 \\
\hline II & 6.99 & 61.43 & 96.03 & 231.01 & 327.04 & 2.5 & 198.17 & 24.66 \\
\hline III & 7.11 & 105.95 & 227.86 & 549.25 & 777.11 & 2.9 & 427.67 & 12.23 \\
\hline IV & 6.87 & 155.69 & 312.08 & 501.54 & 813.62 & 1.7 & 722.17 & 21.13 \\
\hline $\mathbf{V}$ & 7.02 & 137.45 & 227.59 & 603.23 & 830.82 & 2.8 & 116.5 & 18.41 \\
\hline VI & 6.73 & 192.19 & 283.39 & 794.33 & 1077.72 & 2.9 & 181.33 & 29.09 \\
\hline
\end{tabular}

Note: TVA - Total acidity $\left(\mathrm{mgHCOOH} \mathrm{L}{ }^{-1}\right) ; \mathbf{P A}$ - Partial alkalinity $\left(\mathrm{mgCaCO}_{3} \mathrm{~L}^{-1}\right)$; IA - Intermediate alkalinity $\left(\mathrm{mgCaCO}_{3} \mathrm{~L}^{-1}\right)$; TA - Total alkalinity $\left(\operatorname{mgCaCO}_{3} \mathrm{~L}^{-1}\right)$; $\mathbf{T P}$ - Total phosphorus $\left(\mathrm{mgP}^{-1}\right)$; $\mathbf{T K N}$ Total Kjeldahl Nitrogen (mgN L-1).

Table 8. Characterization of UASB influent.

\begin{tabular}{|c|c|c|c|c|c|c|c|c|}
\hline \multicolumn{9}{|c|}{ Parameters } \\
\hline Period & pH & TVA & PA & IA & $\mathbf{T A}$ & IA/PA & $\mathbf{T} \mathbf{P}$ & TKN \\
\hline I & 7.02 & 40.9 & 156.5 & 193.1 & 349.6 & 1.7 & 38.0 & 25.68 \\
\hline II & 7.08 & 40.6 & 150.8 & 283.4 & 434.2 & 2.4 & 141.0 & 35.51 \\
\hline III & 6.83 & 103.0 & 241.7 & 514.7 & 756.3 & 2.5 & 129.7 & 15.37 \\
\hline IV & 6.93 & 118.0 & 431.3 & 485.9 & 917.2 & 1.3 & 186.2 & 19.27 \\
\hline $\mathbf{V}$ & 6.3 & 101.8 & 175.3 & 576.9 & 752.2 & 3.6 & 128.0 & 18.43 \\
\hline VI & 6.5 & 168.4 & 340.1 & 917.4 & 1257.4 & 2.7 & 162.5 & 14.52 \\
\hline
\end{tabular}

Note: TVA - Total acidity (mgHCOOH L L $)$; PA - Partial alkalinity $\left(\operatorname{mgCaCO}_{3} \mathrm{~L}^{-1}\right)$; IA - Intermediate alkalinity (mgCaCO $\left.\mathrm{L}^{-1}\right)$; $\mathbf{T A}$ - Total alkalinity $\left(\mathrm{mgCaCO}_{3} \mathrm{~L}^{-1}\right)$; $\mathbf{T P}$ - Total phosphorus (mgP L $\left.{ }^{-1}\right)$; $\mathbf{T K N}$ - Total Kjeldahl Nitrogen (mgN L-1).

Values of $\mathrm{pH}$ below 6.0 can inhibit the activity of methanogenic archea, negatively affecting the production of methane. Therefore, in order to maintain the UASB methanogenic conditions in periods of sharp decline in $\mathrm{pH}$ due to high acidity, the medium was buffered using the $\mathrm{NaOH}$ solution in the influent (Chen et al., 2008).

Bruno and Oliveira (2013) using a UASB reactor to treat WCWP, evaluated the behavior of the $\mathrm{pH}$ and TVA concentrations and TA influent and effluent in a UASB reactor operating 
as the first stage in two operational conditions. In the first condition, the WCWP had $\mathrm{pH}$ values and concentrations of TVA and TA influent of 6.9; $960 \mathrm{mg} \mathrm{HCOOH} \mathrm{L}^{-1}$ and $730 \mathrm{mgCaCO}_{3} \mathrm{~L}^{-1}$, respectively.

Table 9. Characterization of UASB effluent.

\begin{tabular}{ccccccccc}
\hline \multicolumn{7}{c}{ Parameters } \\
\hline Period & $\mathbf{p H}$ & TVA & PA & IA & TA & IA/PA & TP & TKN \\
\hline I & 7.27 & 46.31 & 281.12 & 174.68 & 455.81 & 0.7 & 32.50 & 23.37 \\
II & 7.19 & 34.66 & 349.69 & 172.32 & 522.01 & 0.5 & 55.67 & 23.22 \\
III & 7.26 & 74.71 & 661.09 & 320.73 & 981.83 & 0.5 & 144.17 & 16.24 \\
IV & 7.34 & 76.36 & 752.16 & 321.04 & 1073.2 & 0.4 & 156.83 & 22.64 \\
V & 6.97 & 50.18 & 460.89 & 315.44 & 776.34 & 0.7 & 122.67 & 18.08 \\
VI & 7.34 & 49.39 & 1048.76 & 366.39 & 1415.15 & 0.4 & 118.00 & 12.58 \\
\hline
\end{tabular}

Note: TVA - Total acidity (mgHCOOH L $\left.{ }^{-1}\right)$; PA - Partial alkalinity $\left(\operatorname{mgCaCO}_{3} \mathrm{~L}^{-1}\right)$; IA - Intermediate alkalinity $\left(\mathrm{mgCaCO}_{3} \mathrm{~L}^{-1}\right)$; $\mathbf{T A}$ - Total alkalinity $\left(\mathrm{mgCaCO}_{3} \mathrm{~L}^{-1}\right)$; $\mathbf{T P}$ - Total phosphorus (mgP L $\left.{ }^{-1}\right)$; TKN - Total Kjeldahl Nitrogen (mgN L $\left.{ }^{-1}\right)$.

The reactor underwent a VOLR of $2.26 \mathrm{COD}_{\mathrm{T}} \mathrm{m}^{-3} \mathrm{~d}^{-1}$ and HRT of $6.2 \mathrm{~d}$ getting values of $\mathrm{pH}$ and concentrations of TVA and TA effluent of 7.5; $103 \mathrm{mg} \mathrm{HCOOH} \mathrm{L} \mathrm{L}^{-1}$ and $2310 \mathrm{mgCaCO}_{3} \mathrm{~L}^{-1}$, respectively, and 91\% COD removal, stable generation of TA and stable consumption TVA. In the second condition, the WCWP presented values of $\mathrm{pH}$ and concentrations of TVA and TA influent of 7.1; $1050 \mathrm{mg} \mathrm{HCOOH} \mathrm{L}^{-1}$ and $1088 \mathrm{mgCaCO}_{3} \mathrm{~L}^{-1}$, respectively.

The reactor underwent a VOLR of $4.53 \mathrm{~kg} \mathrm{COD}_{\mathrm{T}} \mathrm{m}^{-3} \mathrm{~d}^{-1}$ keeping the HRT to $6.2 \mathrm{~d}$ getting values of $\mathrm{pH}$ and concentrations of TVA and TA effluent of 7.2; $1688 \mathrm{mg} \mathrm{HCOOH} \mathrm{L}^{-1}$ and $2351 \mathrm{mgCaCO}_{3} \mathrm{~L}^{-1}$, respectively, and 84\% of COD removal, with unstable generation of TA and TVA.

Analyzing tables 8 and 9, it may be concluded that there was TA generation and consumption of TVA in the UASB reactor during the periods studied, even under progressive increase of VOLR (Table 1). It is therefore possible to conclude that the values of TA and TVA present in WCWP at each period (Table 8) were enough to keep the liquid medium buffered as seen by Bruno and Oliveira (2013). However, even constantly increasing the VOLR, alkalinity generation and consumption in the UASB reactor TVA was stable, operating with values approximately 4 times greater than those obtained by Bruno and Oliveira (2013) in the second condition.

The values for COD removal efficiency (Table 7) were probably different due to the low values of HRT used in this work in relation to those studied by Bruno and Oliveira (2013).

The ratio IA/PA in UASB (Table 9) proved to be far different from the value 0.3 quoted by Ripley et al. (1986). In I-UASB (Table 8), IA, which is attributed to the volatile acids, was greater than the PA, which is a result of bicarbonates. In E-UASB (Table 9), PA was higher than the IA. Due to this fact, we obtained $\mathrm{pH}$ values higher in the influent than in the effluent of the UASB reactor.

Higher removal of phosphorus can be observed in AET (tables 7 and 8), probably due to more intense activity of the hydrolytic and acidogenic bacteria present in AET than due to the biomass of the UASB (Motteran et al., 2013). With respect to the entire system, the results can be considered good, because the average reference of phosphorus removal in secondary 
treatment is about 25\% (Metcalf e Eddy, 2003). The nitrogen values were shown to be close throughout the experiment (Tables 7, 8 and 9). Low levels of nitrogen contribute to the depression of alkalinity in the medium, because of the formation of ammonium bicarbonate, which is partly responsible for alkalinity (Pereira et al., 2013).

During the experiment, each period of growth was monitored by analyzing the volatile solids sludge (TVS). The correlation coefficient for TS / TFS was 0.514 and for TS / TVS, was 0.966, indicating that the increase of TS is more due to the increase of TVS than the TFS. The increase of the solids throughout the experiment (Table 10), the fraction of TVS, shows the growth of biomass in the reactor; this fact is extremely important to the process of anaerobic digestion in order to produce biogas. TS values above $40000 \mathrm{mg} \mathrm{L}^{-1}$ are considered ideal for wastewater treatment, according to Chernicharo (2007). In the treatment of WCWP, the TS reached this value after period V. Comparing tables 4 and 10, it is noted that increasing the concentration of TVS tends to increase the removal of phenolic compounds, showing a more acclimatized biomass. The variations observed are related to changes concerning flows and consequently loads, causing a washing-out of solids from the reactor biomass.

Table 10. Total concentration of solids $\left(\mathrm{g} \mathrm{L}^{-1}\right)$ in the UASB reactor biomass obtained at the end of each period during the steady state condition.

\begin{tabular}{cccc}
\hline Period & TS & TFS & TVS \\
\hline I & 25.605 & 12.279 & 13.327 \\
II & 26.669 & 11.312 & 15.356 \\
III & 40.446 & 18.944 & 21.502 \\
IV & 26.729 & 10.646 & 16.083 \\
V & 48.927 & 14.952 & 33.975 \\
VI & 50.021 & 12.863 & 37.157 \\
\hline
\end{tabular}

Silva et al. (2011a) studied two concentric UASB reactors working in series, on a pilot scale, treating WCWP. The system was operated under a progressive increase of organic load with HRT values varying from 10.56 to $22.35 \mathrm{~h}$, causing an endogenous condition by the low concentration of organic matter and high concentration of phenolic compounds. The authors concluded that in terms of TVS a biomass concentration between 3060 and $4730 \mathrm{mg}_{\text {TVS L }}^{-1}$ was active with apparent methanogenic activity ranging from 0.01 to $0.02 \mathrm{~m}^{3} \mathrm{CH}_{4} \mathrm{kgTVS}^{-1} \mathrm{~d}^{-1}$. The biomass observed under scanning electron microscopy (SEM) analysis presented little morphological diversity with the predominance of coconuts and methanogenic archaea observed using epi-fluorescence microscopy.

Silva et al. (2011b) and Silva et al. (2013) evaluated a pilot-scale hybrid anaerobic reactor (HAR) treating WCWP operating under progressive increase of organic load (VOLR) ranging from 0.15 to $0.75 \mathrm{~kg} \mathrm{COD} \mathrm{m}^{-3} \mathrm{~d}^{-1}$ with values of HRT varying from 12 to $24 \mathrm{~h}$, also under an endogenous condition. The authors used scanning electron microscopy analysis and epi-fluorescence microscopy to observe an active biomass concentration of TVS varying from 3060 and $4730 \mathrm{mg} \mathrm{TVS} \mathrm{L}^{-1}$, varied morphology and presence of methanogenic archaea.

Based on the results of minimum concentrations of TVS for maintenance of biological activity presented by Silva et al. (2011a), Silva et al. (2011b) and Silva et al. (2013), it can be concluded that the biomass of the UASB reactor studied was biologically active in all periods. 
In addition, the increase in concentration of TVS showed that the biomass grew even under organic shocks and a high concentration of phenolic compounds, as shown in Table 4.

The biological growth was determined through the analysis of kinetic parameters described in item 3.2.

\subsection{Kinetics of growth and decay}

The Volumetric Organic Loading Rate (VOLR) presented above the recommended maximum value for domestic wastewater, which is $15 \mathrm{~kg} \mathrm{COD} \mathrm{m}^{-3} \mathrm{~d}^{-1}$, and above the values of the treatment of WCWP obtained by Campos et al. (2002), which were 0.17 to $0.31 \mathrm{~kg} \mathrm{COD} \mathrm{m}^{-3} \mathrm{~d}^{-1}$, demonstrating the capacity of the UASB to withstand high organic and hydraulic loadings (Table 11).

Table 11. Flow, HLR and VOLR in the periods.

\begin{tabular}{|c|c|c|c|c|c|}
\hline Period & $\begin{array}{c}\mathbf{Q} \\
\left(\mathbf{L} \mathbf{h}^{-1}\right)\end{array}$ & $\begin{array}{c}\mathbf{Q} \\
\left(\mathbf{m}^{3} \mathbf{d}^{-1}\right)\end{array}$ & $\begin{array}{c}\text { HLR } \\
\left(\mathbf{m}^{3} \mathbf{m}^{-3} \mathbf{d}-{ }^{-1}\right)\end{array}$ & $\begin{array}{c}\text { VOLR } \\
\left(\operatorname{kgBOD}_{5}{ }^{20^{\circ} \mathrm{C}} \mathrm{m}^{3} \mathrm{~d}^{-1}\right)\end{array}$ & 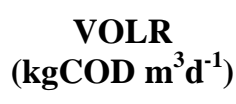 \\
\hline I & 0.203 & 0.0049 & 0.3858 & 0.14 & 0.26 \\
\hline II & 0.413 & 0.0099 & 0.7869 & 0.41 & 0.81 \\
\hline III & 0.409 & 0.0098 & 0.7818 & 0.69 & 1.50 \\
\hline IV & 0.605 & 0.0145 & 1.1483 & 1.57 & 2.80 \\
\hline V & 0.828 & 0.0199 & 1.5789 & 2.29 & 4.20 \\
\hline VI & 1.292 & 0.0310 & 2.4242 & 7.11 & 15.26 \\
\hline
\end{tabular}

The TVS in the reactor, obtained through analysis of the profile of the sludge, showed values from 18257 to $23852 \mathrm{mg} \mathrm{L}^{-1}$. It was observed that, except in the period IV, increasing the Biological Organic Loading Rate (BOLR) increased the concentration of TVS. The average values of the parameters TS, TVS and BOLR in the reactor during the periods, are shown in Table 12.

Table 12. Concentration of TVS and values BOLR in periods I through VI.

\begin{tabular}{|c|c|c|c|c|}
\hline Period & $\underset{\left(\mathbf{m g ~ L ^ { - 1 }}\right)}{\mathbf{T S}}$ & $\begin{array}{l}\text { TVS } \\
\left(\mathbf{m g ~ L ^ { - 1 }}\right)\end{array}$ & $\begin{array}{c}\text { BOLR } \\
\left(\operatorname{kg~COD~kg~TVS~}^{-1} d^{-1}\right)\end{array}$ & $\begin{array}{c}\text { BOLR } \\
\left(\operatorname{kg~BOD}_{5}{ }^{20^{\circ} \mathrm{C}} \operatorname{kgTVS}^{-1} \mathrm{~d}^{-1}\right)\end{array}$ \\
\hline I & 25,605 & 13,326 & 0.05 & 0.03 \\
\hline II & 26,669 & 15,356 & 0.13 & 0.07 \\
\hline III & 40,446 & 21,502 & 0.17 & 0.08 \\
\hline IV & 30,554 & 19,939 & 0.34 & 0.19 \\
\hline V & 47,360 & 33,069 & 0.33 & 0.18 \\
\hline VI & 50,021 & 37,157 & 1.06 & 0.49 \\
\hline
\end{tabular}


The kinetic parameters were determined for quantification of the coefficients $Y, K_{d}, K_{s}$ and $\mu_{\max }$ using the average values found in the six periods studied.

To construct the model, we used the average values presented in Tables 9 and 10. Using Table 13, linear regressions were performed to construct the graph shown in Figure 1, and after generating the linear model $y=a x+b$, the values of the parameters $Y$ and $K_{d}$ were obtained. The equation for $\mathrm{a}=2.722 \mathrm{~b}=0.0205$, resulted in $\mathrm{Y}=0.37 \mathrm{mg}$ TVS (mg COD removed) $)^{-1}$ and $\mathrm{K}_{\mathrm{d}}=0.0075 \mathrm{~d}^{-1}$.

Table 13. Data used for calculating the kinetic parameters: $\mathrm{Y}$ and $\mathrm{K}_{\mathrm{d}}$.

\begin{tabular}{cccccccc}
\hline Period & HRT (h) & $\mathbf{V r}(\mathbf{L})$ & $\begin{array}{c}\mathbf{Q} \\
\left(\mathbf{L} \mathbf{d}^{-\mathbf{1}}\right)\end{array}$ & $\begin{array}{c}\mathbf{C}_{\mathbf{o}} \\
(\mathbf{m g ~ L}-\mathbf{1})\end{array}$ & $\begin{array}{c}\mathbf{C} \\
(\mathbf{m g ~ L}-\mathbf{1})\end{array}$ & $\begin{array}{c}\mathbf{Q}^{*} \\
(\mathbf{C o}-\mathbf{C}) / \mathbf{X r} \mathbf{r} \mathbf{V r}\end{array}$ & $\mathbf{\theta}_{\mathbf{C}}(\mathbf{d})$ \\
\hline I & 62.2 & 5.2 & 4.872 & 658.3 & 173.1 & 0.01513 & 100.2652 \\
II & 30.5 & 5.2 & 9.912 & 1077.0 & 194.4 & 0.04860 & 47.0962 \\
III & 30.7 & 5.2 & 9.816 & 1901.4 & 545.3 & 0.05282 & 27.9885 \\
IV & 20.9 & 5.2 & 14.52 & 2353.3 & 557.4 & 0.11158 & 22.0330 \\
V & 15.2 & 5.2 & 19.872 & 2689.7 & 654.7 & 0.10434 & 20.1757 \\
VI & 9.9 & 5.2 & 31.008 & 5624.8 & 1420.5 & 0.29936 & 8.6583 \\
\hline
\end{tabular}

Legend: $\mathbf{C}_{\mathbf{0}}$ - COD influent; $\mathbf{C}$ - COD effluent; $\mathbf{X r}$ - TVS of biomass; $\mathbf{V r}$ - reactor volume; $\boldsymbol{\theta}_{\mathbf{C}}$ - cell retention time.

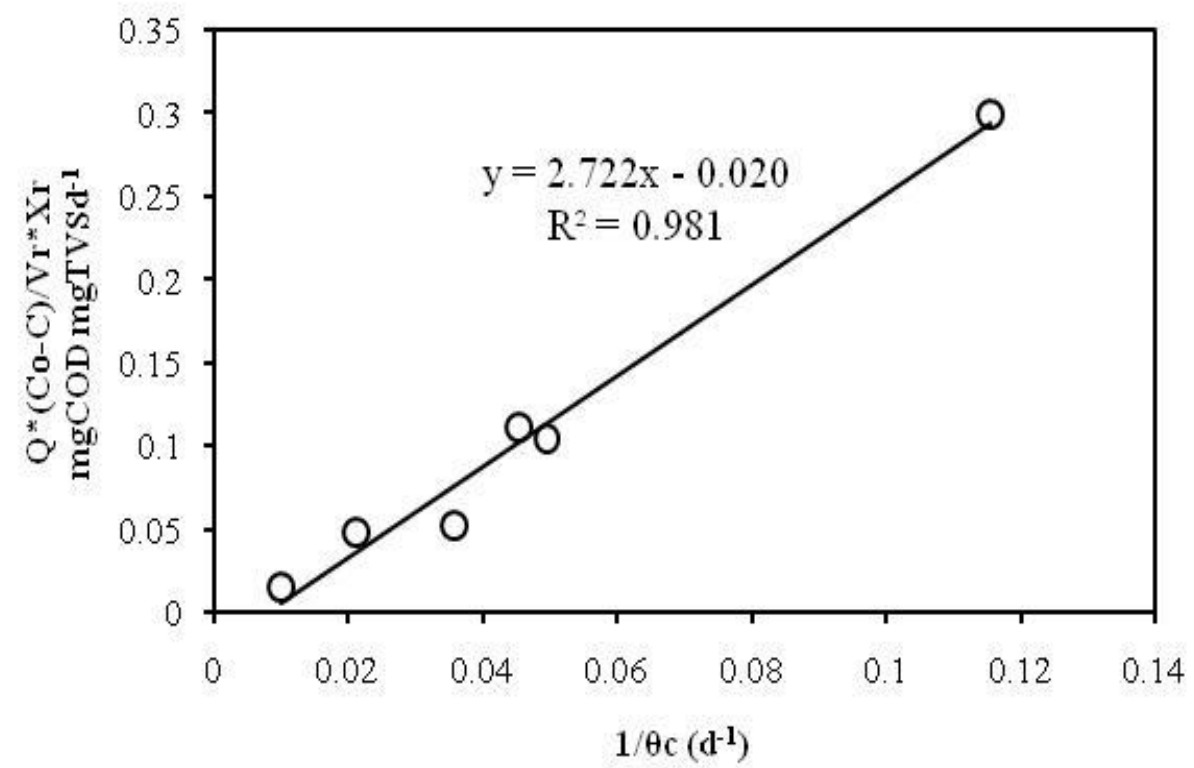

Figure 1. Graph to obtain the parameters $\mathrm{Y}$ and $\mathrm{K}_{\mathrm{d}}$.

Using the Table 14, linear regressions were performed to construct the graph shown in Figure 2, after which the linear model $y=a x+b$ was generated. The values of parameters $K_{s}$ and $\mu_{\max }$ were obtained through the following calculation: $a=\frac{\mathrm{Ks}}{\mu \mathrm{max}} \mathrm{e} b=\frac{1}{\mu \max }$. The equation resulted in $\mathrm{a}=7681.5$ and $\mathrm{b}=5.1085, \mathrm{~K}_{\mathrm{s}}=1504 \mathrm{mg} \mathrm{L}^{-1}$ and $\mu_{\max }=0.2 \mathrm{~d}^{-1}$. 
Table 14. Survey of kinetic parameters $\mathrm{K}_{\mathrm{s}}$ and $\mu_{\max }$.

\begin{tabular}{|c|c|c|c|c|}
\hline Period & $\theta_{\mathrm{C}}(\mathbf{d})$ & $1 / \theta_{\mathrm{C}}$ & $1 / \mathrm{C}$ & $1 /\left(1 / \theta_{C}+K_{d}\right)$ \\
\hline I & 100.265 & 0.0099 & 0.205 & 57.1272 \\
\hline II & 47.096 & 0.0212 & 0.100 & 34.7652 \\
\hline III & 27.988 & 0.0350 & 0.101 & 23.1159 \\
\hline IV & 22.033 & 0.0453 & 0.068 & 18.8972 \\
\hline V & 20.176 & 0.0495 & 0.050 & 17.5144 \\
\hline VI & 8.658 & 0.1154 & 0.032 & 8.1283 \\
\hline
\end{tabular}

Legend: $\mathbf{C}$ - COD effluent; $\boldsymbol{\theta}_{\mathbf{C}}$ - cell retention time; $\mathbf{K}_{\mathbf{d}}$ : endogenous coefficient (decay).

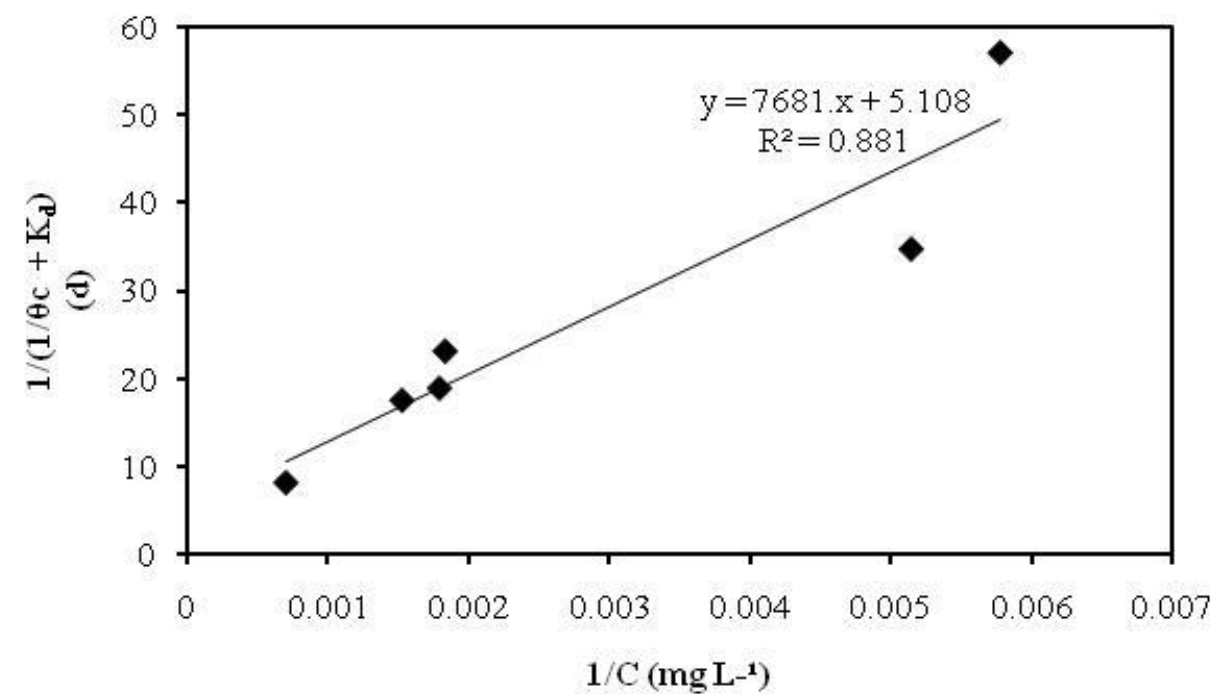

Figure 2. Graph to obtain the kinetic coeficients: $\mathrm{K}_{\mathrm{s}}$ and $\mu_{\max }$.

Using the values of $\mathrm{Y}$ and $\mu_{\max }$ presented in tables 13 and 14, it was possible to determine the specific rate of substrate utilization by biomass $\mathrm{k}=0.54$ mgCOD $_{\text {removed }}$ mgTVS $^{-1} \mathrm{~d}^{-1}$

\section{CONCLUSIONS}

Under a gradual increase of loading rates, the UASB reactor has shown a high efficiency in removing phenolic compounds and organic matter during the treatment of WCWP, even while operating with high values of VOLR, above those recommended by the literature.

The kinetic parameters found during the anaerobic biodegradation of phenolic compounds with minimal concentration of $50 \mathrm{mg} \mathrm{L}^{-1}$, were: $\mathrm{Y}=0.37 \mathrm{mgTVS}$ $\left(\mathrm{mgCOD}_{\text {removed }}\right)^{-1}, \quad \mathrm{~K}_{\mathrm{d}}=0.0075 \mathrm{~d}^{-1}, \mathrm{~K}_{\mathrm{s}}=1504 \mathrm{mg} \mathrm{L}^{-1}, \mu_{\max }=0.2 \mathrm{~d}^{-1}$ and $\mathrm{k}=0.54 \mathrm{mgCOD}_{\text {removed }} \mathrm{mgTVS}^{-1} \mathrm{~d}^{-1}$, demonstrating that the saturation constant $\left(\mathrm{K}_{\mathrm{s}}\right)$ is quite high due to the presence of phenols, showing little affinity between the substrate (WCWP) and the micro-organisms responsible for biological degradation. 


\section{ACKNOWLEDGEMENTS}

The research group would like to acknowledge all undergraduate and postgraduate students who assisted in the development of this research. The group is also grateful to CAPES, CNPq and FAPEMIG, the organizations that provided the funding for the project and scholarships.

\section{REFERENCES}

AMERICAN PUBLIC HEALTH ASSOCIATION - APHA; WATER WORKS ASSOCIATION - WWA; WATER ENVIROMENT FEDERATION - WEF. Standard methods for the examination of water and wastewater. Washington, 2005.

BHUNIA, P.; GHANGREKAR, M. M. Analysis, evaluation, and optimization of kinetic parametersfor performance appraisal and design of UASB reactors. Bioresource Technology, v. 99, p. 2132-2140, 2008.

http://dx.doi.org/10.1016/j.biortech.2007.05.053

BORÉM, F. M. Pós colheita do café. In: BORÉM, F. M. Processamento do café. Lavras: UFLA, 2008. p. 127-158.

BRUNO, M.; OLIVEIRA, R. A. Performance of UASB reactors in two stages followed by post-treatment with activated sludge in wastewater batch of wet-processed coffee. Engenharia Agrícola, v. 33, p. 808-819, 2013. http://dx.doi.org/10.1590/S010069162013000400020

CAMPOS, C. M. M.; CARMO, A. C. do; LUIZ, F. A. R. Impacto ambiental causado pela poluição hídrica proveniente do processamento úmido do café. Revista Cafeicultura, v. 1, n. 4, p. 28-30, 2002.

CAMPOS, C. M. M.; PRADO, M. A. C.; PEREIRA, E. L. Anaerobic digestion of wastewater from coffee and chemical analysis of biogas produced using gas chromatography: quantification of methane, and potential energy gas exchanger. Bioscience Journal, v. 29, n. 3, p. 570-581, 2013.

CAMPOS, C. M. M.; PRADO, M. A. C.; PEREIRA, E. L. Physical-Chemical, Biochemical and Energetic characterization of wastewater originated from wet coffee processing. Bioscience Journal, v. 26, n. 4, p. 514-524, 2010. http://www.seer.ufu.br/index. php/biosciencejournal/article/viewFile/7129/5123

CHEN, Y.; CHENG, J. J.; CREAMER, K. S. Inhibition of anaerobic digestion process: A review. Bioresource Technology, v. 99, p. 4044-4064, 2008.

http://dx.doi.org/10.1016/j.biortech.2007.01.057

CHERNICHARO, C. A. L. Reatores anaeróbios: princípios do tratamento biológico de águas residuárias. Belo Horizonte: Polytécnica, 2007. 379 p.

FIA, F. R. L.; MATOS, A. T.; BORGES, A. C.; FIA, R.; CECON, P. R. Treatment of wastewater from coffee bean processing in anaerobic fixed bed reactors with different support materials: performance and kinetic modeling. Journal of Environmental Management, v. 108, p. 14-21, 2012. http://dx.doi.org/10.1016/j.jenvman.2012.04.033

INSTITUTO ADOLFO LUTZ. Normas analíticas do Instituto Adolfo Lutz. 3. ed. São Paulo: IAL, 1985. v. 1. 
JUNG, K. W.; KIM, D. H.; LEE, M. Y.; SHIN, H. S. Two-stage UASB reactor converting coffee drink manufacturing wastewater to hydrogen and methane. International Journal of Hydrogen Energy, v. 37, p. 7473 - 7481, 2012. http://dx.doi.org/10.1016/j.ijhydene.2012.01.150

METCALF; EDDY. Wasterwater engineering: treatment, disposal and reuse. New York: McGraw-Hill, 2003. 1334 p.

MOTTERAN, F.; PEREIRA, E. L.; CAMPOS, C. M. M. Characterization of an acidification and equalization tank (AET) operating as a primary treatment of swine liquid effluent. Brazilian Archives of Biology and Technology, v. 56, n. 3, p. 485-494. 2013. http://dx.doi.org/10.1590/S1516-89132013000300017

PEREIRA, E. L.; CAMPOS, C. M. M.; MOTERANI, F. Avaliação do desempenho físicoquímico de um reator UASB construído em escala piloto na remoção de poluentes de efluentes de suinocultura. Revista Ambiente \& Agua, v. 5, n. 1, p. 79-88, 2010. http://dx.doi.org/10.4136/ambi.agua.121

PEREIRA, E. L.; CAMPOS, C. M. M.; MOTTERAN, F. Physical-chemical study of pH, alkalinity and total acidity in a system composed of Anaerobic Baffled Reactor in series with Upflow Anaerobic Sludge Blanket reactor in the treatment of pig farming wastewater. Acta Scientiarum Technology, v. 35, p. 477-483, 2013.

PEREIRA, E. L. Treatment of slaughterhouse wastewater using a system consisting of reactors with biofilm. 2013. 214 p. Dissertation (Master of Science) - Escola de Engenharia de Lorena, Universidade de São Paulo, Lorena, 2014.

RAMAKRISHNAN, A.; SURAMPALLI, R. Y. Comparative performance of UASB and anaerobic hybrid reactors for the treatment of complex phenolic wastewater. Bioresource Technology, v. 123, p. 352-359, 2012.

http://dx.doi.org/10.1016/j.biortech.2012.07.072

RIPLEY, L. E.; BOYLE, W. C.; CONVERSE, J.C. Improved alkalimetric monitoring for anaerobic digestion of high- strength wastes. Journal Water Pollution Control Federation, v. 58, n. 5, p. 406-411, 1986. http://www.jstor.org/stable/25042933

SELVAMURUGAN, M.; DORAISAMY, P.; MAHESWARI, M.; An integrated treatment system for coffee processing wastewater using anaerobic and aerobic process. Ecological Engineering, v. 36, p. 1686-1690, 2010.

http://dx.doi.org/10.1016/j.ecoleng.2010.07.013

SILVA, J. F.; CAMPOS, C. M. M.; PEREIRA, E. L.; SILVA, V. G. Avaliação microscópica da endogenia microbiana em reatores UASB concêntricos, tratando água residuária do processamento dos frutos do cafeeiro por via úmida. Acta Scientiarum. Technology, v. 33, n. 2, p. 129-135, 2011a.

SILVA, V. G.; CAMPOS, C. M. M.; PEREIRA, E. L.; SILVA, J. F. Characterization of the biomass of a anaerobic hybrid reactor (AHR) with two types of support material during the treatment of the coffee wastewater. Brazilian Archives of Biology and Technology, v. 56, n. 3, p. 495-504, 2013. http://dx.doi.org/10.1590/S151689132013000300018 
SILVA, V. G.; CAMPOS, C. M. M.; PEREIRA, E. L.; SILVA, J. F. Start-up and steady-state conditions of an Anaerobic Hybrid Reactor (AHR) using mini-filters composed with two types of support medium operating under low loading rates. Brazilian Archives of Biology and Technology, v. 54, n. 5, p. 973-982, 2011b. http://dx.doi.org/10.1590/S1516-89132011000500015

SPEECE, R. E. Anaerobic biotechnology for industrial wastewaters. Vanderbilt University: Archae Pr., 1996. 389p.

ZEEUW, W. J. D. Acclimatization of Anaerobic Sludge for UASB-reactor Start-up. Editora: Agricultural University of Wageningen, 1984. 156p. 


Ambiente \& Água - An Interdisciplinary Journal of Applied Science
ISSN 1980-993X - doi:10.4136/1980-993X
www.ambi-agua.net
E-mail: ambi-agua@agro.unitau.br

\title{
Agricultural recycling of biodigested vinasse for lettuce production
}

\author{
doi: 10.4136/ambi-agua.1313
}

Received: 11 Feb. 2014; Accepted: 26 Sep. 2014

\author{
Camila Roberta Javorski Ueno ${ }^{1 *}$; Antonio Carlos Saraiva da Costa ${ }^{2}$; \\ Marcelino Luiz Gimenes ${ }^{3}$; Gisella Maria Zanin ${ }^{3}$ \\ ${ }^{1}$ Universidade Estadual de Maringá (UEM), Maringá, PR, Brasil \\ Programa de Pós-graduação em Agronomia \\ ${ }^{2}$ Universidade Estadual de Maringá (UEM), Maringá, PR, Brasil \\ Departamento de Agronomia \\ ${ }^{3}$ Universidade Estadual de Maringá (UEM), Maringá, PR, Brasil \\ Departamento de Engenharia Química \\ "Corresponding author: e-mail: crjueno@gmail.com, \\ antoniocscosta@gmail.com,marcelino@deq.uem.br, gisella@deq.uem.br
}

\begin{abstract}
The agricultural use of waste products represents an interesting alternative for nutrient cycling. Biodigested vinasse, the final waste product of vinasse biodigestion and biogas production, can be reused for agricultural purposes. The present work sought to quantify the shoot dry mass production of lettuce plants, as well as foliar nitrogen, phosphorus and potassium content following the application of biodigested vinasse on soil. Biodigested vinasse was produced from anaerobic vinasse digestion, using anaerobic sludge as a source of microorganisms. The treatments, with four replications in entirely randomized design, consisted of anaerobic sludge from a gelatin factory, vinasse in natura, biodigested vinasse and a control treatment. The experiment was conducted over 45 days using $5 \mathrm{~L}$ vases and applying a dose equivalent to $150 \mathrm{~m}^{3} \mathrm{ha}^{-1}$. Lettuce treated with biodigested vinasse showed higher shoot dry mass production and higher accumulation of nitrogen, phosphorus and potassium in its leaves than that treated with vinasse in natura.
\end{abstract}

Keywords: biomass, Lactuca sativa, nutrients, residue, stillage, wastewater.

\section{Reciclagem agrícola de vinhaça biodigerida para produção de alface}

\section{RESUMO}

O uso agrícola de resíduos é uma alternativa interessante para ciclagem de nutrientes. A vinhaça biodigerida, gerada após o processo de sua biodigestão e produção de biogás, permite o reuso agrícola. O presente trabalho quantificou a produção de massa seca da parte aérea em plantas de alface, assim como o acúmulo foliar de nitrogênio, fósforo e potássio após aplicação de vinhaça biodigerida no solo. Os tratamentos, com quatro repetições em um delineamento inteiramente casualizado, utilizaram lodo anaeróbio de indústria de gelatina, vinhaça in natura, vinhaça biodigerida, além de tratamento testemunha. Foi aplicada a dose equivalente a $150 \mathrm{~m}^{3} \mathrm{ha}^{-1}$ em vasos com capacidade para $5 \mathrm{~L}$, sendo o experimento conduzido por 45 dias nos vasos. A vinhaça biodigerida foi produzida a partir da biodigestão anaeróbia de vinhaça, utilizando lodo anaeróbio de indústria de gelatina como fonte de 
micro-organismos. Tratamentos com vinhaça biodigerida demonstraram melhores índices de produção de massa seca da parte aérea e acúmulo de nitrogênio, fósforo e potássio em folhas do que tratamentos utilizando vinhaça in natura.

Palavras-chave: água residuária, biomassa, Lactuca sativa, nutrientes, resíduo, vinhoto.

\section{INTRODUCTION}

In Brazil, the most common final use of vinasse is in crop fertigation, where it is used to meet potassium fertilization requirements and to contribute other essential nutrients. Biogas production has emerged as an additional alternative use of vinasse, with a dual purpose: bioenergy production and production of a waste with fertilization potential.

The beneficial effects of vinasse in agricultural crops are already well known, and studies on vinasse biodigestion have already been performed by several authors, among them Cabello et al. (2009) and Szymanski et al. (2010).

Vinasse biodigestion requires sources of microorganisms for inoculation, such as sludge. The benefits of sludge were evaluated by Chiba (2005), applying $16 \mathrm{t} \mathrm{ha}^{-1}$ of sewage sludge to ratoon cane, in combination with nitrogen fertilizer. The conclusion was that sludge can replace $100 \%$ of nitrogen fertilizer, thus emphasizing the usefulness of sludge in agriculture. In a study by Almeida et al. (2012), the addition of sewage sludge as fertilizer in soil increased the concentrations of $\mathrm{Fe}, \mathrm{Zn}, \mathrm{Cu}, \mathrm{K}, \mathrm{P}$ and organic matter in the soil, favoring the growth of lettuce plants.

Barros et al. (2011) studied the soil application of biosolids treated anaerobically in a UASB (Upflow Anaerobic Sludge Blanket) reactor, and observed an increase in macronutrient levels in the shoot of plants and in the dry matter in corn plants. Moreover, Gajdos et al. (2012) also observed the positive effects of the application of biofertilizers on corn and sunflower dry matter nutrition and production.

Lettuce is a short-cycle annual vegetable, with large leaves and rapid growth. It adapts best to lower temperatures, requiring wide temperature variations and high relative humidity (Cermeño, 1990). According to Simeoni et al. (1984), rapid-growth leafy plants such as lettuce tend to accumulate more metals than grains, leguminous grasses and vegetable crops; however, phosphorus and potassium deficiency can reduce lettuce plant growth (Gadelha et al., 2003). Santos et al. (2010) observed improved performance in crop physiological attributes such as photosynthesis, transpiration, carboxylation efficiency and chlorophyll levels in treatments with higher doses of vinasse in a basic mixture as substrate.

Faced with the lack of works evaluating the effects of biodigested vinasse in agricultural crops, the objective of the present work was to assess its effect in dry matter production and accumulation of nitrogen, phosphorus and potassium in lettuce plants.

\section{MATERIAL AND METHODS}

The experiment was conducted in a greenhouse located at $23^{\circ} 25^{\prime} \mathrm{S}, 51^{\circ} 57^{\prime} \mathrm{W}$, elevation $542 \mathrm{~m}$. The soil used was Dystrophic Red Latosol (EMBRAPA, 2006) collected at an agricultural area located in Iguatemi - PR, at the 0 and $20 \mathrm{~cm}$ depths.

The soil is derived from Caiuá sandstone, and usually occurs in the toposequence associations with Ultisols and Entisols (EMBRAPA, 2006). The mineralogy of this soil is dominated by quartz in the sand fraction and by kaolinite and hematite in the clay fraction. Other minerals detected by x-ray diffraction include muscovite and anatase in the sand fraction and maghemite and gibbsite in the clay fraction (Souza Júnior et al., 2010).

The soil was crushed and sieved through $2 \mathrm{~mm}$ mesh screens. The soil was then transferred to a $5 \mathrm{~L}$ flask. The soil was later chemically characterized and the calcium, 
magnesium and aluminum contents were extracted with $\mathrm{KCl} 1 \mathrm{~mol} \mathrm{~L}^{-1}$; phosphorus and potassium were extracted by Mehlich 1; hydrogen and aluminum were extracted by the SMP method; and carbon was extracted by the Walkley \& Black method. The methods are described in EMBRAPA (2009). The results can be seen in Table 1.

After the characterization, the soil received dolomitic limestone in order to reach $70 \%$ base saturation, based on data from the initial chemical analysis (Table 1). A total of $2.59 \mathrm{t} \mathrm{ha}^{-1}$ dolomitic limestone with 85\% TNRP was required for soil correction.

Table 1. Particle size and chemical attributes of the Dystrophic Red Latosol.

\begin{tabular}{lc}
\hline \multicolumn{1}{c}{ Parameter } & Result \\
\hline $\mathrm{pH}\left(\mathrm{CaCl}_{2}\right)$ & 4.3 \\
$\mathrm{Ca}^{2+}\left(\mathrm{cmol}_{\mathrm{C}} \mathrm{dm}^{-3}\right)$ & 0.77 \\
$\mathrm{Mg}^{2+}\left(\mathrm{cmol}_{\mathrm{c}} \mathrm{dm}^{-3}\right)$ & 0.33 \\
$\mathrm{~K}^{+}\left(\mathrm{cmol}_{\mathrm{C}} \mathrm{dm}^{-3}\right)$ & 0.15 \\
$\mathrm{SB}\left(\mathrm{cmol}_{\mathrm{C}} \mathrm{dm}^{-3}\right)$ & 1.25 \\
$\mathrm{CEC}\left(\mathrm{cmol}_{\mathrm{C}} \mathrm{dm}^{-3}\right)$ & 4.93 \\
$\mathrm{P}\left(\mathrm{mg} \mathrm{dm}^{-3}\right)$ & 2.2 \\
$\mathrm{C}\left(\mathrm{g} \mathrm{dm}^{-3}\right)$ & 4.99 \\
$\mathrm{~N}\left(\mathrm{~g} \mathrm{~kg}^{-1}\right)$ & 0.6 \\
$\mathrm{Sand}\left(\mathrm{g} \mathrm{kg}^{-1}\right)$ & 670 \\
$\mathrm{Silt}\left(\mathrm{g} \mathrm{kg}^{-1}\right)$ & 10 \\
Clay $\left(\mathrm{g} \mathrm{kg}^{-1}\right)$ & 320 \\
Silt / Clay Ratio & 0.031 \\
\hline
\end{tabular}

Note: $\mathrm{Ca}, \mathrm{Mg}$ - extracted with $\mathrm{KCl} 1 \mathrm{~mol} \mathrm{~L}^{-1}$, P, $\mathrm{K}$ - extracted with Mehlich 1, C - method Walkley \& Black (EMBRAPA, 2009); SB - sum of bases; CEC - cation exchange capacity.

The initial biodigested material consisted of a mixture of $80 \%$ vinasse from an ethanol plant and 20\% liquid anaerobic sludge from a gelatin factory, both located in the region of Maringá-PR. The sludge was used as source of microorganisms for anaerobic vinasse biodigestion. The materials were kept in sealed Erlenmeyer flasks. Biodigestion took place for 20 days, at $30^{\circ} \mathrm{C}$ and continuous agitation at $150 \mathrm{rpm}$, using an agitator under controlled temperature. Later, the sludge, vinasse and biodigested vinasse were chemically characterized and the $\mathrm{Ca}$ and $\mathrm{Mg}$ were extracted with $\mathrm{KCl} 1 \mathrm{~mol} \mathrm{~L}^{-1}, \mathrm{P}$ and $\mathrm{K}$ were extracted with Mehlich 1, and the Walkley \& Black method was used to determine C (EMBRAPA, 2009).

No chemical fertilizers were added to the soil for lettuce cultivation - only biodigested vinasse. Following fertigation, there was a 30-day incubation period before transplanting the seedlings of iceberg lettuce (Lactuca sativa), produced in Styrofoam trays with an organic substrate made from pine bark. The 30-day-old seedlings were then transplanted, one per vase, and grown for 45 days under daily irrigation.

The experimental design chosen was entirely randomized, with four replications. The vinasse dosage used was $375 \mathrm{~mL}$, equivalent to $150 \mathrm{~m}^{3} \mathrm{ha}^{-1}$. Four treatments were tested: a control, vinasse, sludge and biodigested vinasse. The treatment with sludge sought to evaluate the sludge's ability to improve crop production, given that biodigested vinasse included $20 \%$ sludge in its formation. 
After 45 days of cultivation, the plants were harvested and the shoot dry mass was determined. To that end, the material was cleansed in running water to remove rough and undesired materials, and then stored in pre-weighed paper bags. The material was then taken to a forced-air oven at $60-70^{\circ} \mathrm{C}$, until constant weight. Next, the paper bags were transferred to a desiccator until completely cooled, followed by weighing of the dry mass of the shoot.

Chemical analyses were conducted on the leaves in order to quantify the nitrogen $(\mathrm{N})$, phosphorus $(\mathrm{P})$ and potassium $(\mathrm{K})$ contents according to the methodology proposed by Malavolta (1997). After being oven-dried at $60-70^{\circ} \mathrm{C}$, the leaves were ground by passing all materials through a $2 \mathrm{~mm}$ mesh sieve. Total nitrogen was determined by the classic Kjeldahl method, phosphorus and potassium were determined by UV/Vis and atomic absorption spectrophotometry of the extracts of the nitro-prechloric digestion, respectively.

The results were statistically analyzed using SAS software (SAS, 1999). Means were compared using Tukey's test, at a 5\% significance level. Multiple regression analyses for estimating dry matter yield of shoot in the treatments was performed using the Stepwise routine of SAS software (SAS, 1999), at a 5\% significance level.

\section{RESULTS AND DISCUSSION}

The chemical attributes and major nutrients added to the soil by the different wastes are shown in Table 2.

Table 2. Values of $\mathrm{pH}$ and nutrient content of the wastes to be added to the soil.

\begin{tabular}{lccc}
\hline Parameter & $\mathbf{S}^{\mathbf{I}}$ & $\mathbf{V}^{\mathbf{I I}}$ & $\mathbf{B V}^{\mathbf{I I}}$ \\
\hline $\mathrm{pH}\left(\mathrm{H}_{2} \mathrm{O}\right)$ & 7.00 & 5.02 & 6.74 \\
Organic Matter $\left(\mathrm{g} \mathrm{L}^{-1}\right)$ & 49.64 & 26.80 & 3.55 \\
$\mathrm{~N}\left(\mathrm{~g} \mathrm{~L}^{-1}\right)$ & 7.00 & 2.38 & 1.26 \\
$\mathrm{C} / \mathrm{N} \mathrm{Ratio}^{-1}$ & $4: 1$ & $6: 1$ & $2: 1$ \\
$\mathrm{CaO}\left(\mathrm{mg} \mathrm{L}^{-1}\right)$ & 3153 & 2823 & 2218 \\
$\mathrm{MgO}\left(\mathrm{mg} \mathrm{L}^{-1}\right)$ & 345 & 1616 & 1296 \\
$\mathrm{~K}_{2} \mathrm{O}\left(\mathrm{mg} \mathrm{L}^{-1}\right)$ & 853 & 3927 & 3640 \\
$\mathrm{P}_{2} \mathrm{O}_{5}\left(\mathrm{mg} \mathrm{L}^{-1}\right)$ & 796.0 & 127.3 & 199.0 \\
\hline
\end{tabular}

Note: ${ }^{\text {I }}$ Sludge; ${ }^{\text {II }}$ Vinasse; ${ }^{\text {III }}$ Biodigested vinasse

Ca, Mg - extracted with KCl 1 mol L $^{-1}$, P, K - extracted with Mehlich 1, C - method Walkley \& Black (EMBRAPA, 2009).

The nutrients present in the biodigested vinasse treatment (Table 2) do not correspond to the sum of $80 \%$ vinasse plus $20 \%$ sludge, thus evidencing that the presence of sludge in the mixture was important for the positive and significant response in the treatments with sludge or biodigested vinasse.

The relatively high losses of $\mathrm{C}$ and $\mathrm{N}$ during the mineralization of the combination of sludge + vinasse were compensated by very high accumulation of phosphate and potassium and the other secondary macronutrients ( $\mathrm{CaO}, \mathrm{MgO})$.

A reduction in nutrient levels and in the $\mathrm{C} / \mathrm{N}$ ratio can be observed in biodigested vinasse compared to vinasse in natura and sludge. This is due mainly to the hydrolysis reactions that took place in the first stage of the anaerobic processes, in which the nutrients are hydrolyzed and solubilized. When water passes through the mass of solid organic waste, it carries dissolved nutrients along with it by lixiviation, thus decreasing their levels after biodigestion. 
Organic materials with a lower $\mathrm{C} / \mathrm{N}$ ratio lead to faster nutrient release (Kiehl, 1998), providing better growth conditions for short-cycle plants, as in the case of lettuce, and can increase moisture retention (Araújo et al., 2008).

There were statistically significant differences $(p<0.05)$ in the biomass production from the shoots when comparing the treatments.

The accumulation of biomass from the lettuce plant shoots subjected to the treatment with added sludge (Table 3) showed the best results for the dry mass productions from the shoot. The high shoot yield in the sludge treatment is due to the superior balance in the chemical attributes of that waste compared to the others (Table 2). The incorporation of organic waste added high levels of nutrients ( $\mathrm{N}, \mathrm{P}, \mathrm{K}, \mathrm{Ca}$ and $\mathrm{Mg}$ ) to the soil, complexed to the organic forms of the wastes and available for absorption by the root system of lettuce plants (Lopes et al., 2005). These complexes, barely found in the original soil, doubled shoot yield compared to the control treatment.

The biodigested vinasse resulted in significantly positive $(p<0.05)$ increases in dry mass shoot (DMS) production as it improved vinasse chemical attributes, providing nutrients, balancing existing biological activity and reducing the impact of salinity of that waste product, which is rich in potassium and other salts (Table 2).

Following the anaerobic digestion of cattle manure, Costa et al. (2006) observed positive interactions on fresh phytomass of the shoot with the use of biofertilizers in the production of two lettuce cultivars.

Ortega e Cazetta (2011), recommend biodigested vinasse concentrate for sugarcane crops as it showed no significant differences in plant growth compared to vinasse in natura.

Franklin (2004) observed that differences in the treatment systems, such as the stabilization procedure used, percentages of $\mathrm{N}^{-\mathrm{NO}_{3}}{ }^{-}$and $\mathrm{N}-\mathrm{NH}_{4}{ }^{+}$, and method of application to the soil (dry, moist), affect the percentage of available $\mathrm{N}$.

Notwithstanding this, the dry mass values are lower than those found by some authors (Martins et al., 2009; Lopes et al., 2005); however, the growing season (warm months) justifies the low yield (Viggiano, 1990). The intense heat particularly affected the control treatment, which featured approximately half the values of the sludge and biodigested vinasse treatments.

The positive response in dry matter production in the shoot of lettuce plants grown with biodigested vinasse, when compared to control treatment and vinasse in natura, is related to the process of biodigestion undergone in vinasse. The active microorganisms in the biodigestion process make nutrients more easily absorbable for plants. In the anaerobic biodigestion of goat waste, Orrico et al. (2011) observed that increasing the amount of concentrate in the animal diet resulted in more absorbable substrates after anaerobic biodigestion, which favored the development of anaerobic microorganisms, thus facilitating the reduction of organic material and biogas production.

With regard to the accumulation of nitrogen, phosphorus and potassium in lettuce leaves, significant differences $(p<0.05)$ were observed resulting from the application of waste on soil (Table 3). The biodigested vinasse treatment significantly favored the accumulation of nitrogen, phosphorus and potassium compared to the other treatments.

The treatment with biodigested vinasse showed significantly higher levels of $\mathrm{N}, \mathrm{P}$ and $\mathrm{K}$ in the plant leaves (Table 3). With the exception of phosphorus, the treatment with added vinasse in natura in soil showed significantly higher amounts of nitrogen and potassium than treatments with added sludge. The control treatment showed the smallest values for all nutrients, but was statistically similar $(p<0.05)$ for nitrogen levels when compared to the treatment with sludge, and resulted in the lowest nutrient levels in the shoot of plants. Therefore, it was not the amount of nitrogen added to the soil via sludge, but rather the amounts of the other nutrients (phosphorus, potassium, calcium and magnesium), biological 
activity and various forms of $\mathrm{N}$ that determined the significant differences (Table 3) in DMS yield when compared to the control treatment.

Table 3. Biomass from lettuce plant shoots and accumulation of nitrogen $(\mathrm{N})$, phosphorus $(\mathrm{P})$ and potassium (K).

\begin{tabular}{lccccc}
\hline \multirow{2}{*}{ Treatment } & Shoot & & $\mathbf{N}$ & $\mathbf{P}$ & $\mathbf{K}$ \\
\cline { 2 - 4 } \cline { 5 - 6 } \multicolumn{1}{c}{$\mathbf{g ~ p l a n t}^{-1}$} & & & $\mathbf{g ~ k g}^{-1}$ & \\
\hline Sludge & $5.86 \pm 0.80^{*} \mathrm{a}$ & & $16.68 \pm 0.32^{*} \mathrm{c}$ & $1.90 \pm 0.01^{*} \mathrm{~b}$ & $19.97 \pm 0.12^{*} \mathrm{c}$ \\
Vinasse in natura & $4.75 \pm 0.17^{*} \mathrm{c}$ & & $24.26 \pm 0.28^{*} \mathrm{~b}$ & $1.80 \pm 0.02^{*} \mathrm{c}$ & $23.87 \pm 0.16^{*} \mathrm{~b}$ \\
Biodigested vinasse & $5.25 \pm 0.04^{*} \mathrm{~b}$ & & $51.17 \pm 0.37^{*} \mathrm{a}$ & $2.13 \pm 0.02^{*} \mathrm{a}$ & $24.53 \pm 0.06^{*} \mathrm{a}$ \\
Control & $2.66 \pm 0.49^{*} \mathrm{~d}$ & & $16.14 \pm 0.15^{*} \mathrm{c}$ & $1.64 \pm 0.02^{*} \mathrm{~d}$ & $15.57 \pm 0.55^{*} \mathrm{~d}$ \\
\hline
\end{tabular}

Note: * Average value \pm standard deviation.

Letters in the same column mean significant difference $(\mathrm{p}<0.05)$ among treatments.

The amount of absorbed nitrogen, phosphorus and potassium were smaller than the values observed in the literature (Martins et al., 2009; Almeida Júnior et al., 2011) due to the warmer conditions as observed previously (Viggiano, 1990).

Higher values of $\mathrm{P}$ and $\mathrm{K}$ in the leaves of lettuce fertilized with organic compounds were observed by Rodrigues and Casali (1998), and by García-Martínez et al. (2009) in tomato cultivation. Camilotti et al. (2006) determined that sewage sludge as a source of $\mathrm{N}$ and vinasse as a source of $\mathrm{K}$ were efficient sources of these minerals, and resulted in increased yields and higher industrial quality of third and fourth ratoon cane.

The low $\mathrm{C} / \mathrm{N}$ ratio of all waste treatments might have contributed to better nutrient accumulation, smaller than 18:1 (Kiehl, 1998).

Thus, biodigested vinasse, which contains sludge and vinasse in its composition, significantly contributes as a source of $\mathrm{N}$ from sludge, and $\mathrm{P}$ and $\mathrm{K}$ from vinasse.

Multiple regression analyses were performed for the variable DMS regarding the different chemical attributes of the soil and plants, in selected treatment clusters (Table 4), using the Stepwise routine of SAS software (SAS, 1999). Potassium was the only dependent variable chooser when the multiple regression equation considered the control $\mathrm{x}$ vinasse $\mathrm{x}$ biodigested vinasse treatments. For the control x sludge treatments, however, no independent variable contributed to DMS at a $5 \%$ probability level. When the vinasse $\mathrm{x}$ biodigested vinasse treatments were used, the independent variable CEC was positively correlated to the DMS.

The multiple regression equations confirmed previous observations, demonstrating that the contribution of vinasse to soil potassium levels was essential for DMS accumulation (Camilotti et al., 2006). With regard to the mixture of vinasse and sludge, the greater contribution comes from sludge, which might have favored the accumulation of organic colloids and significantly increased soil CEC, and consequently DMS yield (Kiehl, 1998).

Table 4. Multiple regression analyses for estimating dry matter yield of shoot in the treatments.

\begin{tabular}{llcc}
\hline Treatments considered & \multicolumn{1}{c}{ Equation } & $\mathbf{R}^{\mathbf{2}}$ & P \\
\hline Control x V x BV & $\mathrm{Y}=-1.59999+0.2728 *$ K folha & 0.94 & $<0.0001$ \\
Control x S & There was no equation & Not significant & \\
V x BV & $\mathrm{Y}=-3.56524+0.0029 *$ CEC & 0.92 & 0.0002 \\
\hline
\end{tabular}

Note: $\mathrm{V}=$ vinasse $\mathrm{BV}=$ Biodigested vinasse. 


\section{CONCLUSIONS}

The absorption of the nutrients nitrogen, phosphorus and potassium in lettuce leaves was significantly greater in the treatment with biodigested vinasse. In the sludge treatment, nitrogen levels in the plants were statistically equal to the control treatment, despite greater DMS yield. Phosphorus and potassium accumulated in the leaves were determining factors for DMS production.

\section{ACKNOWLEDGEMENTS}

This study was supported by the Coordination for the Improvement of Higher Education Personnel (CAPES).

\section{REFERENCES}

ALMEIDA JÚNIOR, A. B.; NASCIMENTO, C. W. A.; SOBRAL, M. F.; SILVA, F. B. V.; GOMES, E. A. Fertilidade do solo e absorção de nutrientes em cana-de-açúcar fertilizada com torta de filtro. Revista Brasileira de Engenharia Agrícola e Ambiental, v. 15, p. 1004-1013, 2011. http://dx.doi.org/10.1590/S141543662011001000003

ALMEIDA, V. C.; SODRÉ, F. F.; VARGAS, A. M. M.; BUKMAN, L.; MARTINS, A. C.; MORAES, J. C. G. et al. Phytotoxicity and distribution of copper in tropical soil amended with sewage sludge and copper sulfate. Chemical Speciation and Bioavailability, v. 24, p. 97-104, 2012. http://dx.doi.org/10.3184/095422912X13334505546124

ARAÚJO, F. F.; TIRITAN, C. S.; FOLONI, J. S. S. Utilização de compostos orgânicos semicurados na produção de alface (Lactuca sativa). Revista Caatinga, v. 21, p. 113117, 2008.

BARROS, I. T.; ANDREOLI, C. V.; SOUZA JÚNIOR, I. G.; COSTA, A. C. S. Avaliação agronômica de biossólidos tratados por diferentes métodos químicos para aplicação na cultura do milho. Revista Brasileira de Engenharia Agrícola e Ambiental, v. 15, p. 630-638, 2011. http://dx.doi.org/10.1590/S1415-43662011000600014

CABELlo, P. E.; SCOGNAMigliO, F. P.; TERÁN, F. J. C. Tratamento de vinhaça em reator anaeróbio de leito fluidizado. Engenharia Ambiental, v. 6, p. 321-338, 2009.

CAMILOTTI, F.; ANDRIOLI, I.; MARQUES, M. O.; SILVA, A. R.; TASSO JUNIOR, L.C.; NOBILE, F. O. et al. Produtividade e qualidade agroindustrial da cana-de-açúcar cultivada com lodo de esgoto, vinhaça e adubos minerais. STAB: Açúcar, Álcool e Subprodutos, v. 24, p. 32-35, 2006.

CERMEÑO, Z. S. Estufas: instalações e manejo. Lisboa: Litexa, 1990.

COSTA, N. E.; RIBEIRO, M. C. C.; LIMA, J. S. S.; CARDOSO, A. A.; OLIVEIRA, G. L. Utilização de biofertilizante na alface para o sistema hidropônico floating. Revista Verde de Agroecologia e Desenvolvimento Sustentável, v. 1, p. 41-47, 2006.

CHIBA, M. K. Uso de lodo de esgoto na cana-de-açúcar como fonte de nitrogênio e fósforo:parâmetros de fertilidade do solo, nutrição da planta e rendimentos da cultura. 2005. 142f. Tese (Doutorado) - Escola Superior de Agricultura Luiz de Queiroz, Piracicaba, 2005. 
EMPRESA BRASILEIRA DE PESQUISA AGROPECUÁRIA - EMBRAPA. Centro Nacional de Pesquisa de Solos. Sistema brasileiro de classificação de solos. Rio de Janeiro: Embrapa CNPS, 2006.

EMPRESA BRASILEIRA DE PESQUISA AGROPECUÁRIA - EMBRAPA. Manual de análises químicas de solos, plantas e fertilizantes. 2. ed. Brasília, DF: Embrapa Informação Tecnológica, 2009.

FRANKLIN, R. Land application of sewage sludge. Clemson: Clemson University, Faculty of Soils and Land Resources. 2004.16 p.

GADELHA R. S. S.; CELESTINO R. C. A.; SHIMOYA, A. Efeito da utilização de urina de vaca na produção da alface. Pesquisa Agropecuária \& Desenvolvimento Sustentável, v. 1, p. 179-182, 2003.

GAJDOS, E.; LÉVAI, L.; VERES, S.; KOVÁCS, B. Effects of biofertilizers on maize and sunflower seedlings under cadmium stress. Communications in Soil Science and Plant Analysis, v. 43, p. 272-279, 2012. http://dx.doi.org/10.1080/00103624.2011.638591

GARCÍA-MARTÍNEZ, S.; GRAU, A.; AGULLÓ, E.; BUSTAMANTE, M. A.; PAREDES, C.; MORAL, R. et al. Use of composts derived from winery wastes in tomato crop. Communications in Soil Science and Plant Analysis, v. 40, p. 445-452, 2009. http://dx.doi.org/10.1080/00103620802695099

KIEHL, E. J. Manual de compostagem: maturação e qualidade do composto. Piracicaba: E. J. Kiehl, 1998.

LOPES, J. C.; RIBEIRO, L. G.; ARAÚJO, M. G.; BERALDO, M. R. B. S. Produção de alface com doses de lodo de esgoto. Horticultura Brasileira, v. 23, p. 143-147, 2005. http://dx.doi.org/10.1590/S0102-05362005000100030

MALAVOLTA, E. Avaliação nutricional das plantas: princípios e aplicação. 2. ed. Piracicaba: [s.n.],1997.

MARTINS, C. M.; MEDEIROS, J. F.; LOPES, W. A. R.; BRAGA, D. F.; AMORIM, L. B. Curva de absorção de nutrientes em alface hidropônica. Revista Caatinga, v. 22, p. 123-128, 2009.

ORRICO, A. C. A.; ORRICO JÚNIOR, M. A. P.; DE LUCAS JÚNIOR, J. Biodigestão anaeróbia dos dejetos de cabritos Saanem alimentados com dietas com diferentes proporções volumoso e concentrado. Revista Brasileira de Zootecnia, v. 40, p. 448453, 2011. http://dx.doi.org/10.1590/S1516-35982011000200029

ORTEGA, K.; CAZETTA, J. O. Crescimento inicial de planta de cana-de-açúcar fertilizada com concentrado de vinhaça biodigerida. Suplemento Ciência \& Tecnologia: FATEC-JB, Jaboticabal, v. 3, 2011.

RODRIGUES, E. T.; CASALI, V. W. Resposta da alface à adubação orgânica. II. Teores, conteúdos e utilização de macronutrientes em cultivares. Revista Ceres, v. 45, p. 437449, 1998.

SANTOS, C. M.; GONÇALVES, E. R.; ENDRES, L.; GOMES, T. C. A.; JADOSKI, C. J.; NASCIMENTO, L. A. et al. Atividade fotossintética em alface (Lactuca sativa L.) submetidas a diferentes compostagens de resíduos agroindustriais. Pesquisa Aplicada \& Agrotecnologia, v. 3, n. 3, p. 95-102, 2010. 
STATISTICAL ANALYSIS SYSTEM INSTITUTE. SAS/STAT Procedure guide for personal computer. Version 5. Cary, NC, 1999.

SIMEONI, L. A.; BRABARICK, K. A.; SABEY, B. R. Effect of a small-scale composting of sewage sludge on heavy metal availability to plants. Journal Environmental Quality, v. 13, n. 2, p. 264-268, 1984.

http://dx.doi.org/10.2134/jeq1984.00472425001300020018x

SOUZA JÚNIOR, I. G.; COSTA, A. C. S.; VILAR, C. C.; HOEPERS, A. Mineralogia e susceptibilidade magnética dos óxidos de ferro do horizonte $\mathrm{B}$ de solos do Estado do Paraná. Ciência Rural, v. 40, n. 3, p. 513-519, 2010. http://dx.doi.org/10.1590/S010384782010000300003

SZYMANSKI, M. S. E.; BALBINOT, R.; NAGEL, W. Biodigestão anaeróbia da vinhaça: aproveitamento energético do biogás e obtenção de créditos de carbono - estudo de caso. Revista Semina: Ciências agrárias, v. 31, n. 4, p. 901-912, 2010. http://dx.doi.org/10.5433/1679-0359.2010v31n4p901

VIGGIANO, J. Produção de sementes de alface. In: CASTELLANE, P. D.; NICOLOSI, W. M.; HASEGAWA, M. (Coord.). Produção de sementes de hortaliças. Jaboticabal: FCAV/FUNEP, 1990. p. 1-13. 


Ambiente \& Água - An Interdisciplinary Journal of Applied Science
ISSN 1980-993X - doi:10.4136/1980-993X
www.ambi-agua.net
E-mail: ambi-agua@agro.unitau.br

\title{
Characteristics of irrigation tube wells on major river flood plains in Bauchi State, Nigeria
}

\author{
doi: 10.4136/ambi-agua.1314
}

Received: 12 Feb. 2014; Accepted: 05 Sep. 2014

\author{
Abdullahi Abubakar Sadiq ${ }^{1 *}$; Sunusi Abubakar Amin ${ }^{1}$; Desa Ahmad ${ }^{2}$; \\ Baba Gana Umara ${ }^{3}$ \\ ${ }^{1}$ Abubakar Tafawa Balewa University (ATB), PMB 0248 Bauchi, Nigeria \\ Agricultural and Bioresource Engineering Department \\ ${ }^{2}$ Universiti Putra Malaysia, 43400 Selangor, DE, Malaysia \\ Department of Biological and Agricultural Engineering \\ ${ }^{3}$ University of Maiduguri, Nigeria \\ Department of Agricultural and Environmental Engineering \\ *Corresponding author: e-mail: asabdullahi@atbu.edu.ng, \\ sunusiabubakar@yahoo.com,desa@upm.edu.my,babazulum@yahoo.com
}

\begin{abstract}
Water for traditional irrigation on flood-plains in Bauchi State is obtained from the Jama'are, Gongola and Komadugu river systems. The plains are replenished during rainy season and farmers often drill wells to irrigate their farm lands. Wells are drilled by jetting techniques and most of the farmers' plots are less than 1 hectare. Well yield varies from 0.6 to 9.4 $\mathrm{Ls}^{-1}$ and water is drawn from a depth of $12 \mathrm{~m}$. From the mean yield, the results indicate higher water abstraction from tube wells located at Jama'are flood plains. The study recommended appropriately locating wells and greater investment in extension services in order to facilitate the growth of farmer associations.
\end{abstract}

Keywords: Fadama, groundwater, Jama'are, NFDP, Savannah.

\section{Características de poços artesianos de irrigação das planícies de inundação dos principais rios no Estado de Bauchi, Nigéria}

\section{RESUMO}

A água para irrigação tradicional nas planícies de inundação no Estado de Bauchi é obtida a partir de sistemas fluviais Jama'are, Gongola e Komadugu. As planícies são recarregadas durante a estação chuvosa e os produtores rurais muitas vezes perfuram poços para irrigar suas terras. Os poços são perfurados usando-se técnicas de jateamento e os talhões irrigados são em sua maioria menores do que 1 ha. $O$ rendimento dos poços varia de 0,6 a 9,4 $\mathrm{Ls}^{-1}$ e a água é obtida a uma profundidade de $12 \mathrm{~m}$. A partir do rendimento médio, os resultados indicam maior captação de água em poços tubulares localizados nas planícies de inundação do Jama'are. O estudo recomenda a adequada implantação dos poços e a ampliação do serviço de extensão para facilitar o crescimento das associações de produtores.

Palavras-chave: águas subterrâneas, Fadama, Jama'are, NFDP, Savana. 


\section{INTRODUCTION}

Agriculture is the economic mainstay of most rural households in Nigeria and is a significant sector in the Nigerian economy. The important benefits of the agricultural sector to Nigeria's economy include: provision of food, contribution to the gross domestic product (GDP), provision of employment, provision of raw materials to agro-allied industries and generation of foreign exchange. Indeed, the rural sector employs nearly half of the country's labor force and accounts for up to 5\% of its total exports (Yahaya, 2002).

Unfortunately, these areas are also home to more than $70 \%$ of the nation's poor. Income and productivity in rural areas are stagnant and low. Farming practices are predominantly at the subsistence level and depend on the vagaries of weather for most of the year. Crop growth is limited by soil salinity and water scarcity, especially in areas with shallow groundwater. The water flowing upward from the groundwater into the root-zone plays an important role by contributing to the water needs of plants in the presence of shallow water tables (Xie et al., 2011).

With abundant land and water resources, the Nigerian agricultural sector has a high potential for growth. This prompted the federal government to institute several plans and programs to enhance the country's agricultural productivity. Some of these programs include the National Accelerated Food Production Program, Operation Feed the Nation, Green Revolution and, of course, the National Fadama Projects (BSADP, 2007). The most recent of these efforts is the National Fadama Development Program (NFDP). The Fadama Irrigation plan is one of the World Bank assisted programs that operated between 1993 and 2010.

The total irrigation potential in Nigeria is estimated at 2.0 million hectare, of which less than 900,000 hectares are currently under irrigation. An estimated $70 \%$ of this potential is in the northern part of the country and about $20 \%$ in the humid south, with the balance in the highland areas of central and western Nigeria. Fadama lands account for about 0.94 million hectares of this potential irrigable land (Takeshima et al., 2010).

Bauchi participated in both NFDP I and II. Farmers often drill shallow wells in the fadama areas for irrigation. Replenishment for these wells is either from the Jama'are, Gongola or Komadugu river systems. Farmers often drill their wells with the aim of maximizing production and thereby generating greater revenue by bringing more land under production. This is often done with no consideration to the inherent pumping capacity of the well, which may subject the wells to excessive pressure through over-extraction. This practice has an adverse effect on the ecosystem.

Accordingly, many studies have shown that irrigation systems are not used as their designers had intended (Ahmad et al., 2009; Kumar et al., 2010). This study investigated some of the characteristics of tube wells on two river system flood-plains.

\section{MATERIALS AND METHODS}

\subsection{Study Area}

The study was conducted in 2007 in eleven of twenty Local Government Areas (LGA's) of Bauchi State, Nigeria. A total of twenty-four villages were considered from the North, South and Central Senatorial zones (Figure 1).

Topographically, Bauchi State is generally divided into two main vegetation zones: the Sudan Savannah in the North and the Sahel Savannah in the South and East. Annual rainfall is about $700 \mathrm{~mm}$ in the Sudan Savannah zone and about $1300 \mathrm{~mm}$ in the Sahel Savannah. 


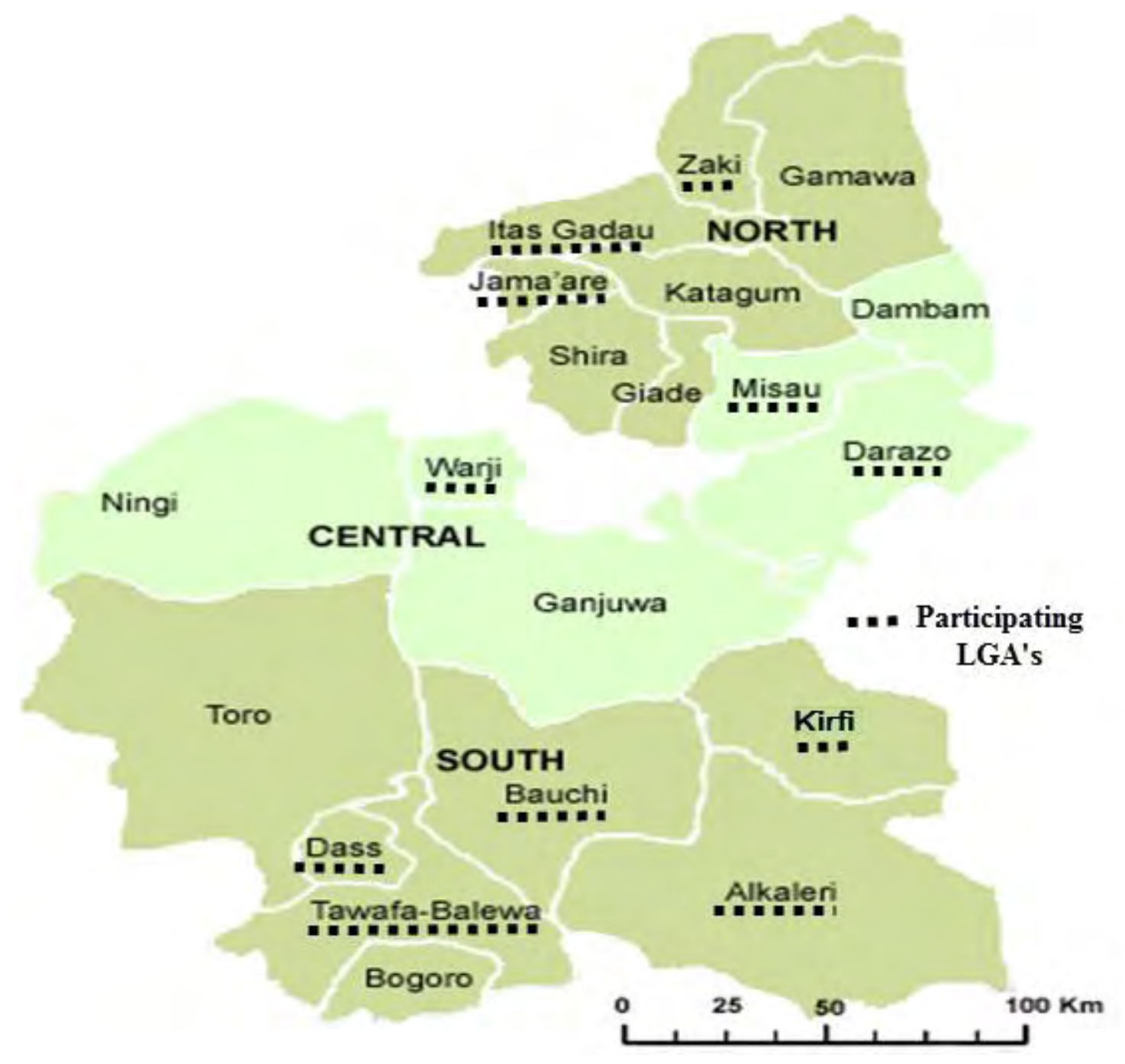

Figure 1. Study locations from Eleven Local Government Areas in Bauchi State. source: Adapted from Google Maps.

The state is located between longitude $8^{\circ} 45^{\prime \prime}$ and $11^{\circ} 45 \mathrm{E}$, and latitude $9^{\circ} 30^{\prime \prime}$ and $12^{\circ} 30^{\prime \prime} \mathrm{N}$. It covers a total land area of $49,259.01 \mathrm{~km}^{2}$ representing $5.3 \%$ of Nigeria's total land. Bauchi State is bordered by seven states, Kano and Jigawa States to the North, Gombe and Yobe States to the East, Taraba and Plateau States to the South and Kaduna State to the West. The climate of the state is generally tropical, with distinct wet and dry seasons. Rainfall in the State shows a marked variation between $1300 \mathrm{~mm}$ per year in the south and only 700 mm per year in the extreme north (BSADP, 2007). Rainfall is concentrated in a short wet season which extends from May to October, while the dry season lasts more than 5 months (with no rain whatsoever). The periods of the wet and dry seasons may vary depending on the prevailing winds blowing across the country at different times of the year.

\subsection{Fadama lands}

"Fadama" are flood plains and low lying areas underlined by shallow aquifers found along Nigeria's river system (World Bank, 2001). These river valley areas are seasonally flooded or that have high water tables for all or most of the year. Fadama irrigation is an ageold tradition in the Nigerian Hausa land, and the season flooding of the valley's bottom allows for the growth of a variety of crops with small-scale irrigation (Yahaya, 2002).

The National Fadama Development Program (NFDP) was designed to assist some of the Federation's States through the World Bank-supported Agricultural Development Program 
(ADP) network. The assistance varies, but may include: financing the provision of shallow tube wells in Fadama lands for small-scale irrigation; simplifying drilling technologies for shallow tube wells; constructing Fadama infrastructure; organizing Fadama farmers for irrigation management, cost recovery and better access to credit, marketing and other services; and the provision of vehicles, pumps and other equipment (Ayanwale and Alimi, 2004).

More specifically, the government's involvement in NFDP and the National Program of Food Security (NPFS) has consisted mostly of providing financial assistance to farmers for acquiring irrigation equipment, to include pumps, tube wells and wash bores (Takeshima et al., 2010).

\subsection{River systems in Bauchi State}

There are three river systems connected to Bauchi State: the Gongola, the Jama'are and the Komadugu. The Gongola River crosses Bauchi State in the Tafawa Balewa Local Government Area in the south and in the Kirfi and Alkaleri Local Government Areas in the east, while the Jama'are River cuts across a number of Local Government Areas in the north.

Moreover, a substantial part of the Hadeja-Jama'are River Basin lies in Bauchi State, which along with various fadama (floodplain) areas in the state provides suitable land for agriculture. Irrigation and grazing along the flood plains (Fadama lands) occur throughout the dry season. Tube wells are replenished mainly from these river systems. In addition to rainfall, Bauchi State receives water from a number of minor rivers (Figure 2). These small rivers are mainly concentrated in the northern part of the State, located at $11^{0} 40^{\prime} \mathrm{N}, 09^{0} 56^{\prime} \mathrm{E}$.

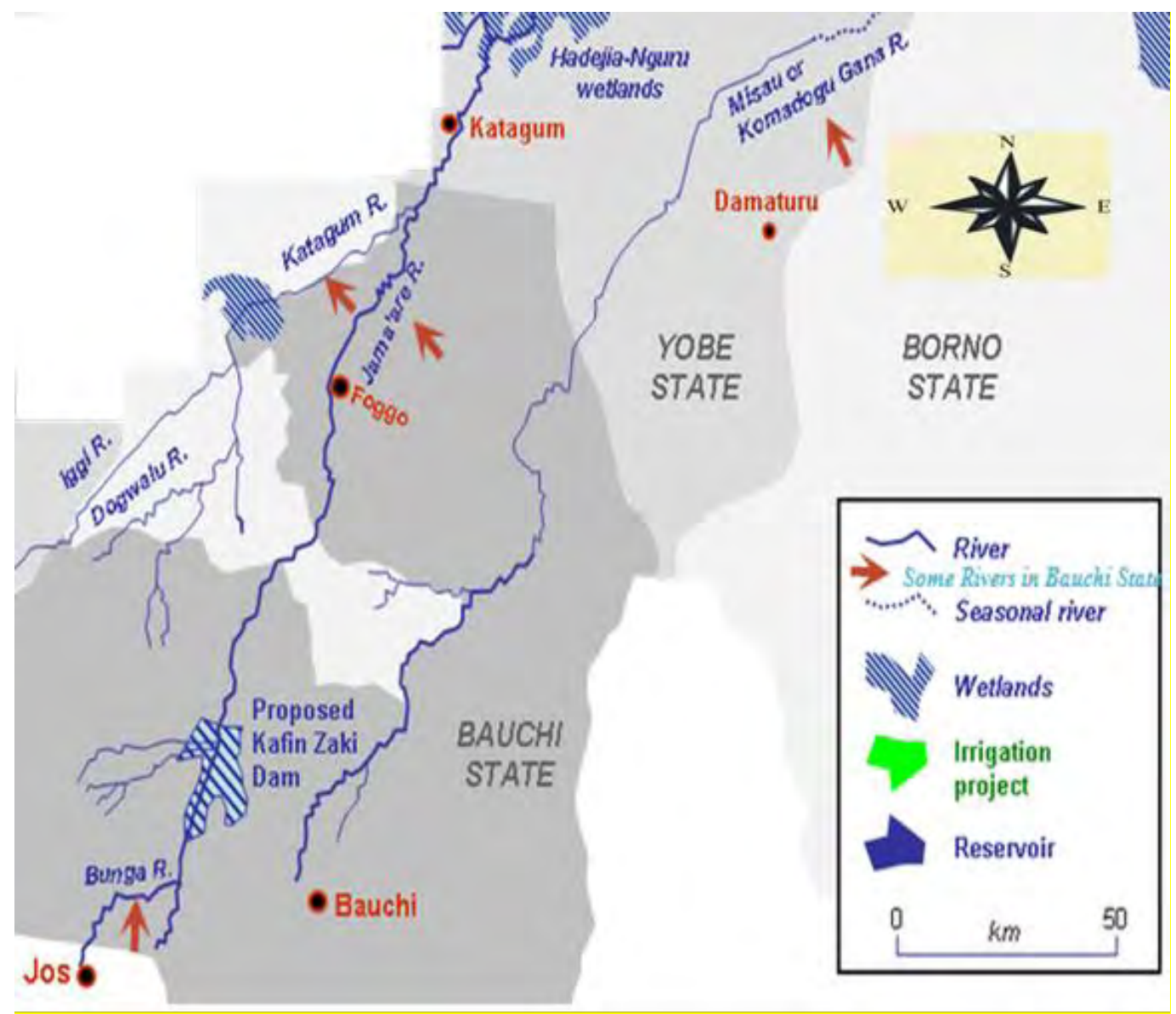

Figure 2. The Komadugu, Jama'are, Katagum and Bunga Rivers in the Northern part of Bauchi State.

Source: Adapted from Google Maps. 
In this study, twenty-five tube wells were selected from the Jama'are and the Gongola River floodplains, 10 and 15 wells respectively. Well parameters such as location, static water level, depth, and discharge were recorded. Tube well recovery was measured during the test pumping. A comparison was done on well performance based on the well's location and the river system.

\section{RESULTS AND DISCUSSION}

Table 1 indicates the characteristics (static water table, well depth, well discharge and well recovery) of tube wells on the Jama'are river system floodplain. The wells' yields are in the range of 0.5 to $6.0 \mathrm{~L} \mathrm{~s}^{-1}$ and water is obtained at a depth of up to $12 \mathrm{~m}$. Several factors may attribute to well performance, most importantly the climatic condition of Local Government Areas. Wells located in the northern part of the State have a limited annual rainfall of $<400$ $\mathrm{mm}$ /annum, while those in the southern part record up to $700 \mathrm{~mm} /$ annum.

Table 1. Irrigation well characteristics of the Jama'are River Floodplain.

\begin{tabular}{|c|c|c|c|c|c|c|}
\hline $\begin{array}{l}\text { Local Govt. } \\
\text { Area }\end{array}$ & Village Name & Well Coordinates & $\begin{array}{c}\text { Static Water } \\
\text { Level (m) }\end{array}$ & $\begin{array}{l}\text { Well Depth } \\
\text { (m) }\end{array}$ & $\begin{array}{l}\text { Discharge, } \\
\mathbf{Q}\left(\mathbf{L ~ s}^{-1}\right)\end{array}$ & $\begin{array}{c}\text { Recovery, } R \\
(\%)\end{array}$ \\
\hline \multirow[t]{2}{*}{ Itas Gadau } & Kashuwa & $\begin{array}{l}11^{0} 45^{\prime} 18.5^{\prime \prime} \mathrm{N} \\
09^{0} 58^{\prime \prime} 45.4^{\prime \prime} \mathrm{E}\end{array}$ & 2.32 & 5.05 & 4.85 & - \\
\hline & Gadau & $\begin{array}{l}11^{0} 5306.5 ” \mathrm{~N} \\
10^{0} 0823.9 " \mathrm{E}\end{array}$ & 3.22 & 12.5 & 4.12 & - \\
\hline \multirow[t]{3}{*}{ Jama'are } & Dogonjeji & $\begin{array}{l}11^{0} 44^{\prime} 40.9^{\prime \prime} \mathrm{N} \\
09^{0} 5845.5^{\prime \prime} \mathrm{E}\end{array}$ & 2.73 & 7.53 & 5.54 & - \\
\hline & Jama'are & $\begin{array}{l}11^{0} 4004.3^{\prime \prime} \mathrm{N} \\
09^{0} 566^{\prime} 44.4^{\prime \prime} \mathrm{E}\end{array}$ & 3.66 & 7.05 & 6.05 & - \\
\hline & Yerima & $\begin{array}{l}11^{0} 17^{\prime} 17.9 " \mathrm{~N} \\
10^{0} 2811.0 \mathrm{E}\end{array}$ & 5.55 & 8.84 & 0.45 & 73 \\
\hline \multirow[t]{2}{*}{ Shira } & Ganuwa & $\begin{array}{l}11^{0} 37^{\prime} 56.5 ” \mathrm{~N} \\
09^{0} 566^{\prime} 43.3 " \mathrm{E}\end{array}$ & 2.97 & 8.35 & 4.44 & - \\
\hline & Disina & $\begin{array}{l}11^{0} 3012.5^{\prime} \mathrm{N} \\
09^{0} 55^{\prime} 49.9^{\prime \prime} \mathrm{E}\end{array}$ & 3.72 & 7.28 & 5.12 & - \\
\hline Warji & Disa & $\begin{array}{l}11^{0} 05^{\prime} 49.9^{\prime \prime} \mathrm{N} \\
09^{0} 39^{\prime} 41.4^{\prime \prime} \mathrm{E}\end{array}$ & 2.64 & 6.35 & 4.80 & 90 \\
\hline \multirow[t]{2}{*}{ Zaki } & Katagum & $\begin{array}{l}12^{0} 17^{\prime} 10.4^{\prime \prime} \mathrm{N} \\
10^{0} 2152.5^{\prime} \mathrm{E}\end{array}$ & 5.62 & 11.6 & 1.50 & 72 \\
\hline & Chibiyayi & $\begin{array}{l}11^{0} 599^{\prime} 47.5^{\prime \prime} \mathrm{N} \\
10^{0} 11^{\prime} 50.2^{\prime \prime} \mathrm{E}\end{array}$ & 4.82 & 12.23 & 2.32 & - \\
\hline Mean & & & 3.73 & 8.68 & 3.92 & \\
\hline
\end{tabular}

The Jama'are is a source of replenishment for minor rivers in the northern part of the state (Figure 3). Wells are drilled to a depth of about $8 \mathrm{~m}$ and the high yield $\left(4.0 \mathrm{~L} \mathrm{~s}^{-1}\right)$ has attracted more farmers and herdsmen to the area. The study also found that most villages near the rivers are involved in irrigation for subsistence during the dry season. 
Table 2 is the result of tube well parameters in eastern and southern parts of Bauchi State. Yields of wells are between 1.6 to $9.4 \mathrm{~L} \mathrm{~s}^{-1}$ and water is available at a depth of $10 \mathrm{~m}$ (Figure 3).

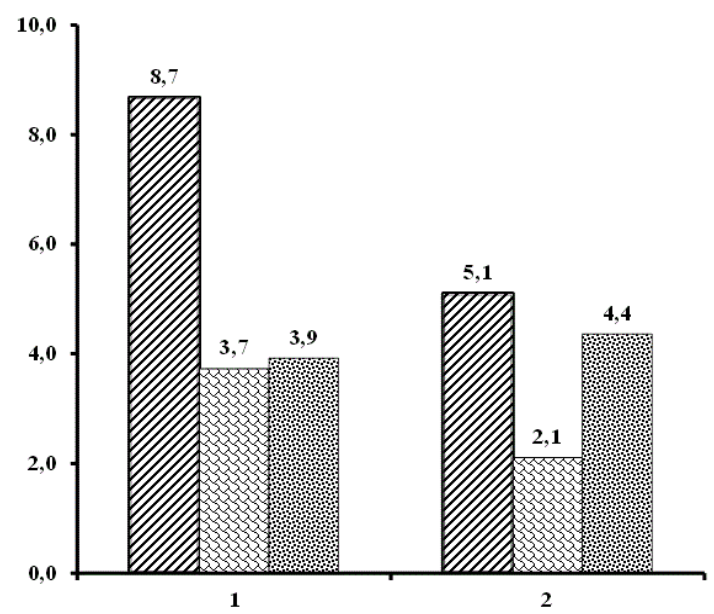

Figure 3. Mean.depth, Static water level (m) and Discharge $\left(\mathrm{Ls}^{-1}\right)$ of Tube wells on Floodplains.

Table 2. Irrigation well characteristics of the Gongola River Floodplain.

\begin{tabular}{|c|c|c|c|c|c|c|}
\hline $\begin{array}{l}\text { Local Govt. } \\
\text { Area }\end{array}$ & $\begin{array}{l}\text { Village } \\
\text { Name }\end{array}$ & Well Coordinates & $\begin{array}{c}\text { Static } \\
\text { Water } \\
\text { Level }(\mathbf{m})\end{array}$ & $\begin{array}{c}\text { Well } \\
\text { Depth (m) }\end{array}$ & $\begin{array}{c}\text { Discharge, } Q \\
\quad\left(\mathrm{~L} \mathrm{~s}^{-1}\right)\end{array}$ & $\begin{array}{c}\text { Recovery, } \mathbf{R} \\
(\%)\end{array}$ \\
\hline \multirow[t]{3}{*}{ Alkaleri } & Fanti & $\begin{array}{l}10^{0} 03,51.1{ }^{\circ} \mathrm{N} \\
10^{0} 16^{4} 41.5 \mathrm{E}\end{array}$ & 2.06 & 2.68 & 1.66 & 100 \\
\hline & Duguri & $\begin{array}{l}10^{0} 16^{\prime} 19.9 ” \mathrm{~N} \\
09^{0} 48^{\prime} 02.4 ” \mathrm{E}\end{array}$ & 1.80 & 4.84 & 4.40 & - \\
\hline & Mainamaji & $\begin{array}{l}10^{0} 03,56.2 " \mathrm{~N} \\
10^{0} 1800.5 " \mathrm{E}\end{array}$ & 2.23 & 5.25 & 6.3 & 82 \\
\hline \multirow[t]{2}{*}{ Bauchi } & Zungur & $\begin{array}{l}09^{0} 58^{\prime} 44.7^{\prime \prime} \mathrm{N} \\
09^{0} 46^{\prime} 31.8^{\prime \prime} \mathrm{E}\end{array}$ & 3.3 & 5.93 & 5.40 & - \\
\hline & Zungur & $\begin{array}{l}09^{0} 58,50.3 " \mathrm{~N} \\
09^{0} 46^{\prime} 40.6^{\prime \prime} \mathrm{E}\end{array}$ & 2.73 & 3.06 & 4.30 & - \\
\hline \multirow[t]{3}{*}{ Dass } & Bagel & $\begin{array}{l}10^{0} 02 \text { '35.3”"N } \\
09^{0} 36 \text { ' 25.8"E }\end{array}$ & 3.00 & 6.00 & 5.47 & - \\
\hline & Kagadama & $\begin{array}{l}10^{0} 10,13.0 " \mathrm{~N} \\
09^{0} 3359.11 \mathrm{E}\end{array}$ & 1.89 & 3.78 & 6.20 & 71 \\
\hline & Wandi & $\begin{array}{l}09^{0} 58,52.2^{\prime \prime} \mathrm{N} \\
09^{0} 30,19.8 ” \mathrm{E}\end{array}$ & 3.00 & 6.93 & 1.82 & 75 \\
\hline Darazo & Tauya & 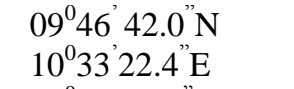 & 2.34 & 5.96 & 2.79 & 88 \\
\hline \multirow[t]{3}{*}{ Kirfi } & Badara & $\begin{array}{l}10^{0} 21^{\prime} 25.5^{\prime \prime} \mathrm{N} \\
10^{0} 20^{\prime} 09.1^{\prime \prime} \mathrm{E}\end{array}$ & 2.81 & 4.08 & 2.08 & 87 \\
\hline & Bara & $\begin{array}{l}10^{0} 21^{\prime} 33.0^{\prime \prime N} \\
10^{0} 46^{\prime} 18.77^{\prime \prime E}\end{array}$ & 0.65 & 2.4 & 2.10 & - \\
\hline & Boli & $\begin{array}{l}10^{0} 32,47.4^{\prime \prime} \mathrm{N} \\
10^{0} 27^{\prime} 11.0^{\prime \prime} \mathrm{E}\end{array}$ & 1.72 & 9.43 & 9.43 & - \\
\hline \multirow[t]{3}{*}{$\begin{array}{l}\text { Tafawa } \\
\text { Balewa }\end{array}$} & Burwat & $\begin{array}{l}09^{0} 49^{\prime} 04.3^{\prime \prime N} \\
09^{0} 51^{\prime} 15.4^{\prime \prime} \mathrm{E}\end{array}$ & 1.72 & 6.84 & 4.85 & - \\
\hline & Dajin & $\begin{array}{l}10^{0} 01,37.9 " \mathrm{~N} \\
09^{0} 3825.6^{\prime \prime} \mathrm{E}\end{array}$ & 1.03 & 5.35 & 6.10 & - \\
\hline & Gori & $\begin{array}{l}09^{0} 51^{\prime} 36.1^{\prime \prime} \mathrm{N} \\
09^{0} 26^{\prime} 10.6^{\prime \prime} \mathrm{E}\end{array}$ & 1.28 & 3.97 & 2.40 & 77 \\
\hline Mean & & & 2.29 & 5.36 & 4.59 & \\
\hline
\end{tabular}


These sites have a shallower static water level $(2-7 \mathrm{~m})$ compared to wells on other floodplains in the state. The average depth and yield from all the study locations was 5.4 to $8.7 \mathrm{~m}$ and $4.6 \mathrm{~L} \mathrm{~s}^{-1}$ respectively.

\section{CONCLUSIONS}

The study revealed that tube wells along the floodplains are replenished by the Jama'are and the Gongola river systems. All of the pumping tests indicated a high yield recovery percentage. A yield recovery of 71 - $100 \%$ was obtained from some wells during the study. From a water conservation perspective, groundwater irrigation may be most favorable on a small-scale level. Many farmers prefer groundwater for the flexibility it allows in irrigation, among other reasons.

Since groundwater is accessible to many farmers and does not always require collective action, less capital and planning is required for implementation as compared to large gravity irrigation projects (Kazmi et al., 2012).

Appropriate well location is essential in such a small holder irrigation plan. This will promote the longevity of well usage despite a growing population in the state. Extension services will promote the cooperation of farmers so that water user groups (WUG), irrigation associations, and other useful organizations may be established

\section{REFERENCES}

AHMAD, M. D.; TURRAL, H.; NAZEER, A. Diagnosing irrigation performance and water productivity through satellite remote sensing and secondary data in a large irrigation system of Pakistan. Agricultural Water Management v. 96, p. 551-564, 2009. http://dx.doi.org/10.1016/j.agwat.2008.09.017

AYANWALE A. B.; ALIMI, T. The impact of the National Fadama facility in alleviating rural poverty and enhancing agricultural development in south-western Nigeria. Journal of Social Sciences, v. 9, n. 3, p. 157-161, 2004.

BAUCHI STATE AGRICULTURAL DEVELOPMENT PROGRAMME - BSADP. Bauchi state Fadama III project environmental baseline survey. 2007. Available in: http://www.fadama.net/html/index.php. Access: 13 Jan. 2014.

KAZMI, I. S.; ERTSENA, M. W.; ASI, M. R. The impact of conjunctive use of canal and tube well water in Lagar irrigated area, Pakistan. Physics and Chemistry of the Earth, v. 47-48, p. 86-98, 2012. http://dx.doi.org/10.1016/j.pce.2012.01.001.

KUMAR, R.; SHUKLA, N.; NIGAM, D. P.; VERMA, V. K. Modernizing Sarda Sahayak canal system: the Masscote approach. Irrigation and Drainage, v. 59, p. 53-75, 2010. http://dx.doi.org/10.1002/ird.554

TAKESHIMA, H.; ADEOTI, A.; OKOLI, S.; SALAU, S.; RHOE, V. Demand characteristics for small-scale private irrigation technologies: knowledge gaps in Nigeria. Abuja: IFPRI, 2010. (Working Paper, n. 0018).

WORLD BANK. Nigeria National Fadama development program II: proposal for Project Development Fund (PDF), Block B Grant. 2001. Available in: www.gefonline.org. Access: 13 Jan. 2014. 
XIE, T.; LIU, X.; SUN, T. The effects of groundwater table and flood irrigation strategies on soil water and salt dynamics and reed water use in the Yellow River Delta, China. $\begin{array}{llllll}\text { Ecological Modelling, } & \text { v. 222, } & \text { p. }\end{array}$ http://dx.doi.org/10.1016/j.ecolmodel.2010.01.012

YAHAYA, M. K. Development and challenges of Bakolori irrigation project in Sokoto State, Nigeria. Nordic Journal of African Studies, v. 11, n. 3, p. 411-430, 2002. 


Ambiente \& Água - An Interdisciplinary Journal of Applied Science
ISSN 1980-993X - doi:10.4136/1980-993X
www.ambi-agua.net
E-mail: ambi-agua@agro.unitau.br

\title{
Identification of volatile organic compounds (VOCs) in plastic products using gas chromatography and mass spectrometry (GC/MS)
}

\author{
doi: 10.4136/ambi-agua.1435
}

Received: 19 Jun. 2014; Accepted: 19 Sep. 2014

\author{
Nerlis Pajaro-Castro; Karina Caballero-Gallardo; Jesus Olivero-Verbel \\ Environmental and Computational Chemistry Group, School of Pharmaceutical Sciences, \\ University of Cartagena, Cartagena, Colombia \\ *Corresponding author: e-mail: joliverov@unicartagena.edu.co, \\ npajaroc@unicartagena.edu.co,kcaballerog@unicartagena.edu.co
}

\begin{abstract}
Plastic materials are widely used in daily life. They contain a wide range of compounds with low molecular mass, including monomeric and oligomeric residues of polymerization, solvent-related chemicals residues, and various additives. Plastic products made of expanded polystyrene (EPS) are currently employed as food containers. This study therefore sought to identify volatile organic compounds released by EPS from food packages and utensils used in Cartagena, Colombia. EPS-based plates, food and soup containers were subjected to various temperatures and released chemicals captured by solid phase microextraction, followed by on-column thermal desorption and gas chromatography/mass spectrometry analysis. The results revealed the presence of at least 30 different compounds in the EPS-based products examined; the most frequently found were benzaldehyde, styrene, ethylbenzene and tetradecane. The release of these molecules was temperature-dependent. It is therefore advisable to regulate the use of EPS products which may be subjected to heating in order to protect human health by decreasing the exposure to these chemicals.
\end{abstract}

Keywords: additives, expanded polystyrene (EPS), solid-phase microextraction (SPME), styrene.

\section{Identificação de compostos orgânicos voláteis (COVs) em produtos plásticos por cromatografia gasosa acoplada a espectrometria de massa (CG/MS)}

\section{RESUMO}

Os materiais plásticos são amplamente usados na vida quotidiana. Eles contêm uma grande variedade de compostos de baixa massa molecular, incluindo os resíduos monoméricos e oligoméricos de polimerização, relacionados com resíduos de solventes químicos, e diferentes aditivos. Atualmente, os produtos de poliestireno expandido (EPS) são empregados como recipientes para alimentos. Assim, o objetivo deste estudo foi identificar os compostos orgânicos voláteis liberados por objetos utilizados diretamente em contato com alimentos disponíveis em Cartagena, Colômbia. Produtos baseados em EPS tais como pratos, recipientes para alimentos e sopa foram submetidos a diferentes temperaturas de aquecimento e as substâncias químicas liberadas foram capturadas empregando-se a técnica de 
microextração em fase sólida, seguida de dessorção térmica e análise por cromatografia a gás/espectrometria de massa. Os resultados revelaram a presença de pelo menos 30 compostos diferentes relacionados aos produtos de EPS examinados, sendo o benzaldeído, estireno, etilbenzeno e tetradecano os mais frequentemente encontrados. A liberação dessas moléculas é dependente da temperatura a que o material é submetido. Portanto, para proteger a saúde humana, diminuindo a exposição a estes agentes químicos, é aconselhável regular o uso de produtos a base de EPS que poderão ser submetidos a aquecimento.

Palavras-chave: aditivos, estireno, micro extração em fase sólida (SPME), poliestireno expandido (EPS).

\section{INTRODUCTION}

The importance of plastic materials for many everyday life applications has increased steadily in recent years (Buchberger and Stiftinger, 2012). Manufactured products made of polymers are generally complex materials, composed of polymers or copolymers, with a variety of additives with different volatilities (Wampler, 2004). Currently, expanded polystyrene (EPS), used to make styrofoam containers, is the most widely used plastic in several countries; in fact, over 30 countries have signed an international agreement to maximize reuse and recycling of EPS (Kusch and Knupp, 2002; De Paula Pereira et al., 2004). These products are obtained by the polymerization of styrene monomer with the addition of pentane as blowing agent (Kusch and Knupp, 2002). Polystyrene is easy to manufacture, fragile, and softens at a temperature of approximately $100{ }^{\circ} \mathrm{C}$, although it may degrade at elevated temperatures in a mixture of low organic molecular mass compounds. In addition, this material contains in its formulation antioxidants, UV stabilizers, lubricants, antistatic agents, plasticizers, and flame retardants (Smith and Taylor, 2002; Lattuati-Derieux et al., 2013).

Among a large number of uses, EPS is employed for food packaging, product protection from damage during transport and storage, as well as for the building industry in the insulation of exterior walls and foundations (Kusch and Knupp, 2002; Shah et al., 2008). Under certain conditions, polystyrene is able to release residual styrene monomer, and other volatile organic compounds (VOCs) at room temperature (Garrigós et al., 2004), including pentane, benzene, toluene, ethylbenzene, xylene isomers, n-propylbenzene, 1,2,4-trimethylbenzene, o-methylstyrene, benzaldehyde, benzyl alcohol, and acetophenone, among others (Kusch and Knupp, 2002; Kusch and Knupp, 2004). These compounds, known environmental pollutants that affect air quality and human health (Lee et al., 2006; Wang et al., 2007), have the capacity of inducing deleterious effects on the mucous membranes of the nose, eyes, throat, skin the face, neck and hands, upper and lower airways (Yorifuji et al., 2012).

Styrene is one of the main compounds released from EPS products, and has been classified as a possible human carcinogen (Group 2B) by the International Agency for Research on Cancer (IARC) (EU, 2014). Therefore, there is a concern about the potential carcinogenicity of styrene, which comes largely from the ability of its metabolite, styrene-7,8-oxide (SO), to bind covalently to DNA, and its activity in a variety of genotoxicity tests. This chemical has also been classified by IARC in Group 2A, as probably carcinogenic to humans (Rueff et al., 2009). Styrene is harmful if inhaled, causing tissue irritation and neurological impairment (Kusch and Knupp, 2002). This study examined the release of VOCs from commercially available products made of EPS in Cartagena, Colombia, and discusses their probable impact on human health. 


\section{MATERIAL AND METHODS}

EPS-based samples of different types, including plates, food and soup containers, were obtained from local stores at Cartagena city. The plastic material was cut into small pieces

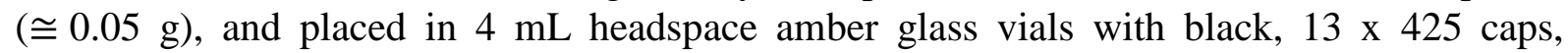
PTFE/silicone septum (Agilent Technologies, USA). Solid phase microextraction (SPME) was used for the extraction of analytes employing a $100 \mu \mathrm{m}$ polydimethylsiloxane (PDMS) fiber (Supelco, Bellefonte, PA, USA). SPME fibers were previously conditioned for 30 minutes at $250{ }^{\circ} \mathrm{C}$ and then placed into the vials containing the samples. These vials were then heated at specific temperatures $\left(55-85^{\circ} \mathrm{C}\right.$, increasing $\left.10^{\circ} \mathrm{C}\right)$ for $30 \mathrm{~min}$ to release chemicals. These temperatures were chosen taking into account the temperature of the food when placed in the container. Immediately after the extraction process, the SPME fiber was removed from the vial, and transferred into the injector of the gas chromatograph for complete thermal desorption, allowing the release and analysis of VOCs (Kusch and Knupp, 2004).

GC/MS analysis was carried out using an Agilent 7890A Gas Chromatograph coupled to an Agilent 5975C mass spectrometer equipped with an HP-5 capillary column, $30 \mathrm{~m}$ long, $0.25 \mu \mathrm{m}$ i.d., and a $0.25 \mu \mathrm{m}$ film thickness. The temperature of the column was programmed from $50{ }^{\circ} \mathrm{C}(2 \mathrm{~min})$ to $120{ }^{\circ} \mathrm{C}$, at a rate of $15{ }^{\circ} \mathrm{C}$ per minute, and the final ramp reached $300{ }^{\circ} \mathrm{C}$, at an increasing temperature rate of $5{ }^{\circ} \mathrm{C}$ per minute. Helium grade 5.0 was used as carrier gas at a flow rate of $1 \mathrm{~mL} /$ minute. Split/splitless (splitless mode) inlet temperature was $280{ }^{\circ} \mathrm{C}$ as was that of the mass spectrometry transfer line (Fu and Kawamura, 2010). The temperature of the ion source was maintained at $230{ }^{\circ} \mathrm{C}$. The mass spectrometer was operated under electron ionization mode at $70 \mathrm{eV}$. Mass spectra and the total ion chromatograms were obtained by automatic scanning a mass range $(\mathrm{m} / \mathrm{z})$ of $45-400$. Three runs per sample $(n=3)$ were performed. The volatile components were identified by comparing the mass spectrum with those available in the Nist08 spectra library. Chemical composition is reported as the percentage of relative area, after obtaining the sum of all peak areas in the chromatogram.

Data are presented as means \pm SD (Standard deviation). Comparisons between groups were achieved using ANOVA, with Dunnett's post-test. Data normality and equality of variances were previously checked by Kolmogorov-Smirnov and Barlett tests, respectively. Statistical analysis was performed with GraphPad 3.00.

\section{RESULTS AND DISCUSSION}

Chromatographic analysis of VOCs released by EPS products revealed the presence of at least 30 major common compounds (Table 1). Typical chromatograms are presented at two different extraction temperatures $\left(55^{\circ} \mathrm{C}\right.$ and $85{ }^{\circ} \mathrm{C}$ ) (Figure 1). At the highest tested temperature, $85{ }^{\circ} \mathrm{C}$, benzaldehyde, pentadecane, tetradecane, ethylbenzene, cumene, acetophenone, and styrene were released at least from $50 \%$ of all sampled materials. The relative frequency of these compounds is shown in Table 1. As expected, data showed the number of released compounds from EPS-based products and their abundance in the chromatogram is temperature-dependent (Table 1, Figure 2), with the greatest number of compounds released at the highest temperature. Several compounds released at $85{ }^{\circ} \mathrm{C}$, in particular high molecular mass alkanes, did not appear at lower temperatures, such as dodecane, tridecane, pentadecane, heptadecane, octadecane, and undecane, among others (Table 1). Interestingly, some chemicals that appeared at lower temperatures did not show up at higher temperatures. The differences in these chromatograms can be attributed, at least in part, to the use of different processing conditions, materials or additives during the manufacture of the products. 
Results presented here are similar to those reported by other authors that also showed that styrene monomer (De Paula Pereira et al., 2004) and other volatile organic compounds are released when EPS containers are heated, and therefore may be available to migrate into the food (Kusch and Knupp, 2002).
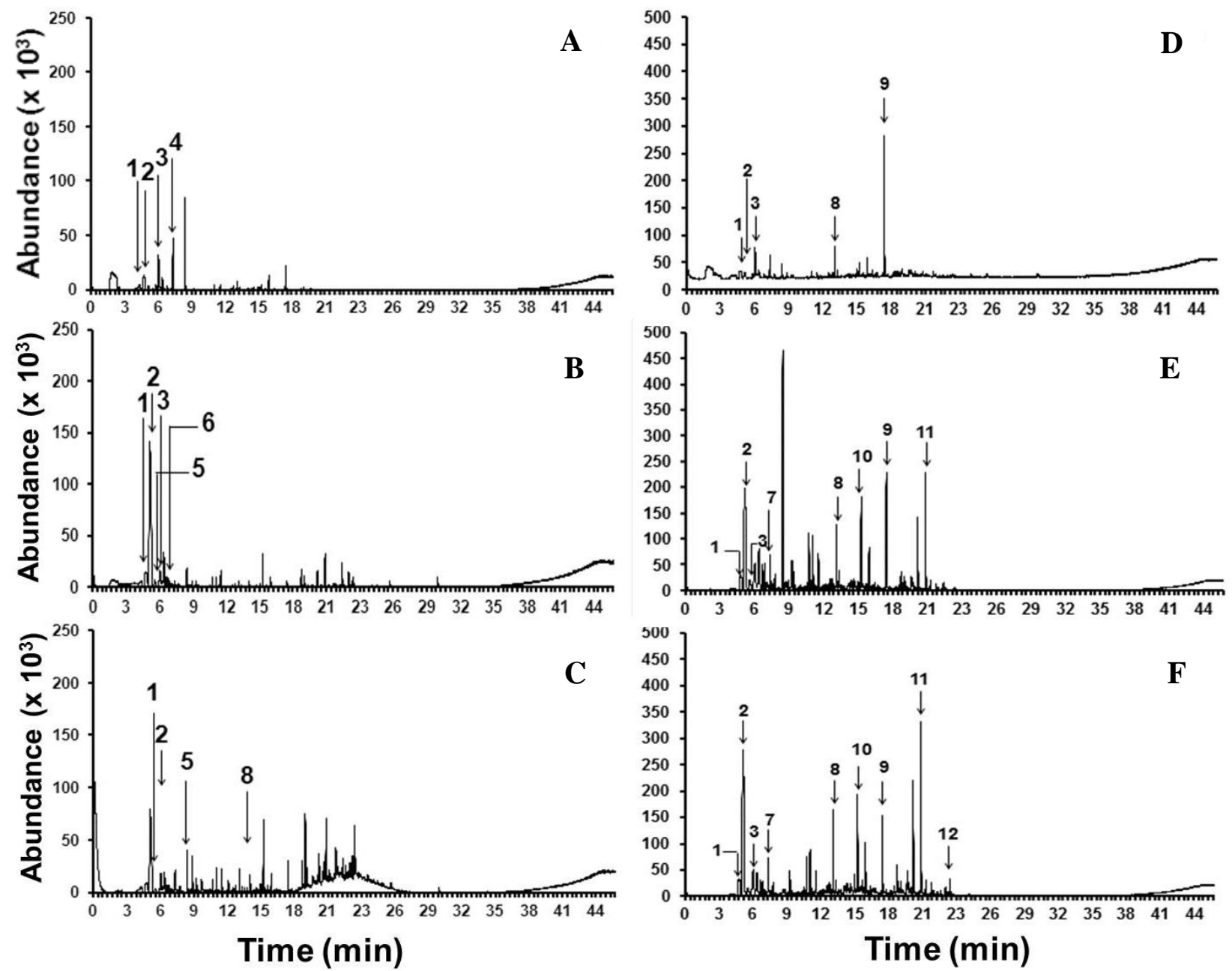

Figure 1. Typical SPME-GC/MS chromatograms of EPS-based products. Soup containers (A, D), food containers $(\mathbf{B}, \mathbf{E})$ and plates $(\mathbf{C}, \mathbf{F})$ at extraction temperatures of $55{ }^{\circ} \mathrm{C}$ and $85{ }^{\circ} \mathrm{C}$, respectively. 1. Ethylbenzene. 2. Styrene. 3. Benzaldehyde. 4. Benzene, (1,1-dimethylethoxy). 5. Cumene. 6. Benzene, (1-methylpropyl). 7. Acetophenone. 8. Tetradecane. 9. Diethyl Phthalate. 10. Pentadecane. 11. Benzene, 1,1'-(1,2-cyclobutanediyl)bis, trans. 12. Nonanal.

The presence of particular VOCs released from EPS has been related to the extraction conditions of the analytes (Kusch and Knupp, 2002). An increase in temperature leads to a raise the diffusion of small molecules in the polymer core, promoting the transfer of these compounds in the headspace phase (Vilaplana et al., 2010). At $55{ }^{\circ} \mathrm{C}$, on average, 19 compounds were detected from tested EPS-based products, whereas at $85{ }^{\circ} \mathrm{C}$ this number increased to 55 (Figure 2a). Moreover, the extraction temperature also determined the relative peak area of the compounds identified in the analyzed EPS-based products (Figure 2b). Kusch and Knupp (2002) also reported the influence of temperature on peak area, in agreement with these results. 
Table 1. Relative frequency of major components identified in EPS-based products at different extraction temperatures.

\begin{tabular}{|c|c|c|c|c|c|c|c|c|}
\hline \multirow{3}{*}{ Components } & \multicolumn{8}{|c|}{ Temperature $\left({ }^{\circ} \mathrm{C}\right)$} \\
\hline & \multicolumn{2}{|c|}{$55 \pm 5^{\circ} \mathrm{C}$} & \multicolumn{2}{|c|}{$65 \pm 5^{\circ} \mathrm{C}$} & \multicolumn{2}{|c|}{$75 \pm 5^{\circ} \mathrm{C}$} & \multicolumn{2}{|c|}{$85 \pm 5^{\circ} \mathrm{C}$} \\
\hline & $\begin{array}{l}\text { Relative } \\
\text { Frequency }\end{array}$ & $\%$ Area & $\begin{array}{l}\text { Relative } \\
\text { Frequency }\end{array}$ & $\%$ Area & $\begin{array}{l}\text { Relative } \\
\text { Frequency }\end{array}$ & $\%$ Area & $\begin{array}{l}\text { Relative } \\
\text { Frequency }\end{array}$ & $\%$ Area \\
\hline $\begin{array}{l}\text { Benzene, 1,1'-(1,2- } \\
\text { cyclobutanediyl)bis }\end{array}$ & $6 / 9$ & $5.1 \pm 2.7$ & --- & --- & $4 / 9$ & $9.7 \pm 6.4$ & --- & --- \\
\hline Styrene & $5 / 9$ & $36.6 \pm 20.1$ & $5 / 9$ & $45.9 \pm 19.4$ & $5 / 9$ & $37.1 \pm 12.0$ & $7 / 9$ & $25.4 \pm 14.1$ \\
\hline Ethylbenzene & $5 / 9$ & $21.2 \pm 33.3$ & $5 / 9$ & $19.5 \pm 27.9$ & $4 / 9$ & $6.3 \pm 1.6$ & $8 / 9$ & $3.3 \pm 2.7$ \\
\hline$\delta$-Cadinene & $3 / 9$ & $2.0 \pm 0.9$ & $3 / 9$ & $1.6 \pm 0.7$ & $7 / 9$ & $2.2 \pm 1.0$ & $7 / 9$ & $2.9 \pm 1.5$ \\
\hline Benzaldehyde & $3 / 9$ & $15.0 \pm 14.1$ & $7 / 9$ & $3.4 \pm 1.3$ & $7 / 9$ & $9.7 \pm 7.3$ & $8 / 9$ & $7.1 \pm 5.4$ \\
\hline Isocumene & $1 / 9$ & $17.0 \pm 0.0$ & $3 / 9$ & $4.0 \pm 2.7$ & $3 / 9$ & $5.9 \pm 4.4$ & $4 / 9$ & $0.9 \pm 0.2$ \\
\hline Tetradecane & --- & --- & $4 / 9$ & $1.0 \pm 0.9$ & $7 / 9$ & $2.9 \pm 1.7$ & $9 / 9$ & $3.5 \pm 1.8$ \\
\hline Cumene & --- & --- & $3 / 9$ & $6.4 \pm 7.9$ & $3 / 9$ & $5.9 \pm 7.9$ & $5 / 9$ & $3.6 \pm 5.1$ \\
\hline DiethylPhthalate & --- & --- & $2 / 9$ & $2.7 \pm 1.8$ & $3 / 9$ & $8.9 \pm 6.0$ & $6 / 9$ & $11.0 \pm 11.3$ \\
\hline Acetophenone & --- & --- & $2 / 9$ & $1.0 \pm 0.5$ & --- & --- & $5 / 9$ & $2.1 \pm 0.3$ \\
\hline Diphenylether & --- & --- & --- & --- & $4 / 9$ & $1.5 \pm 1.3$ & $6 / 9$ & $1.6 \pm 0.9$ \\
\hline Tridecane & --- & --- & --- & --- & $3 / 9$ & $2.7 \pm 0.1$ & $3 / 9$ & $1.6 \pm 0.9$ \\
\hline $\begin{array}{l}\text { Benzene, (1- } \\
\text { methylpropyl) }\end{array}$ & --- & --- & --- & --- & $3 / 9$ & $1.7 \pm 0.5$ & $2 / 9$ & $1.1 \pm 0.1$ \\
\hline Dodecane & --- & --- & --- & --- & $3 / 9$ & $1.1 \pm 0.2$ & $6 / 9$ & $0.9 \pm 0.4$ \\
\hline Nonanal & --- & --- & --- & --- & $1 / 9$ & $2.1 \pm 0.0$ & -- & --- \\
\hline Pentadecane & --- & --- & --- & --- & --- & --- & $6 / 9$ & $3.1 \pm 0.8$ \\
\hline Heptadecane & --- & --- & --- & --- & --- & --- & $4 / 9$ & $1.0 \pm 0.4$ \\
\hline 1,3-diphenylpropane & --- & --- & --- & --- & --- & --- & $4 / 9$ & $1.0 \pm 0.3$ \\
\hline $\begin{array}{l}\text { Benzene, 1-methyl-4- } \\
\text { propyl }\end{array}$ & --- & --- & --- & --- & --- & --- & $3 / 9$ & $1.6 \pm 0.3$ \\
\hline Octadecane & --- & --- & --- & --- & --- & --- & $3 / 9$ & $0.7 \pm 0.4$ \\
\hline Octane, $1,1^{\prime}$-oxybis & --- & --- & --- & --- & --- & --- & $3 / 9$ & $0.6 \pm 0.2$ \\
\hline n-Heptadecanol-1 & --- & --- & --- & --- & --- & --- & $2 / 9$ & $1.0 \pm 0.2$ \\
\hline Undecane & --- & --- & --- & --- & --- & --- & $2 / 9$ & $0.4 \pm 0.1$ \\
\hline Othercompounds & --- & $3.3 \pm 0.8$ & --- & $14.5 \pm 7.4$ & --- & $2.5 \pm 1.1$ & --- & $25.7 \pm 8.3$ \\
\hline
\end{tabular}



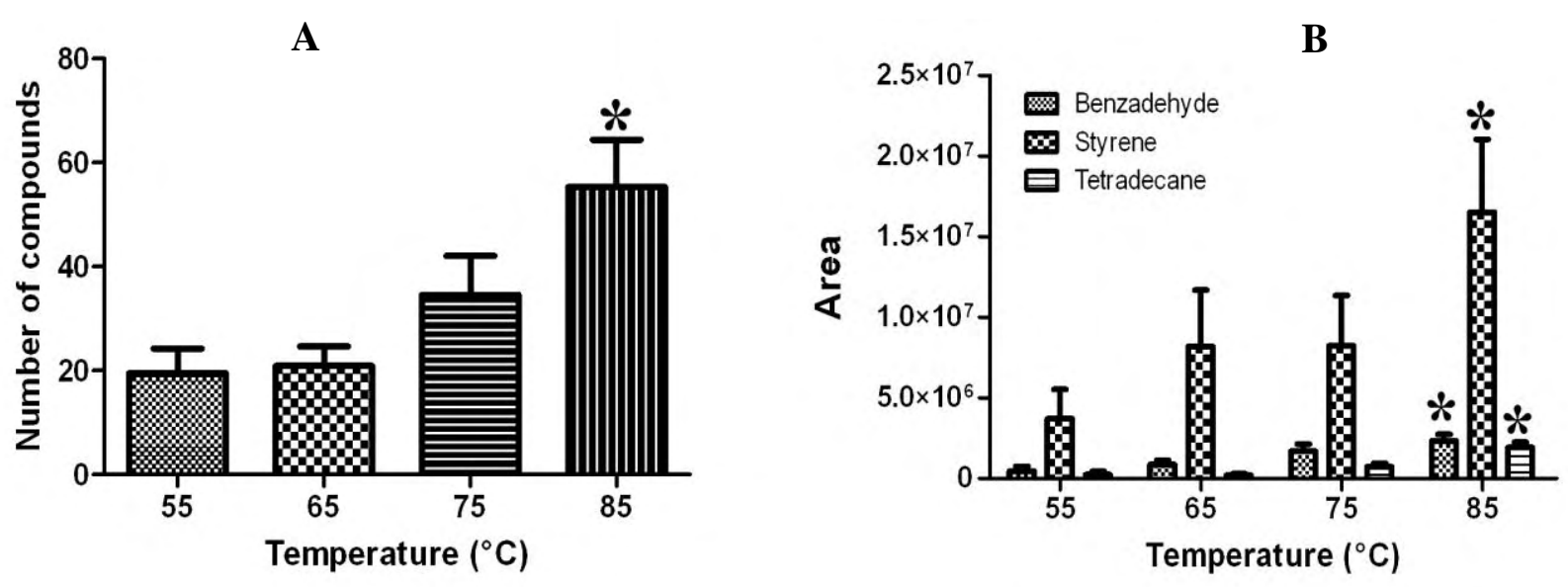

Figure 2. Effect of temperature on the number of compounds released from EPS-based products (A), and on the peak area for specific compounds (B). *Significantly different as compared to $55{ }^{\circ} \mathrm{C}$ $(P<0.05)$.

Many studies have been conducted on volatile emissions during processing and thermal degradation of polymers (Ciucanu et al., 2002; Watanabe et al., 2007; Vilaplana et al., 2010). As shown here, EPS-based products release different chemicals when heated. These substances may migrate into food, and as a consequence, jeopardize the safety of these containers (Date et al., 2002). However, for many of these compounds, little is known about their health effects and most are not regulated by local authorities. The European Union (Regulation No 10/2011) has imposed several restrictions and even banned some substances in certain articles intended for contact with food; however, permissible levels of VOCs released, and possible migration into food, are not included in this regulation (EU, 2014). This problem is not unique to EPS products; several plastic types used as containers release monomers as well as impurities and oxidation products (Camacho and Karlsson, 2000; Kusch and Knupp, 2002; Skjevrak et al., 2003; Kusch and Knupp, 2004; Vilaplana et al., 2010a; Vilaplana et al., 2010b; Lattuati-Derieux et al., 2013) (Figure 3). In fact, some of the identified VOCs may also be formed by thermo-oxidative degradation of EPS when exposed to high temperatures and solar irradiation (Kusch and Knupp, 2004).

Since plastics are highly used in many countries to store and carry different food products, it is evident that their use may pose some risks for human health. The technique of gas chromatography coupled with mass spectrometry allows the identification of the compounds released by these materials, and based on this information, it is possible to perform text mining to identify possible adverse effects linked to their use. Accordingly, this process was carried out to visualize possible health problems associated with different molecules released from tested polystyrene containers, such as styrene, cumene, tretadecane, pentadecane, acetophenone and ethylbenzene (Figure 4) (Leibman, 1975; USEPA, 1988; 2000a; 2000b; Arnedo-Pena et al., 2003; Sliwinska-Kowalska et al., 2003; Seeber et al., 2004; Muhammad et al., 2005; WHO, 2005; ASTDR, 2007; Dusseldorp et al., 2007; OSHA, 2010). These chemicals do possess a broad spectrum of toxicities. In fact, several studies have reported that some are estrogenic (Yang et al., 2011), carcinogenic (Lithner et al., 2011), and also originate human ototoxicity and effects on color discrimination (Gelbke et al., 2014), among other problems. 


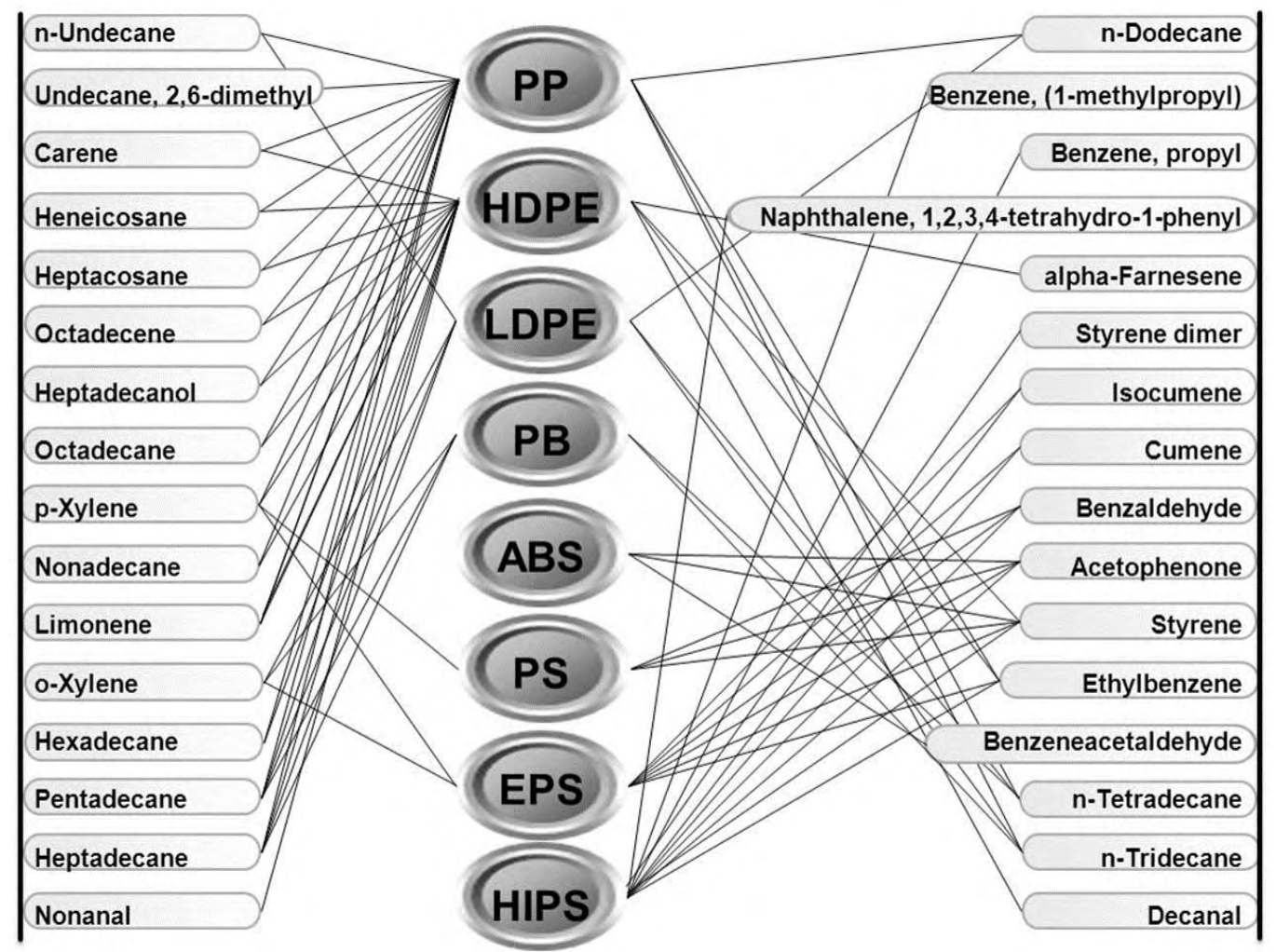

Figure 3. Compounds identified in different plastic-based products $(3,4,8,19,14,15,20)$. PP: Polypropylene, HDPE: High density polyethylene, LDPE: Low density polyethylene, PB: Polybutylene, ABS: Acrylonitrile-Butadiene-Styrene, PS: Polystyrene, EPS: Expanded polystyrene, HIPS: High-impact polystyrene.

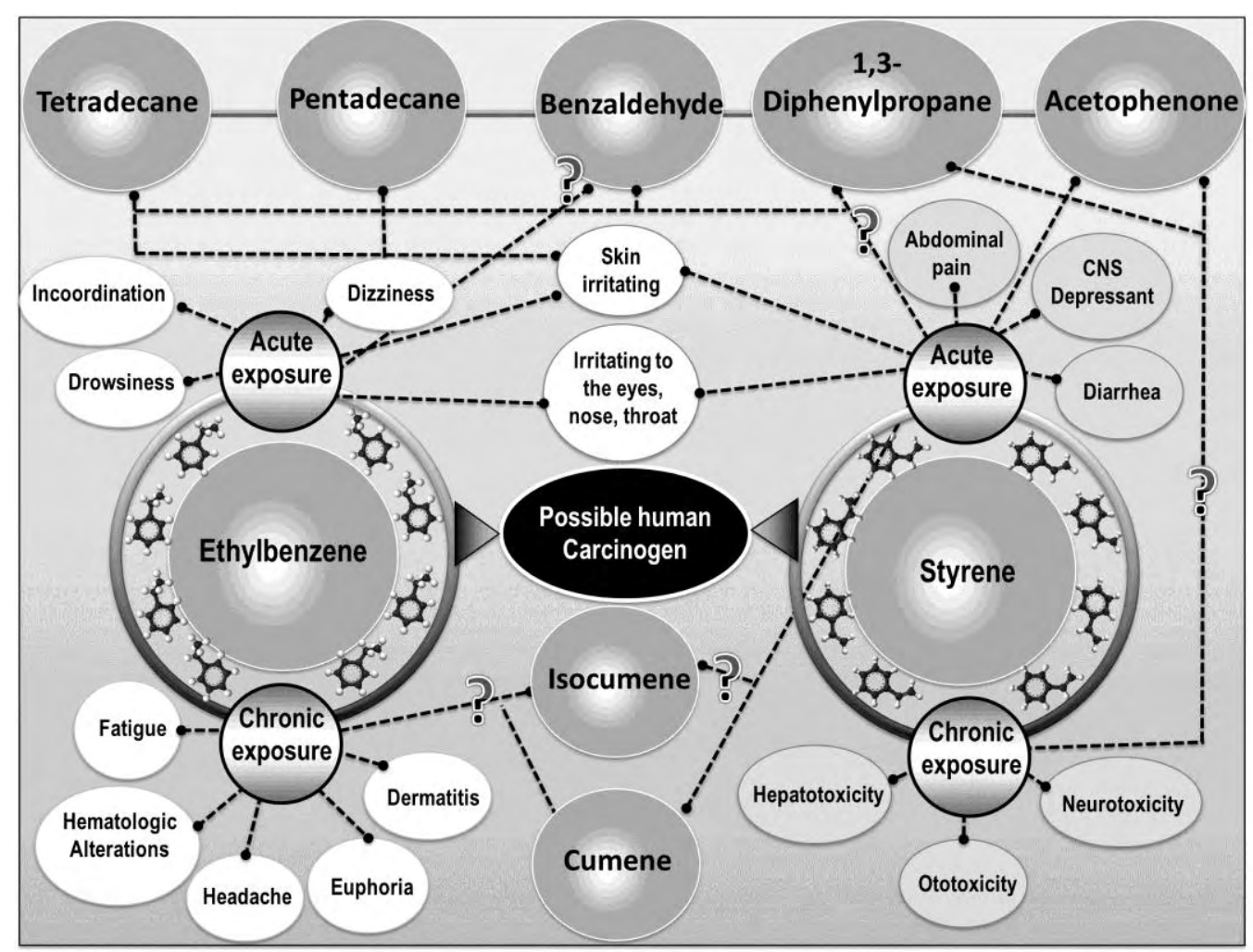

Figure 4. Results from text mining on several chemicals released from EPS-based containers. ?= No information available. 


\section{CONCLUSION}

In conclusion, EPS-based products available in Colombia release several chemicals when heated; some of the most frequently observed are benzaldehyde, pentadecane, tetradecane, ethylbenzene, cumene, isocumene, acetophenone, 1,3-diphenylpropane, and styrene. The emission of these molecules was temperature-dependent; therefore, the use of these materials to store food and hot drinks should be carefully controlled. This preliminary report is sufficient to encourage the development of public policies aimed at protecting people from exposure to these chemicals. Therefore, mandatory legislation should establish appropriate quality characteristics for these EPS-based products.

\section{ACKNOWLEDGMENTS}

The authors wish to thank Colciencias, Bogota (Colombia), and the University of Cartagena, Cartagena (Colombia) for their financial support (Grant 110749326186, 2009); the program to support Research Groups, sponsored by the Vice-Rectory for research of the University of Cartagena (2013-2014), and Juliette Andrea Perez-Romero for her support during the completion of this research. K. Caballero is sponsored by the National Program for Doctoral Formation (Colciencias, 567-2012).

\section{REFERENCES}

ARNEDO-PENA, A.; BELLIDO-BLASCO, J.; VILLAMARIN-VAZQUEZ, J.-L.; ARANDA-MARES, J.-L.; FONT-CARDONA, N.; GOBBA, F. et al. Acute health effects after accidental exposure to styrene from drinking water in Spain. Environmental Health, v. 2, p. 1-9, 2003. http://dx.doi.org/10.1186/1476-069X-2-6

AGENCY FOR TOXIC SUBSTANCES AND DISEASE REGISTRY - ASTDR (USA). Toxicological profile for Ethylbenzene. Atlanta, 2007. Available in: http://www.atsdr.cdc.gov/toxprofiles/tp110.pdf. Accessed: 15 July 2014.

BUCHBERGER, W.; STIFTINGER, M. Analysis of polymer additives and impurities by liquid chromatography/mass spectrometry and capillary electrophoresis/mass spectrometry. Advances in Polymers Science, v. 248, p. 39-67, 2012. http://dx.doi.org/10.1007/12_2011_147

CAMACHO, W.; KARLSSON, S. Quality-determination of recycled plastic packaging waste by identification of contaminants by GC-MS after microwave assisted extraction (MAE). Polymer Degradation Stability, v.71, p. 123-134, 2000.

http://dx.doi.org/10.1016/S0141-3910(00)00163-4

CIUCANU, I.; KAYKHAII, M.; MONTERO, L.; PAWLISZYN, J.; SZUBRA, J. Continuous monitoring of thermooxidative degradation products of polystyrene by membrane extraction with sorbent interface and gas chromatography. Journal of Chromatographic Science, v. 40, p. 350-354, 2002.

http://dx.doi.org/10.1093/chromsci/40.6.350

DATE, K.; OHNO, K.; AZUMA, Y.; HIRANO, S.; KOBAYASHI, K.; SAKURAI, T. et al. Endocrine-disrupting effects of styrene oligomers that migrated from polystyrene containers into food. Food and Chemical Toxicology, v. 40, p. 65-75, 2002. http://dx.doi.org/10.1016/S0278-6915(01)00096-5 
DE PAULA PEREIRA, P. A.; DE OLIVEIRA, R. F. S.; DE ANDRADE, J. B. Determination of styrene content in polystyrene cups by purge-and-trap followed by HRGC-FID. American Laboratory, v. 36, p. 16-18, 2004.

DUSSELDORP, A.; VAN BRUGGEN, M.; DOUWES, J.; JANSSEN, P. J. C. M.; KELFKENS, G. Health-based guideline values for indoor environment. RIVM report 609021044. Bilthoven, 2007. Available in:

http://www.rivm.nl/bibliotheek/rapporten/609021044.pdf. Accessed: 14 Nov. 2007.

EUROPEAN UNION. European Commission - EU. Union Guidelines on Regulation No 10/2011. 2014. Available in: http://ec.europa.eu/food/food/chemicalsafety/foodcontact/ docs/10-2011_plastic_guidance_en.pdf. Accessed: 28 Aug. 2014.

FU, P.; KAWAMURA, K. Ubiquity of bisphenol A in the atmosphere. Environmental Pollution, v. 158, p. 3138-3143, 2010. http://dx.doi.org/10.1016/j.envpol.2010.06.040

GARRIGÓS, M. C.; MARÍN, M. L.; CANTÓ, A.; SÁNCHEZ, A. Determination of residual styrene monomer in polystyrene granules by gas chromatography-mass spectrometry. Journal of Chromatography A, v. 1061, p. 211-216, 2004. http://dx.doi.org/10.1016/j.chroma.2004.10.102

GELBKE, H.-P.; BANTON, M.; FAES, E.; LEIBOLD, E.; PEMBERTON, M.; DUHAYON, S. Derivation of safe health-based exposure limits for potential consumer exposure to styrene migrating into food from food containers. Food and Chemical Toxicology, v. 64, p. 258-269, 2014. http://dx.doi.org/10.1016/j.fct.2013.11.039

KUSCH, P.; KNUPP, G. Analysis of residual styrene monomer and other volatile organic compounds in expanded polystyrene by headspace solid-phase microextraction followed by gas chromatography and gas chromatography/mass spectrometry. Journal of Separation Science, v. 25, p. 539-542, 2002. http://dx.doi.org/10.1002/16159314(20020601)25:8<539::AID-JSSC539>3.0.CO;2-G

KUSCH, P.; KNUPP, G. Headspace-SPME-GC-MS identification of volatile organic compounds released from expanded polystyrene. Journal of Polymers and the Environment, v. 12, p. 83-87, 2004.

http://dx.doi.org/10.1023/B:JOOE.0000010053.20382.d7

LATTUATI-DERIEUX, A.; EGASSE, C.; THAO-HEU, S.; BALCAR, N.; BARABANT, G.; LAVÉDRINE, B. What do plastics emit? HS-SPME-GC/MS analyses of new standard plastics and plastic objects in museum collections. Journal of Cultural Heritage, v.14, p. 238-247, 2013. http://dx.doi.org/10.1016/j.culher.2012.06.005

LEE, C.-W.; DAI, Y.-T.; CHIEN, C.-H.; HSU, D.-J. Characteristics and health impacts of volatile organic compounds in photocopy centers. Environmental Research, v. 100, p. 139-149, 2006. http://dx.doi.org/10.1016/j.envres.2005.05.003

LEIBMAN, K. C. Metabolism and toxicity of styrene. Environmental Health Perspective, v. 11, p. 115-119, 1975.

LITHNER, D.; LARSSON, Å.; DAVE, G. Environmental and health hazard ranking and assessment of plastic polymers based on chemical composition. Science of the Total Environment, v. 409, p. 3309-3324, 2011.

http://dx.doi.org/10.1016/j.scitotenv.2011.04.038 
MUHAMMAD, F.; MONTEIRO-RIVIERE, N. A.; RIVIERE, J. E. Comparative in vivo toxicity of topical JP-8 jet fuel and its individual hydrocarbon components: identification of tridecane and tetradecane as key constituents responsible for dermal irritation. Toxicologic Pathology, v. 33, p. 258-266, 2005.

http://dx.doi.org/10.1080/01926230590908222

RUEFF, J.; TEIXEIRA, J. P.; SANTOS, L. S.; GASPAR, J. F. Genetic effects and biotoxicity monitoring of occupational styrene exposure. Clinica Chimica Acta, v. 399, p. 8-23, 2009. http://dx.doi.org/10.1016/j.cca.2008.09.012

SEEBER, A.; BLASZKEWICZ, M.; GOLKA, K.; HALLIER, E.; KIESSWETTER, E.; SCHÄPER, M. et al. Neurobehavioral effects of experimental exposures to low levels of styrene. Toxicology Letters, v. 151, p. 183-192, 2004.

http://dx.doi.org/10.1016/j.toxlet.2003.12.072

SHAH, A. A.; HASAN, F.; HAMEED, A.; AHMED, S. Biological degradation of plastics: a comprehensive review. Biotechnology Advances, v. 26, p. 246-265, 2008. http://dx.doi.org/10.1016/j.biotechadv.2007.12.005

SKJEVRAK, I.; DUE, A.; GJERSTAD, K. O.; HERIKSTAD, H. Volatile organic components migrating from plastic pipes (HDPE, PEX and PVC) into drinking water. Water Research, v. 37, p. 1912-1920, 2003. http://dx.doi.org/10.1016/S00431354(02)00576-6

SLIWINSKA-KOWALSKA, M.; ZAMYSLOWSKA-SZMYTKE, E.; SZYMCZAK, W.; KOTYLO, P.; FISZER, M.; WESOLOWSKI, W. et al. Ototoxic effects of occupational exposure to styrene and co-exposure to styrene and noise. Journal of Occupational and Environmental Medicine, v. 45, p. 15-24, 2003.

SMITH, S. H.; TAYLOR, L. T. Extraction of various additives from polystyrene and their subsequent analysis. Chromatographia, v. 56, p. 165-169, 2002.

http://dx.doi.org/10.1007/BF02493206

UNITED STATES. Department of Laber. Occupational Safety and Health - OSHA. Guideline for Ethyl Benzene. 2010. Available in: http://www.osha.gov/SLTC/healthguidelines/ethylbenzene/recognition.html\#healthhaza rd. Accessed: 11 Apr. 2010.

UNITED STATES. Environmental Protection Agency - USEPA. Benzaldehyde (CASRN 100-52-7). 1988. Available in: http://www.epa.gov/iris/subst/0332.html. Accessed: 14 Nov. 1988.

UNITED STATES. Environmental Protection Agency - USEPA. Acetophenone. 2000a. Available in: http://www.epa.gov/ttnatw01/hlthef/acetophe.html. Accessed: 14 Jun. 2014.

UNITED STATES. Environmental Protection Agency - USEPA. Cumene. 2000b. Available in: http://www.epa.gov/airtoxics/hlthef/cumene.html. Accessed: 14 Jun. 2014.

VILAPLANA, F.; MARTÍNEZ-SANZ, M.; RIBES-GREUS, A.; KARLSSON, S. Emission pattern of semi-volatile organic compounds from recycled styrenic polymers using headspace solid-phase microextraction gas chromatography-mass spectrometry. Journal of Chromatograpy A, v. 1217, p. 359-367, 2010a. http://dx.doi.org/10.1016/j.chroma.2009.11.057 
VILAPLANA, F.; RIBES-GREUS, A.; KARLSSON, S. Chromatographic pattern in recycled high-impact polystyrene (HIPS) - occurrence of low molecular weight compounds during the life cycle. Polymer Degradation and Stability, v. 95, p. 172-186, 2010b. http://dx.doi.org/10.1016/j.polymdegradstab.2009.11.033

WAMPLER, T. Polymer additive analysis using multi-step thermal sampling-GC/MS. Labint Online, 2004. Available in: http://www.labint-online.com/uploads/tx_ttproducts/ datasheet/polymer-additive-analysis-using-multi-step-thermal-sampling-gcms.pdf.

Accessed: 20 Nov. 2004.

WANG, S.; ANG, H. M.; TADE, M. O. Volatile organic compounds in indoor environment and photocatalytic oxidation: state of the art. Environment International, v. 33, p. 694-705, 2007. http://dx.doi.org/10.1016/j.envint.2007.02.011

WATANABE, M.; NAKATA, C.; WU, W.; KAWAMOTO, K.; NOMA, Y. Characterization of semi-volatile organic compounds emitted during heating of nitrogen-containing plastics at low temperature. Chemosphere, v. 68, p. 2063-2072, 2007. http://dx.doi.org/10.1016/j.chemosphere.2007.02.022

WORLD HEALTH ORGANIZATION - WHO. Cumene. 2005. Available in: http://www.who.int/ipcs/publications/cicad/cicad18_rev_1.pdf. Accessed: 14 Jun. 2014.

YANG, C. Z.; YANIGER, S. I.; JORDAN, V. C.; KLEIN, D. J.; BITTNER, G. D. Most plastic products release estrogenic chemicals: a potential health problem that can be solved. Environmental Health Perspectives, v. 119, p. 989-996, 2011. http://dx.doi.org/10.1289\%2Fehp.1003220

YORIFUJI, T.; NOGUCHI, M.; TSUDA, T.; SUZUKI, E.; TAKAO, S.; KASHIMA, S. et al. Does open-air exposure to volatile organic compounds near a plastic recycling factory cause health effects? Journal of Occupational Health, v. 54, p. 79-87, 2012. http://dx.doi.org/10.1539/joh.11-0202-OA 


Ambiente \& Água - An Interdisciplinary Journal of Applied Science
ISSN 1980-993X - doi:10.4136/1980-993X
www.ambi-agua.net
E-mail: ambi-agua@agro.unitau.br

\title{
Tissue levels of the antioxidant enzymes superoxide dismutase and catalase in fish Astyanax bimaculatus from the Una River Basin
}

\author{
doi: 10.4136/ambi-agua.1473
}

Received: 26 Jul. 2014; Accepted: 29 Sep. 2014

\author{
Maria Tereza Oliveira Batista ${ }^{1}$; Edson Rodrigues Junior ${ }^{2}$; \\ Mariana Feijó-Oliveira ${ }^{2}$; Anne Caroline Ribeiro' ${ }^{1}$; \\ Edson Rodrigues ${ }^{1}$; Cecilia Nahomi Kawagoe Suda ${ }^{1}$; \\ Gannabathula Sree Vani ${ }^{*}$ \\ ${ }^{1}$ Universidade de Taubaté, (UNITAU), Taubaté, SP, Brasil \\ ${ }^{2}$ Universidade Federal do Paraná (UFPR), Curitiba, PR, Brasil \\ *Corresponding author: e-mail: srvani@hotmail.com, \\ maria.tereza@gmail.com, edsonrodj@gmail.com,mari.feijo@bol.com.br, \\ aninha_3001@hotmail.com,rodedson@gmail.com,cnksuda@hotmail.com
}

\begin{abstract}
This paper seeks to identify the biomarker response to oxidative stress in Astyanax bimaculatus, a freshwater fish, collected from the Una River and its associated water bodies. The fish were collected using fishing nets at three different points on the river basin, namely Fazenda Piloto (FP), Ipiranga (IP) and Remédios (RM), during the period from December 2013 to March 2014. Physical and chemical analyses of the water at the sample locations indicate that IP and RM possibly have larger concentration of either natural or anthropic pollutants as compared to FP. FP can therefore be considered as the point less impacted by pollutants than other points. Hepatic activity of antioxidant stress enzymes, superoxide dismutase (SOD) and catalase (CAT), were measured in the specimens. The levels of SOD were reduced at RM while they were elevated in fish collected at IP. The CAT levels for the fish at RM and IP were about $148.9 \%$ and $202.4 \%$ above the values at FP, respectively. These results suggest that antioxidant enzymes could be used as biomarkers to measure oxidative stress caused by pollutants in the Una River Basin.
\end{abstract}

Keywords: biomonitoring, pollution, radical oxygen species.

\section{Níveis teciduais das enzimas antioxidantes superóxido dismutase e catalase no peixe Astyanax bimaculatus da bacia hidrográfica do rio Una}

\section{RESUMO}

O presente trabalho teve como objetivo identificar respostas de biomarcadores de estresse oxidativo no peixe de água doce Astyanax bimaculatus, coletado nos rios e corpos d'água da bacia hidrográfica do rio Una. Os peixes foram coletados com rede de pesca entre dezembro de 2013 e março de 2014, em três diferentes pontos da bacia: Fazenda Piloto (FP), Ipiranga (IP) e Remédios (RM). Análises físico-químicas das amostras de água nos pontos de coleta indicaram que IP e RM possivelmente apresentaram uma maior concentração de poluentes, naturais ou antrópicos, quando comparados ao FP. Portanto, FP pode ser considerado como o 
ponto menos impactado por poluentes em relação aos outros pontos. Níveis hepáticos de atividade das enzimas antioxidantes superóxido dismutase (SOD) e catalase (CAT) foram medidos nos espécimes. Os níveis de SOD foram reduzidos no RM, enquanto que eles foram aumentados em peixes coletados em IP. Os níveis de CAT nos peixes coletados em RM e IP foram $148,9 \%$ e $202,4 \%$ maiores do que os valores encontrados nos peixes do ponto FP, respectivamente. Os resultados sugerem que as enzimas antioxidantes podem ser usadas como biomarcadoras para mensurar os níveis de stress oxidativo causado pelos poluentes na bacia hidrográfica do rio Una.

Palavras-chave: biomonitoramento, espécies reativas de oxigênio, poluição.

\section{INTRODUCTION}

River ecosystems are extremely vulnerable to alterations in the environment due either to natural changes or to anthropic activities. Globally, the biodiversity of freshwater ecosystems has been reduced drastically as a result of human activity (Dahl et al., 2004). The runoff water from agriculture containing fertilizers, pesticides and herbicides, discharge of untreated sewage from urban areas, and heavy metals present in the effluents discharged from industries as well as mining along the river banks are the principal causes of river water pollution. Increasing urbanization and industrialization generate increasing amounts of waste that are dumped directly into freshwater bodies, thereby the lowering the quality of water (Beasley and Kneale, 2003). A large number of studies have shown the negative effect of different pollutants on the aquatic biota resulting in the loss of biodiversity and making the water unfit for life

Water quality, as measured by the physical and chemical parameters, does not give a long-term integrated view of the effect of pollution. The visibly debilitating effects of pollution on organisms in an ecosystem develop over a long period, and by the time they become conspicuous it may already be too late to reverse the degradation of the ecosystem or economically infeasible to take corrective action. It is therefore necessary to investigate methods that lead to early detection of harmful changes in the environment. Biomonitoring, which uses organisms to indicate the health of the environment, is well suited to this purpose as the existing organisms are adapted to the specific ecosystem and any alterations in the environment are reflected in the composition and structure of the biological communities (Alba-Tercedor, 1996; Fonseca et al., 2014). Both invertebrates and vertebrates have been used for bio-monitoring a river. Since fishes occupy an intermediate range in the food pyramid, they are ideally suited for bio-monitoring. Fishes of the genus Astyanax have been used to study the genotoxicity of the aquatic environments (Moreira et al., 2010), and their feasibility as biomarkers of pollution has been investigated (Trujillo-Jiménez et al., 2011).

One method of bio-monitoring is to use biomarkers. Biochemical biomarkers are molecules that are present in the body fluids, cells and tissues of organisms and whose activity is altered by the presence of toxic agents in the environment (McCarthy and Shugart, 1990). One important set of biomarkers is the antioxidant defense enzymes that decompose the Reactive Oxygen Species (ROS). These enzymes have an important role in the control, production and elimination of ROS, which in excess can alter the normal functions of the cell and lead to oxidation of the cell membranes as well as lesions in mitochondria, proteins, DNA and other components of the cell. Natural or anthropic changes in the environment introduce oxidative stress that results in disequilibrium in the cell by increasing the production of ROS (Lushckak, 2011). Superoxide dismutase (SOD) and catalase (CAT) are members of the antioxidant defense enzymes. SOD converts superoxide radicals into hydrogen peroxide. It has been shown that SOD activity is altered in mussels living in areas contaminated by heavy metals and organic pollutants (Binelli and Cogni 2010). The enzyme CAT is widely 
distributed in biological tissues and is involved in the decomposition of hydrogen peroxide into oxygen and water. It is one of the most prominent enzymes involved in defense against oxidative stress in both vertebrates and invertebrates (Goyal and Basak, 2010).

This paper discusses the biomonitoring of the Una River. The Una River Basin is formed by the union of the Ribeirão das Almas Stream with the Rocinha River and its effluents (Itaim, Ribeirão das Pedras or Ipiranga, Ribeirão das Sete Voltas, Rio das Antas, Ribeirão do Registro and other effluents). The basin has an area of $442,85 \mathrm{~km}^{2}$ with $8 \%$ in the municipality of Pindamonhangaba, $8 \%$ in the municipality of Tremembé and the rest (84\%) in the municipality of Taubaté. Geographically, the Una River Basin is on the right bank of the Paraíba do Sul River. The altitude of the basin varies between 500 to $1000 \mathrm{~m}$ (http://www.agro.unitau.br/una/una_plano_bacias_04.html). The importance of the Una River Basin and its tributaries became evident during the evaluation of the Paraíba do Sul River by the Committee on the Hydrography of Paraíba do Sul (CBH-PS). The Committee established a number of guidelines for the effective use and preservation of the river and all of its tributaries. Of the important guidelines established, priority was given to the water supply for public consumption, controlling the rate of urbanization of the basin, resolving conflicts arising from the use of the river water for multiple purposes, restoration of the soils, restoration of the riparian zones and the recuperation of the basin (Batista et al., 2002).

This paper studies the response to oxidative stress in the fish Astyanax bimaculatus, collected at various locations in the Una River Basin. Specifically, it investigates the hepatic levels of SOD and CAT as candidate biomarkers of antioxidant defense in this species.

\section{MATERIAL AND METHODS}

\subsection{Sample collection}

Sampling sites were selected based on the presence of plantations, untreated sewage discharge and regions where there was less human activity near the river or its tributaries. The geographic coordinates of the sites were determined using GPS. The sites used to collect the fish were: 1) Fazenda Piloto (FP), in the Ribeirão Itaim stream located inside Fazenda Piloto (an experimental farm) of the University of Taubaté, S23 $01^{\prime} 38.3^{\prime}$ W045 30'31.6"; 2) Remédios (RM), a ditch which flows to Una River, located in the municipality of Remédios, $\mathrm{S} 23^{\circ}$ 03'26.4' 'W045 $35^{\circ} 23.5^{\prime \prime}$, close to rice cultivation; 3) Ipiranga (IP), a lake near a pasture for cattle and near the municipal highway Dr. José Luiz Cembranelli, S2301'49.4" W45030'16.7" (Figure 1). The last site was visibly polluted and had oil-like slicks on the water surface. The specimen sampling was approved by MMA - SISBIO (authorization No. 41097-1). A single sampling of five specimens of the fish Astyanax bimaculatus (locally called lambari) was collected at each of the three locations between December 2013 and March 2014. A size 20 nylon fishing net was cast in the water and left for a period of 20 minutes, after which any fish that were caught in the net were retrieved and immediately transferred into a large bucket filled with water from that location. The 20 minute interval was used to ensure that the fish caught in the net did not suffer undue stress that could affect the experiment. The fish were photographed for later identification, dissected on an ice tray, and the hepatic tissue was retrieved and transferred to eppendorf tubes which were labeled and kept in ice until transported to the biochemistry laboratory of the Institute of Basic Biosciences (IBB), University of Taubaté (UNITAU), where they were stored in a freezer at $86^{\circ} \mathrm{C}$ for further analysis. 


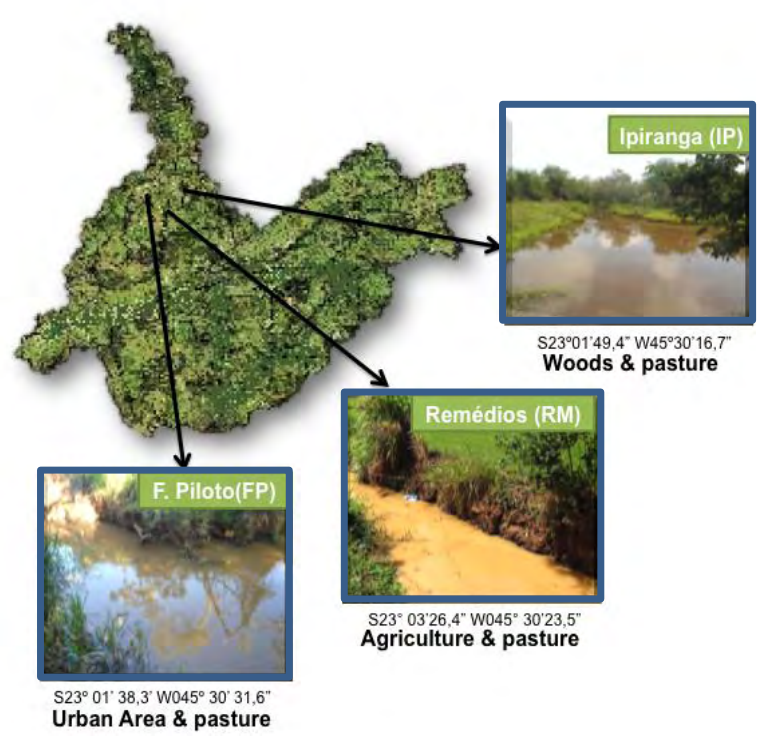

Figure 1. Hydrographic basin of the Una River and the three sites from which fish specimens were collected.

Source: http://www.agro.unitau.br/una.

Samples of the water were also collected for analysis of the physical and chemical parameters. The samples were collected in $300 \mathrm{~mL}$ glass bottles, stored in ice and transported to the water analysis laboratories of Department of Civil Engineering and Department of Agricultural Sciences, University of Taubaté, where they were kept refrigerated between $0^{\circ}$ a $5^{\circ} \mathrm{C}$. The values of $\mathrm{pH}$, hardness, chemical oxygen demand (COD), turbidity, apparent color, conductivity nitrogen content, phosphate and soluble n-hexane were determined using the method of APHA et al. (1998). The quantities of nitrate and nitrite were determined following the methods of Instituto Adolfo Lutz (1985) and Hevel and Marietta (1994), respectively.

\subsection{Biochemical analysis}

The hepatic tissue of the fish was homogenized in a Potter-Elvehjen homogenizer, in the proportion 1:5 of tissue in a Tris- $\mathrm{HCl} 50 \mathrm{mM}$ buffer at a $\mathrm{pH}$ of 7.4. The subcellular structures were broken down with a sonic dismembrator (Model 100, Fisher Scientific) and then centrifuged at $14,000 \mathrm{x} \mathrm{g}$ (5810 R, Eppendorf) for 10 minutes at $4^{\circ} \mathrm{C}$, and only the supernatant was used for further biochemical analysis.

SOD activity was determined using a reaction system containing a sodium carbonate buffer of 100mM (pH 10.2), $17.5 \mu \mathrm{M}$ de EDTA and $1 \mathrm{mM}$ of NBT (nitrotetrazolium blue chloride). The reaction was initiated by the addition of hydroxylamine for a final concentration of $3.7 \mathrm{mM}$. The increase in absorbance was measure at $\lambda=560 \mathrm{~nm}$ by using a microplate reader (Fluorstar Optima, BMG Labtech) (Kono, 1978). One unity of SOD is expressed as a quantity of enzyme that inhibit 50\% of NBT reduction. CAT activity was determined in a reaction system containing $100 \mathrm{mM}$ sodium phosphate buffer ( $\mathrm{pH}$ 7.0), and $12 \mathrm{mM}$ of $\mathrm{H}_{2} \mathrm{O}_{2}$. The reduction in absorbance was determined at $\lambda=240 \mathrm{~nm}$ (spectrophotometer DU 640, Beckman) (Regoli et al., 1997). The total protein concentration was determined using the bicinchoninic acid method (BCA) using the reagent kit made by Sigma-Aldrich with bovine albumin serum as a standard (Smith et al., 1985). The CAT activity is expressed in International Units (U), indicating the quantity of substrate in $\mu \mathrm{mol}$ transformed into product in one minute $\left(\mu \mathrm{mol} \mathrm{min}^{-1}\right)$ and normalized as a function of the total protein concentration in the homogenate $\left(\mu \mathrm{mol} \mathrm{min}{ }^{-1} \mathrm{mg}_{\text {protein }}{ }^{-1} ; \mathrm{U} \mathrm{mg}^{-1}\right)$. 


\subsection{Data analysis}

Statistical analysis was done using Graph Prism for Windows version 5.0. The results are presented as mean \pm SEM (standard error of the mean). Statistical comparison between the groups was done using one way ANOVA, followed by the multiple pairwise Tukey "a posteriori" comparison test. Differences were considered significant for $\mathrm{p}<0.05$.

\section{RESULTS AND DISCUSSION}

The physical and chemical parameters of the water at the sites where the fish were collected are given in Table 1. At FP all of the parameters are within the reference limits except for apparent color and total phosphates. At RM, conductivity, apparent color and Nhexane are well above the recommended limits, whereas at IP, conductivity and COD are well above the reference values.

Table 1. Water parameters at sampling sites on the Una River basin.

\begin{tabular}{|c|c|c|c|c|}
\hline Parameters & $\begin{array}{c}\text { Fazenda } \\
\text { Piloto }\end{array}$ & Remédios & Ipiranga & Reference $^{a}$ \\
\hline Conductivity $\left(\mu \mathrm{S} \mathrm{cm}^{-1}\right)$ & 106.0 & 198.7 & 121.0 & $100^{\mathrm{b}}$ \\
\hline Apparent Color (Pt-Co L $\left.{ }^{-1}\right)$ & 307.0 & 191.5 & 858.0 & $15^{\mathrm{c}}$ \\
\hline Hardness (mg CaCO $\mathrm{L}^{-1}$ ) & 6.02 & 12.05 & 8.43 & $500^{\mathrm{d}}$ \\
\hline $\mathrm{pH}$ & 6.5 & 6.4 & 6.2 & 6.0 to 9.0 \\
\hline Turbidity (NTU) & 30.9 & 22.7 & 101.0 & 100 \\
\hline $\mathrm{COD}\left(\mathrm{mg} \mathrm{O}_{2} \mathrm{~L}^{-1}\right)$ & 8.45 & 10.75 & 64.21 & $20^{\mathrm{e}}$ \\
\hline Total Phosphates (mg L ${ }^{-1}$ ) & 0.3 & ND & ND & $0.1^{\mathrm{f}}$ \\
\hline N-hexane-soluble (mg L ${ }^{-1}$ ) & ND & 1.5 & $N^{f}$ & $\begin{array}{l}\text { Virtually } \\
\text { absent }\end{array}$ \\
\hline $\begin{array}{l}\text { Total Nitrogen Kjeldahl } \\
\left(\mathrm{mg} \mathrm{L}^{-1}\right)\end{array}$ & 0.66 & 0.84 & 0.32 & $3.7^{\mathrm{g}}$ \\
\hline Nitrate $\left(m g L^{-1}\right)$ & $0.523 \pm 0.019$ & $0.279 \pm 0.015$ & $1.064 \pm 0.042$ & 10.0 \\
\hline Nitrite (mg L ${ }^{-1}$ ) & $0.042 \pm 0.014$ & $0.027 \pm 0.004$ & $0.265 \pm 0.003$ & 1.0 \\
\hline
\end{tabular}

Figure 2 shows the hepatic SOD activity of the fish. The SOD levels of fishes from IP are $60 \%$ larger than those at RM and $39.17 \%$ higher than those at FP. There is a significant difference $(p<0.05)$ in the SOD activity of fishes at RM and IP, but no difference in SOD activity for fishes from FP as compared to those from IP or RM. The hepatic SOD activity in the fish at RM had a very large variation, whereas for SOD they were within a very narrow range as compared to the fish from the other two locations. 


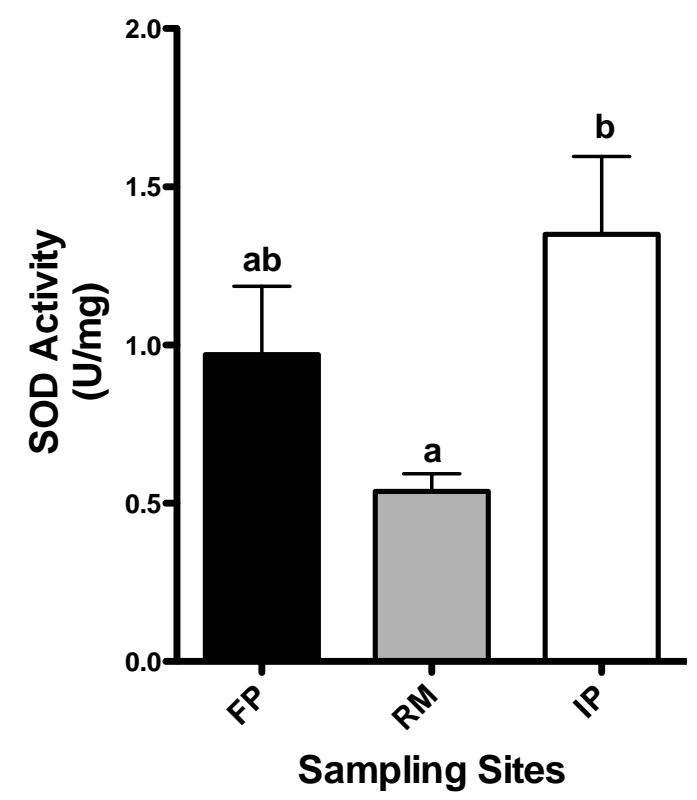

Figure 2. SOD levels in the hepatic tissues of Astyanax bimaculatus at three different points in the Una River Basin. Data presented as mean \pm SEM (standard error of the mean). Different letters above bars indicate significant differences in experimental group means $(\mathrm{p}<0.05)$.

The hepatic CAT activities of fish from three locations are shown in Figure 3. The CAT activity of fish at FP is $148.9 \%$ lower than the activity in fish at RM and $202.36 \%$ lower than those at IP and this difference is significant $(\mathrm{p}<0.005)$. However, there is no difference in the CAT activity of fishes from RM and IP. Further, the variation in CAT activity in the fishes at RM is very small.

Fishes are used as a model for the biomonitoring of the aquatic environment and as sentinel agents for pollutants (Sedeño-Diaz and Lopez-Lopez, 2013). The pollutants affect various organs, particularly gills, which are exposed directly to the contaminants in the environment. However, most of the pollutants are transferred to the blood and transported to the liver, which is the principal detoxification organ for xenobiotic substances. Hepatic tissue is, therefore, the place where most of the pollutants accumulate and therefore where long-term damage is most likely to occur. Most of the pollutants and their metabolites induce toxicity via oxidative stress arising from the increased production of free oxygen radicals. The antioxidant defense enzymes involved in the removal of ROS are the principal candidates for biomarkers of oxidative stress. The antioxidant defense enzymes, however, have great variability and are dependent on the organisms, organ tissues and the nature of the pollutants involved (Sole et al., 2011).

Examining Table 1, it can be seen that COD at IP is elevated. COD is elevated when there is industrial discharge and is an important test to determine the organic content of effluents that may contain toxic substances (Vidal et al., 2014). In addition, conductivity is above the reference values set by CETESB at RM and IP, indicating the presence of dissolved inorganic solids and metals (Vidal et al., 2014). Metals may occur naturally in soils and are leached into water by the action of rain, or they may be due to industrial, agricultural or other anthropogenic activity (Qu et al., 2014). Another parameter, the apparent color, is also high at IP. Iron and other metals either in nature or arising from the discharge of highly corrosive 
products could affect the water color. Copper, iron and lead, measured by CETESB near the water pumping stations on the river (S 230.' $49^{\prime \prime}$ W45 $30^{\prime} 26^{\prime \prime}$ ) indicate that the concentration of these metals increases during the months of December to February, when there are rains. Based on these factors, it may be assumed that IP and RM have a larger quantity of pollutants (of both natural and anthropic origins) as compared to FP. Hence FP may be used as reference point as it was less impacted than the other sampling locations during the period December 2013 to March 2014.

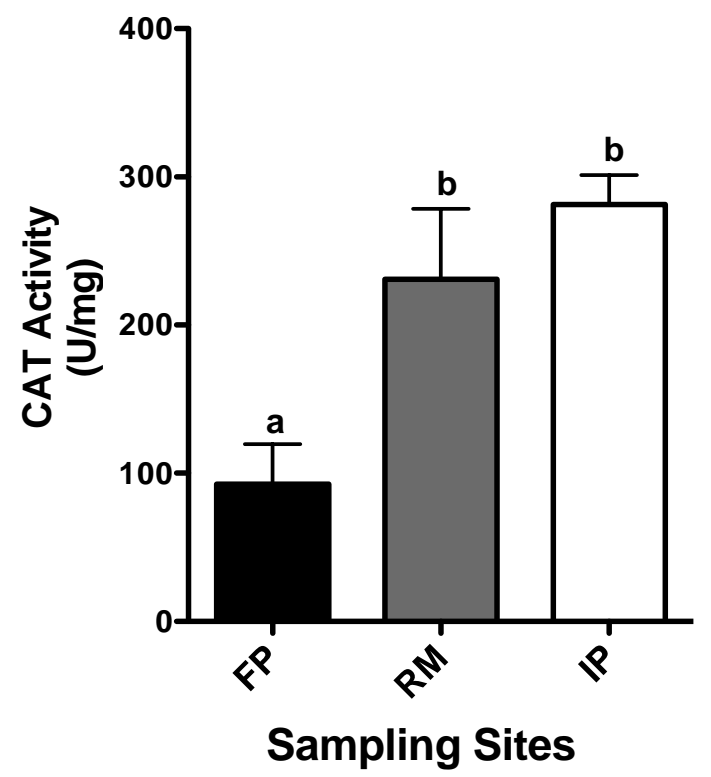

Figure 3. CAT activity in the hepatic tissues of fish, Astyanax bimaculatus, from three different locations in the Una River Basin. Data is presented as mean \pm SEM (standard error of the mean). Different letters above bars indicate significant differences in experimental group means $(\mathrm{p}<0.05)$.

SOD and CAT activity are the most widely used measures of oxidative stress. The hepatic SOD activity of Astyanax bimaculatus was greatly reduced at RM and was elevated at IP. SOD activity is elevated in the presence of heavy metals (Lushchak 2011; Farombi et al., 2007; Kanak et al., 2014). Farombi et al. (2007) have found that SOD activity is enhanced in the hepatic tissues of fish in the Ogun River, Nigeria, near industrial activity. However, there have also been studies that indicate the inhibition of SOD activity in the presence of metals (Ameur et al., 2012) or upon exposure to herbicides and pesticides (Modesto and Martinez, 2010; Sakuragui et al., 2013).

Since the exact nature of the pollutants and their seasonal variations in the Una River Basin are not known, it would be difficult to attribute the SOD activity levels to any specific substance. The reduction in SOD activity at RM could be due to the presence of chemical substances (pesticides) that inhibit the SOD, or due to suppression of SOD activity as a result of oxidative damage to the hepatic tissue, or alternately that fish have been exposed to pollutants for a short time during which the fish did not have time to adapt to the environment and increase SOD activity. SOD activity could also be depleted by prolonged exposure to pollutants at low concentrations (Pandey et al., 2003). The elevated SOD activity at IP could 
be due to adaptation of the fish to the pollutants or to brief exposure for a very short time. Sedeño-Diaz and Lopez-Lopez et al. (2012) found that SOD activity was either enhanced or inhibited depending on the concentration and seasonality of the pollutants.

Sedeño-Diaz and Lopez-Lopez (2012) found enhanced CAT activity with elevated levels of pollutants, principally hydrocarbons and pesticides. The enhanced CAT activity in the presence of herbicides and pesticides was also verified in a study with the freshwater fish Channa puncatatus (Nwani et al., 2010) and with the neotropical fish Astyanax altiparanae used to asses water quality in an agriculture area (Vieira et al., 2014). In the present work, CAT was significantly lower at FP as compared to the RM and IP.

CAT degrades the hydrogen peroxide produced by the dismutation of superoxide ion by SOD during oxidative stress. Hence an increase in SOD activity should result in increased CAT activity. However, this is not always observed in practice and appears to be species dependent (Ferreira et al., 2005; Lushchak, 2011).

\section{CONCLUSIONS}

Based on the analysis, FP could be considered a less-impacted site. Since RM is near an agricultural zone, probable runoff from fertilizers and pesticides depressed the levels of SOD and enhanced CAT. The elevated levels of SOD and CAT at IP could be due to pollutants (visible oil slicks). These results indicate the antioxidant activity of the enzymes SOD and CAT could be used as biomarkers. The possible inductor or inductors responsible for the alterations in the present work was not identified. However, alterations found in this work suggest that there may be micro pollutants that are affecting the metabolism of fish in the hydrographic basin of the Una River. Our results therefore highlight the need for further investigation to determine the presence of pollutants as such herbicides, pesticides and heavy metals, especially around the stretches of RM and IP.

\section{ACKNOWLEDGMENTS}

The authors acknowledge the support of Simone Sano Russi de Rezende and Ana Paula Costa of water analysis laboratories, the members of Fazenda Piloto specially Antonio Cortez Filho and Eduardo Galvão de Aguiar. We also would like to acknowledge National Institute of Science and Technology Antarctic Environmental Research (INCT - APA). Maria Tereza Oliveira Batista and Anne Caroline Ribeiro received the research initiation scholarship PIBIC/ CNPq (IBB_23_2013) and PIC/University of Taubaté (IBB_42_2013), respectively.

\section{REFERENCES}

ALBA-TERCEDOR, J. Macroinvertebrados acuáticos y calidad de las aguas de los ríos. In: SIMPOSIO DEL AGUA DE ANDALUCÍA - SIAGA, 4., 1996, Almería. Anais... [S.l.]: [s.n.], 1996. v. 2. p. 203-213.

AMEUR, W. B.; LAPUENTE, J.; MEGDICHEA, Y.E.; BARHOUMI, B.; TRABELSI, S.; CAMPS, L. et al. Oxidative stress, genotoxicity and histopathology biomarker responses in mullet and sea bass liver from Bizerte Lagoon. Marine Pollution Bulletine, v. 64, p. 241-251, 2012. http://dx.doi.org/10.1016/j.marpolbul.2011.11.026

AMERICAN PUBLIC HEALTH ASSOCIATION - APHA; AMERICAN WATER WORKS ASSOCIATION - AWWA; WATER ENVIRONMENTAL FEDERATION WEF. Stardard methods for the examination of water and wastewater. 20. ed.Washigton, 1998. 
BATISTA, G. T.; TARGA, M.; FIGALDO, E. C. C. Banco de dados ambientais da Bacia do Rio Una, Bacia do Rio Paraíba do Sul. Taubaté: Universidade de Taubaté; Departamento de Ciências Agrarias. Laboratório de Geoprocessamento (LAGEO), 2002. p. 1-16. Available in:

http://www.agro.unitau.br:8080/dspace/bitstream/2315/51/1/Projeto_Una_IBICT.pdf. Access in: Aug. 2014.

BEASLEY, G.; KNEALE, P. Investigating the influence of heavy metals on macroinvertebrate assemblages using Partial Canonical Correspondence Analysis (pCCA). Hydrology and Earth Systems Sciences, v. 7, p. 221-233, 2003. http://dx.doi.org/10.5194/hess-7-221-2003

BINELLI, A.; COGNI, D. Multi-biomarker approach to investigate the state of contamination of the R. Lambro/R. Po confluence (Italy) by zebra mussel (Dreissena polymorpha). Chemosphere, v. 79, p. 518-528, 2010.

http://dx.doi.org/10.1016/j.chemosphere.2010.02.033

BRASIL. Ministério da Saúde. Portaria no 2.914, de 12 de dezembro de 2011. Available in: <http://bvsms.saude.gov.br/bvs/saudelegis/gm/2011/prt2914_12_12_2011.html>.

Access in: July 2014.

BRASIL. Ministério do Meio Ambiente. Conselho Nacional do Meio Ambiente. Resolução n. 257, de 17 de março de 2005. Available in: http://www.mma.gov.br/port/conama/res /res05/res35705.pdf. Access in: Sep. 2014.

COMPANHIA DE TECNOLOGIA DE SANEAMENTO AMBIENTAL - CETESB. Água, rios e reservatórios. São Paulo, 2014. Available in: <http://www.cetesb.sp.gov.br/ agua/\%C3\%81guas-Superficiais/34-Vari\%C3\%A1veis-de-Qualidade-das-

\%C3\%81guas\#condutividade>. Access in Mar. 2014.

CHAPMAN, D.; KIMSTACH, V. Selection of water quality variables. In: CHAPMAN, D. (Ed.). Water quality assessment: a guide to the use of biota, sediments and water in environmental monitoring. $2^{\text {nd }}$ Ed. Cambridge: UNESCO/WHO/UNEP, 1996. Cap. 3. Available in: <http://www.who.int/water_sanitation_health/resources/wqa/en/>. Access in Mar. 2014.

DAHL, J.; JOHNSON R. K.; SANDIN, L. Detection of organic pollution of streams in southern Sweden using benthic macroinvertebrates. Hydrobiologia, v. 516, p. 161-172, 2004. http://dx.doi.org/10.1023/B:HYDR.0000025264.35531.cb

FERREIRA, M.; MORADAS-FERREIRA, P.; REIS-HENRIQUES, M. A. Oxidative stress biomarkers in two resident species, mullet (Mugil cephalus) and flounder (Platichthys flesus) from a polluted site in River Douro Estuary, Portugal. Aquatic Toxicology, v. 71, p. 39-48, 2005. http://dx.doi.org/10.1016/j.aquatox.2004.10.009

FAROMBI, E. O.; ADELOWO, O. A.; AJIMOKO, Y. R. Biomarkers of oxidative stress and heavy metal levels as indicators of environmental pollution in African catfish (Clarias gariepinus) from Nigeria Ogun River. International Journal of Environmental Research and Public Health, v. 4, p. 158-165, 2007.

http://dx.doi.org/10.3390/ijerph2007040011 
FONSECA, V. F.; VASCONCELOS, R. P.; FRANÇA, S.; SERAFIM, A.; LOPES, B.; COMPANY, R. et al. Modelling fish biological responses to contaminants and natural variability in estuaries. Marine Environmental Research, v. 96, p. 45-55, 2014. http://dx.doi.org/10.1016/j.marenvres.2013.10.011

GOYAL, M. M.; BASAK, A. Human catalase: looking for complete identity. Protein cell, v. 1, n. 10, p. 888-897, 2010. http://dx.doi.org/10.1007/s13238-010-0113-z

HEVEL, J. M.; MARIETTA, M. A. Nitric-oxide synthase assays, In: PARKER, L. (Ed.). Methods in enzymology. London: Academic Press, 1994.p. 250-258.

INSTITUTO ADOLFO LUTZ. Normas analíticas do Instituto Adolfo Lutz. V. 1: Métodos químicos e físicos para análise de alimentos. 3. ed. São Paulo: IMESP, 1985. p. 317319.

KANAK E. G.; DOGAN Z.; EROGLU A.; ATLI G.; CANLI M. Effects of fish size on the response of antioxidant systems of Oreochromis nilocicus following metal exposure. Fish Physiology and Biochemistry, v. 40, n. 4, p. 1083-1091, 2014. http://dx.doi.org/10.1007/s10695-014-9907-x

KONO, Y. Generation of superoxide radical during autoxidation of hydroxylamine and an assay for superoxide dismutase. Archives of Biochemistry and Biophysics, v. 186, p. 189-195, 1978.

LUSHCHAK V. I. Environmentally induced oxidative stress in aquatic animals. Aquatic Toxicology, v. 101, p. 13-30, 2011. http://dx.doi.org/10.1016/j.aquatox.2010.10.006

McCARTHY, J. F.; SHUGART, L. Biomarkers of environmental contamination. Boca Raton: Lewis Publishers, 1990.

MODESTO, K. A.; MARTINEZ, C. B. R. Roundup causes oxidative stress in liver and inhibits acetylcholinesterase in muscle and brain of the fish Prochilodus lineatus.

Chemosphere, v. 78, p. 294-299, 2010.

http://dx.doi.org/10.1016/j.chemosphere.2009.10.047

MOREIRA, T. N.; NUNES, E. A.; LEAL, M. E.; SCHULZ, U. H.; LEMOS, C. T. Influência dos métodos de captura de peixes na avaliação genotóxica utilizando diferentes tecidos de Astyanax fasciatus (Osteichthyes, Characidae). Journal of Brazilian Society of Ecotoxicology, v. 5, p. 1-7, 2010. http://dx.doi.org/10.5132/jbse.2010.01.001

NWANI, C. D.; LAKRA, W. S.; NAQPURE, N. S.; KUMAR, R.; KUSHWAHA, B.; SRIVASTAVA, S. K. Toxicity of the herbicide atrazine: effects on lipid peroxidation and activities of antioxidant enzymes in the freshwater fish Channa Punctatus. International Journal of Environmental Research and Public Health, v. 7, p. 32983312, 2010. http://dx.doi.org/10.3390/ijerph7083298

PANDEY, S.; PARVEZ, S.; SAYEED, I.; HAQUE, R.; BIN-HAFEEZ, B.; RAISUDDIN, S. Biomarkers of oxidative stress: a comparative study of river Yamuna fish Wallago attu (Bl. \& Schn.). Science of the Total Environment, v. 309, p. 105-115, 2003. http://dx.doi.org/10.1016/S0048-9697(03)00006-8

QU, R.; FENG, M.; WANG, X.; QIN, L.; WANG, C.; WANG, Z. \& WANG, L. Metal accumulation and oxidative stress biomarkers in liver of freshwater fish Carassius auratus following in vivo exposure to waterborne zinc. Aquatic toxicology, v. 150, p. 9-16, 2014. http://dx.doi.org/10.1016/j.aquatox.2014.02.008 
REGOLI, F.; PRINCIPATO, G. B.; BERTOLI, E.; NIGRO, M.; ORLANDO, E. Biochemical characterization of the antioxidant system in the scallop Adamussium colbecki, a sentinel organismo for monitoring the Antarctic environment. Polar Biology, v. 17, p. 251-258, 1997.

SEDEÑO-DIAZ, J. E.; LÓPEZ-LÓPEZ, E. Fresh water fish as sentinel organism: from the molecular to the population level, a Review. In: TURKER, H. (Ed.). New advances and contributions to fish biology. 2013. http://dx.doi.org/10.5772/54825

SMITH, P. K. et al. Measurement of protein using bicinchoninic acid. Analytical Biochemistry, v. 150, n. 1, p. 76-85, 1985. http://dx.doi.org/10.1016/00032697(85)90442-7

SOLE, M.; BAENA, M.; ARNAUA, S.; CARRASSONB, M.; MAYNOUA, F.; CARTES, J. E. Muscular cholinesterase activites and lipid peroxidation leves as biomarkers in several Mediterranean marine fish species and their relationship with ecological variabels. Enviromental International, v. 36, p. 202-211, 2011. http://dx.doi.org/10.1016/j.envint.2009.11.008

SAKURAGUI, M. M.; PAULINO, M. G.; PEREIRA, C. D. S.; CARVALHO, C. S.; SADAUKAS-HENRIQUE, H.; FERNANDES, M. N. Integrated use of antioxidant enzymes and oxidative damage in two fish species to assess pollution in man made hydoelectic reservoirs. Environmental Pollution, v. 178, p. 41-51, 2013. http://dx.doi.org/10.1016/j.envpol.2013.02.032

TRUJILLO-JIMÉNEZ, P.; SEDEÑO-DÍAZ, J. E.; CAMARGO, J. A.; LÓPEZ-LÓPEZ, E. Assessing environmental conditions of the Río Champotón (México) using diverse indices and biomarkers in the fish Astyanax aeneus (Günther, 1860). Ecological Indicators, v. 11, p. 1636-1646, 2011. http://dx.doi.org/10.1016/j.ecolind.2011.04.007

VIDAL, L.; DOMINI, C. E.; CANALS, A. Main parameters and assays involved with the organic pollution of water. In: NOLLET, L. M. L.; DEBELDER, L. S. P. Handbook of water quality analysis. $3^{\text {rd }}$. Edition. Boca Raton: CRC Press, 2014.

VIEIRA, C. E. D.; ALMEIRA, M. S.; GALINDO, B. A.; PEREIRA, L.; MARTINEZ, C. B. R. Integrated biomarker response index using a neotropical fish to assess the water quality in agricultural áreas. Neotropical Ichtyology, v. 12, p. 153-164, 2014. http://dx.doi.org/10.1590/S1679-62252014000100017 


Ambiente \& Água - An Interdisciplinary Journal of Applied Science
ISSN 1980-993X - doi:10.4136/1980-993X
www.ambi-agua.net
E-mail: ambi-agua@agro.unitau.br

\title{
Diagnóstico físico-ambiental como subsídio a identificação de áreas vulneráveis à erosão na bacia hidrográfica do Ribeirão do Espírito Santo, Juiz de Fora (MG), Brasil
}

\author{
doi: 10.4136/ambi-agua.1416
}

Received: 05 Jun. 2014; Accepted: 26 Aug. 2014

\author{
Vívian Gemiliano Pinto ${ }^{1 *}$; Ricardo Neves de Souza Lima ${ }^{2}$; \\ Celso Bandeira de Melo Ribeiro ${ }^{3}$; Pedro José de Oliveira Machado ${ }^{3}$ \\ ${ }^{\mathbf{1}}$ Instituto Federal de Educação Ciência e Tecnologia do Sudeste de Minas Gerais, Juiz de Fora, MG, Brasil \\ ${ }^{2}$ Instituto Brasileiro de Geografia e Estatística (IBGE), Rio de Janeiro, RJ, Brasil \\ ${ }^{3}$ Universidade Federal de Juiz de Fora (UFJF), Juiz de Fora, MG, Brasil \\ *Autor correspondente: e-mail: viviangemiliano@gmail.com, \\ riksou@yahoo.com.br, celso.bandeira@ufjf.edu.br, \\ pjomachado@gmail.com
}

\section{RESUMO}

Um diagnóstico físico-ambiental pode auxiliar no entendimento dos mecanismos que atuam nas áreas naturais e antropizadas, permitindo orientar as atividades a serem desenvolvidas, de maneira a subsidiar ações preservacionistas e conservacionistas, evitandose intervenções irreversíveis e conservando os recursos naturais da região. Neste contexto, o objetivo deste trabalho foi estudar a Bacia Hidrográfica do Ribeirão do Espírito Santo (BHRES), em Juiz de Fora, Minas Gerais, Brasil, através de um diagnóstico físico ambiental para identificação da vulnerabilidade à erosão superficial, utilizando como ferramentas parâmetros morfométricos, declividade do terreno, uso/cobertura do solo e tipo de solo na região. Apesar de a BHRES ser eminentemente rural, suas características morfométricas, declividade, uso/cobertura e tipo de solo indicam alta vulnerabilidade à erosão superficial, demandando que se adotem ações mitigadoras para preservação das áreas de regeneração da vegetação arbórea, bem como planejamento do manejo de plantações florestais e pastagens, de forma a conservar os corpos hídricos, controlar o crescimento da silvicultura na região, minimizar áreas de solo exposto e gerenciar o crescimento urbano e industrial, uma vez que esta bacia abriga um dos mais importantes mananciais de abastecimento de Juiz de Fora.

Palavras-chave: cobertura do solo, morfometria, zoneamento ambiental.

\section{Physical and environmental diagnosis as a subsidy identifying vulnerable areas to erosion in the Ribeirão do Espírito Santo watershed in Juiz de Fora (MG), Brazil}

\section{ABSTRACT}

A physical environmental diagnosis may help understand the mechanisms that operate in natural and disturbed areas, allowing guidance of the activities to be developed in order to subsidize preservationist and conservationist actions. Thereby, avoiding irreversible interventions and conserving the region's natural resources. In this context, the aim of this 
work is to study the Espírito Santo River Watershed (ESRW), in Juiz de Fora, Minas Gerais, Brazil, by doing a physical environmental assessment to identify vulnerability to surface erosion. In order to achieve that, morphometric parameters, terrain slope, use/land cover and soil type in the region were used. Although ESRW is predominantly rural, its morphometric characteristics, slope, use/cover and soil type indicate high vulnerability to surface erosion. Our findings show a demand by the adoption of mitigation measures for the preservation of regenerating wooded areas, as well as planning the management of forest plantations and pastures. Hence conserving water bodies, controlling the growth of forestry in the region, minimizing areas of exposed soil and managing urban and industrial growth, since this basin is home to one of the most important sources of supply to Juiz de Fora.

Keywords: environmental zoning, land cover, morphometry.

\section{INTRODUÇÃO}

A esculturação do modelo terrestre é fortemente influenciada pelas bacias hidrográficas e suas redes de drenagem, uma vez que as direções preferenciais dos fluxos superficiais definem os mecanismos erosivo-deposicionais preponderantes e são resultados da interação do uso e ocupação do solo, clima, aspectos geológicos, tipo de solo, relevo e cobertura vegetal (Bueno et al., 2010; Veríssimo et al., 1996).

A erosão é um problema ambiental crítico para os ecossistemas terrestres em todo o mundo (Pimentel, 2006). A vegetação mantém uma relação com o processo de erosão natural, atenuando a ação das chuvas no solo. Porém, quando esta vegetação é removida pode se instalar um processo erosivo, que é considerado acelerado quando ocorre de forma mais rápida do que os processos de formação do solo, não permitindo que esse se regenere (Abdon, 2004; Thomaz e Antoneli, 2008). A erosão tem como principais consequências o assoreamento de cursos d'água, degradação do solo, maior frequência e intensidade de enchentes e alterações ecológicas que afetam fauna e flora.

Inúmeros parâmetros podem subsidiar um estudo de vulnerabilidade ambiental. Beltrame (1994) utiliza vegetação, clima, características geológicas, pedológicas e relevo. Ross (1994) considera a declividade, tipos de solos, clima, dissecação do relevo e a proteção dos solos dada pela cobertura vegetal. Crepani et al. (2001), Nascimento e Dominguez (2009) e Melo e Santos (2010) promovem o cruzamento entre geologia, morfometria, formas de relevo, declividade, tipos de solos, vegetação e clima.

Neste contexto, o objetivo deste trabalho foi estudar a Bacia Hidrográfica do Ribeirão do Espírito Santo (BHRES), em Juiz de Fora, Minas Gerais, Brasil, através de um diagnóstico físico-ambiental para identificação da vulnerabilidade à erosão superficial, utilizando como ferramentas parâmetros morfométricos, declividade do terreno, uso/cobertura do solo e tipo de solo na região.

\section{MATERIAL E MÉTODOS}

\section{1. Área de estudo}

A área de estudo compreende a BHRES localizada na região noroeste do município de Juiz de Fora, Minas Gerais, Brasil, compreendida na área delimitada pelas coordenadas $21^{\circ} 36^{\prime} 41^{\prime \prime}$ a $21^{\circ} 44^{\prime} 48^{\prime \prime}$ Sul e $43^{\circ} 26^{\prime} 30^{\prime \prime}$ a $43^{\circ} 37^{\prime} 46^{\prime \prime}$ Oeste com uma área de drenagem de $151,49 \mathrm{~km}^{2}$ (Figura 1).

O Ribeirão Espírito Santo, afluente da margem direita do Rio Paraibuna, que por sua vez é afluente da margem esquerda do Rio Paraíba do Sul, é um importante manancial da cidade de Juiz de Fora, responsável pelo abastecimento de água de cerca de $40 \%$ da população, 
produzindo 620 litros de água tratada por segundo, conforme indicado pela Companhia de Saneamento Municipal (Juiz de Fora, 2010).

No século XIX, a BHRES era ocupada por lavouras de café, o que fez com que boa parte da cobertura vegetal arbórea fosse retirada. Com o abandono das plantações, em virtude dos baixos preços e da intensa industrialização pela qual a cidade passou, essas áreas foram ocupadas por pastagens, em sua maioria, e por áreas de regeneração da vegetação arbórea. Atualmente identificam-se outros sinais das atividades antrópicas, como abertura de estradas, granjeamentos, silvicultura e expansão do distrito industrial da cidade (Faria et al., 2003).

\subsection{Individualização das bacias de drenagem}

O Modelo Digital de Elevação (MDE) da BHRES foi gerado em ambiente SIG (Sistema de Informação Geográfica), utilizando o software ArcGIS Desktop, versão 10.1 (ESRI, 2013). As informações topográficas para a geração do MDE foram provenientes de levantamento por LIDAR (Light Detection and Ranging) e restituição aerofotogramétrica realizados pela Prefeitura de Juiz de Fora. Em razão da escala de estudo e para melhor desempenho computacional, a resolução espacial do MDE foi degradada de $1 \mathrm{~m}$ para $5 \mathrm{~m}$.

O Modelo Digital de Elevação Hidrologicamente Consistente (MDEHC) foi gerado a partir do MDE, utilizando ferramentas de geoprocessamento disponíveis no pacote Hydrology, no módulo Spatial Analyst do SIG ArcGIS, versão 10.1 (ESRI, 2013). Foi aplicado inicialmente a função Fill para preenchimento das depressões espúrias no MDE, ou seja, nivelamento de áreas para permitir a determinação do sentido do escoamento superficial de modo coerente. Em seguida, foi utilizada a função Flow Direction para determinar em cada pixel a direção do escoamento superficial conforme o método desenvolvido por (Jenson e Domingue, 1988).

Como alguns autores (Crepani et al., 2001; Oliveira et al., 2009) sugerem a divisão da área a ser estudada para identificação de áreas vulneráveis, na sequência foi aplicada a função Watershed, para definir em um modelo raster, as áreas de drenagem de interesse. Nesse caso foram utilizados como parâmetros de entrada o raster da direção do escoamento (Flow Direction) e pontos para representar os exutórios de cada sub-bacia. Considerou-se como exutório as confluências dos córregos Taquaras, Gouveia e Penido com o Ribeirão do Espírito Santo, como mostra a Figura 1, enquanto que para a Área de Drenagem de Jusante da Margem Esquerda (ADJME) e Área de Drenagem de Jusante da Margem Direita (ADJMD) foi considerada a foz do Ribeirão Espírito Santo no Rio Paraibuna. Por fim as áreas de drenagem geradas em SIG no formato raster foram convertidas para o formato vetorial.

O MDEHC foi validado segundo o Padrão de Exatidão Cartográfica Altimétrica (PEC) estabelecido pelo Decreto ${ }^{\circ}$. 89.817 de 20 de Junho de 1984 (Brasil, 1984). Para a validação foram levantados 31 pontos na BHRES, utilizando-se GPS, e a altitude desses pontos foram comparadas às altitudes determinadas pelo MDEHC, seguindo metodologia descrita por Poleto et al. (2008). O MDEHC se enquadrou no padrão de exatidão cartográfica classe A, mostrando-se consistente e apresentando precisões compatíveis para a realização de análises hidrológicas apesar de apresentar tendências e erros sistemáticos na imagem referente à altitude.

Para a identificação dos corpos d'água foram utilizados dados vetoriais digitais referentes à hidrografia das cartas topográficas do Instituto Brasileiro de Geografia e Estatística (IBGE), folhas Ewbank da Câmara (SF-23-X-C-VI-2) e Juiz de Fora (SF-23-X-D-IV-1), ambas na escala de 1:50.000.

A BHRES foi dividida em três sub-bacias (Figura 1): sub-bacia do Córrego Taquaras (SBCT), que contém a nascente do Ribeirão Espírito Santo, contudo foi utilizada a nomenclatura do Córrego Taquaras, uma vez que este é o maior curso em extensão da sub-bacia e para distingui-la da BHRES propriamente dita; sub-bacia do Córrego Gouveia 
(SBCG); sub-bacia do Córrego Penido (SBCP); e duas áreas de drenagem, ADJME e ADJMD, mais próximas ao exutório.

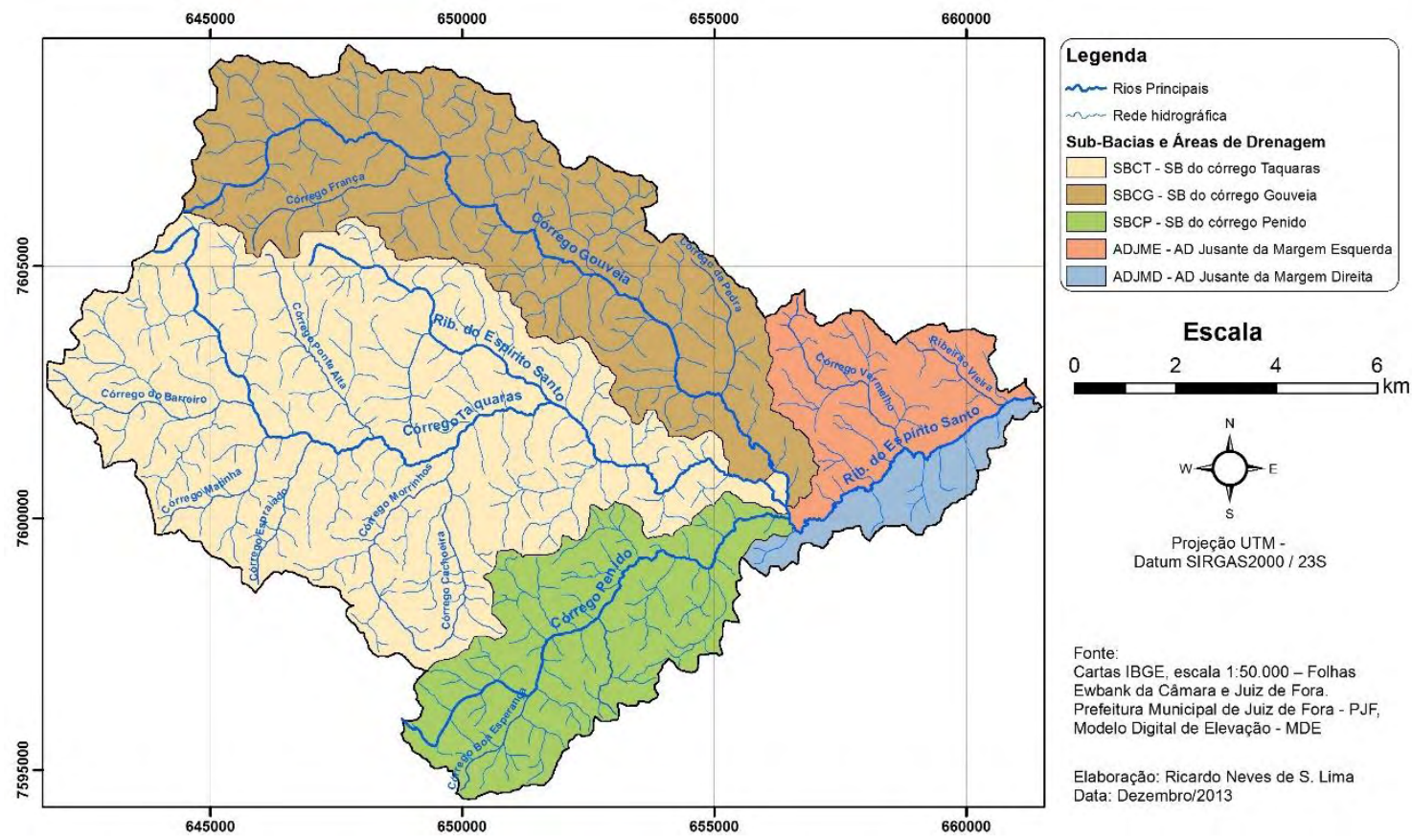

Figura 1. Distribuição espacial das três sub-bacias e das duas áreas de drenagem na Bacia Hidrográfica do Ribeirão do Espírito Santo.

Fonte: (Lima, 2013).

A maior sub-bacia da BHRES é a SBCT, com área de drenagem de 68,7 $\mathrm{km}^{2}$, correspondendo a 45,35\% da área da bacia; seguida da SBCG, com área de 42,73 km² (28,2\% da BHRES); SBCP, com área de 22,71 km² (14,99\% da BHRES); ADJME com 12,37 km² (8,17\% da BHRES); e ADJMD com 4,98 km² (3,29\% da BHRES).

Para o diagnóstico físico-ambiental da BHRES, sub-bacias e áreas de drenagem foram considerados os parâmetros de morfometria, declividade, uso e cobertura do solo e classificação dos solos. Esses parâmetros foram escolhidos por serem fundamentais ao estudo da erosão superficial, e consequentemente, ao processo de assoreamento (Machado, 2012).

A vulnerabilidade de cada sub-bacia e área de drenagem foi calculada em função de cada um dos parâmetros considerados no estudo, estabelecendo-se uma escala de vulnerabilidade: variável de um (muito baixa) a cinco (muito alta), segundo os diferentes intervalos, conforme o parâmetro analisado. Os valores da escala de vulnerabilidade funcionaram como "pesos", a serem atribuídos às diferentes áreas de cada sub-bacia ou área de drenagem.

\subsection{Morfometria}

A caracterização morfométrica de bacias hidrográficas é uma ferramenta importante para subsidiar o planejamento territorial visando a preservação ambiental e a manutenção da produção de água em quantidade e qualidade (Nardini et al., 2013). A combinação de dados morfométricos auxiliam na diferenciação de áreas homogêneas, revelando indicadores físicos específicos de forma a qualificarem as alterações ambientais.

Neste estudo, os parâmetros morfométricos utilizados foram: Densidade de Drenagem, Comprimento de Rampa Médio do Escoamento Superficial e Índice de Rugosidade, descritos na Tabela 1. 
Tabela 1. Descrição dos parâmetros morfométricos utilizados na área de estudo, fórmulas e seu significado.

\begin{tabular}{llll}
\hline Parâmetro & Fórmula & Descrição & Significado \\
\hline
\end{tabular}

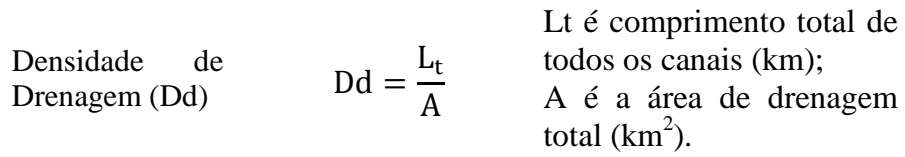

Comprimento de Rampa Médio do Escoamento Superficial (Cr)

$$
\mathrm{Cr}=\frac{1}{4 \mathrm{Dd}} \quad \begin{aligned}
& \text { Dd é a densidade de } \\
& \text { drenagem }\left(\mathrm{km} \mathrm{km}^{-2}\right) .
\end{aligned}
$$

H é a amplitude Índice de $\quad \mathrm{Ir}=\mathrm{H} * \mathrm{Dd} \quad$ altimétrica da bacia $(\mathrm{km})$; Rugosidade (Ir) Ir $=\mathrm{H} * \mathrm{Dd} \quad$ Dd é a densidade de drenagem $\left(\mathrm{km} \mathrm{km}^{-2}\right)$.
Está relacionada com declividade do relevo, cobertura vegetal, resistência e permeabilidade do solo (Rocha e Kurtz, 2001).

É definido como sendo a distância média em que a água da chuva teria que escoar sobre o terreno de uma bacia, caso o escoamento se desse em linha reta desde onde a chuva cai até o ponto mais próximo do leito de um curso d’água da bacia (Villela e Mattos, 1975).

Em uma mesma região, Ir elevado implica em maior potencial de erosão por processos hídricos (Rocha e Kurtz, 2001).

Para cada parâmetro morfométrico calculado, para cada sub-bacia ou área de drenagem, atribuiu-se peso 5 ao maior valor, uma vez que representava a condição mais favorável à erosão; e peso 1 para o menor, condição menos favorável à erosão. Dividindo-se o intervalo entre os valores extremos em cinco classes, obteve-se uma escala de vulnerabilidade, que recebeu pesos variando de 1 a 5, correspondendo, respectivamente, à: muito baixa, baixa, média, alta e muito alta vulnerabilidade.

Após a determinação do peso para cada um dos parâmetros mofométricos (Densidade de Drenagem, Comprimento de Rampa Médio do Escoamento Superficial e Índice de Rugosidade), estes foram somados para cada sub-bacia ou área de drenagem, cujo somatório poderia variar de 3 a 15, uma vez que foram utilizados três parâmetros cujos pesos variavam de 1 a 5. Dividindo-se o intervalo gerado pelo somatório dos pesos relativos aos parâmetros morfométricos em cinco classes obteve-se o intervalo de domínio das classes de vulnerabilidade para morfometria, apresentada na coluna um da Tabela 2.

Tabela 2. Intervalos de domínio das classes de vulnerabilidade para morfometria, declividade, tipo de solo e determinação da vulnerabilidade ambiental da área de estudo.

\begin{tabular}{ccccc}
\hline Morfometria & $\begin{array}{c}\text { Declividade, } \\
\text { Uso e cobertura do } \\
\text { solo e Tipo de solo }\end{array}$ & $\begin{array}{c}\text { Diagnóstico Físico- } \\
\text { ambiental }\end{array}$ & $\begin{array}{c}\text { Vulnerabilidade à } \\
\text { erosão superficial }\end{array}$ & $\begin{array}{c}\text { Escala de } \\
\text { vulnerabilidade }\end{array}$ \\
\hline De 3 até 5,4 & Entre 1 e 1,8 & Entre 4 e 7,2 & Muito baixa & 1 \\
$>5,4$ até 7,8 & $>1,8$ até 2,6 & $>7,2$ até 10,4 & Baixa & 2 \\
$>7,8$ até 10,2 & $>2,6$ até 3,4 & $>10,4$ até 13,6 & Média & 3 \\
$>10,2$ até 12,6 & $>3,4$ até 4,2 & $>13,6$ até 16,8 & Alta & 4 \\
$>12,6$ até 15 & $>4,2$ até 5 & $>16,8$ até 20 & Muito Alta & 5 \\
\hline
\end{tabular}




\subsection{Declividade}

A declividade é uma característica topográfica diretamente relacionada à erosão superficial, pois tem influência na infiltração das águas das chuvas e na velocidade de escoamento superficial (Valladares et al., 2012). A influência desse parâmetro pode ser hierarquizada, como o fizeram diversos pesquisadores (Beltrame, 1994; Crepani et al., 2001; Klais et al., 2012; Ross, 1994). No presente trabalho adotou-se, para as classes de relevo preconizadas pela EMBRAPA (2006), a escala de vulnerabilidade utilizada por Machado (2012), dada as semelhanças entre as áreas de estudo (primeira, quarta e quinta colunas da Tabela 3).

Tabela 3. Escala de vulnerabilidade para os parâmetros declividade, uso e cobertura do solo e tipos de solos.

\begin{tabular}{cllcc}
\hline $\begin{array}{c}\text { Intervalos de } \\
\text { declividade }\end{array}$ & $\begin{array}{c}\text { Uso e Cobertura } \\
\text { do solo }\end{array}$ & Tipos de solos & $\begin{array}{c}\text { Vulnerabilidade } \\
\text { à erosão } \\
\text { superficial }\end{array}$ & $\begin{array}{c}\text { Escala de } \\
\text { vulnerabilidade }\end{array}$ \\
\hline 0 a $3 \%$ & Floresta & - & 1 & Muito baixa \\
$>3$ a $8 \%$ & Agrossilvicultura & $\begin{array}{l}\text { Latossolos Vermelhos e } \\
\text { Vermelhos-amarelos }\end{array}$ & 2 & Baixa \\
$>8$ a $20 \%$ & Silvicultura & Latossolos Amarelos & 3 & Média \\
$>20$ a $45 \%$ & Pastagem & Cambissolos & 4 & Alta \\
$>45 \%$ & $\begin{array}{l}\text { Área construída } \\
\text { Solo exposto }\end{array}$ & - & 5 & Muito Alta \\
\hline
\end{tabular}

Para obter-se a vulnerabilidade à erosão superficial relativa à declividade, multiplicou-se os pesos das respectivas classes de declividade indicados na Tabela 3 pelas áreas correspondentes, somou-se as áreas ponderadas de cada unidade de estudo e dividiu-se pela área real de cada uma delas. Os quocientes gerados para cada sub-bacia e áreas de drenagem variaram de 1 a 5 , cujo intervalo foi dividido em 5 classes apresentadas na Tabela 2 (segunda, quarta e quinta colunas), para identificação da vulnerabilidade à erosão superficial devido à declividade, associada à sua respectiva escala de vulnerabilidade.

\subsection{Uso e cobertura do solo}

Para o mapeamento dos principais tipos de uso e cobertura do solo na BHRES foi realizada a classificação de imagens do satélite RapidEye, com resolução espacial de $5 \mathrm{~m}$ e data de passagem de 27/04/2010. O mapeamento das classes de uso/cobertura do solo foi executado por intermédio de uma classificação automática supervisionada utilizando o método de máxima verossimilhança Gaussiana (Maxver), disponível no software ENVI ${ }^{\circledR}$ versão 4.8.

Faria e Fernandes Filho (2013), Oliveira et al. (2013) e Souza et al. (2011) destacaram o bom desempenho do método Maxver em imagens do RapidEye quando o processo de seleção das amostras de treinamento representam a diversidade espectral da classe a ser mapeada. No caso específico deste trabalho este treinamento foi realizado com as classes corpos d'água, pastagem, floresta, solo exposto e área construída.

Contudo, para distinguir superfícies com características espectrais similares, como áreas de regeneração da vegetação arbórea e silvicultura, que inicialmente haviam sido classificadas como floresta, utilizaram-se imagens de alta resolução do aplicativo Google Earth, versão gratuita, e procedeu-se identificação manual de áreas cobertas por plantios de eucalipto e 
áreas de agrossilvicultura, eucalipto e pasto, as quais foram posteriormente vetorizadas e incluídas no mapa final de uso e cobertura do solo.

A hierarquização do tipo de uso do solo e/ou cobertura vegetal associada à erosão superficial é bastante diversa, conforme as características específicas do local de estudo (Crepani et al., 2001; Ribeiro e Campos, 2007). A densidade de cobertura vegetal do terreno é um fator de proteção contra os processos morfogenéticos que se traduzem na forma de erosão. Dessa forma para altas densidades de cobertura, os valores atribuídos na escala de vulnerabilidade se aproximam da estabilidade (Crepani et al., 2001). Na tentativa de ponderar a densidade de cobertura vegetal associada à vulnerabilidade à erosão, adotou-se uma escala de vulnerabilidade (segunda, quarta e quinta colunas da Tabela 3), idêntica àquela adotada por Machado (2012).

Para o cálculo da vulnerabilidade à erosão superficial relativa ao uso/cobertura do solo, multiplicaram-se os pesos dos respectivos uso/cobertura do solo indicados na Tabela 3 pelas áreas correspondentes, somou-se as áreas ponderadas de cada unidade de estudo e dividiu-se pela área real de cada uma delas. Em seguida, utilizando-se metodologia análoga àquela adotada para declividade, associou-se a vulnerabilidade à erosão superficial gerada pelo uso e cobertura do solo à sua respectiva escala de vulnerabilidade (segunda, quarta e quinta colunas da Tabela 2).

\subsection{Classificação de solos}

A classificação de solos na BHRES foi realizada a partir da vetorização, em SIG, das Unidades de Mapeamento apresentadas no Mapa de Solos do Estado de Minas Gerais, Folha 4, na escala 1:650.000 (FEAM, 2010).

Tomando-se por base os trabalhos de Crepani et al. (2001), Machado (2012) e Ross (1994), estabeleceu-se a escala de vulnerabilidade para os solos da BHRES, segundo sua erodibilidade, com valores de 1 a 5, como apresentados na Tabela 3 (terceira, quarta e quinta colunas).

Para se determinar a vulnerabilidade à erosão superficial relacionada às classes de solo, multiplicou-se os pesos dos respectivos tipos de solo, indicados na Tabela 3, pelas áreas correspondentes. Somaram-se as áreas ponderadas de cada unidade de estudo e dividiu-se pela área real de cada uma delas. Em seguida, utilizando-se metodologia idêntica àquelas adotadas para declividade e uso e cobertura do solo associou-se a vulnerabilidade à erosão superficial gerada pela classificação dos solos à sua respectiva escala de vulnerabilidade (segunda, quarta e quinta colunas da Tabela 2).

\subsection{Diagnóstico de vulnerabilidade físico-ambiental}

Para a determinação da vulnerabilidade físico-ambiental à erosão superficial, somaram-se os valores obtidos na escala de vulnerabilidade para os quatro parâmetros analisados: morfometria, declividade, uso/cobertura do solo e classificação do solo em cada sub-bacia e área de drenagem da BHRES. Como o valor obtido para cada uma das unidades de estudo poderia variar de 4 (mínimo) a 20 (máximo), uma vez que foram utilizados quatro parâmetros cujos pesos variavam de 1 a 5, dividindo-se o intervalo gerado pelo somatório dos pesos relativos em cinco classes obteve-se o intervalo de domínio das classes de vulnerabilidade apresentadas na terceira coluna da Tabela 2.

\section{RESULTADOS E DISCUSSÃO}

\subsection{Características morfométricas}

A BHRES possui padrão de drenagem dendrítico, com grande quantidade de afluentes e subafluentes. Villela e Mattos (1975) classificam bacias com valores de densidade de 
drenagem entre 0,5 e 1,5 km. km² como drenagem regular, entre 1,5 e 2,5 km. km² como boa drenagem, entre 2,5 e $3,5 \mathrm{~km} \cdot \mathrm{km}^{-2}$ como muito boa e acima de $3,5 \mathrm{~km} \cdot \mathrm{km}^{-2}$ como excepcionalmente bem drenadas. A BHRES e suas sub-bacias são muito bem drenadas com densidades de drenagem variando de 2,67 (SBCG) a 3,08 km. $\mathrm{km}^{-2}$ (SBCP). Também consideradas com alta capacidade de drenagem, de acordo com a classificação proposta por Beltrame (1994).

Estudos em outras bacias da região sudeste do Brasil também identificaram boa densidade de drenagem. Silva e Tonello (2014) identificaram densidade de drenagem de $2,72 \mathrm{~km} \cdot \mathrm{km}^{-2}$ na bacia hidrográfica do Ribeirão dos Pinheirinhos em Brotas, São Paulo; Lima et al. (2011) estimaram em 2,37 km. $\mathrm{km}^{-2}$ na bacia hidrográfica do Rio Preto, Minas Gerais; Santos et al. (2012) identificaram 3,49 e 4,10 km.km², respectivamente, nas sub-bacias hidrográficas de Perdizes e Fojo no município de Campos do Jordão, SP. Em contrapartida, na região nordeste brasileira, Rocha et al. (2014) estudando a sub-bacia do rio Poxim-Açu, Sergipe, encontraram densidade de drenagem de $1,82 \mathrm{~km} . \mathrm{km}^{-2}$, valor mais próximo àqueles encontrados na ADJME $\left(2,32 \mathrm{~km} \cdot \mathrm{km}^{-2}\right)$ e ADJMD $\left(1,43 \mathrm{~km} \cdot \mathrm{km}^{-2}\right)$.

Altas densidades de drenagem podem indicar solos pouco permeáveis (Christofoletti, 1980) ou pequena cobertura vegetal ou relevo acidentado, ou ainda situações concomitantes, que favorecem o escoamento superficial e consequentemente o maior carreamento de partículas do solo (Rocha e Kurtz, 2001).

O Comprimento de Rampa Médio do Escoamento Superficial (Cr) também influi diretamente na perda de solo, uma vez que quanto maior for a sua extensão maior tenderá a ser a velocidade do escoamento superficial (Villela e Mattos, 1975). O Cr não apresenta muita discrepância entre as sub-bacias, variando de 0,0811(SBCP) a 0,0936 (SBCG). Porém, são nas áreas de drenagem que se identificam os maiores valores de $\mathrm{Cr}$, principalmente na $\operatorname{ADJMD}(0,1751)$, o que pode influenciar a perda de solo.

O Índice de Rugosidade (Ir) combina a qualidade de declividade e comprimento das vertentes, com a densidade de drenagem (Christofoletti, 1980), seus valores máximo e mínimo indicam, respectivamente, os maiores e menores potenciais de erosão por processos hídricos na BHRES. As três sub-bacias apresentam Ir variando de 0,717 (SBCG) a 0,775 (SBCT) e a ADJMD apresenta o menor Ir $(0,293)$.

Após a atribuição de pesos a cada parâmetro morfométrico, tornou-se possível hierarquizar as áreas de estudo por parâmetro. Somando-se o peso atribuído a cada parâmetro, de cada unidade de estudo e comparando-os com a Tabela 2, identificou-se que as SBCT, SBCP e a BHRES apresentam alta vulnerabilidade à erosão superficial em relação aos parâmetros morfométricos analisados. Enquanto a SBCG apresenta média vulnerabilidade, e a ADJMD e ADJME apresentam baixa vulnerabilidade, devido principalmente a contribuição da Densidade de Drenagem e do Índice de Rugosidade.

\subsection{Declividade}

Todas as unidades de estudo possuem mais de $40 \%$ de sua área com declividade entre 20 e $45 \%$ (Figura 2a), e mais de $20 \%$ de área com declividade acima de $45 \%$, exceto a ADJMD que possui $17 \%$ de área com declividade acima de $45 \%$, e quase $13 \%$ de sua área com declividade entre 0 e $3 \%$.

Em terrenos mais íngremes, a água tende a escoar com maior velocidade, dificultando a infiltração e favorecendo o processo erosivo (Valladares et al., 2012). A BHRES e todas as unidades de estudo, isoladamente, apresentaram alta vulnerabilidade à erosão superficial devido à declividade (Tabela 4), inclusive a ADJMD, ou seja, o maior percentual de área com declividade entre 0 e $3 \%$ não foi suficientemente relevante para fazer com que essa apresentasse vulnerabilidade à erosão superficial devido à declividade inferior as demais áreas estudadas. 
Tabela 4. Determinação da vulnerabilidade à erosão superficial devido à declividade.

\begin{tabular}{|c|c|c|c|c|c|c|c|c|c|c|}
\hline \multirow{4}{*}{$\begin{array}{r}\text { Unidade } \\
\text { de estudo }\end{array}$} & \multicolumn{4}{|c|}{ Classes de Declividade - Área $\left(\mathbf{k m}^{2}\right)$} & \multirow{3}{*}{$\begin{array}{r}\text { Acima } \\
\text { de } 45 \% \\
\end{array}$} & \multirow{4}{*}{$\begin{array}{l}\text { Área } \\
\text { real } \\
\text { total } \\
\left(\mathbf{k m}^{2}\right)\end{array}$} & \multirow{4}{*}{ 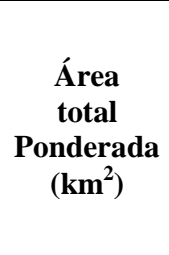 } & \multirow{4}{*}{ 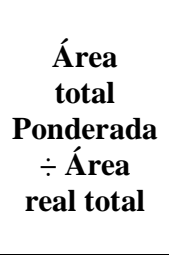 } & \multirow{4}{*}{$\begin{array}{c}\text { Escala de } \\
\text { vulnerabilidade }\end{array}$} & \multirow{4}{*}{$\begin{array}{l}\text { Vulnerabilidade } \\
\text { à erosão } \\
\text { superficial }\end{array}$} \\
\hline & 0 a $3 \%$ & 3 a $8 \%$ & 8 a $20 \%$ & 20 a $45 \%$ & & & & & & \\
\hline & \multicolumn{4}{|c|}{ Peso } & & & & & & \\
\hline & 1 & 2 & 3 & 4 & 5 & & & & & \\
\hline SBCT & 2,50 & 5,84 & 10,82 & 33,46 & 16,09 & 68,70 & 260,90 & 3,80 & 4 & Alta \\
\hline SBCG & 1,49 & 3,54 & 6,39 & 21,01 & 10,30 & 42,73 & 163,26 & 3,82 & 4 & Alta \\
\hline SBCP & 1,16 & 2,57 & 3,89 & 9,44 & 5,64 & 22,71 & 83,96 & 3,70 & 4 & Alta \\
\hline ADJME & 0,72 & 1,25 & 1,84 & 5,26 & 3,30 & 12,37 & 46,29 & 3,74 & 4 & Alta \\
\hline ADJMD & 0,64 & 0,49 & 0,87 & 2,13 & 0,85 & 4,98 & 17,00 & 3,41 & 4 & Alta \\
\hline BHRES & 6,51 & 13,70 & 23,80 & 71,31 & 36,18 & 151,49 & 571,41 & 3,77 & 4 & Alta \\
\hline
\end{tabular}
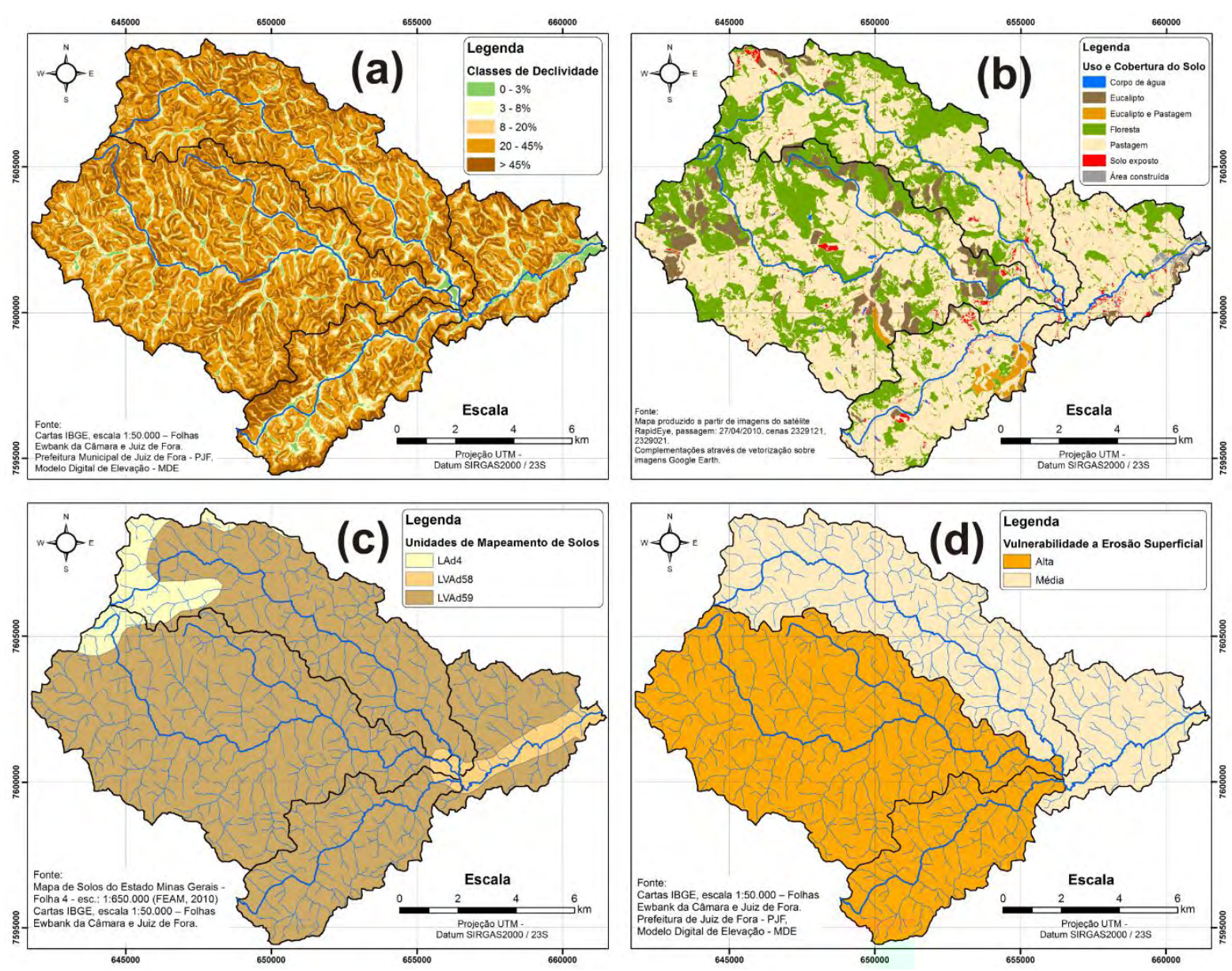

Figura 2. Mapas de declividade, uso e cobertura do solo, classificação do solo e vulnerabilidade à erosão superficial nas sub-bacias e áreas de drenagem da BHRES.

(a) Declividade (b) Uso e cobertura do solo (c) Classificação do solo (d) Vulnerabilidade à erosão superficial.

Fonte: (Lima, 2013). 


\subsection{Uso e cobertura do solo}

A BHRES é caracterizada por predominante ocupação rural (Figura 2b), com 98,24\% da sua área ocupada por pastagens, silvicultura e mata. Sendo que nas SBCT e SBCG não foram identificadas áreas construídas, pois as construções nessas áreas se restringiram a pequenas edificações rurais dificultando seu reconhecimento no nível de resolução utilizado. Nessas duas sub-bacias, apesar do predomínio de pastagens, acima de $60 \%$, identificam-se as maiores áreas de mata da BHRES, porém na SBCT cerca de $10 \%$ da área já é ocupada pela silvicultura, sendo $6,68 \mathrm{~km}^{2}(9,72 \%)$ de plantações de eucalipto e $0,24 \mathrm{~km}^{2}(0,35 \%)$ de agrossilvicultura (eucalipto e pastagem).

Cabe considerar que plantações florestais de crescimento rápido como o Eucalipto consomem mais água do que a vegetação de menor porte e culturas agrícolas não irrigadas, podendo em algumas situações levar à uma redução significativa do deflúvio na escala de microbacias (Lima, 2010; Poore e Fries, 1985). Neste contexto, Calder (2007) alerta que o percentual de ocupação da área da microbacia pelas plantações florestais é um fator muito importante para a ocorrência ou não de redução de deflúvio, uma vez que alguns trabalhos em microbacias experimentais indicaram alteração no deflúvio em situações em que as plantações florestais ocupavam apenas até $20 \%$ da área da microbacia hidrográfica. Sendo assim, talvez seja o momento para a criação de políticas públicas que: possam controlar o uso e ocupação da BHRES pela silvicultura, de forma a manter a disponibilidade hídrica, uma vez que a bacia contém um dos mais importantes mananciais da cidade de Juiz de Fora; e, de forma simultânea, corrobore para a minimização da erodibilidade do solo por meio da agrossilvicultura, evitando situações de solo exposto, comuns na época do corte do eucalipto.

A BHRES possui 28,95\% de sua área coberta por floresta, ou seja, áreas de regeneração da vegetação arbórea. Com maiores concentrações na SBCG (34,70\%) e SBCT (33,85\%), porém na SBCP (15,12\%), ADJME (17,54\%) e principalmente ADJMD (3,25\%) estes percentuais caem expressivamente.

Já as áreas de solo exposto correspondem a 1,17\% da BHRES, sendo uma parte delas correspondente às estradas vicinais, sem pavimentação. Contudo, merecem atenção algumas áreas de solo exposto concentradas, uma em área de cabeceira na SBCG, e outra em área central da SBCT (Figura 2b).

A SBCP é a sub-bacia com menor área de solo exposto, porém maior percentual (1,45\%), o que é justificado pelo avanço do processo de ocupação, principalmente granjeamentos. Além disto, entre as sub-bacias, foi a única onde foi possível mensurar a área construída, $0,09 \mathrm{~km}^{2}(0,39 \%)$. Possui $75,77 \%$ de sua área ocupada por pastagens e apenas $15,12 \%$ de área de regeneração da vegetação arbórea.

Porém, a área mais antropizada da BHRES é a ADJMD, com 0,34 $\mathrm{km}^{2}$ de área construída, seguida pela ADJME, com $0,20 \mathrm{~km}^{2}$. A área construída corresponde a apenas 0,42\% da BHRES, concentrada próxima ao exutório, especialmente em uma área que abrange parte do distrito industrial de Juiz de Fora.

Apesar da predominante cobertura vegetal, a BHRES, SBCT e SBCG apresentaram média vulnerabilidade à erosão superficial (Tabela 5). Entretanto a SBCP, ADJME e ADJMD, todas mais próximas ao exutório, apresentaram alta vulnerabilidade dada as características de ocupação já descritas.

\subsection{Classificação dos solos}

Tomando-se por base o mapeamento de solos do Estado de Minas Gerais (FEAM, 2010), a BHRES é predominantemente composta de latossolo vermelho-amarelo, LVAd59; as cabeceiras dos Córregos Taquaras e Gouveia são compostas por latossolo amarelo, LAd4; a as áreas próximas ao exutório, nas sub-bacias, e regiões marginais ao Ribeirão do Espírito Santo, nas áreas de drenagem, são compostas por latossolo vermelho-amarelo, LVAd58 (Figura 2c). 
Cabe destacar que perfis de solos localizados em áreas muito declivosas tendem a serem menos espessos, pois tal posição favorece a morfogênese, levando estes solos a um constante rejuvenescimento por erosão (Ippoliti et al., 2005).

As sub-bacias e áreas de drenagem da BHRES não se distinguem em relação à vulnerabilidade à erosão superficial devido às classes de solo (Tabela 6), todas apresentando média vulnerabilidade.

Tabela 5. Determinação da vulnerabilidade à erosão superficial devido ao uso/cobertura do solo.

\begin{tabular}{|c|c|c|c|c|c|c|c|c|c|c|c|}
\hline \multirow{4}{*}{$\begin{array}{l}\text { Unidade } \\
\text { de estudo }\end{array}$} & \multicolumn{6}{|c|}{ Uso/cobertura do solo - Área $\left(\mathbf{k m}^{2}\right)$} & \multirow{4}{*}{$\begin{array}{l}\text { Área } \\
\text { real } \\
\text { total } \\
\left(\mathbf{k m}^{2}\right)\end{array}$} & \multirow{4}{*}{$\begin{array}{l}\text { Área } \\
\text { total } \\
\text { ponderada } \\
\left(\mathbf{k m}^{2}\right)\end{array}$} & \multirow{4}{*}{$\begin{array}{l}\text { Área total } \\
\text { ponderada } \\
\div \text { Área } \\
\text { real total }\end{array}$} & \multirow{4}{*}{$\begin{array}{c}\text { Escala de } \\
\text { vulnerabilidade }\end{array}$} & \multirow{4}{*}{$\begin{array}{c}\text { Vulnerabilidade } \\
\text { à erosão } \\
\text { superficial }\end{array}$} \\
\hline & $\mathbf{A}$ & $\mathbf{B}$ & $\mathbf{C}$ & D & $\mathbf{E}$ & $\mathbf{F}$ & & & & & \\
\hline & \multicolumn{6}{|c|}{ Peso } & & & & & \\
\hline & 5 & 3 & 2 & 1 & 4 & 5 & & & & & \\
\hline SBCT & 0,00 & 6,68 & 0,24 & 23,26 & 37,83 & 0,59 & 68,59 & 198,03 & 2,89 & 3 & Média \\
\hline SBCG & 0,00 & 1,16 & 0,00 & 14,82 & 26,19 & 0,50 & 42,67 & 125,55 & 2,94 & 3 & Média \\
\hline SBCP & 0,09 & 0,35 & 1,22 & 3,43 & 17,20 & 0,33 & 22,63 & 77,83 & 3,44 & 4 & Alta \\
\hline ADJME & 0,20 & 0,00 & 0,00 & 2,17 & 9,87 & 0,12 & 12,36 & 43,24 & 3,50 & 4 & Alta \\
\hline ADJMD & 0,34 & 0,24 & 0,00 & 0,16 & 3,98 & 0,24 & 4,97 & 19,73 & 3,97 & 4 & Alta \\
\hline BHRES & 0,63 & 8,43 & 1,46 & 43,85 & 95,08 & 1,77 & 151,22 & 464,38 & 3,07 & 3 & Média \\
\hline
\end{tabular}

A: Área construída; B: Silvicultura; C: Agrossilvicultura; D: Floresta; E; Pastagem; F: Solo exposto.

Tabela 6. Determinação da vulnerabilidade à erosão superficial devido tipo de solo.

\begin{tabular}{|c|c|c|c|c|c|c|c|c|c|c|c|c|c|c|c|}
\hline \multirow{6}{*}{$\begin{array}{l}\text { Unidade } \\
\text { de estudo }\end{array}$} & \multicolumn{10}{|c|}{ Tipos de solo - Área $\left(\mathbf{k m}^{2}\right)$} & \multirow{6}{*}{ 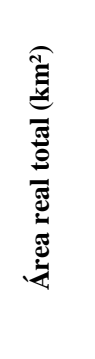 } & \multirow{6}{*}{ 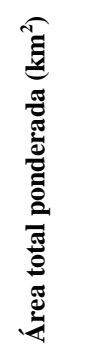 } & \multirow{6}{*}{ 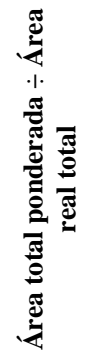 } & \multirow{6}{*}{ 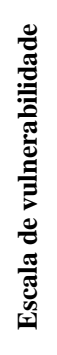 } & \multirow{6}{*}{ 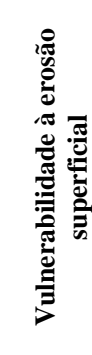 } \\
\hline & \multicolumn{4}{|c|}{ LVAd58 $^{1}$} & \multicolumn{3}{|c|}{ LVAd59 $^{1}$} & \multicolumn{3}{|c|}{ 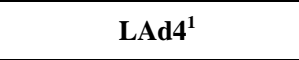 } & & & & & \\
\hline & LVA $^{2}$ & $\mathbf{L A}^{\mathbf{3}}$ & $\mathbf{C}^{5}$ & $L V^{4}$ & $\mathbf{L V A}^{2}$ & $\mathbf{L A}^{\mathbf{3}}$ & $\mathbf{C}^{5}$ & $\mathbf{L A}^{3}$ & LVA $^{2}$ & $\mathbf{C}^{5}$ & & & & & \\
\hline & $40 \%$ & $30 \%$ & $20 \%$ & $10 \%$ & $60 \%$ & $20 \%$ & $20 \%$ & $40 \%$ & $40 \%$ & $20 \%$ & & & & & \\
\hline & & & & & & eso & & & & & & & & & \\
\hline & 2 & 3 & 4 & 2 & 2 & 3 & 4 & 3 & 2 & 4 & & & & & \\
\hline SBCT & 0,23 & 0,17 & 0,11 & 0,06 & 1,28 & 0,43 & 0,43 & 26,40 & 26,40 & 13,20 & 68,70 & 191,88 & 2,79 & 3 & Média \\
\hline SBCG & 0,16 & 0,12 & 0,08 & 0,04 & 4,10 & 1,37 & 1,37 & 14,20 & 14,20 & 7,10 & 42,73 & 118,22 & 2,77 & 3 & Média \\
\hline SBCP & 0,15 & 0,11 & 0,07 & 0,04 & - & - & - & 8,93 & 8,93 & 4,47 & 22,71 & 63,54 & 2,80 & 3 & Média \\
\hline ADJME & 1,03 & 0,77 & 0,51 & 0,26 & - & - & - & 3,92 & 3,92 & 1,96 & 12,37 & 34,39 & 2,78 & 3 & Média \\
\hline ADJMD & 0,72 & 0,54 & 0,36 & 0,18 & - & - & - & 1,28 & 1,28 & 0,64 & 4,98 & 13,76 & 2,76 & 3 & Média \\
\hline BHRES & 2,29 & 1,71 & 1,14 & 0,57 & 5,38 & 1,79 & 1,79 & 54,72 & 54,72 & 27,36 & 151,49 & 421,80 & 2,78 & 3 & Média \\
\hline
\end{tabular}

$\mathbf{1}^{1}$ Tipos de latossolos que apresentam suas composições discriminadas na tabela; ${ }^{2}$ Latossolo vermelho-amarelo; ${ }^{3}$ latossolo amarelo; ${ }^{4}$ latossolo vermelho; ${ }^{5}$ cambissolo. 


\subsection{Diagnóstico físico-ambiental da BHRES}

De maneira geral a BHRES é altamente vulnerável à erosão superficial, fortemente impactada pela declividade acentuada e grande cobertura de pastagens. O tipo de solo e a declividade do terreno, não auxiliaram na distinção entre as áreas mais e menos favoráveis à erosão, uma vez que toda a bacia indicou média suscetibilidade a erosão devido ao tipo de solo e alta suscetibilidade devido à declividade. Os parâmetros morfometria e uso e cobertura do solo foram os fatores preponderantes.

A SBCP e SBCT possuem as densidades de drenagem e os índices de rugosidade mais favoráveis à erosão superficial. Com relação ao uso e cobertura do solo, a SBCP é a sub-bacia que apresenta maiores sinais da intervenção antrópica, com menor percentual de cobertura florestal e maior percentual de cobertura por pastagens, o que culminou em alta vulnerabilidade à erosão superficial (Figura 2d). Enquanto a SBCT, apesar de um uso/cobertura medianamente vulnerável, dada a morfometria altamente vulnerável, conduziu também ao diagnóstico final de altamente vulnerável.

Contudo, a área mais antropizada da BHRES, a ADJMD que possui o maior percentual de área construída, pastagem, eucalipto e solo exposto, e, consequentemente, o menor percentual de floresta $(3,25 \%)$, foi classificada como de média vulnerabilidade dadas suas características morfométricas, assim como a ADJME (Figura 2d). A SBCG também foi classificada de média vulnerabilidade, uma vez que possui características morfométricas um pouco menos severas que as demais sub-bacias.

\section{CONCLUSÃO}

A metodologia utilizada, com implementação de parâmetros morfométricos, declividade do terreno, uso/cobertura do solo e tipo de solo, em ambiente SIG, mostrou-se adequada para realizar um diagnóstico físico-ambiental visando a identificação da vulnerabilidade à erosão superficial na Bacia Hidrográfica do Ribeirão do Espírito Santo.

Os resultados indicaram alta vulnerabilidade das unidades hidrográficas à erosão nas subbacias do Córrego Taquaras (SBCT) e Sub-Bacia do Córrego Penido (SBCP) e média na SubBacia do Córrego Gouveia (SBCG) e Área de Drenagem de Jusante da Margem Esquerda e Direita (ADJME e ADJMD).

A predominância de alta susceptibilidade à erosão na Bacia Hidrográfica do Ribeirão do Espírito Santo sugere a necessidade de se implementarem medidas mitigadoras direcionadas para a preservação das áreas de regeneração da vegetação arbórea, bem como um plano de manejo de plantações florestais e pastagens, de forma a conservar os corpos hídricos, controlar o crescimento da silvicultura na região, minimizar áreas de solo exposto, principalmente na SBCP e SBCT, que abrigam um manancial estratégico para a cidade de Juiz de Fora - MG.

O estudo realizado indicou a potencialidade à erosão nas bacias, e teve como vantagem a necessidade de utilização de um pequeno número de parâmetros representativos (pedológicos, fisiográficos e de uso do solo), especializados em ambiente SIG. Entretanto, recomenda-se que em estudos futuros, sejam utilizadas metodologias que levem em consideração outros parâmetros relacionados aos processos erosivos do solo, tais como: climáticos (precipitação), manejo do solo e técnicas conservacionistas (edáficas, vegetativas e mecânicas).

\section{AGRADECIMENTOS}

Os autores agradecem à Fundação de Amparo à Pesquisa do Estado de Minas Gerais - FAPEMIG pelo apoio financeiro a execução do projeto (Processo TEC _ APQ.02118-12). 


\section{REFERÊNCIAS}

ABDON, M. D. M. Os impactos ambientais no meio físico - erosão e assoreamento na Bacia Hidrográfica do Rio Taquari, MS, em decorrência da pecuária. 2004. 302f. Tese (Doutorado em Engenharia Ambiental) - Universidade de São Paulo, São Carlos, 2004.

BELTRAME, Â. D. V. Diagnóstico do meio físico de bacias hidrográficas: modelo e aplicação. Florianópolis: Ed. da UFSC, 1994. 111p.

BRASIL. Casa Civil. Decreto $n^{\circ}$ 89.817, de 20 de junho de 1984. Estabelece as instruções reguladoras das normas técnicas da cartografia nacional. Diário Oficial da União, Brasília, 1984.

BUENO, C. R. P.; ARRAES, C. L.; PEREIRA, G. T.; CORA, J. E.; CAMPOS, S. Análise multivariada na determinação do risco de erosão em solos sob irrigação. Irriga, Botucatu, v. 15, n. 1, p. 23-35, 2010.

CALDER, I. R. Forests and water-Ensuring forest benefits outweigh water costs. Forest Ecology and Management, v. 251, n. 1-2, p. 110-120, 2007. http://dx.doi.org/10.1016/j.foreco.2007.06.015

CHRISTOFOLETTI, A. A análise de bacias hidrográficas. In: Geomorfologia. São Paulo: Edgard Blücher, 1980. cap. 4, p.102-127.

CREPANI, E.; MEDEIROS, J. S. D.; FILHO, P. H.; FLORENZANO, T. G.; DUARTE, V.; BARBOSA, C. C. F. Sensoriamento remoto e geoprocessamento aplicados ao zoneamento ecológico-econômico e ao ordenamento territorial. São José dos Campos: INPE , 2001. 124p.

EMPRESA BRASILEIRA DE PESQUISA AGROPECUÁRIA - EMBRAPA. Centro Nacional de Pesquisa de Solos. Sistema brasileiro de classificação de solos. 2. ed. Rio de Janeiro, 2006. 306p.

ENVIRONMENTAL SYSTEMS RESEARCH INSTITUTE - ESRI. The new ArcGIS at 10.1. Redlands, 2013.

FARIA, A. L. L. D.; SILVA, J. X. D.; GOES, M. H. D. B. Análise ambiental por geoprocessamento em áreas com susceptibilidade à erosão no solo da Bacia do Ribeirão do Espírito Santo, Juiz de Fora (MG). Caminhos de Geografia, Uberlândia, v. 4, n. 9, p. 50-65, jun 2003.

FARIA, M. M.; FERNANDES FILHO, E. I. Avaliação dos algoritmos SVM e Maxver para a classificação de sistemas florestais monodominantes de candeia (Eremanthus sp.) In: SIMPÓSIO BRASILEIRO DE SENSORIAMENTO REMOTO, 16., 13-18 Abr., Foz do Iguaçu. Proceedings... São José dos Campos: INPE 2013. p.3222-3229.

FUNDAÇÃO ESTADUAL DO MEIO AMBIENTE - FEAM (MG). Mapa de solos do Estado de Minas Gerais: legenda expandida. Belo Horizonte, 2010. 49p.

IPPOLITI R, G. A.; COSTA, L. M. D.; SCHAEFER, C. E. G. R.; FERNANDES FILHO, E. I.; GAGGERO, M. R. Análise digital do terreno: ferramenta na identificação de pedoformas em microbacia na região de "Mar de Morros" (MG). Revista Brasileira de Ciência do Solo, Viçosa, v. 29, p. 269-276, 2005. 
JENSON, S. K.; DOMINGUE, J. O. Extracting topographic structure from digital elevation data for geographic information system analysis. Photogrammetric Engineering and Remote Sensing, v. 54, n. 11, p. 1593-1600, 1988.

JUIZ DE FORA. Companhia de Sanemanto Municipal - CESAMA. Mananciais: Ribeirão Espíriro Santo. Juiz de Fora, 2010. Disponível em: <http://www.cesama.com.br/? pagina=resanto $>$. Acesso em: $10 \mathrm{dez} .2013$.

KLAIS, T. B. A.; DALMAS, F. B.; MORAIS, R. P.; ATIQUE, G.; LASTORIA, G.; FILHO, A. C. P. Vulnerabilidade natural e ambiental do município de Ponta Porã, Mato Grosso do Sul, Brasil Revista Ambiente \& Água, Taubaté, v. 7, n. 2, p. 277-290, 2012. http://dx.doi.org/10.4136/ambi-agua.786

LIMA, C. D. S.; CORRÊA, A. C. D. B.; NASCIMENTO, N. R. D. Analysis of the morphometric parameters of the rio Preto basin, Serra do Espinhaço (Minas Gerais, Brazil). Geociências, São Paulo, v. 30, n. 1, p. 105-112, 2011.

LIMA, R. M. S. (Elab.). Cartas IBGE, escala 1:50.000 - folhas Ewbank da Câmara e Juiz de Fora. Modelo digital de elevação. Juiz de Fora: Prefeitura municipal, 2013.

LIMA, W. D. P. A silvicultura e a água: ciência, dogmas e desafios. Rio de Janeiro: Instituto BioAtlântica, 2010. 54p.

MACHADO, P. J. D. O. Diagnóstico ambiental e ordenamento territorial - instrumentos para a gestão da Bacia de Contribuição da Represa de Chapéu D'Uvas/MG. 2012. 243f. Tese (Doutorado em Geografia) - Universidade Federal Fluminense, Niterói, 2012.

MELO, O. A. G. D.; SANTOS, M. L. D. Análise comparativa da vulnerabilidade ambiental potencial ou emergente da Bacia Hidrográfica do Rio Baiano - Assis Chateaubriand/PR. Boletim de Geografia, Maringá, v. 28, n. 2, p. 17-27, 2010. http://dx.doi.org/10.4025/bolgeogr.v28i2.10375

NARDINI, R. C.; POLLO, R. A.; CAMPOS, S.; BARROS, Z. X. D.; CARDOSO, L. G.; GOMES, L. N. Análise morfométrica e simulação das áreas de preservação permanente de uma micobacia hidrográfica. Irriga, Botucatu, v. 18, n. 4, p. 687-699, 2013.

NASCIMENTO, D. M. C.; DOMINGUEZ, J. M. L. Avaliação da vulnerabilidade ambiental como instrumento de gestão costeira nos municípios de Belmonte e Canavieiras, Bahia. Revista Brasileira de Geociências, São Paulo, v. 39, p. 395-408, 2009.

OLIVEIRA, F. P. de; FERNANDES FILHO, E. I.; SOARES, V. P.; SOUZA, A. L. D. Mapeamento de fragmentos florestais com monodominância de aroeira a partir da classificação supervisionada de imagens RapidEye. Revista Árvore, Viçosa, v. 37, n. 1, p. 151-161, 2013. http://dx.doi.org/10.1590/S0100-67622013000100016

OLIVEIRA, P. T. S. D.; RODRIGUES, D. B. B.; SOBRINHO, T. A.; ELÓIPANACHUKI. Processo analítico hierárquico aplicado a vulnerabilidade natural a erosão. Geociências, São Paulo, v. 28, p. 417-424, 2009.

PIMENTEL, D. Soil erosion: a food and environmental threat. Environment, Development and Sustainability, v. 8, p. 119-137, 2006. http://dx.doi.org/10.1007/s10668-005$1262-8$ 
POLETO, L. J. D. C.; SILVA, C. H. C. D.; JÚNIOR, S. R.; VIEIRA, C. A. O.; SANTOS, A. D. P. D. Validação de Modelo Digital de Elevação Hidrologicamente Consistente (MDEHC) In: SIMPÓSIO BRASILEIRO DE CIÊNCIAS GEODÉSICAS E TECNOLOGIAS DA GEOINFORMAÇÃO, 2., 8-11 Set., Recife. Proceedings... Recife: UFPE, 2008. 1 CD-ROM.

POORE, M. E. D.; FRIES, C. The ecological effects of eucalyptus. Roma: FAO, 1985. 88p.

RIBEIRO, F. L.; CAMPOS, S. Vulnerabilidade à erosão do solo da Região do Alto Rio Pardo, Pardinho, SP. Revista Brasileira de Engenharia Agrícola e Ambiental, Campina Grande, v. 11, n. 6, p. 628-636, 2007. http://dx.doi.org/10.1590/S141543662007000600012

ROCHA, J. S. M. D.; KURTZ, S. M. D. J. M. Manual de Manejo Integrado de Bacias Hidrográficas: 4. Santa Maria: CCR/UFSM, 2001. 302p.

ROCHA, R. M.; LUCAS, A. A. T.; ALMEIDA, C. A. P. D.; NETO, E. L. M.; NETTO, A. D. O. A. Caracterização morfométrica da sub-bacia do rio Poxim-Açu, Sergipe, Brasil. Revista Ambiente \& Água, Taubaté, v. 9, n. 2, p. 276-287, Apr. / Jun. 2014. http://dx.doi.org/10.4136/ambi-agua.1289

ROSS, J. L. S. Análises e sínteses na abordagem na abordagem geográfica da pesquisa para o planejamento ambiental. RDG Revista do Departamento de Geografia da Universidade de São Paulo, São Paulo, v. 8, p. 65-75, 1994.

SANTOS, A. M. D.; TARGA, M. D. S.; BATISTA, G. T.; DIAS, N. W. Análise morfométrica das sub-bacias hidrográficas Perdizes e Fojo no município de Campos do Jordão, SP, Brasil. Revista Ambiente \& Água, Taubaté, v. 7, n. 3, 2012. http://dx.doi.org/10.4136/ambi-agua.945

SILVA, J. L.; TONELLO, K. C. Morfometria da bacia hidrográfica do Ribeirão dos Pinheirinhos, Brotas - SP. Irriga, Botucatu, v. 19, n. 1, p. 103-114, Jan. / Mar. 2014.

SOUZA, K. R.; VIEIRA, T. G. C.; ALVES, H. M. R.; ALVES, M. L. V.; ANJOS, L. A. P. D.; SOUZA, C. G.; ANDRADE, L. N. Classificação automática de imagem do satélite RapidEye para o mapeamento de áreas cafeeiras em Carmo de Minas, MG. In: SIMPÓSIO DE PESQUISA DOS CAFÉS DO BRASIL, 7., 22-25 Ago., Araxá. Proceedings... Araxá: Consórcio Pesquisa Café, 2011. 1 CD-ROM.

THOMAZ, E. L.; ANTONELI, V. Erosão e degradação do solo em área cultivada com ervamate (Ilex paraguariensis), Guarapuava - PR. Geociências, São Paulo, v. 27, p. 21-30, 2008.

VALLADARES, G. S.; GOMES, A. D. S.; TORRESAN, F. E.; RODRIGUES, C. A. G.; GREGO, C. R. Modelo multicritério aditivo na geração de mapas de suscetibilidade à erosão em área rural. Pesquisa Agropecuária Brasileira, Brasília, v. 47, n. 9, p. 13761383, set. 2012. http://dx.doi.org/10.1590/S0100-204X2012000900023

VERÍ́SSIMO, M. E. Z.; NOVO, E. M. L. M.; VERÍSSIMO, C. U. V. Estudo da Bacia Hidrográfica do Rio Passaúna-PR, através de parâmetros morfométricos da rede de drenagem. Revista de Geologia, Fortaleza, v. 9, p. 97-109, 1996.

VILLELA, S. M.; MATTOS, A. Hidrologia aplicada. São Paulo: Mc Graw Hill, 1975. 245p. 


\begin{tabular}{|} 
Ambiente \& Água - An Interdisciplinary Journal of Applied Science \\
ISSN 1980-993X - doi:10.4136/1980-993X \\
www.ambi-agua.net \\
E-mail: ambi-agua@agro.unitau.br
\end{tabular}

\title{
Condições físico-químicas e biológicas em águas superficiais do Rio Tapajós e a conservação de Floresta Nacional na Amazônia, Brasil
}

\author{
doi: 10.4136/ambi-agua.1304
}

Received: 05 Feb. 2014; Accepted: 13 Sep. 2014

\author{
Sarah Suely Alves Batalha ${ }^{1 *}$; Lucieta Guerreiro Martorano ${ }^{2}$; \\ Adriele Giaretta Biase ${ }^{3}$; Gundisalvo Piratoba Morales ${ }^{1}$; \\ Altem Nascimento Pontes ${ }^{1}$; Leonardo Sousa dos Santos ${ }^{4}$ \\ ${ }^{1}$ Universidade do Estado do Pará (UEPA), Belém, PA, Brasil \\ ${ }^{2}$ Empresa Brasileira de Pesquisa Agropecuária (EMBRAPA) Amazônia Oriental, Belém, PA, Brasil \\ ${ }^{3}$ Universidade de São Paulo (USP), Piracicaba, SP, Brasil \\ ${ }^{4}$ Universidade Federal Rural da Amazônia (UFRA), Belém, PA, Brasil \\ "Autor correspondente: e-mail: ssa.batalha@gmail.com, \\ lucieta.martorano@embrapa.br, adrielegbiase@gmail.com, \\ gundymorales@yahoo.com.br, altempontes@hotmail.com, \\ leonardocbmpa@yahoo.com.br
}

\section{RESUMO}

A bacia amazônica detém uma grande quantidade de água que deve ser conservada para atender as necessidades desta e das futuras gerações. O objetivo deste trabalho foi avaliar condições físico-químicas e biológicas em águas superficiais do Rio Tapajós como indicadores da conservação de Floresta Nacional na Amazônia. Para a tomada de decisão quanto ao período de coleta levou-se em consideração apoio logístico e financeiro, sendo possível as coletas na época de menor oferta pluvial com base em informações climáticas na Flona e seu entorno. As coletas no rio Tapajós ocorreram em áreas de influência quanto ao uso e ocupação do solo. Foram realizadas avaliações no local, bem como análises em laboratório. Os resultados apontaram que dezembro de 2012 foi mais chuvoso em relação a climatologia. Os resultados do Índice de Qualidade de Água (IQA) indicaram o predomínio na qualidade "boa" a "ótima", nas quais as faixas variaram entre $70<$ IQA $\leq 90$ e $90<$ IQA $\leq 100$, totalizando 70,0\% das amostras coletadas. Os balneários de Alter do Chão e Pindobal foram os que apresentaram valores elevados de coliformes termotolerantes, possivelmente devido os efeitos antrópicos que poderiam ser mitigados com práticas de turismo adequadas. O maior IQA e a maior transparência da água, identificados próximo a Tauarí, evidenciaram efeitos mínimos nas águas superficiais pela ação antrópica nessa localidade. Conclui-se que os corpos hídricos são sensíveis a alterações na cobertura da terra e estas podem ameaçar à manutenção de áreas de uso conservacionista.

Palavras-chave: qualidade de água, unidade de conservação. 


\title{
Physico-chemical and biological conditions in surface waters of the Tapajós River and the conservation of the National Forest in the Amazon, Brazil
}

\begin{abstract}
The Amazon Basin has a large amount of water that must be conserved to meet the needs of this and future generations. This study evaluated evidence of the effects of human disturbance in the Tapajos National Forest and its surroundings using physicochemical and biological variables in surface waters as indicators. In order to accomplish this, we first analyzed the data series of precipitation in the region. Samples were collected from the Tapajos River in areas influenced by land use and occupation. We made on-site assessments and collected samples for laboratory analysis. Rainfall in December 2012 was higher than the climatology indicated. The results of the Water Quality Index (WQI) indicated the predominance of the "good" to "great"; its values ranged between $70<$ WQI $\leq 90$ and $90<\mathrm{WQI} \leq 100$, in $70.0 \%$ of the samples collected. The balnearies Alter do Chão and Pindobal had the highest levels of fecal coliform, possibly due to anthropogenic effects that could be mitigated by adequate tourist practices. The highest WQI and greater transparency of the water near Tauari, showed minimal effects of human activities in nearby surface waters. It is concluded that water bodies are sensitive to changes in land use and those changes may threaten the maintenance of conservation areas.
\end{abstract}

Keywords: conservation unit, water quality.

\section{INTRODUÇÃO}

A conservação de áreas de florestas na Amazônia vai além dos discursos idealistas, pois esses ambientes fornecem serviços ambientais essenciais que vão desde a manutenção do ciclo hidrológico e da biodiversidade até a garantia de oferta em possíveis mercados de carbono (Fearnside, 2013).

O Brasil possui condições ambientais favoráveis que o coloca em vantagens frente aos recursos naturais disponíveis, principalmente quanto ao aspecto bacias hidrográficas, como é o caso da Bacia Amazônica. Com isso, o uso conservacionista dos recursos hidrológicos demanda de investigações para apontar áreas críticas à preservação de ecossistemas aquáticos (Artaxo, 2007).

Um corpo hídrico em equilíbrio ecológico, que garanta a saúde e o bem-estar humano, depende que parâmetros físicos, químicos e biológicos estejam dentro de um nível de qualidade avaliado por condições e padrões específicos que assegurem seus usos preponderantes, conforme Resolução $n^{\circ}$ 357, do Conselho Nacional do Meio Ambiente (CONAMA, 2005). A Companhia Ambiental do Estado de São Paulo (CETESB, 2012) destaca, por exemplo, que variações bruscas de temperatura em uma faixa de 3,0 a $4,0^{\circ} \mathrm{C}$ no mesmo dia podem ser letais para algumas espécies e que condições de $\mathrm{pH}$ podem corresponder à formação de um ecossistema mais diversificado tanto em meios aeróbicos quanto em anaeróbicos (CETESB, 2006).

Silva et al. (2008) apontam 6 (seis) parâmetros fundamentais: temperatura, pH, turbidez, condutividade elétrica, oxigênio dissolvido e sólidos em suspensão. Na Amazônia, em específico, os ecossistemas aquáticos são importantes tanto para o ciclo da água regional, 
quanto para a energia hidrelétrica e utilizações da água em outras regiões do globo (Fearnside, 2004; 2013).

As avaliações de qualidade hídrica expressam o estado de uso e conservação em uma bacia hidrográfica e, portanto, auxiliam na tomada de decisão sobre a manutenção do equilíbrio ecológico. Espera-se que áreas legalmente protegidas na Amazônia possam fornecer bens e serviços ecossistêmicos às populações, bem como manter a biodiversidade. No entanto, percebe-se que muitas Unidades de Uso Sustentável estão sendo ameaçadas com perdas de suas áreas demarcadas, como é o caso da Floresta Nacional do Tapajós, localizada a oeste do estado do Pará, na Amazônia brasileira. Observa-se que, desde a sua criação na década de 70 do século passado (Brasil, 1974), houve redução de aproximadamente 4\% do território demarcado. A recente retirada do município de Aveiro e da comunidade São Jorge (Brasil, 2012) reforçam que processos históricos associados a possíveis pressões decorrentes da expansão da fronteira agrícola na região, por exemplo, podem ameaçar a sustentabilidade se os sistemas de produção não utilizarem práticas conservacionistas, conforme ressaltam Martorano et al. (2004; 2012). Os processos de degradação das terras estão associados a fatores edáficos, climáticos e antrópicos (Manzatto et al., 2002).

A análise integrada dos sistemas aquático e terrestre, no espaço e no tempo, permite concluir que a degradação da qualidade da água se deve às alterações no uso e cobertura da terra e ao aumento populacional, traduzidos em fontes difusas e pontuais de poluição (Prado e Novo, 2006). Ao avaliarem constituintes oticamente ativos na água, usando imagens hiperespectrais, Rudorff et al. (2006) identificaram três padrões de variação temporal e espacial no período de cheia e de vazante em águas brancas do Amazonas e águas claras do Tapajós, ou seja, aumento e reduções nas concentrações de matéria inorgânica em suspensão nos rios e de ocorrência de fitoplânctons nos lagos, refletindo na qualidade da água desses rios.

Quanto ao diagnóstico de qualidade de água, destacam-se na Amazônia os trabalhos de Siqueira et al. (2012) e Alves et al. (2012). No primeiro, os autores ressaltam a influência da expansão urbana ao longo do rio Parauapebas em áreas próximas às reservas de mata ciliar. $\mathrm{O}$ segundo trabalho, realizado no rio Arari, na Ilha do Marajó, revelou um processo de eutrofização natural, com fontes de contaminação antrópica incipientes, o que, no entanto, não anula o alerta em um processo de longo prazo.

Nesse contexto, objetivou-se avaliar condições físico-químicas e biológicas em águas superficiais para apontar evidências de uso conservacionista em áreas no entorno da Flona Tapajós (oeste do estado do Pará) para subsidiar possíveis estratégias sustentáveis na região de estudo.

\section{MATERIAL E MÉTODOS}

\section{1. Área de estudo}

A Unidade de Uso Sustentável, Floresta Nacional do Tapajós, está localizada a oeste do estado do Pará, com coordenadas geográficas $2^{\circ} 45^{\prime}$ a $4^{\circ} 10^{\prime} \mathrm{S}$ e $54^{\circ} 45^{\prime}$ a $55^{\circ} 30^{\prime} \mathrm{W}$. A Floresta Nacional do Tapajós é a $13^{\mathrm{a}}$ Flona criada no país em um total de 66 existentes em 2004 e, a segunda criada na região Norte, bem como a segunda no Estado do Pará. Pela Lei Federal $\mathrm{n}^{\circ} 12.678$ de junho de 2012, a área da Flona Tapajós foi reduzida em aproximadamente 4\% de seu tamanho original. Estas áreas passaram a ser consideradas como áreas de amortecimento desta UC. Esta redução pode acarretar em possíveis ameaças na manutenção de bens e serviços que a Flona oferece às populações, provocando com o passar dos anos, alterações no modo de vida das comunidades da Flona e entorno, aumentando assim as pressões nesta unidade de conservação. De acordo com o Sistema Nacional de Unidades de 
Conservação (SNUC, 2002), uma Floresta Nacional (ou Flona) caracteriza-se como uma área com cobertura florestal com predominância de espécies nativas e seu objetivo básico é o uso múltiplo sustentável dos recursos florestais e a pesquisa científica.

Com base no Plano de Manejo da Flona Tapajós, existe a integração de diferentes agrupamentos humanos que desenvolvem atividades tradicionais de sistema de produção, combinando cultivo de roçados, extrativismo, manejo agroflorestal, caça, criação de pequenos animais e pesca. As populações integradas são: comunidades ribeirinhas, indígenas, assentamentos e posseiros (IBAMA, 2004), totalizando, atualmente 25 (vinte e cinco) comunidades, das quais 23 (vinte e três) estão situadas na zona ribeirinha.

Quanto ao acesso, este pode ser por vias fluviais, principalmente pelo rio Tapajós, ou terrestres, através da Rodovia BR-163 (Cuiabá-Santarém).

A rede hidrográfica da Flona caracteriza-se pela divisão de calhas do rio Tapajós, além de abrigar a nascente do rio Moju, afluente do rio Curuá-Una, cuja foz é no rio Amazonas, na região urbana de Santarém.

\subsection{Levantamento de dados de campo}

Tendo em vista as dificuldades financeiras e a distância entre Belém e a área de estudo, localizada próximo a Santarém, decidiu-se planejar as coletas de campo na Flona Tapajós no período de menor oferta pluvial na região. Ressalta-se que esses pressupostos metodológicos foram apenas em função de custos e apoio logístico.

Para subsidiar as avaliações do regime pluvial, utilizou-se uma série histórica de 40 anos (1972 a 2012) do município de Belterra (2,63 ${ }^{\circ}$ Latitude S; 44,95 ${ }^{\circ}$ Longitude W e 155,74 metros de Altitude), a partir dos dados meteorológicos disponibilizados pelo Instituto Nacional de Meteorologia (INMET). Também foram utilizados dados das Normais Climatológicas (INMET, 2009), bem como os dados referentes ao ano de 2012, gentilmente cedidos pelo INMET, utilizando acesso permitido no Banco de Dados Meteorológicos para Ensino e Pesquisa (BDMEP). Assim sendo, no período de menor oferta pluvial procurou-se identificar ao longo do rio Tapajós elementos que apontassem evidências do estado de conservação na Unidade de Uso Sustentável (Flona).

O trabalho ocorreu após a capacitação da equipe, contando com o planejamento, separação de materiais e definição de variáveis investigadas a campo. Nessa etapa foram listados os itens necessários para garantir o sucesso do trabalho de campo. Cada item foi cuidadosamente conferido (check-list) para preservação, manuseio e transporte das amostras, bem como as possibilidades de análises in situ e ex situ dentro dos prazos de validade, seguindo os protocolos de amostragem e análise de corpos d'água, padronizada pelo Standard Methods for Water and Wastewater (APHA, 2005) e regulamentados no Brasil pela Companhia de Tecnologia de Saneamento Ambiental do Estado de São Paulo (CETESB, 2011).

O período de viagem foi de 17 a 20 de dezembro de 2012. Nos dias anteriores fez-se reconhecimento e identificação de uso e cobertura do solo, utilizando o GPS (Global Position System) da marca Garmin Etrex de 12 canais, do tipo métrico de navegação, com precisão planimétrica aceitável. Essas informações foram coletadas via terrestre, ao longo da Rodovia BR-163, e via fluvial, no dia de coletas para compor a base de dados no âmbito do Projeto ROBIN (Role of Biodiversity in Climate Change Mitigation), no qual a pesquisa foi inserida.

Os dados obtidos com o GPS foram descarregados e plotados pela equipe do Projeto ROBIN. As informações dos locais de coletas foram identificadas no mapa de localização, contando-se com colaboração da equipe de geoprocessamento que utilizou a ferramenta Quantum Gis 2.0, licenciado pela General Public License. Os pontos foram associados à base de dados agregados do Instituto Brasileiro de Geografias e Estatísticas (IBGE, 2013). 
As coletas de água no rio Tapajós, no entorno da Flona, ocorreram no dia 19 de Dezembro. As amostras foram armazenadas, transportadas para Belém e levadas aos laboratórios para análise dos parâmetros. Foram selecionados 10 (dez) pontos de coleta no rio Tapajós e, em cada ponto, foram retiradas 4 (quatro) alíquotas, totalizando 40 (quarenta) amostras.

Neste contexto, a campanha iniciou às 6 h00 do dia 19 de dezembro de 2012 com a saída das docas da cidade de Santarém, no entanto a primeira coleta só ocorreu após as 13h00, devido à distância da Flona e o período de reconhecimento via fluvial. A conclusão com retorno à Santarém foi às 20 h00 do mesmo dia.

Ressalta-se que a equipe contou com o apoio oficial do $4^{\circ}$ Grupamento Bombeiros Militar (Santarém, Pará), que forneceu suporte de pessoal e lancha para deslocamento no rio Tapajós.

As amostras de água foram coletadas em frascos de polietileno quimicamente inertes com tampas autolacráveis e frascos para oxigênio dissolvido, de vidro borossilicato com tampa esmerilhada e estreita (pontiaguda) e foram transportadas em caixas térmicas lacradas e mantidas em conservação a uma temperatura de $\pm 4,0^{\circ} \mathrm{C}$.

Com a utilização de um termômetro de mercúrio aferiu-se a temperatura $\left({ }^{\circ} \mathrm{C}\right)$ superficial em cada ponto de coleta. Além disso, utilizou-se o disco de Secchi para determinar a coluna de transparência da água. O disco circular possui quatro divisões intercaladas com cores pretas e brancas e um cabo graduado para auxiliar na identificação da profundidade de visualização do disco. De acordo com a CETESB (2011), a medida de transparência pode ser considerada uma variável de qualidade, uma vez que estima a profundidade da zona fótica, ou seja, a profundidade de penetração vertical da luz solar na coluna d'água, que indica o nível da atividade fotossintética naquele corpo hídrico.

Os demais parâmetros (pH, Sólidos Totais, Fósforo total, Oxigênio Dissolvido, Demanda Bioquímica de Oxigênio, Turbidez, Nitrogênio Total, Coliformes Totais, Coliformes Termotolerantes e Condutividade) foram determinados em laboratório.

Deu-se prioridade às análises que demandavam prazo de conservação menor que 24 horas, como: Demanda Bioquímica de Oxigênio (DBO), Coliformes Totais e Termotolerantes e Nitrogênio Total (Nt).

Destaca-se que o as amostras para Oxigênio Dissolvido (OD) foram fixadas, a campo, com $2 \mathrm{~mL}$ de Iodeto de Azida e $2 \mathrm{~mL}$ de Sulfato de Manganês, sendo levadas ao laboratório onde foram retiradas alíquotas para determinação do oxigênio dissolvido pelo método titulométrico de Winkler (Gatti et al., 2002), como descrito em APHA (2005). As alíquotas foram rigorosamente codificadas em consonância com a respectiva marcação em GPS e o horário da coleta, além de serem detalhadas em fichas individuais que incluíam as coordenadas, condições de tempo como chuva, nebulosidade e temperatura do ar, no dia da coleta e nas últimas vinte e quatro horas.

Os dados adquiridos por via terrestre e fluvial foram georreferenciados e geraram o mapa de localização (Figura 1) da região contemplada nas ações desta pesquisa. Observa-se que as amostras foram coletadas no rio Tapajós próximo a comunidades e regiões de potencial atrativo turístico.

Um corpo hídrico pode também ser caracterizado por meio da inferência de um indicativo de qualidade. O Índice de Qualidade de Água (IQA) foi desenvolvido pela National Sanitation Foundation (NSF), dos Estados Unidos, e sintetiza em um fator único global a qualidade de água, a partir da ponderação de nove parâmetros (Coliformes Termotolerantes, pH, DBO, Nitrogênio e Fósforo total, Temperatura, Turbidez, Sólidos e Oxigênio Dissolvido) considerados mais representativos para a caracterização da qualidade da água (Von Sperling, 2007). No Brasil, o IQA da NSF foi modificado pela CETESB, que substituiu o Nitrato por Nitrogênio total e amplia as faixas nacionais de tolerância de níveis de IQA. 


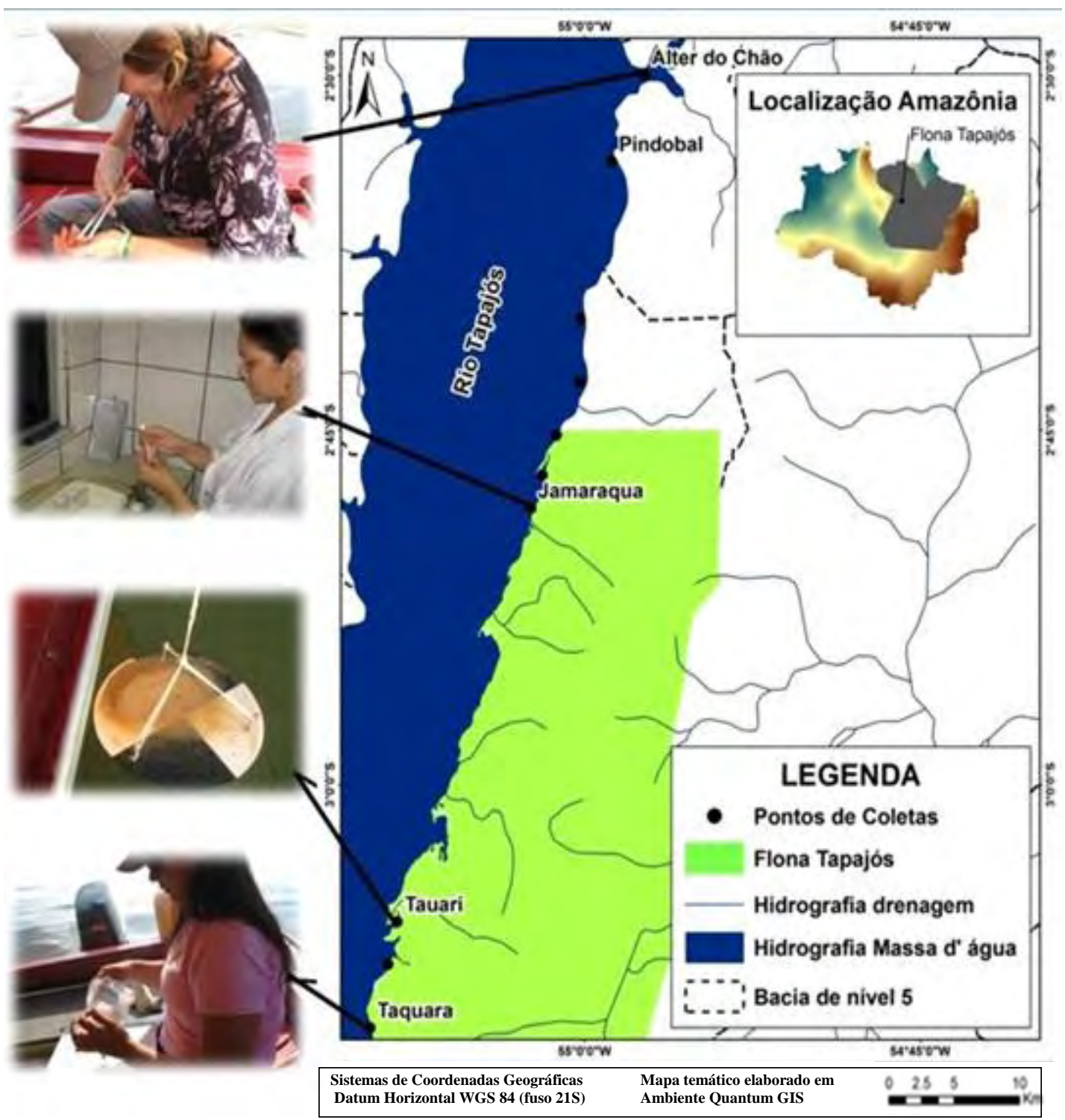

Figura 1. Localização dos pontos de coleta no rio Tapajós - Amazônia, Brasil.

A cada parâmetro aplica-se um peso e o resultado das equações das curvas de qualidade são calculados a partir da Equação 1, que é o produtório das notas individuais de cada parâmetro, elevada aos respectivos pesos:

$$
I Q A=\prod_{i=1}^{n} q_{i}^{w 1}
$$

em que,

IQA representa o Índice de Qualidade das Águas (número entre 0 e 100);

qi é a qualidade do i-ésimo parâmetro, um número entre 0 e 100, obtido da respectiva "curva média de variação de qualidade", em função de sua concentração ou medida;

$\mathrm{W}_{\mathrm{i}}$ é o peso correspondente ao i-ésimo parâmetro, um número entre 0 e 1, atribuído em função da sua importância para a conformação global de qualidade e

i refere-se ao número do parâmetro, variando de 1 a 9 , ou seja, o número de parâmetros que compõem o IQA. 
Os valores dos índices variam entre 0 e 100 e a qualidade da água é classificada por faixas de IQA (Tabela 1).

Tabela 1. Faixas para classificação do IQA, segundo NSF e CETESB.

\begin{tabular}{lllc}
\hline & Nível & Cor & Faixa de IQA \\
\hline & Excelente & Azul & $90<$ IQA $\leq 100$ \\
IQA & Bom & Verde & $70<$ IQA $\leq 90$ \\
NSF & Médio & Amarela & $50<$ IQA $\leq 70$ \\
& Ruim & Laranja & $25<$ IQA $\leq 50$ \\
& Muito Ruim & Vermelha & $0<$ IQA $\leq 25$ \\
\hline & Ótima & Azul & $80 \leq$ IQA $\leq 100$ \\
IQA & Boa & Verde & $52 \leq \mathrm{IQA}<80$ \\
CETESB & Aceitável & Amarela & $37 \leq \mathrm{IQA}<52$ \\
& Ruim & Laranja & $20 \leq \mathrm{IQA}<37$ \\
& Péssima & Vermelha & $0 \leq \mathrm{IQA}<20$ \\
\hline
\end{tabular}

Fonte: Von Sperling (2007).

\subsection{Análise estatística descritiva, agrupamentos e componentes principais}

As análises estatísticas foram realizadas com o apoio de parceiros científicos da ESALQ/USP, que utilizaram o programa SAS (SAS, 2008). As variáveis usadas no tratamento estatístico foram: $\mathrm{pH}$, Sólidos Totais $\left(\mathrm{mg} \mathrm{L}^{-1}\right)$, Fósforo total (mg L ${ }^{-1}$ ), Oxigênio Dissolvido (mg L ${ }^{-1}$ ), Demanda Bioquímica de Oxigênio ( $\mathrm{mg} \mathrm{L}^{-1}$ ), Turbidez (UNT), Temperatura da água $\left({ }^{\circ} \mathrm{C}\right)$, Nitrogênio Total $\left(\mathrm{mg} \mathrm{L}^{-1}\right)$, Coliformes Termotolerantes e Coliformes Totais (NMP $\left.100 \mathrm{~mL}^{-1}\right)$, Transparência (cm), Condutividade $\left(\mu \mathrm{S} \mathrm{cm}{ }^{-1}\right)$ e Índice de Qualidade de Água (IQA).

Destaca-se que foram aplicados dois métodos de análises multivariadas: agrupamento (clusters) e análise de componentes principais. Os componentes principais foram obtidos por meio da matriz de correlação para que não houvesse predominância em relação às variáveis com maiores variâncias. A partir da matriz de correlação foram obtidos os autovalores e autovetores, os quais indicam o sentido da rotação dos eixos das coordenadas definidos pelas variáveis originais. Os autovalores representam as variâncias destes novos eixos coordenados. O número de componentes principais retidos na análise foi definido com base em dois discernimentos: pela porcentagem cumulativa da explicação da variação total e pela representação gráfica do Screen plot (gráfico não apresentado nesse trabalho). A obtenção dos componentes principais é descrita por Manly (2004) e Mingoti (2005).

Após análise dos componentes principais foram representadas graficamente em um plano bidimensional, o Biplot e o Triplot, buscando identificar as observações discrepantes e o comportamento da correlação entre as variáveis, para observar as associações entre os pontos amostrais e as variáveis, bem como indicar quais variáveis são responsáveis pela explicação de cada ponto (Ferreira, 2011).

$\mathrm{Na}$ análise dos clusters utilizaram-se procedimentos hierárquicos, o cálculo das distâncias entre os objetos foi realizado com o conjunto de dados padronizados com o objetivo de dar um peso igual a cada um dos atributos. 


\section{RESULTADOS E DISCUSSÃO}

Ao avaliar o regime pluvial mensal em Belterra (Figura 2) observa-se que de julho a dezembro existe a menor oferta pluvial. Observando a série histórica de 1972 a 2012, as médias pluviais foram superiores aos totais de precipitação ocorridos nos meses de fevereiro a junho e agosto a novembro de 2012. Os demais meses, em 2012, foram mais pluviosos em relação à série histórica. Ao comparar com o volume precipitado, com base nas normais climatológicas, nota-se que na série de 40 anos a pluviosidade segue o padrão semelhante na maioria dos meses, com exceção de maio e dezembro. Nesses meses ocorrem as maiores flutuações no regime pluvial, expressas pelo desvio padrão. Em dezembro, a média de chuvas é da ordem de 150,0 mm, e em 2012 choveu 250,0 mm, apontando uma oferta pluvial de 100,0 mm acima da média da série histórica de 40 anos, bem como em termos de normais climatológicas.

De dezembro a maio as chuvas mensais ultrapassam os $100 \mathrm{~mm}$ mensais sendo que janeiro a abril o total varia entre 150,0 a $320,0 \mathrm{~mm}$. A climatologia aponta que valores mais elevados, em termos de cotas pluviais, ocorrem em março. Em termos de quantidade de água precipitada, o mês de dezembro de 2012 foi mais pluvioso em relação às normais climatológicas e à série de 40 anos analisada.

Antes da coleta (19/12/2012), na estação meteorológica de Belterra, houve um período de 15 dias sem registros de chuva, indicando condições propícias às avaliações em águas superficiais, no Rio Tapajós, conforme os pressupostos metodológicos da pesquisa. Ao observar os valores diários, identificou-se que no dia 01 de dezembro choveu $72,8 \mathrm{~mm}$, prolongando-se as chuvas no dia 02 e dia 03, que recebeu o segundo maior registro com 43,0 mm, totalizando nos três primeiros dias $119,0 \mathrm{~mm}$. Ou seja, quase a metade dos eventos de chuvas nesse período ocorreu 15 dias antes da campanha, não comprometendo as coletas das amostras pelo baixo volume precipitado na bacia hidrográfica.

Em termos de totais anuais, a climatologia indica que em em média são contabilizados 1.950,0 a 2.200,0 mm, sendo as áreas mais pluviosas na porção Sul da Flona Tapajós (Figura 3), onde também encontram-se as áreas mais declivosas com valores entre 18 e 24\% de declividade (Figura 4), subdividindo a Flona em padrões topopluviais.

Reforça-se ainda, que na primeira quinzena de Dezembro, as chuvas se concentraram no primeiro quinquídio, representando cerca de 48,0\% dos eventos, sendo, o restante, distribuídas no quinto, quarto e sexto quinquídio do referido mês. Esses resultados corroboram com as avaliações de Martorano et al. (2004) que ressalntam que as chuvas em dezembro concentram-se na segunda quinzena, bem como aos resultados observados por Marengo (2005) em seus estudos climáticos na Amazônia. Esses dados reforçam que as coletas foram realizadas no período de menor oferta pluvial. Em períodos de baixo aporte de águas pluviais, espera-se que as variáveis hídricas expressem mudanças decorrentes de efeitos antrópicos, principalmente influenciada pela população ribeirinha.

Ao analisar as variáveis físico-hídricas foi possível observar que a água apresentou maior transparência (2 metros) próximo a comunidade do Tauarí com pH próximo de 5,5. Notou-se também que nas proximidades de Alter do Chão o $\mathrm{pH}$ apresentou mais próximo da neutralidade em relação aos demais pontos coletados (Figura 5). Os valores de coliformes totais foram mais elevados próximo à Taquara, seguido de Alter do Chão e os menores valores próximos ao Tauarí (Figura 6). Também em Alter do Chão os valores de oxigênio dissolvidos foram mais elevados (Figura 7). Por outro lado, a condutividade em Alter do Chão foi mais baixa em relação às demais localidades (Figura 8). 


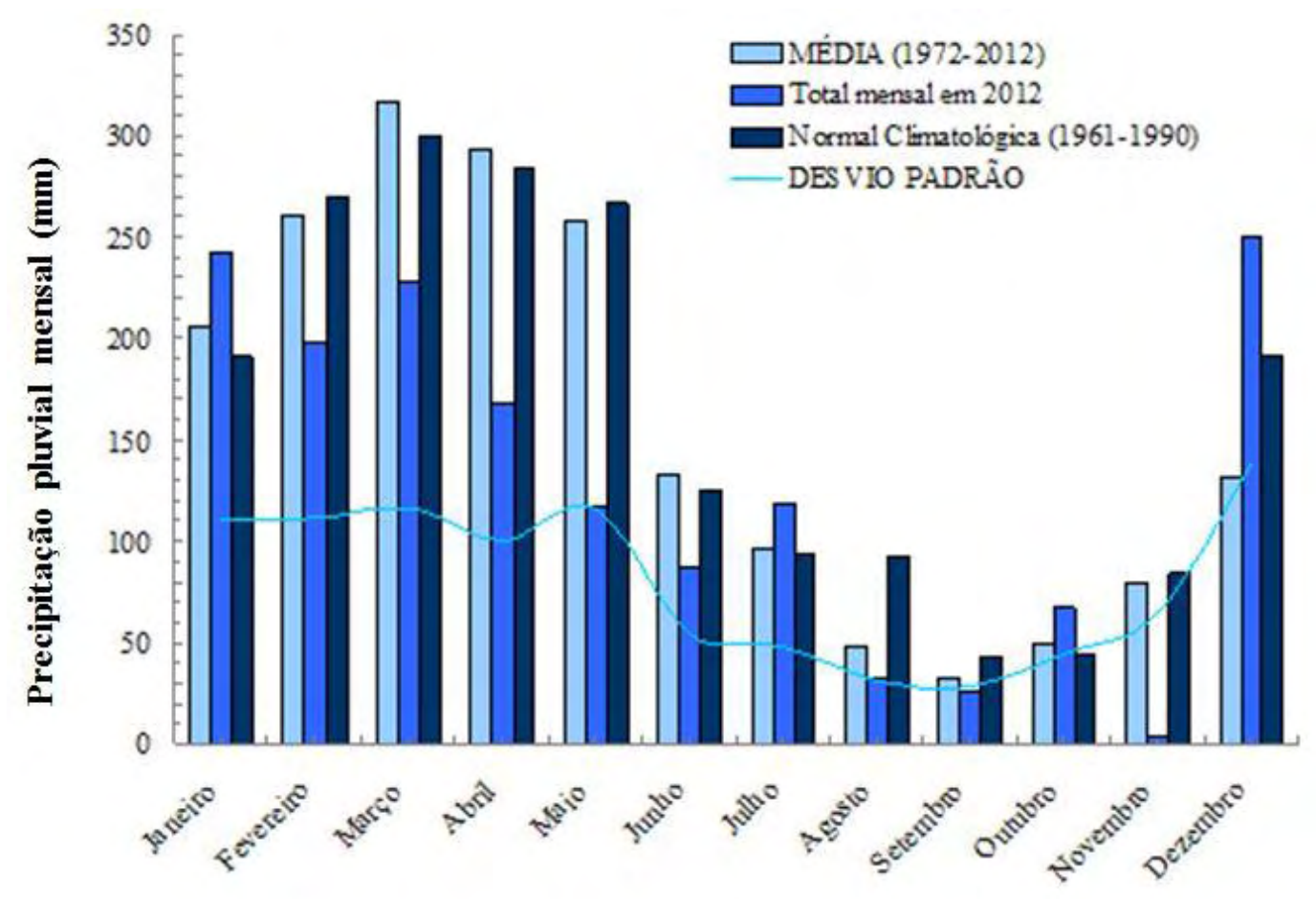

Meses

Figura 2. Precipitação pluvial mensal (mm) e desvio padrão em Belterra (PA) nos três períodos analisados (Normal climatológica - 1961 a 1990; Média - 1972 a 2012 e no ano de 2012).

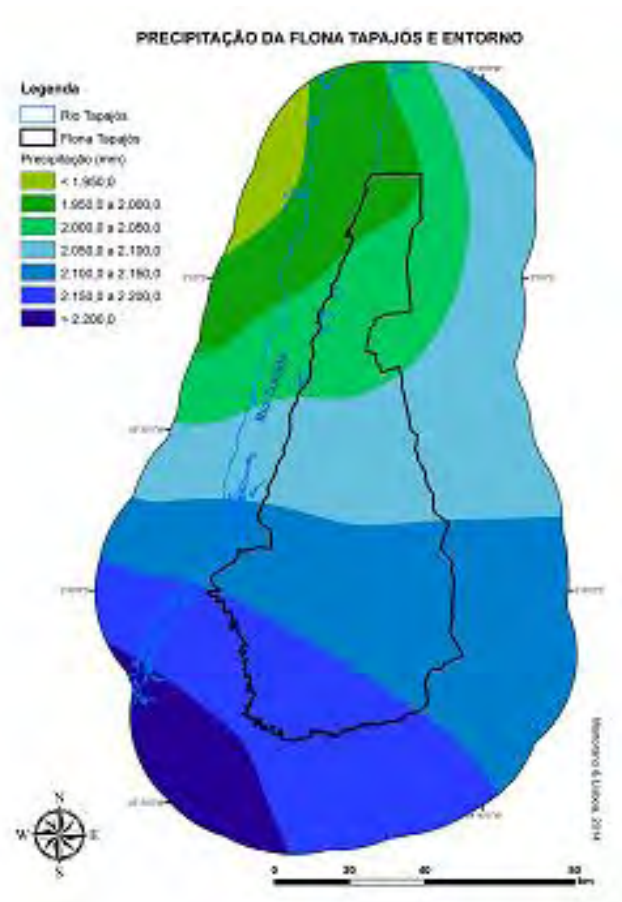

Figura 3. Precipitação pluvial anual $(\mathrm{mm})$ na Flona Tapajós e seu entorno.

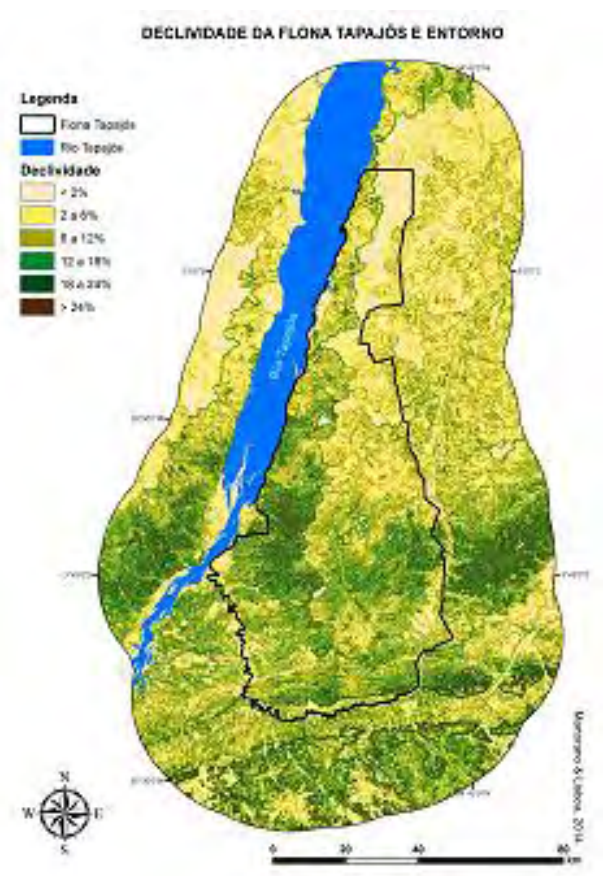

Figura 4. Classes de declividade na Flona Tapajós e seu entorno. 


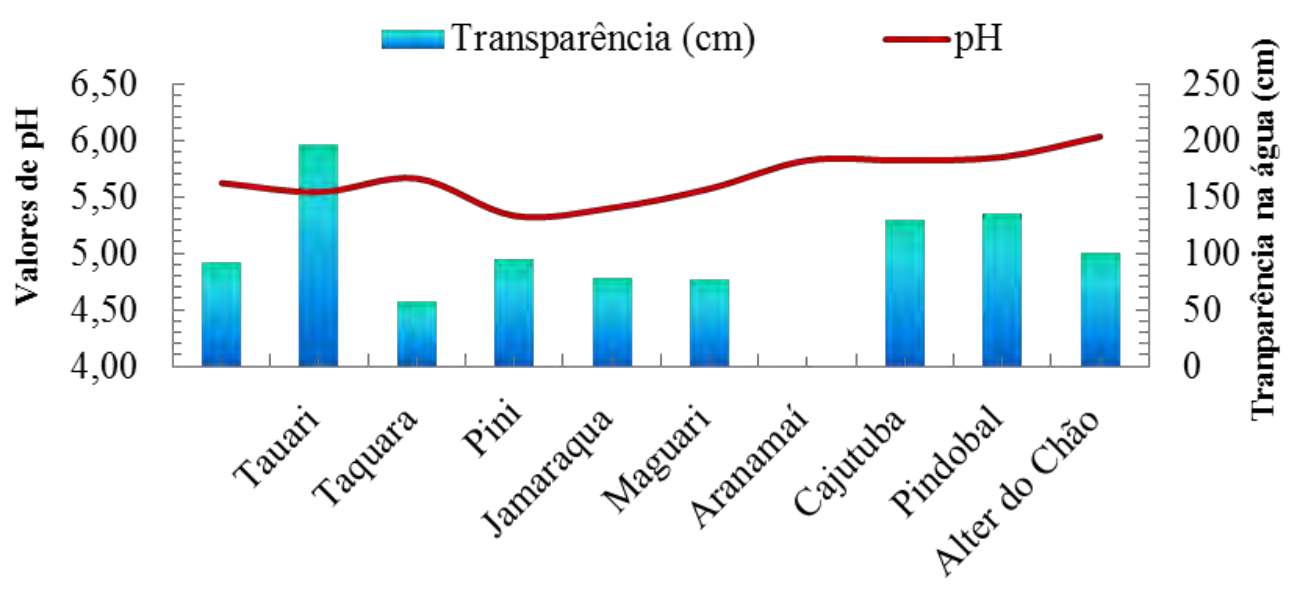

Figura 5. Valores de transparência e pH avaliadas no rio Tapajós na Flona Tapajós e seu entorno.

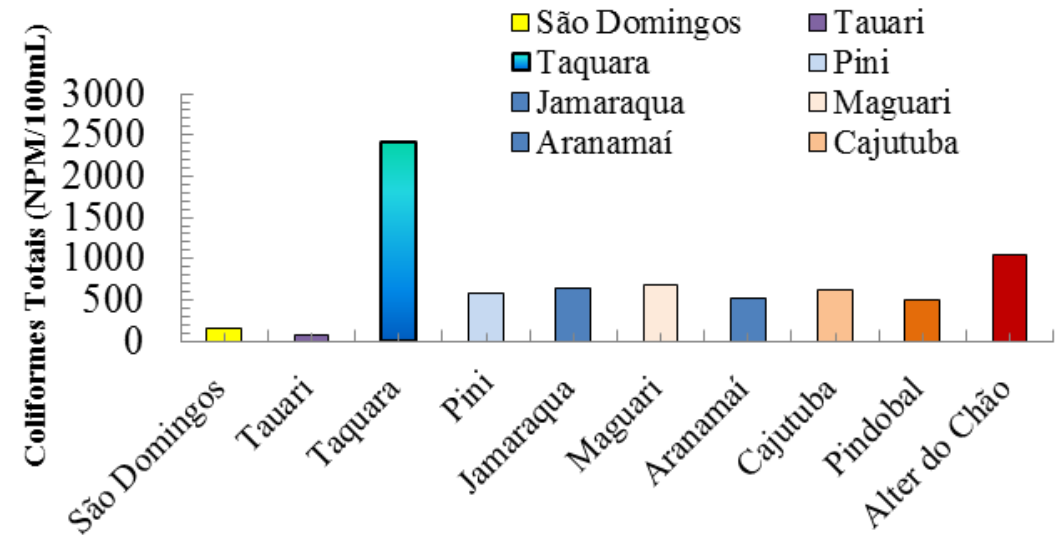

Figura 6. Coliformes Totais avaliadas no rio Tapajós na Flona Tapajós e seu entorno.

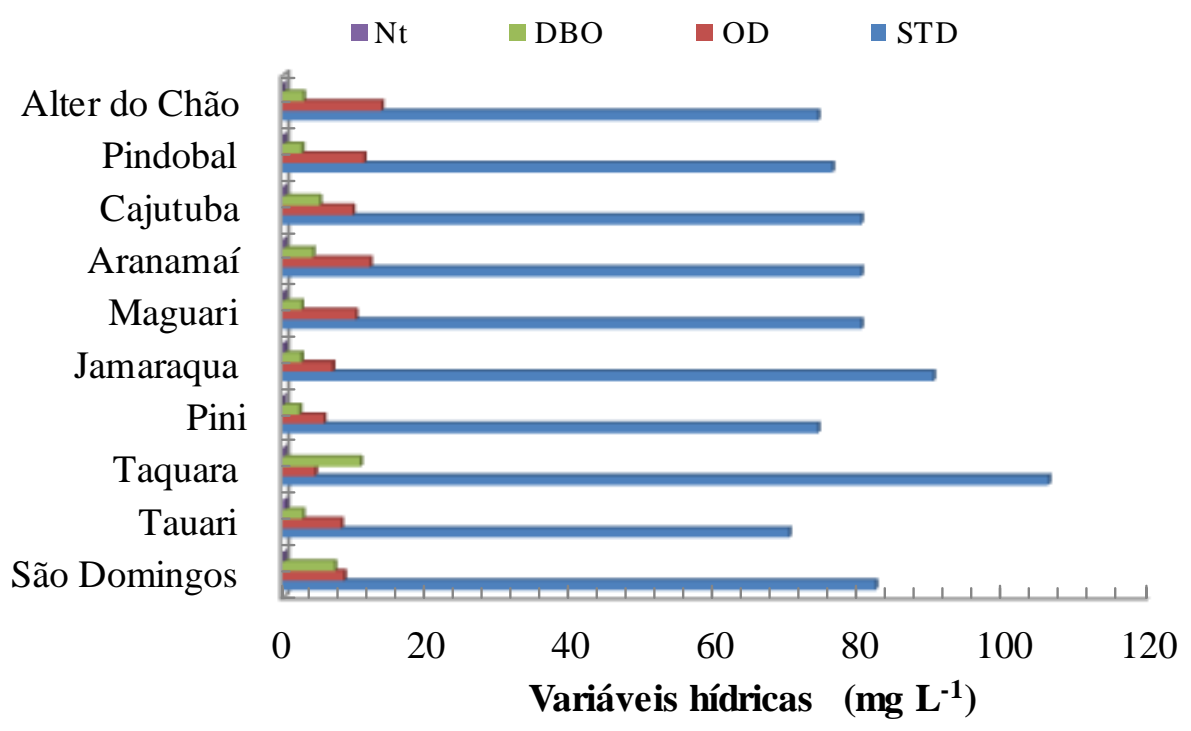

Figura 7. Variáveis hídricas (Nt, DBO, OD e SDT) avaliadas no rio Tapajós na Flona Tapajós e seu entorno. 


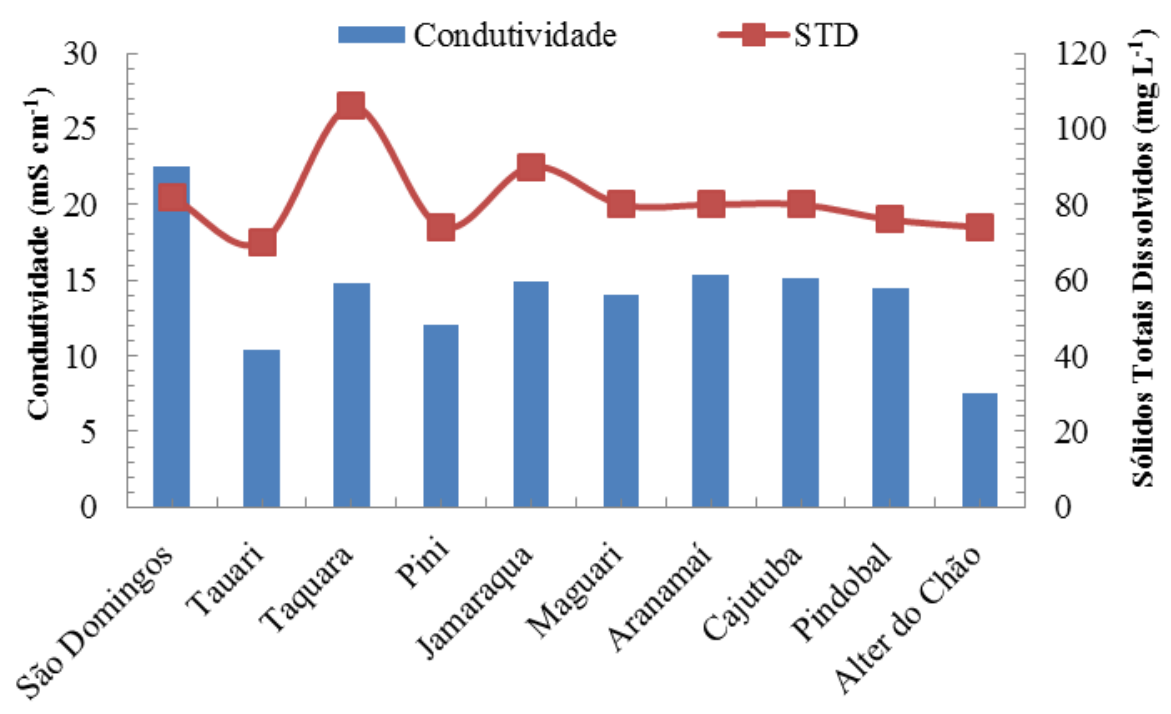

Figura 8. Condutividade e Sólidos Totais avaliados no rio Tapajós na Flona Tapajós e seu entorno.

Os resultados da qualidade hídrica superficial são apresentados na Tabela 2, na qual se observa que 7 dos 10 pontos de coleta, enquadram-se na faixa de boa qualidade de água para os padrões de comparação internacional, estabelecidos pela NSF. Comparados aos padrões nacionais, $80,0 \%$ enquadram-se na faixa de boa qualidade e $20,0 \%$ com ótima qualidade. Merece destaque o IQA das amostras próximas a Tauarí, com o valor de 85.

Os locais considerados com média qualidade de água, nas faixas da NSF foram São Domingos, Pindobal e Alter do Chão, que nas faixas da CETESB passaram para a condição de boa qualidade de água. Todavia, é importante ressaltar que para os padrões nacionais e internacionais o uso conservacionista na Flona Tapajós e seu entorno pode garantir a manutenção do potencial turístico, principalmente nos balneários ao longo dessa Unidade de Uso Sustentável, na Amazônia.

Tabela 2. Índice de Qualidade da Água (IQA) em localidades na Flona Tapajós e seu entorno.

\begin{tabular}{lllc}
\hline Pontos (Comunidade) & IQA & NSF & CETESB \\
\hline F1 (São Domingos) & 64 & Médio & Boa \\
F2 (Tauari) & 85 & Bom & Ótima \\
F3 (Taquara) & 71 & Bom & Boa \\
F4 (Pini) & 72 & Bom & Boa \\
F5 (Jamaraquá) & 79 & Bom & Boa \\
F6 (Maguari) & 78 & Bom & Boa \\
F7 (Aranamaí) & 75 & Bom & Boa \\
F8 (Cajutuba) & 81 & Bom & Ótima \\
F9 (Pindobal) & 70 & Médio & Boa \\
F10 (Alter do Chão) & 70 & Médio & Boa \\
\hline
\end{tabular}


Utilizando-se as Análises de Agrupamento, é possível identificar pelo método de vizinhos mais próximos que as condições físico-químicas expressas em $\mathrm{pH}$, sólidos totais, fósforo, oxigênio dissolvidos, DBO, turbidez, temperatura da água, coliformes termotolerantes e totais, transparência, condutividade e IQA são semelhantes em Jamaraquá e Maguarí (Figura 9). Também, nas localidades de Pindobal e Alter do Chão as condições apresentam semelhanças físico-químicas e biológicas, entre si. Taquara e Aramanaí apresentaram bom IQA, mas pela análise de clusters suas características físico-químicas foram distintas, possivelmente devido aos efeitos da presença de coliformes termotolerantes e totais, os quais foram praticamente 5 vezes superiores aos valores obtidos em Aramanaí, bem como os de sólidos em suspensão que em Taquara foram cerca de 33,0\% a mais do que em Aramanaí, evidenciando possíveis perturbações no ambiente aquático investigado. Os valores de $\mathrm{pH}$ nos dez pontos coletados variaram de 5,33 (Pinim) a 6,03 (Alter do Chão). Caracterizado por Sioli (1984) como um rio de água clara, o rio Tapajós possui águas não muito ácidas. Porém, observou-se nos dados, $\mathrm{pH}$ abaixo da neutralidade, tendendo à acidez. Isto pode ser atribuído à decomposição de matéria orgânica que influencia a acidez natural das águas.

Alves et al. (2012) verificaram valores do IQA variando de "Ruim" e "Regular" no Rio Arari, na Ilha do Marajó, os quais provavelmente relacionados aos elevados níveis de coliformes fecais, baixas concentrações de oxigênio dissolvido e $\mathrm{pH}$ ácido. Os autores encontraram valores de $\mathrm{pH}$ no período chuvoso em média de 5,22 e no menos chuvoso de 6,28 no rio Arari.

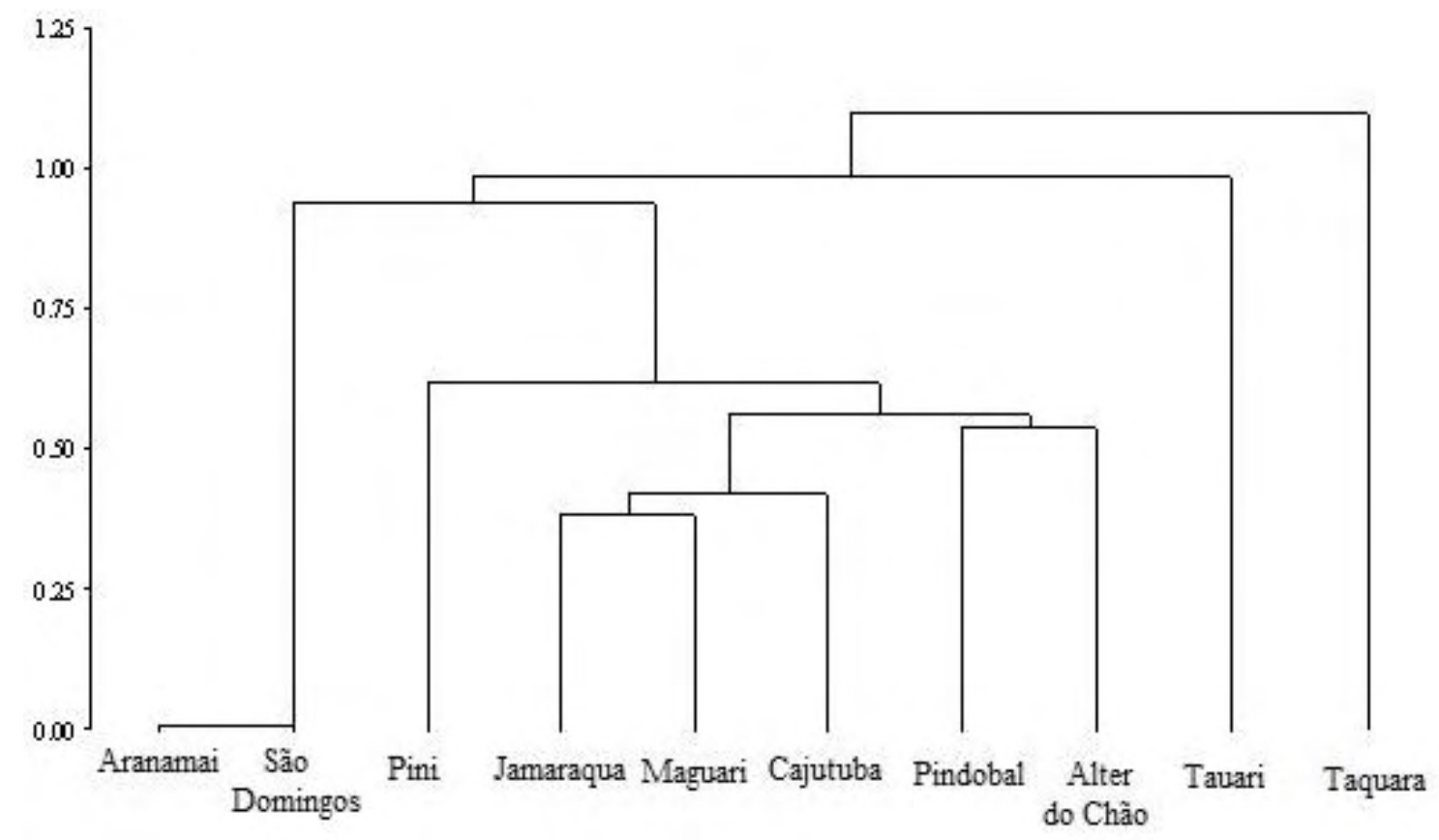

Figura 9. Análise de agrupamento pelo método do vizinho mais próximo nos 10 pontos de coletas na Flona Tapajós e seu entorno.

Os autovalores da matriz de correlação foram 5,15; 3,44; 1,77; 1,28; 0,96; 0,22; 0,12 e 0,05 ; e para os demais iguais a 0,00 . No total, esses somam 13,0 e representam a variação total das condições hídricas analisadas. Assim, o primeiro componente principal explica $(5,15 / 13) \quad 100,0 \%$, ou seja, cerca de $40,0 \%$ da variância total. Similarmente, os outros componentes principais na respectiva ordem contam com 27,0\%, 14,0\% e o restante distribuído nos demais componentes principais da variância total. O primeiro componente principal é, portanto o mais importante. 
Os três primeiros componentes principais explicam juntos cerca de $80,0 \%$ do total da variação. Considerando um corte de 30,0\%, o primeiro componente principal pode ser representado por $\mathrm{CP}_{1}=0,399276 \times($ Sólidos Totais $)+0,367019 \times($ Demanda Bioquímica de Oxigênio) $+0,405918 \times($ Turbidez $)+0,329060 \times$ (Coliformes Totais) $-0,356658 \times$ (Transparência). O segundo componente principal é $\mathrm{CP}_{2}=0,347818 \times(\mathrm{pH})+0,354770 \times$ (Fósforo total) $+0,349963 \times$ (Oxigênio Dissolvido) $-0,452938 \times$ (Nitrogênio Total ) $+0,456894 \times$ (Coliformes Termotolerantes) $-0,304178 \times($ IQA). O terceiro componente principal é $\mathrm{CP}_{3}=0,454304 \times($ Temperatura da água $)+0,454460 \times$ (Coliformes Totais) $0,475798 \times($ Condutividade $)+0,404885 \times($ IQA $)$.

$\mathrm{O} \mathrm{CP}_{1}$ indica um contraste existente entre sólidos totais, demanda bioquímica de oxigênio, turbidez e coliformes totais com a transparência da água. Portanto, os locais São Domingos e Taquara são caracterizados por apresentar altos índices de efeitos positivos dessa equação e baixo índice para a transparência da água. O gráfico Biplot apresentado na Figura 10a corrobora com o que esta sendo discutido. Por outro lado, Tauari, por exemplo, destaca-se pela transparência da água e por apresentar baixos índices de sólidos totais, demanda bioquímica de oxigênio, turbidez e coliformes totais.

No $\mathrm{CP}_{2}$ observa-se um contraste entre $\mathrm{pH}$, oxigênio dissolvido, fósforo total, coliformes termotolerantes com o nitrogênio total e o índice da qualidade da água. Nota-se que os locais Alter do Chão e Pindobal possuem altos índices de $\mathrm{pH}$, oxigênio dissolvido, fósforo total e coliformes termotolerantes localizando na parte positiva do eixo do $\mathrm{CP}_{2}$. Esses mesmos locais apresentam índices mais baixos para nitrogênio total e o índice da qualidade da água. Tauari e Jamaraqua ao contrário de Alter do Chão e Pindobal possuem índices mais elevados para nitrogênio total e o IQA localizando-se na parte negativa do eixo do $\mathrm{CP}_{2}$ na Figura $10 \mathrm{a}$.

O CP3 mede o contraste entre temperatura, coliformes totais e índice de qualidade da água com a condutividade. Os locais onde foram feitas as análises em Pini e São Domingos foram os que apresentaram altos índices para condutividade e índices baixos para temperatura, coliformes totais e índice de qualidade da água. Nessa mesma equação, destaca-se Cajutuba, Taquara, Jamaraqua e Tauarí por apresentarem valores mais elevados de temperatura, coliformes totais e índice de qualidade da água e baixos índices para condutividade. O gráfico Triplot apresentado na Figura 10b confirma essas relações.

Destacam-se as comunidades de Maguari, Pini e Cajutuba por apresentarem uma média geral em relação às demais variáveis avaliadas, indicando que essas comunidades ficam no centro do gráfico Biplot, apontando o ponto médio.

O Biplot Figura 10a e o Triplot ilustrado na Figura 10b evidenciam a contribuição de cada local onde foram realizadas as coletas e cada variável por um vetor [pH, Sólidos Totais (mg L $\left.{ }^{-1}\right)$, Fósforo total (mg L ${ }^{-1}$ ), Oxigênio Dissolvido $\left(\mathrm{mg} \mathrm{L}^{-1}\right)$, Demanda Bioquímica de Oxigênio (mg L $\left.{ }^{-1}\right)$, Turbidez (UNT), Temperatura da água $\left({ }^{\circ} \mathrm{C}\right)$, Nitrogênio Total $\left(\mathrm{mg} \mathrm{L}^{-1}\right)$, Coliformes Termotolerantes e Totais (NMP $100 \mathrm{~mL}^{-1}$ ), Transparência (cm), Condutividade $\left(\mu \mathrm{cm}^{-1}\right)$ e IQA], permitindo assim, avaliar as semelhanças ou não, entre os mesmos. Pelo Biplot, representado na Figura 10a, verificou-se uma forte correlação positiva entre as variáveis: Turbidez, Demanda Bioquímica de Oxigênio e Sólidos Totais.

Também, existe uma correlação entre Temperatura da água e Oxigênio Dissolvido. Houve correlações negativas entre as variáveis IQA e Fósforo total, assim como, Transparência e Coliformes Totais. Todas essas correlações puderam ser observadas também na matriz de correlação (não apresentada nesse trabalho). Em se tratando das análises de componentes principais, representadas na Figura 10b Triplot, estas reforçam que os pontos com alta presença de coliformes termotolerantes em Alter do Chão e Pindobal, verificada entre $\mathrm{CP}_{2}$ e $\mathrm{CP}_{3}$, são diametralmente opostos aos valores de Turbidez, observados em Jamaraquá e Taquara. No ponto próximo a comunidade de Tauarí, os valores de Oxigênio Dissolvido foram os mais elevados e a coluna de transparência, verificada in situ, atingiu 
quase dois metros, reforçando o estado de conservação mais expressivo nas variáveis hídricas investigadas, localizados próximo ao eixo $\mathrm{CP}_{3}$.

Ainda analisando o gráfico Biplot, pela proximidade do ponto, consolida-se a forte correlação da comunidade Tauarí com o eixo do IQA. Pode-se ponderar o fato de nesta região não ocorrer o acesso para uso turístico, refletindo, portanto, nas melhores condições hídricas, em relação aos demais locais avaliados na Flona e seu entorno.
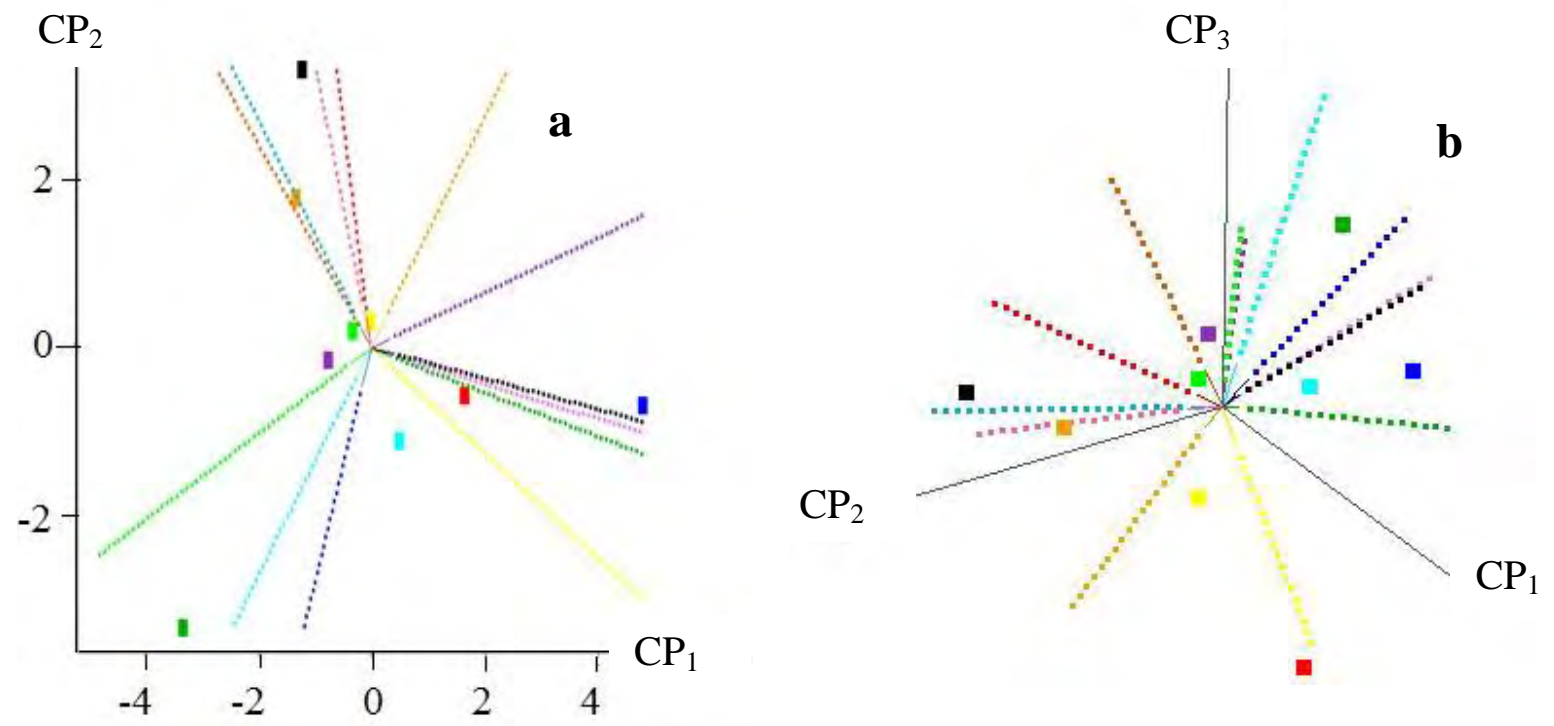

Legenda:

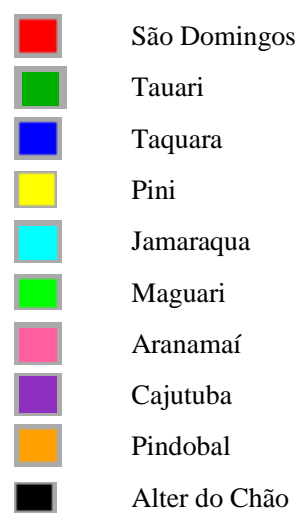

$\mathrm{pH}$
Sólidos Totais $\left(\mathrm{ml} \mathrm{L}^{-1}\right)$
Fósforo Total $\left(\mathrm{ml} \mathrm{L}^{-1}\right)$
Oxigênio Dissolvido. $\left(\mathrm{ml} \mathrm{L}^{-1}\right)$
Demanda Bioquímica de Oxigênio $\left(\mathrm{ml} \mathrm{L}^{-1}\right)$
Turbidez $(\mathrm{UNT})$

Figura 10. a) Biplot dos escores nos dez pontos de coletas dos dois componentes principais mais importantes referentes as 13 variáveis do estudo; b) Triplot dos escores dos três componentes principais mais importantes referentes as 13 variáveis do estudo nos dez pontos de coletas.

Entre as 10 localidades avaliadas os maiores valores de DBO foram observados em Taquara, indicando que há maior incremento de matéria orgânica e, portanto, possíveis comprometimentos no equilíbrio ecossistêmico, como, por exemplo, a oferta de pescado que é base da alimentação de comunidades ribeirinhas, na Amazônia.

\section{CONCLUSÕES}

Com base nos resultados obtidos conclui-se:

O ritmo climático evidenciou que o mês de Dezembro marca a fase intermediária entre o fim do período de menor oferta pluvial e o início das chuvas;

Chove mais na porção sul onde também ocorrem as áreas mais declivosas apresentando um padrão topo pluvial diferenciado na Flona Tapajós e seu entorno; 
A análise de indicadores hídricos pode mostrar possíveis ameaças à manutenção de bens e serviços que o rio Tapajós oferece às populações;

O IQA pode ser um dos índices de avaliação em corpos hídricos sob a influência de Unidades de Uso Sustentável como é o caso da Flona Tapajós;

Nas proximidades da comunidade do Tauarí a coluna de transparência da água, o IQA e a baixa ocorrência de coliformes termotolerantes evidenciam o estado de conservação refletido nas variáveis hídricas avaliadas;

As águas próximas aos balneários de Alter do Chão e Pindobal apontam efeitos de antropização devido à alta presença de coliformes termotolerantes em relação aos demais pontos analisados;

Nos balneários (Alter do Chão e Pindobal), apesar dos valores estarem dentro dos limites aceitáveis com IQA nas faixas entre médio e bom, alerta-se para cuidados quanto ao uso sustentável e para a manutenção do seu potencial turístico;

Os valores elevados de DBO em Taquara indicam que há maior disponibilidade de incremento de matéria orgânica, o que pode induzir ao completo esgotamento de oxigênio na água e comprometer a vida aquática;

Ações conservacionistas necessitam ser aplicadas em áreas no entorno da Flona Tapajós para garantir bens e serviços ambientais que o rio Tapajós presta à sociedade como, por exemplo, o fornecimento de água com índices de alta qualidade para uso alimentar, higiene e manutenção do potencial balneário na região;

Os corpos hídricos são sensíveis às alterações no uso e cobertura do solo e podem evidenciar possíveis alterações capazes de ameaçar o equilíbrio em áreas de uso conservacionista como é o caso da Floresta Nacional do Tapajós; e,

Espera-se que os resultados obtidos nesta pesquisa possam subsidiar avaliações de uso conservacionista em bacias hidrográficas para garantir os serviços ecossistêmicos prestados pelas comunidades em áreas legalmente protegidas na Amazônia.

\section{AGRADECIMENTOS}

Os autores expressam seus agradecimentos à Coordenação de Aperfeiçoamento de Pessoal de Nível Superior (CAPES) pelo financiamento da bolsa de mestrado da primeira autora; à Universidade do Estado do Pará e ao Programa de Mestrado em Ciências Ambientais; à coordenação e à equipe do Projeto ROBIN; à Embrapa Amazônia Oriental; ao Núcleo Médio Amazonas da Embrapa; ao Instituto Chico Mendes de Conservação da Biodiversidade (ICMBio) de Santarém e ao $4^{\circ}$ Grupamento Bombeiro Militar de Santarém (Pará).

\section{REFERÊNCIAS}

AMERICAN PUBLIC HEALTH ASSOCIATION - APHA. Standard methods for examination of water and wastewater. 21. ed. Washington, 2005. 4358 p.

ALVES, I. C. C.; EL-ROBRINI, M.; SANTOS, M. L. S.; MONTEIRO, S. M.; BARBOSA, L. P. F.; GUIMARÃES, J. T. F. Qualidade das águas superficiais e avaliação do estado trófico do Rio Arari (Ilha de Marajó, norte do Brasil). Acta Amazônia, v. 42, n. 1, p. 115-124, 2012. http://dx.doi.org/10.1590/S0044-59672012000100014

ARTAXO, P. Opportunities for research in global changes in the field of chemistry. Journal of the Brazilian Chemical Society, v. 18, n. 2, 2007. http://dx.doi.org/10.1590/S010350532007000200001 
BRASIL. Decreto $\mathrm{n}^{\circ}$ 73.684, de 19 de fevereiro de 1974. Cria a Floresta Nacional do Tapajós e dá outras providências. Diário Oficial [da] União, Seção 1, p. 1987, 20 fev. 1974.

. Lei 12.678, de 25 de junho de 2012. Dispõe sobre alterações nos limites dos Parques Nacionais da Amazônia, dos Campos Amazônicos e Mapinguari, das Florestas Nacionais de Itaituba I, Itaituba II e do Crepori e da Área de Proteção Ambiental do Tapajós; altera a Lei no 12.249, de 11 de junho de 2010; e dá outras providências. Diário Oficial [da] União, Seção 1, 26 jun. 2012.

COMPANHIA DE TECNOLOGIA E SANEAMENTO AMBIENTAL - CETESB. Relatório de qualidade das águas interiores no Estado de São Paulo 2005. São Paulo, 2006.

Guia nacional de coleta e preservação de amostras: água, sedimento, comunidades aquáticas e efluentes líquidos. Brasília: CETESB; ANA, 2011. 326 p.

.Águas superficiais: variáveis de qualidade de água. São Paulo, 2012. Disponível em: $<$ http://www.cetesb.sp.gov.br>. Acesso em 01 ago. 2012.

CONSELHO NACIONAL DO MEIO AMBIENTE - CONAMA (Brasil). Resolução no 357, de 17 de março de 2005. Brasília, 2005.

FEARNSIDE, P. M. A água de São Paulo e a floresta amazônica. Ciência Hoje, v. 34, p. 6365, 2004.

Serviços ambientais provenientes de florestas intactas, degradadas e secundárias na Amazônia brasileira. In: PERES, C. A.; GARDNER T. A.; BARLOW, J.; VIEIRA, I. C. G. (eds.). Conservação da biodiversidade em paisagens antropizadas do Brasil. Curitiba: Editora da Universidade Federal do Paraná, 2013. p. 29-62.

FERREIRA, D. F. Estatística multivariada. 2. ed. Lavras: Editora UFLA, 2011. v. 1. 675 p.

GATTI, S.; BREY, T.; MULlER, W. E. G.; HEILMAYER, O.; HOLST, G. Oxygen microoptodes: a new tool for oxygen measurements in aquatic animal ecology. Marine Biology, v. 40, n. 6, p. 1075-1085, 2002. http://dx.doi.org/10.1007/s00227-002-0786-9

INSTITUTO BRASILEIRO DE GEOGRAFIAS E ESTATÍSTICAS - IBGE. Banco de dados agregados ao sistema IBGE de recuperação automática (SIDRA). 2013. Disponível em: <http://www.ibge.gov.br>. Acesso em: 04 fev. 2014.

INSTITUTO BRASILEIRO DO MEIO AMBIENTE E DOS RECURSOS NATURAIS RENOVÁVEIS - IBAMA. Floresta Nacional do Tapajós: plano de manejo: vol. I informações gerais. 2004. Disponível em: http://www.icmbio.gov.br/portal/images /stories/imgs-unidades-coservacao/flona_tapajoss.pdf. Acesso em: set. 2014.

INSTITUTO NACIONAL DE METEOROLOGIA - INMET (Brasil). Normais climatológicas do Brasil. Brasília, 2009. 465p.

MANLY, B. F. J. Multivariate statistical methods a primer. 3. ed. New York: Chapman \& Hall, 2004. 215p.

ANZATTO, C. V.; FREITAS JUNIOR, E.; PERES, J. R. R. Uso agrícola dos solos brasileiros. Rio de Janeiro: Embrapa Solos, 2002. 174 p.

MARENGO, J. Characteristics and spacio-temporal variability of the Amazon river basin water budget. Climate Dynamics, v. 24, n. 1, p. 11-22, 2005.

http://dx.doi.org/10.1007/s00382-004-0461-6 
MARTORANO, L. G.; NECHET, D.; MANZATTO, C. V.; REBELLO, E.; BERTOLOSSI, R. Pluviometric variations as subsidiary information for agricultural planning in the Amazon. In: INTERNATIONAL SOIL CONSERVATION ORGANIZATION CONFERENCE - ISCO, 13., 2004, Brisbane. Papers... Disponível em: http://tucson.ars.ag.gov/isco/isco13/PAPERSM-Q/MARTORANO.pdf. Acesso em: set. 2014.

MARTORANO, L. G.; BERGAMASCHI, H.; FARIA, R. T.; DALMAGO, G. A. Decision Strategies for Soil Water Estimations in Soybean Crops Subjected to No-Tillage and Conventional Systems, in Brazil. In: INTECH. Problems, perspectives and challenges of agricultural water management. 1 ed. 2008. Disponível em: Decision_ strategies_for_soil_water_estimations_in_soybean_crops_subjected_to_no_tillage_and_ conventional_systems_in_brazil. Acesso em: set. 2014.

MINGOTI, S. A. Análise de dados através de métodos de Estatística Multivariada: uma abordagem aplicada. Belo Horizonte: Editora UFMG, 2005. 295p.

PRADO, B. P.; NOVO, M. L. M. N. Análise espaço-temporal da relação do estado trófico do reservatório de Barra Bonita (SP) com o potencial poluidor da Bacia hidrográfica. São José dos Campos: INPE, 2006.

RUDORFF, C. M.; NOVO, E. M. L. M.; GALVÃO, L. S. Spectral mixture analysis for water quality assessment over the Amazon foodplain using Hyperion/EO-1 images. Revista Ambient. Água, v. 1, n. 2, p. 65-79, 2006. http://dx.doi.org/10.4136/ambi-agua.13

SAS INSTITUTE INC. SAS statistical software. Release 9.2. Cary, 2008.

SILVA, A. E. P.; ANGELIS, C. F.; MACHADO, L. A. T.; WAICHAMAN, A. V. Influência da precipitação na qualidade da água do Rio Purus. Acta Amazonia, v. 38, n. 4, p. 733742, 2008. http://dx.doi.org/10.1590/S0044-59672008000400017

SIOLI, H. The Amazon: limnology and landscape ecology of a migth tropical river and it's basin. Monographie Biologicae, v. 56, 1984.

SIQUEIRA, G. W.; APRILE, F.; MIGUÉIS A. M. Diagnóstico da qualidade da água do rio Parauapebas (Pará - Brasil). Acta Amazonia, v. 42, n. 3, p. 413-422, 2008. http://dx.doi.org/10.1590/S0044-59672012000300014

SISTEMA NACIONAL DE UNIDADES DE CONSERVAÇÃO SNUC. Texto da Lei $\mathbf{9 . 9 8 5}$ de 18 de julho de 2000 e vetos da presidência da República ao PL aprovado pelo Congresso Nacional. 2. ed. São Paulo: Conselho Nacional da Reserva da Biosfera da Mata Atlântica, 2002. 76 p.

VON SPERLING, M. Estudos e modelagem da qualidade da água de rios. Belo Horizonte: DESA, 2007. 588 p. 


Ambiente \& Água - An Interdisciplinary Journal of Applied Science
ISSN 1980-993X - doi:10.4136/1980-993X
www.ambi-agua.net
E-mail: ambi-agua@agro.unitau.br

\title{
Uso de imagens do LISS-3/Resourcesat-1 e do OLI/Landsat-8 no estudo espacial da queda do nível de água no lago de Furnas no ano de 2012
}

\author{
doi: 10.4136/ambi-agua.1430
}

Received: 17 Jun. 2014; Accepted: 16 Sep. 2014

\author{
Gabriel Thomé Brochado $^{1^{*}}$; Lucrêncio Silvestre Macarringue ${ }^{2}$ \\ ${ }^{1}$ Instituto Nacional de Pesquisas Espaciais (INPE), São José dos Campos, SP, Brasil \\ Departamento de Sensoriamento Remoto \\ ${ }^{2}$ Instituto de Formação em Administração de Terras e Cartografia (INFATEC), \\ Cidade da Matola, província de Maputo, Moçambique \\ Departamento de Investigação e Extensão \\ *Autor correspondente: e-mail: gabrow@gmail.com, \\ lusimac@gmail.com
}

\section{RESUMO}

O presente trabalho teve como objetivo analisar, por meio de imagens de diferentes sensores e técnicas de geoprocessamento, o efeito da queda do nível de água que ocorreu no Lago de Furnas no ano de 2012. Esta análise foi feita com base nas imagens satélites em três distintos anos: antes do evento (imagens de 2010), durante o evento (imagens de 2012) e depois do evento (imagens do ano de 2013). Para realizar o mapeamento do nível de água nos anos de 2010 e 2012 foram utilizadas imagens do LISS3/Resourcesat-1 e para o ano de 2013 imagens do OLI/Landsat-8, todas processadas e interpretadas em ambiente SIG. O produto final apresenta quatro classes: i) superfície de água permanente nos três anos, ii) superfície seca permanente nos três anos, iii) superfícies de água recuperada e iv) não recuperada até ao último ano (2013). A metodologia consistiu de cinco etapas: preparo, fatiamento, álgebra de mapas, edição matricial e cálculo de áreas. O mapa da redução do nível de água do Lago foi gerado a partir de uma operação matricial algébrica entre as máscaras de superfície de água extraídas das bandas do infravermelho próximo, cujo resultado foi editado manualmente para corrigir erros de classificação. Para validar o mapa foram usadas fotografias veiculadas pela imprensa local, durante o evento de redução de nível de água. Os resultados desta pesquisa permitiram concluir que esta metodologia é fácil de ser reproduzida e pode ser utilizada em outras regiões.

Palavras-chave: imagens orbitais, interpretação de imagens, processamento, reservatório de Furnas.

\section{Spatial study using LISS-3/Resourcesat-1 and OLI/Landsat-8 images to characterize the water level drop in Furnas Lake during 2012}

\begin{abstract}
This study used satellite images and GIS techniques to analyze the effect of the decrease in water level in Furnas Lake during 2012. The analysis was based on satellite images captured during three different periods: prior to the event (images of 2010), during the year of the event (images of 2012) and after the event (images of the year 2013).
\end{abstract}


LISS3/Resourcesat-1 images were used for the years 2010 and 2012 and OLI/Landsat-8 images for the year 2013. The images were processed and interpreted into a GIS environment. The final product had four classes: i) permanent water surface during the three periods, ii) permanent dry surface during the three periods, iii) recovered water surfaces and iv) not recovered until the last period (2013). The methodology consisted of five stages: preparation, density slice, map algebra, raster editing and area calculation. The map of the water level drop in the Furnas Lake was generated by an algebraic matrix operation between the surface water mask drawn based on the near-infrared bands. The result of this operation was manually edited in order to correct classification errors. For data validating, we compared photographs published by local media during the event with the generated maps. The results showed that this methodology is straightforward and easily reproduced and can be used to assess other regions.

Keywords: Furnas reservoir, image processing and interpretation, orbital images.

\section{INTRODUÇÃO}

O Lago de Furnas situa-se na região sul do Estado de Minas Gerais e é o maior reservatório de água do estado, sendo por isso conhecido como Mar de Minas. O lago foi criado em 1963 para servir de represa para a hidrelétrica de Furnas e desde então muitas atividades econômicas têm sido desenvolvidas na região, principalmente relacionadas ao turismo e à pesca (Com chuvas de verão..., 2013). Com a criação do lago, trinta e quatro (34) municípios tiveram parte de seus territórios inundados com o represamento das águas.

Estes municípios, a fim de explorar turisticamente as transformações advindas da criação da represa, buscando a sustentabilidade econômica e a preservação ambiental dos municípios banhados pelo lago, formaram a Associação dos Municípios do Lago de Furnas (ALAGO).

No ano de 2012, o lago sofreu uma grande queda no seu nível de água, chegando a ficar até 13 metros abaixo do seu nível normal (Silva 2012). A redução da lâmina de água no lago foi ocasionada devido à necessidade da hidrelétrica de gerar energia elétrica e, para tal, foram abastecidos outros reservatórios a jusante da barragem. Segundo a empresa Furnas, a geração de energia elétrica é a prioridade, sendo, portanto, um procedimento normal manter as hidrelétricas em funcionamento o ano inteiro (Com chuvas de verão..., 2013). As estimativas para a recuperação do nível de água normal da represa indicavam 3 ou 4 anos, fato que ameaçava a estabilidade da economia local, baseada principalmente em atividades ligadas ao turismo, à agricultura e à pesca. Todavia, os efeitos da queda foram atenuados devido às grandes chuvas que ocorreram no final do ano de 2012 e início de 2013 nas cabeceiras dos rios que alimentam a represa (Com chuvas de verão..., 2013).

Vários estudos que focam nas questões de preservação e conservação de recursos hídricos, ocupação e monitoramento de áreas inundáveis, dinâmicas dos reservatórios de recursos hídricos usando geotecnologias e imagens orbitais têm sido amplamente difundidos (Pinto-Coelho et al., 1994; Butzke, 1995; Mota, 1995; Câmara et al., 1996; Tundisi, 1999). À luz desses estudos, neste trabalho se propõe analisar qualitativamente, por meio de imagens de diferentes sensores orbitais, os efeitos da queda de nível de água na represa e quantificar a área impactada e recuperada por município abrangido.

\section{MATERIAL E MÉTODO}

\section{1. Área de estudo}

O Lago de Furnas é a maior extensão de água do estado de Minas Gerais, ocupando uma área de $1.440 \mathrm{~km}^{2}$. O lago é formado por dois "braços", um a leste e outro a sul da barragem. Do lado leste o principal rio que desagua no lago é o Rio Grande. Do lado sul a represa é 
formada da junção dos rios Verde, Sapucaí, Machado, além de muitos ribeirões e córregos (Figura1) (IPT, 2008).

\section{LAGO DE FURNAS (Minas Gerais)}

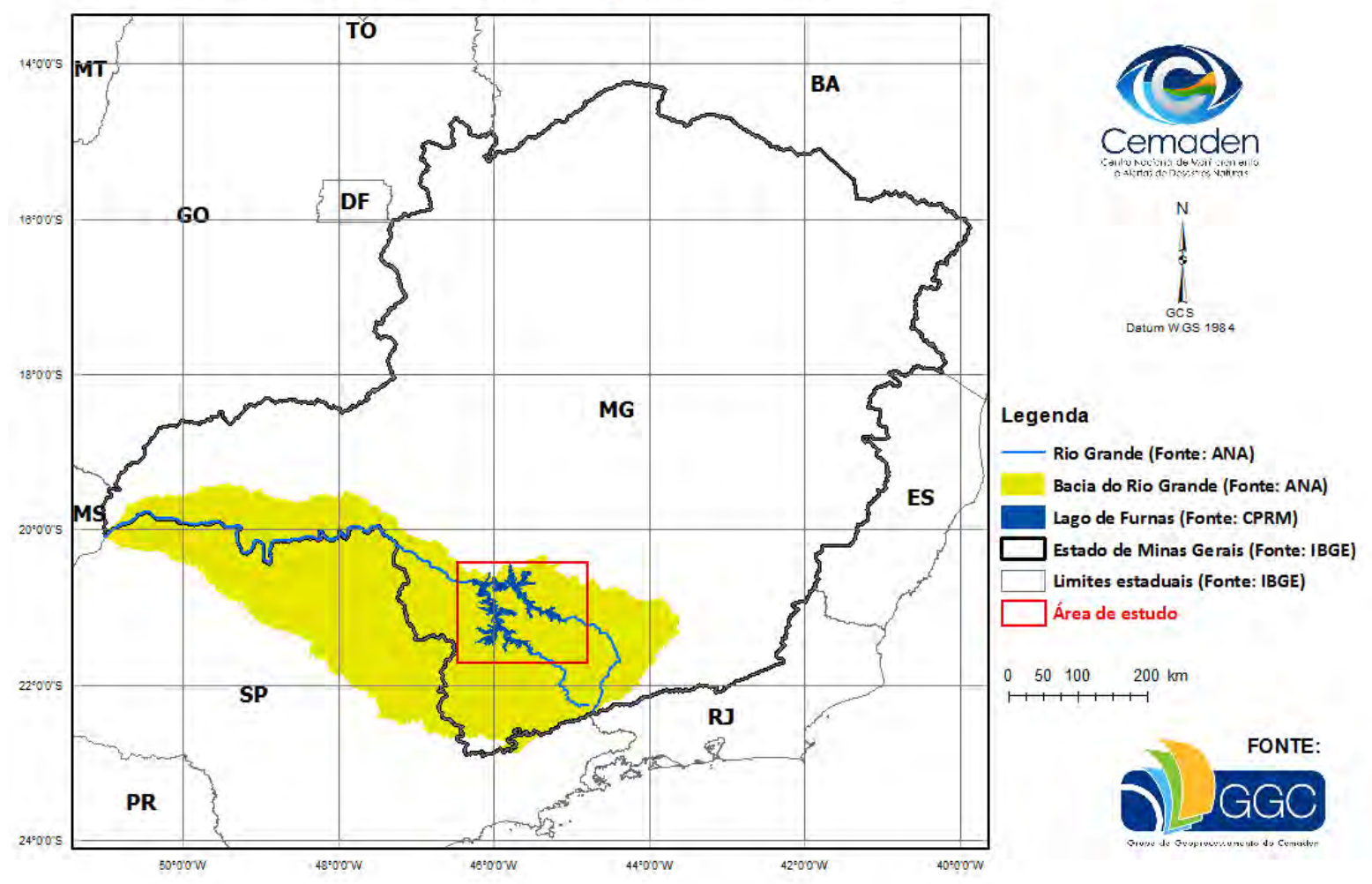

Figura 1. Localização geográfica do lago de furnas na região Sul/Sudoeste do estado de Minas Gerais.

Fonte: Cemaden (2014).

O nível de armazenamento do lago é de 768 metros acima do nível do mar, com o nível máximo de 769,3 metros e o nível mínimo de operação de 750 metros. Ao longo de sua extensão, o lago exibe diversas paisagens com contornos sinuosos, por causa do "mar de morros" sobre o qual a represa foi formada. Na região de Capitólio, existem os cânions do Lago de Furnas, que possuem cerca de 20 metros de altura com várias cachoeiras e reentrâncias, formando uma bela paisagem.

A região insere-se num contexto paisagístico de transição entre a Mata Atlântica e o Cerrado, no entanto, a cobertura vegetal nativa é representada pela Floresta Estacional Semidecídua, constituída por fragmentos de diversos tamanhos e formas que se apresentam como um mosaico heterogêneo (Nascimento et al., 1999 apud Ferreira et al., 2008, Santos et al., 2011). As unidades geomorfológicas mais expressivas da região são caracterizadas por colinas de topo aplainado, com rampas expressivas e os solos predominantes são os Latossolos, com ocorrência de Podzólicos, Litólicos e Cambissolos. O relevo é, em grande parte, constituído por rochas cristalinas (Camargo et al., 1962, apud CAMPOS e SILVA, 1998).

\subsection{Material}

Foram utilizados três conjuntos de imagens para compor os anos, conforme apresentado na Tabela 1. 
Tabela 1. Imagens orbitais utilizadas na composição dos anos.

\begin{tabular}{ccccc}
\hline Ano & Plataforma & Sensor & Órbita/Ponto & Data \\
\hline $\mathbf{2 0 1 0}$ & - & - & $331 / 092$ & $05 / 08 / 2010$ \\
- & - & - & - & - \\
- & - & - & $331 / 093$ & $24 / 08 / 2010$ \\
- & Resourcesat-1 & LISS-3 & $332 / 093$ & $24 / 08 / 2010$ \\
$\mathbf{2 0 1 2}$ & - & - & $331 / 092$ & $17 / 11 / 2012$ \\
- & - & - & $331 / 093$ & $17 / 11 / 2012$ \\
- & - & - & $332 / 093$ & $22 / 11 / 2012$ \\
$\mathbf{2 0 1 3}$ & Landsat-8 & OLI & $219 / 074$ & $12 / 05 / 2013$ \\
- & - & - & $219 / 075$ & $12 / 05 / 2013$ \\
\hline
\end{tabular}

Estas datas foram as que apresentaram melhores imagens (fraca cobertura de nuvens) para este estudo, assume-se que a relativa diferença entre as datas das imagens de 2010 e 2012 pode afetar os resultados desta pesquisa.

A utilização do LISS-3 foi devido ao fato do TM-Landsat 5 estar inoperacional parte do período em análise, que veio a ser substituído pelo Landsat 8, e por outro lado existem aproximações entre as faixas espectrais e resoluções espacial e temporal destes sensores além do fato do OLI ser novo e apresentar relativas vantagens que os anteriores sensores da mesma série que podem ser exploradas tais como maior número de bandas e ortoretificação.

O sensor LISS-3 (Linear Imaging Self Scanning Sensor), um dos 3 sensores a bordo do ResourceSat-1, opera em três faixas espectrais: visível, infravermelho próximo (NIR) e infravermelho de ondas curtas ou médio (SWIR) (NRSA, 2003; Chander, 2013). As especificações técnicas deste sensor são apresentadas na Tabela 2.

Tabela 2. Características das imagens do LISS-3 do satélite ResourceSat-1.

\begin{tabular}{llccccc}
\hline \multicolumn{1}{c}{ Sensor } & Bandas Espectrais & $\begin{array}{c}\text { Resolução } \\
\text { Espectral }\end{array}$ & $\begin{array}{c}\text { Resolução } \\
\text { Espacial }\end{array}$ & $\begin{array}{c}\text { Resolução } \\
\text { Temporal }\end{array}$ & $\begin{array}{c}\text { Área } \\
\text { Imageada }\end{array}$ & $\begin{array}{c}\text { Resolução } \\
\text { Radiométrica }\end{array}$ \\
\hline & Verde & $0.52-0.59 \mu \mathrm{m}$ & & & & \\
$\begin{array}{l}\text { LISS III } \\
\text { (Linear Imaging }\end{array}$ & Vermelho & $0.62-0.68 \mu \mathrm{m}$ & & & & \\
$\begin{array}{l}\text { Self-Scanner) } \\
\text { Satélite IRS-P6 } \\
\text { (Resourcesat-1) }\end{array}$ & $\begin{array}{l}\text { Infravermelho } \\
\text { próximo }\end{array}$ & $0.77-0.86 \mu \mathrm{m}$ & & & & \\
& $\begin{array}{l}\text { Infravermelho } \\
\text { médio }\end{array}$ & $1.55-1.70 \mu \mathrm{m}$ & & & & \\
& & & & & & \\
& & & & & & \\
& & & & & & \\
\end{tabular}

Fonte: INPE (2013).

Os sensores OLI (Operational Land Imager) e TIRS (Thermal Infrared Sensor) do Landsat 8 operam em 11 bandas espectrais. As imagens obtidas por estes sensores apresentam três resoluções espaciais distintas, conforme mostrado na Tabela 3. São imagens quase prontas, contendo correções geométricas (USGS, 2012a; 2012b) e ambos sensores podem ser usadas de forma compensatória ou complementar (Johnson, 2008). Para este estudo, foram utilizadas as bandas 4, 5 e 6 e 8 (OLI). 
Tabela 3. Características das imagens do OLI e TIRS do satélite Landsat 8.

\begin{tabular}{ccccc}
\hline Banda & Sensor & Faixa espectral $(\boldsymbol{\mu m})$ & Significado & $\begin{array}{c}\text { Resolução } \\
\text { Espacial (m x m) }\end{array}$ \\
\hline Banda 1 & - & $0,43-0,45$ & Aerossol, costeira* & 30 \\
Banda 2 & - & $0,45-0,51$ & Azul & 30 \\
Banda 3 & - & $0,53-0,59$ & Verde & 30 \\
Banda 4 & - & $0,64-0,67$ & Vermelho & 30 \\
Banda 5 & OLI & $0,85-0,88$ & IV Próximo & 30 \\
Banda 6 & - & $1,57-1,65$ & SWIR 1 & 30 \\
Banda 7 & - & SWIR 2 & 30 \\
Banda 8 & - & $2,11-2,29$ & Pancromático & 15 \\
Banda 9 & - & $0,50-0,68$ & Cirrus & 30 \\
Banda 10 & TIRS & $1,36-1,38$ & - & 100 \\
Banda 11 & - & $10,60-11,19$ & - & 100 \\
\hline
\end{tabular}

"utilizada para estudo de aerossol e ambiente costeiro; ${ }^{* *}$ estudar as nuvens cirrus.

Fonte: USGS (2012a; 2012b).

Foi utilizada também a base cadastral dos municípios brasileiros na escala 1:250.000 e o cadastro das localidades do ano de 2010 (IBGE, 2010).

Todos os procedimentos computacionais foram realizados nos aplicativos Envi 4.7 e Spring 4.3.3, e o programa FME 2013 foi usado para o cálculo das informações dispostas na Tabela 4 de impacto/recuperação.

\subsection{Método}

A análise do efeito da queda do nível de água no lago de Furnas e o quanto foi recuperado no ano seguinte foi baseada em uma situação estável do ano de 2010, tomada como referência. A partir do cruzamento do mapa base (ano de 2010) com os mapas do ano de ocorrência do evento (2012) e do ano seguinte (2013) foi possível gerar uma nova informação, relativa à diferença nos níveis de água nos três momentos e quantificar esta diferença para cada município limítrofe do lago.

O mapa base foi obtido através da delimitação do perímetro da lâmina de água no mosaico de imagens na banda do infravermelho próximo, tendo em vista que a água absorve praticamente toda energia radiante nesta região do espectro eletromagnético em contraste com os demais alvos no entorno do lago (Jensen, 2009). Tanto o mapa base, quanto os demais foram gerados a partir de uma operação matricial algébrica, denominada 'fatiamento'. Os erros de delimitação do perímetro da água que surgiram durante a extração semiautomática foram eliminados por meio da edição matricial manual.

No mapa final, foram definidas quatro classes: superfície de água permanente nos três anos, superfície seca permanente nos três anos e superfícies de água recuperada e não recuperada até a data das imagens no ano de 2013. A partir do mapa final, obtido a partir do cruzamento dos três mapas nas três datas (Figura 2), foi gerada uma tabela para quantificar a área que foi impactada e recuperada em cada município banhado pelas águas livres do lago.

A metodologia desenvolvida continha cinco etapas: preparo das imagens, fatiamento, álgebra de mapa, edição matricial e cálculo de área (Figura 2). 


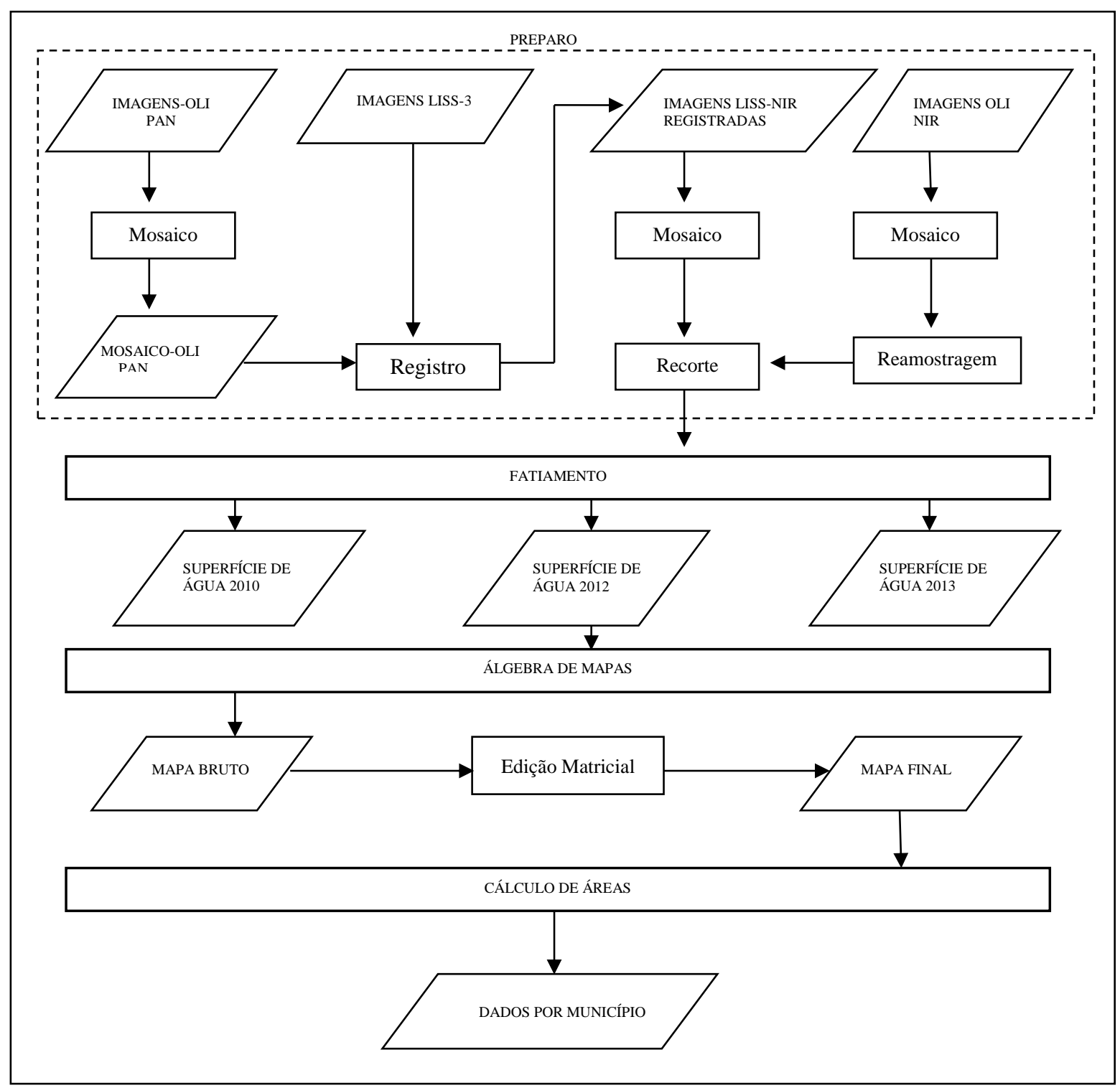

Figura 2. Fluxograma do método.

\subsubsection{Preparo do material}

O preparo consistiu em uma série de operações (Figura 2) necessárias para que a extração da superfície de água livre observável nas imagens pudesse ser realizada através de um programa computacional.

Como a região do lago de Furnas abrange duas cenas do Landsat, órbita/ponto 219/74 e 75 , foi necessário realizar um mosaico dessas duas cenas para obter uma área contínua de todo lago de Furnas. O mosaico, feito com as imagens pancromáticas (banda 8) deste sensor, foi utilizado para o registro das imagens LISS-3/Resourcesat-1. Ao final desta operação as imagens da região do infravermelho próximo de ambos os sensores foram reamostradas para 15 metros e gerado um mosaico para cada ano. Estes mosaicos foram recortados para uma área cujos limites distam cerca de 300 metros do limite da superfície de água livre no ano de 2010 (Figura 3). Esta operação foi realizada com intuito de facilitar os processos subsequentes. 


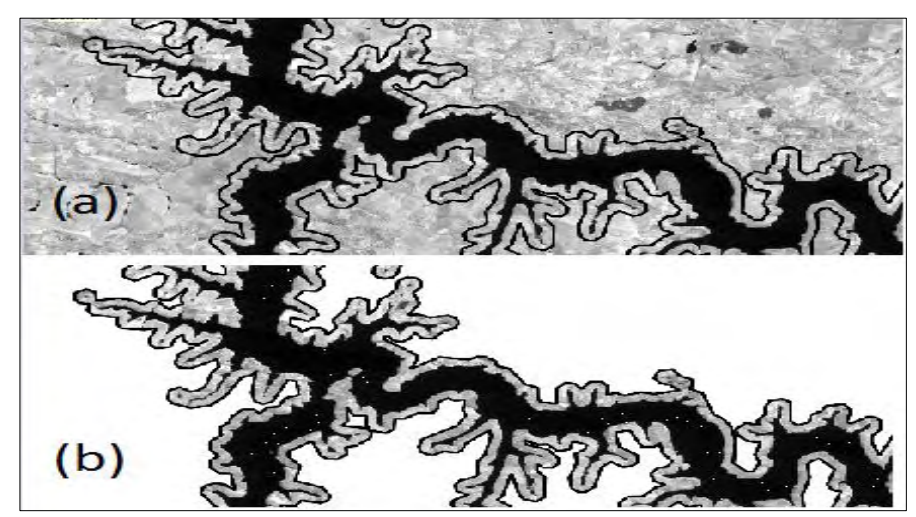

Figura 3. Recorte das imagens. (a) Mosaico das imagens de 2010 com o vetor da área do buffer de $300 \mathrm{~m}$. (b) Resultado do recorte, eliminando o restante da imagem.

\subsubsection{Fatiamento}

A superfície de água livre foi extraída dos mosaicos de cada ano utilizando um procedimento semi-automático, denominado fatiamento. É determinado, para cada ano, um valor de nível de cinza, abaixo do qual os pixels foram classificados como "água" e acima do qual como "seco". Este valor é encontrado empiricamente a partir da análise do histograma do mosaico de cada ano e da inspeção visual do intérprete.

A Figura 4 apresenta os histogramas dos mosaicos, em que pode ser observada a presença de dois "picos", um relativo à resposta espectral da água e outro da região seca. Portanto, o limiar ótimo de separabilidade entre água e solo está no vale de máxima inflexão dos histogramas. Os valores dos limiares encontrados para os anos 2010, 2012 e 2013 foram respectivamente 35,55 e 35 . A Figura 5 apresenta o resultado do fatiamento para o ano de 2010.
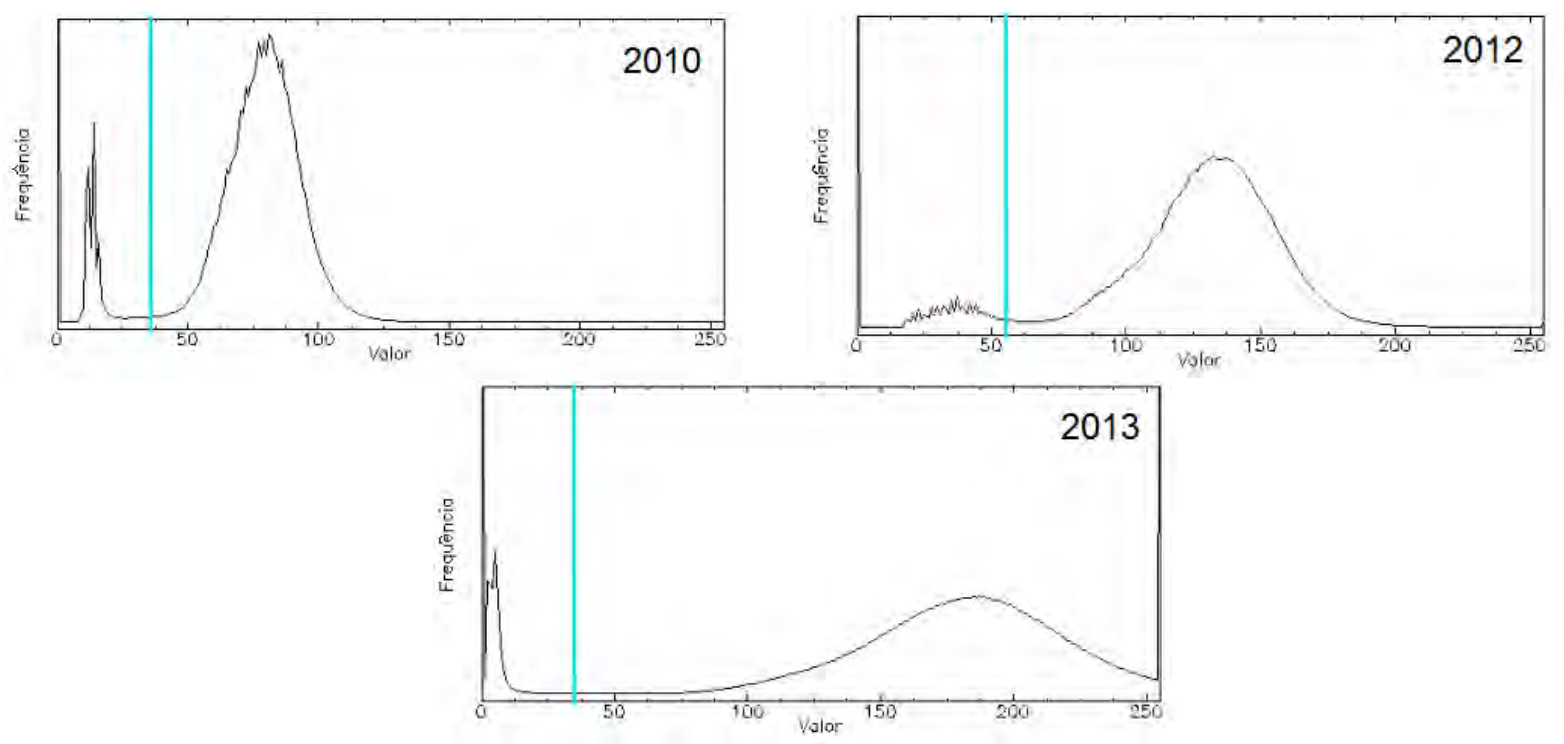

Figura 4. Histogramas dos mosaicos para os anos de 2010, 2012 e 2013, com valores de limiares de 35, 55 e 35 respectivamente (linha vertical em ciano).

\subsection{3. Álgebra de mapas e edição matricial}

Os resultados dos fatiamentos dos três anos foram combinados por meio de uma operação realizada pixel a pixel dentro da área delimitada como água na imagem base, gerando assim o mapa da redução da superfície de água livre. Desta forma, foi adotada a seguinte lógica: (i) se um pixel de água em 2010 foi classificado como sendo água em 2012 ele foi associado a classe permanente; (ii) se um 
pixel de água em 2010 foi classificado como não-água em 2012 ele foi associado classe de área inundada que foi perdida em 2012 e (iii) se um pixel classificado como sendo água em 2010 e não-água em 2012 e água em 2013 foi associado a classe recuperada. A Figura 6 apresenta um esquema desta operação.

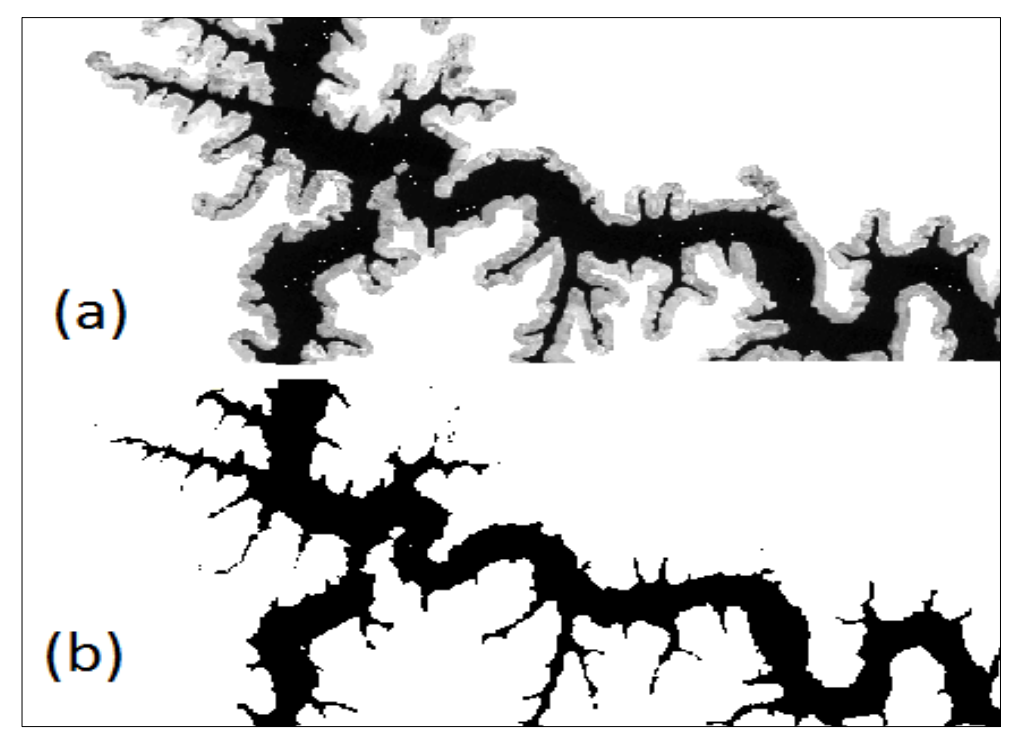

Figura 5. Fatiamento. Imagem a ser fatiada (a) e resultado do fatiamento (b) para o ano 2010.

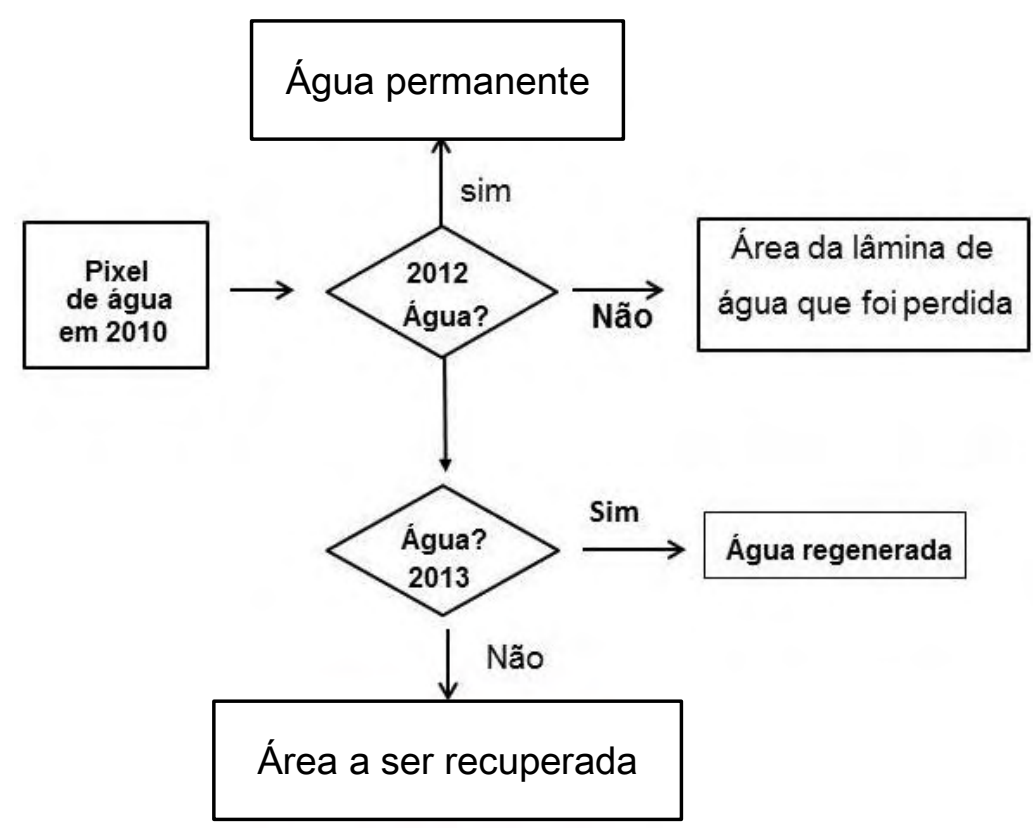

Figura 6. Fluxograma dos critérios de decisão adotados para classificar a área de estudo.

Qualquer que seja o procedimento de classificação, sempre haverá erros, que podem ser de inclusão ou de omissão (Camara et al., 1996). Os erros de inclusão são áreas que foram indevidamente classificadas como uma determinada classe, quando na verdade não era. Já os erros de omissão correspondem às áreas que não foram classificadas como uma dada classe de uso do solo, quando na verdade era. Para corrigir estes erros utiliza-se o procedimento de Edição Matricial (Moreira, 2005). 


\subsubsection{Cálculo das áreas}

O mapa resultante do processo de edição matricial foi cruzado com a base cadastral dos municípios brasileiros na escala 1:250.000 para a obtenção das áreas de superfícies de água permanente, recuperada e não recuperada por município. Primeiramente foi realizada uma interseção espacial, na qual foram selecionados apenas os municípios atravessados pela superfície de água do Lago no ano de referência (2010) (Figura 7). Na sequência foram calculadas as áreas de redução da superfície de água permanente para cada município. Os valores das áreas de cada classe foram utilizados para calcular as relações percentuais que constam na tabela de impacto/ recuperação (Tabela 4).

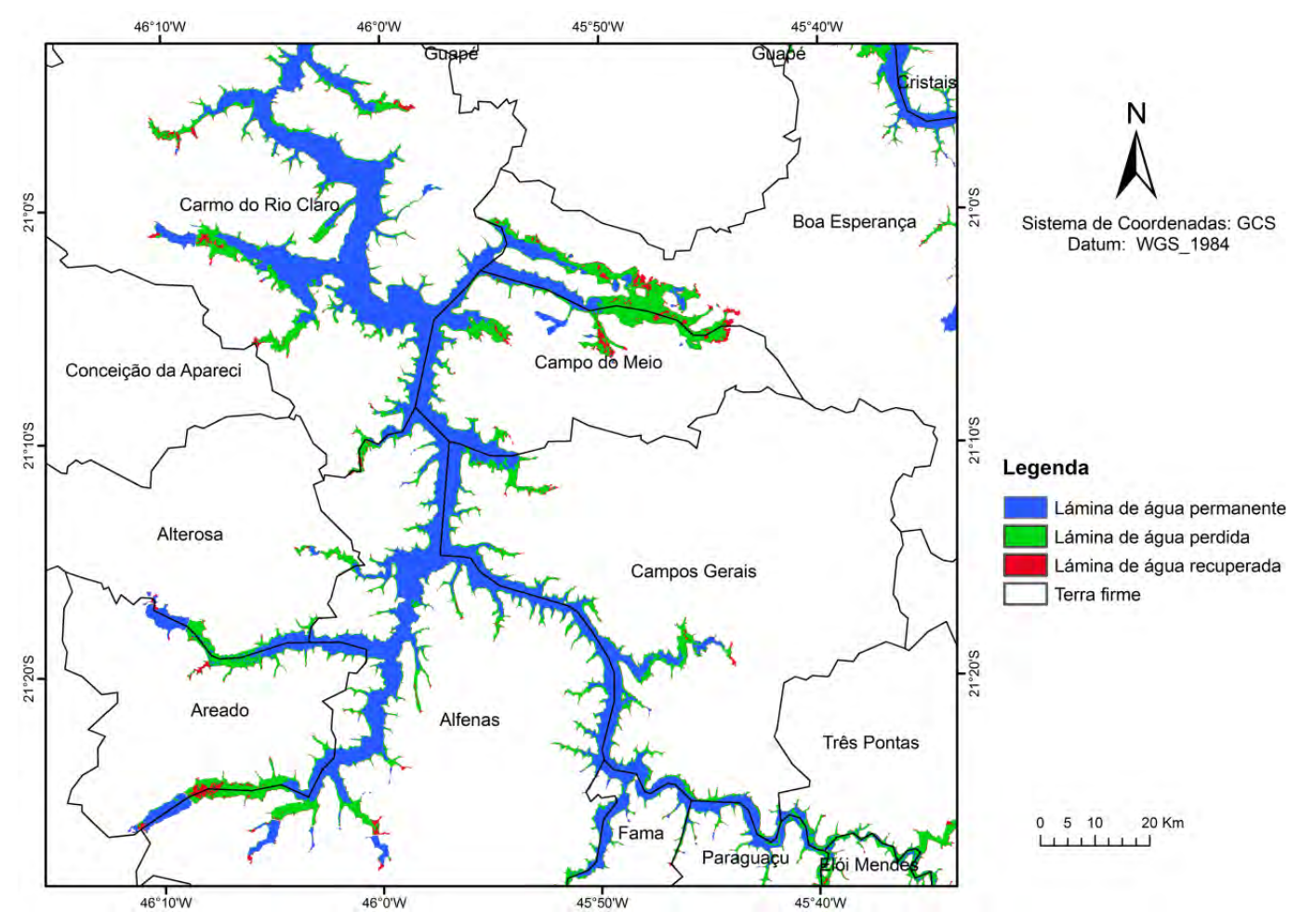

Figura 7. Municípios abrangidos pela superfície de água livre do Lago de Furnas.

\section{RESULTADOS E DISCUSSÃO}

\subsection{Correção dos erros de fatiamento}

Após o fatiamento observou que o mapa resultante apresentou erros tanto de inclusão quanto de omissão. Estes erros foram, então, corrigidos através da ferramenta Edição Matricial, disponíveis nos aplicativos de processamento de imagens. A Figura 8 mostra um recorte da área, seguido do mapa sem correção e do corrigido através da edição matricial.

Acredita-se que, devido à grande dimensão da área de estudo, os erros ocasionados por falhas na distinção entre a superfície de água e outras coberturas nos fatiamentos se deram, em grande parte, pela utilização de um único valor de limiar por ano para realizar esta separação. Estes erros foram detectados principalmente em relação ao ano de 2012 (durante o evento), o qual apresenta mais regiões em estados intermediários, entre o seco e o inundado, portanto é possível que a variabilidade espacial das respostas espectrais da superfície de água livre não tenha sido bem representada por um único valor de limiar neste ano. 


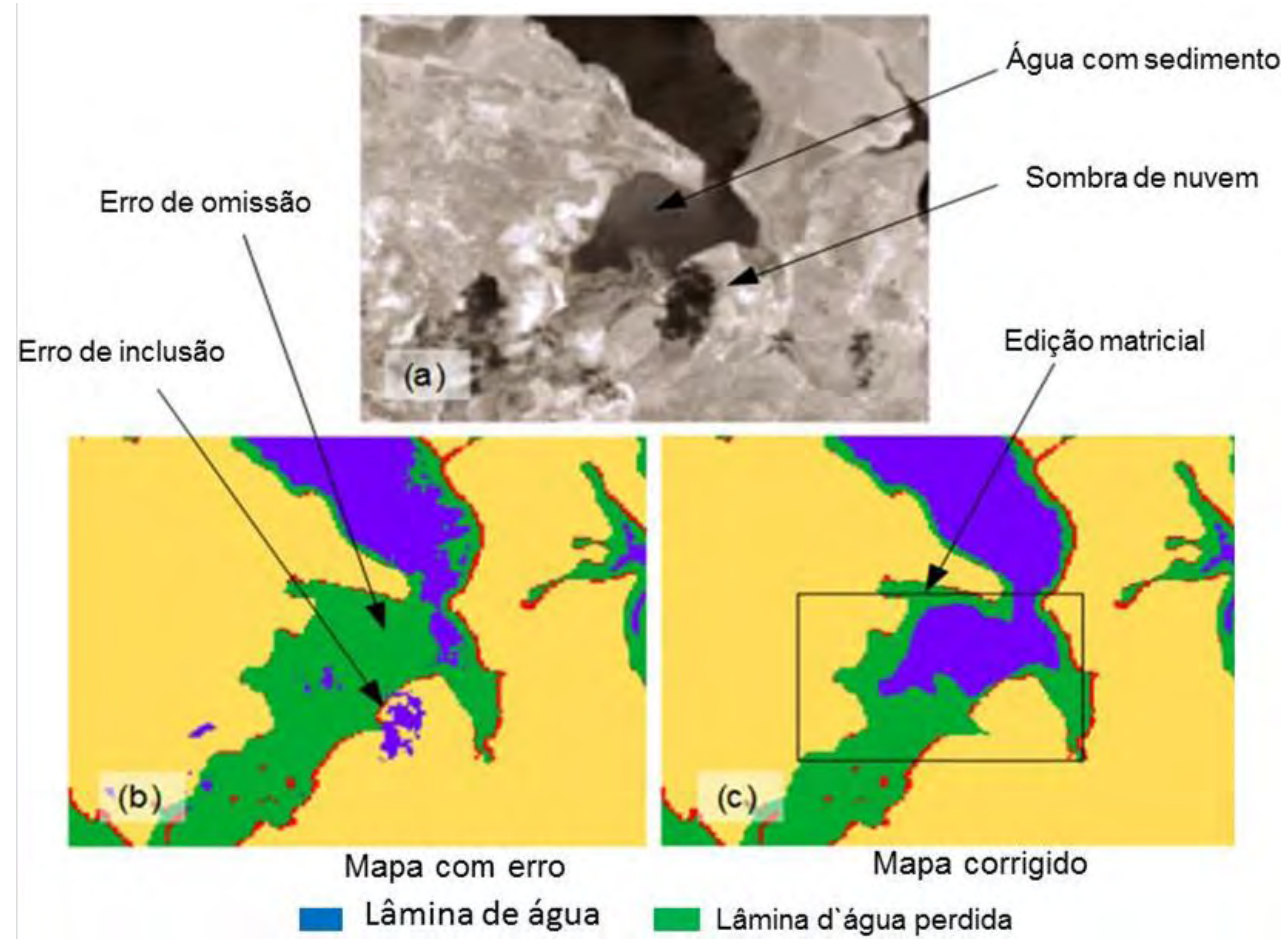

Figura 8. Recorte da área de estudo e os resultados do fatiamento para mostrar a correção dos erros de inclusão e omissão.

Na Figura 9 é mostrado o mapa com a espacialização da lâmina de água que prevaleceu no ano de 2012.

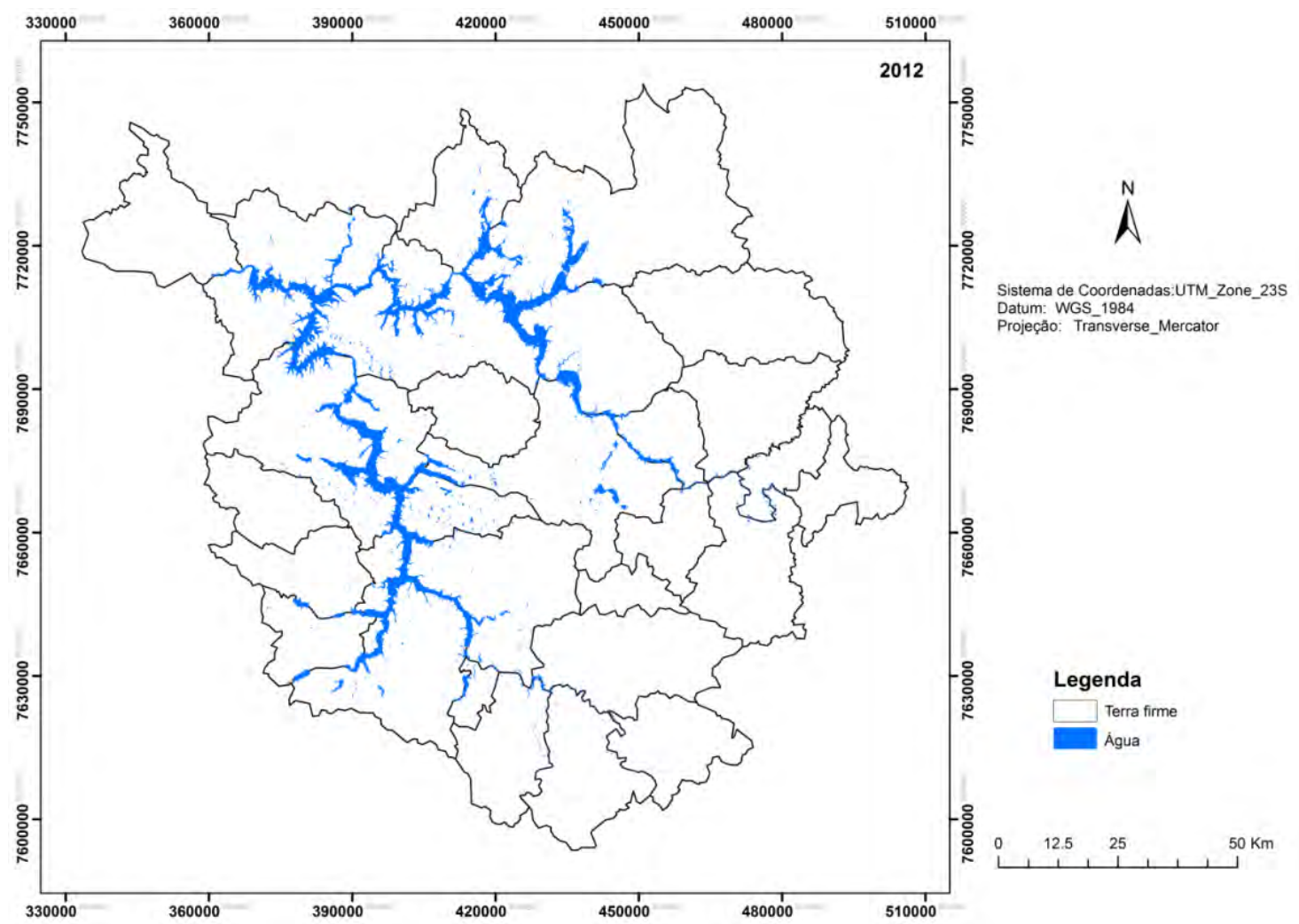

Figura 9. Área do Lago de Furnas coberta por água livre em 2012. 
Após realizar as devidas correções dos erros de fatiamento nos mapas dos três anos obteve-se, então, a espacialização da lâmina de água (permanente perdida e a recuperada). As informações contidas nos mapas foram sobrepostas e gerou-se um único mapa para mostrar a espacialização da lâmina de água que foi perdida no ano de 2012 e lâmina que foi recuperada no ano de 2013 (Figura 10).

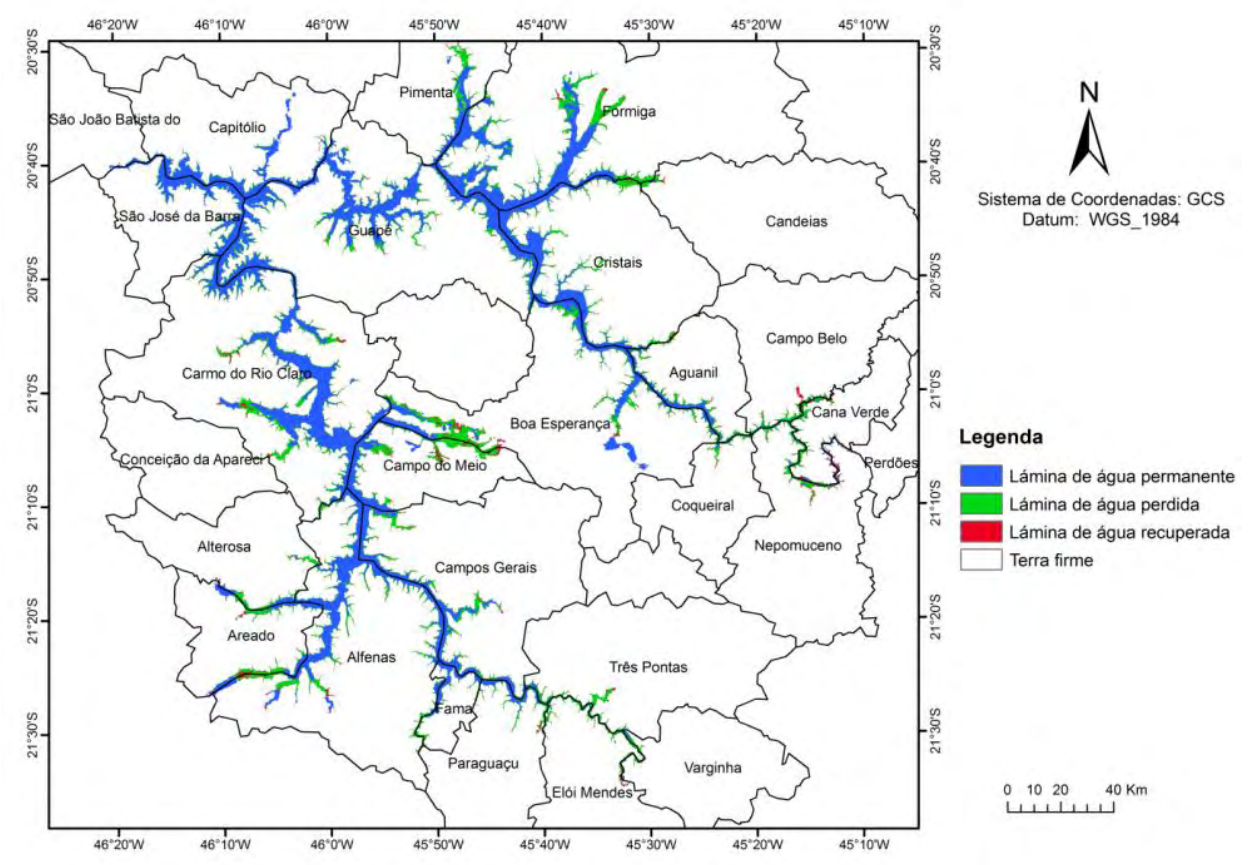

Figura 10. Redução da superfície de água livre do Lago Furnas.

Observando o mapa da Figura 10, nota-se que a situação foi muito grave em toda extensão do lago de Furnas, porém foi mais agravante próximo as nascentes. Detalhes podem ser visualizados na Figura 11, onde são mostradas ampliações de dois recortes, em duas regiões banhadas pelo lago de Furnas: um em Carmo do Rio Claro, localidade do Aterro de Santa Quitéria e outro em Campo Belo, distrito de Porto dos Mendes.

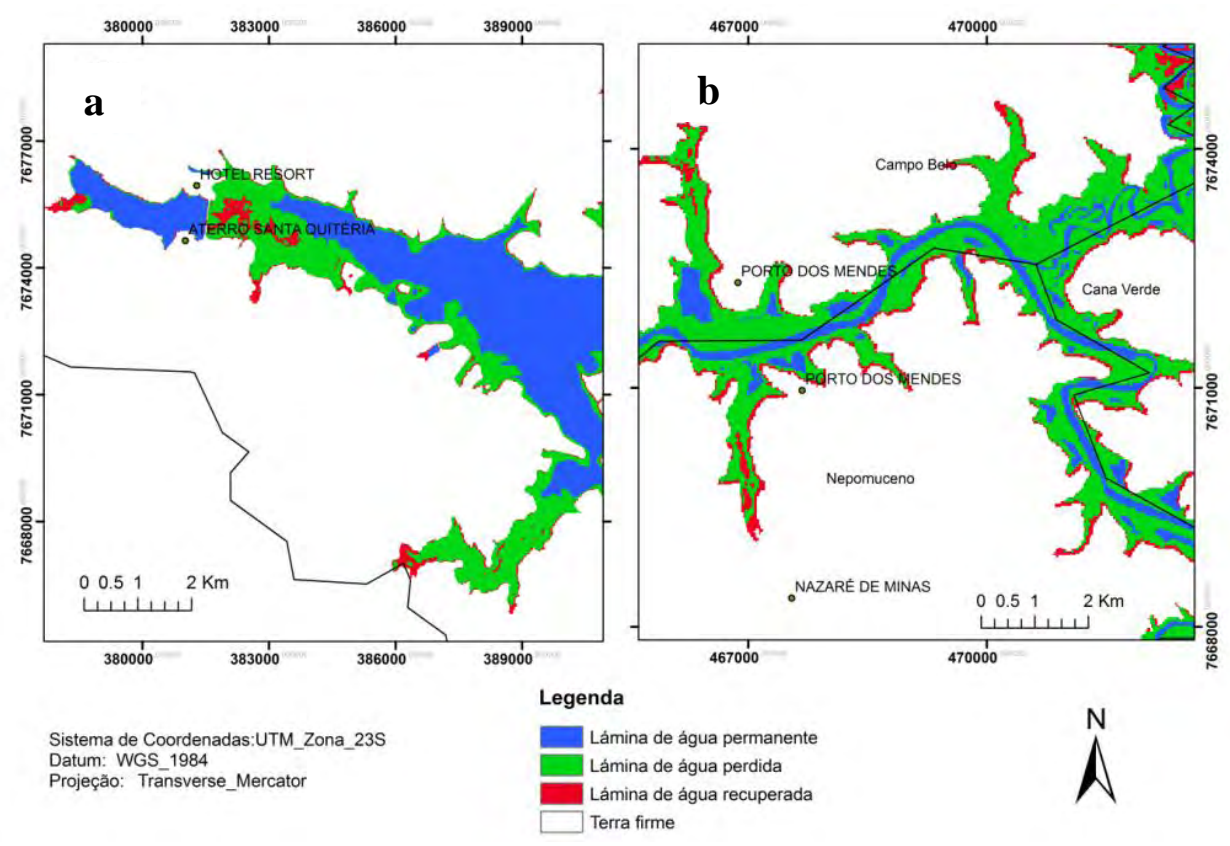

Figura 11. Ampliação do mapa da redução da superfície de água livre para alocalidadede Aterro de Santa Quitéria, em Carmo do Rio Claro (a) e distrito de Porto dos Mendes em Campo Belo- MG (b). 
Para realizar a avaliação quantitativa do mapa, o ideal seria que fosse realizada a comparação do resultado com medidas multi-temporais de réguas de medição de nível de água localizadas ao longo de todo o reservatório e com posições geográficas conhecidas. Todavia, este tipo de dado não foi obtido.

O mapa do ano de 2012 foi sobreposto com planos de informação contendo os municípios atravessados pelo lago e o cadastro de localidades do IBGE, permitindo assim identificar quais municípios foram mais afetados pela diminuição da lâmina de água.

A partir dos mapas e da malha municipal, foi possível quantificar o percentual da área do município coberto pelas águas do lago de Furnas em 2010, a porcentagem da superfície do município que estava seca em 2012 e a área recuperada em 2013 (Tabela 4).

Tabela 4. Porcentagem de área do município que estava coberta com água em 2010 (a), porcentagem de área perdida pelo afastamento da lâmina de água (b) e área recuperada de (b).

\begin{tabular}{|c|c|c|c|}
\hline Município & $\begin{array}{l}\text { Área do município } \\
\text { coberta com água em } \\
2010(\%)(a)\end{array}$ & $\begin{array}{l}\text { Porcentagem de (a) que estava } \\
\text { seca com a fuga da lâmina de } \\
\text { água }(\%)(b)\end{array}$ & $\begin{array}{l}\text { Porcentagem da área } \\
\text { recuperada de (b) (\%) }\end{array}$ \\
\hline Aguanil & 9,94 & 46,13 & 82,16 \\
\hline Alfenas & 14,43 & 32,80 & 81,20 \\
\hline Alterosa & 3,31 & 59,21 & 88,26 \\
\hline Areado & 10,23 & 49,72 & 79,65 \\
\hline Boa Esperança & 11,48 & 47,77 & 81,09 \\
\hline Campo Belo & 1,87 & 82,34 & 71,07 \\
\hline Campo do Meio & 17,35 & 17,35 & 81,69 \\
\hline Campos Gerais & 8,21 & 36,56 & 83,37 \\
\hline Cana Verde & 7,13 & 78,00 & 68,12 \\
\hline Candeias & 0,42 & 94,37 & 77,63 \\
\hline Capitólio & 9,23 & 16,44 & 82,88 \\
\hline Carmo do Rio Claro & 17,62 & 28,05 & 81,35 \\
\hline Coqueiral & 1,45 & 79,69 & 79,26 \\
\hline Cristais & 13,20 & 31,29 & 82,17 \\
\hline Elói Mendes & 2,59 & 82,41 & 81,36 \\
\hline Fama & 17,29 & 32,96 & 80,84 \\
\hline Formiga & 9,52 & 34,29 & 87,46 \\
\hline Guapé & 19,37 & 23,72 & 81,77 \\
\hline Nepomuceno & 2,95 & 76,90 & 67,92 \\
\hline Paraguaçu & 3,64 & 49,54 & 78,42 \\
\hline Pimenta & 6,99 & 46,60 & 88,50 \\
\hline São José da Barra & 14,59 & 17,24 & 82,45 \\
\hline Três Pontas & 1,84 & 78,02 & 83,90 \\
\hline Varginha & 1,12 & 76,93 & 81,17 \\
\hline TOTAL & & 36,14 & 81,55 \\
\hline
\end{tabular}


A partir dos dados contidos na Tabela 4 foram calculadas medidas de dispersão dos percentuais de área impactada e recuperada (Tabela 5). Os valores de média e desvio-padrão encontrados permitem inferir que a regeneração da superfície de água ocorreu mais uniformemente do que a sua secagem.

Os valores relativamente altos de regeneração encontrados podem ser explicados pelo bom regime de chuvas ocorrido no início do ano de 2013 nas cabeceiras dos rios que abastecem Furnas, todavia o reservatório só deve voltar ao seu nível normal em dois anos (Com chuvas de verão..., 2013; Mesmo com chuva..., 2013).

Tabela 5. Medidas de dispersão dos percentuais de área impactada e recuperada.

\begin{tabular}{lcc}
\hline Medida de dispersão & $\begin{array}{c}\text { Área impactada/área de referência } \\
(\%)\end{array}$ & $\begin{array}{c}\text { Área recuperada/área impactada } \\
(\%)\end{array}$ \\
\hline Média & 52,17 & 80,57 \\
Desvio Padrão & 23,01 & 5,12 \\
\hline
\end{tabular}

\section{CONCLUSÃO}

De acordo com os resultados do trabalho chegou-se às seguintes conclusões:

As imagens dos sensores LISS3/Resourcesat e do OLI/Landsat 8 permitiram avaliar espacialmente o impacto e a recuperação das áreas no entorno do lago de Furnas.

Foi possível quantificar por município a área que foi atingida pela diminuição do nível de água.

A metodologia utilizada é de fácil utilização e pode ser empregada no monitoramento das águas do lago e de outras represas.

Como recomendação para futuros trabalhos, é sugerido avaliar o mapa com dados coletados a campo, tanto de medidas de réguas de nível d'água, como medidas de precipitação.

\section{AGRADECIMENTOS}

O segundo autor agradece ao Banco Mundial pelo financiamento dos estudos de nível de mestrado. Ao Ministério da Ciência e Tecnologia de Moçambique, gestora dos fundos da Bolsa e à Universidade Estadual de Feira de Santana (UEFS) pelo ingresso e frequência no programa de mestrado (PPGM).

\section{REFERÊNCIAS}

BUTZKE, I. C. Ocupação de áreas inundáveis em Blumenau (SC). 1995. $245 f$. Dissertação (Mestrado em Geografia) - Universidade Estadual Paulista, Rio Claro, 1995.

CÂMARA G.; SOUZA, R. C. M.; FREITAS, U. M.; GARRIDO, J. Spring: integrating remote sensing and GIS by object oriented data modelling. Computers \& Graphics, v. 20, n. 3, p. 395-403, 1996. http://dx.doi.org/10.1016/0097-8493(96)00008-8

CAMPOS, J. C. de; SILVA, A. C. Avaliação do desmatamento na região de Alfenas no período de 1964 a 2001 através do sensoriamento remoto. Revista Universidade de Alfenas, Alfenas, v. 4, p. 111-114, 1998. 
CENTRO NACIONAL DE MONITORAMENTO E ALERTAS DE DESASTRES NATURAIS - CEMADEN. Localização do Lago de Furnas na bacia do Rio Grande e detalhamento do Lago de Furnas, com destaque para as usinas hidrelétricas e contexto municipal. Elaborado por Claudia de Albuquerque Linhares. Cachoeira Paulista, 2014.

CHANDER, G. Overview of the Resourcesat-1 (IRS-P6). Disponível em: $<$ http://calval.cr.usgs.gov/documents/IRSP6.pdf>. Acesso em: 09 jul. 2013.

COM chuvas de verão, Lago de Furnas começa a recuperar seu nível. G1, Sul de Minas, jan. 2013. Disponível em: http://g1.globo.com/mg/sul-de-minas/noticia/2013/01/comchuvas-de-verao-lago-de-furnas-comeca-recuperar-seu-nivel.html. Acesso em: 16 ago. 2013.

FERREIRA, M. F. M.; OLIVEIRA, R. L. de S.; GARÓFALO, D. F. T. Delimitação e caracterização das unidades de paisagem da região de Alfenas, sul de Minas Gerais, a partir de dados do radar SRTM e imagem orbital ETM+ Landsat 7. In: SIMPÓSIO NACIONAL DE GEOMORFOLOGIA, 8., ENCONTRO LATINO AMERICANO DE GEOMORFOlOGIA, 2., 2008, Belo Horizonte-MG. Anais... Belo Horizonte: IGCUFMG, 2008.

INSTITUTO BRASILEIRO DE GEOGRAFIA E ESTATISTICA - IBGE. Web site. 2010. Disponível em: <www.ibge.gov.br>. Acesso em: 15 ago. 2013.

INSTITUTO DE PESQUISAS TECNOLÓGICAS -IPT. Diagnóstico da situação dos recursos hídricos na Bacia Hidrográfica do Rio Grande (BHRG) - SP/MG (Relatório Síntese - R3). Relatório Técnico no 96.581-205 - i/ii. [S.1.], mar. 2008. p. 52.

INSTITUTO NACIONAL DE PESQUISAS ESPACIAIS - INPE. Características técnicas do sensor LISS-3. Disponível em: http://www.dgi.inpe.br/CDSR/ir-p6.html. Acesso em: 09 jul. 2013.

JENSEN, J. R. Sensoriamento remoto do ambiente: uma perspectiva em recursos terrestres. [S.1.]: Parêntese, 2009.

JOHNSON, D. M. A comparison of coincident Landsat-5 TM and Resourcesat-1 AWiFS Imagery for classifying croplands. Photogrammetric Engineering \& Remote Sensing, v. 74, n. 11, p. 1413-1423, 2008.

http://dx.doi.org/10.14358/PERS.74.11.1413

MESMO com chuva, Lago de Furnas só deve voltar ao normal em 2 anos. G1, Sul de Minas, fev. 2013. Disponível em: http:/g1.globo.com/mg/sul-de-minas/noticia/ 2013/02/mesmo-com-chuva-lago-de-furnas-so-deve-voltar-ao-normal-em-2-anos.html. Acesso em: 16 ago. 2013.

MOREIRA, M. Fundamentos do sensoriamento remoto e metodologias de aplicação. 3. ed. Viçosa: UFV, 2005. p. 307.

MOTA, S. Preservação e conservação de recursos hídricos. 2. ed. São Paulo: ABES, 1995.

NATIONAL REMOTE SENSING AGENCY - NRSA. RESOURCESAT - 1 (IRS - P6): DATA USER'S HANDBOOK. IRS-P6/NRSA/NDC/HB-10/03, India. [S.1.], Oct. 2003. p. 142. 
PINTO-COELHO, R.; GIANI, A.; VON SPERLING, E. (eds.). Ecology and human impact on lakes and reservoirs in Minas Gerais with special reference to future development and management strategies. Belo Horizonte: SEGRAC, 1994. p. 193.

SANTOS, C.; MARTINS, M.; MARTINS, B. Uso da terra nas margens do reservatório de Furnas, sul de Minas Gerais, Brasil. SIMPÓSIO BRASILEIRO DE SENSORIAMENTO REMOTO - SBSR, 15., 30 abr. a 05 maio 2011, Curitiba. Anais... São José dos Campos: INPE, 2011. p. 6246.

SILVA, Samantha. Lago de Furnas enfrenta pior seca em 10 anos, diz associação em MG. G1, Sul de Minas, nov. 2012. Disponivel em: http://g1.globo.com/mg/sul-deminas/noticia/2012/11/lago-de-furnas-enfrenta-pior-seca-em-10-anos-diz-alago.html. Acesso em: 05 jul. 2013.

TUNDISI, J. G. Reservatórios como sistemas complexos: teoria, aplicações e perspectivas para usos múltiplos. In: HENRY, R. (Ed.). Ecologia de reservatórios: estrutura, função e aspectos sociais. Botucatu: FAPESP; FUNDIBIO, 1999. p. 22-38.

UNITED STATES GEOLOGICAL SURVEY - USGS. Landsat Data Continuity Mission (Ldcm), Level 0 Reformatted (LOr) Data Format Control Book (Dfcb). LDCMDFCB-002 Version 9.0. Sioux Falls: EROS, 2012. p. 97.

UNITED STATES GEOLOGICAL SURVEY - USGS. Landsat Data Continuity Mission (Ldcm), Level 1 (L1) Data Format Control Book (DFCB). LDCM-DFCB-004 Version 6.0. Sioux Falls: EROS, 2012.p. 81. 


Ambiente \& Água - An Interdisciplinary Journal of Applied Science
ISSN 1980-993X - doi:10.4136/1980-993X
www.ambi-agua.net
E-mail: ambi-agua@agro.unitau.br

\title{
Estudo da aplicação de tanino no tratamento de água para abastecimento captada no rio Tubarão, na cidade de Tubarão, SC
}

\author{
doi: 10.4136/ambi-agua.1303
}

Received: 04 Feb. 2014; Accepted: 05 Sep. 2014

\author{
Everton Skoronski $^{1 *}$; Bruno Niero ${ }^{2}$; Mylena Fernandes ${ }^{2}$; \\ Mauricio Vicente Alves ${ }^{3}$; Viviane Trevisan ${ }^{1}$ \\ ${ }^{1}$ Universidade do Estado de Santa Catarina (UDESC), Lages, SC, Brasil \\ Departamento de Engenharia Ambiental \\ ${ }^{2}$ Universidade Federal de Santa Catarina (UFSC), Florianópolis, SC, Brasil \\ Departamento de Engenharia Química e Alimentos \\ ${ }^{3}$ Universidade do Oeste de Santa Catarina (UNOESC), Xanxerê, SC, Brasil \\ Departamento de Agronomia \\ *Autor correspondente: e-mail: skoronski@cav.udesc.br, \\ bruno.niero@unisul.br,mylena.fernandes@gmail.com, \\ mauriciovicente@gmail.com, a2vt@cav.udesc.br
}

\section{RESUMO}

Nas estações de tratamento de água para abastecimento, a adequação da qualidade da água é realizada por meio do processo de coagulação e floculação, seguido de sedimentação e filtração. Normalmente são utilizados coagulantes inorgânicos como sais de ferro e alumínio que geram lodos que precisam ser dispostos em aterros específicos. Desta forma, a utilização do tanino como coagulante possibilita um tratamento que gera lodo com maiores possibilidades de manejo. Este trabalho teve como objetivo avaliar o uso de um tanino obtido a partir da acácia negra, no tratamento da água do rio Tubarão. Foram avaliados parâmetros como concentração de tanino, cor aparente, turbidez, alcalinidade, fenóis e volume de lodo gerado. As concentrações ótimas para coagulação da água captada no rio situaram-se entre 1,0 e 7,5 mg L $\mathrm{m}^{-1}$, dependendo da qualidade da água coletada no rio. Nas condições ótimas de dosagem de coagulante, a alcalinidade apresentou redução máxima de $30 \%$ após o tratamento, a cor aparente situou-se entre 4,2 e 7,6 uC, a turbidez entre 0 e 2 uT e o volume de lodo gerado apresentou valores entre 5 e $20 \mathrm{~mL} \mathrm{~L}^{-1}$. A concentração de fenol na água tratada ficou abaixo de $0,003 \mathrm{mg} \mathrm{L}^{-1}$. Neste sentido, os valores obtidos atenderam à portaria ${ }^{0}$ 2914/2011 do Ministério da Saúde em relação aos parâmetros analisados. Estes resultados motivam estudos mais aprofundados sobre a viabilidade de aplicação do tanino como coagulante, sobretudo em relação aos efeitos tóxicos de compostos que possam ser agregados à água após o tratamento.

Palavras-chave: coagulação, coagulante vegetal, floculação, potabilidade.

\section{Study of the application of tannin in the treatment of drinking water from the Tubarão River at Tubarão, SC}

\section{ABSTRACT}

Water quality acceptance in treatment plants is dependent upon the coagulation and flocculation processes, followed by settling and filtration. Normally inorganic coagulants such 
as salts of iron and aluminum are used but generate sludge that must be disposed of at special landfills. The use of tannins as coagulants would allow easier sludge management. This study evaluated the use of tannin derived from the black wattle tree in the treatment of water from the Tubarão River. The study analyzed parameters such as concentration of tannins, apparent color, turbidity, alkalinity, phenols and the volume of sludge generated. The optimal concentrations for coagulation of water sampled from the river were between 1.0 and $7.5 \mathrm{mg} \mathrm{L}^{-1}$, depending on the quality of the water collected. Under the optimum conditions of coagulant dosage, alkalinity showed a maximum reduction of $30 \%$ after treatment, the apparent color was between 4.2 and $7.6 \mathrm{uC}$, turbidity between 0 and $2 \mathrm{NTU}$ and the volume of sludge generated was between 5 and $20 \mathrm{ml} \mathrm{L}^{-1}$. The phenol concentration in the treated water was below $0.003 \mathrm{mg} \mathrm{L}^{-1}$. In this sense, the values are in accordance with those established by Regulation number 2914/2011 of the Brazilian Ministry of Health with respect to the parameters analyzed. These results motivate further research on the feasibility of application of tannin as a coagulant, especially in relation to the toxic effects of compounds that can be added to water after treatment.

Keywords: coagulation, drinking water, flocculation, vegetable coagulant.

\section{INTRODUÇÃO}

A água utilizada para abastecimento público necessita atender aos padrões de potabilidade estabelecidos pela Portaria n 2914 do Ministério da Saúde (Brasil, 2011). Dentre os sessenta e sete parâmetros instituídos por esta, pode-se citar a cor aparente e a turbidez. A turbidez se deve a partículas em suspensão ou coloides: argilas, limo, terra finamente dividida, etc. Um alto valor de turbidez prejudica a condição estética da água e estudos técnicos constatam o efeito de proteção física de microrganismos pelas partículas causadoras da turbidez, diminuindo a eficiência de tratamentos. A cor aparente de uma amostra de água, por sua vez, está associada ao grau de redução de intensidade que a luz sofre ao atravessá-la (e esta redução ocorre devido a absorção de parte da radiação eletromagnética), sobretudo pela presença de sólidos dissolvidos, principalmente material em estado coloidal orgânico e inorgânico (Cavinatto, 2003). A portaria anteriormente citada, também estabelece os planos de amostragem descrevendo os tipos, a quantidade e a frequência que as análises devem ser feitas.

Nas estações de tratamento de água (ETA), a adequação da cor aparente e da turbidez aos limites máximos exigidos pela legislação é realizada por meio do processo de coagulação e floculação seguido de sedimentação e filtração. Para essa atividade, normalmente são utilizados coagulantes inorgânicos como sais de ferro e alumínio. Apesar de eficientes coagulantes, estes produtos geram lodos não biodegradáveis que precisam ser dispostos em aterros específicos. Segundo a NBR 10004 (ABNT, 2004), este lodo normalmente é classificado como classe IIA (Não Inerte) e deve ser disposto em aterro específico para resíduo de classe IIA, havendo acréscimo nos custos de deposição e do transporte do lodo até o aterro (Imhoff e Imhoff, 1998). O alumínio, um dos metais mais comuns presente nos coagulantes inorgânicos, tem uma característica acumulativa. Com o passar do tempo a quantidade de alumínio acumulada, nos lençóis e até nas águas de superfície, já poderão representar risco por si só (Fiorentini, 2005). Além de problemas ambientais, o uso de coagulantes inorgânicos pode prejudicar também a saúde das pessoas que consomem a água tratada. Dependendo da dosagem de alumínio acumulada no organismo, ele pode ser tóxico causando grandes danos à saúde como doenças de coordenação motora e demência, Alzheimer e mal de Parkinson (Fiorentini, 2005).

Diante disto, existe uma tendência para o desenvolvimento de novos produtos que possam ser utilizados como coagulantes no tratamento de água para abastecimento, que não 
apresentem tantos problemas como os sais de alumínio e eventualmente de ferro. De fato, alguns estudos têm demonstrado que resíduos vegetais podem ser aplicados para o fim até aqui discutido (Bongiovani et al., 2010), como por exemplo através da extração de tanino (Da Silva, 1999).

Os taninos são definidos como moléculas fenólicas biodegradáveis com capacidade de formar complexos com proteínas e outras macromoléculas e minerais. São extraídos da casca de vegetais, como da Acacia mearnsi de Wild (acácia negra) que possui altas concentrações de tanino e é facilmente encontrada no Brasil (Beltrán-Heredia et al., 2011). Os taninos estão presentes na forma hidrolisada e condensada, sendo a forma condensada responsável por mais de 90\% da produção mundial de tanino (Pizzi, 2008). Segundo Da Silva (1999), os taninos são moléculas com propriedades coagulantes, que desestabilizam os coloides com a eliminação da camada de solvatação, diminuindo o potencial zeta durante o processo de coagulação e, assim, permitindo a formação de flocos. Desta forma, podem ser utilizados no tratamento de águas residuais e de abastecimento no processo de coagulação e floculação. Comercialmente o tanino é utilizado como base para produção de coagulante (Figura 1), a partir da reação entre o tanino condensado e o cloreto de imínio (formado pela reação do cloreto de amônio, por exemplo, e o aldeído fórmico), formando um polímero orgânico catiônico (Mangrich et al., 2014).

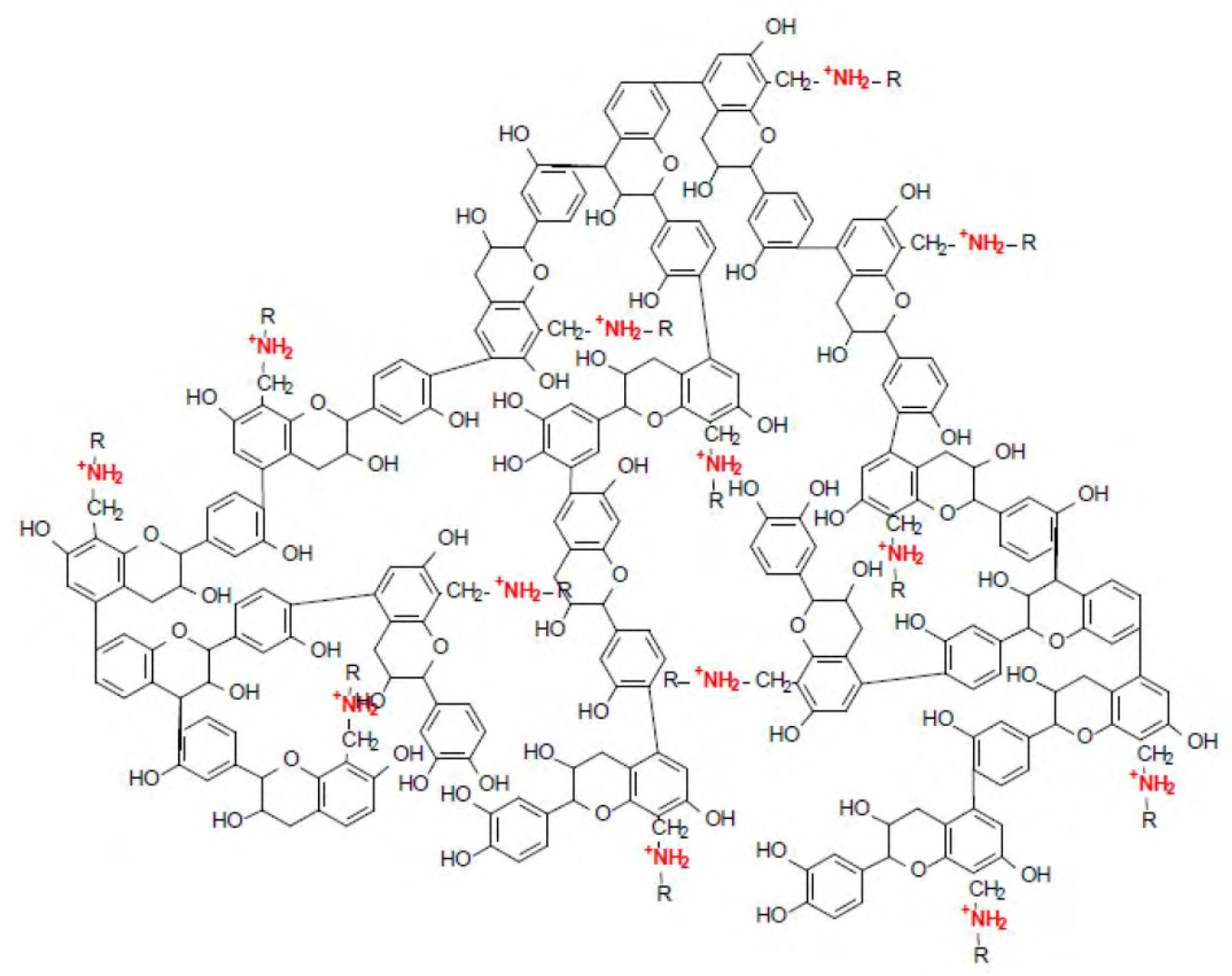

Figura 1. Estrutura do coagulante TANFLOC da empresa TANAC, obtido a partir do tanino extraído da Acácia Negra.

Fonte: Mangrich et al. (2014).

Por ser de origem vegetal, a utilização de coagulante a base de tanino possibilita um tratamento que gera lodo biodegradável e sem necessidade de correção posterior de $\mathrm{pH}$ (Beltrán-Heredia et al., 2010). Além disto, a obtenção deste coagulante a partir de fontes renováveis pode auxiliar na diminuição de acúmulo de resíduos. 
O estudo foi aplicado para avaliação do tratamento de água no Rio Tubarão, na cidade de Tubarão/SC. Este rio nasce no município de Lauro Muller/SC e desemboca em Laguna/SC. O uso e ocupação da bacia hidrográfica apresentam atividades agroindustriais e industriais diversificadas, além de não existir sistemas de esgotamento sanitário no município. Desta forma, a qualidade da água sofre significativas alterações em relação às suas características naturais. Na região abrangente do estudo, a intensidade e a diversidade de impactos antrópicos são os principais desafios para a gestão da água (Giacomeli et al., 2000). Além dos problemas comuns às demais bacias brasileiras, como conflitos em seu uso e ocupação, a bacia do rio Tubarão e o complexo Lagunar distingue-se das demais por ser considerada severamente poluída. Esta bacia coloca-se em décimo lugar entre as mais poluídas do Brasil, constituindo uma das três regiões consideradas críticas no estado (Santa Catarina, 1998).

Desta forma, o objetivo deste trabalho foi avaliar o potencial de aplicação do tanino como coagulante para o tratamento da água para abastecimento obtida no rio Tubarão, na cidade de Tubarão/SC.

\section{MATERIAIS E MÉTODOS}

\subsection{Coleta de amostras}

Foram coletadas 5 amostras de água do rio Tubarão que percorre várias cidades da região sul de Santa Catarina, ao longo dos seus $130 \mathrm{~km}$ de extensão, até desembocar no oceano Atlântico. As amostras foram coletadas no canal de entrada da água captada para abastecimento da cidade de Tubarão/SC. A escolha deste local de coleta permitiu utilizar no laboratório a água com as mesmas características daquela utilizada para o tratamento pela concessionária. A ETA onde foram realizadas as coletas de água possui capacidade para o tratamento de $420 \mathrm{~L} \mathrm{~s}^{-1}$, sendo a principal fornecedora de água para abastecimento na região. As coletas foram realizadas de acordo com NBR 9897 - Planejamento de amostragem de efluentes líquidos corpos receptores, e NBR 9898 - Preservação e técnicas de amostragem de efluentes líquidos e corpos receptores, de julho de 1987 (ABNT, 1987a, 1987b). Para a coleta foram utilizadas embalagens de polipropileno de 5 litros. A primeira coleta ocorreu em dia chuvoso e as demais em período sem precipitação pluviométrica.

\subsection{Ensaios de tratabilidade}

Para a otimização da dosagem de coagulante (TANFLOC SG, Tanac S.A.) foram realizados ensaios de coagulação/floculação em Jar-test. Em cada jarro foi colocado $500 \mathrm{~mL}$ de amostra e diferentes concentrações de coagulante, entre 0 e $10 \mathrm{mg} \mathrm{L}^{-1}$, sob agitação de 100 rpm por 1 minuto (etapa de coagulação) e de $30 \mathrm{rpm}$ durante 10 minutos (etapa de floculação). Após a coagulação e floculação, esperou-se a sedimentação do lodo gerado. Após 30 minutos foram coletadas amostras do sobrenadante para análise.

\subsection{Avaliação da eficiência do ensaio de tratabilidade}

Para avaliar a eficiência de tratabilidade das amostras de água do rio Tubarão, com a adição de tanino como coagulante, foram realizados os seguintes ensaios: alcalinidade, condutividade, $\mathrm{pH}$, cor aparente, turbidez, fenóis totais e volume de lodo gerado. A alcalinidade foi determinada através de titulação com solução de ácido sulfúrico $0,01 \mathrm{~mol} \mathrm{~L}^{-1}$. A condutividade e o pH foram determinadas através de um analisador multiparâmetro de bancada (Thermo Scientific) sendo a condutividade expressa em $\mu S \mathrm{~cm}^{-1}$. As análises de cor aparente e turbidez foram determinados por espectrofotometria, com um espectrofotômetro Spectroquant NOVA 60 (Merck), utilizando os métodos pré-estabelecidos 32 e 77, respectivamente. $\mathrm{O}$ volume de lodo foi determinado com um cone IMHOFF. Para determinação da concentração de fenóis totais foi aplicado o método colorimétrico com 
4-aminoantipirina, (APHA, 2005), com posterior extração com clorofórmio e leitura a $505 \mathrm{~nm}$ em um espectrofotômetro Spectroquant NOVA 60 (Merck).

\section{RESULTADOS}

A aplicação de um coagulante para remoção de cor aparente e turbidez, em uma amostra, deve garantir que substâncias adicionais não elevem a concentração de substâncias dissolvidas no meio e que, dentre outros efeitos, pode promover uma diminuição no $\mathrm{pH}$ do meio. Desta forma, a utilização de coagulante a base de tanino torna-se atrativa por possuir a propriedade de não alterar o pH da água tratada. Os coagulantes a base de tanino não consomem significativamente a alcalinidade do meio, além de poder ser aplicado em uma ampla faixa de pH, entre 4,5 a 8 (Da Silva, 1999; Barradas, 2004). De fato, com a ampla faixa de pH apresentado pelo tanino, normalmente é eliminada a necessidade da utilização de alcalinizantes, como soda ou cal, reduzindo o volume de lodo gerado. Os resultados das análises das amostras para alcalinidade, e pH são apresentados nas Figuras 2 e 3.

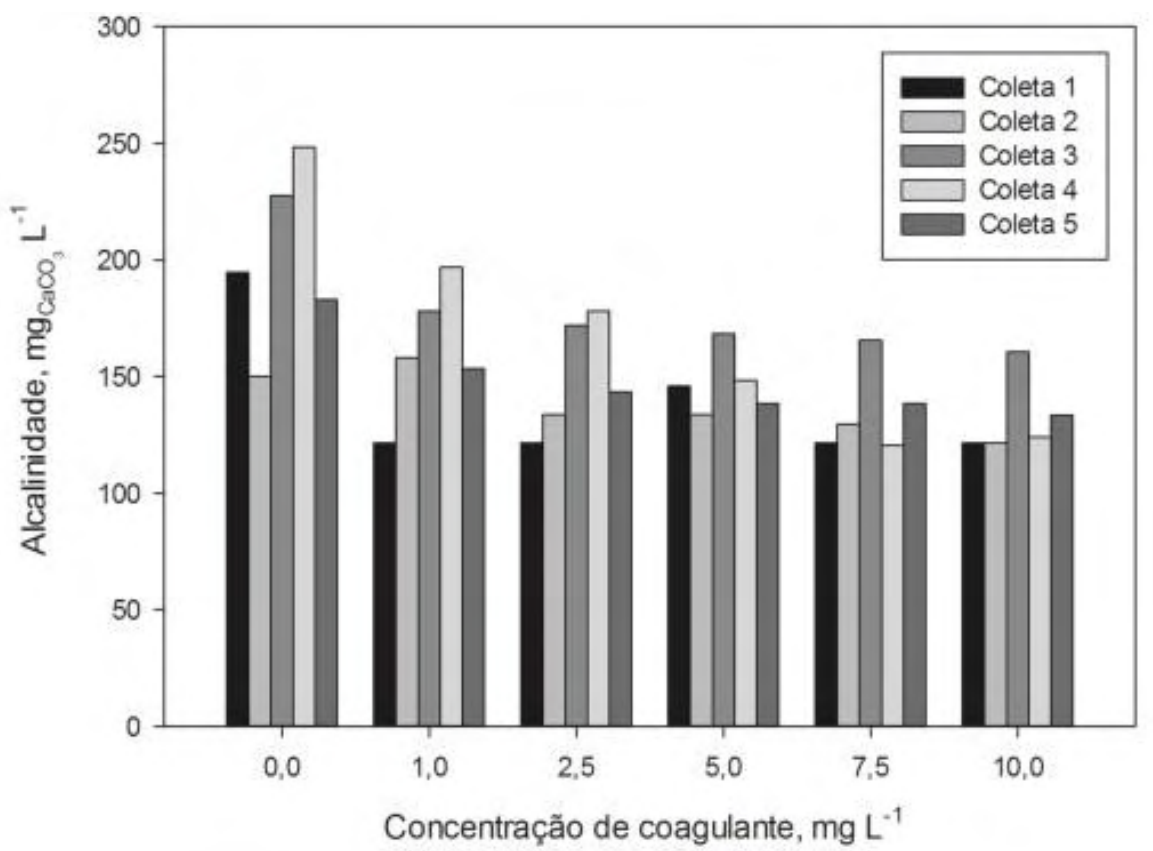

Figura 2. Valores de alcalinidade obtidos para a água bruta e para a água tratada com tanino com concentrações de 1, 2,5, 5,0, 7,5 e $10,0 \mathrm{mg} \mathrm{L}^{-1}$.

Como se pode observar, a alcalinidade das amostras após os ensaios de tratabilidade apresentou decaimento proporcional ao aumento na dosagem de coagulante. O consumo de alcalinidade variou entre 10,8 e $37,5 \%$ entre as cinco coletas realizadas (Figura 2). No entanto, os valores de $\mathrm{pH}$ permaneceram em todas as faixas de concentração de coagulante dentro do limite estabelecido pela Portaria no 2914 (Limite Superior Permitido - LSP = 9,5 e Limite Inferior Permitido - LIP =6,0). De outra forma, com a utilização de um coagulante inorgânico, como o sulfato de alumínio, provocaria redução na alcalinidade total e no $\mathrm{pH}$ da água tratada, necessitando a adição de cal hidratada para correção da alcalinidade e pH, por exemplo, no sentido de favorecer o processo de coagulação (Imhoff e Imhoff, 1998). Para o tanino, o pH observado na água para tratamento situou-se dentro da faixa ótima de trabalho, dispensando a correção do pH da água anteriormente à coagulação. 


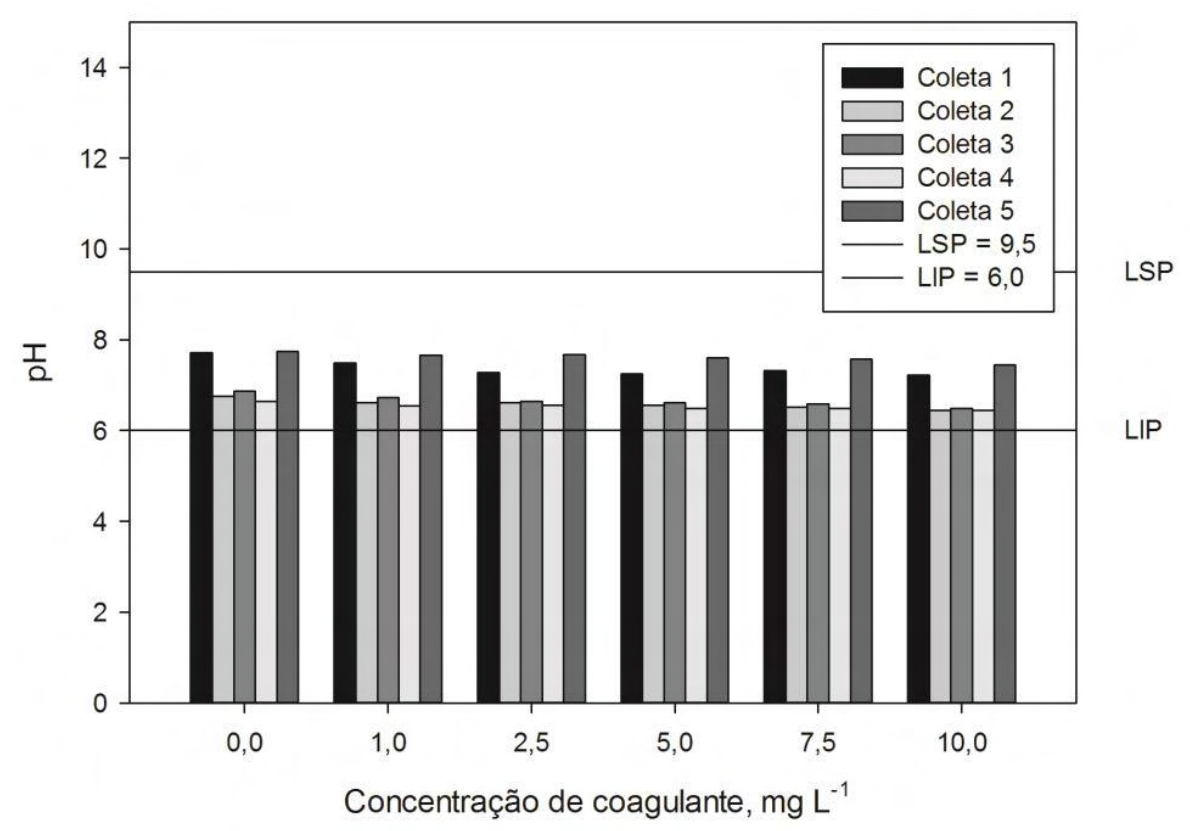

Figura 3. Valores de $\mathrm{pH}$ obtidos para a água bruta e para a água tratada com tanino com concentrações de 1, 2,5, 5,0, 7,5 e $10,0 \mathrm{mg} \mathrm{L}^{-1}$.

Os resultados obtidos nos ensaios de condutividade, Figura 4, mostram que a adição de tanino nas condições determinadas (até $10 \mathrm{mg} \mathrm{L}^{-1}$ ), não alteram a condutividade do meio, que neste trabalho situaram-se entre 49 a $81 \mu \mathrm{S} \mathrm{cm}$. . Estes valores evidenciam uma importante característica do tanino, enquanto coagulante, relacionada ao pequeno efeito na variação das condições da água tratada em termos de substâncias dissolvidas.

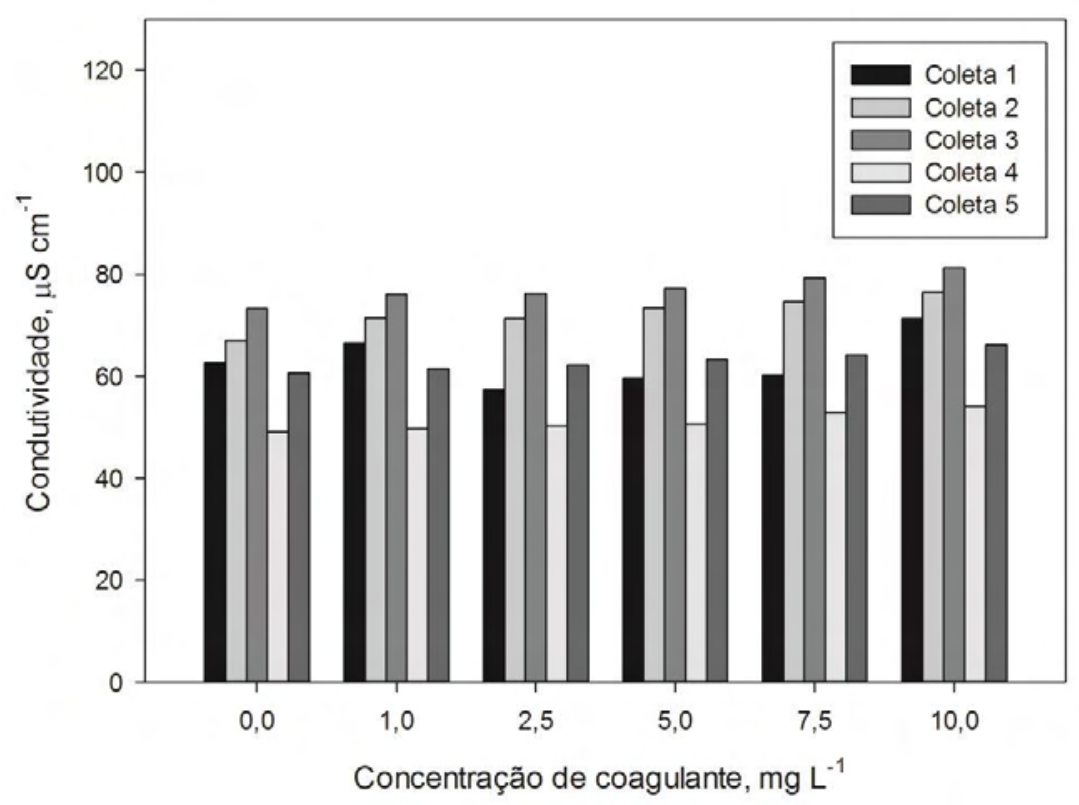

Figura 4. Valores de condutividade obtidos para a água bruta e para a água tratada com tanino com concentrações de $1,2,5$, 5,0, 7,5 e $10,0 \mathrm{mg} \mathrm{L}^{-1}$.

Outra característica importante para a aplicação de coagulantes no tratamento de água é a sua capacidade de remoção de sólidos suspensos através do incremento na velocidade de 
sedimentação provocada pelo aumento no diâmetro dos contaminantes, sendo este processo conhecido como floculação. Neste sentido, parâmetros como sólidos suspensos, cor aparente e turbidez são os indicadores mais comuns para avaliar a eficiência dos processos citados anteriormente.

Na Figura 5, observa-se que existe uma dosagem onde os efeitos de remoção de cor aparente e turbidez são maximizados. Na coleta 2, por exemplo, foi possível alcançar valores de turbidez nula e cor aparente de 5,4 uC para a aplicação de 2,5 $\mathrm{mg} \mathrm{L}^{-1}$ de tanino. A permanência das características da água tratada, em conformidade a Portaria $n^{0} 2914$, é observada até mesmo para amostras com elevada cor aparente e turbidez, como na coleta 1 em que a água bruta apresentou cor aparente e turbidez de $223 \mathrm{uC}$ e $159 \mathrm{uT}$, respectivamente. Com estas condições foi possível obter água tratada com cor aparente e turbidez iguais a 6,7 uC e 1 uT para uma dosagem de tanino igual a 7,5 $\mathrm{mg} \mathrm{L}^{-1}$.

Em termos de normatização nacional, a Portaria n 2914 do Ministério da Saúde exige que a cor aparente e a turbidez da água tratada apresentem valores abaixo de $15 \mathrm{uC}$ e $5 \mathrm{uT}$, respectivamente. Os resultados obtidos mostram que a água tratada apresenta valores abaixo destes limites, evidenciando o potencial do tanino para os fins aqui propostos, conforme pode ser observado na Figura 5.

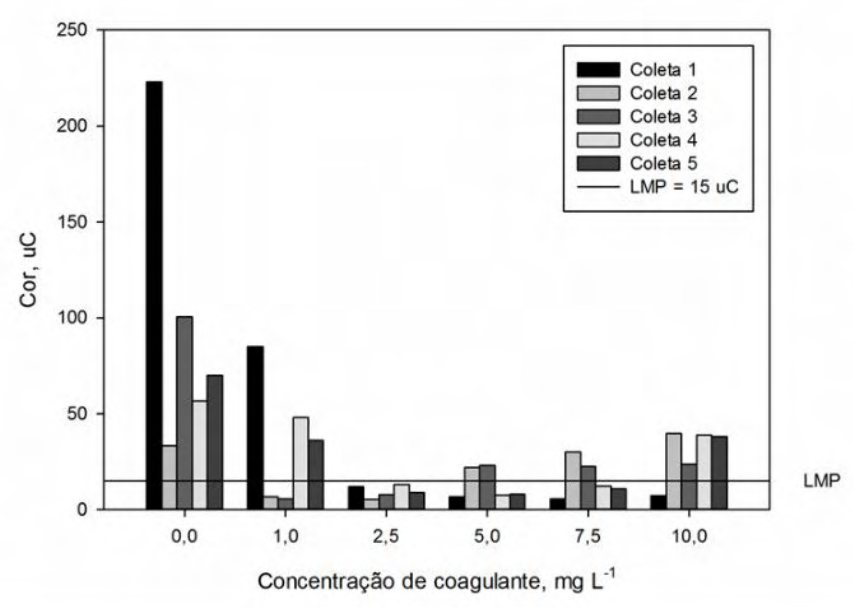

(A)

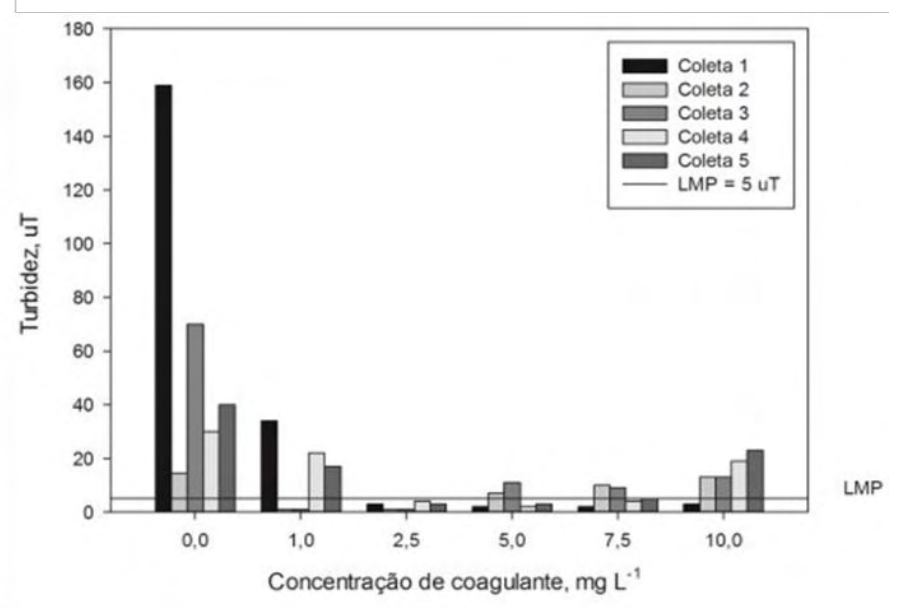

(B)

Figura 5. Valores de cor aparente (A) e turbidez (B) obtidos para a água bruta e para a água tratada com tanino com concentrações de $1,2,5,5,0,7,5$ e $10,0 \mathrm{mg} \mathrm{L}^{-1}$.

A concentração de sólidos suspensos, embora não abordada pela Portaria $n^{0}$ 2914, é também um importante parâmetro para avaliar o processo de coagulação. Em algumas situações é possível obter água tratada com concentração de sólidos suspensos igual a zero, sendo que a cor aparente residual nestes casos pode estar associada a substâncias dissolvidas na água que não foram removidas por coagulação e floculação. Esta informação é bastante pertinente, uma vez que as águas do rio Tubarão são severamente prejudicadas pelo lançamento descontrolado de resíduos das atividades de mineração, suinocultura e esgoto doméstico. Além disso, a ocupação inadequada do solo nas margens do rio, contribuem para elevados valores de sólidos suspensos na água, sobretudo em épocas de cheias onde as margens são assoreadas.

Outro fator importante considerado foi o volume de lodo gerado no processo, que apresenta custos relacionados à sua correta disposição. Nas condições ótimas de coagulação, o volume de lodo gerado apresentou valores entre 5 e $20 \mathrm{~mL} \mathrm{~L}^{-1}$. Cabe salientar que o lodo produzido pelo tratamento com tanino apresenta potencial para valorização deste resíduo, quer seja como fertilizante através de compostagem ou mesmo seu uso para a produção de 
energia por biodigestão ou processos térmicos. Estudos referentes a recuperação deste coagulante devem ainda ser considerados de forma a ampliar a gama de aplicações deste resíduo.

Com relação a concentração de fenol na água tratada, esta ficou abaixo de $0,003 \mathrm{mg} \mathrm{L}^{-1}$, limite máximo permitido para a classificação da água como classe II pela resolução CONAMA 357 (Brasil, 2005). No entanto, as análises realizadas nas amostras de água tratada foram para concentrações de fenóis totais que reagem com a 4-aminoantipirina. Desta forma, compostos fenólicos em menor concentração que não reagem com o reagente citado, podem ser incorporados à água devido ao tratamento com tanino, de forma que um estudo mais aprofundado sobre esta questão deve ser considerado.

\section{CONCLUSÃO}

A realização deste estudo reforçou algumas observações prévias relacionadas à aplicação do tanino como coagulante no tratamento de água para abastecimento, sendo que a sua aplicação no tratamento das águas do rio Tubarão promoveu a obtenção de água com algumas características físico-químicas em conformidade com a Portaria $\mathrm{n}^{\circ} 2914$, como pH, cor, turbidez. A concentração ótima de tanino para a coagulação e floculação foi influenciada pela qualidade da água antes do tratamento. Embora não tenham sido detectadas concentrações de compostos fenólicos na água, estudos mais aprofundados devem ser realizados no sentido de avaliar a toxicidade da água obtida e, assim, incentivar o uso deste coagulante que provoca impactos ao meio ambiente de forma menos intensa que os coagulantes inorgânicos, como o sulfato de alumínio e policloreto de alumínio e também os sais de íon férrico. Além disto, um estudo mais aprofundado com relação à avaliação de todos os parâmetros da Portaria n 2914 deve ser considerado.

\section{REFERÊNCIAS}

AMERICAN WATER WORKS ASSOCIATION. Standard methods for the examination of water and wastewater. Washington, DC, 2005.

ASSOCIAÇÃO BRASILEIRA DE NORMAS TÉCNICAS. NBR 10004: resíduos sólidos Classificação. Rio de Janeiro, 2004.

ASSOCIAÇÃO BRASILEIRA DE NORMAS TÉCNICAS. NBR 9897: planejamento de amostragem de efluentes líquidos e corpos receptores - Procedimento. Rio de Janeiro, 1987.

ASSOCIAÇÃO BRASILEIRA DE NORMAS TÉCNICAS. NBR 9898: preservação e técnicas de amostragem de efluentes líquidos e corpos receptores. Rio de Janeiro, 1987.

BARRADAS, J. L. D. Tanino - Uma solução ecologicamente correta: agente floculante biodegradável de origem vegetal no tratamento de água. Novo Hamburgo: Publicação Técnica, 2004.

BELTRÁN-HEREDIA, J.; SÁNCHEZ-MARTÍN, J.; GÓMEZ-MUÑOZ, M. C. New coagulant agents from tannin extracts: Preliminary optimization studies. Chemical Engineering Journal, v. 162, p. 1019-1025, 2010.

http://dx.doi.org/10.1016/j.cej.2010.07.011 
BELTRÁN-HEREDIA, J.; SÁNCHEZ-MARTÍN, J.; MARTÍN- SÁNCHEZ, C. Remediation of dye-polluted solutions by a new tannin-based coagulant. Industrial \& Engineering Chemistry Research, v. 50, p. 686-693, 2011. http://dx.doi.org/10.1021/ie101148y

BONGIOVANI, M. C.; KONRADT-MORAES, L. C.; BERGAMASCO, R.; LOURENÇO, B. S. S.; TAVARES, C. R. G. Os benefícios da utilização de coagulantes naturais para a obtenção de água potável. Acta Scientiarum. Technology, v. 32, n. 2, p. 167-170, 2010. http://dx.doi.org/10.4025/actascitechnol.v32i2.8238

BRASIL. Conselho Nacional do Meio Ambiente - CONAMA. Resolução no 357, de 17 de março de 2005. Brasília, 2005.

BRASIL. Ministério da Saúde. Secretaria de Vigilância em Saúde. Coordenação-Geral de Vigilância em Saúde Ambiental. Portaria MS n. 2914/2011. Brasília, 2011.

CAVINATTO, V. M. Saneamento básico: fonte de saúde e bem-estar. São Paulo: Moderna, 2003.

DA SILVA, T. S. S. Estudo de tratabilidade físico-química com uso de taninos vegetais em água de abastecimento e de esgoto. Dissertação (Mestrado) - Fundação Oswaldo Cruz, Rio de Janeiro, 1999.

FIORENTINI, V. Uso do tanino no processo de tratamento de água como melhoria em sistema de gestão ambiental. Dissertação (Mestrado) - Universidade Federal de Santa Maria, Santa Maria, 2005.

GIACOMELI, M. B. O.; LIMA, M. C.; BORTOLUZZI, I. P.; KLUG, M.; STÜPP, V. Determinação de metais pesados em sedimentos do Rio Tubarão-SC. Engenharia Sanitária e Ambiental, v. 5, p. 178-185, 2000.

IMHOFF, K.; IMHOFF, K. R. Manual de tratamento de águas residuárias. São Paulo: Edgard Blücher, 1998.

MANGRICH, A. S.; DOUMER, M. E.; MALLMANN, A. S.; WOLF, C. R. Química verde no tratamento de águas: uso de coagulante derivado de tanino de Acacia mearnsii. Revista Virtual de Química, v. 6, p. 2-15, 2014. http://dx.doi.org/10.5935/19846835.20140002

PIZZI, A. Tannins: major sources, properties and applications. In: BELGACEM; GANDINI (Eds.). Monomers, polymers and composites from renewable resources. Elsevier: Amsterdam, 2008. p. 179-199.

SANTA CATARINA. Diagnóstico dos recursos hídricos e organização dos agentes da bacia hidrográfica do Rio Tubarão e Complexo Lagunar. Florianópolis: Secretaria de Estado do Desenvolvimento Urbano e Meio Ambiente, 1998. 163 p. 


Ambiente \& Água - An Interdisciplinary Journal of Applied Science
ISSN 1980-993X - doi:10.4136/1980-993X
www.ambi-agua.net
E-mail: ambi-agua@agro.unitau.br

\title{
Determinação simultânea de estriol, $\beta$-estradiol, $17 \alpha$-etinilestradiol e estrona empregando-se extração em fase sólida (SPE) e cromatografia líquida de alta eficiência (HPLC)
}

\author{
doi: $10.4136 / a m b i-a g u a .1346$ \\ Received: 19 Mar. 2014; Accepted: 17 Sep. 2014

\begin{abstract}
Marina da Silva Daniel; Elizabete Campos de Lima*
Universidade Federal do ABC (UFABC), Santo André, SP, Brasil

*Autor correspondente: e-mail: elizabete.lima@ufabc.edu.br, marina.daniel.91@gmail.com
\end{abstract}

\section{RESUMO}

Os hormônios $\beta$-Estradiol, estrona, estriol e $17 \alpha$-etinilestradiol vêm sendo detectados em efluentes principalmente porque os atuais processos de tratamento de esgotos são incapazes de removê-los, sendo uma parte descartada em corpos receptores. Estas substâncias causam danos à saúde humana e ambientais (organismos aquáticos e terrestres) por isso o seu monitoramento é necessário. No presente trabalho, empregou-se extração em fase sólida (SPE) utilizando cartuchos adsorventes de octadecil sílica $\left(\mathrm{C}_{18}\right)$ e análise por cromatografia líquida de alta eficiência (HPLC) para a determinação simultânea desses hormônios em amostra de água do Córrego Tubarão. A análise cromatográfica foi realizada em modo isocrático, fase móvel $50 \% \mathrm{ACN}: \mathrm{H}_{2} \mathrm{O} \mathrm{pH} 3,0$; coluna $\mathrm{C}_{18}$, vazão $1 \mathrm{mLmin}^{-1}$, injeção $10 \mu \mathrm{L}, \lambda=281 \mathrm{~nm}, \mathrm{~T}=40^{\circ} \mathrm{C}$. Os limites de quantificação encontrados foram de $3,75 \mu \mathrm{gL}^{-1}$ para o $17 \alpha$-etinilestradiol a $7,75 \mu \mathrm{gL}^{-1}$ para o estriol. Os limites de detecção encontrados foram de $1,12 \mu \mathrm{gL}^{-1}$ para o $17 \alpha$-etinilestradiol a $2,32 \mu \mathrm{gL}^{-1}$ para o estriol. Na faixa de 0 a 60 $\mu g L^{-1}$, os hormônios analisados apresentaram altos coeficientes de correlação $\left(R^{2} \geq 0,99\right)$. A precisão (inter e intra-ensaio) avaliada em 4 diferentes níveis de concentração apresentou coeficiente de variância (\%CV) e exatidão inferiores a 3\%. Foram realizados diferentes testes de extração SPE mostrando que o condicionamento utilizando-se acetonitrila, eluição com metanol mostrou valores de recuperação superiores a $75 \%$. A metodologia validada foi aplicada na análise de uma amostra de água do córrego Tubarão (Santo André, SP) destacando-se a presença dos hormônios estriol $0,4 \mathrm{gL}^{-1}$ e estrona $0,32 \mathrm{gL}^{-1}$. A metodologia proposta apresentou-se adequada para a determinação de hormônios estrógenos em águas naturais.

Palavras-chave: contaminação, desreguladores endócrinos, poluentes emergentes, poluição aquática.

\section{Simultaneous determination of estriol, $\beta$-estradiol, $17 \alpha$-ethinyl estradiol and estrone employing solid phase extraction (SPE) and high performance liquid chromatography (HPLC)}

\section{ABSTRACT}

The hormones $\beta$-estradiol, estrone, estriol and $17 \alpha$-ethinyl estradiol have been detected in effluents because the current processes of sewage treatment are unable to remove them; the 
residue is being discarded into receiving bodies. These substances cause harm to human and environmental health (aquatic and terrestrial organisms), which is why there is a need for monitoring them. In the present work, we used SPE methodology using C18 cartridges and a HPLC method for simultaneous determination of these hormones in effluent samples. HPLC analysis was performed in isocratic mode, mobile phase $50 \%$ ACN: $\mathrm{H}_{2} \mathrm{O} \mathrm{pH} 3.0$, C18 column, flow $1 \mathrm{mLmin}^{-1}$ Injection $10 \mu \mathrm{L}, \lambda=281 \mathrm{~nm}, \mathrm{~T}=40^{\circ} \mathrm{C}$. The measurements ranged from $3.75 \mu \mathrm{gL}^{-1}$ for $17 \alpha$-ethinylestradiol to $7.75 \mu \mathrm{gL}^{-1}$ for estriol. Detection limits varied from $1.12 \mu \mathrm{gL}^{-1}$ for $17 \alpha$-ethinylestradiol to $2.32 \mu \mathrm{gL}^{-1}$ for estriol. In the range of $0-60 \mu \mathrm{gL}^{-1}$ the hormones analyzed showed high correlation coefficient $\left(\mathrm{R}^{2} \geq 0.99\right)$. The precision (inter- and intra-assay) assessed at 4 different concentration levels presented coefficient of variance (\%CV) and accuracy lower than 3\%. Different tests have been performed showing that the SPE extraction using acetonitrile elution with methanol showed recovery values higher than $75 \%$. The validated methodology was applied in the analysis of a sample of water from Tubarão Stream (Santo André, SP) highlighting the presence of the hormones estriol $0.4 \mu \mathrm{gL}^{-1}$ and estrone $0.32 \mu \mathrm{gL}^{-1}$. The proposed methodology was found to be adequate for the determination of estrogen hormones in natural water.

Keywords: contamination, emerging pollutants, endocrine disrupters, water pollution.

\section{INTRODUÇÃO}

Desreguladores endócrinos são substâncias exógenas capazes de causar efeitos adversos à saúde, interferindo no sistema endócrino de organismos aquáticos, e nos últimos anos têm sido um dos principais tópicos de pesquisa em diferentes áreas do conhecimento (Chang et al., 2009).

O estrogênio sintético $17 \alpha$-etinilestradiol (EE2), amplamente usado na medicina em terapias de reposição e métodos contraceptivos, e os naturais estrona (E1), 17ß-estradiol (E2) e estriol (E3) são considerados como responsáveis pela maioria dos efeitos de desregulação endócrina (Reis Filho et al., 2006) pois afetam o sistema endócrino de peixes em concentrações de $1 \mathrm{ngL}^{-1}$, podendo ser encontrados no ambiente em concentrações da ordem de $\mu g L^{-1}$ a ngL ${ }^{-1}$ (Bila e Dezotti, 2007).

A persistência da atividade dos estrogênios tem origem na contínua introdução em ambientes aquáticos por meio da disposição inadequada de esgoto sanitário e industrial, como também pelo uso de lodo ativado de estação de tratamento de esgoto na agricultura. (Reis Filho et al., 2006; Qiujin et al., 2009; Lin et al., 2013).

O uso de águas superficiais para o consumo humano, bem como a transformação de seus mananciais como receptores de esgotos sanitários tratados ou não, tem sido os principais motivos de preocupação acerca da contaminação das fontes de água.

Há trabalhos que demonstraram que as substâncias estrogênicas não só são importantes na fase aquosa, mas também podem se acumular em sedimentos marinhos e assim afetar os organismos presentes no meio. Porém, pouco é conhecido sobre a exposição de organismos em ambientes aquáticos a substâncias estrogênicas presentes em sedimentos marinhos (Legler et al., 2002).

Diante da problemática de poluição dos compartimentos aquáticos que servem de fonte de captação de água para o abastecimento público, há consideráveis possibilidades de contaminação também da água potável, por esses estrógenos. Além disso, os tratamentos convencionais de água e de esgoto sanitário não são capazes de remover completamente tais substâncias, que permanecem no meio aquático. Diversos trabalhos têm sido dedicados a desenvolver métodos para determinação e quantificação de desreguladores endócrinos e avaliação de sua atividade estrogênica em organismos aquáticos (Chang et al., 2009). 
Técnicas de preparo de amostras (SPE, SPME) (Girotto et al., 2007; Servos et al., 2005) e cromatográficas (LC, GC) com diferentes detectores (DAD, FLD, MS) e outras fundamentadas em testes toxicológicos (YES, ELISA, E-screen, ELRA) (Verbinenn et al., 2010) têm sido desenvolvidas.

Estudos conduzidos por pesquisadores de Campinas, SP, apontaram a presença de hormônios estrógenos no Rio Atibaia, que abastece 92\% do município (Ghiselli, 2006). Em 2006, Sodré e colaboradores (Sodré et al., 2010) identificaram, neste mesmo ecossistema aquático, em um ponto à jusante da cidade de Campinas, níveis de $17 \beta$-estradiol e $17 \alpha$-etinilestradiol que chegaram a 2,51 e $0,31 \mu \mathrm{g} \mathrm{L}{ }^{-1}$, respectivamente.

No presente trabalho foi desenvolvida uma metodologia de extração e clean-up utilizando cartuchos de extração em fase sólida (SPE) comerciais $\left(\mathrm{C}_{18}\right)$ e também uma metodologia via cromatografia líquida de alta eficiência (HPLC) para a determinação simultânea de estriol, $\beta$-estradiol, $17 \alpha$-etinilestradiol e estrona em amostra de agua do córrego Tubarão na divisa entre Santo André e Mauá que deságua na Represa Billings.

\section{MATERIAIS E MÉTODOS}

Desenvolveu-se e otimizou-se uma metodologia HPLC com detecção UV utilizando-se um sistema Agilent 1220 Infinity gradiente equipado com detector DAD, sistema de degaseificação online, forno para coluna, injetor automático e software de aquisição e análise de dados OpenLab EZChrom. As condições de análise foram: fase móvel 50\% ACN: $\mathrm{H}_{2} \mathrm{O}$ acidificada com uma solução $3 \mathrm{mmolL}^{-1}$ de ácido fosfórico (v/v) pH 3,0; coluna $\mathrm{C}_{18}(2,1 \mathrm{~mm}$ x $250 \mathrm{~mm}, 5 \mu \mathrm{m}$ procedência Supelco), fluxo $1 \mathrm{mLmin}^{-1}$, injeção $10 \mu \mathrm{L}, \lambda=281 \mathrm{~nm}$, $\mathrm{T}=40^{\circ} \mathrm{C}$. Para a otimização do método foram utilizados os padrões de hormônios estriol, $\beta$-estradiol, 17 $\alpha$-etinilestradiol e estrona (procedência Sigma-Aldrich). Os padrões de estrogênio, grau analítico foram pesados em balança analítica e dissolvidos com os solventes da fase móvel antes do uso na concentração de $100 \mathrm{mgL}^{-1}$ e armazenados em frasco âmbar com $2 \mathrm{~mL}$ de capacidade e conservados em geladeira antes do uso por até 48horas. A metodologia foi validada segundo o protocolo ICHQ2R1 (ICH, 2005).

No desenvolvimento da metodologia de extração em fase sólida foram utilizados cartuchos SPE C18 (Strata Phenomenex C18-E, 100 mg, 3 mL).

\section{RESULTADOS E DISCUSSÃO}

Na Tabela 1 são mostrados os limites de detecção e quantificação obtidos pela metodologia HPLC desenvolvida e otimizada. Os limites de detecção e quantificação foram avaliados utilizando-se curva analítica empregando-se a leitura do branco analítico do sistema. A curva analítica foi obtida a partir da análise cromatográfica de diluições em água a partir de uma solução estoque contendo os 4 padrões de estrogênio de $100 \mathrm{mgL}^{-1}$.

Tabela 1. Limites de detecção (LD), quantificação (LQ) obtidos para os hormônios analisados e linearidade na faixa de concentração estudada $\left(0\right.$ a $\left.60 \mu \mathrm{gL}^{-1}\right)$.

\begin{tabular}{lccc}
\hline Hormônio & $\mathbf{L Q}\left(\boldsymbol{\mu \mathbf { g L } ^ { - \mathbf { 1 } } )}\right.$ & $\mathbf{L D}\left(\boldsymbol{\mu \mathbf { g L }} \mathbf{- 1}^{\mathbf{1}}\right)$ & $\begin{array}{c}\text { Linearidade obtida e coeficiente de correlação } \\
\text { obtido }\left(\mathbf{R}^{\mathbf{2}}\right)\end{array}$ \\
\hline estriol & 7,75 & 2,32 & $\mathrm{y}=7397 \mathrm{x}+11,579, \mathrm{R}^{2}=0,9998$ \\
$\beta$-estradiol & 5,41 & 1,62 & $\mathrm{y}=10624 \mathrm{x}+150,75, \mathrm{R}^{2}=0,9999$ \\
$17 \alpha$-etinilestradiol & 3,75 & 1,12 & $\mathrm{y}=9784 \mathrm{x}+231,23, \mathrm{R}^{2}=0,9998$ \\
estrona & 5,25 & 1,57 & $\mathrm{y}=6956 \mathrm{x}+551,82, \mathrm{R}^{2}=0,9999$ \\
\hline
\end{tabular}


Na Figura 1 é mostrada a separação otimizada obtida experimentalmente.

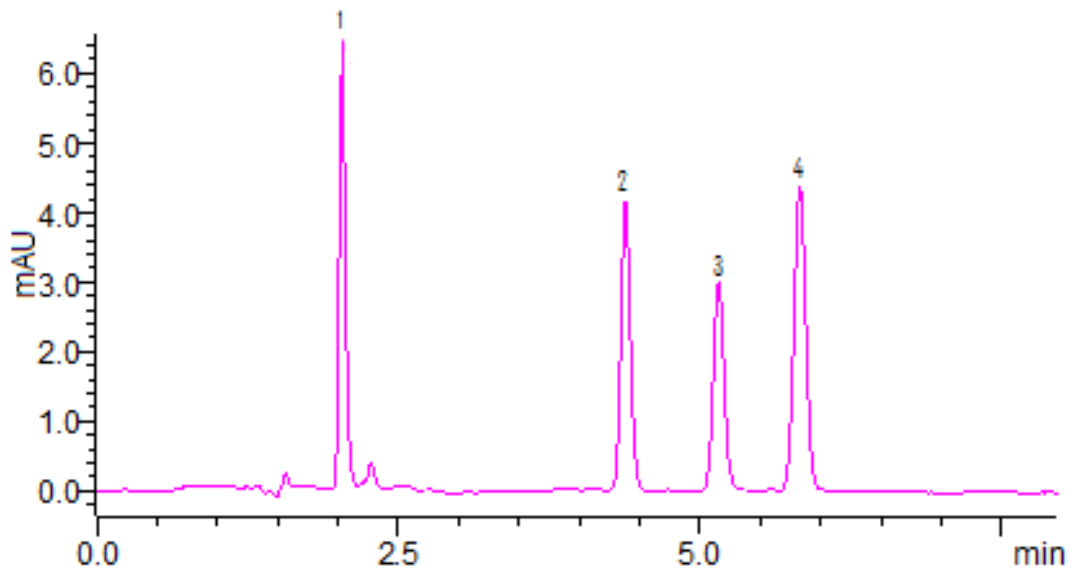

Figura 1. Cromatograma obtido para (1) estriol, (2) $\beta$-estradiol, (3) $17 \alpha$-etinilestradiol e (4) estrona. As condições de análise foram: fase móvel 50\% ACN: $\mathrm{H}_{2} \mathrm{O}$ acidificada com solução $3 \mathrm{mmolL}^{-1}$ de $\mathrm{H}_{3} \mathrm{PO}_{4} \mathrm{pH}$ 3,0 (v/v) coluna $\mathrm{C}_{18}$, fluxo $1 \mathrm{mLmin}^{-1}$, injeção $10 \mu \mathrm{L}$, $\lambda=281 \mathrm{~nm}, \theta=40^{\circ} \mathrm{C}$.

Observando-se a Tabela 1 e a Figura 1 verifica-se que a separação cromatográfica obtida é excelente com resolução na linha de base para todos os analitos e com tempo de análise inferior a $7 \mathrm{~min}$. A metodologia proposta apresenta limites de detecção e quantificação adequados, e os valores obtidos são satisfatórios para a determinação de hormônios estrógenos em esgoto doméstico e água tratada. A validação foi realizada utilizando-se replicata de amostra e de injeção $(n=36$, sendo 3 replicatas de cada concentração e 3 injeções diferentes de cada uma das 3 replicatas de amostras).

Na Tabela 2 são apresentados os valores obtidos para as figuras de mérito avaliadas.

Tabela 2. Valores de coeficiente de variância (\%CV) para as figuras de mérito avaliadas na validação da metodologia HPLC utilizando o protocolo ICHQ2R1 (n=36).

\begin{tabular}{|c|c|c|c|c|c|c|c|c|c|c|c|c|}
\hline \multirow{3}{*}{ Compostos } & \multirow{2}{*}{\multicolumn{4}{|c|}{$\begin{array}{l}\text { intra-ensaio }(\% \mathrm{CV}) \\
\begin{array}{l}\text { Níveis de concentração } \\
\text { avaliados }\left(\mu \mathrm{gL}^{-1}\right)\end{array}\end{array}$}} & \multirow{2}{*}{\multicolumn{4}{|c|}{$\begin{array}{l}\text { inter-ensaio }(\% \mathrm{CV}) \\
\begin{array}{l}\text { Níveis de concentração } \\
\text { avaliados }\left(\mu \mathrm{gL}^{-1}\right)\end{array}\end{array}$}} & \multirow{2}{*}{\multicolumn{4}{|c|}{$\begin{array}{l}\text { Exatidão }(\% \mathrm{CV}) \\
\text { Níveis de concentração } \\
\text { avaliados }\left(\mu \mathrm{gL}^{-1}\right)\end{array}$}} \\
\hline & & & & & & & & & & & & \\
\hline & 1,25 & 2,5 & 5 & 10 & 1,25 & 2,5 & 5 & 10 & 1,25 & 2,5 & 5 & 10 \\
\hline estriol & 0,1 & 3,2 & 1,9 & 1 & 0,1 & 3,2 & 1,9 & 1 & 0,1 & 2,6 & 1 & 0,2 \\
\hline$\beta$-estradiol & 2,2 & 1,4 & 0,3 & 2,4 & 1,7 & 0,8 & 0,2 & 0,1 & 1,62 & 1 & 0,2 & 0,2 \\
\hline $17 \alpha-$ etinilestradiol & 0,5 & 2,4 & 0,9 & 0,4 & 0,3 & 2,6 & 1 & 0,3 & 2 & 0,8 & 0,5 & 0,3 \\
\hline estrona & 2,9 & 0,1 & 1,5 & 0,2 & 2 & 0,2 & 0,8 & 0,2 & 2,1 & 1 & 0,2 & 0,2 \\
\hline
\end{tabular}

A metodologia cromatográfica proposta apresenta valores de precisão e exatidão para os quatro níveis de concentração estudados aceitáveis e menores que 3\%. Os valores obtidos são satisfatórios para a determinação de hormônios estrógenos em esgoto doméstico, água tratada e cursos de água natural, uma vez que essas substâncias têm potencial presença em água potável, o que exige o seu monitoramento utilizando-se métodos analíticos que alcancem níveis de traços. 
Para o desenvolvimento do processo de extração e clean-up dos hormônios estudados foram utilizados $100 \mathrm{~mL}$ de uma solução aquosa contendo $1 \mathrm{mgL}^{-1}$ de cada um dos hormônios em análise. Baseado no trabalho de Verbinenn et al. de 2010 publicado na revista Química Nova. Foram realizados testes de condicionamento e eluição dos cartuchos C18 comercias conforme é mostrado no fluxograma da Figura 2:

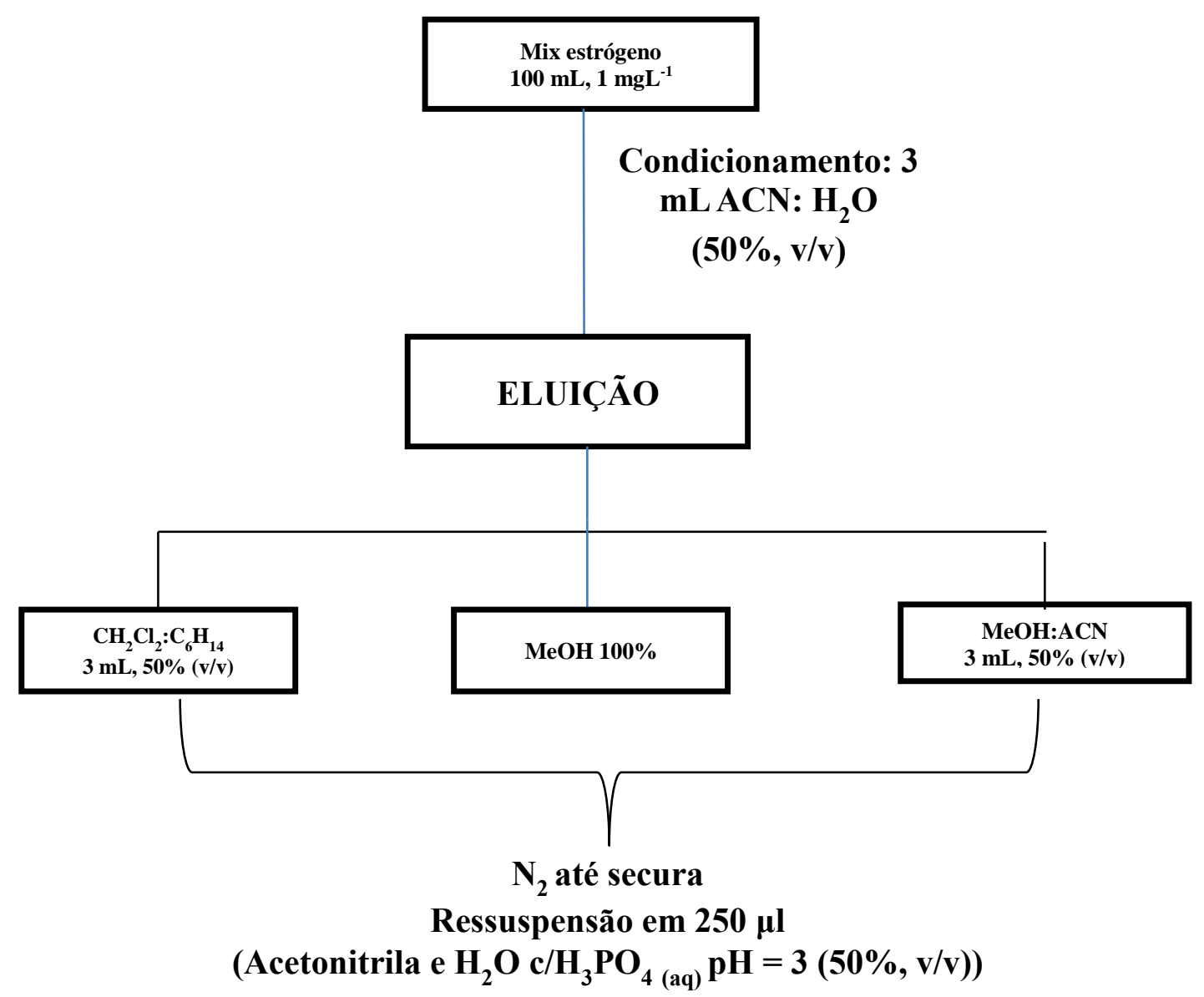

Figura 2. Esquema mostrando os testes experimentais realizados para extração e clean-up dos hormônios estrógenos utilizando cartuchos SPE C18.

A partir dos testes experimentais realizados e após a quantificação dos extratos SPE obtidos através da metodologia HPLC desenvolvida pode-se afirmar que o processo que gerou os melhores resultados, avaliados em termos de recuperação para os compostos analisados (\%R) (Miller e Miller, 2005) foi a rota de extração utilizando o condicionamento do cartucho SPE com 3 mL de ACN; $\mathrm{H}_{2} \mathrm{O}$ (50\%, v/v) seguida da eluição em metanol (MEOH). Na Tabela 3 são mostrados os valores de recuperação alcançados pelo processo. Os valores são correspondentes à análise de triplicata de preparo de amostra seguida da triplicada de injeção de cada uma das amostras $(n=36)$. A recuperação dos analitos foi obtida comparando-se a concentração obtida após o ensaio e a adicionada inicialmente.

Na Tabela 3 observa-se que os valores obtidos variaram de 88,6 a $78,4 \%$ e são reprodutíveis com base nos valores de exatidão apresentados.

Foram realizados testes de sensibilidade utilizando-se o hormônio estanozolol e verificou-se que o mesmo não coelui com nenhum dos picos referentes aos hormônios estrógenos estudados assim como não provoca modificações no tempo de retenção dos mesmos. 
Tabela 3. Valores de Recuperação alcançados para a extração SPE com cartucho C18 utilizando-se condicionamento com acetonitrila:água (50\%, v/v) seguida da eluição com metanol para os 4 hormônios estudados.

\begin{tabular}{lcc}
\hline \multicolumn{1}{c}{ Hormônios } & $\mathbf{\% R}$ & Exatidão $(\% \mathbf{C V})$ \\
\hline estriol & $88,6 \pm 0,8$ & 0,009 \\
$\beta$-estradiol & $86,6 \pm 0,4$ & 0,004 \\
17 $\alpha$-etinilestradiol & $78,4 \pm 0,8$ & 0,010 \\
estrona & $84 \pm 1,4$ & 0,017 \\
\hline
\end{tabular}

A metodologia validada foi aplicada a uma amostra de água retirada do córrego Tubarão que fica localizado na divisa entre os municípios de Santo André e Mauá (SP) e deságua na represa Billings. Na Figura 3 é mostrado o cromatograma para a amostra de água analisada. Foi submetida à análise uma alíquota de $100 \mathrm{~mL}$ da amostra coletada.

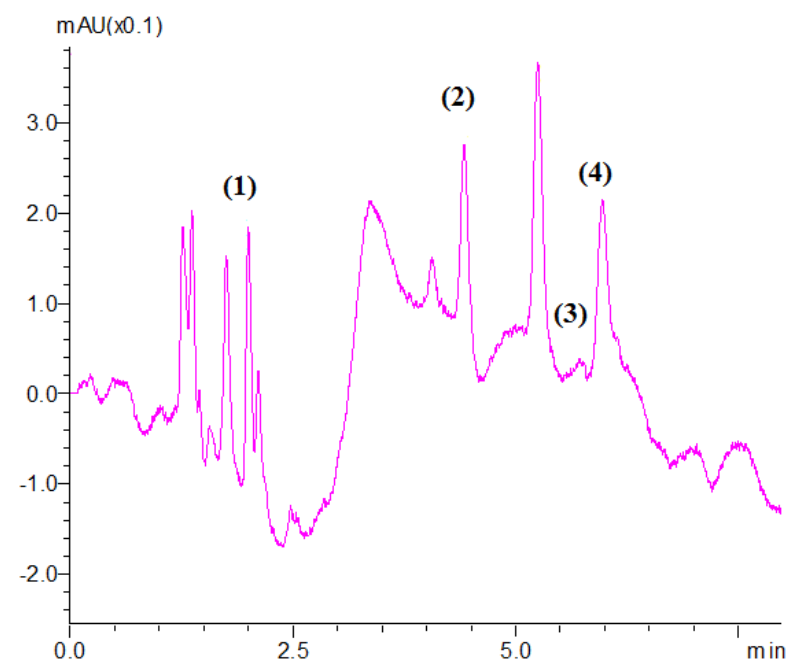

Figura 3. Cromatograma obtido para amostra de água do córrego Tubarão da região metropolitana de Santo André. As condições analíticas são as mesmas descritas na Figura 1.

A análise da amostra de água revelou a presença de estriol, $\beta$-estradiol, $17 \alpha$-etinilestradiol e estrona. A identificação dos picos foi feita através de pureza espectral e adição de padrão destaca-se a presença dos hormônios estriol $0,4 \mathrm{gL}^{-1}$ e estrona $0,32 \mathrm{gL}^{-1}$ na amostra analisada.

\section{CONCLUSÃO}

A metodologia proposta apresenta limites de detecção e quantificação adequados, além de valores de precisão e exatidão para os níveis de concentração estudados e menores que 3\%. Os valores obtidos são satisfatórios para a determinação de hormônios estrógenos em esgoto doméstico, água tratada e efluentes uma vez que essas substâncias têm potencial de presença em água potável, o que exige o seu monitoramento utilizando-se métodos analíticos que 
alcancem níveis de traços uma vez que os tratamentos atuais de água e esgoto não são capazes ainda de retirar esses compostos durante o processo.

\section{AGRADECIMENTOS}

Os autores agradecem a empresa Chemical Trends pela doação dos padrões de hormônios estrógenos utilizados para a realização do presente trabalho, ao Dr. Clovis Lucio da Silva na etapa de desenvolvimento da metodologia cromatográfica e a FAPESP, Processo 2013/12569-8 pelo apoio financeiro.

\section{REFERÊNCIAS}

BILA, D. M.; DEZOTTI, M. Desreguladores endócrinos no meio ambiente: efeitos e conseqüências. Quim. Nova, v. 30, p. 651-666, 2007. http://dx.doi.org/10.1590/S010040422007000300027

CHANG, H.S.; CHOO, K. H.; CHO, S.J. The methods of identification, analysis, and removal of endocrine desrupting compounds (EDCs). J. Hazard. Mater., v. 172, p. 1-12, 2009. http://dx.doi.org/10.1016/j.jhazmat.2009.06.135

GHISELLI, G. Avaliação da qualidade das águas destinadas ao abastecimento público na região de Campinas: ocorrência e determinação de Interferentes Endócrinos (IE) em produtos farmacêuticos e de higiene pessoal 2003-2006. 2006. 130f. Dissertação (Doutorado em Ciências área de concentração: Química) - Instituto de Química da Unicamp, Campinas, 2006.

GIROTTO, G.; NOGUEIRA, K. L.; MOURA, J. A.; SOUZA, J. B.; GIACOMETTI, L. L.; MARCHI, M. R. R. et al. Estrógenos em água: otimização da extração em fase sólida utilizando ferramentas quimiométricas. Ecl. Quím., v. 32, n. 2, p. 61-67, 2007. http://dx.doi.org/10.1590/S0100-46702007000200010

INTERNATIONAL CONFERENCE ON HARMONISATION OF TECHNICAL REQUIREMENTS FOR REGISTRATION OF PHARMACEUTICALS FOR HUMAN USE (ICH). Harmonised tripartite guideline - validation of analytical procedures: text and methodology Q2(R1). Geneva, 2005.

QIUJIN, Z.; LIPING, W.; SHENGFANG, W.; WASSWA, J.; XIAOHONG, G.; JIAN, T. Selectivity of molecularly imprinted solid phase extraction for sterol compounds. Food Chem., v. 113, n. 2, p. 608-615, 2009. http://dx.doi.org/10.1016/j.foodchem.2008.07.044.

LEGLER, J.; DENNEKAMP, M.; VETHAAK, A. D.; BROWWER, A.; KOEMAN, J. H.; VAN DER BURG, B. et al. Detection of estrogenic activity in sediment-associated compounds using in vitro reporter gene assays. Sci. Total Environ., v. 293, p.69-83, 2002. http://dx.doi.org/10.1021/jf052864f

LIN, Z.; HE, Q.; WANG, L.; WANG, X.; DONG, Q.; HUANG, C. Preparation of magnetic multi-functional molecularly imprinted polymer beads for determining environmental estrogens in water samples. J. of Haz. Mat., v. 252- 253, p. 57- 63, 2013. http://dx.doi.org/10.1016/j.jhazmat.2013.02.041

MILLER, J. N.; MILLER, J. C. Statistics and chemometrics for analytical chemistry. 5th Edition. London: Pearson Prentice Hall, 2005. 268 p. 
REIS FILHO, R. W.; ARAUJO, J. C.; VIEIRA, E. M. Hormônios sexuais estrógenos: contaminantes bioativos. Quim. Nova, v. 29, p. 817-822, 2006. http://dx.doi.org/10.1590/S0100-40422006000400032

SERVOS, R. M.; BENNIE, T. D.; BURNISON, K. B.; JURKOVIC, A; MCINNIS, R.; NEHELI, T. et al. Distribution of estrogens, 17h-estradiol and estrone in Canadian municipal wastewater treatment plants. Science of Tot. Environ., v. 336, n. 1, p. 155170, 2005. http://dx.doi.org/10.1016/j.scitotenv.2004.05.025

SODRÉ, F. F.; MONTAGNER, C. C.; LOCATELLI, M. A. F.; JARDIM, W. F. Sistema limpo em linha para extração em fase sólida de contaminantes emergentes em águas naturais. Quim. Nova, v. 33, p. 216-219, 2010. http://dx.doi.org/10.1590/S010040422010000100037

VERBINENN, R. T.; NUNES, G. S.; VIEIRA, E. M. Determinação de hormônios estrógenos em água potável utilizando CLAE-DAD. Quim. Nova, v. 33, p. 1837-1842, 2010. http://dx.doi.org/10.1590/S0100-40422010000900003 


Ambiente \& Água - An Interdisciplinary Journal of Applied Science
ISSN 1980-993X - doi:10.4136/1980-993X
www.ambi-agua.net
E-mail: ambi-agua@agro.unitau.br

\title{
Avaliação da qualidade da água para abastecimento no assentamento de reforma agrária Canudos, Estado de Goiás
}

\author{
doi: 10.4136/ambi-agua.1386 \\ Received: 27 Apr. 2014; Accepted: 18 Aug. 2014

\begin{abstract}
Paulo Sérgio Scalize*; Elaine Franciely dos Santos Barros; Lorena Acelina Soares; Karla Emmanuela Ribeiro Hora; Nilson Clementino Ferreira; Luis Rodrigo Fernandes Baumann
\end{abstract} \\ Universidade Federal de Goiás (UFG), Goiânia, GO, Brasil \\ Programa de Pós-graduação em Engenharia do Meio Ambiente (PPGEMA) \\ *Autor correspondente: e-mail: pscalize.ufg@gmail.com, \\ elainefranciely@gmail.com, acelinasoares@gmail.com, karlaemmanuela@gmail.com, \\ nclferreira@gmail.com, fbaumann@mat.ufg.br
}

\section{RESUMO}

O presente trabalho avaliou a qualidade da água usada pela população do Assentamento Canudos, Goiás, tanto na fonte de abastecimento (captação) como no ponto de consumo (torneiras), além de registrar as condições construtivas e a presença de possíveis focos de contaminação. Os locais foram escolhidos de forma aleatória, considerando no mínimo uma amostra em cada sub-bacia existente no assentamento. Ao todo foram analisadas 35 amostras de água coletadas em 35 lotes (10,6\% do total de lotes) e os parâmetros determinados foram E. coli, turbidez, cor aparente, $\mathrm{pH}$, condutividade elétrica (CE), além da identificação e avaliação dos tipos de captações utilizadas, verificando as conformidades com as normas construtivas e de conservação. A análise de representatividade da amostra foi realizada considerando sua quantidade e qualidade, assim como o erro amostral. Os resultados obtidos apontaram que $77,1 \%$ utilizam poços rasos, $20 \%$ mini poços e 2,9\% nascente. Foram detectadas $E$. coli em $85,7 \%$ das captações, sendo observada a maior presença nos locais que utilizavam poços rasos, aliadas às piores condições estruturais e de saneamento. As análises mostraram que a qualidade da água consumida pelos moradores do assentamento necessita de melhorias significativas.

Palavras-chave: área rural, pequena comunidade, tratamento de água.

\section{Assessing the quality of the water supply in the agrarian reform settlement of Canudos, State of Goiás}

\section{ABSTRACT}

This study evaluated the quality of the water used by the agrarian reform settlement of Canudos, located in Goiás State, considering water supply sources, consumption sites (taps), well construction conditions and the presence of possible contamination sources. Locations were chosen randomly with at least one sample from each sub-basin in the settlement. Thirty-five samples of water were analyzed in 35 land lots (10.6\% of total) considering the parameters of $E$. coli, turbidity, apparent color, $\mathrm{pH}$, and electrical conductivity (EC). The 
study also identified and assessed the types of water supply used as well as compliance with construction standards and conservation efforts. The representativeness of the samples was analyzed considering their quantity, quality, and the sampling error. The results showed that $77.1 \%$ of the population use shallow wells, $20 \%$ mini wells and $2.9 \%$ springs. E. coli was found in $85.71 \%$ of all water supply sources; with the greatest concentration in shallow wells with bad structural and inadequate sanitation conditions. The analyses showed that the quality of water consumed by the population of the agrarian reform settlement needs considerable improvement.

Keywords: rural area, small communities, water treatment.

\section{INTRODUÇÃO}

A infraestrutura relacionada ao saneamento possui implicações diretas na salubridade de uma residência e visa gerar impactos positivos no ambiente e consequentemente na saúde e desenvolvimento da população (Hora et al., 2012). Essa deve ser eficiente e acessada igualmente por todos, como prevê a Lei $n^{\circ} 11.445$, que estabelece diretrizes nacionais para 0 saneamento básico (Brasil, 2007). No entanto, pesquisas demonstram que grande parte dos investimentos e infraestruturas está localizada nos centros urbanos quando comparado com as áreas rurais. Tal situação pode gerar impactos no ambiente e na saúde da população rural, além de aumentar os gastos públicos no tratamento de doenças. Gazzinelli et al. (1998), em estudo no Estado de Minas Gerais, sugerem uma relação entre a fonte de água, condições sanitárias e a ocorrência de doenças transmitidas pela água.

Teixeira e Heller (2004) destacam, estudando áreas de assentamento subnormal na cidade de Juiz de Fora - MG, que para o controle das helmintoses intestinais são imprescindíveis a boa cobertura e qualidade dos serviços de abastecimento de água, bem como a eliminação da disposição dos esgotos nos terrenos. Razolini e Günther (2008) relatam que a falta ou a precariedade do acesso a água potável representa uma situação de risco que propicia o aumento da incidência de doenças. Citam ainda que, para reverter esse cenário, seria necessária a implementação integrada de políticas públicas, com ações conjuntas envolvendo saneamento, saúde, habitação entre outras.

A água de consumo humano é um dos mais importantes veículos de enfermidades, o que torna primordial sua avaliação. Para que seja considerada potável, a água deve adequar-se a parâmetros de qualidade estabelecidos na Portaria 2914 do Ministério da Saúde, que dispõe sobre os procedimentos de controle e de vigilância da qualidade da água para consumo humano e seu padrão de potabilidade (Brasil, 2011). Barcelos et al. (2006), estudando duas áreas rurais situadas nas sub-bacias dos ribeirões Água Limpa e Santa Cruz, inseridas no município de Lavras-MG, relatam que, de maneira geral, a água utilizada para consumo doméstico, dessedentação de animais e irrigação de culturas oferece risco à saúde da população estudada, sendo que não encontraram relação entre os tipos de mananciais e o nível de contaminação por coliformes termotolerantes.

As ações de controle de qualidade da água no meio rural, segundo Amaral et al. (2003), por parte das autoridades públicas é praticamente inexistente, ficando a cargo de cada proprietário a responsabilidade de utilização e manutenção das fontes de água utilizadas para o seu próprio abastecimento. Essa postura pode ser considerada incorreta, visto que a população no meio rural muitas vezes não conta com informações adequadas acerca das condições de saneamento, quanto à proteção das fontes de água e os riscos causados pelo armazenamento inadequado da água, fato que aumenta consideravelmente a possibilidade de contaminação e má qualidade da água utilizada para o consumo. Ressalta-se ainda que as diferentes formas de captações podem estar vinculadas às condições socioeconômicas, sendo 
que em razão do baixo custo e facilidade de perfuração, a captação de água em aquífero livre é mais utilizada em áreas rurais no Brasil (Silva e Araújo, 2003).

Diante disso, o presente estudo teve como objetivo avaliar a qualidade da água utilizada no Assentamento Canudos, Goiás, na fonte de abastecimento e no ponto de consumo, bem como a avaliação das condições de abastecimento e a presença de possíveis focos de contaminação.

\section{MATERIAL E MÉTODOS}

O Assentamento Canudos localiza-se na bacia hidrográfica do rio dos Bois, abrangendo os municípios de Palmeiras de Goiás, Campestre de Goiás e Guapó, Estado de Goiás. Possui uma área de aproximadamente 13 mil hectares e abriga 329 famílias assentadas com um total de 987 habitantes, considerando 3 habitantes por lote.

As amostragens de água nas fontes de abastecimento (poço raso - escavado com diâmetro de 1,0 m, mini poço - perfurado com diâmetro de $100 \mathrm{~mm}$ ou nascente) e ponto de consumo (pias e tanques), foram realizadas no período sazonal de cheia, entre os meses de abril e maio em 2011, em um total de 35 lotes (10,6\% do total de lotes do assentamento). Os pontos foram escolhidos de forma aleatória distribuída pela área do assentamento, considerando no mínimo um ponto em cada sub-bacia da área de estudo (Figura 1). Desses, 15 pertencem ao município Campestre, 13 à Palmeiras e 7 à Guapó, dos quais 77,1\% utilizam-se de poços rasos como fonte de abastecimento, 20,0\% mini poço e 2,9\% (1/35) nascente (Figura 1).

As amostras de água foram coletadas, acondicionadas e preservadas de acordo com o Guia da Cetesb (2011) e NBRs 9897 (1987a) e 9898 (1987b). Os parâmetros turbidez, cor aparente, $\mathrm{pH}$, condutividade elétrica (CE) e E. coli, foram analisados conforme preconiza APHA et al. (2005). Durante as amostragens foram identificados os tipos de fontes de abastecimento de água e se estavam condizentes com as normas construtivas e de conservação, conforme orientações da Funasa (2006). Registrou-se a profundidade e nível d'água dos poços rasos, obtendo a coluna de água.

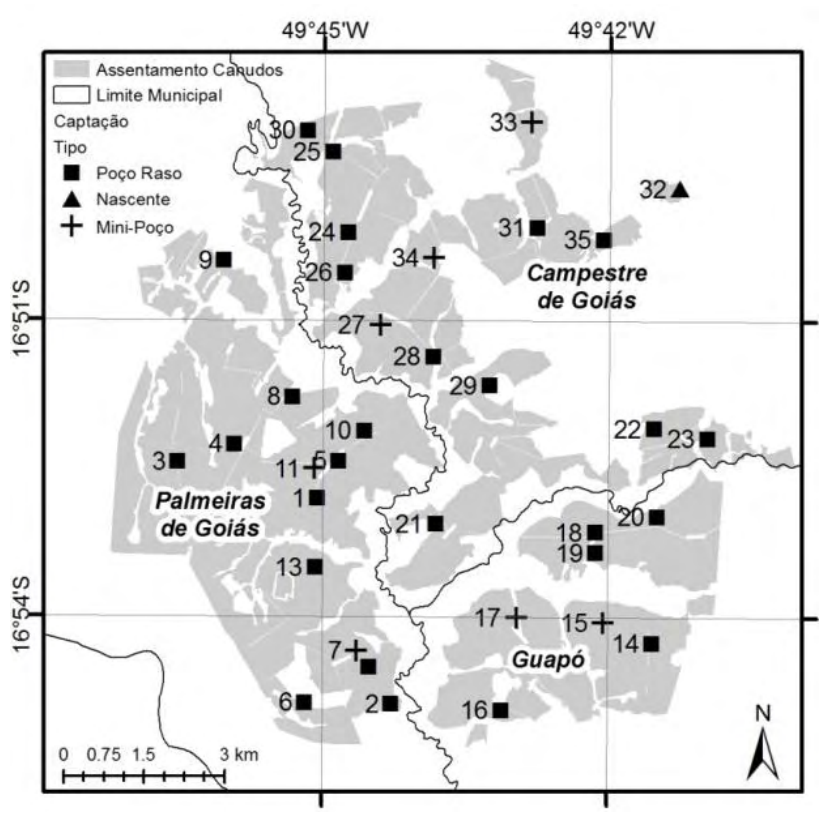

Figura 1. Distribuição espacial dos pontos no Assentamento Canudos-GO, onde foram realizadas coletas de dados e de amostras de água para realização da pesquisa. 
Para avaliar a vulnerabilidade das fontes foi verificada a distância dessas com possíveis focos de contaminações tais como fossas, pocilgas, estábulos e disposição de efluentes e resíduos.

A partir de dados amostrais, distribuídos no espaço, foi realizada estimativa dos valores de cada variável utilizando a geoestatística, que é um ramo da estatística que une o conceito de variáveis aleatórias com o conceito de variáveis regionalizadas (Druck et al., 2004).

A presença de possível erro não amostral foi verificada por meio de um gráfico do tipo boxplot para detectar presença de dados discrepantes (outliers). Os erros amostrais foram avaliados através de intervalos de confiança construídos para estimar médias e proporções populacionais. Um intervalo de confiança para a média ou proporção populacional $\theta$ com nível de confiança $\delta$ foi definido pela Equação 1 e 2.

$$
\begin{aligned}
& I C(\theta, \delta)=\hat{\theta} \pm E \\
& I C(\theta, \delta)=(\hat{\theta}-E, \hat{\theta}+E)
\end{aligned}
$$

em que:

$\widehat{\theta}$ é a estimativa do parâmetro populacional $\theta$;

$E$ é a margem de erro ou também chamado de erro máximo de estimativa, de tal forma que $|\hat{\theta}-\theta|<E$.

O nível de confiança $\delta$ é uma probabilidade, dada pela Equação 3.

$$
P(|\hat{\theta}-\theta|<E)=\delta
$$

ou seja,

se $\hat{\theta}$ é usado como uma estimativa de $\theta$, pode-se então estar $100 \delta \%$ confiantes de que o erro não excederá $E$.

Foram considerados vários níveis de confiança para os intervalos e para cada nível foi observado o erro máximo da estimativa da média e de proporções populacionais. Com isso, obteve-se o grau de precisão dada pela estimativa intervalar baseado nos diferentes níveis de confiança das estimativas. Para o caso da estimativa da média, a margem de erro é definida pela Equação 4.

$$
E=s Z_{\delta} \sqrt{\frac{N-n}{(N-1) n}}
$$

em que:

$s$ é o desvio padrão da amostra,

$\mathrm{Z}_{\delta}$ é o valor crítico que corresponde ao grau de confiança $\delta$,

$N$ é o tamanho da população e $n$ é o tamanho da amostra.

No caso de estimativas proporções, a margem de erro é definida pela equação 5. 


$$
E=\sqrt{\hat{p}(1-\hat{p})} Z_{\delta} \sqrt{\frac{N-n}{(N-1) n}}
$$

em que:

$\hat{p}$ é uma estimativa da proporção populacional $p$.

\section{RESULTADOS E DISCUSSÃO}

Os resultados das análises das águas coletadas foram apresentados por fonte de abastecimento, bem como as características construtivas e sua localização.

\subsection{Poços rasos}

$\mathrm{Na}$ Tabela 1, pode-se observar que $100 \%$ das amostras coletadas nos 27 poços rasos, e em seus respectivos pontos de consumo, apresentaram presença de E. coli. Esses resultados não estão de acordo com o que é preconizado pela Portaria 2914 (Brasil, 2011) que determina a ausência de $E$. coli em água para consumo humano, visto que sua presença indica contaminação fecal e, consequentemente, a possibilidade de ter-se microrganismos patogênicos, evidenciando a precariedade desse tipo de fonte de abastecimento. Pode-se observar ainda que as amostras com valores inferiores a $100 \mathrm{NMP} / 100 \mathrm{~mL}$ de E. coli representam $63,0 \%$ de ocorrência na fonte e $55,6 \%$ no ponto de consumo. Situação similar foi encontrada por Amaral et al. (2003), estudando uma região rural no Nordeste do Estado de São Paulo, onde evidenciou que 90,0\% das amostras de água das fontes de abastecimento apresentavam condições fora dos padrões microbiológicos para consumo humano. Giatti et al. (2007), analisando 65 amostras coletadas na região da sede do distrito de Iauarerê, área indígena na Amazônia legal, encontraram em 89,2\% das amostras a presença de coliformes termotolerantes, indicando uma água imprópria para consumo humano. Outros estudos mostram condições similares com relação à qualidade da água (Wright et al., 2004; França e Silveira, 2011; Araújo et al., 2011; Schmidt e Dotto, 2012; Almeida et al., 2013).

Pode-se observar na Tabela 1 que os valores de cor aparente apresentaram-se dentro dos padrões de potabilidade $(<15 \mathrm{uH})$ em $55,6 \%$ e $51,9 \%$ das amostras coletadas, na fonte e no ponto de consumo, respectivamente. Já a turbidez, em 40,7\% das amostras na fonte e em $48,1 \%$ das amostras coletadas no ponto de consumo, esteve em conformidade com a Portaria 2914 (Brasil, 2011), sendo que em 7,4\% e 18,5\% foi ultrapassado o limite de 5,0 UNT na captação e no ponto de consumo, respectivamente. A água com baixa turbidez constitui uma medida preventiva, uma vez que sua origem pode ser inorgânica (areia, argila, silte) e/ou orgânica (matéria orgânica, organismos patogênicos). O resultado da análise geoestatística apresentado na Figura 2 permite observar uma tendência do aumento dos valores de $E$. coli, turbidez e cor aparente na região leste.

Quanto aos valores de $\mathrm{pH}$, três amostras na fonte e duas no ponto de consumo apresentaram-se menores que 6,0, as demais ficaram na faixa recomendada pela legislação, que é de 6,0 a 9,5, apresentando uma média de 6,6 com coeficiente de variação (CV) de 7,7\%.

Na Tabela 1 e Figura 2 observa-se que a profundidade nos poços rasos variou até $20 \mathrm{~m}$, com uma maior quantidade abaixo de $10 \mathrm{~m}$ (55,5\%). Quanto ao nível de água em relação ao solo, $59,3 \%$ dos poços raros apresentou uma profundidade de até $5,0 \mathrm{~m}$, e o restante entre 5 e $15 \mathrm{~m}$, possibilitando uma altura útil (diferença entre o fundo e o nível de água) entre 1,2 e 6,6 m de coluna d'água. É possível ainda observar que na região oeste do assentamento têm-se maiores profundidades e altura útil de água. Baixa profundidade do poço corrobora com a maior possiblidade de contaminação das águas, pois alturas inferiores a $20 \mathrm{~m}$ diminui o tempo de contato entre a água superficial que infiltra e o solo, que tem a função filtrante (Amaral et al., 2003). Essa altura pode não ser o melhor índice para verificar o risco de 
contaminação da água, pois deve-se também considerar o nível d'água, tipo de solo, padrão construtivo do poço, etc. Na Figura 2 pode-se observar que no lado leste do assentamento têm-se maiores valores de $E$. coli, turbidez e cor aparente coincidindo com as menores profundidades e alturas úteis de água.

Tabela 1. Quantidade e ocorrências de E. coli, cor aparente e turbidez na fonte de abastecimento (poços rasos e mini poços) e ponto de consumo.

\begin{tabular}{|c|c|c|c|c|c|c|}
\hline \multirow{2}{*}{$\begin{array}{l}\text { Tipo de } \\
\text { Fonte }\end{array}$} & \multirow{2}{*}{ Parâmetro } & \multirow{2}{*}{ Resultado } & \multicolumn{2}{|c|}{ Fonte } & \multicolumn{2}{|c|}{ Ponto de consumo } \\
\hline & & & Quantidade & Ocorrência (\%) & Quantidade & Ocorrência $(\%)$ \\
\hline \multirow{14}{*}{$\begin{array}{l}0 \\
\text { त्र } \\
0 \\
0 \\
0 \\
0\end{array}$} & \multirow{4}{*}{$\begin{array}{c}\text { E. coli } \\
\text { (NMP/100 mL) }\end{array}$} & Ausentes & 0 & 0,0 & 0 & 0,0 \\
\hline & & 1 a 100 & 17 & 63,0 & 15 & 55,6 \\
\hline & & 101 a 1050 & 9 & 33,3 & 11 & 40,7 \\
\hline & & $>2400$ & 1 & 3,7 & 1 & 3,7 \\
\hline & \multirow{2}{*}{$\begin{array}{l}\text { Cor aparente } \\
\quad(\mathrm{uH})\end{array}$} & $\leq 15$ & 15 & 55,6 & 13 & 51,9 \\
\hline & & $>15$ & 22 & 44,4 & 14 & 48,1 \\
\hline & \multirow{3}{*}{$\begin{array}{l}\text { Turbidez } \\
\text { (UNT) }\end{array}$} & $\leq 1,0$ & 11 & 40,7 & 13 & 48,1 \\
\hline & & 1 a 5 & 14 & 51,9 & 9 & 33,3 \\
\hline & & $>5,0$ & 2 & 7,4 & 5 & 18,5 \\
\hline & \multirow{2}{*}{$\begin{array}{l}\text { Profundidade } \\
\text { (m) }\end{array}$} & $<10$ & 15 & 55,5 & $*$ & $*$ \\
\hline & & 10,1 a 20 & 12 & 44,5 & $*$ & $*$ \\
\hline & \multirow{3}{*}{$\begin{array}{l}\text { Nível de água em } \\
\text { relação ao solo } \\
\text { (m) }\end{array}$} & $<5$ & 16 & 59,3 & $*$ & $*$ \\
\hline & & 5 a 10 & 9 & 33,3 & * & * \\
\hline & & 10,1 a 15 & 2 & 7,4 & $*$ & $*$ \\
\hline \multirow{7}{*}{$\begin{array}{l}\stackrel{0}{8} \\
\stackrel{\circ}{\circ} \\
\stackrel{\Xi}{*}\end{array}$} & \multirow{2}{*}{$\begin{array}{c}\text { E. coli } \\
\text { (NMP/100 mL) }\end{array}$} & Ausente & 6 & 85,7 & 6 & 85,7 \\
\hline & & $<10$ & 1 & 14,3 & 1 & 14,3 \\
\hline & \multirow{2}{*}{$\begin{array}{l}\text { Cor aparente } \\
(\mathrm{uH})\end{array}$} & $\leq 15$ & 4 & 57,1 & 4 & 57,1 \\
\hline & & $>15$ & 3 & 42,9 & 3 & 42,9 \\
\hline & \multirow{3}{*}{$\begin{array}{l}\text { Turbidez } \\
\text { (UNT) }\end{array}$} & $\leq 1,0$ & 3 & 42,9 & 4 & 57,1 \\
\hline & & 1 a 5 & 2 & 28,6 & 2 & 28,6 \\
\hline & & $>5,0$ & 2 & 28,6 & 1 & 14,3 \\
\hline
\end{tabular}

(*) não aplicável.

Com relação aos possíveis focos de contaminações, foram constatados que em 22,2\% dos lotes não tinham fossa, 18,5\% estavam a uma distância inferior a $15 \mathrm{~m}$ de possíveis focos de contaminação, 33,3\% entre 15 e $30 \mathrm{~m}$ e 26,0\% estavam a uma distância superior a $30 \mathrm{~m}$. Segundo Funasa (2006), deve-se respeitar a distância mínima de 15 m entre o poço e a fossa seca e a distância de $45 \mathrm{~m}$ para os demais focos de contaminação tais como fossas rudimentares, chiqueiros, estábulos, galinheiros, etc. Em alguns casos foi observada a presença de animais próximos ou sobre os poços, morcegos, baratas, sapos ou girinos no interior dos poços, lançamento de efluentes próximo ao poço e disposição de resíduos de maneira inadequada, o que também colabora para a contaminação das águas.

Foi verificado que os poços possuíam tampas construídas em diferentes materiais, tais como concreto, madeira, materiais alternativos e alguns sem tampa, dos quais 88,9\% sem vedação, possibilitando a entrada de insetos e animais. Segundo Funasa (2006), recomenda-se o uso de tampas a fim de impedir a entrada de objetos que possam trazer prejuízos à qualidade da água. Observou-se que 3 poços $(11,1 \%)$ não tinham prolongamento acima do nível do solo possibilitando a contaminação das águas pela entrada de água de enxurradas ou por meio de despejo superficial, além do que alguns poços também não possuíam revestimento interno. 


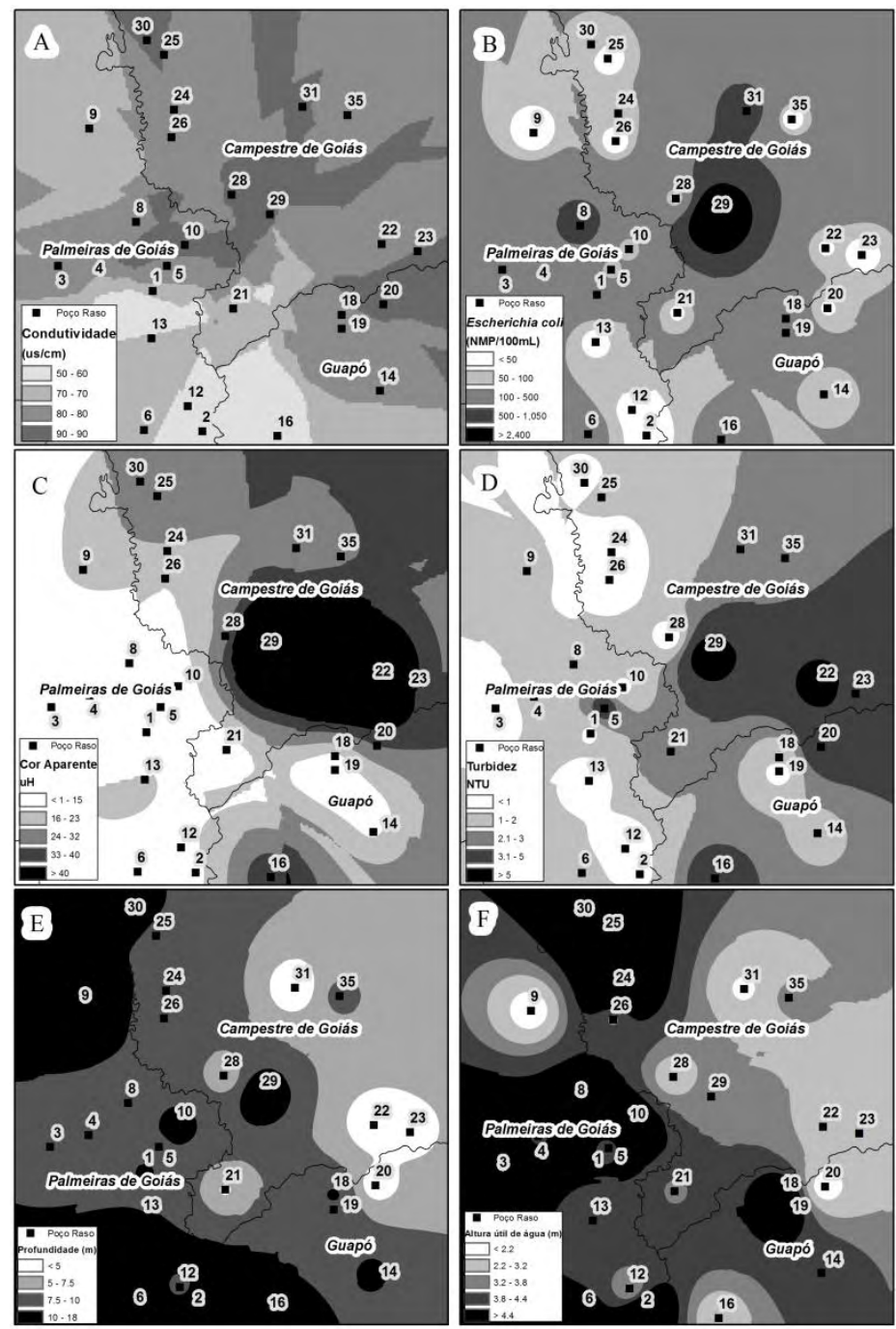

Figura 2. Análise geoestatística dos valores dos parâmetros condutividade elétrica (A), E. coli (B), cor aparente (C) e turbidez (D) obtidos nos ensaios realizados com as amostras coletadas nos poços rasos ao longo da área de estudo. Os valores de profundidade (E) e altura útil de água (F) foram obtidos nas atividades de campo.

\subsection{Mini poços}

Entre os 7 mini poços analisados, 14,3\%, ou seja, apenas um, apresentou presença de E. coli, na água de captação e no ponto de consumo. Na Tabela 1 observa-se que a cor aparente ficou com 42,9\% dos valores acima de $15 \mathrm{uH}$, em ambos locais de amostragem. Quanto à turbidez, com exceção de duas amostras na fonte e uma no ponto de consumo, os valores ficaram abaixo do limite estabelecido na Portaria 2914 (Brasil, 2011).

Apenas uma amostra na fonte apresentou o $\mathrm{pH}$ abaixo de 6,0, as demais ficaram entre $6 \mathrm{e}$ 9,5 (média $=6,7 ; \mathrm{CV}=9,1 \%$ ). Os resultados da CE foram superiores aos encontrados nas demais fontes, variando de 23 a 330,2 $\mu \mathrm{S} \mathrm{cm}^{-1}$ (média $=116,8 \mu \mathrm{S} \mathrm{cm}^{-1}$; $\mathrm{CV}=80,6 \%$ ).

Foi constatada que a profundidade dos mini poços são inferiores a $32 \mathrm{~m}$ e as características construtivas são satisfatórias, dificultando a contaminação da água. Nesses locais, duas situações podem contaminar o lençol freático: através da utilização de equipamentos de bombeamento e canalização sujos ou por meio de infiltrações de contaminantes, isso quando localizado em partes baixas do terreno. Com relação ao foco de contaminação, existe um chiqueiro e uma fossa com 10 m de distância no ponto 11 e, entre os 
demais mini poços, 2 apresentaram fossa com menos de $10 \mathrm{~m}, 3$ entre 22,5 e 27,5 m e 1 com distância de 272 m.

\subsection{Nascente}

Os resultados da única nascente utilizada para abastecimento (ponto 32), mostraram a presença de $E$. coli na fonte (345 NMP/100 mL) e no ponto de consumo (105 NMP/100 mL). Com relação aos demais parâmetros, a cor aparente na captação não atende à Legislação, estando em $40 \mathrm{uH}$. Os valores de turbidez, pH e CE foram de 1,3 e 0,8 NTU, 111,9 e $115,9 \mu \mathrm{S} \mathrm{cm}^{-1}, 7,2$ e 7,5, respectivamente para a captação e o ponto de consumo. A água captada é transportada por gravidade, estando longe de focos de contaminações.

\subsection{Erro Amostral}

Observa-se na Figura 3 a presença de dados discrepantes, sendo que dentre os parâmetros estudados, a variável pH não apresentou discrepância. Para as outras variáveis, os pontos amostrais que apresentaram discrepância foram analisados para verificar presença de erros não amostrais. Constatou-se que apenas no ponto amostral 29 pode ter ocorrido um erro técnico na coleta dos dados, acarretando a exclusão de tal ponto das análises.

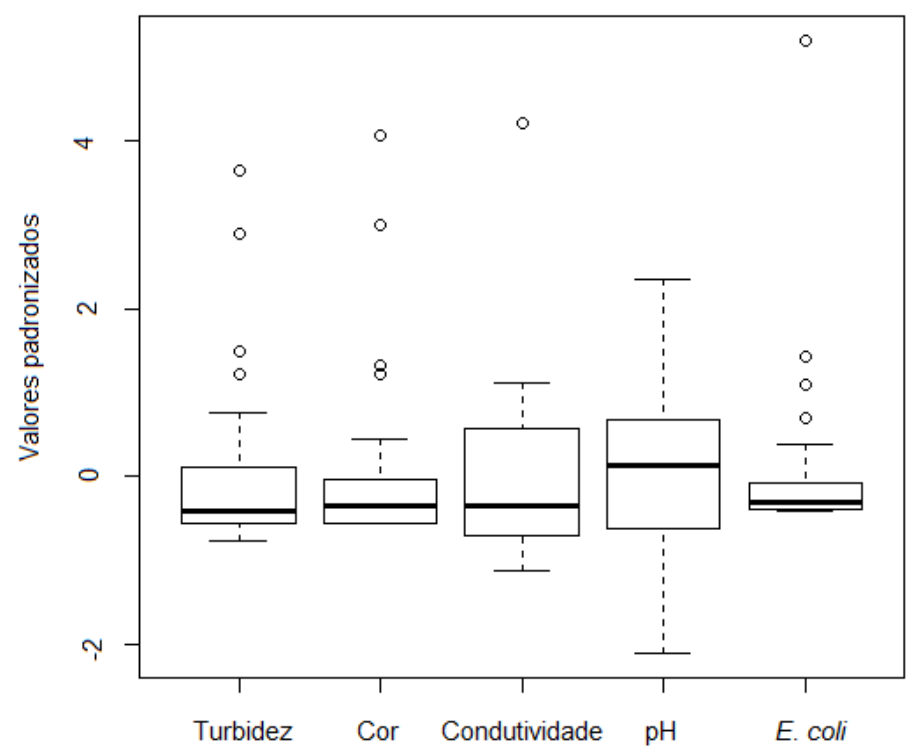

Figura 3. Boxplot dos dados referentes às variáveis relacionadas a fonte de captação de água.

\subsection{Turbidez}

Na Tabela 2 podem ser verificadas as estimativas intervalares da turbidez média e da proporção de lotes com turbidez menor ou igual a 5 UNT, com as respectivas margens de erro das estimativas. Pode-se afirmar, com 99,0\% de confiança, que o intervalo entre 1,1 e 3,6 contém a turbidez média da água no Assentamento Canudos, ou seja, com nível de confiança considerado, pode-se dizer que em média a turbidez está abaixo de 5 UNT.

\subsection{Cor aparente}

Conforme dados constantes na Tabela 2, com 90,0\% de confiança, o intervalo de 15,4 a 47,3 uH contém a cor aparente média da água do Assentamento Canudos, ou seja, em média, esse parâmetro está fora do recomendado pela Portaria 2914 (Brasil, 2011) que limita em 15 uH. Com 95,0\% de confiança, o intervalo de 48,0\% a 63,7\% contém a proporção de lotes com cor aparente na fonte de abastecimento menor que $15 \mathrm{uH}$. 


\subsection{Condutividade Elétrica (CE)}

Esse parâmetro foi analisado considerando uma constante entre Sólidos Totais Dissolvidos (STD) e CE de 0,55. Dessa forma, conforme Tabela 2, pode-se afirmar, com 99,0\% de confiança, que o intervalo de 94,7 a 187,6 mg/L contém a média de STD, ou seja, com esse nível de confiança, podemos considerar que, em média, a água das fontes está abaixo de 1000 mg/L, limite estabelecido na Portaria 2914 (Brasil, 2011). Por outro lado, pode-se afirmar com 99,0\% de confiança que o intervalo de 95,9\% a 98,3\% contém a proporção de lotes com STD em níveis menores ou iguais a $500 \mathrm{mg} / \mathrm{L}$.

\section{8. $\mathrm{pH}$}

Segundo a Portaria 2914 (Brasil, 2011), o valor recomendado para o pH deve estar entre 6,0 e 9,5. Na Tabela 2 encontra-se as estimativas intervalares do $\mathrm{pH}$ médio e da proporção de lotes com $\mathrm{pH}$ na faixa recomendada, com as respectivas margens de erro das estimativas. Pode-se afirmar, com 99,0\% de confiança, que o intervalo entre 6,4 e 6,8 contém o pH médio da água no Assentamento, ou seja, dentro da faixa recomendada.

\subsection{Escherichia coli}

Segundo a Portaria 2914 (Brasil, 2011), as águas de consumo não devem apresentar $E$. coli. Na Tabela 2 estão as estimativas intervalares para $E$. coli média e da proporção de lotes com ausência de $E$. coli, com suas respectivas margens de erro. Pode-se afirmar com 99,0\% de confiança, que o intervalo de 30,1 a 187,6 contém a $E$. coli média dos lotes, ou seja, com o nível de confiança 99,0\%, podemos considerar que, em média, as águas não atendem a legislação. Pode-se observar que, com 99,0\% de confiança, o intervalo de $11,6 \%$ a $23,7 \%$ contém a proporção de lotes com ausência de E. coli. Podemos afirmar que a proporção de lotes que atendem as especificações em relação aos níveis de $E$. coli é mínima. Vale ressaltar que a Portaria 2914 recomenda que novas coletas sejam realizadas após a determinação de uma amostra com presença de E. coli.

Tabela 2. Intervalos de confiança e margens de erros para a média $(\mu)$ e a proporção (p) dos parâmetros pesquisados no Assentamento Canudos.

\begin{tabular}{|c|c|c|c|c|c|}
\hline \multirow{2}{*}{ Parâmetro } & \multirow{2}{*}{$\begin{array}{c}\text { Confiança } \\
(100 \delta \%)\end{array}$} & \multicolumn{2}{|c|}{ Média $(\mu)$} & \multicolumn{2}{|c|}{ Proporção (p) } \\
\hline & & $I C(\mu, \delta)$ & Margem de erro & $I C(\mathbf{p}, \delta)$ & $\%$ \\
\hline \multirow{3}{*}{$\begin{array}{l}\text { Turbidez } \\
\text { (UT) }\end{array}$} & $90 \%$ & $(1,53 ; 3,13)$ & 0,80 & $(89,02 \% ; 93,33 \%)$ & 2,15 \\
\hline & $95 \%$ & $(1,38 ; 3,28)$ & 0,95 & $(88,61 \% ; 93,74 \%)$ & 2,56 \\
\hline & $99 \%$ & $(1,08 ; 3,58)$ & 1,25 & $(87,81 \% ; 94,55 \%)$ & 3,37 \\
\hline \multirow{3}{*}{$\begin{array}{l}\text { Cor aparente } \\
(\mathrm{uH})\end{array}$} & $90 \%$ & $(15,43 ; 47,34)$ & 15,95 & $(49,29 \% ; 62,48 \%)$ & 6,59 \\
\hline & $95 \%$ & $(12,37 ; 50,39)$ & 19,01 & $(48,02 \% ; 63,74 \%)$ & 7,85 \\
\hline & $99 \%$ & $(6,40 ; 56,37)$ & 25,98 & $(45,55 \% ; 66,21 \%)$ & 10,32 \\
\hline \multirow{3}{*}{$\begin{array}{l}\text { Condutividade } \\
\text { elétrica }(\mu \mathrm{S} / \mathrm{cm})\end{array}$} & $90 \%$ & $(111,19 ; 159,12)$ & 29,07 & $(96,29 \% ; 97,82 \%)$ & 0,76 \\
\hline & $95 \%$ & $(105,62 ; 168,75)$ & 34,64 & $(96,15 \% ; 97,97 \%)$ & 0,91 \\
\hline & $99 \%$ & $(94,73 ; 187,57)$ & 45,53 & $(95,86 \% ; 98,25 \%)$ & 1,19 \\
\hline \multirow{3}{*}{$\mathrm{pH}$} & $90 \%$ & $(6,47 ; 6,76)$ & 0,14 & $(85,46 \% ; 91,01 \%)$ & 2,77 \\
\hline & $95 \%$ & $(6,44 ; 6,79)$ & 0,17 & $(84,93 \% ; 91,54 \%)$ & 3,31 \\
\hline & $99 \%$ & $(6,39 ; 6,84)$ & 0,23 & $(83,69 \% ; 92,58 \%)$ & 4,34 \\
\hline \multirow{3}{*}{$\begin{array}{l}\text { E. coli } \\
(\mathrm{NMP} / 100 \mathrm{~mL})\end{array}$} & $90 \%$ & $(58,59 ; 159,12)$ & 50,26 & $(13,76 \% ; 21,53 \%)$ & 3,89 \\
\hline & $95 \%$ & $(48,96 ; 168,75)$ & 59,89 & $(13,01 \% ; 22,28 \%)$ & 4,63 \\
\hline & $99 \%$ & $(30,14 ; 187,57)$ & 78,71 & $(11,56 \% ; 23,73 \%)$ & 6,09 \\
\hline
\end{tabular}




\section{CONCLUSÃO}

O presente trabalho permitiu concluir que a água utilizada no Assentamento Canudos não é de boa qualidade na maioria dos pontos de consumo, sendo que a água captada nos mini-poços apresenta qualidade superior àquelas captadas em poços rasos e nascente.

Há predominância do uso de poços rasos, especialmente na porção leste do assentamento, onde se localizam os poços com menores profundidades e alturas úteis, e onde também foram encontradas águas com as piores qualidades.

De acordo com os níveis de confiança e margens de erros considerados, pode-se concluir que existem parâmetros que não atendem às especificações da Portaria 2914/MS, sendo que as variáveis cor aparente e $E$. coli apresentaram os níveis mais críticos em relação aos aceitáveis para consumo humano. Já a turbidez, $\mathrm{pH}$ e condutividade, com certo nível de confiança e margem de erro, se encontram dentro das especificações para consumo humano.

Independente da forma de captação, percebe-se a necessidade de melhoria estrutural, aliada à educação sanitária dos assentados, orientando-os quanto às condições e manutenções a serem feitas nas fontes de captação. Além disso, o incentivo a práticas simples como o uso de filtração, cloração ou fervura da água pode contribuir para uma melhoria na qualidade da água consumida por essa população. Isso poderia ser realizado através de Políticas Públicas.

\section{REFERÊNCIAS}

ASSOCIAÇÃO BRASILEIRA DE NORMAS TÉCNICAS - ABNT. NBR 9897, Planejamento de amostragem de efluentes líquidos e corpos receptores. Rio de Janeiro, 1987a.

ASSOCIAÇÃO BRASILEIRA DE NORMAS TÉCNICAS - ABNT. NBR 9898, Preservação e técnicas de amostragem de efluentes líquidos e corpos receptores. Rio de Janeiro, 1987b.

ALMEIDA, J.; FARIA, A.; DALLEMOLE, D. Desenvolvimento socioambiental e passivo hídrico em projetos de assentamento de Mato Grosso. Sociedade e Desenvolvimento Rural, v. 7, n. 4, p. 44-61, 2013.

AMARAL, L. A.; NADER FILHO, A.; ROSSI JUNIOR, O. D.; FERREIRA, L. A.; BARROS, L. S. S. Água de consumo humano como fator de risco à saúde em propriedades rurais. Revista de Saúde Pública, São Paulo, v. 37, n. 4, ago. 2003. http://dx.doi.org/10.1590/S0034-89102003000400017.

AMERICAN PUBLIC HEALTH ASSOCIATION - APHA; AMERICAN WATER WORKS ASSOCIATON - AWWA; WATER ENVIRONMENT FEDERATION - WEF. Standard methods for the examination of water and wastewater. $21 \mathrm{st} \mathrm{Ed}$. Washington, DC, 2005.

ARAÚJO, G. F. R. et al. Qualidade físico-química e microbiológica da água para o consumo humano e a relação com a saúde: estudo em uma comunidade rural no estado de São Paulo. O Mundo da Saúde, v. 35, n. 1, p. 98-104, 2011.

BARCELLOS, M. C.; ROCHA, M.; RODRIGUES, L. S.; COSTA, C. C.; OLIVEIRA, P. R.; SILVA, I. J. et al. Avaliação da qualidade da água e percepção higiênico-sanitária na área rural de Lavras, Minas Gerais, Brasil, 1999-2000. Caderno de Saúde Pública, Rio de Janeiro, v. 22, n. 9, set. 2006. http://dx.doi.org/10.1590/S0102-311X2006000900028. 
BRASIL. Lei $\mathrm{n}^{\circ} 11.445$, de 5 de janeiro de 2007. Estabelece diretrizes nacionais para o saneamento básico e dá outras providências. Diário Oficial [da] União, Brasília, 08 jan. 2007.

BRASIL. Ministério de Estado da Saúde. Portaria n 2914, de 12 de dezembro de 2011. Dispõe sobre os procedimentos de controle e de vigilância da qualidade da água para consumo humano e seu padrão de potabilidade. Diário Oficial [da] União, Brasília, 14 dez. 2011.

COMPANHIA AMBIENTAL DO ESTADO DE SÃO PAULO - CETESB. Guia nacional de coleta e preservação de amostras: água, sedimento, comunidades aquáticas e efluentes líquidos. São Paulo, 2011. 326p.

DRUCK, S. CARVALHO, M. S.; CÂMARA, G.; MONTEIRO, A. V. M. Análise espacial de dados geográficos. Brasília: EMBRAPA, 2004.

FRANÇA, E. S.; SILVEIRA, Y. M. S. C. Água, saúde e estratégia saúde da família (ESF): uso e desafios no assentamento Estrelas Do Norte - Motes Claros, Minas Gerais, Brasil. Revista Geográfica de América Central, v. 2, n. 47E, p. 17, 2011.

FUNDAÇÃO NACIONAL DE SAÚDE - FUNASA (Brasil). Manual de saneamento. 3. ed. Brasília, 2006. 408p.

GAZZINELLI, A.; SOUZA, M. C. C.; NASCIMENTO, I.; SÁ, I. R.; CADETE, M. M.; KLOOS, H. Domestic water use in a rural village in Minas Gerais, Brazil, with an emphasis on spatial patterns, sharing of water, and factors in water use. Caderno de Saúde Pública, Rio de Janeiro, v. 14, n. 2, abr. 1998. http://dx.doi.org/10.1590/S0102311X1998000200011.

GIATTI, L. L.; ROCHA, A. A.; TOLEDO, R. F.; BARREIRA, L. P.; RIOS, L.; PELICIONI, M. C. F. et al. Condições sanitárias e socioambientais em Iauaretê, área indígena em São Gabriel da Cachoeira, AM. Ciência \& Saúde Coletiva, Rio de Janeiro, v. 12, n. 6, dez. 2007. http://dx.doi.org/10.1590/S1413-81232007000600032.

HORA, K. E. R.; SILVA, M. F.; SOUSA, A. C. L.; OLIVEIRA, V. T.; SCALIZE, P. S. Saneamento rural em áreas de reforma agrária no Brasil. In: ENCONTRO DE ENGENHARIA SANITÁRIA E AMBIENTAL, 15., 2012, Évora. Anais eletrônicos... [S.l.]: APESB, 2012. p. 1-8.

RAZZOLINI, M. T. P.; GUNTHER, W. M. R. Impactos na saúde das deficiências de acesso a água. Saúde e Sociedade, São Paulo, v. 17, n. 1, mar. 2008. http://dx.doi.org/10.1590/S0104-12902008000100003.

SCHMIDT, C. A. P.; DOTTO, K. R. Levantamento microbiológico e de hábitos de consumo de água e alimentos em Santa Helena-PR. Saúde e Pesquisa, v. 5, n. 3, p. 455-461, 2012.

SILVA, R. C. A.; ARAUJO, T. M. Qualidade da água do manancial subterrâneo em áreas urbanas de Feira de Santana (BA). Ciência \& Saúde Coletiva, São Paulo, v. 8, n. 4, 2003. http://dx.doi.org/10.1590/S1413-81232003000400023.

TEIXEIRA, J. C.; HELLER, L. Fatores ambientais associados às helmintoses intestinais em áreas de assentamento subnormal, Juiz de Fora, MG. Engenharia Sanitária e Ambiental, Rio de Janeiro, v. 9, n. 4, dez. 2004. http://dx.doi.org/10.1590/S141341522004000400006. 
WRIGHT, J.; GUNDRY, S.; CONROY, R. Household drinking water in developing countries: a systematic review of microbiological contamination between source and point-of-use. Tropical Medicine \& International Health, v. 9, n. 1, p. 106-117, 2004. http://dx.doi.org/10.1046/j.1365-3156.2003.01160.x 


Ambiente \& Água - An Interdisciplinary Journal of Applied Science
ISSN 1980-993X - doi:10.4136/1980-993X
www.ambi-agua.net
E-mail: ambi-agua@agro.unitau.br

\title{
Correlação entre condição da superfície do solo agrícola e o coeficiente de absorção acústica
}

\author{
doi: 10.4136/ambi-agua.1423
}

Received: 12 Jun. 2014; Accepted: 13 Aug. 2014

\author{
Rosane Freire $^{1 *}$; Célia Regina Granhen Tavares²; Paulo Fernando Soares ${ }^{3}$; \\ Marco Henrique Meletti de Abreu ${ }^{4}$ \\ ${ }^{\mathbf{1}}$ Universidade Estadual Paulista "Júlio de Mesquita Filho" (UNESP), Presidente Prudente, SP, Brasil \\ Departamento de Física, Química e Biologia \\ ${ }^{2}$ Universidade Estadual de Maringá (UEM), Maringá, PR, Brasil \\ Departamento de Engenharia Química \\ ${ }^{3}$ Universidade Estadual de Maringá (UEM), Maringá, PR, Brasil \\ Departamento de Engenharia Civil \\ ${ }^{4}$ Universidade de São Paulo (USP), São Paulo, SP, Brasil \\ Departamento de Geografia \\ *Autor correspondente: e-mail: rofreire@gmail.com, \\ celiagranhen@gmail.com, paulofsoares@gmail.com, \\ marcohenriquema@gmail.com
}

\section{RESUMO}

Objetivou-se com esse trabalho aplicar a técnica acústica com o intuito de relacionar a resposta de um sinal sonoro emitido em diferentes superfícies, medido em nível de pressão sonora equivalente, com os fatores que regem a perda de solos. Em campo foram construídas quatro parcelas em escala reduzida, com dimensões de 2,0 x 12,5 m, com diferentes usos (rugosidades). Em relação ao tipo de cobertura, uma parcela permaneceu com solo exposto e as demais com pastagem (Brachiaria), cultura de milho e com cultura temporária de soja/trigo, seguindo as práticas agrícolas sazonais implantadas na bacia hidrográfica na qual o estudo foi realizado. Para o sistema acústico, utilizou-se o ruído rosa nas medições do monitoramento proposto, coletando informações sobre o nível de pressão sonora equivalente $\left(\mathrm{L}_{\mathrm{EQ}}\right)$ das ondas incidentes e refletidas. Em relação aos ensaios acústicos, os resultados apontaram que não houve diferenciação entre o tipo de cobertura do solo instaladas nas parcelas erosivas e o coeficiente de absorção acústico medido em $\mathrm{L}_{\mathrm{EQ}}$.

Palavras-chave: perda de solo, nível de pressão sonora equivalente $\left(\mathrm{L}_{\mathrm{EQ}}\right)$, ruído rosa.

\section{Correlation between condition of agricultural soil surface and the sound absorption coefficient}

\begin{abstract}
This work applied acoustic technique to relate the response of a signal sound to different surfaces, measured in equivalent sound pressure level, with the factors governing soil loss. Four erosion plots in reduced scale $(2.0 \times 12.5 \mathrm{~m})$ were built on the field. One plot contained
\end{abstract}


barren soil while the others contained forage grass (Brachiaria), corn and temporary crop soybean/wheat, following the seasonal agricultural practices implemented in the watershed where the study was conducted. Pink noise was used in the measurements of the acoustic system to collect information regarding the equivalent sound pressure level $\left(\mathrm{L}_{\mathrm{EQ}}\right)$ of incident and reflected waves. The results of the noise tests indicated that there was no differentiation between the type of ground cover and the acoustic absorption coefficient measured in $\mathrm{L}_{\mathrm{EQ}}$.

Keywords: equivalent sound pressure level $\left(\mathrm{L}_{\mathrm{EQ}}\right)$, loss of soil, pink noise.

\section{INTRODUÇÃO}

As avaliações experimentais diretas e, portanto, mais confiáveis dos fatores que governam a perda de solo, de acordo com as normas preconizadas na literatura, além de demandarem excessivos gastos também exigem muito tempo nas suas determinações. Contudo, sem ainda chegar a uma metodologia consistente e que leve à obtenção de dados confiáveis, a determinação indireta da perda de solo vêm apresentando uma série de limitações às quais inspiram várias pesquisas.

Embora não muito empregada em prática, a técnica acústica possui algumas finalidades na determinação de propriedades dos solos. Os estudos sobre o assunto são relativamente recentes, datam do final da década de 60 e tem despertado a atenção da comunidade científica por ser um método rápido, de baixo custo, fácil de utilizar e com alto potencial de aplicação direta em campo.

Vitorino et al. (2001) utilizaram o ultrassom para a dispersão de argila na análise granulométrica. Carolino de Sá et al. (2002) empregaram a técnica para a determinação de estabilidade de agregados em Latossolos e Nitossolos e, Ribeiro et al. (2009) estudaram a relação entre a desagregação de amostras de solo pela energia ultrassônica, como efeito de desagregação do solo causado pela energia cinética de gotas de chuvas.

Do ponto de vista da agricultura, Sharma e Gupta (2010) determinaram a umidade do solo utilizando a resposta de um sinal acústico de sensor portátil e estimaram efeito do teor de água sobre a velocidade do som em um solo com textura variando de silto-argilosa para arenosa utilizando ondas acústicas contínuas.

Em um posicionamento voltado para a conservação do solo, Chambers e Sabatier (2002) propuseram utilizar a acústica como um método de mensuração da rugosidade da superfície do solo de modo que ela possa ser devidamente inclusa como mais um fator da Equação Universal da Perda de Solo (EUPS). Os testes laboratoriais foram realizados utilizando materiais com diferentes tamanhos de grão (pequeno, médio e grande). O teste em campo (in situ) foi realizado um experimento em um local recentemente arado, apresentando diferentes tamanhos de torrões, proporcionando uma escala de pequena, média e grande rugosidade. No experimento, os resultados obtidos em campo mostraram efeitos proporcionais aos testes obtidos no laboratório, ou seja, houve atenuação do sinal emitido nos diferentes materiais estudados sendo possível correlacionar o tamanho do grão com o grau de rugosidade medido.

A hipótese que rege é a de que utilizando o mesmo princípio técnico, seria igualmente possível relacionar a rugosidade superficial de determinado tipo de uso do solo com o valor de reflexão de um sinal sonoro por ela emitida. Desse modo, o presente estudo tem por objetivo propor a aplicação da relação entre a resposta de um sinal sonoro emitido por diferentes superfícies agrícolas (rugosidades), medido em nível de pressão sonora equivalente $\left(\mathrm{L}_{\mathrm{EQ}}\right) \mathrm{com}$ os fatores da perda de solos. Espera-se elucidar uma ferramenta importante, rápida e precisa no levantamento e determinação de fatores que regem a perda de solos e que visa, acima de 
tudo, contribuir com o avanço dos estudos e inserção de novas tecnologias na área ambiental, focando a preservação e conservação dos recursos naturais.

\section{FUNDAMENTAÇÃO DA TEORIA E CÁLCULOS}

\subsection{Perda de solo}

Na formulação da Equação Universal da Perda de Solo (EUPS), Wichmeier e Smith (1978) concluíram empiricamente que a perda de solos de uma determinada área é a relação direta entre a intensidade da chuva (fator de erosividade), as propriedades inerentes ao solo (fator de erodibilidade), o comprimento e o grau do declive da vertente, o uso e manejo adotado e a presença de práticas conservacionistas. Esses fatores combinam-se linearmente, como expresso na Equação (1).

$$
A=R \cdot K \cdot L S \cdot C \cdot P
$$

em que:

$$
\begin{aligned}
& A=\text { perda de solo }\left(\mathrm{Mg} \mathrm{ha}^{-1} \mathrm{ano}^{-1}\right) \text {; } \\
& R=\text { fator de erosividade }\left(\mathrm{MJ} \mathrm{mm} \mathrm{ha}{ }^{-1} \mathrm{ano}^{-1}\right) \text {; } \\
& K=\text { fator de erodibilidade do solo }\left(\mathrm{Mg} \mathrm{MJ}^{-1} \mathrm{~mm}^{-1}\right) \text {; } \\
& L S=\text { fator topográfico do solo, representa o comprimento de rampa (m) e grau de } \\
& C=\text { fator de uso e manejo }\left(\left(\mathrm{Mg} \mathrm{ha}^{-1}\right)\left(\mathrm{Mg} \mathrm{ha}^{-1}\right)^{-1}\right) \text {; } \\
& P=\text { práticas conservacionistas (-). }
\end{aligned}
$$
declive (\%);

Quando os outros fatores da EUPS são mantidos constantes, as perdas de solo ocasionadas pelas chuvas nos terrenos cultivados são diretamente proporcionais ao valor do produto de sua energia cinética $(\mathrm{Ec})$ e sua intensidade máxima em trinta minutos $\left(\mathrm{I}_{30}\right)$, como apresentado na Equação (2).

$$
E I_{30}=E_{c} \cdot I_{30}
$$

em que:

$$
\begin{aligned}
& E I_{30}=\text { índice de erosão }\left(\mathrm{MJ} \mathrm{mm} \mathrm{ha}{ }^{-1} \mathrm{~h}^{-1}\right) ; \\
& E c=\text { energia cinética da chuva }\left(\mathrm{MJ} \mathrm{ha}^{-1} \mathrm{~mm}^{-1}\right) ; \\
& I_{30}=\text { intensidade máxima em } 30 \text { minutos }\left(\mathrm{mm} \mathrm{h}^{-1}\right) .
\end{aligned}
$$

A energia cinética da chuva pode ser calculada pela Equação 3. A soma dos valores dos índices de erosividade $\left(\mathrm{EI}_{30}\right)$ de cada chuva em certo período proporciona uma avaliação numérica do fator erosividade (Fator R) da chuva.

$$
E_{c}=0,119+0,0873 \log I
$$

em que:

$$
I=\text { intensidade da chuva }\left(\mathrm{mm} \mathrm{h}^{-1}\right) .
$$

O fator de erodibilidade (K) é representado pela relação entre a perda de solo (Fator A) e o fator erosividade da chuva (Fator R), quando tais dados são obtidos em um determinado 
período, como apresentado na Equação (4). Tais quantificações são efetuadas nas condições de parcela padrão e conhecidas como método direto.

$$
\text { Fator } K=\frac{\text { Fator } A}{\text { Fator } R}
$$

em que:

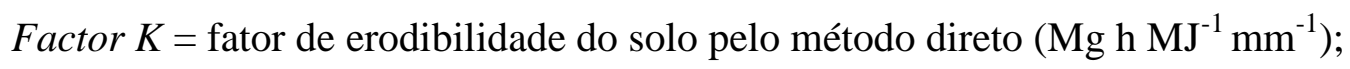

Factor $A$ = perda de solo $\left(\mathrm{Mg} \mathrm{ha}^{-1}\right)$;

Factor $R=$ fator de erosividade $\left(\mathrm{MJ} \mathrm{mm} \mathrm{ha}{ }^{-1} \mathrm{~h}^{-1}\right)$.

A intensidade da erosão hídrica é afetada tanto pela distância ao longo do qual se processa o escoamento superficial quanto pela declividade do terreno, representados pelo fator topográfico (LS). Este fator pode ser determinado experimentalmente e a Equação 5 mostra a estimativa apresentada em Bertoni e Lombardi Neto (2010).

$$
L S=\frac{\sqrt{L}}{100} \cdot\left(1,36+0,97 \cdot S+0,1385 \cdot S^{2}\right)
$$

em que:

$L=$ comprimento do declive (m);

$S$ = grau do declive (\%).

O fator de uso e manejo (C) é calculado por meio do somatório do produto entre a razão de perda de solo (RPS) e a fração do índice de erosividade (FEI $\left.\mathrm{F}_{30}\right)$ de cada estádio do ciclo da cultura, como apresentado na Equação 6.

$$
\text { Fator } C=\sum R P S_{i} \cdot F E I_{30}=\sum \frac{\text { Fator } A_{m}}{\text { Fator }_{1}} \cdot \frac{R_{i}}{R}
$$

em que:

Factor $C$ = uso e manejo do solo $\left(\left(\mathrm{Mg} \mathrm{ha}^{-1}\right) \cdot\left(\mathrm{Mg} \mathrm{ha}^{-1}\right)^{-1}\right)$;

$i$ = estádio da cultura;

$R S L_{i}=$ razão de perdas de terra no estádio i;

FactorA $_{m}=$ perda de solo no cultivo $\mathrm{m}\left(\mathrm{kg} \mathrm{ha}^{-1}\right)$;

Factor $A_{l}=$ perda de solo na parcela $1\left(\mathrm{~kg} \mathrm{ha}^{-1}\right)$;

$R_{i}=$ erosividade no estádio i $\left(\mathrm{MJ} \mathrm{mm} \mathrm{ha}{ }^{-1} \mathrm{~h}^{-1}\right)$;

$R=$ erosividade do ciclo $\left(\mathrm{MJ} \mathrm{mm} \mathrm{ha}{ }^{-1} \mathrm{~h}^{-1}\right.$ ).

O fator de práticas conservacionistas (P) representa o efeito de práticas implantadas na área rural expressando a relação entre a perda de solo com determinada prática e a correspondente perda quando a cultura está implantada no sentido do declive (morro abaixo).

\subsection{Absorção acústica}

Após a incidência da onda sonora em um obstáculo, o som incidente (I) divide-se, principalmente, em som refletido (R), som absorvido (A) e som transmitido (T). 
O coeficiente de reflexão $\left(\mathrm{R}_{\mathrm{p}}\right)$ pode ser obtido a partir da relação entre o nível de pressão sonora incidente $\left(\mathrm{NPS}_{\mathrm{I}}\right)$ sobre uma superfície e o nível de pressão sonora refletida $\left(\mathrm{NPS}_{\mathrm{R}}\right)$ à superfície do material a ser testado, conforme apresentado na Equação 7.

$$
R_{p}=K \cdot \frac{N P S_{R}}{N P S_{I}}
$$

em que:

$$
\begin{aligned}
& R_{p}=\text { coeficiente de reflexão (-); } \\
& K=\text { constante para o espalhamento geométrico (-); } \\
& S P L_{R}=\text { nível de pressão sonora refletida (dB); } \\
& S P L_{I}=\text { nível de pressão sonora incidente (dB). }
\end{aligned}
$$

De acordo com Kutruff (2009), a intensidade de uma onda plana é proporcional ao quadrado da amplitude de pressão. Portanto, a intensidade da onda refletida é menor por um fator $\left|R_{p}\right|^{2}$ do que a onda incidente. A fração $1-\left|R_{p}\right|^{2}$ da energia incidente é perdida durante a reflexão e esta quantidade também é chamada "coeficiente de absorção" da superfície. Para cada ângulo de reflexão $(\theta)$, $\alpha$ pode ser calculado usando a Equação 8.

$$
\alpha(\theta)=1-\left|R_{p}(\theta)\right|^{2}
$$

em que:

$\alpha(\theta)=$ coeficiente de absorção para diferentes ângulos de incidência;

$R_{p}(\theta)=$ coeficiente de reflexão para diferentes ângulos de incidência.

Em teste de sinais, o valor do coeficiente de absorção de uma superfície reflete as características físicas do material, sendo a variável analisada em muitas aplicações acústicas, principalmente no caso de atenuação sonora em campo aberto.

O sinal emitido para avaliar o coeficiente de absorção de uma superfície deve ter um comportamento sonoro conhecido. O ruído rosa tem a propriedade de ser um ruído constante através de todas as bandas de frequência, possuindo distribuição Gaussiana, garantindo que a mesma quantidade de energia estimule o sistema nas bandas analisadas (Everest e Pohlmann, 2009).

O nível de pressão sonora equivalente $\left(\mathrm{L}_{\mathrm{EQ}}\right)$, dos níveis de pressões incidentes $\left(\mathrm{NPS}_{\mathrm{I}}\right)$ e níveis de pressões refletidas $\mathrm{NPS}_{\mathrm{R}}$, como sugerido por Fracastoro (2003), é calculado utilizando a Equação 9.

$$
L_{E Q}=10 \cdot \log \left\lceil\frac{1}{t} \cdot \sum_{i=1}^{n} t_{i} \cdot 10^{\left(\frac{N P S i}{10}\right)}\right\rceil
$$

em que:

$L_{E Q}=$ Nível de pressão sonora equivalente $(\mathrm{dB})$;

$t=$ Período de amostragem (h);

$S P L_{i}=$ sound pressure level “i” (dB);

$t_{i}=$ Tempo parcial $(\mathrm{h})$. 


\section{MATERIAL E MÉTODOS}

\subsection{Monitoramento da perda de solo}

As parcelas experimentais de perda de solo (P) foram construídas seguindo as recomendações descritas por Wischmeier e Smith (1978). Em razão da área disponível para o estudo, foram construídas quatro parcelas erosivas delimitadas em alvenaria, com dimensões de $2,0 \mathrm{~m} \mathrm{x} \mathrm{12,5} \mathrm{m,} \mathrm{correspondendo} \mathrm{a} 25 \mathrm{~m}^{2}$, proporcionais ao tipo "padrão" recomendado pela literatura. À jusante de cada parcela foi instalado um sistema coletor do escoamento superficial composto por calha direcionadora e tanque de sedimentação (S), com capacidade de $1000 \mathrm{~L}$.

O estudo foi conduzido nas proximidades do córrego Mandacaru, afluente da bacia hidrográfica do ribeirão Maringá, localizado a $23^{\circ} 24^{\prime} \mathrm{S}$ e $51^{\circ} 57^{\prime} \mathrm{W}$, na zona norte do município de Maringá - PR. A área de estudo está localizada em média-baixa vertente, a 500 metros de altitude, sobre um Nitossolo Vermelho Distroférrico latossólico, possui declividade de $9 \%$ e permaneceu em pousio de plantio por mais de cinco anos (Figura 1). A área encontra-se sob clima tipo Cfa, de Köppen, com precipitação média anual entre 1.250 a 1.500 $\mathrm{mm}$, verões quentes e chuvosos, invernos com menor índice pluviométrico, mas sem estação seca definida.

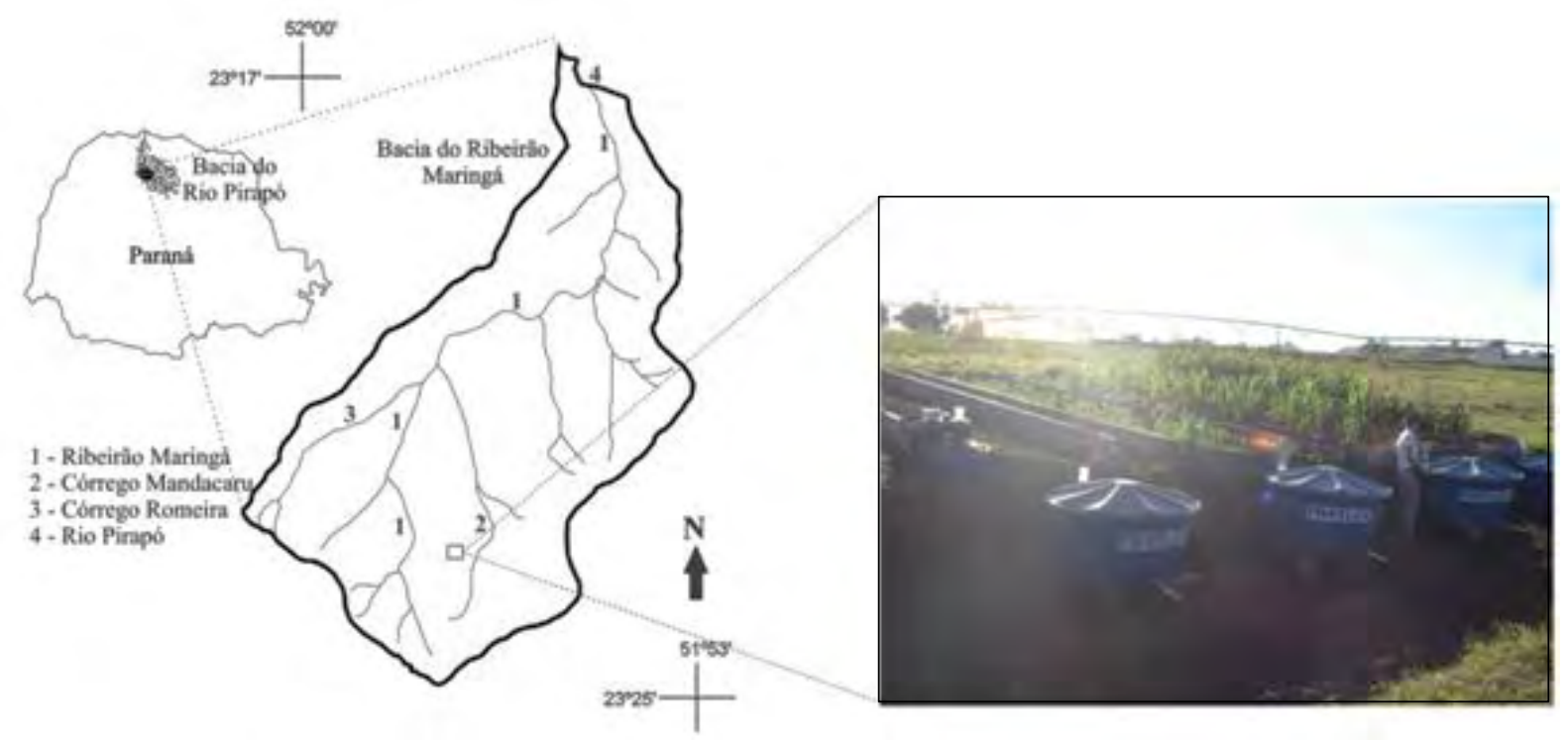

Figura 1. Localização da área de estudo.

O monitoramento da perda de solo foi realizado por meio de ciclos de cultivo, mantendo uma parcela com solo exposto (P1) e outra com vegetação (Brachiaria decumbens) (P2). Os ciclos foram compostos de culturas do período chuvoso (verão), com cultivo de milho (P3) e soja (P4), e culturas típicas do período de estiagem (inverno), com o cultivo do milho safrinha (P3) e trigo (P4).

As coletas de amostras de material transportado se totalizaram em seis campanhas no ciclo chuvoso e em sete campanhas no ciclo de estiagem, compreendendo o período de um ano. Em virtude do grande volume de água de escoamento superficial transportado para os sedimentadores (S) houve necessidade de realizar amostragem. Para tanto, realizou-se a raspagem do fundo dos sedimentadores, de modo a suspender os sedimentos, e prosseguiu-se a agitação do material com a finalidade de homogeneizar a solução água-solo e logo, coletar quantidade suficiente para as análises laboratoriais. 
Todas as amostras coletadas eram armazenadas em frascos de polietileno tereftalato (PET), anteriormente lavados. A sistemática de preservação das amostras seguiu a metodologia proposta em Standard Methods for Examination of Water and Wastewater (APHA, 1998).

A quantificação de solo transportado para cada sedimentador (S), em massa, seguiu o procedimento para a determinação de sólidos totais $\left(\mathrm{mg}\right.$. $\mathrm{L}^{-1}$ ), descrito em APHA (1998), sendo este resultado multiplicado pelo respectivo volume escoado encontrado em cada sedimentador.

A estimativa para a quantificação do volume da solução água-solo transportada para os sedimentadores foi realizada medindo-se a altura da lâmina d'água, com auxílio de trena. Posteriormente, essa medida foi aplicada na equação de volume, considerando que os sedimentadores possuem forma geométrica próxima a um cilindro.

A perda de sólidos totais por área da parcela experimental monitorada em relação ao volume escoado $\left(\mathrm{kg} \mathrm{ha}^{-1}\right)$ foi considerada numericamente equivalente ao Fator A da EUPS.

Logo após cada coleta amostral, os tanques eram esvaziados e lavados para que não houvesse a mistura com o material das chuvas subsequentes. As análises eram realizadas no Laboratório de Gestão, Controle e Preservação Ambiental (LGCPA), do Departamento de Engenharia Química da Universidade Estadual de Maringá (UEM).

Os dados de precipitação pluviométrica e de intensidade de chuva eram fornecidos pela Estação Climatológica da Universidade Estadual de Maringá (ECUEM), localizada a 1,8 km da área experimental, representando, portanto, satisfatoriamente as condições do local de estudo. Para a erosividade (Fator R), considerando o período de realização do experimento e o regime de chuvas, optou-se pelo equacionamento proposto em Bertoni e Lombardi Neto (2010). Para isso foram utilizadas as Equações 2 e 3.

A erodibilidade do solo (Fator $\mathrm{K}$ ) teve seu valor determinado experimentalmente em campo, nas condições da Parcela 1 (método direto), aplicando a Equação 4. Em prática, o fator topográfico (Fator LS) foi computado utilizando a Equação 5.

O fator de uso e manejo (Fator C) para as demais parcelas foi estimado por meio da relação entre a razão de perda de solo (RPS) e a fração do índice de erosividade (FEI ${ }_{30}$ ), conforme a Equação 6. Quanto ao Fator P, nas parcelas de erosão não foram utilizadas quaisquer práticas conservacionistas. O plantio foi realizado morro abaixo, levando, portanto, a um valor do Fator P igual 1,0.

\subsection{Sistema acústico}

O sistema acústico era composto por equipamentos responsáveis pela emissão do som, tais como amplificador de potência (ONEAL ${ }^{\circledR}$, modelo OP-2000), alto-falante (NATTS ${ }^{\circledR}, 200$ W RMS), driver (SELENIUM ${ }^{\circledR}$, modelo D-250X) no qual emitia o ruído rosa. Este sistema era alimentado por uma bateria automotiva comum acoplada a um inversor de tensão $\left(\right.$ SMART $\left.^{\circledR} 2000 \mathrm{~W}\right)$, que promovia a conversão da voltagem de $12 \mathrm{~V}$ para $127 \mathrm{~V}$, utilizada pelos equipamentos.

Para emprego em campo, foi elaborado um suporte para sustentação do alto-falante, driver e medidor de nível de pressão sonora da onda incidente e refletida. O NPS I era coletado a uma distância de $0,3 \mathrm{~m}$ da fonte sonora em uma altura de $0,8 \mathrm{~m}$ em relação à base, enquanto que o $\mathrm{NPS}_{\mathrm{R}}$ era coletado a uma distância de 2,0 m da fonte, em 1,00 m de altura (microfone à base). Para evitar a sobreposição de ondas incidentes e refletidas, a fonte sonora e o medidor acústico apresentavam uma inclinação de $42,5^{\circ}$ em relação à normal do suporte (Figura 2).

Em cada medição, o suporte contendo o sistema de emissão e recepção sonora foi posicionado no ponto central das parcelas por apresentar maior homogeneidade quanto à cobertura da superfície. 
Foi utilizado um sonômetro digital portátil da ICEL ${ }^{\circledR}$, modelo DL 4200, para medição do nível de pressão sonora da onda incidente e refletida $\left(\mathrm{NPS}_{\mathrm{I}}\right.$ e $\left.\mathrm{NPS}_{\mathrm{R}}\right)$. O equipamento utilizado é para medição de nível de pressão sonora de uso geral (classe 2), pois a ideia do trabalho era verificar o potencial de utilização de um equipamento de campo para estimar a capacidade de erosão. Em campo, foram aplicadas as seguintes configurações no equipamento: modo de coleta FAST, em escala dB C, com amplitude de 30 a $130 \mathrm{~dB}$, e durante um período total de 1 minuto e 30 segundos.

A)

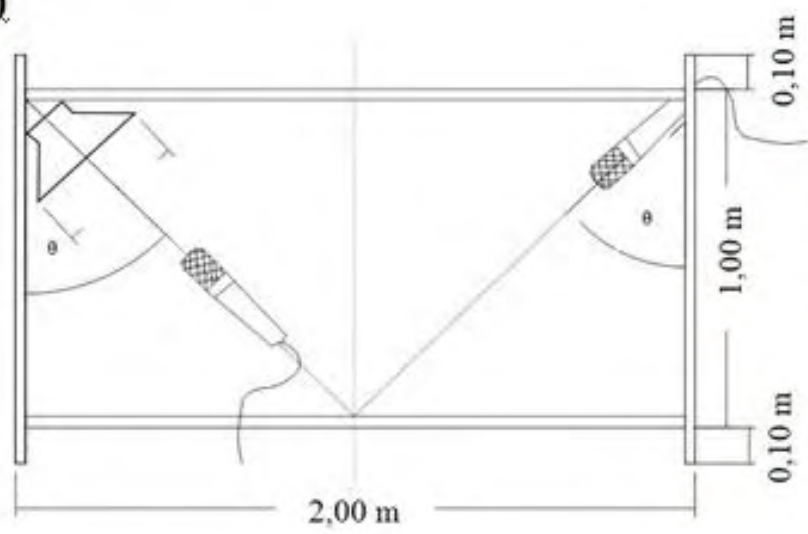

B)

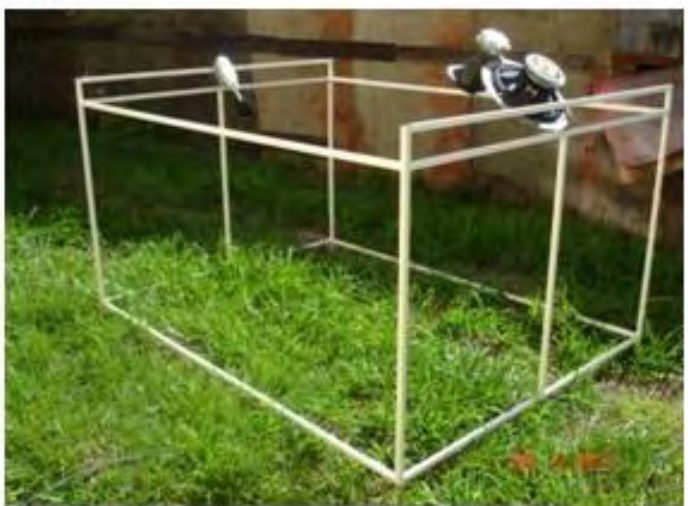

Figura 2. Disposição do suporte para sustentação do alto-falante, driver e medidor de nível de pressão sonora da onda incidente e refletida.

Os testes acústicos eram realizados o mais próximo possível da data de coleta do material transportado para os sedimentadores (S). No ciclo chuvoso foram realizadas quatro campanhas e na estiagem três campanhas. Os dados coletados eram armazenados no Data Logger do equipamento e foram processados por meio do cálculo do nível de pressão sonora equivalente $\left(\mathrm{L}_{\mathrm{EQ}}\right)$, dos níveis de pressões incidentes $\left(\mathrm{NPS}_{\mathrm{I}}\right)$ e níveis de pressões refletidas $\mathrm{NPS}_{\mathrm{R}}$, usando a Equação 9.

O efeito de cada cobertura das parcelas erosivas foi avaliado por meio do coeficiente de absorção sonora aparente da superfície $(\alpha)$ para a associação com os diferentes tipos de manejo e cobertura presentes nas parcelas. A Equação 7 (com $K=1$ - adotado) e a Equação 8 foram utilizadas para o cálculo. Ressalta-se que não foi medida a profundidade de penetração da onda incidente no solo.

\subsection{Análise estatística}

Para associação das propriedades acústicas $(\alpha)$ com os fatores da EUPS, foram realizados testes de correlação entre o coeficiente de absorção sonora aparente $(\alpha)$ e os valores de perda de solo (A), Fator K e Fator C obtidos nas superfícies das parcelas monitoradas.

Por se tratar de poucos dados disponíveis, em razão dos testes realizados diretamente em campo, assumiu-se distribuição linear dos resultados encontrados permitindo o emprego do método de correlação de Pearson. Os coeficientes de correlação de Pearson foram determinados utilizando-se o software Statistica ${ }^{\circledR}$.

\section{RESULTADOS E DISCUSSÃO}

\subsection{Monitoramento da perda de solo}

Os dados de precipitação pluviométrica e das intensidades pluviométricas para cada mês em que houve coleta de dados encontram-se apresentados na Figura 3.

De acordo com os dados pluviométricos históricos, fornecidos pela ECUEM, o intervalo de março a agosto refere-se aos meses em que a precipitação pluvial não é tão marcante e, por 
isso, pode ser considerado como um período aqui denominado como estiagem. Para efeito do presente estudo, os meses de outubro a fevereiro foram considerados como chuvosos.

Considerando os dados pluviométricos para os anos de 2011 e 2012, foi observada uma irregularidade no regime de chuvas durante o período de trabalho, caracterizando uma atipicidade local, segundo informações da rede de monitoramento online do Centro de Previsão do Tempo e Estudos Climáticos do Instituto Nacional de Pesquisas Espaciais (CPTEC- INPE).

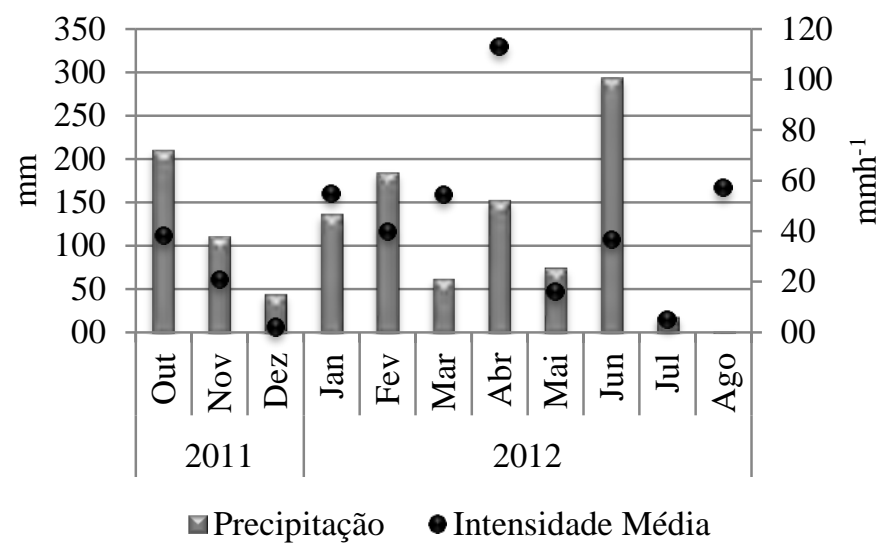

Figura 3. Precipitação pluviométrica (mm) e intensidade da precipitação $\left(\mathrm{mm} \mathrm{h}^{-1}\right)$.

Em relação às intensidades das chuvas, os dados obtidos apresentaram grande variabilidade: em dezembro, caracterizado por ser um mês em que as chuvas são fortes e constantes, a intensidade máxima medida foi de $2,0 \mathrm{~mm} \mathrm{~h}^{-1}$; e, em abril ocorreram chuvas com intensidades de até $113,0 \mathrm{~mm} \mathrm{~h}^{-1}$. Com os resultados apresentados, destaca-se que a condição de atipicidade e a variabilidade dos dados pluviométricos se mostraram críticas na projeção dos resultados do efeito erosivo sob a ação da chuva.

A quantificação do material total e efetivamente transportado aos sedimentadores $\left(\mathrm{kg} \mathrm{ha}^{1}\right)$ e das demais variáveis que regem a EUPS estão apresentadas na Tabela 1. Estes resultados refletem de modo satisfatório o tipo de manejo aplicado neste período do experimento e refletem também os eventos atípicos de precipitação ocorridos.

No que se refere à carga transferida das vertentes da bacia ao curso d'água principal, considerando que a bacia do ribeirão Maringá possui aproximadamente 6.300 ha ocupados por área rural com predominância dos Nitossolos Vermelhos Distroférrico latossólico (Santos e Morais, 2012), no total foram exportados ao exutório da bacia 15.753,15 toneladas de solo provenientes das áreas agrícolas no período de estudo. Em geral, as perdas foram maiores na parcela com solo exposto (91,5\%), seguida pela parcela com cultivo de milho $(4,4 \%)$, soja/trigo (2,5\%) e, por ultimo, a parcela com pastagem (1,6\%). O período de estiagem foi aquele em que o transporte de massa ao longo da vertente foi mais intenso, em função a atipicidade pluviométrica.

Em relação à erosividade, é extremamente importante destacar que os índices de erosividade (FEI) e o fator de erosividade (Fator R) calculados correspondem unicamente aos efeitos da intensidade das chuvas ocorridas durante a realização dos trabalhos experimentais, obtendo-se 65,8 MJ mm ha ${ }^{-1} \mathrm{~h}^{-1}$ no período chuvoso e de 74,3 $\mathrm{MJ} \mathrm{mm} \mathrm{ha}^{-1} \mathrm{~h}^{-1}$ no período de estiagem. De acordo com a classe de interpretação proposta por Silva et al. (2007), em geral, o grau da erosividade encontrado pode ser considerado "muito fraco".

Com inclinação da vertente em $9 \%$ e o comprimento de rampa de $12,5 \mathrm{~m}$, o fator topográfico (LS) estimado para as parcelas erosivas foi de 21,35. O valor total estimado para a erodibilidade (Fator $\mathrm{K}$ ), 16,3 $\mathrm{kg} \mathrm{h} \mathrm{MJ}^{-1} \mathrm{~mm}^{-1}$, mostrou-se dentro da faixa apresentada em 
Bertoni e Lombardi Neto (2010) para os Nitossolos. Westphalen (2007) alerta sobre a média resistência à erosão laminar que os Nitossolos argilosos apresentam devido aos mesmos estarem situados à média vertente, onde a ação das forças de escoamento são maiores.

Em relação ao uso e manejo (Fator C), observou-se a influência de cada tipo de cultura na perda de solo: a parcela com pastagem obteve total anual de $0,09 \mathrm{~kg} \mathrm{ha}^{-1} / \mathrm{kg} \mathrm{ha}^{-1}$; no período chuvoso a parcela 3 permaneceu com $0,59 \mathrm{~kg} \mathrm{ha}^{-1} / \mathrm{kg} \mathrm{ha}^{-1}$ e a parcela $4 \mathrm{com} 0,25 \mathrm{~kg}$ $\mathrm{ha}^{-1} / \mathrm{kg} \mathrm{ha}^{-1}$; no período de estiagem a parcela 3 permaneceu com $0,31 \mathrm{~kg} \mathrm{ha}^{-1} / \mathrm{kg} \mathrm{ha}^{-1}$ e a parcela 4 com $0,15 \mathrm{~kg} \mathrm{ha}^{-1} / \mathrm{kg} \mathrm{ha}^{-1}$. Em termos de manejo conservacionista, a presença de vegetação rasteira promoveu uma maior proteção ao solo.

Tabela 1. Variáveis da EUPS.

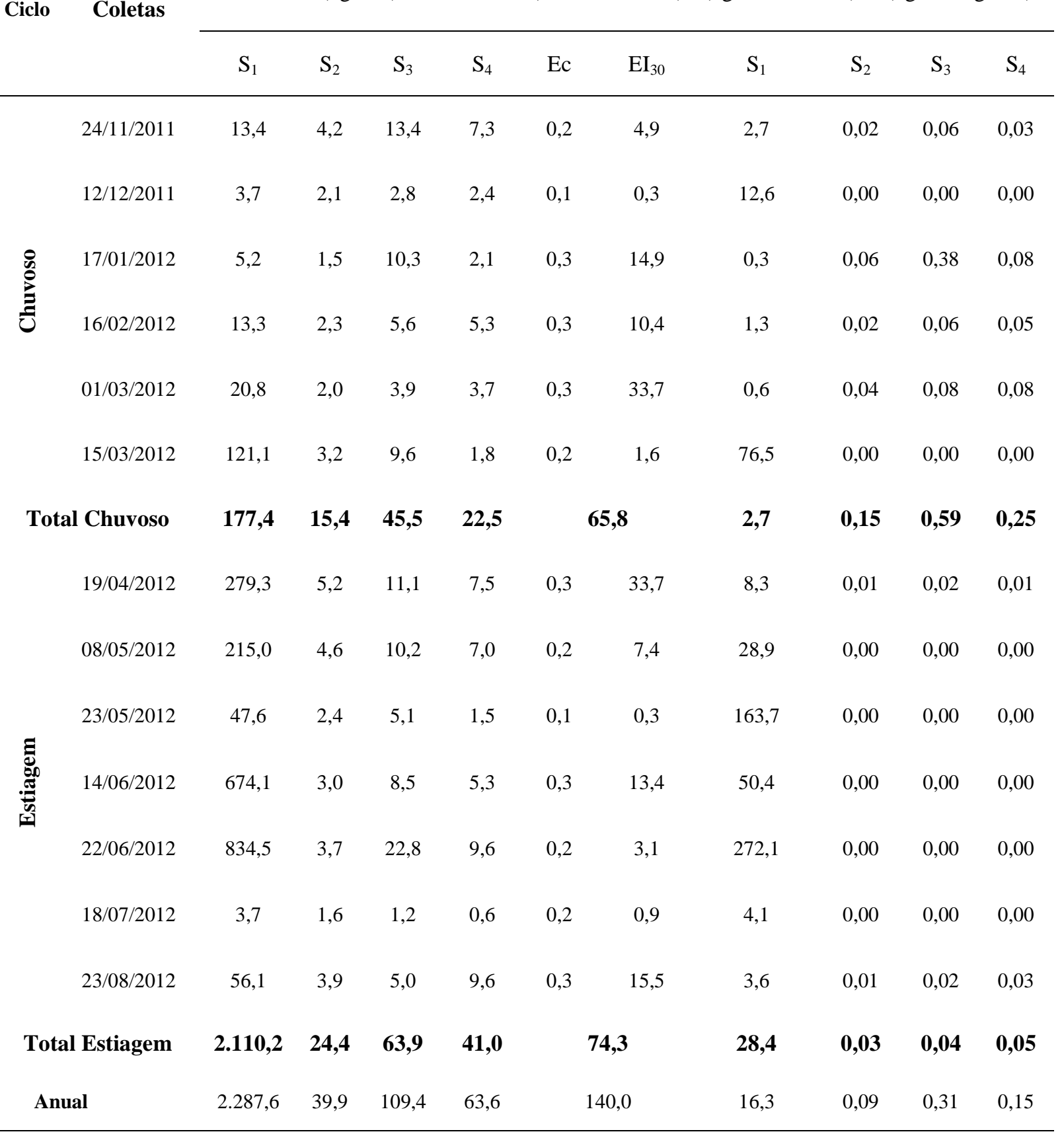




\subsection{Resposta acústica da superfície}

Os resultados obtidos no monitoramento acústico do nível de pressão sonora equivalente $\left(\mathrm{L}_{\mathrm{EQ}}\right)$, para os níveis equivalentes incidentes $\left(\mathrm{L}_{\mathrm{EQI}}\right)$ e aqueles refletidos $\left(\mathrm{L}_{\mathrm{EQR}}\right)$ pelas parcelas erosivas (P1, P2, P3 e P4), bem como os valores do coeficiente de absorção $(\alpha)$, calculados para as parcelas, encontram-se apresentados na Figura 4.

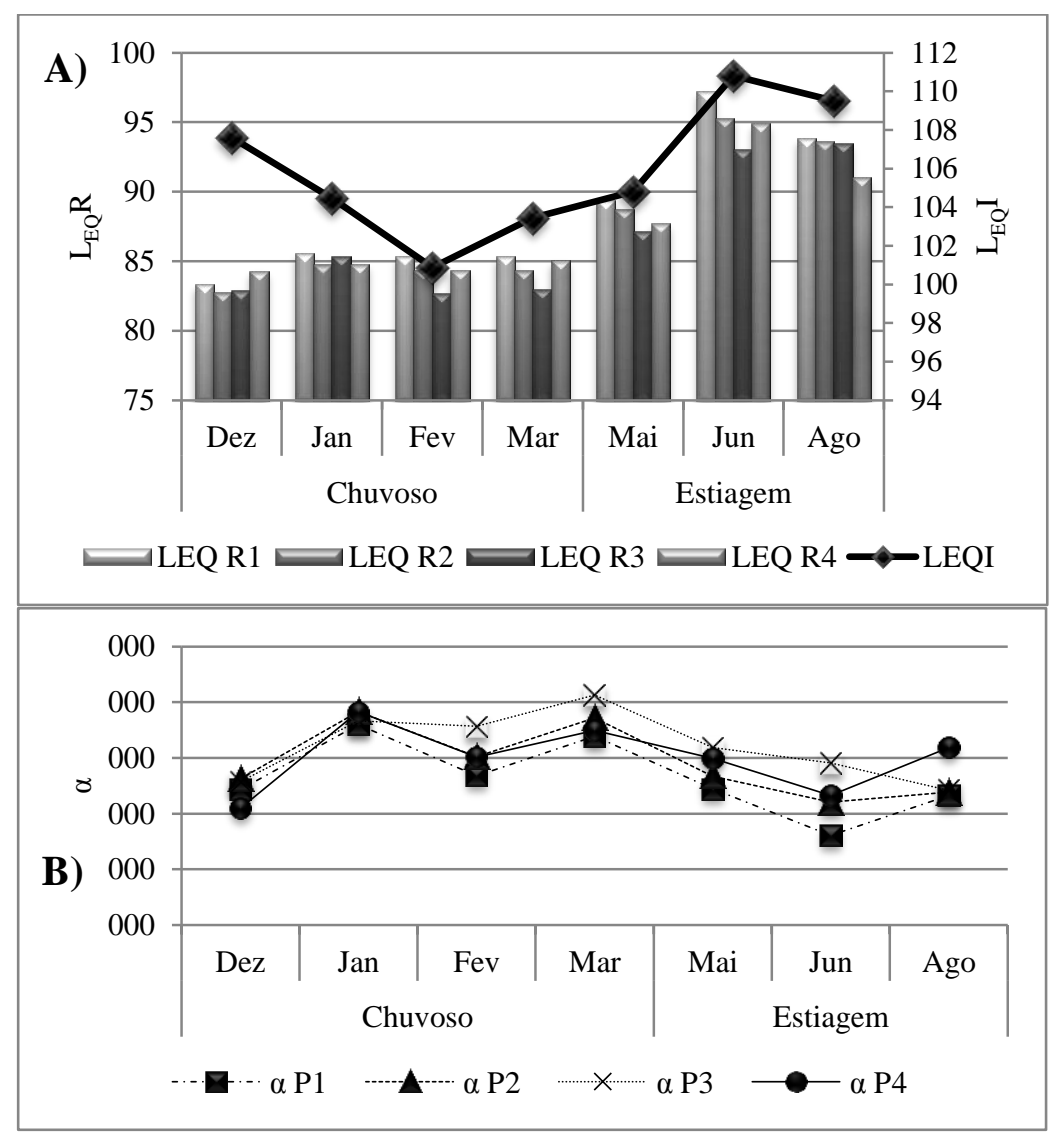

Figura 4. A) Nível de pressão sonora equivalente $\left(\mathrm{L}_{\mathrm{EQ}}\right)$ do sinal incidente (I) e refletido (R); B) Coeficiente de absorção sonora nas parcelas experimentais.

Inicialmente observou-se na Figura 4A que os valores obtidos para o $\mathrm{L}_{\mathrm{EQI}}$ não correspondem fielmente a uma quantidade constante de energia emitida, típica do ruído rosa. Os valores do $\mathrm{L}_{\mathrm{EQI}}$ permaneceram entre 103,4 e 110,8 dB, apresentando variações ao longo do tempo; já os valores do refletida $L_{\mathrm{EQR}}$, em geral, variaram entre 82,7 e 97,2 dB. É importante enfatizar que os valores do NPS e do $\mathrm{NPS}_{\mathrm{R}}$ contem as interferências ambientais ocorridas durante a realização dos testes. $\mathrm{O}$ vento, por exemplo, sempre foi um fator presente durante a realização dos ensaios em campo. Contudo, os fatores ambientais atuantes, e de difícil controle para testes ideais, foram levados de forma positiva visto que a maioria dos trabalhos existentes sobre o assunto limita-se a escala laboratorial, onde as condições de controle não representam fielmente a dinâmica real do ambiente natural e que são de interesse para o presente trabalho.

A variação dos fatores ambientais contidas nos níveis sonoros estudados não prejudicou a confiabilidade dos valores obtidos com o cálculo do coeficiente de absorção in situ ( $\alpha$ ), pois os NPS $S_{R}$ foram medidos imediatamente após o NPS I e nas mesmas condições de campo.

Ao analisar os resultados apresentados foi possível observar a interferência dos fatores de atenuação na propagação do som, com o nível sonoro incidente sempre maior que o refletido. 
Entre esses efeitos cabe salientar a distância entre fonte e receptor, variações de umidade e temperatura do ar, bem como os efeitos do solo e presença de vegetação.

Analisando os coeficientes de absorção, Figura 4B, verificou-se que houve uma diferença na resposta entre as parcelas, durante o período de estudo, indicando o efeito entre as diferentes rugosidades das superfícies. As parcelas com a presença de pastagem e as parcelas com os cultivos apresentam valores de $\alpha$ diferenciam-se mês a mês. Tal diferença poderia ser justificada pelo desenvolvimento, tipo de folha, caule e crescimento da vegetação ao longo do tempo.

Segundo Bistafa (2011), a vegetação e o solo existentes entre a fonte e o receptor tanto podem absorver como também espalhar o som incidente em $\pm 3 \mathrm{~dB}$. Contudo, não foi observado um padrão de absorção que prevaleceu com o tempo de monitoramento e que reforçasse essa teoria para as condições estudadas.

Considerando que os ensaios foram realizados dentro de um período de um ano, é provável que os efeitos da umidade do ar, variação na direção dos ventos e os gradientes verticais de temperatura que ocorreram entre os testes acústicos tenham colaborado fortemente nos $\mathrm{L}_{\mathrm{EQR}}$ medidos e, consequentemente, nos coeficientes $\alpha$ estimados. As condições ambientais locais, cujo controle é impraticável em campo, contribuíram para que não houvesse uma distinção clara ao longo do tempo de monitoramento entre os coeficientes de absorção sonora e o tipo de cobertura instalada nas parcelas.

Em média, o solo exposto (P1) apresentou o menor valor de absorção $(0,26)$ e, entre as parcelas com cultivo, a superfície com cultura do milho (P3) apresentou o maior coeficiente de absorção $(0,32)$, seguida pela cultura de soja/trigo $(0,31)$ e pastagem $(0,31)$.

\subsection{Correlação entre os fatores da EUPS e os coeficientes de absorção.}

Os coeficientes de correlação entre absorção acústica e alguns fatores da EUPS para cada ciclo de experimento encontram-se na Tabela 2, destacados em negrito.

Tabela 2. Coeficientes de correlação entre $\alpha$ e variáveis da EUPS

\begin{tabular}{ccccccccc}
\hline \multicolumn{7}{c}{ Período Chuvoso } \\
\hline & $\mathrm{A}_{1}$ & $\mathrm{~A}_{2}$ & $\mathrm{~A}_{3}$ & $\mathrm{~A}_{4}$ & $\mathrm{k}_{1}$ & $\mathrm{C}_{2}$ & $\mathrm{C}_{3}$ & $\mathrm{C}_{4}$ \\
\hline$\alpha_{1}$ & $\mathbf{0 , 4 1}$ & $-0,80$ & 0,87 & $-0,56$ & $\mathbf{0 , 3 3}$ & 0,53 & 0,65 & 0,37 \\
$\alpha_{2}$ & 0,48 & $\mathbf{- 0 , 7 3}$ & 0,86 & $-0,50$ & 0,37 & $\mathbf{0 , 4 9}$ & 0,59 & 0,37 \\
$\alpha_{3}$ & 0,70 & $-0,26$ & $\mathbf{0 , 6 1}$ & $-0,20$ & 0,53 & 0,21 & $\mathbf{0 , 5 0}$ & 0,22 \\
$\alpha_{4}$ & 0,36 & $-0,65$ & 0,91 & $\mathbf{- 0 , 4 5}$ & 0,20 & 0,62 & 0,65 & $\mathbf{0 , 5 6}$ \\
\hline & & & $\mathbf{P e r i ́ o d o ~ d e ~ E s t i a g e m ~}$ & & & \\
\hline & $\mathrm{A}_{1}$ & $\mathrm{~A}_{2}$ & $\mathrm{~A}_{3}$ & $\mathrm{~A}_{4}$ & $\mathrm{k}_{1}$ & $\mathrm{C} 2$ & $\mathrm{C}_{3}$ & $\mathrm{C}_{4}$ \\
\hline$\alpha_{1}$ & $\mathbf{- 0 , 9 9}$ & $-0,05$ & $-0,99$ & $-0,09$ & $\mathbf{0 , 3 6}$ & 0,32 & $-0,60$ & 0,35 \\
$\alpha_{2}$ & $-0,80$ & $\mathbf{- 0 , 5 4}$ & $-0,78$ & $-0,57$ & 0,77 & $\mathbf{- 0 , 1 9}$ & $-0,92$ & $-0,16$ \\
$\alpha_{3}$ & 0,15 & $-1,00$ & $\mathbf{- 0 , 1 9}$ & $-0,99$ & 0,92 & $-0,96$ & $\mathbf{- 0 , 7 8}$ & $-0,95$ \\
$\alpha_{4}$ & $-0,97$ & 0,29 & $-0,98$ & $\mathbf{0 , 2 6}$ & 0,02 & 0,63 & $-0,29$ & $\mathbf{- 0 , 6 5}$ \\
\hline
\end{tabular}


Nesse estudo, foram encontradas correlações fracas-moderadas entre $\alpha$ e o Fator A, com valores em módulo variando entre 0,41 e 0,73 no período chuvoso e valores variando entre 0,19 e 0,99 no período de estiagem. Entre $\alpha$ e o Fator C, os valores em módulo variaram entre 0,49 a 0,56 para o período chuvoso, indicando relação matemática diretamente proporcional, e entre -0,19 e -0,78 no período de estiagem, indicando relação matemática inversamente proporcional. Entre $\alpha$ e o Fator K, os coeficientes de correlação obtidos no período chuvoso e no de estiagem puderam ser considerados como "fraco", com valores variando entre 0,33 e 0,36 .

A partir dos resultados apresentados, não é possível obter uma explicação plausível para os fenômenos realmente atuantes no processo de absorção sonora utilizando para o cálculo o valor de $\mathrm{L}_{\mathrm{EQ}}$ e as variáveis envolvidas no processo de perda de solo. É muito provável que, além das condições de atipicidade pluviométrica, condições atmosféricas (vento, umidade), a condição de saturação do solo no momento da realização dos ensaios tenha sido um fator determinante, como constatado em Sharma e Gupta (2010). De acordo com Lo et al. (2007), a condição de saturação pode estar relacionada ainda à outras propriedades físicas do solo, tal como a condição de porosidade, permeabilidade e densidade do solo, que não foram medidas em campo no momento do ensaio o que, contudo, abre espaço para novas pesquisas na área.

Considerando a metodologia adotada no presente trabalho, apesar dos resultados não se apresentarem favoráveis para concepção da técnica acústica na predição dos fatores de perda de solo, é possível haver alguma relação entre os efeitos da incidência de uma onda acústica conhecida sobre diferentes rugosidades de superfície agrícolas considerando o espectro de frequência acústico. Os pequenos comprimentos de onda, característicos de alta freqüência, podem sensibilizar mais adequadamente à superfície em estudo e reproduzir resultados mais satisfatórios. Trabalhos futuros devem ser desenvolvidos sobre essa perspectiva.

\section{CONCLUSÃO}

Considerando que o presente estudo foi realizado em um período de eventos atípicos de precipitação pluviométrica, 91,5\% dos materiais transportados foram oriundos da parcela com solo exposto, 4,4\% foram do cultivo de milho, $2,5 \%$ foram da cultura de soja/trigo e 1,6\% foram da área com pastagem.

O Fator R total computado refletiu de modo satisfatório as observações feitas em campo. O Fator K permaneceu dentro da faixa típica da classe Nitossolos e indica um solo com média resistência aos processos erosivos. O cálculo do Fator $\mathrm{C}$ indicou a potencialidade do cultivo de milho e soja/trigo em relação à perda de solo nas parcelas.

Em relação à análise acústica das superfícies e considerando a metodologia adotada, os resultados apontaram que não houve grande diferenciação entre o coeficiente de absorção acústico e o tipo de cobertura do solo das parcelas erosivas.

\section{REFERÊNCIA}

AMERICAN PUBLIC HEALTH ASSOCIATION - APHA. Standard methods for the examination of water and wastewater. Washington, 1998. 1600p.

BERTONI, J.; LOMBARDI NETO, F. Conservação do solo. 4. ed. São Paulo: Ícone, 2010. 355p.

BISTAFA, S. R. Acústica aplicada ao controle do ruído. São Paulo: Edgard Blücher, 2011. 384p. 
CAROLINO de SÁ, M. A.; LIMA, J. M.; MELLO, C. R. Nível de energia ultrassônica para estudo da estabilidade de agregados de um latossolo sob diferentes usos. Pesquisa Agropecuária Brasileira, v. 37, p. 1649-1655, 2002. http://dx.doi.org/10.1590/S0100204X2002001100017

CHAMBERS, J. P.; SABATIER, J. M. Recent advances in utilizing acoustics to study surface roughness in agricultural surfaces. Applied Acoustics, v. 63, p.795-812, 2002. http://dx.doi.org/10.1016/S0003-682X(01)00057-3

EVEREST, F. A.; POHLMANN, K. C. Master handbook of acoustics. 5. ed. New York: Mc Graw-Hill, 2009. 510p.

FRACASTORO, G. V. Física tecnica ambientale. Parte III: acustica aplicata. Progetto Didattica in Rete. Dipartamento di Energetica. 1. ed. Torino: Otto, 2003. 39p.

KUTRUFF. H. Room acoustics. 5. ed. Spon Press, 2009. 389p.

LO, W. C.; YEH, C. L.; TSAI, C. T. Effect of soil texture on the propagation and attenuation of acoustic wave at unsaturated conditions. Journal of Hydrology, v. 38, p. 273-284, 2007. http://dx.doi.org/10.1016/j.jhydrol.2007.02.034

RIBEIRO, B. T.; LIMA, J. M.; MELLO, C. R.; CAROLINO de SÁ, M. A., OLIVEIRA, G. C. Relationship between raindrops and ultrasonic energy on the disruption of a Haplic Cambisol. Ciência e Agrotecnologia, v. 33, p. 814-823, 2009. http://dx.doi.org/10.1590/S1413-70542009000300021

SANTOS, M. L.; MORAIS, E. S. Produção de sedimento na bacia hidrográfica de pequena ordem: uso de modelos matemáticos, bacia do Ribeirão Maringá, Paraná - Brasil. Revista Brasileira de Geomorfologia, v. 13, p. 139-150, 2012.

SHARMA, R. K.; GUPTA, A. K. Continuous wave acoustic method for determination of moisture content in agricultural soil. Computers and Eletronics Agriculture, v. 73, p. 105-111, 2010. http://dx.doi.org/10.1016/j.compag.2010.06.002

SILVA, A. M.; SCHULZ, H. E.; CAMARGO, P. B. Erosão e hidrossedimentologia em bacias hidrográficas. São Carlos: RiMa, 2007. 153p.

VITORINO, A. C. T.; FERREIRA, M. M.; OLIVEIRA, G. C.; JÚNIOR, M. C.; CAROLINO de SÁ, M. A.; LIMA, J. M. et al. Níveis de energia ultrassônica na dispersão de argila em solos da região de Lavras (MG). Ciência e Agrotecnologia, v. 25, p. 1330-1336, 2001.

WESTPHALEN, L. A. Avaliação e classificação da erodibilidade dos solos do noroeste do Estado do Paraná: subsídio ao uso e ocupação da terra. Revista Eletrônica do Programa de Pós-Graduação em Geografia, v. 2, p. 42-42, 2007.

WISCHMEIER, W. H.; SMITH, D. D. Predicting rainfall erosion losses: a guide to conservation planning. Washington: U. S. Department of Agriculture, 1978. 67p. (Agriculture Handbook, n. 537). 


Ambiente \& Água - An Interdisciplinary Journal of Applied Science
ISSN 1980-993X - doi:10.4136/1980-993X
www.ambi-agua.net
E-mail: ambi-agua@agro.unitau.br

\title{
Variabilidade espaço-temporal da temperatura e difusividade térmica do solo de Lagoa Seca-PB
}

\author{
doi: 10.4136/ambi-agua.1474
}

Received: 30 Jul. 2014; Accepted: 19 Sep. 2014

\author{
Júlio Mannuel Tavares Diniz ${ }^{1 *}$; Renilson Targino Dantas ${ }^{1}$; \\ José Fideles Filho ${ }^{2}$ \\ ${ }^{1}$ Universidade Federal de Campina Grande (UFCG), Campina Grande, PB, Brasil \\ Unidade Acadêmica de Ciências Atmosféricas \\ ${ }^{2}$ Universidade Estadual da Paraíba (UEPB), Campina Grande, PB, Brasil \\ Centro de Ciências e Tecnologia \\ *Autor correspondente: e-mail: julio_mannuel@hotmail.com, \\ renilson@dca.ufcg.edu.br, fidelesfilho@uol.com.br
}

\section{RESUMO}

O objetivo deste trabalho foi investigar a variabilidade espaço-temporal da temperatura e difusividade térmica do solo de Lagoa Seca-PB. Para alcançar este objetivo foram utilizados sensores de temperatura, programados a operar ininterruptamente ao longo dos ciclos diários, instalados em quatro profundidades distintas do solo. Estes, por sua vez, monitoraram o comportamento térmico do solo durante todo o ano de 2010 e 2011. A fim de estimar a difusividade térmica do solo foram empregados três métodos distintos: método da amplitude, método do arco tangente e método logarítmico. O regime térmico do solo, no que diz respeito às horas e aos meses de ocorrência das máximas e mínimas temperaturas, apresentaram-se bastante semelhantes em ambos os anos. O método do arco tangente, para o caso específico da camada compreendida entre 5 e $50 \mathrm{~cm}$ de profundidade, não é adequado para a estimativa da difusividade térmica do solo.

Palavras-chave: difusividade térmica, física do solo, regime térmico, temperatura do solo.

\section{Spatial-temporal variability of temperature and soil thermal diffusivity from Lagoa Seca-PB}

\begin{abstract}
This work investigated the spatial-temporal variability of temperature and thermal diffusivity of Lagoa Seca-PB soil. To achieve this, we used temperature sensors, programmed to operate continuously over the daily cycles, installed in four distinct depths of soil. We monitored the soil's thermal behavior throughout a one-year period from 2010 to 2011. In order to estimate the soil's thermal diffusivity, we employed three distinct methods: the amplitude method, the arctangent method and the logarithmic method. The soil's thermal regime, i.e., the hours and months of occurrence of maximum and minimum temperatures, was very similar in both years. The arctangent method was inadequate to estimate the soil's thermal diffusivity, considering the specific layer between 5 and $50 \mathrm{~cm}$ depth.
\end{abstract}

Keywords: soil physics, soil temperature, thermal diffusivity, thermal regime. 


\section{INTRODUÇÃO}

De acordo com Lal e Shukla (2004), um dos elementos de maior importância para o desenvolvimento das plantas é a temperatura do solo. A atividade microbiológica poderá ser interrompida, as sementes poderão não germinar e as plantas não se desenvolverem, caso o solo não apresente uma temperatura dentro dos limites fisiológicos dos processos envolvidos (Prevedello, 1996). Esta também intervém diretamente nas propriedades e movimentação da água no interior do solo, na difusão dos solutos e dos gases, nas reações químicas e em uma série de outros processos importantes (Reichardt e Timm, 2004).

A temperatura do solo está em constante mudança visto que este é continuamente perturbado pela "entrada" de calor mediante incidência de radiação solar como também pela "saída" através de processos físicos como a evaporação (Diniz et al., 2014). A variação da temperatura do solo que uma planta consegue suportar é relativamente ampla, no entanto, seu desenvolvimento é seriamente comprometido a partir do momento em que o solo passa a assumir temperaturas abaixo ou acima de certos valores extremos (Hillel, 2004).

Quando uma mesma quantidade de energia está disponível para solos distintos o processo de aquecimento e resfriamento pode ser bastante variável em virtude de suas propriedades térmicas específicas (Diniz et al., 2013b). Basicamente, as propriedades térmicas dos solos que intervêm diretamente em seu regime de temperatura são denominadas de calor específico, condutividade térmica e difusividade térmica. A difusividade térmica do solo está diretamente relacionada à capacidade desse meio em conduzir calor através de seu perfil vertical, ou seja, é um indicativo da rapidez com que o calor difunde-se no solo. Esta propriedade é função da constituição, granulometria, densidade e estrutura do solo (Silans et al., 2006).

Sabendo-se da sua importância e uma vez que cada tipo de solo possui características específicas, faz-se necessário que sejam identificadas para cada situação particular as suas propriedades térmicas (Danelichen e Biudes, 2011). Até então, poucos estudos dessa natureza foram realizados pela comunidade científica para os solos do Brasil (Diniz et al., 2013c). Portanto, a fim de contribuir para o desenvolvimento desta área científica, o presente trabalho tem como objetivo investigar a variabilidade espaço-temporal das temperaturas e difusividade térmica do solo de Lagoa Seca-PB.

\section{MATERIAL E MÉTODOS}

\subsection{Descrição da área de estudo}

O estudo foi desenvolvido na Estação Experimental de Lagoa Seca $\left(7,16^{\circ} \mathrm{S} ; 35,85^{\circ} \mathrm{O}\right.$ e altitude média de $634 \mathrm{~m}$ ), pertencente à Empresa Estadual de Pesquisa Agropecuária da Paraíba - EMEPA/PB. Esta se encontra situada no Sítio Imbaúba, mesorregião do agreste paraibano, cerca de $15 \mathrm{~km}$ da cidade de Campina Grande-PB. Possui uma área total de 110 ha (hectares), sendo esta composta por áreas experimentais e reservas florestais. Segundo a classificação climática de Köppen, o clima da região é do tipo tropical chuvoso, com estação seca no verão. A precipitação média anual é da ordem de $940 \mathrm{~mm}$ (maior concentração de chuva ocorre no período compreendido entre março e agosto), com uma umidade relativa e temperatura média anual do ar de aproximadamente $65 \%$ e $21,6^{\circ} \mathrm{C}$, respectivamente (Araújo et al., 2010).

De acordo com Araújo (2008), o solo da região é classificado como Neossolo Regolítico (também denominado Regossolo). Neossolos são solos pouco desenvolvidos e geralmente pouco profundos, em via de formação devido à reduzida atuação dos processos pedogenéticos (conseqüência da resistência do material de origem ao intemperismo, condição climática ou geomorfológica) ou ao pouco tempo de ação dos agentes intempéricos e pedológicos (Pedron, 2007). O Neossolo Regolítico é um tipo de solo que apresenta textura arenosa e baixa capacidade de adsorção de nutrientes, quando comparado com solos argilosos 
(Tito et al., 1997); naturalmente, possui baixo teor de matéria orgânica e nitrogênio que diminuem, após alguns anos de uso.

\subsection{Dados}

Para o desenvolvimento da presente pesquisa foram utilizados dados obtidos ao longo dos anos de 2010 e 2011, a partir de uma estação meteorológica automática em funcionamento na Estação Experimental de Lagoa Seca. Com o objetivo de monitorar o regime térmico do solo foram utilizados sensores de temperatura operando ininterruptamente ao longo dos ciclos diários (o datalogger encontra-se programado a fornecer a magnitude média horária desta variável), instalados em quatro profundidades distintas do solo: 5, 15, 30 e 50 centímetros. Também se fez uso de um pluviômetro, instalado de acordo com as especificações da Organização Mundial de Meteorologia (OMM), a fim de obter informações acerca dos totais pluviométricos.

\subsection{Difusividade térmica do solo}

A fim de estimar a difusividade térmica considerou-se o solo um meio homogêneo, isotrópico, sem fontes ou sumidouros de calor, restringindo a análise apenas aos processos que ocorrem na direção vertical (Fideles Filho, 1988; Diniz et al., 2013a). A partir dessas considerações irá ser aplicado o tratamento clássico de condução de calor a um meio homogêneo proposto por Fourier que permite conhecer as amplitudes e fases da onda de calor.

Uma vez que a difusividade térmica é calculada para certas camadas específicas do solo, faz-se necessário que sejam destacados os critérios adotados nesta pesquisa. Devido à disponibilidade de dados as estimativas foram realizadas para as porções do solo denominadas de camada 1 (estende-se desde 5 até 15 centímetros de profundidade), camada 2 (estende-se desde 15 até 30 centímetros de profundidade), camada 3 (estende-se desde 30 até 50 centímetros de profundidade) e camada 4 (estende-se desde 5 até 50 centímetros de profundidade).

Mediante as informações e considerações anteriores foram empregados determinados métodos a fim de se estimar a difusividade térmica do solo, cujos detalhes podem ser encontrados em Gao et al. (2009). Os utilizados na presente pesquisa são denominados de método da amplitude, método do arco tangente e método logarítmico.

\subsection{Simulação da temperatura do solo}

A representação matemática mais simples do regime de temperatura do solo é obtida assumindo-se que, para todo o perfil vertical, a temperatura oscila como uma pura função harmônica (senoidal) do tempo em torno de um valor médio. Esta pode ser uma aproximação grosseira (as variações reais não são ordenadas), no entanto, em determinadas situações pode fornecer valores bastante satisfatórios. Partindo deste pressuposto, após algumas considerações e manipulações matemáticas, obtém-se a Equação 1.

$$
\mathrm{T}(\mathrm{z}, \mathrm{t})=\mathrm{T}_{\text {média }}+\mathrm{A}_{\mathrm{o}} \mathrm{e}^{(-\mathrm{z} / \mathrm{d})}\left[\sin \left(\omega \mathrm{t}-\frac{7 \pi}{12}-\frac{\mathrm{z}}{\mathrm{d}}\right)\right]
$$

em que:

$\mathrm{T}_{\text {média }}$ a a temperatura média da superfície,

$\mathrm{A}_{\mathrm{o}}$ é a amplitude da flutuação de temperatura da superfície,

$\mathrm{z}$ é a profundidade em análise,

t é o instante para o qual se deseja simular a temperatura, 
$\omega$ é a velocidade angular da Terra $\left(\omega=7,27 \times 10^{-5} \mathrm{~s}^{-1}\right) \mathrm{e}$

d é a profundidade de amortecimento.

A fim de empregar a Equação 1, uma vez que não há equipamento destinado a mensurar a temperatura da superfície, considera-se nesta pesquisa que a $\mathrm{T}_{\text {média }}$ é igual aquela obtida para a profundidade de $5 \mathrm{~cm}$. A profundidade de amortecimento é obtida a partir da Equação 2.

$$
d=\left(\frac{2 \alpha}{\omega}\right)^{1 / 2}
$$

em que:

$\omega$ é a velocidade angular da Terra e

$\alpha$ é a difusividade térmica do solo.

Verifica-se, portanto, que a única informação desconhecida e necessária para simular a temperatura do solo é aquela referente à difusividade térmica do presente meio.

A Equação 1, fazendo uso das magnitudes da difusividade térmica do solo obtidas mediante as considerações e métodos apresentados anteriormente, será utilizada na simulação da temperatura do solo para diferentes profundidades e cada hora do dia. Temperaturas próximas daquelas mensuradas indica que os métodos utilizados forneceram valores condizentes com a realidade (Diniz, 2014).

\subsection{Análise dos dados}

Após simular a temperatura do solo empregando as diferentes magnitudes da difusividade térmica, faz-se necessário verificar o quanto estes valores se aproximam daqueles obtidos pelos sensores térmicos. Diferentes indicadores estatísticos podem ser utilizados a fim de alcançar este objetivo. Os utilizados nesta pesquisa são aqueles denominados de coeficiente de correlação (r) e índice de concordância (d) cujos detalhes podem ser encontrados em Larson e Farber (2004) e Willmott et al. (1985), respectivamente.

O índice de confiança (c) também será utilizado na presente pesquisa a fim de verificar o desempenho da Equação 1, na simulação da temperatura do solo para diferentes profundidades e horas do dia. De acordo com Camargo e Sentelhas (1997), a magnitude deste pode ser obtida a partir da Equação 3.

$$
\mathrm{c}=\mathrm{rxd}
$$

em que:

r é o coeficiente de correlação e

d é o índice de concordância.

O desempenho da Equação 1, avaliado a partir do índice de confiança, será classificado de acordo com a Tabela 1. 
Tabela 1. Classificação de desempenho com base no índice de confiança (Fonte: Zonta et al., 2012).

\begin{tabular}{cl}
\hline Valor de c & Desempenho \\
\hline$>0,85$ & Ótimo \\
0,76 a 0,85 & Muito bom \\
0,66 a 0,75 & Bom \\
0,61 a 0,65 & Mediano \\
0,51 a 0,60 & Sofrível \\
0,41 a 0,50 & Mau \\
$\leq 0,40$ & Péssimo \\
\hline
\end{tabular}

\section{RESULTADOS E DISCUSSÃO}

A partir dos dados de temperatura do solo tornou-se possível o estudo do regime térmico diário e anual do presente meio. Encontra-se exposto nas Figuras 1 e 2, para aquelas profundidades em estudo, o comportamento térmico do solo observado durante os anos de 2010 e 2011, respectivamente.

Verifica-se, a partir da análise das Figuras 1 e 2, que o comportamento térmico do solo observado em ambos os ciclos anuais são significativamente semelhantes. As temperaturas mais elevadas observadas em todo o perfil vertical foram aquelas oriundas dos primeiros e últimos meses dos respectivos anos (Janeiro-Março e Outubro-Dezembro). Para todo o período de análise as máximas foram registradas entre os dias 01 e 21 de março do ano de 2010, alcançando magnitudes da ordem dos $45^{\circ} \mathrm{C}$ (temperatura referente a profundidade de $5 \mathrm{~cm}$ ). Em contrapartida, as mínimas foram observadas em torno do mês de Junho, sendo registradas magnitudes da ordem dos $16^{\circ} \mathrm{C}$ (temperatura referente a profundidade de $5 \mathrm{~cm}$ ). Esse comportamento, uma vez que a responsável pelo aquecimento é a energia advinda do Sol, já era esperado visto que no verão (inverno) há uma maior (menor) disponibilidade de energia solar à superfície (Diniz et al., 2013d).

Uma vez que as regiões mais profundas foram as que apresentaram menor variabilidade térmica anual, pode-se considerar que estas grandezas estão inversamente relacionadas. Verifica-se, para a profundidade de $5 \mathrm{~cm}$, uma amplitude térmica em torno dos $29^{\circ} \mathrm{C}$ e $23^{\circ} \mathrm{C}$ para os ciclos anuais de 2010 e 2011, respectivamente. Em contrapartida, aquela referente à profundidade de $50 \mathrm{~cm}$, não chega a ultrapassar os $13^{\circ} \mathrm{C}$. O ciclo anual que apresentou maior variabilidade térmica foi aquele de 2010. A precipitação pluvial foi a principal responsável pelo fenômeno mencionado anteriormente, a registrada para todo o ano de 2010 foi quase que a metade daquela precipitada em 2011, uma vez que esta ocasiona uma alteração considerável no teor de umidade do solo e é capaz de impedir que uma parcela significativa da energia proveniente do Sol incida na superfície. De acordo com Carneiro et al. (2014), o regime pluviométrico exerce grande influência na incidência de radiação solar à superfície sendo, portanto, de grande contribuição para a variabilidade da temperatura do solo no decorrer do ano. Devido à disponibilidade energética pouco se alterar ao longo do ano em regiões próximas ao equador geográfico (baixas latitudes), a variabilidade anual das condições térmicas do solo não é acentuada como a oriunda de demais regiões (médias e altas latitudes). 

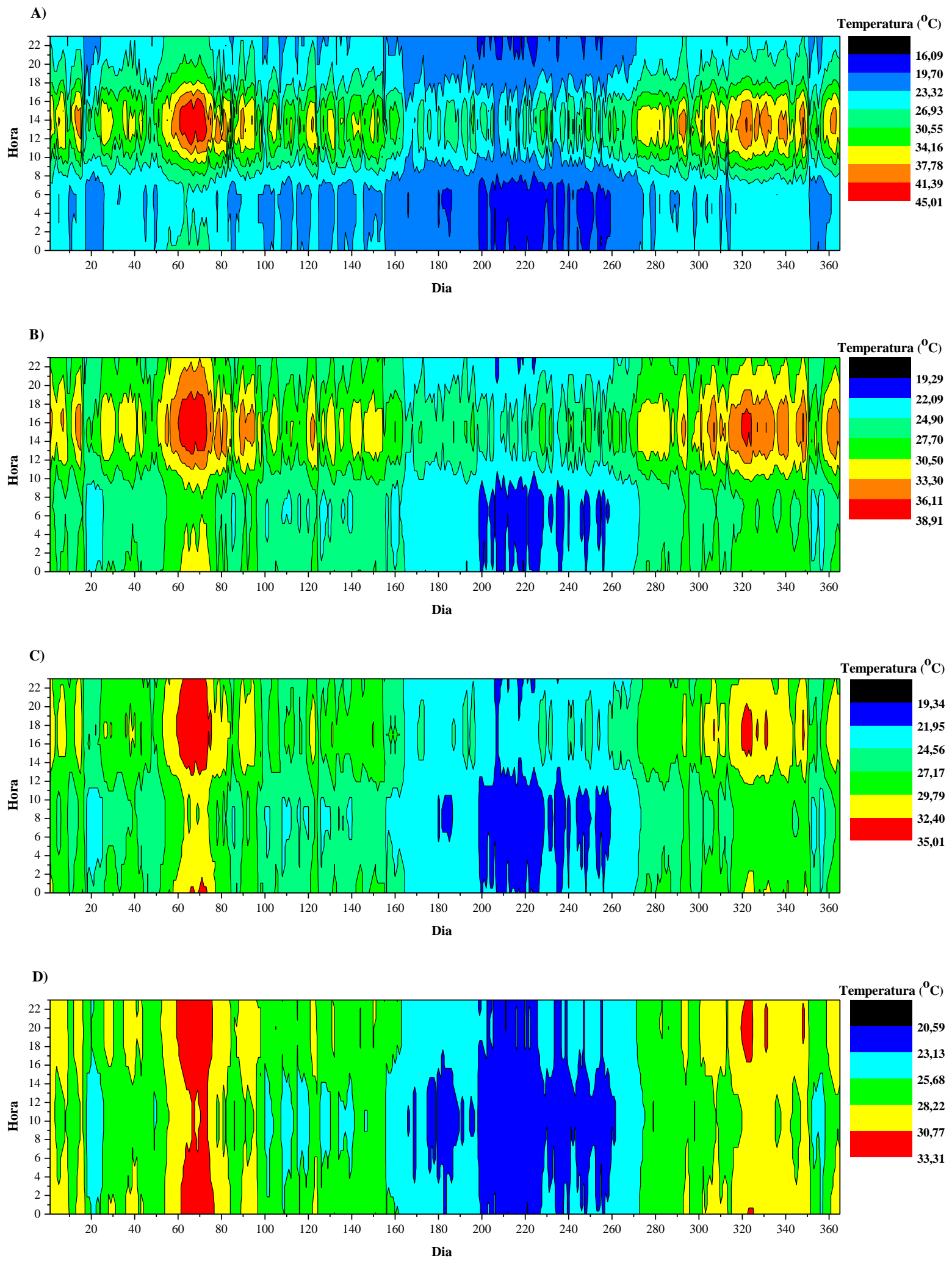

Figura 1. Comportamento térmico do solo de Lagoa Seca-PB, observado ao longo de todo o ano de 2010, referente às seguintes profundidades: $5 \mathrm{~cm}(\mathrm{~A}), 15 \mathrm{~cm}$ (B), $30 \mathrm{~cm}(\mathrm{C})$ e $50 \mathrm{~cm}(\mathrm{D})$. 

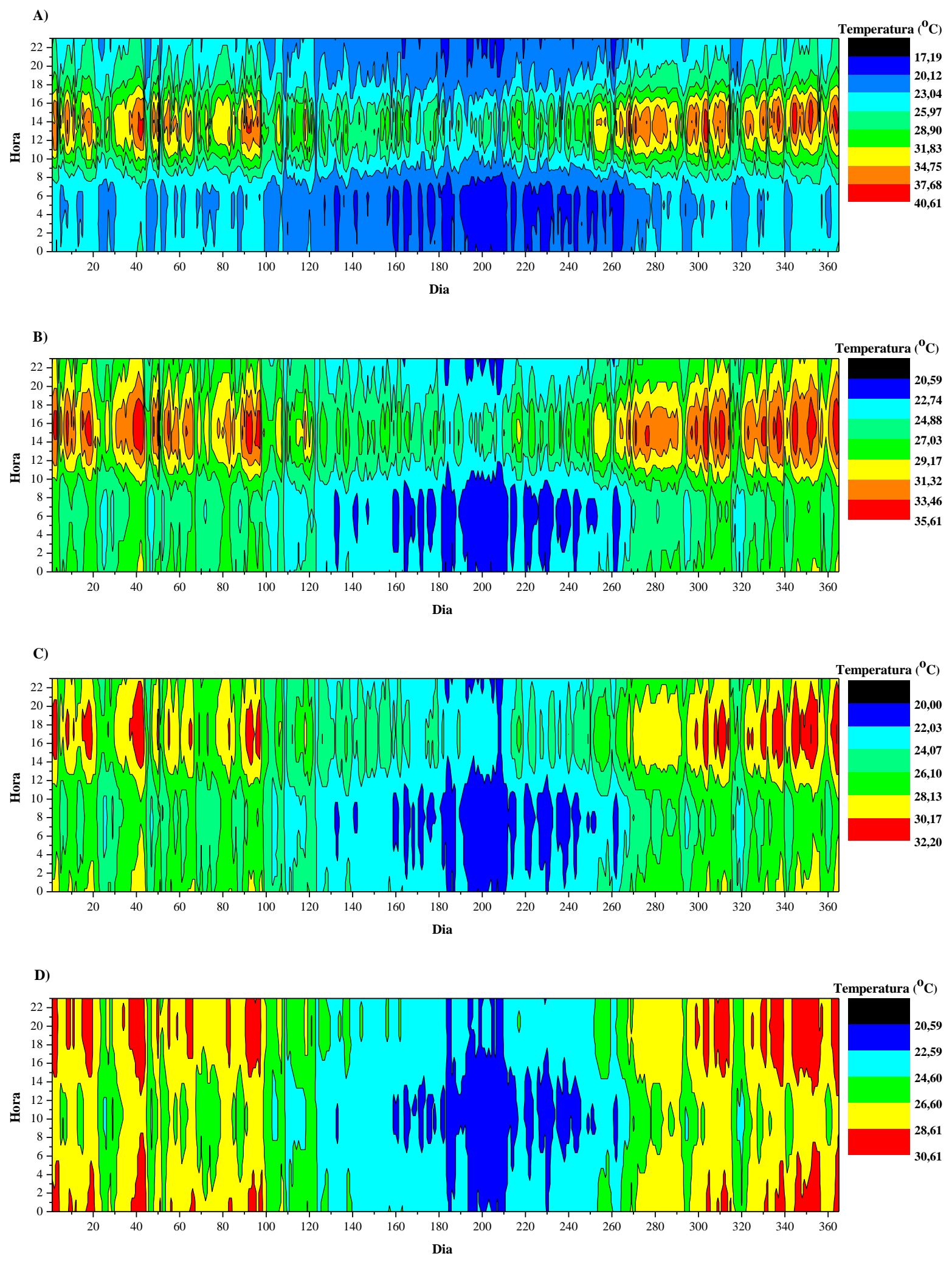

Figura 2. Comportamento térmico do solo de Lagoa Seca-PB, observado ao longo de todo o ano de 2011, referente às seguintes profundidades: $5 \mathrm{~cm}$ (A), $15 \mathrm{~cm}(\mathrm{~B}), 30 \mathrm{~cm}(\mathrm{C})$ e $50 \mathrm{~cm}(\mathrm{D})$.

A precipitação pluvial é capaz de alterar significativamente o comportamento térmico diário do solo. Na ausência deste fenômeno, verifica-se que os ciclos térmicos diários são bastante semelhantes, divergindo basicamente quanto às magnitudes das temperaturas. Neste caso específico, constata-se até meados das 10 horas da manhã o progressivo aumento das 
temperaturas à medida que se avança em profundidade, com os valores máximos sendo observados em $50 \mathrm{~cm}$. Após esse período, em conseqüência da incidência mais acentuada de radiação solar, a temperatura da superfície do solo e de regiões adjacentes passa a apresentar um significativo aumento de suas magnitudes. No entanto, à medida que se avança em profundidade verifica-se que a variabilidade térmica tende a diminuir (variações bastante sutis), de modo que as temperaturas permanecem quase que constante ao longo dos ciclos diários na profundidade de $50 \mathrm{~cm}$. Portanto, como já havia sido destacado anteriormente para o ciclo anual, ambas apresentam-se novamente inversamente relacionadas (quanto maior a profundidade, menor será a variabilidade térmica diária e anual). Segundo Azevedo e Galvani (2003), quanto mais próximo da superfície, maior é a amplitude térmica e mais imediata é a resposta da temperatura do solo à incidência da radiação solar. De acordo com Gasparim et al. (2005), pode-se definir a profundidade de $20 \mathrm{~cm}$ como a profundidade de transição entre as grandes e as pequenas variações da temperatura do solo. As regiões mais próximas a superfície apresentam maior amplitude térmica diária em decorrência da maior facilidade em ganhar (período diurno) e perder (período noturno) calor durante os ciclos diários.

As temperaturas mais elevadas observadas ao longo dos ciclos diários foram aquelas registradas em torno dos seguintes horários: 14 horas (profundidade de $5 \mathrm{~cm}$ ), 16 horas (profundidade de $15 \mathrm{~cm}$ ) e 18 horas (profundidade de $30 \mathrm{~cm}$ ). Em particular, para a profundidade de $50 \mathrm{~cm}$, estas foram registradas nas primeiras e últimas horas do ciclo diário. Oliveira et al. (2010), fazendo uso de dados obtidos em uma localidade relativamente próxima, verificaram que em regiões superficiais as máximas temperaturas são observadas entre as 13 e 14 horas. Ainda segundo estes autores, em profundidades intermediárias as máximas são observadas entre o fim da tarde e início da noite. Ao comparar à hora de ocorrência das máximas temperaturas do solo verifica-se, portanto, que estas não ocorrem simultaneamente ao longo de todo o perfil vertical. Este fenômeno está associado ao fato de que o solo exerce certa "resistência" a propagação de calor (quanto menor esta "resistência", menor será a defasagem de ocorrência das temperaturas máximas), variando de acordo com as suas propriedades térmicas específicas. Portanto, esta mudança em comparação a região mais superficial é consequência do fluxo de calor no interior do solo ocorrer de maneira relativamente lenta.

Os dados de temperatura foram utilizados para estimar a difusividade térmica diária média mensal do solo. Esta grandeza, mediante o emprego de métodos distintos, foi estimada para quatro camadas específicas do respectivo meio. Nas Tabelas 2 e 3 estão apresentados os valores obtidos a partir de dados coletados ao longo do ano de 2010 e 2011, respectivamente.

As estimativas da difusividade térmica do solo estão de acordo com aquelas obtidas em Rao et al. (2005), Oliveira et al. (2010), Danelichen e Biudes (2011), Diniz et al. (2013e). No que diz respeito à camada-1, com base na análise das Tabelas 2 e 3 , verifica-se que as mais elevadas magnitudes da difusividade térmica são aquelas oriundas do método do arco tangente. Neste caso específico, de acordo com o observado por Rao et al. (2005), apresentaram-se bastante semelhantes as estimativas provenientes dos métodos da amplitude e logarítmico. Para todo o ano de 2010, ainda com relação à camada-1, observa-se que as mais elevadas magnitudes são aquelas associadas ao mês de Junho. Portanto, comparados aqueles referentes aos demais meses deste ano, pode-se concluir que os ciclos diários pertencentes a este mês possuíram em média maior capacidade de conduzir calor através desta camada particular do solo. Este resultado é conseqüência da elevada precipitação pluvial registrada neste mês (159,8 milímetros), o espaço poroso do solo passa então a ser preenchido por água, propiciando a esta maior capacidade de condução (vale ressaltar que a condutividade térmica da água é bastante superior a do ar). Uma vez que este fenômeno não foi observado nas camadas adjacentes, pode-se deduzir que a água não infiltrou de maneira considerável através do perfil vertical do solo. 
Tabela 2. Difusividade térmica diária média mensal do solo $\left(x 10^{-6} \mathrm{~m}^{2} / \mathrm{s}\right)$, referente a quatro camadas específicas, estimada a partir de métodos distintos e de dados coletados ao longo do ano de 2010.

\begin{tabular}{|c|c|c|c|c|c|}
\hline \multirow{2}{*}{ Mês } & \multirow{2}{*}{ Método } & \multicolumn{4}{|c|}{ Camadas $(\mathbf{m})$} \\
\hline & & $0,05-0,15$ & 0,15-0,30 & $0,30-0,50$ & $0,05-0,50$ \\
\hline \multirow[t]{3}{*}{ Janeiro } & Amplitude & 0,75 & 2,57 & 2,51 & 1,80 \\
\hline & Arco Tangente & 1,26 & 2,46 & 2,28 & 4,87 \\
\hline & Logarítmico & 0,70 & 2,21 & 2,86 & 1,77 \\
\hline \multirow[t]{3}{*}{ Fevereiro } & Amplitude & 0,83 & 2,72 & 3,56 & 2,16 \\
\hline & Arco Tangente & 1,33 & 2,66 & 2,60 & 4,25 \\
\hline & Logarítmico & 0,86 & 2,24 & 3,54 & 2,05 \\
\hline \multirow[t]{3}{*}{ Março } & Amplitude & 0,76 & 2,68 & 2,80 & 1,90 \\
\hline & Arco Tangente & 1,18 & 3,11 & 2,67 & 4,13 \\
\hline & Logarítmico & 0,83 & 2,43 & 3,34 & 2,03 \\
\hline \multirow[t]{3}{*}{ Abril } & Amplitude & 0,75 & 2,54 & 3,47 & 2,01 \\
\hline & Arco Tangente & 1,30 & 2,53 & 2,26 & 4,79 \\
\hline & Logarítmico & 0,70 & 2,46 & 3,70 & 1,99 \\
\hline \multirow[t]{3}{*}{ Maio } & Amplitude & 1,02 & 2,47 & 2,65 & 2,01 \\
\hline & Arco Tangente & 1,38 & 2,58 & 2,32 & 4,54 \\
\hline & Logarítmico & 1,08 & 2,17 & 2,89 & 2,03 \\
\hline \multirow[t]{3}{*}{ Junho } & Amplitude & 1,11 & 2,20 & 1,93 & 1,75 \\
\hline & Arco Tangente & 1,98 & 2,61 & 1,72 & 4,83 \\
\hline & Logarítmico & 1,09 & 1,96 & 2,07 & 1,73 \\
\hline \multirow[t]{3}{*}{ Julho } & Amplitude & 1,00 & 2,49 & 3,12 & 2,13 \\
\hline & Arco Tangente & 1,52 & 2,12 & 1,77 & 5,81 \\
\hline & Logarítmico & 0,92 & 2,57 & 2,47 & 1,92 \\
\hline \multirow[t]{3}{*}{ Agosto } & Amplitude & 1,09 & 2,59 & 3,19 & 2,24 \\
\hline & Arco Tangente & 1,61 & 2,31 & 2,18 & 4,68 \\
\hline & Logarítmico & 1,07 & 2,22 & 3,74 & 2,23 \\
\hline \multirow[t]{3}{*}{ Setembro } & Amplitude & 0,87 & 2,54 & 3,15 & 2,05 \\
\hline & Arco Tangente & 1,51 & 2,52 & 2,22 & 4,55 \\
\hline & Logarítmico & 0,88 & 2,27 & 2,78 & 1,90 \\
\hline \multirow[t]{3}{*}{ Outubro } & Amplitude & 0,59 & 2,05 & 2,88 & 1,62 \\
\hline & Arco Tangente & 1,28 & 2,33 & 2,20 & 5,10 \\
\hline & Logarítmico & 0,62 & 1,74 & 3,09 & 1,62 \\
\hline \multirow[t]{3}{*}{ Novembro } & Amplitude & 0,92 & 2,91 & 3,04 & 2,15 \\
\hline & Arco Tangente & 1,15 & 2,73 & 2,55 & 4,52 \\
\hline & Logarítmico & 0,91 & 2,65 & 3,28 & 2,15 \\
\hline \multirow[t]{3}{*}{ Dezembro } & Amplitude & 0,91 & 2,56 & 3,03 & 2,06 \\
\hline & Arco Tangente & 1,53 & 2,78 & 2,27 & 4,29 \\
\hline & Logarítmico & 1,01 & 2,28 & 3,17 & 2,09 \\
\hline
\end{tabular}


Tabela 3. Difusividade térmica diária média mensal do solo $\left(\times 10^{-6} \mathrm{~m}^{2} / \mathrm{s}\right)$, referente a quatro camadas específicas, estimada a partir de métodos distintos e de dados coletados ao longo do ano de 2011.

\begin{tabular}{|c|c|c|c|c|c|}
\hline \multirow{2}{*}{ Mês } & \multirow{2}{*}{ Método } & \multicolumn{4}{|c|}{ Camadas (m) } \\
\hline & & $0,05-0,15$ & 0,15-0,30 & $0, \mathbf{3 0 - 0 , 5 0}$ & $0,05-0,50$ \\
\hline \multirow[t]{3}{*}{ Janeiro } & Amplitude & 1,14 & 3,09 & 2,92 & 2,31 \\
\hline & Arco Tangente & 1,59 & 2,70 & 1,91 & 4,79 \\
\hline & Logarítmico & 1,17 & 2,88 & 2,99 & 2,30 \\
\hline \multirow[t]{3}{*}{ Fevereiro } & Amplitude & 1,06 & 3,00 & 3,55 & 2,41 \\
\hline & Arco Tangente & 1,66 & 2,54 & 1,97 & 4,74 \\
\hline & Logarítmico & 1,07 & 2,46 & 4,04 & 2,38 \\
\hline \multirow[t]{3}{*}{ Março } & Amplitude & 0,89 & 2,73 & 3,70 & 2,24 \\
\hline & Arco Tangente & 1,97 & 2,75 & 1,83 & 4,53 \\
\hline & Logarítmico & 1,05 & 2,46 & 4,00 & 2,35 \\
\hline \multirow[t]{3}{*}{ Abril } & Amplitude & 1,03 & 2,66 & 4,09 & 2,42 \\
\hline & Arco Tangente & 1,73 & 2,75 & 1,79 & 4,83 \\
\hline & Logarítmico & 1,17 & 2,40 & 4,93 & 2,59 \\
\hline \multirow[t]{3}{*}{ Maio } & Amplitude & 0,98 & 3,02 & 3,43 & 2,33 \\
\hline & Arco Tangente & 1,63 & 2,48 & 1,50 & 5,98 \\
\hline & Logarítmico & 1,13 & 2,38 & 3,87 & 2,36 \\
\hline \multirow[t]{3}{*}{ Junho } & Amplitude & 0,92 & 2,74 & 4,21 & 2,37 \\
\hline & Arco Tangente & 1,49 & 2,66 & 1,93 & 4,90 \\
\hline & Logarítmico & 0,85 & 2,70 & 4,48 & 2,34 \\
\hline \multirow[t]{3}{*}{ Julho } & Amplitude & 0,97 & 2,64 & 4,35 & 2,41 \\
\hline & Arco Tangente & 1,66 & 2,74 & 1,33 & 6,31 \\
\hline & Logarítmico & 0,94 & 2,45 & 3,14 & 2,08 \\
\hline \multirow[t]{3}{*}{ Agosto } & Amplitude & 1,06 & 2,49 & 2,87 & 2,10 \\
\hline & Arco Tangente & 1,89 & 3,02 & 1,34 & 5,67 \\
\hline & Logarítmico & 1,05 & 2,23 & 2,67 & 1,97 \\
\hline \multirow[t]{3}{*}{ Setembro } & Amplitude & 0,95 & 2,95 & 2,67 & 2,08 \\
\hline & Arco Tangente & 1,72 & 3,21 & 2,19 & 3,97 \\
\hline & Logarítmico & 0,96 & 2,60 & 2,65 & 2,00 \\
\hline \multirow[t]{3}{*}{ Outubro } & Amplitude & 0,94 & 3,19 & 2,79 & 2,15 \\
\hline & Arco Tangente & 1,71 & 3,40 & 2,33 & 3,76 \\
\hline & Logarítmico & 0,99 & 2,81 & 2,83 & 2,13 \\
\hline \multirow[t]{3}{*}{ Novembro } & Amplitude & 0,95 & 3,87 & 3,07 & 2,36 \\
\hline & Arco Tangente & 1,55 & 3,42 & 2,22 & 3,99 \\
\hline & Logarítmico & 0,89 & 3,54 & 3,15 & 2,28 \\
\hline \multirow[t]{3}{*}{ Dezembro } & Amplitude & 0,74 & 4,04 & 3,28 & 2,23 \\
\hline & Arco Tangente & 1,39 & 3,55 & 2,53 & 3,81 \\
\hline & Logarítmico & 0,76 & 3,83 & 3,35 & 2,24 \\
\hline
\end{tabular}


Com relação à camada-2, para ambos os anos de análise, verifica-se que as mínimas magnitudes da difusividade térmica são aquelas oriundas do método do logarítmico. Não se pode destacar entre os demais métodos, visto que não há uma expressiva predominância, aquele que fornece as máximas magnitudes para esta camada. As estimativas referentes a esta, obtidas a partir dos métodos da amplitude e arco tangente, mostraram-se bastante semelhantes em determinados meses de ambos os anos. Ao analisar as estimativas associadas à camada-3, para grande parte dos meses de ambos os anos, constata-se que as mais elevadas magnitudes são aquelas provenientes do método do logarítmico. Segundo os métodos da amplitude e logarítmico, ao comparar com as demais camadas, esta é a que apresenta maior capacidade de conduzir calor através de seu perfil vertical.

No caso específico da camada-4, de modo similar à camada-1, as magnitudes mais elevadas são aquelas oriundas do método do arco tangente. No entanto, estas magnitudes são superiores as obtidas para as demais camadas a partir do emprego deste método. Por uma questão de lógica, visto que neste caso está sendo considerado todo o perfil vertical do solo, esperava-se que estas estivessem entre aquelas oriundas das demais camadas. Este aspecto é observado ao examinar as estimativas provenientes dos demais métodos. Portanto, com base na análise dos resultados, pode-se constatar que não são satisfatórias as estimativas obtidas a partir do método do arco tangente para a camada-4. O fato de está sendo considerada uma camada de espessura apreciável, visto que nas demais este se adéqua a estimativa desta grandeza, deve ser a principal causa deste erro. Bellaver (2010), ao estimar a difusividade térmica para uma camada mais espessa que as demais (estendendo-se desde 0,01 até 0,30 metros de profundidade), verificou que o método do arco tangente passou a superestimar a magnitude desta grandeza para todos os ciclos diários em estudo. Outro aspecto que merece destaque é o fato de que as estimativas associadas à camada-3 e camada-4, obtidas a partir do emprego dos métodos da amplitude e logarítmico, são novamente bastante semelhantes.

De maneira geral, em consequência do elevado total pluviométrico, as mais elevadas magnitudes desta grandeza estão associadas ao ano de 2011. Com relação a este ano, ao contrário do que se esperava levando em consideração o total pluviométrico, as máximas não estiveram associadas ao mês de Maio (a precipitação deste superou significativamente a registrada nos demais meses). De acordo com Prevedello (1996), a difusividade térmica do solo eleva-se com o aumento do teor de umidade do solo, até alcançar certo valor máximo. A partir desse momento, a condutividade térmica do solo não mais se eleva com o aumento da umidade do solo e, por conseguinte, a difusividade térmica decresce.

Em uma primeira análise das referidas tabelas, com exceção do caso particular associado à camada-4, não se pode determinar com exatidão o método que menos se adéqua a estimativa desta grandeza física. Uma maneira eficaz de determinar a precisão dos métodos empregados consiste em, fazendo uso das estimativas da difusividade térmica, simular as temperaturas para diferentes horários e profundidade do solo a partir da Equação 1. Temperaturas próximas daquelas mensuradas indica que o método se adéqua a estimativa desta grandeza física. As ferramentas estatísticas utilizadas, como mencionado anteriormente na metodologia, têm como objetivo indicar o quanto as temperaturas mensuradas se aproximam daquelas simuladas. As magnitudes destas, para cada profundidade e método empregado, são expostas na Tabela 4.

Verifica-se, a partir da análise da Tabela 4, que as temperaturas simuladas estão fortemente correlacionadas aquelas mensuradas. Para o ano de 2010, fazendo uso das estimativas oriundas do método do arco tangente para a profundidade de $50 \mathrm{~cm}$, chegou-se a obter uma correlação em torno dos $99 \%$. De acordo com o índice "d", similarmente ao verificado por Otunla e Oladiran (2013), há uma concordância quase que perfeita entre as temperaturas simuladas e aquelas mensuradas. A concordância entre ambas, com exceção daquela associada à profundidade de $15 \mathrm{~cm}$, encontra-se superior a $97 \%$. Portanto, ambos os índices estatísticos indicam que as temperaturas simuladas são significativamente semelhantes 
aquelas mensuradas. Estes resultados, visto que a única variável necessária para simular as temperaturas são as magnitudes da difusividade térmica, demonstram que os métodos utilizados forneceram excelentes estimativas. O desempenho da Equação 1, de acordo com o índice de confiança, é ótimo para a simulação da temperatura do solo. Portanto, mesmo sendo uma das maneiras mais simples de representar o regime térmico diário do solo para diferentes profundidades, mostrou-se bastante eficaz o emprego desta equação.

Tabela 4. Resultados obtidos a partir do emprego das seguintes ferramentas estatísticas: coeficiente de correlação "r", índice de concordância "d" e índice de confiança "c".

\begin{tabular}{|c|c|c|c|c|c|c|}
\hline \multirow{2}{*}{ Ano } & \multirow{2}{*}{ Método } & \multirow{2}{*}{$\begin{array}{c}\text { Ferramenta } \\
\text { Estatística }\end{array}$} & \multicolumn{4}{|c|}{ Profundidade } \\
\hline & & & $5 \mathrm{~cm}$ & $15 \mathrm{~cm}$ & $30 \mathrm{~cm}$ & $50 \mathrm{~cm}$ \\
\hline \multirow[t]{9}{*}{2010} & Amplitude & $r$ & 0,9553 & 0,9762 & 0,9749 & 0,9822 \\
\hline & & $\mathrm{d}$ & 0,9765 & 0,9564 & 0,9833 & 0,9872 \\
\hline & & c & Ótimo & Ótimo & Ótimo & Ótimo \\
\hline & Arco Tangente & $r$ & 0,9567 & 0,9789 & 0,9726 & 0,9908 \\
\hline & & d & 0,9779 & 0,9575 & 0,9819 & 0,9925 \\
\hline & & c & Ótimo & Ótimo & Ótimo & Ótimo \\
\hline & Logarítmico & $r$ & 0,9555 & 0,9768 & 0,9817 & 0,9785 \\
\hline & & d & 0,9767 & 0,9567 & 0,9877 & 0,9850 \\
\hline & & c & Ótimo & Ótimo & Ótimo & Ótimo \\
\hline \multirow[t]{9}{*}{2011} & Amplitude & $r$ & 0,9526 & 0,9761 & 0,9577 & 0,9648 \\
\hline & & d & 0,9754 & 0,9309 & 0,9734 & 0,9764 \\
\hline & & c & Ótimo & Ótimo & Ótimo & Ótimo \\
\hline & Arco Tangente & $\mathrm{r}$ & 0,9513 & 0,9709 & 0,9611 & 0,9863 \\
\hline & & d & 0,9750 & 0,9323 & 0,9754 & 0,9884 \\
\hline & & c & Ótimo & Ótimo & Ótimo & Ótimo \\
\hline & Logarítmico & $r$ & 0,9526 & 0,9765 & 0,9663 & 0,9606 \\
\hline & & $\mathrm{d}$ & 0,9755 & 0,9315 & 0,9788 & 0,9742 \\
\hline & & c & Ótimo & Ótimo & Ótimo & Ótimo \\
\hline
\end{tabular}

\section{CONCLUSÕES}

O solo apresenta um regime térmico diário e anual bem definido.

O método do arco tangente, para o caso específico da camada compreendida entre 5 e $50 \mathrm{~cm}$ de profundidade, não é adequado para a estimativa da difusividade térmica do solo.

Os demais métodos mostram-se amplamente eficazes para estimativa da difusividade térmica do solo.

A equação destinada a simular as temperaturas do solo fornece resultados bastante satisfatórios.

\section{AGRADECIMENTOS}

Os autores agradecem ao Conselho Nacional de Desenvolvimento Científico e Tecnológico (CNPq) pela concessão de bolsa de estudo, bem como a Empresa Estadual de Pesquisa Agropecuária da Paraíba (EMEPA/PB) pelo fornecimento dos dados utilizados neste estudo. 


\section{REFERÊNCIAS}

ARAÚJO, T. S. Influência de elementos meteorológicos sobre o desenvolvimento da alface em diferentes ambientes. 2008. 93p. Dissertação (Mestrado em Meteorologia) Universidade Federal de Campina Grande, Campina Grande, 2008.

ARAÚJO, T. S.; FIDELES FILHO, J.; KUMAR, K. K.; RAO, T. V. R. Crescimento da alface-americana em função dos ambientes, épocas e graus-dias. Revista Brasileira de Ciências Agrárias, v. 5, p. 441-449, 2010. http://dx.doi.org/10.5039/agraria.v5i4a480

AZEVEDO, T. R.; GALVANI, E. Ajuste do ciclo médio mensal horário da temperatura do solo em função da temperatura do ar. Revista Brasileira de Agrometeorologia, v. 11, p. 123-130, 2003.

BELLAVER, V. Difusividade térmica do solo em área monodominante de cambará no norte do Pantanal Matogrossense. 2010. 70p. Dissertação (Mestrado em Física Ambiental) - Universidade Federal de Mato Grosso, Cuiabá, 2010.

CAMARGO, A. P.; SENTELHAS, P. C. Avaliação do desempenho de diferentes métodos de estimativa da evapotranspiração potencial no estado de São Paulo, Brasil. Revista Brasileira de Agrometeorologia, v. 5, p. 89-97, 1997.

CARNEIRO, R. G.; MOURA, M. A. L.; SILVA, V. P. R.; SILVA JUNIOR, R. S.; ANDRADE, A. M. D.; SANTOS, A. B. Variabilidade da temperatura do solo em função da liteira em fragmento remanescente de mata atlântica. Revista Brasileira de Engenharia Agrícola e Ambiental, v. 18, p. 99-108, 2014.

http://dx.doi.org/10.1590/S1415-43662014000100013

DANELICHEN, V. H. M.; BIUDES, M. S. Avaliação da difusividade térmica de um solo no norte do Pantanal. Ciência e Natura, v. 33, p. 227-240, 2011.

DINIZ, J. M. T. Caracterização das propriedades térmicas do solo de Lagoa Seca-PB. 2014. 72p. Dissertação (Mestrado em Meteorologia) - Universidade Federal de Campina Grande, Campina Grande, 2014.

DINIZ, J. M. T.; ALBUQUERQUE, E. M.; RAFAEL, R. A. Estudo acerca da variabilidade térmica do solo. Scientia Plena, v. 10, p. 1-7, 2014.

DINIZ, J. M. T.; ALVINO, F. C. G.; SOUSA JÚNIOR, J. R.; WANDERLEY, J. A. C.; SOUSA, E. P.; MARACAJÁ, P. B. Características térmicas do solo de João Pessoa-PB. Agropecuária Científica no Semiárido, v. 9, p. 69-74, 2013 a.

DINIZ, J. M. T.; ARANHA, T. R. B. T.; SOUSA, E. P.; WANDERLEY, J. A. C.; SOUSA, E. P.; MARACAJÁ, P. B. Avaliação da difusividade térmica do solo de Campina GrandePB-Brasil. Agropecuária Científica no Semiárido, v. 9, p. 55-60, 2013 b.

DINIZ, J. M. T.; CARNEIRO, R. G.; ALVINO, F. C. G.; SOUSA, E. P.; SOUSA, E. P.; SOUSA JÚNIOR, J. R. Avaliação do comportamento térmico diário do solo de Campina Grande-PB. Agropecuária Científica no Semiárido, v. 9, p. 77-82, 2013c.

DINIZ, J. M. T.; RAFAEL, R. A.; FIDELES FILHO, J.; SOUSA JÚNIOR, J. R.; FERNANDES, A. A. Características térmicas do solo observadas em cidades distintas do estado da Paraíba. Revista Verde de Agroecologia e Desenvolvimento Sustentável, v. 8, p. 117-126, 2013d. 
DINIZ, J. M. T.; SOUSA, E. P.; WANDERLEY, J. A. C.; FIDELES FILHO, J.; MARACAJÁ, P. B. Variabilidade diária da temperatura do solo: um estudo de caso. Revista Verde de Agroecologia e Desenvolvimento Sustentável, v. 8, p. 01-06, 2013e.

FIDELES FILHO, J. Estrutura térmica de solos do Nordeste do Brasil. 1988. 85p. Dissertação (Mestrado em Meteorologia) - Universidade Federal da Paraíba, Campina Grande, 1988.

GAO, Z.; WANG, L.; HORTON, R. Comparison of six algorithms to determine the soil thermal diffusivity at a site in the Loess Plateau of China. Hydrology and Earth System Sciences Discussions, v. 6, p. 2247-2274, 2009.

http://dx.doi.org/10.5194/hessd-6-2247-2009

GASPARIM, E.; RICIERI, R. P.; SILVA, S. L.; DALLACORT, R.; GNOATTO, E. Temperatura no perfil do solo utilizando duas densidades de cobertura e solo nu. Acta Scientiarum, v. 27, p. 107-115, 2005.

http://dx.doi.org/10.4025/actasciagron.v27i1.2127

HILLEL, D. Introduction to environmental soil physics. Amsterdam: Elsevier Academic Press, 2004. 494p.

LAL, R.; SHUKLA, M. K. Principles of soil physics. New York: Marcel Dekker Inc., 2004. $716 p$.

LARSON, R.; FARBER, B. Estatística aplicada. São Paulo: Prentice Hall, 2004. 476p.

OLIVEIRA, S. S.; FIDELES FILHO, J.; OLIVEIRA, S. V.; ARAÚJO, T. S. Difusividade térmica do solo de Campina Grande para dois períodos do ano. Revista de Geografia, v. 27, p. 179-189, 2010.

OTUNLA, T. A.; OLADIRAN, E. O. Evaluation of soil thermal diffusivity algorithms at two equatorial sites in West Africa. Annals of Geophysics, v. 56, p. 1-12, 2013. http://dx.doi.org/10.4401/ag-6170

PEDRON, F. A. Mineralogia, morfologia e classificação de saprolitos e neossolos derivados de rochas vulcânicas no Rio Grande do Sul. 2007. 160p. Tese (Doutorado em Ciência do Solo) - Universidade Federal de Santa Maria, Santa Maria, 2007.

PREVEDELLO, C. L. Física do solo com problemas resolvidos. Curitiba: SaleswardDiscovery, 1996. 446p.

RAO, T. V. R.; SILVA, B. B.; MOREIRA, A. A. Características térmicas do solo em Salvador, BA. Revista Brasileira de Engenharia Agrícola e Ambiental, v. 9, p. 554559, 2005. http://dx.doi.org/10.1590/S1415-43662005000400018

REICHARDT, K.; TIMM, L. C. Solo, planta e atmosfera: conceitos, processos e aplicações. Barueri: Manole, 2004. 478p.

SILANS, A. P.; SILVA, F. M.; BARBOSA, F. A. R. Determinação in loco da difusividade térmica num solo da região de caatinga (PB). Revista Brasileira de Ciência do Solo, v. 30, p. 41-48, 2006. http://dx.doi.org/10.1590/S0100-06832006000100005

TITO, G. A.; ChAVES, L. H. G.; CARVAlHO, H. O.; AZEVEDO, N. C. Aplicação de bentonita em um regossolo eutrófico. II. Efeitos sobre as propriedades químicas do solo. Revista Brasileira de Engenharia Agrícola e Ambiental, v. 1, p. 25-27, 1997. 
WILLMOTT, C. J.; ACKLESON, S. G.; DAVIS, R. E.; FEDDEMA, J. J.; KLINK, K. M.; LEGATES, D. R. et al. Statistics for the evaluation and comparison of models. Journal of Geophysical Research, v. 90, p. 8995-9005, 1985.

http://dx.doi.org/10.1029/JC090iC05p08995

ZONTA, J. H.; MARTINEZ, M. A.; SILVA, D. D.; PRUSKI, F. F.; SANTOS, M. R. Modelagem da infiltração em solos com encrostamento superficial. Parte II: Condutividade hidráulica variando no tempo. Revista Brasileira de Engenharia Agrícola e Ambiental, v. 16, p. 471-479, 2012. http://dx.doi.org/10.1590/S141543662012000500002 


Ambiente \& Água - An Interdisciplinary Journal of Applied Science
ISSN 1980-993X - doi:10.4136/1980-993X
www.ambi-agua.net
E-mail: ambi-agua@agro.unitau.br

\title{
Efeito da aplicação de esgoto doméstico primário na produção de milho no assentamento Milagres (Apodi-RN)
}

\author{
doi: 10.4136/ambi-agua.1417
}

Received: 05 Jun. 2014; Accepted: 03 Sep. 2014

\section{Zailton Vagner Barreto da Costa; Marcelo Tavares Gurgel ${ }^{*}$; Lucas Ramos Costa; Sandra Maria Campos Alves; Miguel Ferreira Neto; Rafael Oliveira Batista}

\author{
Universidade Federal Rural do Semi Árido (UFERSA), Mossoró, RN, Brasil \\ *Autor correspondente: e-mail: marcelo@ufersa.edu.br, \\ zailtonvagner@hotmail.com, lucas_ramosjp@hotmail.com, \\ sandraalves@ufersa.edu.br,miguel@ufersa.edu.br, \\ rafaelbatista@ufersa.edu.br
}

\section{RESUMO}

A aplicação de esgoto doméstico tratado é uma forma efetiva de controle da poluição ambiental, sendo uma alternativa viável para aumentar a disponibilidade hídrica nas regiões áridas e semiáridas. O presente estudo objetivou analisar a produção de milho (Zea mays L) fertirrigado com esgoto doméstico primário do Assentamento Rural Milagres em Apodi-RN. No período experimental as características avaliadas na cultura do milho foram: altura de planta (AP), diâmetro do caule (DC), número de folhas (NF), peso médio de espiga com e sem palha (PMECP), (PMESP), peso úmido e seco de grãos (PUG), (PSG). Os resultados do estudo indicaram que a fertirrigação com esgoto doméstico primário proporcionou maiores valores de altura de planta (AP), diâmetro do caule (DC), número de folhas (NF), peso de espiga com palha (PMECP), peso de espiga sem palha (PMESP), peso úmido dos grãos (PUG), peso seco dos grãos (PSG) e produtividade de grãos em relação às mesmas características obtidas com água do poço artesiano. O uso de esgoto doméstico consiste em uma fonte de nutriente para produção agrícola.

Palavras-chave: agricultura familiar, reúso, Zea mays L.

\section{Effect of primary sewage application on corn production at the settlement of Milagres (Apodi-RN)}

\begin{abstract}
The application of treated domestic wastewater is an effective way to control environmental pollution, and is a viable option for increasing water availability in arid and semiarid regions. This study analyzed the production of maize (Zea mays L) fertilized with primary sewage at the rural settlement of Milagres in Apodi-RN. The study evaluated the following characteristics of maize: plant height, stem diameter, number of leaves, average ear weight with and without straw, wet and dry grain weight. The study found that fertigation with primary sewage resulted in higher values of plant height $(\mathrm{PH})$, stem diameter, number of leaves, husked ear weight, ear weight without straw, wet weight of grains, dry weight of
\end{abstract}


grains and grain yield compared to the same characteristics when artesian well water was used. Domestic sewage provides a source of nutrients for agricultural production.

Keywords: family agriculture, reuse, Zea mays L.

\section{INTRODUÇÃO}

Na região semiárida do Brasil, a utilização de esgoto doméstico tratado, minimiza a poluição dos mananciais hídricos, possibilita a economia com gastos com fertilizantes, adiciona matéria orgânica ao solo e podendo-se ser uma fonte alternativa de água e nutrientes principalmente o nitrogênio, com possibilidades de assegurar e incrementar a produção agrícola durante as estiagens prolongadas; em especial ao nível da agricultura familiar, contribuindo para a fixação do homem no campo (Sousa e Leite, 2008).

Os maiores benefícios dessa forma de reuso são associados aos aspectos econômicos, ambientais e de saúde pública. Nas duas últimas décadas, o uso de esgotos doméstico tratados na irrigação de culturas aumentou significativamente, devido à escassez de água para irrigação, custo elevado de fertilizantes, aperfeiçoamento das técnicas de tratamento e uso agrícola, custo elevado das técnicas de tratamento para lançamento em corpo hídrico, aceitação sócio-cultural da prática do reuso agrícola e o reconhecimento pelos órgãos gestores de recursos (Hespanhol, 2008; Sousa e Leite, 2008).

O tratamento e a utilização de esgotos domésticos são apontados como fonte alternativa de água e fertilizante para a agricultura; porém, devido as suas limitações químicas, físicas e biológicas, devem ser avaliadas e manejadas adequadamente com o desenvolvimento de técnicas que viabilizem seu uso, tendo em vista a segurança ambiental, a garantia da qualidade de vida e a geração do desenvolvimento socioeconômico rural. Além disso, o tratamento de esgotos domésticos reduz as enfermidades no meio rural e a poluição dos corpos hídricos (Hespanhol, 2008).

Os efeitos da aplicação de água residuária nas propriedades químicas do solo, só sãopronunciados após longo período de aplicação, pelos atributos que definem sua composiçãofísica e química, pelas condições de clima e pelo tipo de solo. Ayers e Westcot (1999) relatam que a limitação principal do uso de águas residuárias na agricultura é a sua composição química (totais de sais dissolvidos, presença de íons tóxicos e concentração relativa de sódio) e a tolerância das culturas a este tipo de efluente.

Vários estudos comprovaram a importância da irrigação com efluentes de esgoto parasuprir, em parte, as quantidades dos elementos, principalmente nitrogênio, fósforo e potássio, requeridos pelas culturas, chegando a aumentar a produtividade agrícola (Hespanhol, 2008; Kouraa et al., 2002; Meli et al., 2002).

Para a agricultura familiar o cultivo agrícola com o milho apresenta grande importância na alimentação humana e animal onde sua utilização pura ou como ingrediente de outros produtos, é uma importante fonte energética. A cultura do milho (Zea mays L.) apresenta grande importância econômica e social no Brasil, segundo dados da Companhia Nacional de Abastecimento (CONAB, 2011). Essa cultura é considerada uma das principais espécies de cereais utilizadas no mundo. Anualmente são cultivados cerca de 140 milhões de hectares, os quais contribuem para a produção de, aproximadamente, 668 milhões de toneladas de grãos (Instituto FNP, 2006).

Segundo Pizarro (1990), os sais solúveis contidos nas águas de irrigação podem, em certas condições climáticas, salinizar o solo e modificar a composição iônica no complexo sortivo, alterando as características físicas e químicas do solo, como o regime de umidade, aeração, nutrientes, desenvolvimento vegetativo e produtividade.

O milho é o mais tradicional cereal produzido no Brasil, e tem passado por notáveis transformações. A melhoria de tecnologia tem resultado em aumentos consideráveis em 
produtividade de grãos. A adubação é o principal fator que mais contribui para o aumento da produtividade do milho, podendo também influenciar na qualidade dos grãos (Ferreira, 2000). O nitrogênio é o nutriente mais exigido pela cultura do milho e que apresenta maior resposta em termos de produtividade (Peixoto et al., 2003).

O grande desafio deste estudo é desenvolver tecnologias para minimizar a escassez de água, potencializando o uso de águas de qualidade superior para o consumo humano e a utilização dos esgotos tratados na produção de culturas agrícolas. A possibilidade de reuso de água libera água doce para o consumo humano, além de possibilitar a solução de culturas agrícolas apropriadas para produção de alimentos vegetais, necessários à população e alimentação animal, gerando proteínas destinadas ao consumo humano.

Levando-se em consideração outros aspectos, objetivou-se neste trabalho, analisar o efeito do esgoto doméstico tratado na produção do milho cultivado no Assentamento Milagres Apodi-RN.

\section{MATERIAL E MÉTODOS}

\section{1. Área de estudo}

O estudo foi desenvolvido no projeto de Assentamento Rural Milagres em Apodí-RN, situado a $100 \mathrm{~km}$ de Mossoró-RN, cujas coordenadas geográficas centrais são $5^{\circ} 35^{\prime} 17^{\prime}$ ' S e 3754'07' W, altitude de $153 \mathrm{~m}$ ao nível do mar, coordenado pelo Instituto Nacional de Colonização e Reforma Agrária (INCRA). O assentamento possui 28 residências e dispõe de rede coletora e interceptora de esgoto, além de uma estação para tratamento preliminar e primário do esgoto doméstico bruto.

De acordo com a classificação de Köppen, o clima predominante na região é do tipo BSw'h', caracterizado por ser muito quente e semiárido, com a estação chuvosa se atrasando para o outono.

O experimento foi realizado no período de agosto a dezembro de 2011, as sementes utilizadas foram da variedade cruzeta precoce (Zea mays L.) desenvolvido pela Empresa de Pesquisa Agropecuária do Rio Grande do Norte (EMPARN) para atender as exigências de lavouras de sequeiros, apresentando potencial produtivo de $6.000 \mathrm{~kg} / \mathrm{ha}$ e ciclo de 65 dias da germinação à colheita, para o mercado de milho verde e 100 dias à colheita na forma de grãos secos, desta forma trazendo benefícios diretos aos produtores rurais, como precocidade e qualidade, que diminui os custos de produção e a garantia de um bom produto no mercado.

\subsection{Metodologia}

O experimento foi instalado em campo, onde a área total cercada possuía as seguintes medidas 27 x $50 \mathrm{~m}$, os blocos $25 \times 2,5 \mathrm{~m}$, as parcelas $5 \times 2,5 \mathrm{~m}$. O tratamento da água envolve um reator anaeróbio do tipo decanto digestor com tanque séptico e filtros anaeróbios de fluxo descendente, uma cisterna para armazenamento do esgoto tratado com capacidade para $10 \mathrm{~m}^{3}$.

O espaçamento foi o de $1,0 \mathrm{~m}$ x 0,30 m colocando-o quatro sementes por cova, após 10 dias da emergência das plântulas foi realizado o desbaste, deixando duas plantas por cova, foram realizadas capinas manuais para que o experimento ficasse ausente de plantas que competidoras. Antes de realizar a semeadura, foi efetuada uma irrigação, para elevar a umidade do solo à de capacidade de campo.

A escolha do milho utilizado no estudo se deu devido à exploração da cultura em praticamente todos os assentamentos e municípios da região nordeste do Brasil, em que predomina o sistema de cultivo de sequeiro. A maior parte da produção é feita em pequenas propriedades, por agricultores que, em geral, utilizam cultivares pouco produtivas e práticas culturais inadequadas, obtendo deste modo, rendimentos baixos. 
A geração diária de esgoto bruto foi em torno de $25 \mathrm{~m}^{3}$, onde o mesmo era tratado e disponibilizado como água e nutrientes para o cultivo agrícola do milho cruzeta. Para armazenamento da água do poço artesiano foi construído uma cisterna com capacidade para $10 \mathrm{~m}^{3}$.

Foi instalado um sistema automatizado acoplado a dois conjuntos moto - bomba de 1,5 CV para irrigação do experimento. O método de irrigação utilizado foi por gotejamento utilizando-se linhas laterais de polietileno com $16 \mathrm{~mm}$ dotados de emissores com vazão nominal 1,6 $\mathrm{Lh}^{-1}$ e espaçados a cada $0,30 \mathrm{~m}$. A área recebeu irrigações diárias para assegurar ao solo condições favoráveis a uma boa germinação das sementes. As necessidades hídricas do milho foram estimadas com base no balanço de água no solo e na evapotranspiração da cultura pela metodologia FAO (Allen et al., 2006).

Para caracterização do esgoto doméstico primário e da água do poço artesiano foram coletadas amostras que foram preservadas em caixa isotérmica com gelo á temperatura de $4^{\circ} \mathrm{C}$. Em seguida as amostras foram encaminhadas para ao Laboratório de Análise de Solo Água e Planta (LASAP), Laboratório de Inspeção de produtos de origem animal, ambos da UFERSA e o Laboratório de Diagnóstico Físico-Químico da UERN para obtenção das características físico-químicas e microbiológicas, conforme a Tabela 1.

Tabela 1. Características físico-químicas e biológicas do esgoto doméstico primário e da água do poço artesiano.

\begin{tabular}{|c|c|c|c|}
\hline Esgoto primário & Concentração & Água do poço & Concentração \\
\hline $\mathrm{CE}\left(\mathrm{dSm}^{-1}\right)$ & 1,2 & $\mathrm{CE}\left(\mathrm{dSm}^{-1}\right)$ & 0,10 \\
\hline $\mathrm{pH}$ & 7,3 & $\mathrm{pH}$ & 7,0 \\
\hline $\mathrm{SS}\left(\mathrm{mgL}^{-1}\right)$ & 44 & $\mathrm{SS}\left(\mathrm{mgL}^{-1}\right)$ & 0 \\
\hline $\mathrm{SD}\left(\mathrm{mgL}^{-1}\right)$ & 350 & $\mathrm{SD}\left(\mathrm{mgL}^{-1}\right)$ & 50 \\
\hline $\mathrm{Fe}\left(\mathrm{mgL}^{-1}\right)$ & 0,60 & $\mathrm{Fe}\left(\mathrm{mgL}^{-1}\right)$ & 0,40 \\
\hline $\operatorname{Mn}\left(\mathrm{mgL}^{-1}\right)$ & 0,20 & $\operatorname{Mn}\left(\mathrm{mgL}^{-1}\right)$ & 0,07 \\
\hline $\mathrm{Ca}^{2+}\left(\mathrm{mmolcL}^{-1}\right)$ & 0,80 & $\mathrm{Ca}^{2+}$ & 0,30 \\
\hline $\mathrm{Mg}^{2+}\left(\mathrm{mmolcL}^{-1}\right)$ & 0,70 & $\mathrm{Mg}^{2+}$ & 0,50 \\
\hline $\mathrm{Cu}\left(\mathrm{mgL}^{-1}\right)$ & 0,06 & $\mathrm{Cu}\left(\mathrm{mgL}^{-1}\right)$ & - \\
\hline $\mathrm{Zn}\left(\mathrm{mgL}^{-1}\right)$ & 0,09 & $\mathrm{Zn}\left(\mathrm{mgL}^{-1}\right)$ & - \\
\hline $\mathrm{DQO}\left(\mathrm{mgL}^{-1}\right)$ & 60,00 & $\mathrm{DQO}\left(\mathrm{mgL}^{-1}\right)$ & - \\
\hline $\mathrm{DBO}\left(\mathrm{mgL}^{-1}\right)$ & 19,40 & $\mathrm{DBO}\left(\mathrm{mgL}^{-1}\right)$ & - \\
\hline $\mathrm{N}$ total $\left(\mathrm{mgL}^{-1}\right)$ & 72,00 & $\mathrm{~N}$ total $\left(\mathrm{mgL}^{-1}\right)$ & 0 \\
\hline$P$ total $\left(\mathrm{mgL}^{-1}\right)$ & 7,5 & $\mathrm{P}$ total $\left(\mathrm{mgL}^{-1}\right)$ & - \\
\hline $\mathrm{N}-\mathrm{NO}_{-3}\left(\mathrm{mgL}^{-1}\right)$ & 0,10 & $\mathrm{~N}-\mathrm{NO}_{-3}\left(\mathrm{mgL}^{-1}\right)$ & 0 \\
\hline $\mathrm{Cl}^{-}\left(\operatorname{mmol}_{\mathrm{C}} \mathrm{L}^{-1}\right)$ & 2,40 & $\mathrm{Cl}^{-}\left(\mathrm{mmol}_{\mathrm{c}}\right.$ & - \\
\hline $\begin{array}{l}\text { Coliformes termotolerantes } \\
\left(\mathrm{NMP} 100 \mathrm{~mL}^{-1} \text { ) }\right.\end{array}$ & $8,6 \times 10^{4}$ & $\begin{array}{l}\text { Coliformes } \\
\text { termotolerantes } \\
\left(\mathrm{NMP}_{\left.100 \mathrm{~mL}^{-1}\right)}\right.\end{array}$ & 0 \\
\hline
\end{tabular}

Para caracterização inicial do solo foram coletadas amostras compostas nas profundidades de 0 a $0,20 \mathrm{~m} ; 0,20$ a $0,40 \mathrm{~m}$ e 0,40 a $0,60 \mathrm{~m}$, colocadas em sacos plásticos e 
encaminhadas para ao Laboratório de análise de solos, seguindo as recomendações da Embrapa (1997). Na Tabela 2 constam as características químicas do solo antes da aplicação do esgoto doméstico. O solo da área foi classificado como Argissolo de acordo com o Sistema Brasileiro de Classificação de Solos (Embrapa, 2006).

Tabela 2. Características químicas do Argissolo antes da aplicação do esgoto tratado.

\begin{tabular}{lccc}
\hline \multirow{2}{*}{ Características químicas } & \multicolumn{3}{c}{ Profundidade $(\mathbf{m})$} \\
\cline { 2 - 4 } pH em $\mathrm{H}_{2} \mathrm{O}$ & $\mathbf{0 , 0} \mathbf{~ a ~ 0 , 2 0}$ & $\mathbf{0 , 2 0} \mathbf{a ~ 0 , 4 0}$ & $\mathbf{0 , 4 0} \mathbf{a} \mathbf{0 , 6 0}$ \\
$\mathrm{P}\left(\mathrm{mg} / \mathrm{dm}^{3}\right)$ & 6,7 & 7,2 & 6,5 \\
$\mathrm{~K}\left(\mathrm{mg} / \mathrm{dm}^{3}\right)$ & 7,7 & 1,4 & 0,7 \\
$\mathrm{Ca}\left(\mathrm{cmol}_{\mathrm{c}} / \mathrm{dm}^{3}\right)$ & 138 & 106 & 134 \\
$\mathrm{Mg}\left(\mathrm{cmol}_{\mathrm{c}} / \mathrm{dm}^{3}\right)$ & 2,1 & 1,8 & 3,5 \\
$\mathrm{SB}\left(\mathrm{cml}_{\mathrm{c}} \mathrm{dm}^{3}\right)$ & 0,6 & 0,6 & 1,3 \\
$\mathrm{CTC}(\mathrm{t})$ & 3,05 & 2,67 & 5,14 \\
$\mathrm{CTC}(\mathrm{T})$ & 3,05 & 2,67 & 5,14 \\
$\mathrm{~V}(\%)$ & 4,04 & 3,17 & 6,63 \\
$\mathrm{MO}\left(\mathrm{Da} / \mathrm{kg}^{3}\right)$ & 75 & 84 & 78 \\
$\mathrm{Zn}\left(\mathrm{mg} / \mathrm{dm}^{3}\right)$ & 1,8 & 1,2 & 1,1 \\
$\mathrm{Fe}\left(\mathrm{mg} / \mathrm{dm}^{3}\right)$ & 3,1 & 0,5 & 0,4 \\
$\mathrm{Mn}\left(\mathrm{mg} / \mathrm{dm}^{3}\right)$ & 9,0 & 9,4 & 22,9 \\
$\mathrm{Cu}\left(\mathrm{mg} / \mathrm{dm}^{3}\right)$ & 159,2 & 71,8 & 19,7 \\
$\mathrm{~B}\left(\mathrm{mg} / \mathrm{dm}^{3}\right)$ & 0,7 & 0,9 & 0,5 \\
& 0,3 & 0,2 & 0,3 \\
\hline
\end{tabular}

O delineamento experimental utilizado foi o de blocos casualizados, com cinco tratamentos e cinco repetições, totalizando 25 parcelas, cada parcela possuía 80 plantas sendo 52 como bordaduras e 28 úteis. Foram adotados cinco tratamentos (T1=100\%; T2=75\%; T3=50\%; T4=25 \%, de água residuária e T5=100 \% de água de abastecimento proveniente de um poço artesiano).

Os intervalos de coletas de dados adotados foi a cada 20 dias, após a semeadura. Foram analisadas variáveis de crescimento e produção do milho de acordo com Benincasa (1988), para determinação da altura da planta utilizou-se trena métrica com $3 \mathrm{~m}$ de comprimento; para se medir o diâmetro do caule foi utilizado paquímetro digital de $1500 \mathrm{~mm}$; o número folhas foi a média de cinco plantas por parcelas; para o peso da espiga com e sem palha e peso úmido e seco de 400 grãos para determinação das respectivas variáveis, foi utilizada uma balança Shimadzu BL3200h, graduação máxima 3.200 g e mínima 0.5 g, produtividade de grãos médias de 5 espigas por parcelas.

Os dados foram tabulados e submetidos à análise de variância utilizando-se o teste " $\mathrm{F} " \mathrm{a}$ $5 \%$ de probabilidade. Em seguida, as médias foram comparadas pelo teste de Tukey a $5 \%$. Os modelos de regressão foram escolhidos com base na significância do coeficiente de regressão utilizando-se o teste " $t$ " com nível de $5 \%$ de probabilidade, no valor do coeficiente de determinação $\left(\mathrm{R}^{2}\right)$. Nas análises estatísticas foi utilizado o programa computacional SISVAR 5.0 (Ferreira, 2000). 


\section{RESULTADOS E DISCUSSÃO}

Na Tabela 3 encontra-se o resumo das análises de variância e médias da variável altura de planta (AP), de acordo com aplicação das proporções de esgoto doméstico tratado, dos 20 aos 60 dias após a semeadura (DAS). Observou-se efeito significativo dos tratamentos na variável altura de planta (AP) considerando as etapas de desenvolvimento da cultura (20, 40 e 60 DAS). Não houve diferença estatística entre os tratamentos T1, T2, T3 e T4 aos 20 e 40 DAS, porém, estes diferiram estatisticamente do tratamento T5, em análise visual a Figura 1 constata-se os resultados pronunciados anteriormente. Aos 60 DAS, o tratamento T1 diferiu estatisticamente dos demais tratamentos á $5 \%$ de probabilidade pelo teste de Tukey. $\mathrm{O}$ tratamento T1 proporcionou o maior crescimento das plantas, em função provavelmente do maior aporte de nutrientes encontrados em esgoto doméstico, em particular o nitrogênio.

Tabela 3. Resumo da análise de variância e médias da altura de plantas (AP) de milho (Zea mays), variedade cruzeta (dias após a semeadura DAS).

\begin{tabular}{lcccc}
\hline \multirow{2}{*}{ Fonte variação } & GL & \multicolumn{3}{c}{ Quadrado médio } \\
\cline { 2 - 5 } & 4 & AP 20 DAS & AP 40 DAS & AP 60 DAS \\
\hline Tratamentos & $220,19 * *$ & $4246,72 * *$ & $20103,62 * *$ \\
Blocos & 4 & 6,98 & 39,13 & 192,23 \\
Erro & 16 & 11,72 & 73,40 & 220,03 \\
Cv (\%) & 14,61 & 11,68 & 9,42 \\
DMS & 6,63 & 16,60 & 28,75 \\
\hline Tratamentos & & Médias (cm) & \\
\hline T1(100\% água residuária) & $29,20 \mathrm{~A}$ & $97,93 \mathrm{~A}$ & $223,60 \mathrm{~A}$ \\
T2(75\% água residuária) & $24,86 \mathrm{~A}$ & $83,80 \mathrm{~A}$ & $176,73 \mathrm{~B}$ \\
T3(50\% água residuária) & $24,94 \mathrm{~A}$ & $72,80 \mathrm{~A}$ & $153,53 \mathrm{~B}$ \\
T4(25\% água residuária) & $26,24 \mathrm{~A}$ & $88,46 \mathrm{~A}$ & $179,66 \mathrm{~B}$ \\
T5(0\% água residuária) & $12,00 \mathrm{~B}$ & $23,80 \mathrm{~B}$ & $53,40 \mathrm{C}$ \\
\hline
\end{tabular}

Nota:* Significativo a $5 \%$ de probabilidade pelo teste F. $* *$ significativo a $1 \%$ de probabilidade pelo teste $\mathrm{F}$. Médias seguidas de mesma letra na coluna não diferem entre si a 5\% pelo teste Tukey. CV- coeficiente de variação.

Os valores de altura de planta em função das proporções de esgoto doméstico tratado e água do poço artesiano aos 20, 40 e 60 dias após a semeadura, verificando-se neste último período que a planta atingiu o estágio de inflorescência masculina, como apresentado na tabela 3. Comportamento da altura de planta nos dias 20 (A), 40 (B) e 60 (C) dias após a semeadura (DAS) em função das proporções de água residuária.

Nota-se na Tabela 3 quando aplicados T1 (100\% de água residuária) a planta obteve crescimento médio na ordem de 223,6 cm (60 DAS), valor superior aos demais tratamentos, principalmente, em relação a aplicação de T5 (água de poço artesiano) que obteve crescimento médio de 53,4 cm (60 DAS), resultado que foi evidente pela exigência da cultura em nutrientes, principalmente nitrogênio, fósforo e potássio. Costa et al. (2009) constataram efeito isolado tanto do biossólido quanto da água de irrigação, ao longo do ciclo da cultura. Estudos realizados por Vieira José et al. (2009) revelaram que o efeito da aplicação de efluente de abatedouro bovino tratado em lagoas de estabilização no solo e no desenvolvimento do milho resultaram em valores médios na altura de planta de 129,1 a 148,1 cm, não corroborando com esse trabalho quando aplicado proporções de esgoto doméstico tratado, em que se obteve valores médios de 153,53 a 223,6 cm de altura de planta. 


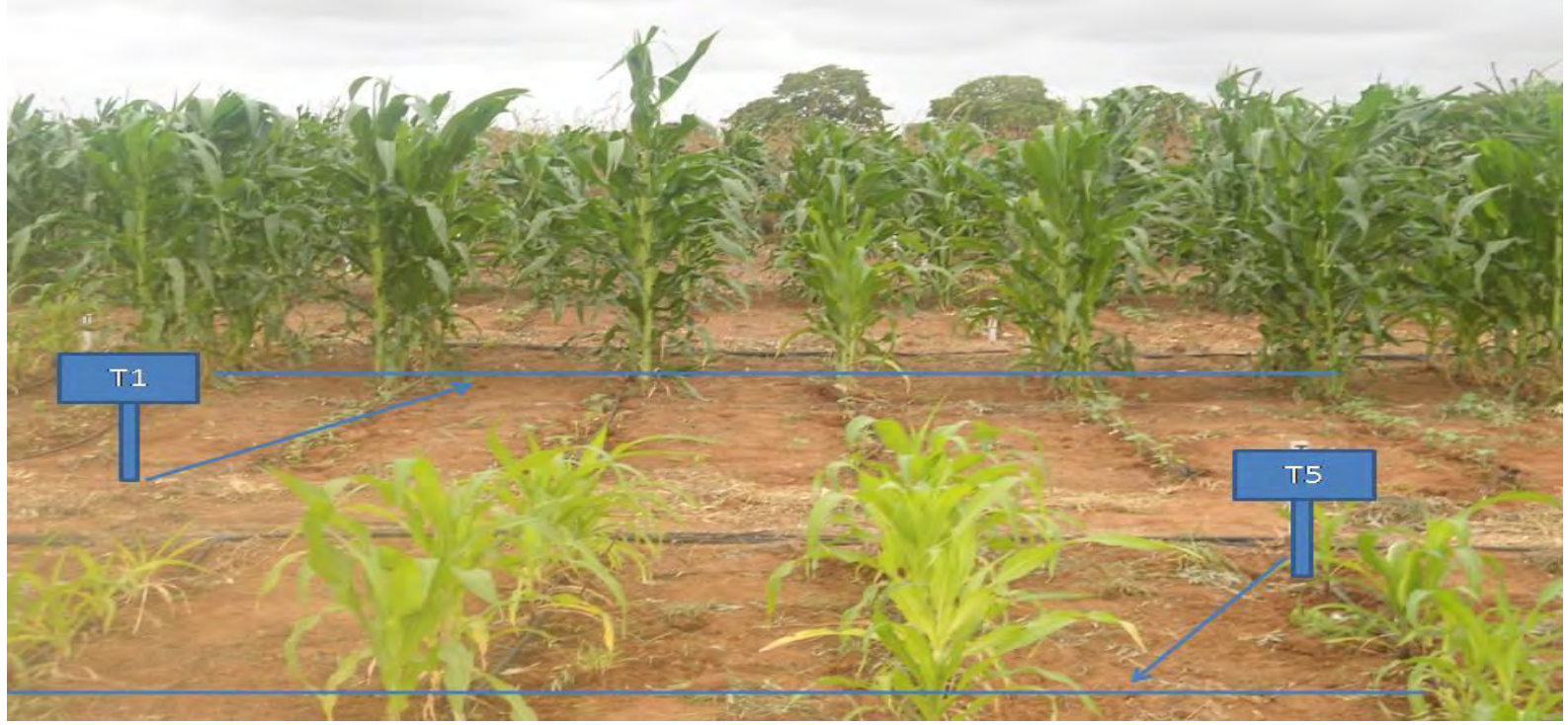

Figura 1. Análise visual da altura do milho fertirrigado com esgoto (T1) e irrigado com água do poço artesiano (T5).

Segundo Lousane et al. (2008), diferentes tipos de água residuária utilizados na fertirrigação de plantas ornamentais, não apresentaram diferença estatística na variável altura de planta, resultado este que não se assemelha com os encontrados por Azevedo e Oliveira (2005) que obtiveram aumento na produção de pepino, da ordem de 40,7 \%, utilizando águas residuárias; da mesma forma, trabalhos realizados por Mota et al. (1997) mostraram que as culturas de sorgo, algodão e forrageiras fertirrigadas com esgoto tratado, apresentaram produção superior em relação às culturas que receberam água limpa. Resultados satisfatórios e semelhantes ao do presente trabalho foram encontrados por Nascimento (2003) e Ferreira (2003).

Segundo Pons (1980) quando não existe nitrogênio suficiente para a realização da síntese protéica e da clorofila, as plantas permanecem raquíticas e se tomam rapidamente cloróticas, em consequência, a planta sofre inibição de sua capacidade de assimilação e formação de glicídios (carboidratos); tais sintomas foram semelhantes às plantas submetidas ao tratamento T5 (0 \% esgoto doméstico primário) deste experimento. Duarte (2007) obteve aumento da altura das plantas de pimentão, quando fertirrigadas com esgoto doméstico tratado, resultado este que corrobora com o presente trabalho.

De acordo com os resultados da Tabela 4 e as variáveis diâmetro do caule e número de folhas, constata-se no tratamento T5 menor efeito das proporções de esgoto doméstico em relação aos demais, de modo que os tratamentos T1 (100\% de água residuária) até o T4 (25\% de água residuária) se comportaram de maneira semelhantes não diferindo entre si, a $5 \%$ de probabilidade pelo teste de Tukey. Tais resultados demonstram o que já foi mencionado por diversos autores a respeito dessas águas, que são bastante ricas em nutrientes e, consequentemente, com maiores valores (Bouwer, 1992; Fasciolo et al., 2002; Xavier, 2007).

Diante dos resultados expostos na Tabela 4 verifica-se, para o diâmetro do caule (DC) do milho que os efeitos dos tratamentos foram distintos e se acentuaram ao longo do ciclo, em que o diâmetro de caule foi influenciado pela proporção de água residuária (T1 a T4) em relação a T5 cuja grande diferença pode ser atribuída ao aporte de nutrientes da água residuária. Segundo Guimarães et al. (2009), o diâmetro do caule é uma característica importante, uma vez que, quanto maior o seu valor, maior o vigor, a robustez e a resistência 
da planta. Resultados semelhantes foram encontrados por Fidelis Filho et al. (2005) que observaram maiores valores de diâmetro caulinar das plantas de algodão BRS Verde fertirrigadas com efluente decantado comparado com água de poço.

Tabela 4. Resumo das análises de variância e médias do diâmetro do caule (DC) e número de folhas (NF) de plantas de milho (Zea mays L.), variedade cruzeta.

\begin{tabular}{lccccc}
\hline \multirow{2}{*}{ Fonte variação } & GL & \multicolumn{4}{c}{ Quadrado médio } \\
\cline { 3 - 6 } & & DC 20 & DC 40 & DC 60 & NF \\
\hline Tratamentos & 4 & $84,68 * *$ & $249,45^{* *}$ & $224,79 * *$ & $13,75^{* *}$ \\
Blocos & 4 & 17,97 & 2,151 & 5,22 & 0,30 \\
Erro & 16 & 3,82 & 3,36 & 8,57 & 0,58 \\
Cv (\%) & 15.11 & 7.69 & 10.90 & 4.78 \\
DMS & 3,78 & 3,55 & 5,67 & 6,35 \\
\hline Tratamentos & & Médias (cm) & \\
\hline T1(100\% água residuária) & $14,65 \mathrm{~A}$ & $27,33 \mathrm{~A}$ & $29,90 \mathrm{~A}$ & $16,80 \mathrm{~A}$ \\
T2(75\% água residuária) & $14,89 \mathrm{~A}$ & $27,17 \mathrm{~A}$ & $31,12 \mathrm{~A}$ & $16,86 \mathrm{~A}$ \\
T3(50\% água residuária) & 13,81 A & 25,14 A & $26,66 \mathrm{~A}$ & $16,53 \mathrm{~A}$ \\
T4(25\% água residuária) & $15,63 \mathrm{~A}$ & $28,16 \mathrm{~A}$ & $31,32 \mathrm{~A}$ & $16,86 \mathrm{~A}$ \\
T5(0\% água residuária) & $5,66 \mathrm{~B}$ & $11,35 \mathrm{~B}$ & $15,35 \mathrm{~B}$ & $13,07 \mathrm{~B}$ \\
\hline
\end{tabular}

Nota:* Significativo a 5\% de probabilidade pelo teste F;** significativo a $1 \%$ de probabilidade pelo teste $\mathrm{F}$. Médias seguidas de mesma letra na coluna não diferem entre si a 5\% pelo teste Tukey; CV- coeficiente de variação.

Em seus trabalhos Xavier (2007) notou diferenças significativas no diâmetro das plantas da mamoneira da cultivar BRS Nordestina fertirrigadas com águas residuárias de três indústrias de Campina Grande, $\mathrm{PB}$, em que as diferenças foram atribuídas ao aporte de nutrientes das águas residuárias e este não corroboram resultados de Sampaio et al. (2011).

Para Mota et al. (2011), o efeito de água residuária em mudas de melancia foi significativo para o número de folhas. Resultados de Cruz et al. (2008) assemelham aos encontrados por Alves et al. (2009) e corroboram os resultados do presente trabalho em que os tratamentos com água residuária foram superiores ao T5 (água de poço artesiano).

Segundo Malavolta e Dantas (1987), quando existe pouco nitrogênio no solo, as plantas se tornam raquíticas e suas folhas serão verde azulada, pequenas e finas; os caules ficam finos e fracos, estes sintomas foram observados nas plantas do tratamento T5.

Diante dos modelos matemáticos propostos pelo programa computacional, SIVAR (Ferreira, 2000), o modelo quadrático foi o que melhor se ajustou, obtendo dose máxima na ordem de $68,9 \%$ para um número na ordem de 17,3 folhas por plantas. Vieira et al. (2009) analisando o efeito da aplicação de efluente de abatedouro bovino tratado em lagoas de estabilização no solo e no desenvolvimento do milho, encontrou resposta siginficativa para variavel número de folhas na ordem de 14 folhas por plantas, não corroborando com o encontrado nesse trabalho, onde o valor médio obtido foi de 17 folhas por plantas.

De acordo com Tavares et al. (2005), os efeitos do esgoto doméstico secundário e da adubação orgânica na produção de alface, não apresentou diferenças significativas para variável número de folhas, já para Baumgartner et al. (2005), a irrigação com águas 
residuárias propiciou diferenças significativas para o número de folhas da cultura da alface (Lactuca sativa L.), resultado esse que corrobora com os encontrados nesse trabalho.

Diante das médias expostas na Tabela 5, para as variáveis: peso de espiga com e sem palha (PMECP e PMESP), o tratamento T5 teve efeito inferior em relação os demais; já as variáveis peso úmido (PUG) e seco (PSG) de grãos, os tratamentos se comportaram de forma semelhantes entre si não havendo diferença estatística.

Tabela 5. Resumo das análises de variância e médias para variáveis de produção, peso médio de espiga com (PMECP) e sem palha (PMESP), peso úmido (PUG) e seco (PSG) de grãos.

\begin{tabular}{lccccc}
\hline \multirow{2}{*}{$\begin{array}{l}\text { Fonte de } \\
\text { variação }\end{array}$} & GL & \multicolumn{4}{c}{ Quadrado médio } \\
\cline { 3 - 6 } & & PMECP & PMESP & PUG & PSG \\
\hline Tratamentos & 4 & $15272,12^{* *}$ & $15079,74^{* *}$ & 66,70 & 200,36 \\
Blocos & 4 & 1619,21 & 1522,53 & 148,80 & 144,66 \\
Erro & 16 & 1088,86 & 899,84 & 108,37 & 70,03 \\
Cv (\%) & 12,52 & 12,86 & 6,68 & 6,43 \\
MDS & 63,95 & 58,14 & 20,17 & 16,22 \\
\hline \multirow{2}{*}{ Tratamentos } & & \multicolumn{2}{c}{ Médias (g) } \\
\hline T1 (100\%água residuária) & 287,40 A & $261,24 \mathrm{~A}$ & $161,0 \mathrm{~A}$ & $135,6 \mathrm{~A}$ \\
T2 (75\% água residuária) & $275,36 \mathrm{~A}$ & $243,56 \mathrm{~A}$ & $154,2 \mathrm{~A}$ & $132,8 \mathrm{~A}$ \\
T3 (50\% água residuária) & 306,24 A & 275,6 A & $156,4 \mathrm{~A}$ & $131,4 \mathrm{~A}$ \\
T4 (25\% água residuária) & 282,04 A & 248,72A & $156,4 \mathrm{~A}$ & $131,6 \mathrm{~A}$ \\
T5 (0\% água residuária) & 166,88 B & 137,64B & $151,0 \mathrm{~A}$ & $119,2 \mathrm{~A}$ \\
\hline
\end{tabular}

Nota:* Significativo a $5 \%$ de probabilidade pelo teste $\mathrm{F}^{* *}$ significativo a $1 \%$ de probabilidade pelo teste $\mathrm{F}$; Médias seguidas de mesma letra na coluna não diferem entre si em níveis de 5\% pelo teste Tukey, CV.Coeficiente de Variação.

Diante dos resultados apresentados na Tabela 5 notam-se efeitos significativos entre as proporções de água residuária em relação à água de poço artesiano (T5), onde o tratamento (T3) foi o que proporcionou maior peso médio de espiga com e sem palha (PMECP e PMESP), obtendo-se média de 4,654 $\mathrm{kg}$ por $12,5 \mathrm{~m}^{2}$ equivalente à $\left(37,23 \mathrm{t} \mathrm{ha}^{-1}\right)$, porém diferindo a 5\% de probabilidade pelo teste de Tukey, apenas do tratamento T5 diante das respectivas variáveis analisadas. (Azevedo et al., 2007) observaram que, com o uso da água residuária tratada na fertirrigação, foi possível obter produtividade satisfatória para o milho forrageiro, chegando-se a 117,318 kg por $40 \mathrm{~m}^{2}\left(29,33 \mathrm{t} \mathrm{ha}^{-1}\right)$ porém a produtividade foi menor que a encontrada nesse trabalho. Ainda este mesmo autor constatou que o maior peso de espiga foi influenciado pela aplicação de água residuária.

Nos estudos de Freitas et al. (2004) foi constatado que o uso da água da suinocultura aumentou significativamente os valores de produtividade e peso de espiga bem como variáveis. Silva et al. (2005) relataram que a absorção de nitrogênio ocorre em todo seu ciclo vegetativo do milho, mesmo que na fase inicial, as exigências nutricionais sejam menores, o nitrogênio induz o crescimento mais rápido e consequentemente o aumento na produção de grãos. Resultados este corroboram com os encontrados no presente trabalho. Vasquez-Montiel et al. (1996) citam resultados de pesquisa realizada com milho submetido a irrigação com água residuária e de abastecimento e observaram que a fertirrigação com o esgoto tratado 
aumentou a absorção de nitrogênio e fósforo pelas plantas de milho e, consequentemente, a produtividade delas.

Os resultados expotos na Figura 2 mostram que a proporção de 100\% de água residuária induziu o peso úmido e seco (PUG e PSG) à valores superiores em relação aos demais tratamentos, embora não diferindo estatisticamente entre si. Em seus estudos, Cavallet et al. (2006) utilizaram doses de 160 e 320 t ha ${ }^{-1}$ de águas residuárias proveniente da indústria de enzimas e calcário NPK sobre a produção de grãos de milho encontrou efeitos semelhantes entre duas doses de águas residuárias em relação ao calcário NPK; enquanto Souza et al. (2010) estudaram a produtividade da mamona, observaram que os tratamentos influenciaram significativamente a produtividade da mamoneira quando fertirrigado com água residuária, resultado esse corrobora com o presente trabalho.

É importante ressaltar que a utilização do grão úmido para nutrição animal tem algumas vantagens agronômicas, como significativa redução das perdas no campo, liberação antecipada da área, redução dos custos com o processo de secagem.

As pesquisas relacionadas com umidade de grãos de milho tem demonstrado que existe diminuição no consumo de alimentos e ganhos equivalentes na utilização do milho úmido em relação ao milho seco, com consequente melhora da eficiência alimentar. Embora exista alguma variação, principalmente em função do teor de umidade do grão e do nível de inclusão na dieta, um efeito de cerca de $10 \%$ na eficiência de ganho tem sido observado de acordo com Stock et al. (1990).

Entretanto os resultados experimentais têm sido variáveis, principalmente em decorrência do teor de umidade do grão, do processamento antes e após o armazenamento, do método de armazenamento e do nível de inclusão na dieta dos animais. Tonroy et al. (1974) verificaram diminuição no consumo de alimentos e ganhos equivalentes na utilização do milho úmido em relação ao milho seco, com melhoras de 9 a 25\% na eficiência alimentar, e sugeriram a ocorrência de uma melhora na digestibilidade dos nutrientes.

Os resultados encontrados neste estudo corroboram com a literatura, confirmando os benefícios do reuso de água residuária na irrigação de milho, reduzindo desta forma os impactos ambientais causados por este tipo de efluente doméstico.

(A)

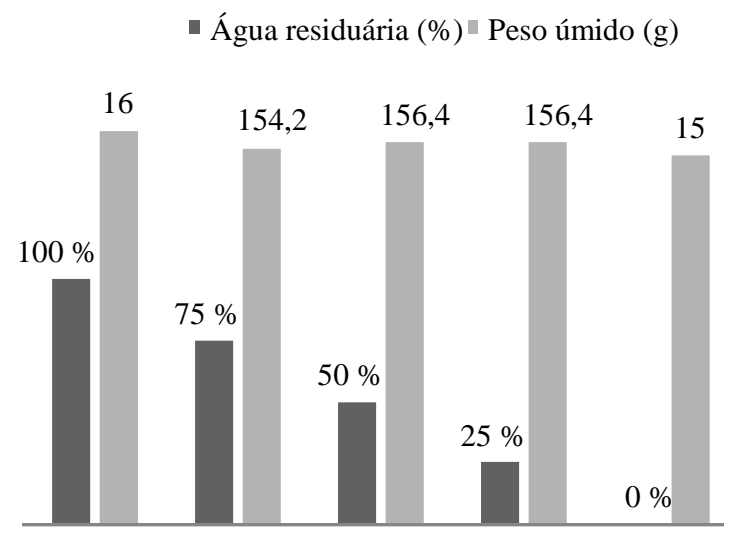

(B) Peso seco de grãos (g)

- Água residuária (\%) 『 Peso seco (g)

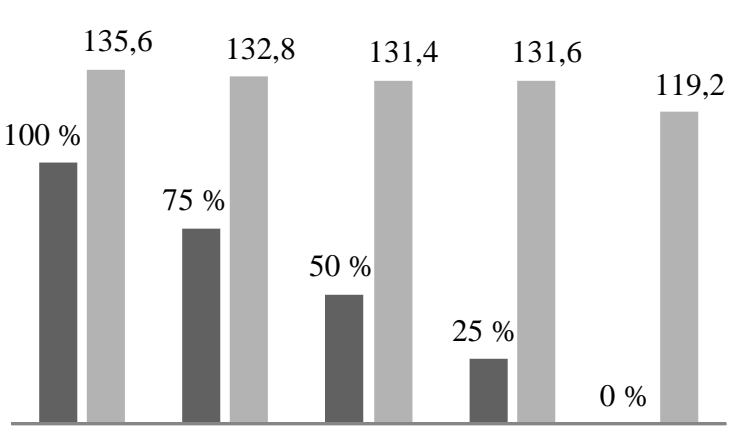

Figura 2. (A) Peso úmido, (B) Peso seco de 400 grãos de milho em função da aplicação das proporções de esgoto doméstico tratado e água de poço artesiano.

Nota-se na Figura 3 quando aplicados T3 (50\% de água residuária), a produtividade de grãos de milho obteve média na ordem de $14,4 \mathrm{t} \mathrm{ha}^{-1}$, valor superior aos demais tratamentos, principalmente, em relação à aplicação de T5 (100\% de água de poço artesiano) que obteve uma produtividade de $7,4 \mathrm{t} \mathrm{ha}^{-1}$, resultado que foi evidente, por essas águas possuírem grandes 
quantidades de nutrientes. De acordo com Lucas Filho et al. (2001), os fatores de produção do milho foram positivos e significativos quando submetidos à fertirrigação com água residuária, resultados esses que se assemelham aos obtidos neste trabalho.

Cavallet et al. (2006) observaram produção de grãos de milho superior em todos os tratamentos utilizados em relação a testemunha corroborando Azevedo et al. (2007) que observaram que a irrigação apenas com água residuária promoveu um incremento na produtividade do milho forrageiro híbrido AG 1051 em relação à produção alcançada quando se utilizou somente a água de abastecimento, corroborando o presente trabalho.

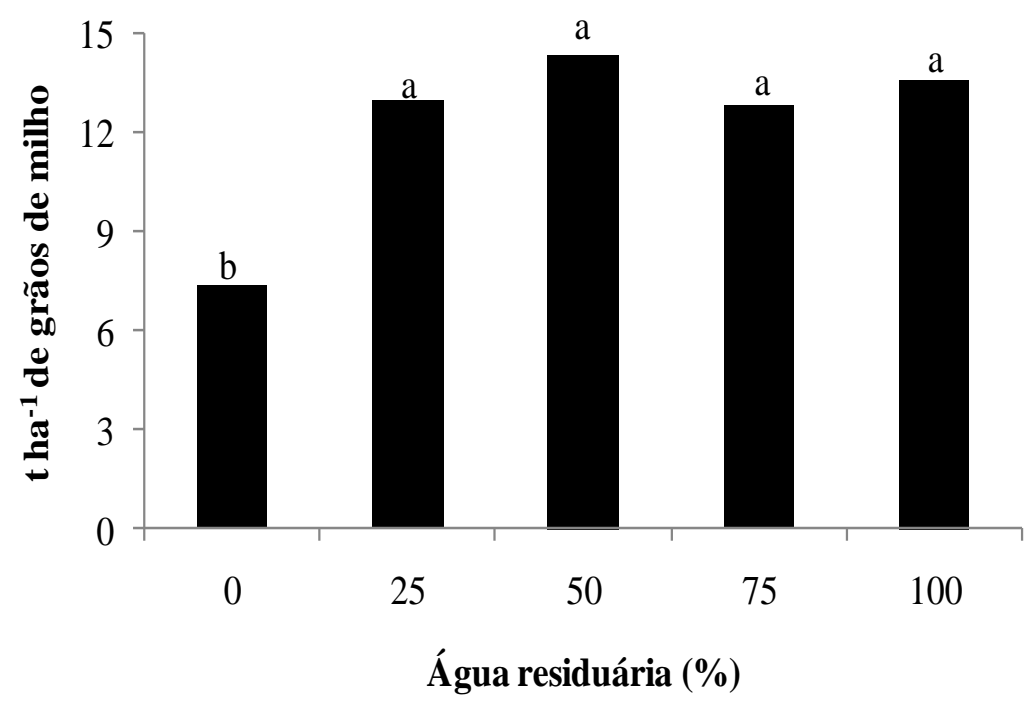

Figura 3. Produtividade de grãos de milho por hectare $\left(\mathrm{t} \mathrm{ha}^{-1}\right)$ em função da aplicação das proporções de esgoto doméstico tratado e água de poço artesiano. Barras seguidas da mesma letra não diferem entre si (Tukey 5\%).

\section{CONCLUSÕES}

A fertirrigação com esgoto doméstico proporcionou maiores valores de altura de planta, diâmetro do caule, e número de folhas.

Apesar do esgoto doméstico tratado ser uma alternativa viável na irrigação do milho, é necessário realizar o acompanhamento das possíveis alterações nos atributos físicos, químicos e microbiológicos do solo em questão ao longo de sucessivos cultivos.

O uso de esgoto doméstico primário na cultura do milho pode ser considerado como fonte alternativa de fertilizantes para produção de alimento em assentamento rural.

O esgoto doméstico tratado é uma alternativa viável na irrigação do milho contribuindo deste modo para redução do uso de água de boa qualidade na agricultura.

\section{AGRADECIMENTOS}

Ao Banco do Nordeste do Brasil (BNB) e ao Conselho Nacional de Desenvolvimento Científico e Tecnológico (CNPq) pelo apoio financeiro.

\section{REFERÊNCIAS}

ALLEN, R. G.; PEREIRA, L. S.; RAES, D.; SMITH, J. Evapotranspiration del cultivo: guias para La determinación de los requerimientos de agua de los cultivos. Roma: FAO, 2006. 298 p. 
ALVES, W. W. A. et al. Área foliar do algodoeiro irrigado com água residuária adubado com nitrogênio e fósforo. Revista Verde de Agroecologia e Desenvolvimento Sustentável, Mossoró, v. 4, n. 1, p. 41- 46, 2009.

AYERS, R. S.; WESTCOT, D. W. A qualidade da água na agricultura. 2. ed. Campina Grande: UFPB, 1999. 153p.

AZEVEDO, M. R. Q.; KÖNIG, A.; BELTRÃO, N. E. M.; AZEVEDO, C. A. V.; TAVARES, T. L.; SOARES, F. A. L. Efeito da irrigação com água residuária tratada sobre a produção de milho forrageiro. Revista Brasileira de Ciências Agrárias, Recife, v. 2, n. 1, p. 63-68, 2007.

AZEVEDO, L. P.; OLIVEIRA, E. L. Efeitos da aplicação de efluente de tratamento de esgoto na fertilidade do solo e produtividade de pepino sob irrigação subsuperficial. Engenharia Agrícola, v. 25, n. 1, p. 253-263, 2005. http://dx.doi.org/10.1590/S010069162005000100028

BAUMGARTNER, D.; SAMPAIO, S. C.; SILVA, T. R.; TEO, C. R. P. A.; GOMES, B. M. Alface irrigada com águas residuárias de atividades agroindustriais. Acta Scientiarum. Biological Sciences, Maringá, v. 27, n. 4, p. 697-705, 2005.

BOUWER, H. Agricultural and municipal use of wastewater. Water Science Technology, Oxford, v. 26, n. 7-8, p. 1583-91, 1992. http://handle.nal.usda.gov/10113/50335

BENINCASA, M. M. P. Análise de crescimento de plantas. Jaboticabal: FUNEP, 1988. 42p.

CAVALLET, L. E.; LUCCHESI, L. A. C.; MORAES, A.; SCHIMIDT, E.; PERONDI, M. A.; FONSECA, R. A. Melhoria da fertilidade do solo decorrentes da adição de água residuária da indústria de enzimas. Revista Brasileira de Engenharia Agrícola e Ambiental, Campina Grande, v. 10, n. 3, p. 724-729, 2006. http://dx.doi.org/10.1590/S1415-43662006000300027

COMPANHIA NACIONAL DE ABASTECIMENTO - CONAB. Acompanhamento de safra brasileira: grãos, sétimo levantamento, Safra 2010/2011. - Brasília: Conab, abril 2011. Disponível em:

<http://www.conab.gov.br/conabweb/download/safra/estudo_safra.pdf>. Acesso em: 23 jan. 2012.

COSTA, F. X.; LIMA, V. L. A.; BELTRÃO, N. E. M.; AZEVEDO, C. A. V.; SOARES, F. A. L.; ALVA, I. D. M.Efeitos residuais da aplicação de biossólidos e da irrigação com água residuária no crescimento do milho. Revista Brasileira de Engenharia Agrícola e Ambiental, Campina Grande, v. 13, n. 6, p. 687-693, 2009.

http://dx.doi.org/10.1590/S1415-43662009000600004

CRUZ, M. C. M. et al. Utilização de água residuária de suinocultura na produção de mudas de maracujazeiro azedo cV redondo amarelo. Revista Brasileira de Fruticultura, Jaboticabal, v. 30, n. 4, p. 1107-1112, 2008. http://dx.doi.org/10.1590/S010029452008000400043

DUARTE, A. S. Reuso de água residuária tratada na irrigação da cultura do pimentão (Capsicumannun L.). Piracicaba: ESALQ/USP, 2007. 187p. 
EMPRESA BRASILEIRA DE PESQUISA AGROPECUÁRIA - EMBRAPA. Centro Nacional de Pesquisas de Solos. Sistema brasileiro de classificação de solos. 2. ed. Rio de Janeiro: Embrapa Solos; Brasília: Sistema de Produção de Informação, 2006. 306p.

EMPRESA BRASILEIRA DE PESQUISA AGROPECUÁRIA - EMBRAPA. Manual de métodos de análise de solo. Rio de Janeiro; Embrapa Solos, 1997. 212p.

FASCIOLO, G. E.; MECA, M. I.; GABRIEL, E.; MORÁBITO, J. Effects on crops of irrigation with treated municipal wastewaters. Water Science and Technology, Oxford, v. 45, n. 1, p. 133-8, 2002.

FERREIRA, O. E. Efeitos da aplicação de água residuária doméstica tratada e adubação nitrogenada na cultura do algodão herbáceo e no meio edáfico. 2003. $78 f$. Dissertação (Mestrado em Agronomia) - Faculdade de Ciências Agrárias, Universidade Federal de Campina Grande, Campina Grande, 2003.

FERREIRA, P. V. Estatística experimental aplicada à agronomia. 3. ed. Maceió: UFAL, 2000. $604 \mathrm{p}$.

FIDELIS FILHO, J.; NÓBREGA, J. Q.; SOUSA, J. T. DE; DANTAS, J. P. Comparação dos efeitos de água residuária e de poço no crescimento e desenvolvimento do algodoeiro. Revista Brasileira de Engenharia Agrícola e Ambiental, Campina Grande, v. 9, (Suplemento), p. 328-332, 2005.

FREITAS, W. S.; OLIVEIRA, R. A.; PINTO, F. A.; CECON, P. R.; GALVÃO, J. C. C. Efeito da aplicação de águas residuárias de suinocultura sobre a produção do milho para silagem. Revista Brasileira de Engenharia Agrícola e Ambiental, Campina Grande, v. 8, n. 1, p. 120-125, 2004. http://dx.doi.org/10.1590/S1415-43662004000100018

GUimARÃES, A. S.; MACEDO, B. N. E.; COSTA, S. G. Fontes e doses crescentes de adubos orgânicos e mineral no crescimento inicial de pinhão manso. Mens agitat, Boa Vista, v. 04, n. 1, p. 17-22, 2009.

HESPANHOL, I. Potencial de reúso de água no Brasil - agricultura, indústria, municípios, recarga de aqüíferos. In: MANCUSO, C. S. A.; SANTOS, H. F. (Eds.). Reúso de água. Barueri: Manole, 2008. p.37-95.

INSTITUTO FNP. Agrianual: anuário da agricultura brasileira - 2006. São Paulo, 2006. 504p.

KOURAA, A.; FETHI, F.; LAHLOU, A.; OuazzaniI N. Reuse of urban wastewater by combined stabilization pond system en Benslimane (Marocco). Urban Water, v. 4, p. 373-378, 2002. http://dx,doi.org/10.1016/S1462-0758(01)00067-X

LOUSANE, L.; FADIGAS, F. S.; PEREIRA, F. A.; GLOAGUEN, T. V.; COSTA, J. A. Desenvolvimento de Heliconia psittacorum e Gladiolus hortulanus irrigados com águas residuárias tratadas. Revista Brasileira de Engenharia Agrícola e Ambiental, Campina Grande, v. 12, n. 6, p. 606-613, 2008. http://dx.doi.org/10.1590/S141543662008000600006 
LUCAS FILHO, M.; PEREIRA, M. G.; LIMA, A. SILVA, M.; D. A.; FONSECA, F.C. E. Avaliação preliminar do potencial de reuso de águas residuárias tratadas em culturas de milho (Zea mays) In: CONGRESSO BRASILEIRO DE ENGENHARIA SANITÁRIA E AMBIENTAL, 21., 2001, João Pessoa. Anais... Paraíba: Universidade Federal de Campina Grande; Sociedade Brasileira de Engenharia Sanitária e Ambiental, 2001. CD Rom.

MALAVOLTA, E.; DANTAS, J. P. Nutrição e adubação do milho. In: PATERNIANI, E.; VIEGAS, G.P. (Eds.). Melhoramento e produção do milho. 2. ed. Campinas: Fundação Cargill, 1987. v. 2. p. 541.

MELI, S.; PORTO, M.; BELligNO, A.; BUFO, S. A.; MAZZATURA, A.; SCOPA, A. Influence of irrigation with lagooned urban wastewater on chemical and microbiological soil parameters in a citrus orchard under Mediterranean condition. The Science ofthe Total Environment, v. 285, p. 69-77, 2002. http://dx.doi.org/10.1016/S00489697(01)00896-8

MOTA, A. F.; ALMEIDA, J. P. N.; SANTOS, J. S.; AZEVEDO, J.; GURGEL, M. T. Desenvolvimento inicial de mudas de melancia 'CRIMSON SWEET' irrigadas com águas residuárias. Revista Verde, Mossoró, v. 6, n. 2, p. 98 - 104, 2011.

MOTA, S.; BEZERRA, F. C.; TOMÉ, L. M. Avaliação do desempenho de culturas irrigadas com esgotos tratados. CONGRESSO BRASILEIRO DE ENGENHARIA SANITÁRIA E AMBIENTAL, 19., 1997, Foz do Iguaçu. Anais... Foz do Iguaçu: Associação Brasileira de Engenharia Sanitária e Ambiental, 1997. p. 20-26.

NASCIMENTO, M. B. H. do. Modificações no ambiente edáfico, na água e na mamoneira, submetidas ao uso de biossólidos e água residuária. 2003. $78 \mathrm{f}$. Dissertação (Mestrado em Engenharia Agrícola) - Universidade Federal de Campina Grande, Paraíba, 2003.

PEIXOTO, C. M.; HENTSCHKE, C.; AGUIRRE, A. Manejo do nitrogênio, caderno técnico. Revista Cultivar, Pelotas, n. 54, p. 10, 2003.

PIZARRO, F. Riegos localizados de alta frecuencia: Goteo, microaspersion, exudacion. 2. ed. Madrid: Mundi-Prensa, 1990. 461p

PONS, A. L. Instituto de Pesquisa Agropecuária. IP AGRO, n. 23, p. 51,1980.

SAMPAIO, P. R. F.; ALMEIDA, J. P. N.; MOTA, A. F.; COSTA, L. R.; GURGEL, M. T. Utilização de águas residuárias na germinação e desenvolvimento inicial de mudas de meloeiro amarelo ouro. Revista Verde, Mossoró, v. 6, n. 1, p. 179 - 187, 2011.

SILVA, E. C.; FERREIRA, S. M.; SILVA, G. P.; ASSIS, R. L.; GUIMARÃES, G. L. Épocas e formas de aplicação de nitrogênio no milho sob plantio direto em solo do cerrado. Revista Brasileira de Ciência do Solo, Viçosa, v. 29, p. 725-733, 2005. http://dx.doi.org/10.1590/S0100-06832005000500008

SOUZA, N. C.; MOTA, S. B.; BEZERRA, F. M. L.; AQUINO, B. F.; SANTOS, A. B. Produtividade da mamona irrigada com esgoto doméstico tratado. Revista Brasileira de Engenharia Agrícola e Ambiental, Campina Grande, v. 14, n. 5, p. 478-484, 2010. http://dx.doi.org/10.1590/S1415-43662010000500004

SOUSA, J. T.; LEITE, V. D. Tratamento e utilização de esgotos domésticos na agricultura. 2. ed. Campina Grande: UEPB, 2008. 135p. 
STOCK, R. A.; SINDT, M. H.; CLEALE, R. M. et al. High-moisture corn utilization in finishing cattle. Journal of Animal Science, v. 69, n. 4, p. 1645-1656, 1990.

TAVARES, T. de L.; KÖNIG, A.; CEBALLOS, B. S. O. de; AZEVEDO, M. R. de Q. A. Efeitos da adubação do solo e da irrigação sobre os componentes de produção da alface. Revista Brasileira de Engenharia Agrícola e Ambiental, Campina Grande, v. 9, Suplemento, p. 231-5, 2005.

TONROY, B. R.; PERRY, T. W.; BEESON, W. M. Dry, ensiled high-moisture, ensiled reconstituted high-moisture and volatile fatty acid treated high moisture corn for growing-finishing beef cattle. Journal of Animal Science, v. 39, n. 5, p. 931-936, 1974.

VASQUEZ-MONTIEL, O.; HORAN, N. J.; MARA, D. D. Management of domestic wastewater for reuse in irrigation. Water Science and Tecnology, v. 33, n. 10-11, p. 355-362, 1996. http://dx.doi.org/10.1016/0273-1223(96)00438-6

VIEIRA JOSÉ, J.; RIBAS, M. M. F.; FREITAS, P. S. L.; FRANCISCONI JUNIOR, J. P. Efeito da aplicação de efluente de abatedouro bovino tratado em lagoas de estabilização no solo e no desenvolvimento do milho. Pesquisa Aplicada e Agrotecnologia, v. 2, n. 1, p. 52-59, 2009.

XAVIER, J. F. Águas residuárias provenientes de indústrias e seus efeitos no crescimento e desenvolvimento da mamoneira BRS Nordestina. 2007. 101f. Dissertação (Mestrado em Engenharia Agrícola) - Universidade Federal de Campina Grande, Campina Grande, 2007. 


\begin{tabular}{|} 
Ambiente \& Água - An Interdisciplinary Journal of Applied Science \\
ISSN 1980-993X - doi:10.4136/1980-993X \\
www.ambi-agua.net \\
E-mail: ambi-agua@agro.unitau.br
\end{tabular}

\title{
Degradação de trilhas na Reserva Ecológica da Juatinga em Paraty - Rio de Janeiro
}

\author{
doi: 10.4136/ambi-agua.1434
}

Received: 19 Jun. 2014; Accepted: 10 Sep. 2014

\author{
Luana de Almeida Rangel*; Antonio José Teixeira Guerra \\ Universidade Federal do Rio de Janeiro (UFRJ), Rio de Janeiro, RJ, Brasil \\ Departamento de Geografia \\ *Autor correspondente: e-mail: luarangel@ufrj.br, \\ antoniotguerra@gmail.com
}

\section{RESUMO}

A utilização de trilhas em áreas de reserva ecológica pode acarretar diversos impactos, quando não for feito planejamento e implementação adequados. Diante disso, o presente trabalho teve como objetivo avaliar os impactos e a degradação de duas trilhas (Laranjeiras-Praia do Sono e Praia do Sono-Praia de Antigos) no sul da Reserva Ecológica da Juatinga (REJ), em Paraty (RJ). Foram analisados os índices de agregação e os teores de matéria orgânica do solo, bem como, foram observadas a presença de áreas degradadas. Os resultados obtidos mostram que a trilha Praia do Sono-Praia de Antigos está muito degradada, pois apresenta índice de agregação do solo inferior a $1 \mathrm{~mm}$, e teores de matéria orgânica menores que a 3,5\%. Além disso, a presença de ravinas é constante. Conclui-se que deve ser feita a recuperação dessas áreas mais impactadas com a utilização de técnicas de manejo adequadas, como canaletas de drenagem para orientar o fluxo de água e a aplicação de geotêxteis para recuperar o talude e a vegetação.

Palavras-chave: agregação do solo, erosão hídrica, feições erosivas, Floresta Atlântica.

\section{Trail degradation in Juatinga Ecological Reserve, municipality of Paraty - Rio de Janeiro State}

\begin{abstract}
Without proper planning, the use of trails in ecological reserves may result in various negative impacts. This research therefore evaluated the impacts and degradation of two trails (Laranjeiras-Praia do Sono and Praia do Sono-Praia de Antigos) in southern Juatinga Ecological Reserve in Paraty, Rio de Janeiro State. To accomplish this, the study analyzed the rate of aggregation and the organic matter content of the soil; the presence of degraded areas was also observed. The results indicated that the Laranjeiras-Praia do Sono trail is rather degraded, and has a low rate of soil aggregation at less than $1 \mathrm{~mm}$ with organic matter content lower than 3.5\%; it also has several ravine erosions. The study concluded that the degraded areas should be reclaimed through the use of drainage channels to control water flow and through the use of geotextiles to protect the slope and vegetation.
\end{abstract}

Keywords: Atlantic Forest, erosive features, hydric erosion, soil aggregation. 


\section{INTRODUÇÃO}

O aumento da preocupação social com relação à utilização dos recursos naturais tem contribuído para o desenvolvimento de estudos que colaboraram para criação de um pensamento que tem no ambiente o objeto de reflexão. A partir disso, conhecer as potencialidades e fragilidades de determinada área, como oferta de recursos naturais, ocorrência de processos erosivos e movimentos de massa, facilita a elaboração desses estudos e a conservação do meio ambiente.

O fato é que o conceito de Unidade de Conservação (UC) passou a agregar a função de instrumento de recursos naturais e de gestão territorial, adotando desde a proteção integral da natureza, até a gestão ordenada do território e dos recursos que o ser humano pode obter dos ecossistemas.

Antes da criação do SNUC (2000), existia uma categoria de área protegida chamada Reserva Ecológica, porém após sua criação, essa categoria foi extinta. No decreto de criação fica determinado que as Reservas Ecológicas são: "áreas de preservação permanente, públicas ou particulares, que tem por finalidade manter os ecossistemas naturais de importância regional ou local e regular o uso admissível dessas áreas, de modo a compatibilizá-lo com os objetivos da conservação ambiental” (Brasil, 1984).

Conforme estabelecido, haveria necessidade de reclassificação das antigas nomenclaturas ao novo sistema. Entretanto, nem todas as denominações foram modificadas pelos governos. Um desses casos é o da Reserva Ecológica da Juatinga/RJ, Unidade de Conservação estadual e objeto deste estudo.

Quando a utilização de UC é feita sem planejamento podem ocorrer impactos negativos e degradação do ambiente natural. Cunha e Guerra (2006) destacam que a degradação é considerada um problema social, uma vez que os processos naturais, que ocorrem com e sem a interferência humana (por exemplo: erosão, movimentos de massa e cheias), para serem identificados como "degradação" são carregados de critérios sociais, porque relacionam as terras aos seus usos em curso.

Segundo Araújo et al. (2013), a redução de potenciais recursos renováveis causada por combinações de processos que agem sobre as terras leva à sua degradação. A degradação do solo é definida pela Associação Brasileira de Normas Técnicas (ABNT), pela NBR 10703, como a "alteração adversa das características do solo em relação aos seus diversos usos possíveis, tanto os estabelecidos em planejamento, como os potenciais” (ABNT, 1989).

Sendo assim, a atividade turística, com utilização das trilhas, pode provocar degradação do solo. Andrade (2005) destaca que: "as trilhas são os únicos meios de acesso às Unidades de Conservação e que elas oferecem oportunidade do contato efetivo com a natureza". Sendo assim, as trilhas no interior das UCs podem impactar não só a dinâmica do solo, mas também, o ecossistema como um todo.

Pode-se pensar que a implantação de trilhas não influencia na dinâmica da paisagem e do ecossistema, devido as suas dimensões pouco expressivas, no entanto, trilhas instaladas em locais mais propensos à degradação, sob uso intensivo e sem manejo podem, comprometer os objetivos gerais das UCs (Kroeff, 2010).

Nessa conjectura, o monitoramento da qualidade do solo, isto é, da capacidade que um determinado tipo de solo apresenta para desempenhar funções relacionadas à sustentação da diversidade biológica, à manutenção da qualidade do ambiente, à promoção da saúde de plantas e animais e à sustentação de estruturas socioeconômicas e de habitação humana, é fundamental para que haja a adoção de práticas de manejo que ajudem na conservação do mesmo (Doran e Parkin, 1994).

Neste sentido, a utilização de indicadores de qualidade do solo é considerada como relevante, pois, possibilita o monitoramento de impactos, positivos ou negativos, de 
fenômenos naturais ou de ações antrópicas (Arshad e Martin, 2002), pensando-se na sustentabilidade ambiental, agrícola e econômica.

Os índices de agregação avaliados pela estabilidade em água (Yoder, 1936) podem ser considerados indicadores de qualidade do solo. Nesse sentido, podem ser usados: o diâmetro médio geométrico (DMG), que é uma estimativa do tamanho médio dos agregados que mais ocorrem no solo, o diâmetro médio ponderado (DMP), que é tanto maior quanto maior for a percentagem de agregados grandes retidos nas peneiras com malhas maiores e o índice de estabilidade de agregados (IEA), que é uma medida da agregação total, sem considerar as classes de distribuição de tamanho dos agregados, que pode refletir na resistência do solo à erosão (Castro Filho et al., 1998).

Sendo assim, o presente trabalho tem como objetivos avaliar os impactos e a degradação do solo ocasionada pela utilização de trilhas na Reserva Ecológica da Juatinga (REJ), visando à melhor gestão da área e à conservação de fragmentos de Mata Atlântica.

\section{MATERIAL E MÉTODOS}

\subsection{Localização da área de estudo}

A Reserva Ecológica da Juatinga possui 8.000 hectares e está situada no município de Paraty, no litoral Sul do estado do Rio de Janeiro. Ela foi criada pelo decreto Estadual $\mathrm{n}^{\mathrm{0}} 17.981$, de 30 de outubro de 1992 e tem como principal objetivo promover o fomento da cultura caiçara residente na REJ, compatibilizando seu modo de vida e a utilização dos recursos naturais com a conservação ambiental.

Rangel e Guerra (2013, p. 793) destacam que "a REJ possui condições especiais na sua criação, por ser uma área com intensos conflitos fundiários, onde a população caiçara sofre ameaças de grileiros e a ocupação irregular vem crescendo ao longo do tempo".

A região da REJ destaca-se pela topografia acidentada, caracterizada por elevadas altitudes e amplitudes das formas de relevo, derivado do contraste entre o domínio de escarpas e reversos da Serra do Mar com a planície costeira, gerando elevações que se estendem do nível do mar até cotas superiores a 1.000 metros (Guerra et al., 2013).

O arcabouço geológico é formado predominantemente por granitos e gnaisses do Complexo Gnáissico-Granitóide de idade proterozóica, os quais se associam sedimentos de idade cenozóica. O tipo de solo predominante na REJ é o Cambissolo Háplico, ocupando quase toda a escarpa da Serra do Mar. Os outros tipos de solos presentes são associações de Latossolo Vermelho-Amarelo e Cambissolo Húmico (ICMBio, 2004).

A classificação climática regional desta área corresponde ao tipo de clima tropical úmido, com sazonalidade no regime das precipitações (estação chuvosa x seca), onde no município de Paraty, a pluviosidade anual varia entre 768 a 2.045 mm (ICMBio, op. cit.).

Há predominância no domínio de floresta ombrófila densa, ocorrendo também floresta de restinga e manguezal. Por toda região encontra-se também vegetação que já foi alterada anteriormente em diferentes estágios sucessionais, como campos de ocupação agropecuária, capoeiras e vegetação secundária (Marques, 1997).

As trilhas Laranjeiras-Praia do Sono e Praia do Sono-Praia de Antigos estão localizadas no sul da REJ e foram escolhidas por apresentar grande fluxo de visitantes e grandes apelos ao ambiente natural (Figura 1).

A trilha Laranjeiras-Praia do Sono (início: 2319'50.91"'S e 44³9'39.68" O; término: 2319'51.98"S e 4438'18.19”') - que possui um trecho na Área de Proteção Ambiental de Cairuçu - possui aproximadamente $3 \mathrm{~km}$ de extensão e está inserida em ambiente de floresta ombrófila densa, em estágio avançado de sucessão. Porém, em alguns trechos, é possível observar mudança na vegetação, com a presença de gramíneas e de vegetação arbustiva, isso ocorre principalmente em encostas degradadas. 
Já a trilha Praia do Sono - Praia de Antigos (início: 23²0’14.12”S e 44³7’41.51" O; término: $23^{\circ} 20^{\prime} 19.42^{\prime \prime}$ S e $\left.44^{\circ} 37^{\prime} 27.49^{\prime \prime}\right)$ está totalmente inserida na REJ e possui extensão de aproximadamente 600 metros, a vegetação predominante é arbustiva e está localizada em uma encosta com declividade de aproximadamente $40^{\circ}$, evidenciando diversas feições erosivas e áreas degradadas provocadas pela concentração do fluxo de água.

Além do acesso as praias, as trilhas proporcionam contato direto com fragmentos de Mata Atlântica e possibilitam uma visão privilegiada da Praia do Sono.

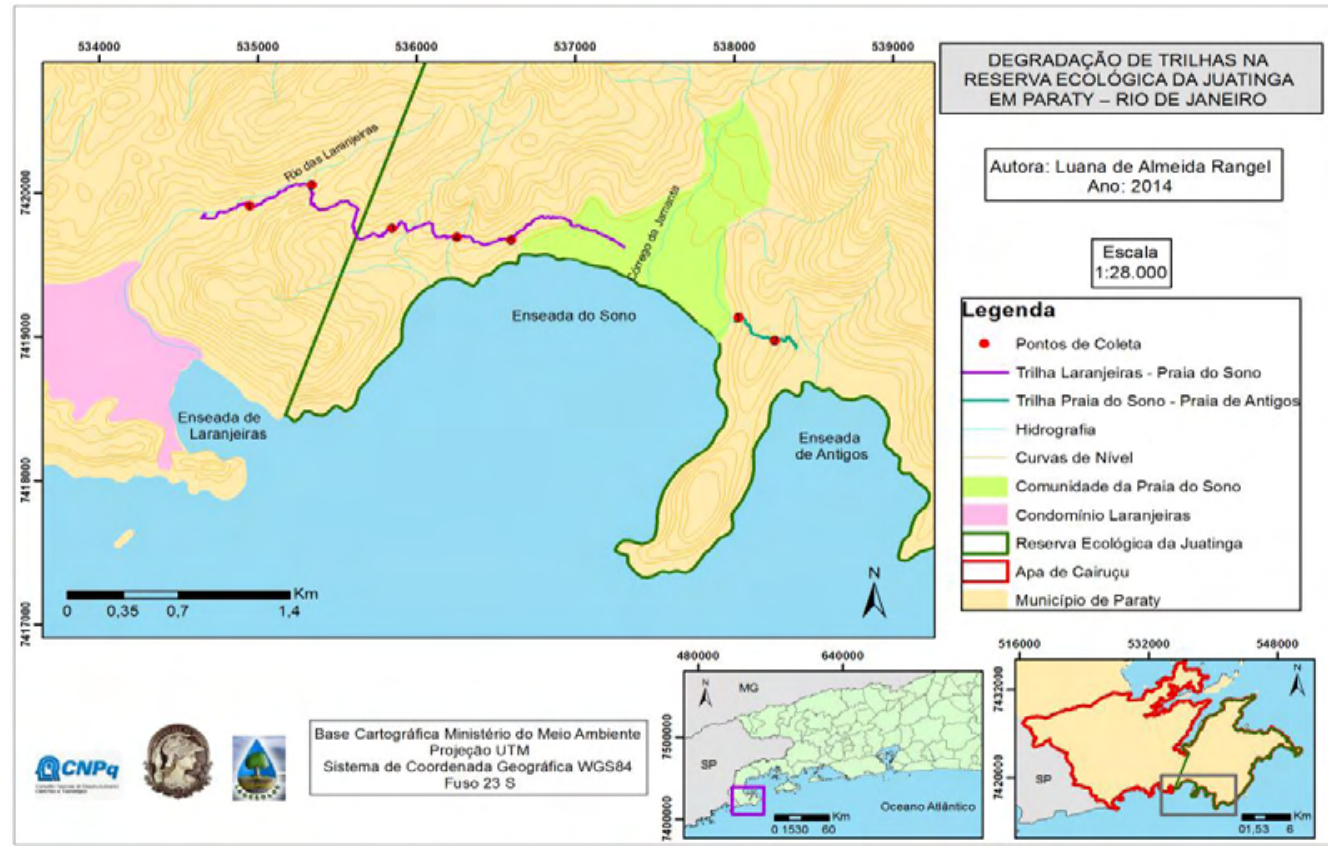

Figura 1. Localização da Reserva Ecológica da Juatinga e dos pontos de coleta nas trilhas analisadas.

Fonte: Modificado de Rangel et al. (2013).

\subsection{Análises laboratoriais}

Foram coletadas amostras de solo na área de trilha e na área de borda da trilha, em três repetições na profundidade de $0-10 \mathrm{~cm}$, em cinco pontos na trilha Laranjeiras - Praia do Sono e em dois pontos na trilha Praia do Sono - Praia de Antigos. As coletas foram feitas nos meses de setembro e outubro de 2012.

Seguiu-se o que foi proposto por Leung e Marion (1999), que concluem que o intervalo ideal das amostragens é de até 100 metros para se atingir a máxima acurácia, sendo que intervalos entre 100 e 600 metros são recomendados para se atingir um balanço apropriado entre acurácia e eficiência.

Para analisar os índices de agregação do solo, que refletem a quebra do agregado e, portanto, o efeito do pisoteio nas trilhas, foi utilizado o método proposto por Yoder (1936) de estabilidade de agregados em água. Assim, foram coletados blocos de solo, que depois de quebrados e homogeneizados em peneiras de $4 \mathrm{~mm}$ e $2 \mathrm{~mm}$, foram transferidas para 0 aparelho de Yoder, adaptado com peneiras de malhas de 2,0, 1,0, 0,5, 0,25 e 0,125 mm de abertura. As amostras oscilaram durante 15 minutos, com aproximadamente 32 rotações por minuto (Embrapa, 1997). Após o término das oscilações, o conteúdo retido em cada uma das peneiras foi levado à estufa a $105^{\circ} \mathrm{C}$ durante 24 horas.

Após pesados, os valores obtidos nos peneiramentos são usados para cálculo do Diâmetro Médio Ponderado (DMP), Diâmetro Médio Geométrico (DMG) e Índice de Estabilidade dos Agregados (IEA), por meio das equações modificadas por Castro Filho et al. (1998) de Kemper e Rosenau (1986): onde o DMP é obtido pela Equação 1. 


$$
\operatorname{DMP}(\mathrm{mm})=\sum_{i=1}^{n}\left(x_{i} \cdot w_{i}\right),
$$

em que:

$\mathrm{w}_{\mathrm{i}}=$ proporção (\%) de cada classe em relação ao total; e

$\mathrm{x}_{\mathrm{i}}=$ diâmetro médio das classes.

O DMG é obtido pela Equação 2.

$D M G(m m)=\exp \frac{\sum w_{i} \ln x_{i}}{\sum w_{i}}$,

em que:

$\mathrm{w}_{\mathrm{i}}=$ proporção (\%) de cada classe em relação ao total; e

$\mathrm{x}_{\mathrm{i}}=$ diâmetro médio das classes.

O IEA é obtido pela Equação 3.

$\operatorname{IEA}(\%)=\frac{\text { peso total dos agregados }- \text { peso dos agregados }<0,25 \mathrm{~mm}}{\text { peso da amostra seca }} \times 100$

A análise dos teores de matéria orgânica foi feita a partir da utilização dos macroagregados $(>0,25 \mathrm{~mm})$ e microagregados $(<0,25 \mathrm{~mm})$ do solo. Foram utilizados dois métodos, o de queima de matéria orgânica no forno mufla (Ball, 1964) - que superestima os resultados - e o de oxidação por dicromato de potássio (EMBRAPA, 1997) - que subestima os resultados - portanto, foi feita a média entre os valores encontrados em cada método.

O método de queima consiste em levar os agregados do solo ao forno mufla em temperatura de $375^{\circ} \mathrm{C}$ durante 16 horas. Passado este período, os cadinhos com as amostras são retirados do forno, novamente deixados resfriar no dessecador, para não ganhar umidade, e os novos pesos foram registrados. Assim é possível determinar a porcentagem de matéria orgânica no solo, por meio da Equação 4.

$$
M O=\frac{100 x(b-a)}{b}
$$

em que:

$\mathrm{MO}$ = porcentagem de matéria orgânica;

$\mathrm{a}=$ peso (g) do solo seco a $375^{\circ} \mathrm{C}$ (g) e

$\mathrm{b}=$ peso (g) do solo antes de ser levado a mufla.

Para o método de oxidação, são pesadas 0,5 gramas de solo que são tituladas com o dicromato de potássio, ácido ortofosfórico e sulfato ferroso amoniacal. Quando a coloração azul desaparece, cedendo lugar à verde, deve ser anotado o volume de sulfato ferroso amoniacal gasto. Assim, o teor de Carbono Orgânico (g/kg) é obtido pela Equação 5.

$$
C=(40-v) \times f \times 0,6
$$

em que:

$\mathrm{C}=$ carbono,

$\mathrm{f}=$ volume do sulfato ferroso gasto na prova em branco e

$\mathrm{v}=$ volume gasto $(\mathrm{ml})$. 
A percentagem de matéria orgânica é calculada multiplicando-se o resultado do carbono orgânico por 1,724. Este fator é utilizado em virtude de se admitir que, na composição média do húmus, o carbono participa com 58\%.

\section{RESULTADOS E DISCUSSÃO}

\subsection{Trilha Laranjeiras - Praia do Sono}

$\mathrm{Na}$ trilha foram observados pequenos movimentos de massa, áreas descampadas, desbarrancamento da encosta e feições erosivas, dois exemplos de feições erosivas no leito da trilha, estão destacados na Figura 2. Rangel (2014) destaca que essas ravinas estão associadas à concentração do escoamento superficial e a áreas com declividade acentuada.
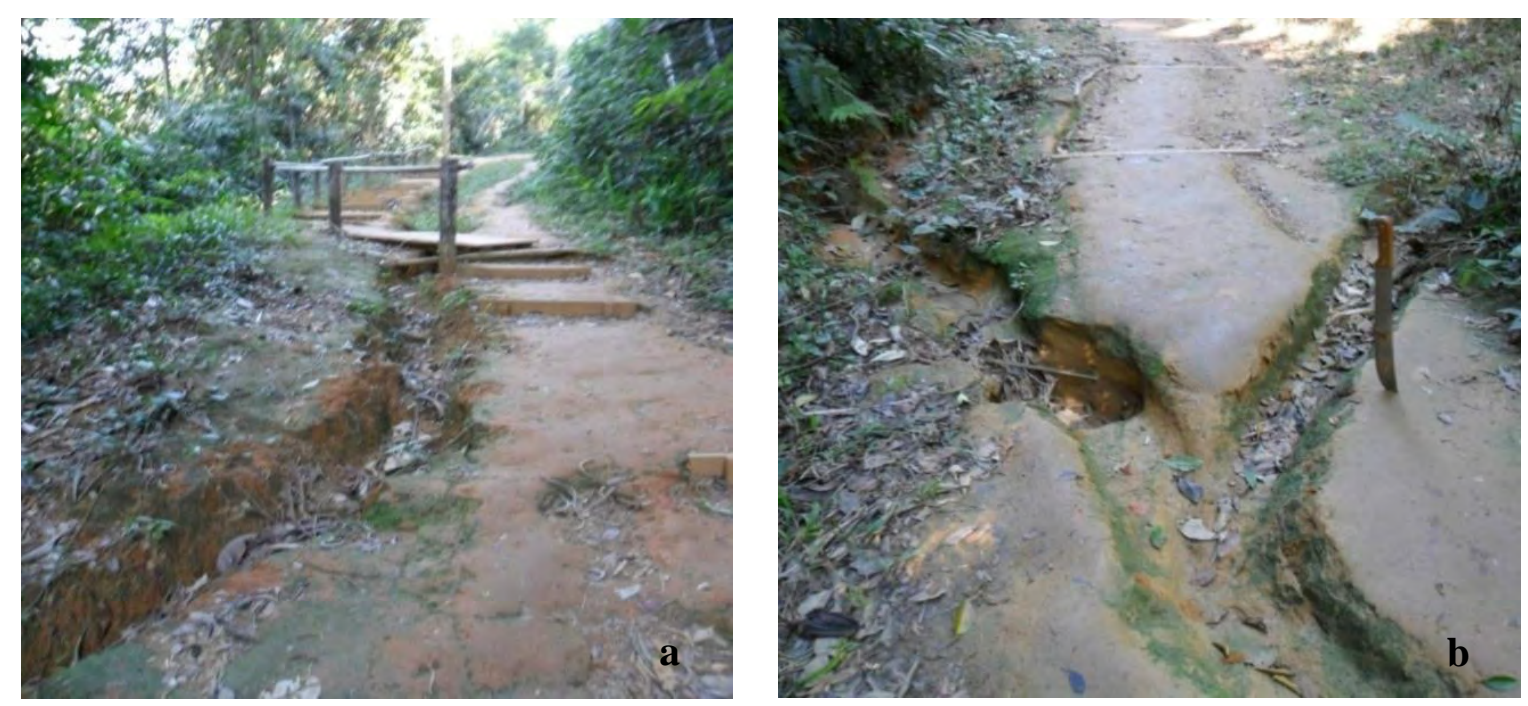

Figura 2. (a) Ravina desenvolvida com fluxo preferencial para a borda da trilha e acúmulo de serapilheira. (b) Ponte em cima de ravina no leito da trilha. Acervo L. A. Rangel, 2012.

O pisoteio nas trilhas compacta o solo e altera sua porosidade, elevando a resistência mecânica do solo à penetração de raízes e à infiltração de água. Esta afirmação pode ser confirmada a partir da avaliação dos teores de densidade aparente e de porosidade do leito e da borda da trilha (Tabela 1). É possível observar que apenas o ponto 4, no leito da trilha, apresentou densidade e porosidade do solo inferior a borda $\left(1,39 \mathrm{~g} / \mathrm{cm}^{3}\right.$ e $43,01 \%$ no leito e $1,44 \mathrm{~g} / \mathrm{cm}^{3}$ e $40,45 \%$ na borda da trilha). Já no ponto 2 foi observada a maior taxa de densidade do solo no leito da trilha $\left(1,72 \mathrm{~g} / \mathrm{cm}^{3}\right)$, evidenciando, portanto, elevada compactação do solo.

Baixos valores de porosidade e elevados valores de densidade do solo contribuem para menor infiltração de água da chuva, aumentando o escoamento superficial, acelerando a formação de ravinas e de erosão laminar, removendo os minerais do topo do solo.

Segundo Kiehl (1979), valores de densidade aparente entre 1,1 e 1,6 g/ $\mathrm{cm}^{3}$ representam predominância de frações minerais e manejo inadequado do solo, enquanto que em florestas a densidade aparente pode variar entre 0,6 e $0,8 \mathrm{~g} / \mathrm{cm}^{3}$. Conclui-se que mesmo as áreas de borda da trilha, possuem altos valores de densidade do solo, indicando que está havendo algum tipo de interferência e maior compactação do solo nos pontos analisados.

A partir dos resultados de estabilidade de agregados em água, é possível analisar não só o impacto do pisoteio, mas também, a influência da água da chuva que reage de formas diferentes à superfície com e sem vegetação. Portanto, a erosividade da chuva e a erodibilidade do solo são fatores que respondem de diferentes formas. 
Tabela 1. Densidade e porosidade do solo nos cinco pontos analisados da trilha Laranjeiras - Praia do Sono.

\begin{tabular}{|c|c|c|c|c|c|c|c|c|c|c|}
\hline \multirow{2}{*}{ Parâmetros } & \multicolumn{2}{|c|}{ Ponto 1} & \multicolumn{2}{|c|}{ Ponto 2} & \multicolumn{2}{|c|}{ Ponto 3} & \multicolumn{2}{|c|}{ Ponto 4} & \multicolumn{2}{|c|}{ Ponto 5} \\
\hline & Trilha & Borda & Trilha & Borda & Trilha & Borda & Trilha & Borda & Trilha & Borda \\
\hline Densidade $\left(\mathrm{g} / \mathrm{cm}^{3}\right)$ & 1,44 & 1,38 & 1,72 & 1,24 & 1,36 & 1,21 & 1,39 & 1,44 & & 1,18 \\
\hline Porosidade (\%) & 40,96 & 44,96 & 30,34 & 48,75 & 45,04 & 47,97 & 43,01 & 40,45 & 30,88 & 51,03 \\
\hline
\end{tabular}

Analisando a estabilidade de agregados (Tabela 2), verifica-se que os valores do Diâmetro Médio Ponderado (DMP) e consequentemente, do Diâmetro Médio Geométrico (DMG), foram maiores na borda da trilha. Utilizando-se o teste estatístico de Kruskal-Wallis, foi possível inferir que o pisoteio no leito da trilha está afetando significativamente os pontos 1, 2 e 5, para o DMP, e os pontos 1, 3, 4 e 5, para o DMG.

Isto pode estar ocorrendo porque os pontos 1, 2, 3 e 4 estão localizados em áreas de convergência de fluxos, onde a concentração de água pode provocar diferença entre os índices de agregação na área de borda e no leito da trilha. Já o ponto 5, apresenta pequeno limite de área pisoteada, fator que provoca maior compactação e influência na diferença entre os índices de agregação e na quebra dos agregados do solo do leito da trilha.

Os valores de DMP, relativamente baixos na trilha, refletem o baixo teor de matéria orgânica no solo, que influenciam diretamente na agregação do mesmo (Castro Filho e Logan, 1991). Isto pode estar ocorrendo, devido ao intenso pisoteio que provoca a quebra da estrutura do agregado, principalmente nos primeiros centímetros do solo.

É importante destacar que no ponto 4, no leito da trilha, o valor do DMP foi de 1,43 mm. Este valor é considerado baixo e reitera o que foi afirmado por Castro Filho et al. (1998), que quanto menor for o agregado, menor será o DMP e os espaços porosos entre agregados, diminuindo, portanto a infiltração, aumentando a erosão.

Bronick e Lal (2005) afirmam que além de aspectos como manejo e clima, a agregação também está associada à textura do solo, sendo assim, o baixo teor de argila ou de matéria orgânica, pode estar influenciando na não formação de agregados maiores.

Tabela 2. Análise de estabilidade de agregados do solo em água nos cinco pontos analisados da trilha Laranjeiras - Praia do Sono.

\begin{tabular}{|c|c|c|c|c|c|c|c|c|c|c|}
\hline \multirow{2}{*}{ Parâmetros } & \multicolumn{2}{|c|}{ Ponto 1} & \multicolumn{2}{|c|}{ Ponto 2} & \multicolumn{2}{|c|}{ Ponto 3} & \multicolumn{2}{|c|}{ Ponto 4} & \multicolumn{2}{|c|}{ Ponto 5} \\
\hline & Trilha & Borda & Trilha & Borda & Trilha & Borda & Trilha & Borda & Trilha & Borda \\
\hline DMP (mm) & 1,78 & $2,42 *$ & 1,87 & $2,6^{*}$ & 2,46 & 2,73 & 1,43 & 2,17 & 2,53 & $2,85^{*}$ \\
\hline $\mathrm{DMG}(\mathrm{mm})$ & 1,2 & $1,95^{*}$ & 1,32 & 2,18 & 1,92 & $2,5^{*}$ & 1,19 & $2,24^{*}$ & 2,1 & $2,68^{*}$ \\
\hline IEA (\%) & 88,76 & $94,72 *$ & 89,6 & 94,89 & 92,82 & $98,38 *$ & 79,54 & $96,49 *$ & 95,49 & $98,41^{*}$ \\
\hline $\begin{array}{l}\text { Agregados > } \\
2 \text { mm (\%) }\end{array}$ & 41,13 & $72,44^{*}$ & 47,71 & $81,39 *$ & 76,01 & 86,5 & 40,18 & $80,82 *$ & 77,92 & $92,79 *$ \\
\hline
\end{tabular}

Nota: Quando existe diferença significativa pelo teste de Kruskal-Wallis entre a área de borda e o leito da trilha em um mesmo ponto, o teste aparece na coluna referente à borda. ${ }^{*} \mathrm{p}<0,05$. Quando existe diferença significativa entre os pontos, o teste (letras diferentes) aparece na coluna referente ao ponto diferente, podendo ser na coluna da trilha (quando a diferença ocorre entre os leitos) ou na coluna da borda (quando a diferença ocorre entre as bordas).

Além dos menores valores de DMP (1,43 mm) e DMG (1,19 mm), o ponto 4 apresentou menores valores de IEA (79,54 \%) e de agregados > 2 mm (40,18 \%) no leito, demonstrando, 
ser o ponto mais degradado. Em contrapartida, o ponto 5, sofre menos impacto tanto do pisoteio, quanto da ação da água da chuva, pois os valores de DMP (2,53 mm), DMG (2,1 mm), IEA (95,49 \%) e de agregados > 2 mm (77,92 \%), foram altos.

Matos et al. (2008) destacam que agregados estáveis em água contribuem para um solo mais poroso, e consequentemente, favorecem a infiltração e a resistência à erosão. Já os agregados não estáveis, quando presentes na superfície, tendem a desaparecer e dispersar-se sob o impacto das gotas de chuva (Assis e Bahia, 1998).

Com relação à matéria orgânica (MO) do solo, foram elaboradas duas tabelas que expressam os valores obtidos pelo processo de queima na mufla e pelo processo de oxidação por dicromato. A porcentagem de MO nos macroagregados é apresentada na Tabela 3 e nos microagregados é apresentada na Tabela 4. Como foi dito anteriormente, enquanto um processo superestima o teor de matéria orgânica, o outro subestima, portanto, foi feita a média entre os teores obtidos nos dois processos.

Tabela 3. Teores de matéria orgânica nos macroagregados do solo, no leito e na borda da trilha, resultado da utilização dos métodos de queima e de oxidação, e valores médios dos teores entre os dois métodos.

\begin{tabular}{|c|c|c|c|c|c|c|}
\hline \multirow{2}{*}{ Locais } & \multicolumn{2}{|c|}{ \% M.O. Macroagregados (Mufla) } & \multicolumn{2}{|c|}{ \% M.O. Macroagregados (Dicromato) } & \multicolumn{2}{|c|}{ Média } \\
\hline & Trilha & Borda & Trilha & Borda & Trilha & Borda \\
\hline Ponto 1 & 3,76 & 6,75 & 0,25 & 1,67 & 2,01 & 4,21 \\
\hline Ponto 2 & 7,54 & 8,36 & 1,35 & 2,96 & 4,45 & 5,66 \\
\hline Ponto 3 & 4,53 & 6,21 & 2,21 & 4,03 & 3,37 & 5,12 \\
\hline Ponto 4 & 2,85 & 4,01 & 0,67 & 5,03 & 1,76 & 4,52 \\
\hline Ponto 5 & 4,93 & 5,89 & 1,31 & 2,57 & 3,12 & 4,23 \\
\hline
\end{tabular}

Valores inferiores a 3,5\% de matéria orgânica significam instabilidade e maior suscetibilidade erosiva (Fullen e Catt, 2004; Morgan, 2005). Isto ocorreu no leito da trilha em quase todos os pontos, com exceção do teor nos macroagregados do ponto 2 (4,45\%).

Tabela 4. Teores de matéria orgânica nos microagregados do solo, no leito e na borda da trilha Laranjeiras- Praia do Sono, resultado da utilização dos métodos de queima e de oxidação, e valores médios dos teores entre os dois métodos.

\begin{tabular}{|c|c|c|c|c|c|c|}
\hline \multirow{2}{*}{ Locais } & \multicolumn{2}{|c|}{ \% M.O. Microagregados (Mufla) } & \multicolumn{2}{|c|}{ \% M.O. Microagregados (Dicromato) } & \multicolumn{2}{|c|}{ Média } \\
\hline & Trilha & Borda & Trilha & Borda & Trilha & Borda \\
\hline Ponto 1 & 3,23 & 5,36 & 0,32 & 1,55 & 1,78 & 3,45 \\
\hline Ponto 2 & 5,94 & 6,58 & 0,75 & 1,58 & 3,34 & 4,08 \\
\hline Ponto 3 & 3,55 & 4,37 & 2,72 & 0,71 & 3,13 & 2,54 \\
\hline Ponto 4 & 1,78 & 3,38 & 0,86 & 3,02 & 1,32 & 3,20 \\
\hline Ponto 5 & 2,69 & 3,79 & 1,37 & 2,01 & 2,03 & 2,90 \\
\hline
\end{tabular}

Os teores de MO na borda da trilha foram maiores, em todos os pontos, do que os teores encontrados no leito. Isso ocorre devido à falta de vegetação no leito da trilha que ocasiona o menor input de matéria orgânica no solo. Esta questão é destacada por Christensen (2001), que afirma que além das interações entre os minerais, a interação destes com a matéria 
orgânica, constituindo complexos organominerais, afeta o tamanho dos agregados estáveis em água.

Destaca-se que o ponto 4 apresentou os menores teores de MO no leito da trilha, tanto nos macro quanto nos microagregados, corroborando os baixos valores dos índices de agregação apresentados na Tabela 1. Denef et al. (2001) destacam a importância dos macroagregados em controlar a estabilização do carbono e da matéria orgânica no solo.

Já na área de borda da trilha, o ponto 2 apresentou os maiores teores de MO, tanto para os macroagregados quanto para os microagregados, evidenciando maior incorporação da vegetação ao solo. Sendo assim, a ciclagem de nutrientes se torna fundamental para a melhor estabilidade de agregados, pois pela incorporação de vegetação e do input de matéria orgânica ao solo, a formação de macroagregados ocorre com maior frequência.

\subsection{Trilha Praia do Sono - Praia de Antigos}

A trilha tem início próximo a um córrego onde é possível observar diversos blocos rochosos, que formam um nível de base. A vegetação inicial é mais desenvolvida e a trilha mais estreita, após 30 metros ela se alarga e a vegetação se torna mais arbustiva. A partir desse ponto, até o interflúvio, a trilha apresenta raízes e blocos rochosos expostos, e diversas feições erosivas muito desenvolvidas. As coletas foram feitas em dois ambientes vegetacionais distintos, o primeiro com vegetação arbustiva e o leito mais erodido e o segundo em ambiente de floresta ombrófila com nenhuma feição erosiva aparente (Figura 3).

Os percentuais de porosidade encontrados, com exceção da borda da trilha no ponto 1, podem ser considerados de baixa a média suscetibilidade à erosão (entre 35 e 55 \%) segundo o que foi proposto por Lima (2008) no estudo feito na bacia hidrográfica do rio Macaé.

Analisando a Tabela 5, pode-se constatar que todos os pontos possuem solos minerais segundo Kiehl (1979), pois os valores de densidade aparente encontrados estão entre 1,1 e $1,6 \mathrm{~g} / \mathrm{cm}^{3}$. Além disso, observa-se que os valores de densidade no leito da trilha, mais uma vez, estão maiores do que na borda da trilha, onde há mais vegetação e não há pisoteio (Tabela 5).

Os resultados obtidos estão em acordo com os dados apresentados por Maganhotto et al. (2010) e Oliveira et al. (2013), que também encontraram valores de densidade aparente maiores no leito das trilhas em relação à área de borda.

Analisando a estabilidade de agregados do solo (Tabela 6), verifica-se que os valores do DMP, do DMG e do IEA foram maiores na borda da trilha. Através do teste estatístico realizado, foi possível inferir que o pisoteio no leito da trilha está afetando significativamente todos os índices de agregação no ponto 1, e o DMG, o IEA e a porcentagem de agregados maiores que $2 \mathrm{~mm}$ no ponto 2 .

O DMG no primeiro ponto de coleta foi muito baixo $(0,37 \mathrm{~mm})$ evidenciando que o solo está bastante degradado e sofre com a falta de cobertura vegetal, e, portanto, com escoamento de água e com o intenso pisoteio. Kiehl (1979) destaca que agregados com diâmetro médio acima de $0,5 \mathrm{~mm}$ são considerados relativamente resistentes ao esboroamento, e podendo ser bons condutores de água e ar. O DMP no leito da trilha do ponto 1, também foi muito baixo $(0,73 \mathrm{~mm})$. Fattet et al. (2011) encontraram resultados semelhantes ao analisarem o efeito de diferentes coberturas vegetais na erosão do solo.

Estes baixos valores de DMG e DMP no leito da trilha do ponto 1 são corroborados pela porcentagem de agregados $>2 \mathrm{~mm}$ (8,39\%). Este valor muito baixo evidencia que os agregados estão sofrendo rápida quebra pela ação da água, logo, não está ocorrendo incorporação de matéria orgânica, uma das responsáveis pela cimentação dos agregados.

O ponto 2 mostra-se menos degradado, tanto na área do leito, quanto na área de borda da trilha, nas duas profundidades, isto pode estar relacionado com a declividade, que é maior no 
ponto 1 e com a presença de vegetação arbórea no ponto 2, que diminui o efeito splash no leito da trilha.
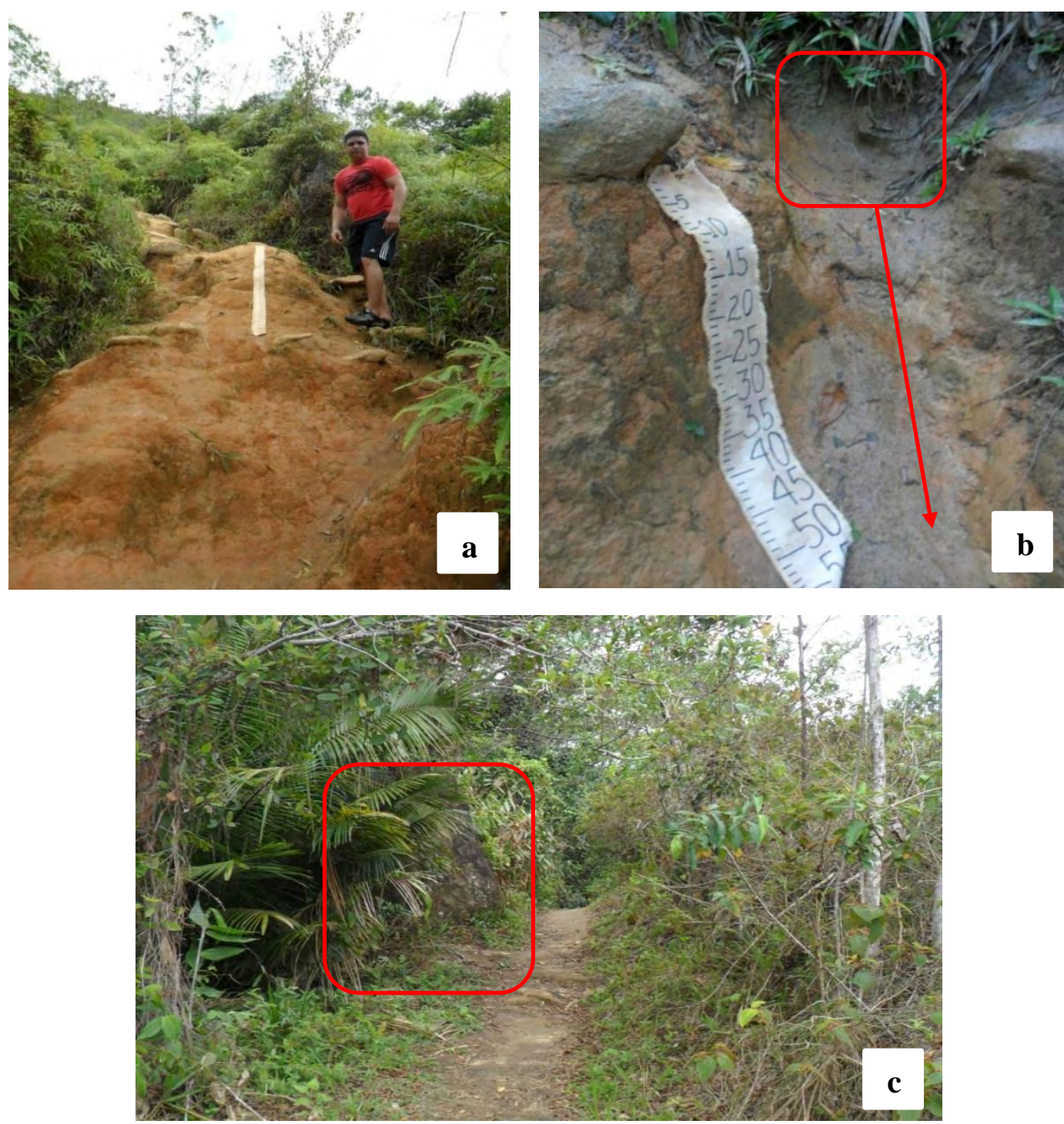

Figura 3. (a) Vista geral do primeiro ponto de coleta e canal preferencial de água que drena da área de borda para o leito da trilha (b); (c)Visão geral do segundo ponto de coleta com a presença de raízes no leito da trilha e de bloco rochoso (destaque em vermelho). Acervo: L. A. Rangel, 2012.

A estabilidade dos agregados na camada superficial de solo está diretamente relacionada com a ocorrência do escoamento superficial e com a erodibilidade do solo (Fattet et al., 2011), sendo assim, ao analisarmos o IEA, o leito da trilha mostra-se instável nos dois pontos de coleta.

Ao analisar a matéria orgânica (Tabelas 7 e 8), verifica-se que a média dos teores em todos os pontos foi inferior a 3,5\% indicando maior instabilidade e propensão à erosão segundo Fullen e Catt (2004). Como era esperado, os teores de matéria orgânica na borda da trilha foram maiores do que os teores encontrados no leito nos dois pontos analisados. Isso ocorre devido à presença de vegetação na borda da trilha. Campos et al. (1999) constatam que a umidade e a cobertura vegetal do solo têm uma estreita relação com a agregação do mesmo, sendo assim, a incorporação de MO na borda da trilha favorece a agregação, o que é 
confirmado ao comparar os resultados de agregação do solo com os teores de matéria orgânica.

Tabela 5. Densidade e porosidade do solo nos cinco pontos analisados da Praia do Sono - Praia de Antigos.

\begin{tabular}{lllllc}
\hline \multirow{2}{*}{ Parâmetros } & \multicolumn{3}{c}{ Ponto 1 } & & \multicolumn{2}{c}{ Ponto 2 } \\
\cline { 2 - 3 } \cline { 5 - 6 } & Trilha & Borda & & Trilha & Borda \\
\hline Densidade $\left(\mathrm{g} / \mathrm{cm}^{3}\right)$ & 1,38 & 1,29 & & 1,3 & 1,1 \\
Porosidade (\%) & 44,08 & 47,11 & & 47,15 & 54,55 \\
\hline
\end{tabular}

Tabela 6. Resultado da análise de estabilidade de agregados em água nos cinco pontos analisados da trilha Praia do Sono - Praia de Antigos.

\begin{tabular}{llllll}
\hline \multirow{2}{*}{ Parâmetros } & \multicolumn{2}{c}{ Ponto 1 } & & \multicolumn{2}{c}{ Ponto 2 } \\
\cline { 2 - 3 } \cline { 5 - 6 } \cline { 5 - 6 } & Trilha & Borda & & Trilha & Borda \\
\hline DMP (mm) & 0,73 & $2,42^{*}$ & & $1,92^{\mathrm{A}}$ & 2,16 \\
DMG (mm) & 0,37 & $1,74^{*}$ & & $1,17^{\mathrm{A}}$ & $2,22^{*}$ \\
IEA (\%) & 63,86 & $93,94^{*}$ & & 78,53 & $95,47^{*}$ \\
Agregados $>2$ mm (\%) & 8,39 & $65,33^{*}$ & & $42,28^{\mathrm{A}}$ & $82,38^{*}$ \\
\hline
\end{tabular}

Nota: Quando existe diferença significativa pelo teste de Kruskal-Wallis entre a área de borda e o leito da trilha em um mesmo ponto, o teste aparece na coluna referente à borda. ${ }^{*} \mathrm{p}<0,05$. Quando existe diferença significativa entre os pontos, o teste (letras diferentes) aparece na coluna referente ao ponto diferente, podendo ser na coluna da trilha (quando a diferença ocorre entre os leitos) ou na coluna da borda (quando a diferença

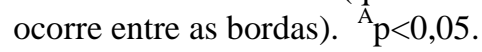

Além disso, destaca-se que o primeiro ponto apresentou teores de matéria orgânica inferiores aos encontrados no ponto 2. Este fator está diretamente relacionado às condições encontradas no ponto em questão: declividade acentuada, presença de feições erosivas, e baixos índices de agregação.

Tabela 7. Teores de matéria orgânica nos macroagregados do solo, no leito e na borda da trilha Praia do Sono - Praia de Antigos, resultado da utilização dos métodos de queima e de oxidação, e valores médios dos teores entre os dois métodos.

\begin{tabular}{|c|c|c|c|c|c|c|}
\hline \multirow{2}{*}{ Locais } & \multicolumn{2}{|c|}{ \% M.O. Macroagregados (Mufla) } & \multicolumn{2}{|c|}{ \% M.O. Macroagregados (Dicromato) } & \multicolumn{2}{|c|}{ Média } \\
\hline & Trilha & Borda & Trilha & Borda & Trilha & Borda \\
\hline Ponto 1 & 1,78 & 3,38 & 0,19 & 0,78 & 0,99 & 2,08 \\
\hline Ponto 2 & 2,85 & 4,01 & 1,36 & 2,00 & 2,11 & 3,01 \\
\hline
\end{tabular}

Tabela 8. Teores de matéria orgânica nos microagregados do solo, no leito e na borda da trilha Praia do Sono - Praia de Antigos, resultado da utilização dos métodos de queima e de oxidação, e valores médios dos teores entre os dois métodos.

\begin{tabular}{|c|c|c|c|c|c|c|}
\hline \multirow{2}{*}{ Locais } & \multicolumn{2}{|c|}{ \% M.O. Microagregados (Mufla) } & \multicolumn{2}{|c|}{ \% M.O. Microagregados (Dicromato) } & \multicolumn{2}{|c|}{ Média } \\
\hline & Trilha & Borda & Trilha & Borda & Trilha & Borda \\
\hline Ponto 1 & 0,32 & 1,54 & 0,18 & 0,54 & 0,3 & 1,04 \\
\hline Ponto 2 & 2,39 & 3,47 & 1,34 & 1,95 & 1,9 & 2,71 \\
\hline
\end{tabular}


Logo, é possível concluir que a incorporação de matéria orgânica na trilha é baixa. Isto afeta a dinâmica do solo influenciando negativamente nas propriedades químicas e físicas do mesmo, facilitando a ocorrência de feições erosivas e áreas degradadas.

Nas áreas onde as feições erosivas estão desenvolvidas, como observado na Figura 3a e 3b, são necessárias técnicas de bioengenharia, como a aplicação de geotêxteis que são malhas de fibras ou de materiais sintéticos biodegradáveis, que controlam a erosão e auxiliam na recuperação de áreas degradadas. Funcionam como proteção imediata e temporária ao solo contra os agentes erosivos, como as gotas de chuva e o escoamento superficial, enquanto a vegetação não se estabelece na encosta. Após o estabelecimento da vegetação, as raízes das plantas e as fibras do geotêxtil agirão juntas e aumentarão a coesão das partículas do solo (Guerra et al., 2010).

Além disso, a utilização de canaletas de drenagem em áreas de convergência de fluxos para evitar concentração do fluxo; o ordenamento do sistema de drenagem; a utilização de barreiras que retenham os sedimentos e a colocação de degraus de madeira - principalmente na trilha Praia do Sono-Praia de Antigos - para garantir acessibilidade e orientar o fluxo de visitantes, podem auxiliar na conservação das trilhas. Outra forma de manejo adequada seria a recuperação das encostas com reflorestamento, que irá proteger o talude e regular o volume de solo e água que pode sobrecarregar o leito e drenagem da trilha.

\section{CONCLUSÃO}

A comparação das áreas impactadas e não impactadas das trilhas permitiu nortear o planejamento, o manejo e sugerir algumas propostas para recuperação das áreas degradadas nas trilhas e no seu entorno, visando auxiliar os gestores da REJ.

Destaca-se que os procedimentos metodológicos, bem como, os resultados obtidos permitiram alcançar os objetivos definidos no estudo da avaliação do impacto da utilização de trilhas. Além disso, os resultados das propriedades físicas e químicas do solo mostraram-se satisfatórios e complementares para o melhor desenvolvimento da pesquisa.

Os resultados apontam para a importância dos estudos de campo, do planejamento e da recuperação das trilhas. O desenvolvimento dessas atividades auxilia na elaboração de diagnósticos de degradação das trilhas que venham a compor a proposição de medidas reparadoras, visando à diminuição do impacto na Unidade de Conservação.

A falta de planejamento na criação das trilhas provocou diversas alterações na qualidade do solo e impactos significativos dentro da Unidade de Conservação. Portanto, se antes da instalação das trilhas tivesse sido feito um planejamento adequado, a atividade turística não seria prejudicada.

Comparando as duas trilhas, percebe-se que a trilha Praia do Sono - Praia de Antigos está mais degradada, pois, possui feições erosivas mais desenvolvidas, não possui nenhuma estrutura de manejo, acarretando risco elevado para os usuários, que podem escorregar e cair da encosta. Estes fatores evidenciam áreas prioritárias para recuperação.

Conclui-se que as trilhas podem ser consideradas forças de tensão, como no caso da trilha Praia do Sono-Praia de Antigos, que está afetando consideravelmente a dinâmica do solo, e, com o aprofundamento das feições erosivas, amplia as áreas degradadas e interfere na dinâmica do ecossistema e na recuperação de fragmentos de Mata Atlântica.

\section{AGRADECIMENTOS}

À Fundação de Amparo à Pesquisa do Estado do Rio de Janeiro (FAPERJ) e ao Conselho Nacional de Desenvolvimento Científico e Tecnológico (CNPq) pelo financiamento da pesquisa. 


\section{REFERÊNCIAS}

ASSOCIAÇÃO BRASILEIRA DE NORMAS TÉCNICAS - ABNT. Nbr 10703:1989. Define os termos empregados nos estudos, projetos, pesquisas e trabalhos em geral, relacionados à análise, ao controle e à prevenção da degradação do solo. Rio de Janeiro, 1989.

ANDRADE, W. J. Manejo de trilhas para o ecoturismo. In: NEIMAN, Z.; MENDONÇA, R. Ecoturismo no Brasil. São Paulo: Manole, 2005.

ARAÚJO, G. H. de S.; ALMEIDA, J. R. de; GUERRA, A. J. T. Gestão ambiental de áreas degradadas. Rio de Janeiro: Bertrand Brasil, 2013. 322p.

ARSHAD, M. A.; MARTIN, S. Identifying critical limits for soil quality indicators in agroecosystems. Agriculture, Ecosystems and Environment, Amsterdan, v. 88, p. 153160, 2002. http://dx.doi.org/10.1016/S0167-8809(01)00252-3

ASSIS, R. L.; BAHIA, V. G. Práticas mecânicas e culturais de recuperação de características físicas dos solos degradados pelo cultivo. Informe Agropecuário, v. 19, p. 71-78, 1998.

BALL, D. F. Loss-on-ignition as an estimate of organic matter and organic carbon in non calcareous soils. Journal of Soil Science, v. 15, n. 1, p. 84-92, 1964.

BRASIL. Decreto no 89.336, de 31 de janeiro de 1984. Dispões sobre as Reservas Ecológicas e Áreas de Relevante Interesse Ecológico, e dá outras providencias. Disponível em: http://www2.camara.leg.br/legin/fed/decret/1980-1987/decreto-8933631-janeiro-1984-439049-norma-pe.html. Acesso em: 13 jul. 2012.

BRONICK, C. J.; LAL, R. Soil structure and management: a review. Geoderma, v. 124, p. 3-22, 2005.

CAMPOS, B. C. D.; REINERT, D. J.; NICOLODI, R.; CASSOL, L. C. Dinâmica da agregação induzida pelo uso de plantas de inverno para cobertura do solo. Revista Brasileira de Ciência do solo, v. 23, p. 33-391, 1999.

CASTRO FILHO, C.; LOGAN, T. J. Liming effects on the stability and erodibility of some Brazilian Oxisols. Soil Science Society of America, v. 55, p. 1407-1413, 1991. http://dx.doi.org/10.2136/sssaj1991.03615995005500050034x

CASTRO FILHO, C.; MUZILLI, O.; PODANOSCHI, A. L. Estabilidade dos agregados e sua relação com o teor de carbono orgânico num Latossolo Roxo Distrófico, em função de sistemas de plantio, rotações de culturas e métodos de preparo das amostras. Revista Brasileira de Ciência do Solo, v. 22, p. 527-538, 1998.

CHRISTENSEN, B. T. Physical fractionation of soil and structural and functional complexity in organic matter turnover. Europe Journal Soil Science, v. 52, p. 345-353, 2001. http://dx.doi.org/10.1046/j.1365-2389.2001.00417.x

CUNHA, S. B. GUERRA, A. J. T. Degradação ambiental. In: CUNHA, S. B.; GUERRA, A. J. T. (Org.). Geomorfologia e meio ambiente. 6. ed. Rio de Janeiro: Bertrand Brasil, 2006. p. 337-379. 
DENEF, K.; SIX, J.; PAUSTIAN, K.; MERCKX, R. Importance of macroaggregate dynamics in controlling soil carbon stabilization: short-term effects of physical disturbance induced by dry-wet cycles. Soil Biology and Biochemistry, v. 33, p. 2145-2153, 2001. http://dx.doi.org/10.1016/S0038-0717(01)00153-5

DORAN, J. W. PARKIN, T. B. Defining and assessing soil quality. In: DORAN, J. W.; COLEMAN, D. C.; BEZDICEK, D. F.; STEWART, B. A. (Org.). Defining soil quality for a sustainable environment. Soil Science Society of America Journal, Madison, Special Publication, n. 35, p. 3-22, 1994.

EMPRESA BRASILERA DE PESQUIS AGROPECUÁRIA - EMBRAPA. Centro Nacional de Pesquisa de Solos. Manual de métodos de análise de solo. Rio de Janeiro, 1997. 212p.

FATTET, M.; FU, Y.; GHESTEM, M.; MA, W.; FOULONNEAU, M.; NESPOULOUS, J. LE; BISSONNAIS, Y. et al. Effects of vegetation type on soil resistance to erosion: Relationship between aggregate stability and shear strength. Catena, v. 87, p. 60-69, 2011. http:/dx.doi.org/10.1016/j.catena.2011.05.006

FULLEN, M. A.; CATT, J. A. Soil management: problems and solutions. London: Arnold, 2004.

GUERRA, A. J. T.; BEZERRA, J. F. R.; LIMA, L. D. M.; MENDONÇA, J. K. S.; GUERRA, T. T.; BUHMANN, C. et al. Land rehabilitation with the use of biological geotextiles, in two different countries. Sociedade \& Natureza, Uberlândia, v. 22, n. 3, p. 431-446, 2010. http://dx.doi.org/10.1590/S1982-45132010000300002

GUERRA, A. J. T.; BEZERRA, J. F. R.; JORGE, M. C. O.; FULLEN, M. A The geomorphology of Angra dos Reis and Paraty Municipalities, Southern Rio de Janeiro State. Revista Geonorte, v. 9, n. 1, p. 1-21, 2013.

INSTITUTO CHICO MENDES DE CONSERVAÇÃO DA BIODIVERSIDADE - ICMBIO. Plano de manejo da APA de Cairuçu. 2004. Disponível em: http://www.icmbio.gov.br/portal/biodiversidade/unidades-de-conservacao/biomasbrasileiros/marinho/unidades-de-conservacao-marinho/2240-apa-de-cairucu.html. Acesso em: 06 ago. 2012.

KEMPER, W. D.; ROSENAU, R. C. Aggregate stability and size distribution. In: KLUTE, A. (Ed.). Methods of soil analysis - Part I: Physical and minerological methods. Wisconsin: Madison, 1986. p. 425-442.

KIEHL, E. J. Manual de edafologia, relações solo-planta. São Paulo: Ceres, 1979.

KROEFF, L. L. Contribuição metodológica ao planejamento de trilhas ecoturísticas no Parque Nacional da Serra dos Órgãos (PARNASO), RJ. 2010. Dissertação (Mestrado em Geografia) - Instituto de Geociências, Universidade Federal do Rio de Janeiro, Rio de Janeiro, 2010.

LEUNG, Y.; MARION, J. L. The influence of sampling interval on the accuracy of trail impact assessment. Landscape and Urban Planning, v. 43, n. 4, p. 167-179, 1999. http://dx.doi.org/10.1016/S0169-2046(98)00110-8 
LIMA, L. D. da M. Suscetibilidade à erosão dos solos nas sub-bacias do médio e altocursos da bacia do Rio Macaé/RJ. 2008. 127 f. Dissertações (Mestrado em Geografia) - Instituto de Geociências - Universidade Federal do Rio de Janeiro, Instituto de Geociências, Rio de Janeiro, 2008.

MAGANHOTTO, R. F.; SANTOS, L. J. C.; SOUZA, L. C. P.; MIARA, M. A. Variação dos atributos físicos do solo devido ao trânsito de pessoas em trilha localizada na Região de Paranaguá - Pr. Revista Geografar, Curitiba, v. 5, n. 2, p. 94-114, jul./dez. 2010.

MARQUES, M. C. M. (Org.). Mapeamento da cobertura vegetal e listagem das espécies ocorrente na Área de Proteção Ambiental de Cairuçu, município de Paraty, RJ. Rio de Janeiro: Jardim Botânico, 1997. 96 p.

MATOS, E. S.; MENDONÇA, E. S.; LEITE, L. F. C.; GALVÃO, J. C. C. Estabilidade de agregados e distribuição de carbono e nutrientes em Argissolo sob adubação orgânica e mineral. Pesquisa Agropecuária Brasileira, v. 43, p. 1221-1230, 2008. http://dx.doi.org/10.1590/S0100-204X2008000900017

MORGAN, R. P. C. Soil erosion and conservation. England: Blackwell, 2005.

OLIVEIRA, J. G. R.; FILHO TAVARES, J.; BARBOSA, G. M. C. Qualidade física do solo das trilhas do parque estadual do Cerrado - PR. Ciências Agrárias, Londrina, v. 34, n. 4, p. 1715-1722, 2013. http://dx.doi.org/10.5433/1679-0359.2013v34n4p1715

RANGEL, L. A.; GUERRA, A. J. T.; BRIZZI, R. R.; SOUZA, H. S. O uso de trilhas em unidades de conservação: o caso da Apa de Cairuçu, Paraty - RJ. Geografia, Londrina, v. 22, n. 1, p.79-93, 2013.

RANGEL, L. A.; GUERRA, A. J. T. O impacto na dinâmica do solo através da utilização da trilha Ponta Negra-Praia de Galhetas na Reserva Ecológica da Juatinga em Paraty. In: CONGRESSO NACIONAL DE PLANEJAMENTO E MANEJO DE TRILHAS, 2., 2013, Rio de Janeiro. Anais... Rio de Janeiro: Rede Sirius-Rede de Biblioteca, 2013. $1236 \mathrm{p}$.

RANGEL, L. A. O Impacto da Utilização de Trilhas na Área de Proteção Ambiental de Cairuçu - Paraty - Rio de Janeiro. 2014. 186f. Dissertação (Mestrado em Geografia) - Universidade Federal do Rio de Janeiro, Instituto de Geociências, Rio de Janeiro, 2014.

YODER, R. E. A direct method of aggregate analysis of soils and a study of the physical nature of erosion losses. Journal American Society Agronomy, v. 28, p. 337-351, 1936. http://dx.doi.org/10.2134/agronj1936.00021962002800050001x 